

\section{REVISTA BRASILEIRA DE POLÍTICAS PÚBLICAS}




\section{REVISTA BRASILEIRA DE POLÍTICAS PÚBLICAS \\ Brazilian Journal of Public Policy}

Programa de Mestrado e Doutorado em Direito do UniCEUB

Centro Universitário de Brasília

Reitor

Getúlio Américo Moreira Lopes

Presidente do Conselho Editorial do UniCEUB

Elizabeth Regina Lopes Manzur

Diretor do ICPD

João Herculino de Souza Lopes Filho

Coordenador do Programa de Mestrado e Doutorado e Editor

Marcelo Dias Varella

\section{Linha editorial}

"A Revista Brasileira de Políticas Públicas é um periódico acadêmico da área jurídica que tem como finalidade constituir instrumento de veiculação de trabalhos científicos e doutrinários que abordem questões jurídicas da contemporaneidade e, ainda, aspectos da interação entre Direito e Políticas Públicas. Direciona, portanto, seu objeto de interesse a questões referentes a governabilidade, integração, participação cidadã, desenvolvimento e outros temas envolvendo o Estado, a Sociedade e o Direito.

Sendo assim, a proposta de linha editorial a ser seguida pela Revista Brasileira de Políticas Públicas é apresentada a partir de três áreas fundamentais, que se subdividem:

I) Democracia, Políticas de Estado e de Governo e seus aspectos jurídicos: tendências do Direito Constitucional e do Direito Administrativo; teoria das políticas públicas; sistema de governo; sistema eleitoral e cidadania; sistema de partidos e reforma constitucional

II) Políticas Públicas de desenvolvimento econômico e social e suas interfaces com o Direito: políticas de desenvolvimento econômico e produção local/regional, desenvolvimento sustentável e meio-ambiente, desenvolvimento humano e planejamento da ação governamental".

\section{CONSELHO EDITORIAL}

Marie-Pierre Lafranchi, Université d'Aix-en-Provence, Faculté de droit et de science politique, Provence-Alpes-Côte d'Azur, França Frederico Augusto Barbosa, Centro Universitário de Brasília, Programa de Mestrado e Doutorado em Direito, Brasília/DF, Brasil Gilberto Bercovici, Universidade de São Paulo, Faculdade de Direito, Departamento de Direito Econômico-Financeiro, São Paulo/SP, Brasil João Maurício Adeodato, Universidade Federal de Pernambuco, Centro de Ciências Jurídicas, Departamento de Teoria Geral do Direito e do Direito Privado, Recife/PE, Brasil

José Adercio Leite Sampaio, Escola Superior Dom Helder Câmara, Escola de Direito, Belo Horizonte/MG, Brasil

José Heder Benatti, Universidade Federal do Pará, Instituto de Ciências Jurídicas, Belém/PA, Brasil

\section{EDITOR}

Marcelo D. Varella, Centro Universitário de Brasília, Programa de Mestrado e Doutorado em Direito, Brasília/DF, Brasil

\section{EQUIPE TÉCNICA}

Priscila Pereira de Andrade, Centro Universitário de Brasília, Revista Brasileira de Políticas Públicas, Brasília/DF, Brasil Yuri Valente do Nascimento, Centro Universitário de Brasília, Revista Brasileira de Políticas Públicas, Brasília/DF, Brasil Max Meirelles Gonzaga, Centro Universitário de Brasília, Revista Brasileira de Políticas Públicas, Brasília/DF, Brasil Aline Assunção Santos, Centro Universitário de Brasília, Revista Brasileira de Políticas Públicas, Brasília/DF, Brasil

\section{Layout capa}

Departamento de Comunicação / ACC UniCEUB

\section{Diagramação}

S2 Books

\section{Disponível em:}

http://www.rbpp.uniceub.br

\section{Circulação}

Acesso aberto e gratuito

Matérias assinadas são de exclusiva responsabilidade dos autores.

Citação parcial permitida com referência à fonte. 
Revista Brasileira de Políticas Públicas / Programa de Mestrado e Doutorado em Direito do UniCEUB. - vol. 6, n. 2 (out. 2016) - . Brasília : UniCEUB, 2011

Quadrimestral.

ISSN 2236-1677

Disponível também on-line: www.rbpp.uniceub.br

1. Direito. 2. Políticas Públicas. I. Programa de Mestrado e Doutorado em Direito do UniCEUB

CDU $34+338.26$

Ficha catalográfica elaborada pela Biblioteca Reitor João Herculino

A partir desse volume a RBPP passará a ter exemplares quadrimestrais 
UMA PERSPECTIVA COMPARAdA ACERCA DA (NÃo) EFETIVIDADE DA DEMOCRACIA LOCAL NO BRASIL E EM PoRTUGAL................................................................................................12 Matheus Passos Silva

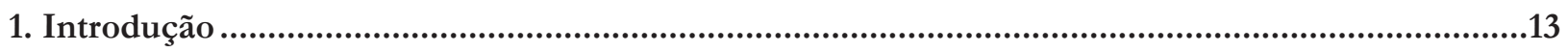

2. O modelo de democracia ocidental no século XXI .......................................................................14

3. A falta de representatividade na democracia contemporânea.......................................................17

4. Democracia local: Revitalizando a representação política (?) ..................................................... 20

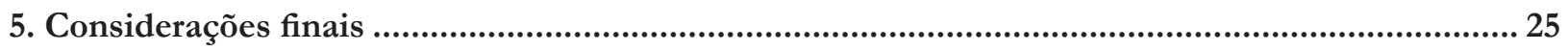

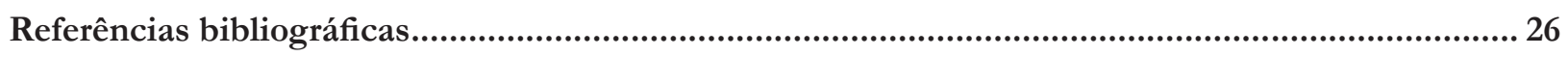

A “ATIVIDADE-AÇÃO” PUNITIVO-DISCIPLINAR. INTERATIVIDADE E COMPLEXIDADE ENTRE ATO, PROCEDIMENTO E PROCESSO ADMINISTRATIVO ......................................................30

Sandro Lucio Dezan e Paulo Afonso Cavichioli Carmona

1. Introdução

2. Distinção epistemológica por dependência dos objetos material e processual do direito punitivo estatal.

3. Administração Pública, processo punitivo "interna corporis" e função administrativa.................. 34

4. Interação complexa entre os sub-ramos do direito punitivo estatal e entre o ato, o procedimento e o processo, no âmbito da função punitiva disciplinar............................................................................ 35

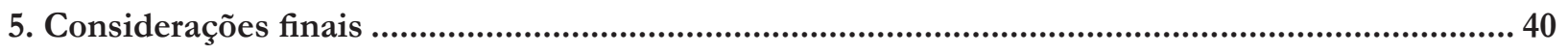

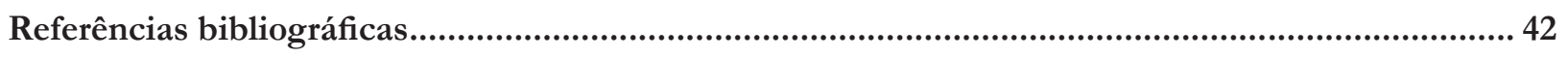

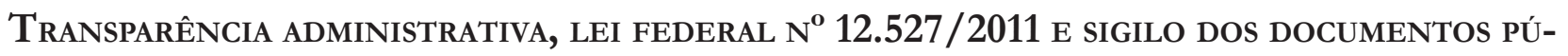
Blicos: A INCONSTituCiONALIDAdE DAS RESTRiÇÕES AO ACESSO À INFORMAÇÃo .....................46 Emerson Affonso da Costa Moura

1. Introdução. 47

2. A administração pública brasileira e o controle social .............................................................. 48

3. A transparência administrativa e a lei de acesso à informação ...................................................... 52

4. A inconstitucionalidade das restrições da lei 12.527/11 ao acesso à informação............................ 54

5. Estudo de caso: O sigilo na Casa Civil da Presidência da República e o controle social das informações públicas. 
A influência do Direito Administrativo Global no processo brasileiro de Contrata-

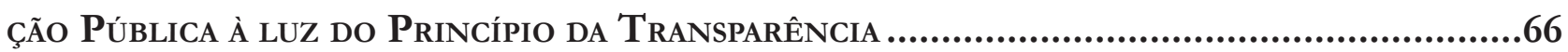

Alice Rocha da Silva e Ruth Maria Pereira dos Santos

1. Introdução 67

2. O Princípio da Transparência como valor global no processo de contratação pública 68

3. O princípio da transparência como base do processo de contratação pública no contexto da união europeia e global.

4. A aplicabilidade do princípio da transparência às regras brasileiras de contratação pública ........ 73

5. A atual ausência de accountability no processo brasileiro de contratação pública 77

6. A inserção dos valores globais de transparência no processo de contratação pública: proteção dos direitos individuais e implementação dos ideais democráticos 79

7. Considerações finais 85

Referências bibliográficas. 86

Interna Corporis Acta e os limites do Controle JUdicial dos ATOS Legislativos. .90 Cintia Garabini Lages

1. Introdução 91

2. A natureza normativa dos interna corporis acta. 92

3. Controle judicial dos interna corporis acta 95

4. Direito positivo, legitimidade e processo: o papel do processo legislativo na modernidade e o caráter cogente das normas regimentais sobre processo legislativo.

5. Considerações finais

Referências bibliográficas.

\section{A RELEITURA DO PRINCÍPIO DA ACTIO NATA QUANTO AOS DIREITOS DIFUSOS NA JUDICIALIZAÇÃO}

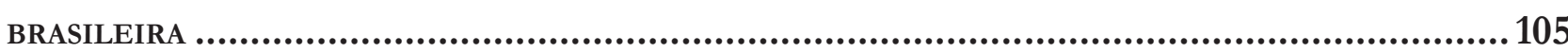

Luiz Gustavo Gonçalves Ribeiro e Lorena Machado Rogedo Bastianetto

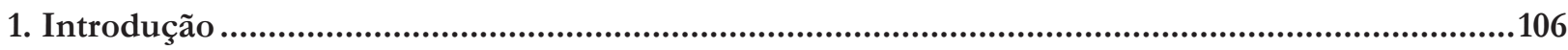

2. A natureza reflexiva do direito ao meio ambiente equilibrado ...................................................107

3. A origem da "pretensão" ................................................................................................109

4. Considerações finais ....................................................................................................... 113

Referências bibliográficas...........................................................................................113 
Antonio Henrique Graciano Suxberger e Alberto Carvalho Amaral

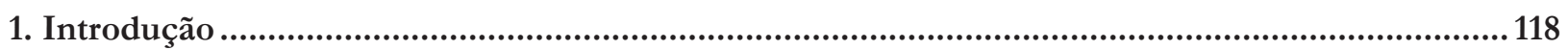

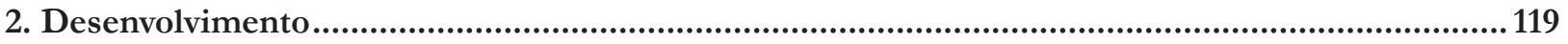

2.1. A constitucionalização das garantias fundamentais: o contexto latino-americano ..................................... 119

2.2. A Defensoria Pública como órgão instrumentalizador da garantia constitucional processual de acesso à

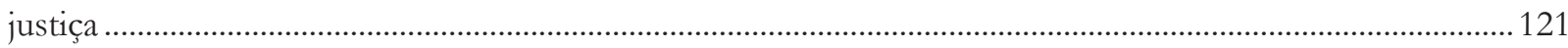

2.3. A Defensoria Pública como garantia constitucional processual de acesso à justiça ................................... 125

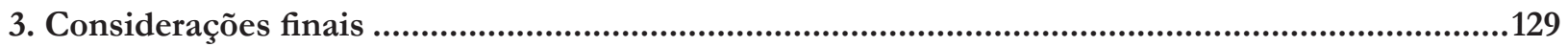

Referências bibliográficas.............................................................................................................130

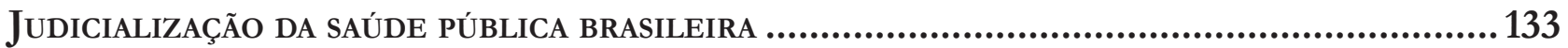

Maria Socorro de Araújo Dias, Diógenes Farias Gomes, Thaís Araújo Dias, Lielma Carla Chagas da Silva, Maria da Conceição Coelho Brito e Manoel de Castro Carneiro Neto

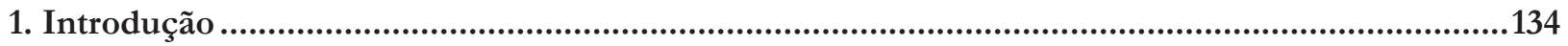

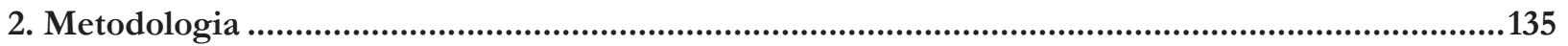

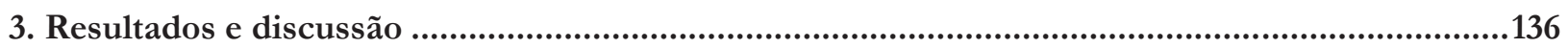

4. Judicialização da saúde: origem e enfoques no sistema de saúde brasileiro .............................139

5. Efeitos da judicialização no Estado brasileiro ..................................................................................... 141

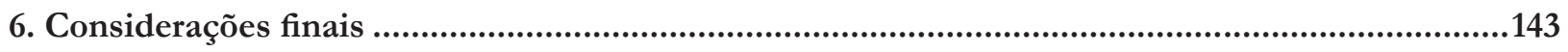

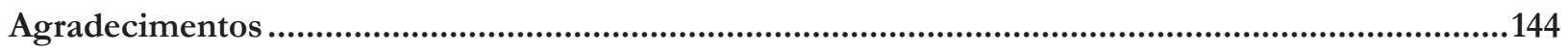

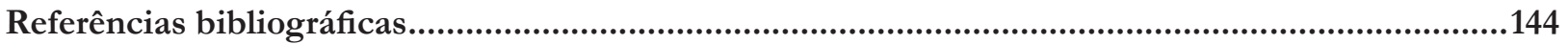

A política de assistênCia social e a promoção ao trabalho: uma ANÁlise do PRONATEC BSM COM BASE EM UM ESTUdO COM EGRESSOS EM FORTALEZA-CE .......................... 147 Aline de Araújo Araújo Martins e Mônica Duarte Cavaignac

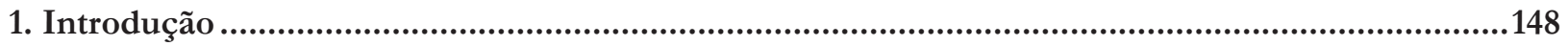

2. Questão social, assistência social e a ênfase na erradicação da pobreza no Brasil contemporâneo .... 150

4. O PRONATEC BSM no município de Fortaleza: percepções de profissionais e egressos do progra-

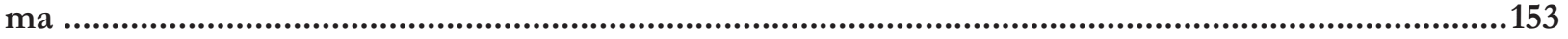

5. Considerações finais .......................................................................................................................160

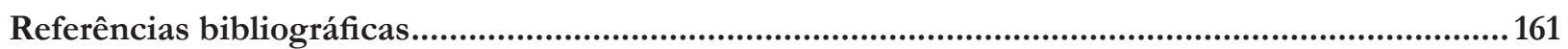


INTERVENÇÃo ESTATAL NA AGRICULTURA: A POSSIBILIDADE DE UMA AÇÃo ÉTICA A FIM DE MATE-

RIALIZAR A CONSTITUIÇÃO BRASILEIRA.................................................................. 164

Davi Augusto Santana de Lelis e Giovani Clark

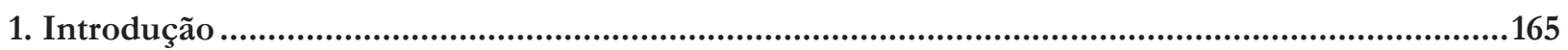

2. Panorama do setor agrícola brasileiro nos anos 1990 .................................................................166

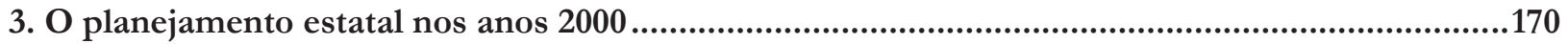

4. A teoria e a prática: a obediência a constituição nas políticas públicas agrícolas é possível? ......177

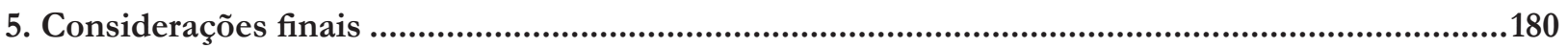

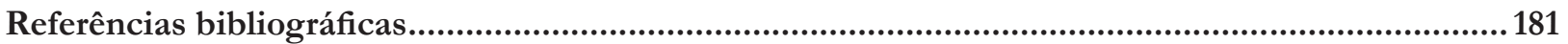

Agricultura orgânica: SoluÇão para o SÉCUlo XXI? ................................................ 185

Eloir Trindade Vasques Vieira, Denilson de Oliveira Guilherme, Luis Carlos Vinhas Itavo e Lucelia da Costa Nogueira Tashima

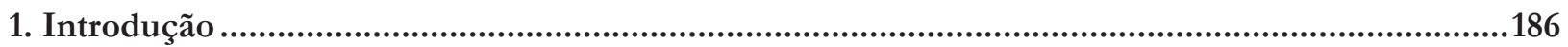

2. Agricultura familiar....................................................................................................................187

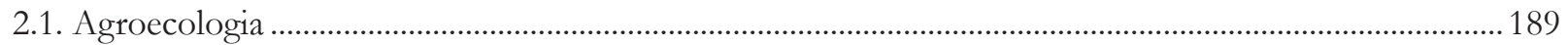

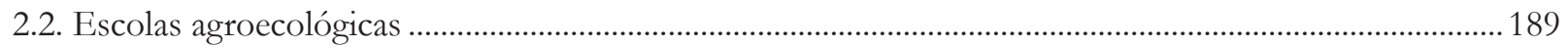

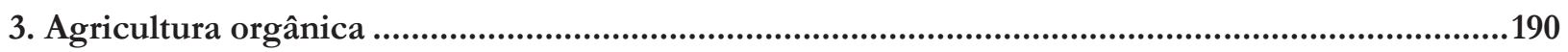

3.1. Produtividade dos produtos agrícolas ........................................................................................................ 191

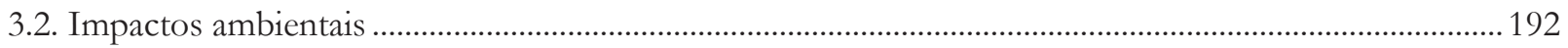

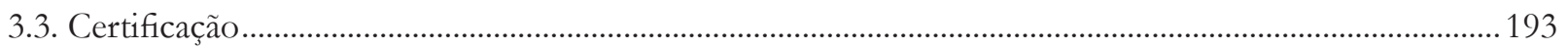

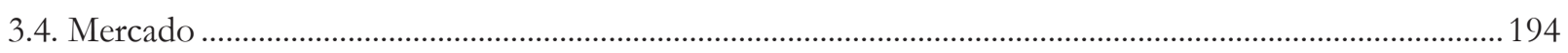

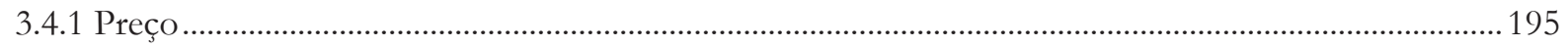

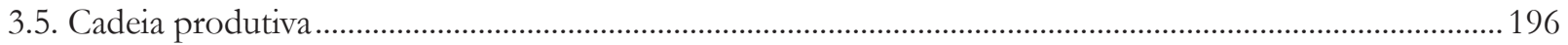

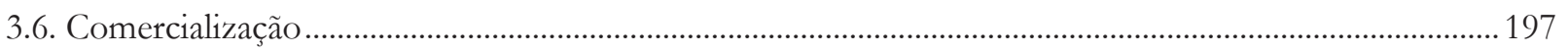

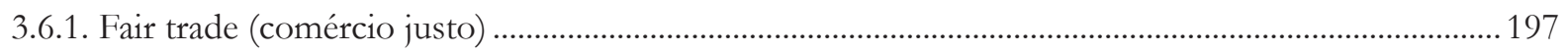

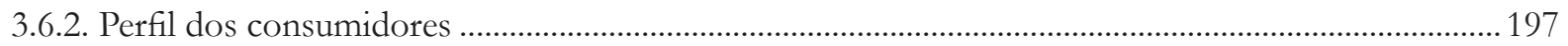

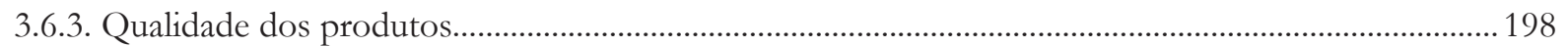

4. Considerações finais .....................................................................................................................199

Referências bibliográficas..................................................................................................................199 
Pablo Leurquin e Mariana Magalhães Avelar

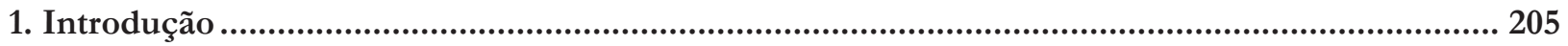

2. Relevância da aviação regional na universalização do serviço .................................................. 205

3. A contração da aviação regional brasileira e a necessidade da intervenção estatal...................... 209

4. O programa nacional de aviação regional: entre a urgência e a ficção .........................................212

5. Considerações finais ........................................................................................................................217

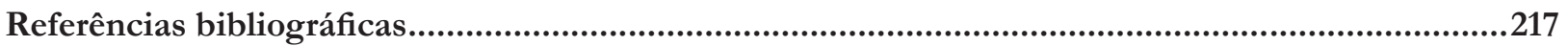

HoMESCHOOLING NO BRASIL: CONFORMAÇÃo DEÔNTICO-AXIOLÓGICA DO SISTEMA JURÍDICO COMO PLUS À POLÍTICA PÚBLICA DE EDUCAÇÃO FUNDAMENTAL .......................................222

Cláudio Márcio Bernardes, Carlos Alberto Simões Tomaz

1. Introdução 222

2. O ensino doméstico: um fenômeno social que vem crescendo no Brasil e no mundo 223

3. A teoria do status de Jellinek no âmbito do direito-dever à educação fundamental. 224

4. O ensino escolarizado garantido e imposto pela forte presença estatal na Constituição da República de 1988 225

5. A liberdade individual de os próprios pais promoverem o ensino dos seus filhos no âmbito doméstico - Homeschooling ..... 229

6. Análise deôntico-axiológica da (im)possibilidade do ensino domiciliar no Brasil.. 231

7. Considerações finais 234

Referências bibliográficas 235

BARREIRAS À CIDADANIA NAS POLÍTICAS SOCIAIS PARA A POPUlAÇÃo EM SITUAÇão DE RUA. 237 Luciano Roberto Gulart Cabral Júnior e José Ricardo Caetano Costa

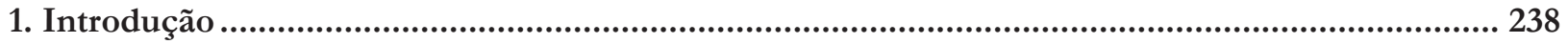

2. População em situação de rua: delimitação ........................................................................ 238

3. Políticas sociais para a população em situação de rua................................................................... 240

4. Cidadania e população em situação de rua ........................................................................................ 244

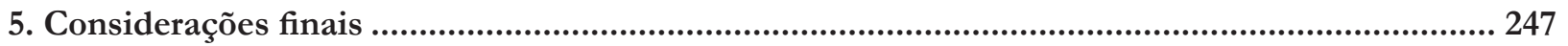

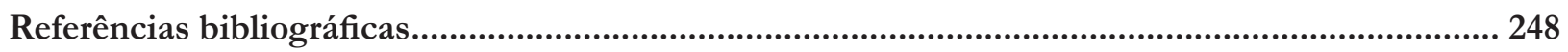


O CORTE DO FORNECIMENTO DE ÁGUA EM FACE DO INADIMPLEMENTO DO CONSUMIDOR: ANÁLISE

À LUZ DO DIÁLOGO DAS FONTES ............................................................................. 251

Leonardo Roscoe Bessa e Gabriela Gomes Acioli César

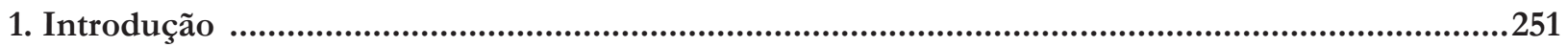

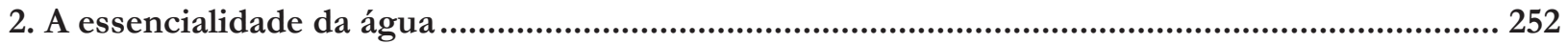

3. $\mathrm{O}$ fornecimento de água como dever do Estado ........................................................................... 253

4. Código de Defesa do Consumidor e a proteção conferida a serviços públicos essenciais........... 255

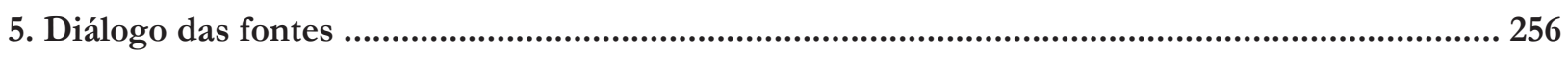

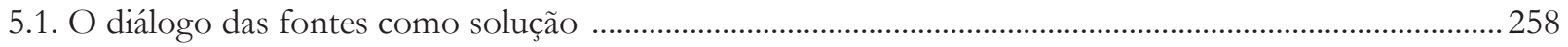

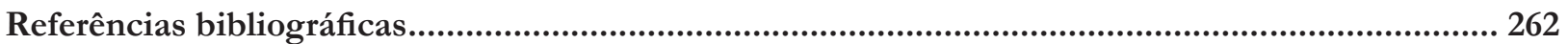

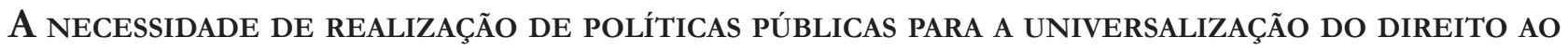

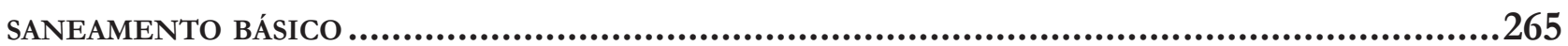

Ruth Santos e Renata Menezes

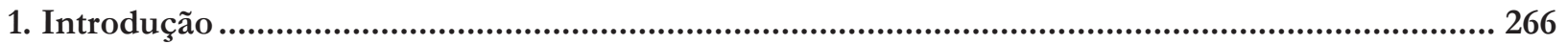

2. A efetivação do direito humano ao saneamento básico .......................................................... 267

3. A aplicação do direito ao saneamento a partir do princípio do mínimo existencial ecológico ... 270

4 Efetivação do direito humano ao saneamento básico: o exemplo colombiano de políticas públicas ... 272

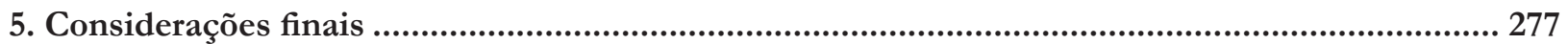

Referências bibliográficas................................................................................................................ 277

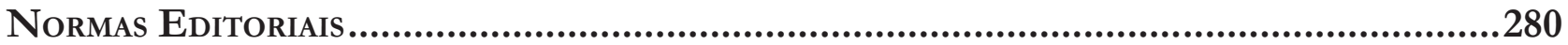

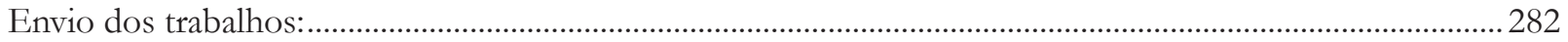




\section{REVISTA BRASILEIRA DE POLÍTICAS PÚBLICAS BRAZILIAN JOURNAL OF PUBLIC POLICY}
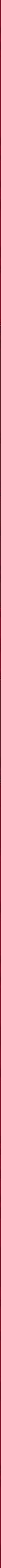


\title{
Uma perspectiva comparada acerca da (não) efetividade da democracia local no Brasil e em Portugal*
}

\author{
A comparative perspective on the (non) \\ effectiveness of local democracy in Brazil \\ and Portugal
}

Matheus Passos Silva**

\section{Resumo}

O objetivo do texto é fazer uma análise comparativa entre a legislação portuguesa e a brasileira que se refere ao exercício de poderes políticos, por parte dos cidadãos, em âmbito local. A perspectiva adotada é a de que a participação política dos cidadãos deve ser ampliada para além do momento eleitoral por meio da chamada cidadania ativa. Na primeira parte, apresenta-se uma definição teórica do conceito de democracia, com ênfase à definição do termo feita por Norberto Bobbio. Na segunda parte, são mostradas as principais falhas da democracia representativa em seu modelo atual. Por fim, na terceira parte, é feita uma análise da legislação portuguesa e brasileira em que se conclui que, em ambos os casos, a despeito da existência de previsão legal para a atuação política do cidadão, esta não ocorre. Para solucionar esse problema, sugere-se a redefinição jurídica do conceito de cidadania em direção à chamada cidadania ativa, que atribui ao cidadão não apenas o direito de participar mas também o dever de fazê-lo. O artigo se fundamenta em uma metodologia eminentemente bibliográfica, com a apresentação de conceitos teóricos sobre os temas analisados, bem como de estatísticas que comprovam que o modelo atual, fundado exclusivamente na participação eleitoral, gera distanciamento do cidadão em relação à res publica. O tema é relevante especialmente quando se considera o contexto atual da representação política, em que novas formas de participação cidadã se apresentam como necessárias dado o verdadeiro desencantamento com a política existente em grande parte das sociedades ocidentais.

Palavras-chave: democracia; representação; cidadania; dever fundamental; Brasil; Portugal.

* Recebido em 02/09/2016 Aprovado em 24/09/2016

** Doutorando em Direito Constitucional pela Faculdade de Direito da Universidade de Lisboa (Portugal). Mestre em Ciência Política pela Universidade de Brasília (Brasil). Bolsista CAPES - Proc. nº 1791/15-0. Investigador não doutorado do CEDIS da Faculdade de Direito da Universidade Nova de Lisboa. Professor no Centro Universitário UniProjeção. E-mail: contato@profmatheus.com

\section{Abstract}

The objective of this article is to make a comparative analysis between Portuguese and Brazilian legislation concerning the exercise of political power by citizens at the local level. The adopted perspective is that citizens' political participation should be expanded beyond the election time by the so-called active citizenship. The first part presents a theoretical definition of 
the concept of democracy, emphasizing the definition of this concept by Italian jurist Norberto Bobbio. In the second part it is shown the main failures of representative democracy in its current model. Finally, the third part consists of an analysis of the Portuguese and Brazilian law which concluded that in both cases, despite the existence of legal provision for the political activity of citizens, the same does not occur. To solve this problem, it is suggested the legal redefinition of the concept of citizenship towards to what is called active citizenship, which gives the citizen not only the right to participate but also the duty to do so. The article is based on an eminently literature methodology, with the presentation of theoretical concepts on the topics analyzed, as well as statistics which show that the current model, essentially based exclusively on the electoral representation, generates detachment of the citizen from the res publica. The theme is particularly relevant when considering the current context of political representation, in which new forms of citizen participation are presented as necessary given the real disenchantment with the existing politics in most Western societies.

Keywords: democracy; representation; citizenship; fundamental duty; Brazil; Portugal.

\section{INTRODUÇÃo}

Uma das definições clássicas e mais difundidas da ideia de democracia é a que se encontra presente na famosa frase do presidente dos Estados Unidos, Abraham Lincoln, que afirmou que a democracia corresponde ao "governo do povo, pelo povo e para o povo". Seguindo um pensamento que então se desenvolvia na Europa, o presidente americano acreditava que não bastava haver representação política do cidadão, mas sim que competia a este tomar parte na condução do governo para que, em última instância, se concretizasse a liberdade individual.

Nessa perspectiva o conceito de democracia acabou por reformular o próprio conceito de representação política que já então existia (fala-se neste artigo sobre fins do século XIX), de maneira que os eleitos passaram não apenas a representar os cidadãos — em uma espécie de contrato social - mas também a efetivamente permitir que os cidadãos tomassem decisões na esfera política, especialmente quando se considera a expansão do sufrágio ocorrida com base no início do século XX e concretizada, em maior ou menor grau, ao final da Segunda Guerra Mundial.

Contudo, apesar da contínua ampliação do direito ao sufrágio - o que permite o entendimento de que cada vez mais e mais cidadãos passaram a ter a possibilidade de intervir nos rumos do Estado -, o que se percebe, na atualidade, é que ocorre um verdadeiro descontentamento do cidadão com a política de maneira geral. Em maior ou menor grau, os cidadãos têm vindo a rechaçar "a política", ou a "classe política", como sendo algo que, a cada dia, parece deixar de ser um "mal necessário" para se transformar em verdadeiro incômodo na vida cotidiana.

Uma das maneiras encontradas pela doutrina jurídico-política para a solução desse problema foi a defesa da ideia de que a prioridade, no que diz respeito ao exercício do poder político pelo cidadão, deveria ser dada à administração local. Por outras palavras, muitos são os autores que defendem que uma maior - e verdadeira - democratização da sociedade passa pela ampliação das possibilidades garantidas aos cidadãos para que interfiram nas esferas de poder que administram aquilo que está mais próximo do cotidiano desses cidadãos, fazendo com que estes possam intervir, de maneira mais incisiva, naquilo que diz respeito à coletividade.

Contudo, a despeito de iniciativas jurídicas existentes em Portugal e no Brasil que caminham nesta direção, o que se vê é que tais iniciativas parecem não contribuir para o verdadeiro exercício da cidadania. O que aqui se argumenta é que existem aberturas jurídicas à participação do cidadão, mas tais aberturas não são suficientes para que o cidadão perceba a importância do seu envolvimento com aquilo que diz respeito à sua comunidade.

Dessa forma, parece ser clara e premente a necessidade de se ressignificar a ideia de cidadania, transformando-a em verdadeira cidadania ativa, de maneira a fazer com que o cidadão não apenas tenha a oportunida- 
de efetiva de participar do processo de tomada de decisão - nomeadamente no âmbito das políticas públicas - mas também de maneira a fazer com que o cidadão seja responsável pelas consequências de seus atos, cumprindo verdadeiro dever fundamental de participação política que vai além da esfera eleitoral.

É esta, em síntese, a proposta deste texto. Para tanto, na primeira parte, apresenta-se uma conceitualização teórica da ideia de democracia, tendo-se por base o pensamento político-jurídico do jurista italiano Norberto Bobbio. Em seguida faz-se um apanhado dos principais problemas que, na atualidade, levam à falta de participação política do cidadão - e, em consequência, geram deficit de representação política, a qual estimula, ainda mais, a falta de participação política, em verdadeiro círculo vicioso. Por fim são analisadas as legislações portuguesa e brasileira, de maneira comparativa, com o objetivo de mostrar que ainda não há, nesses dois países, a necessária abertura à efetiva participação política dos cidadãos, de maneira que estes sejam efetivamente responsáveis não apenas pelo sucesso, mas também pelo eventual fracasso das decisões administrativas que dizem respeito à coletividade.

\section{O MODELO DE DEMOCRACIA OCIDENTAL NO SÉCULO XXI}

Quando se fala em democracia, na atualidade, talvez a primeira ideia que venha à mente do cidadão seja a de eleições. A associação entre o conceito de democracia e a prática eleitoral é automática, especialmente, em países, tais como o Brasil e Portugal, que implantaram regimes político-jurídico democráticos por meio de uma ruptura com o passado autoritário: se antes, no período ditatorial, não havia eleições — ou se quando existiam eram reconhecidamente manipuladas -, estas passaram a ser um dos símbolos mais visíveis, para o cidadão, do novo regime democrático.

Contudo, a ideia de democracia vai muito além da simples realização de eleições periódicas para a escolha de governantes. É plenamente possível afirmar que a democracia está diretamente relacionada não apenas a regras constitucionais mas também a princípios e, mais ainda, que a democracia é verdadeiro valor jurídico da atualidade ${ }^{1}$.

O processo de surgimento desse valor, contudo, é relativamente tortuoso. É, apenas, a partir das revoluções liberais de fins do século XVIII e início do século XIX que surgem as ideias de limitação do poder do Estado, por um lado, e de representação de parcelas da população, por outro. É de se destacar, entretanto, que, nesse período, o que existia era muito mais uma teoria da representação do que uma Teoria Democrática. Em outras palavras, desenvolveram-se teorias que justificavam a representação dos estratos mais elevados da sociedade sem que houvesse verdadeira democratização da sociedade como um todo²: legitimavam-se os governantes por meio do consentimento dos governados sem que estes, necessariamente, tivessem participação efetiva nos comandos do Estado. Mais ainda, pode-se entender o governo representativo como um sistema político-jurídico no qual o cidadão se via incapaz (ou impedido) de exercer o poder político - em outras palavras, de ser o efetivo titular do poder político, restando, portanto, ao representante, ou poder-se-ia dizer, ao delegado do poder político pelo cidadão, a função governativa ${ }^{3}$.

É apenas a partir da Primeira Guerra Mundial que se torna possível falar a respeito de regimes democráticos e não apenas representativos. Nesse sentido, a expansão do direito de sufrágio para o exercício da capacidade

1 É importante destacar que a democracia, mais do que relacionada à ideia de voto, está relacionada à ideia de que o cidadão deixou de ser objeto do poder político do Estado para ser seu sujeito. Em outras palavras, o estabelecimento de um regime democrático objetiva "converter os súbditos em cidadãos completos" de maneira a "elevar os homens na Cidade de simples sujeitos ao poder a verdadeiros sujeitos do poder". MIRANDA, Jorge. Manual de direito constitucional. Tomo III. Estrutura constitucional do Estado. Coimbra: Coimbra, 2014, p. 366.

2 Talvez a única exceção à teoria político-jurídica da democracia à época seja Rousseau que, com seu Contrato Social, buscou fazer com que todos os homens pudessem participar politicamente.

3 MIRANDA, Jorge. Manual de direito constitucional. Tomo VII. Estrutura constitucional da democracia. Coimbra: Coimbra, 2007, p. $15-17$. 
eleitoral ativa devido ao fim de critérios censitários - e, mais ainda, para o exercício da capacidade eleitoral passiva -, e, ainda, à expansão da garantia de liberdades individuais - especialmente aquelas relacionadas à liberdade de expressão - são alguns dos elementos que permitiram a expansão e a consolidação de um modelo democrático constitucional que se mantém até os dias atuais. Além disso, deve-se chamar a atenção a uma mudança fundamental em relação aos governos representativos do século XIX - qual seja, o fato de que os regimes político-jurídicos do século XX só se tornaram efetivamente democráticos quando os cidadãos passam a ser titulares do poder político, de maneira a fazer com que sua vontade pudesse ser “jurídica e politicamente eficaz"4 no que diz respeito à definição dos rumos do Estado.

Contudo, o conceito de democracia pode vir a ser manipulado, no sentido de ser utilizado para designar como democráticos regimes político-jurídicos que não o são. O conceito, que traz embutido em si valores caros à chamada "sociedade ocidental", é, atualmente, tão banalizado que até mesmo Estados com regimes político-jurídicos claramente ditatoriais se utilizam da palavra para se autodefinirem; da mesma forma, tais regimes se utilizam de mecanismos claramente vinculados à democracia para tentarem demonstrar seu "caráter democrático" Nesse sentido, torna-se relevante a definição conceitual de democracia de maneira a ter-se claro o que o conceito significa para que o mesmo possa ser analisado, mais à frente, em sua aplicação concreta na realidade.

O jurista italiano Norberto Bobbio afirma que "por Democracia se foi entendendo um método ou um conjunto de regras de procedimento para a constituição de Governo e para a formação das decisões políticas (ou seja, das decisões que abrangem a toda a comunidade)" ${ }^{\text {. }}$. Dessa maneira, para que determinado regime venha a ser considerado como democrático torna-se necessária a presença desse conjunto de regras de procedimento 7 em seu ordenamento jurídico, as quais são sintetizadas pelo referido autor da seguinte maneira:

1. o poder Legislativo deve ser composto por membros eleitos direta ou indiretamente pelo povo;

2. junto ao poder Legislativo deve haver outras instituições com dirigentes eleitos, tais como órgãos da administração local ou o chefe de Estado;

3. todos os cidadãos que tenham atingido a maioridade, sem distinção de raça, de religião, de censo e de sexo, devem ser eleitores;

4. todos os eleitores devem ter voto igual;

5. todos os eleitores devem ser livres em votar segundo a própria opinião formada o mais livremente possível - em outras palavras, é necessário haver liberdade de expressão, tanto do ponto de vista do eleitor quanto do ponto de vista do candidato;

6. todos os eleitores devem ser livres também no sentido em que devem ser postos em condição de ter reais alternativas - ou seja, devem existir no mínimo dois partidos políticos para que o cidadão tenha liberdade de escolha;

7. tanto para as eleições dos representantes como para as decisões do poder Legislativo vale o princípio da maioria numérica, podendo ser estabelecidas várias formas de maioria;

8. nenhuma decisão tomada pela maioria deve limitar os direitos da minoria, de um modo especial o direito de tornar-se maioria, em paridade de condições;

\footnotetext{
4 MIRANDA, Jorge. Manual de direito constitucional. Tomo VII. Estrutura constitucional da democracia. Coimbra: Coimbra, 2007 , p. 17. 5 Basta, a este respeito, visualizar o Brasil durante o regime ditatorial militar, quando o Congresso Nacional esteve em funcionamento, bem como dois partidos políticos e, ainda, com a realização de eleições periódicas - fatos utilizados pelo regime político de então para se autointitular como democrático, o que, logicamente, não o era.

6 BOBBIO, Norberto. Verbete "democracia”. In: BOBBIO, Norberto; MATTEUCCI, Nicola; PASQUINO, Gianfranco. Dicionário de política. Trad. Carmen C. Varriale et al.; coord. trad. João Ferreira; rev. geral João Ferreira e Luís Guerreiro Pinto Cacais. 11 ed. Brasília: UnB, 1998, p. 326.

7 É necessário destacar que as regras a seguir apresentadas são vinculadas diretamente ao critério eleitoral, ou seja, estão vinculadas à cidadania em sentido restrito, não em sentido amplo. Sobre esta distinção entre cidadania em sentido amplo e sentido restrito ver GOMES, José Jairo. Direito eleitoral. 11 ed. rev. atual. e ampl. São Paulo: Atlas, 2015.
} 
9. O órgão do Governo deve gozar de confiança do Parlamento ou do chefe do poder executivo, por sua vez, eleito pelo povo ${ }^{8}$.

É importante destacar, entretanto, que a simples presença de tais regras no ordenamento jurídico de determinado Estado não o transforma automaticamente em um regime democrático. A esse respeito, não é possível nem mesmo afirmar quantas regras são necessárias para que um Estado seja considerado como democrático; a única certeza que se tem é que um Estado que não possua em seu regime jurídico nenhuma destas regras certamente não é uma democracia. Assim, o que se pode afirmar é que uma vez que esteja presente ao menos uma das regras acima elencadas, os Estados classificar-se-ão como mais ou menos democráticos, uns em comparação a outros ${ }^{9}$.

A análise da democracia, entretanto, se torna incompleta quando o conceito é analisado apenas do ponto de vista formal, ou seja, quando analisado apenas com base na presença ou ausência destas regras no ordenamento jurídico de determinado Estado. A título de exemplo, veja-se o caso brasileiro quando se compara o regime ditatorial anterior à Constituição de 1988 ao regime pós-Constituição de 1988. Comparando-se os dois momentos e tendo-se em vista apenas as regras acima apresentadas, é possível afirmar que as regras indicadas nos números 5 e 8 não estavam presentes durante o regime militar, enquanto é possível afirmar que, no período pós-Constituição, todas as regras estão presentes no ordenamento jurídico brasileiro. Nessa interpretação seria forçoso admitir que o regime pré-1988 era menos democrático do que o atual, ainda que não necessariamente uma ditadura completa.

Torna-se necessário, portanto, complementar a conceitualização acima apresentada com o entendimento de que a democracia não pode ser vista apenas sob o ponto de vista da presença ou ausência de regras jurídicas, mas também no sentido de ser um princípio estruturante do Estado moderno - especificamente do Estado pós-Segunda Guerra Mundial. Nesse contexto a democracia se afigura como elemento de destaque na proteção da própria dignidade bumana10, já que o respeito a tal princípio se encontra na base de qualquer regime político-jurídico que se pretenda como democrático ${ }^{11}$ - ou seja, a democracia passou a ser vista não apenas do ponto de vista jurídico, mas também axiológico, como verdadeiro direito humano ${ }^{12}$.

Da mesma maneira, nunca é demais ressaltar que um regime político-jurídico, efetivamente democrático, pressupõe, conforme dito anteriormente, que a titularidade do poder político seja dos cidadãos. É necessário que a estes sejam dadas todas as condições para o real exercício do poder político de maneira que possam formar uma vontade política autônoma frente aos governantes - ou seja, "a vontade do povo, quando manifestada nas formas constitucionais, deve ser o critério de acção dos governantes” ${ }^{13}$. Da mesma maneira, espera-se que em um regime político-jurídico democrático os cidadãos sejam titulares não apenas do poder

8 BOBBIO, Norberto. Verbete “democracia”. In: BOBBIO, Norberto; MATTEUCCI, Nicola; PASQUINO, Gianfranco. Dicionário de política. Trad. Carmen C. Varriale et al.; coord. trad. João Ferreira; rev. geral João Ferreira e Luís Guerreiro Pinto Cacais. 11 ed. Brasília: UnB, 1998, p. 327.

9 BOBBIO, Norberto. Verbete "democracia”. In: BOBBIO, Norberto; MATTEUCCI, Nicola; PASQUINO, Gianfranco. Dicionário de política. Trad. Carmen C. Varriale et al.; coord. trad. João Ferreira; rev. geral João Ferreira e Luís Guerreiro Pinto Cacais. 11 ed. Brasília: UnB, 1998, p. 327.

10 "Dignidade da pessoa humana é a qualidade intrínseca e distintiva reconhecida em cada ser humano que o faz merecedor do mesmo respeito e consideração por parte do Estado e da comunidade, implicando, neste sentido, um complexo de direitos e deveres fundamentais que assegurem a pessoa tanto contra todo e qualquer ato de cunho degradante e desumano, como venham a lhe garantir as condições existenciais mínimas para uma vida saudável, além de propiciar e promover sua participação ativa e corresponsável nos destinos da própria existência e da vida em comunhão com os demais seres bumanos" MENDES, Gilmar Ferreira; STRECK, Lenio Luiz; SARLET, Ingo Wolfgang; LEONCY, Léo Ferreira; CANOTILHO, J. J. Gomes. Comentários à Constituição do Brasil. Série IDP. São Paulo: Saraiva/Almedina, 2013, p. 444, grifo nosso. Recurso digital.

11 GOMES, José Jairo. Direito eleitoral. 11 ed. rev. atual. e ampl. São Paulo: Atlas, 2015, p. 39.

12 Destacam-se neste contexto de democracia como direito humano o artigo XXI da Declaração Universal dos Direitos Humanos e o artigo 25 do Pacto Internacional de Direitos Civis e Políticos.

13 MIRANDA, Jorge. Manual de direito constitucional. Tomo VII. Estrutura constitucional da democracia. Coimbra: Coimbra, 2007, p. 60 . 
constituinte mas também do poder constituído, o que corresponde à possibilidade dos cidadãos terem "meios actuais e efectivos de determinar ou influir nas directrizes políticas dos órgãos das várias funções estatais (legislativa, administrativa etc.)"14.

É importante chamar a atenção, contudo, ao fato de que a titularidade do poder político pelo cidadão não lhe dá o direito de agir conforme bem entender, ou seja, não se pode imaginar que o poder político dos cidadãos seja absoluto. Convém, sempre, ter em mente que um regime democrático precisa respeitar não apenas a vontade da maioria, mas também a vontade da minoria (vide regra 8 acima). Em outras palavras, um sistema democrático é aquele que respeita - e concretiza - a vontade da maioria mas não de maneira absoluta, negando e/ou retirando direitos das minorias; caso assim agisse, um regime democrático seria tão absolutista quanto um regime ditatorial. Também o poder político do qual os cidadãos são titulares é limitado, não sendo possível pressupor, portanto, que a vontade da maioria deva ser concretizada a todo e qualquer custo: sendo a democracia um direito humano, a vontade da maioria está limitada pela própria preservação da dignidade humana como uma espécie de ultima ratio protetiva dos direitos fundamentais de todos - e não apenas da maioria.

\section{A falta de REPRESENTATIVIDADE NA DEMOCRACiA CONTEMPORÂNEA}

Não há dúvida alguma de que Portugal e Brasil, ao menos do ponto de vista constitucional, são regimes político-jurídicos democráticos. Até mesmo por serem documentos jurídicos implantados em um momento de ruptura com os regimes ditatoriais prévios, as Constituições desses países concretizam aquilo que doutrinariamente se espera de um Estado democrático de direito.

Há, nas Constituições desses países, um elemento fundamental para que uma democracia seja concretizada: é a participação política do cidadão. Em outras palavras, a democracia, entendida como valor jurídico fundante dos sistemas constitucionais atuais ${ }^{15}$, pressupõe não apenas regras e princípios constitucionalmente estabelecidos mas também a atuação do cidadão nesse arcabouço jurídico que é propiciado pelo Estado, já que não tem sentido a existência de um regime político-jurídico que propicie a participação do cidadão se esta não ocorrer.

Vale destacar que a participação política não é entendida no sentido do cidadão votar de dois em dois anos, como ocorre no caso brasileiro: acreditar que participar politicamente significa apenas o ato de votar corresponde a uma redução não apenas da própria ideia de participação política mas, também, da própria ideia de cidadania, já que passa-se a entender a mesma como mero ato eleitoral desconsiderando-se todos os demais aspectos sociais, da vida em coletividade, que interferem não apenas no próprio ato eleitoral como ainda, em última instância, na própria cidadania.

O que se quer colocar com tal pensamento é que o ideal de cidadania pressupõe não apenas o ato do cidadão se dirigir à cabine de votação para exprimir suas opiniões políticas por meio do voto. Logicamente, o ato de votar talvez possa ser entendido como o principal mecanismo democrático dos Estados contemporâneos, mas não deve ser entendido como o único mecanismo, como parece ser na realidade. Nunca é demais destacar que a cidadania ateniense pressupunha também a unidade da própria sociedade, ou seja, se fundamentava no reconhecimento de um sentimento de pertencimento comum a uma coletividade ${ }^{16}$ que garantia a responsabilidade daqueles que, em dado momento, exerciam as funções públicas, especialmente devido à possibilidade de rotatividade no exercício de tais funções.

14 MIRANDA, Jorge. Manual de direito constitucional. Tomo III. Estrutura constitucional do Estado. Coimbra: Coimbra, 2014, p. 176, grifo nosso.

15 Ou ao menos nos sistemas constitucionais ocidentais, que é o modelo aplicado pelos Estados aqui analisados.

16 FIORAVANTI, Maurizio. Constitución: de la Antigüedad a nuestros días. Trad. Manuel Martínez Neira. Madrid: Editorial Trotta, 2001, p. 17-9. 
Quando se olha para a situação real da atual participação política, talvez seja razoável afirmar que seja impossível, por razões técnicas e materiais, o envolvimento direto do cidadão na esfera político-pública como ocorria na Atenas antiga, especialmente no sentido de todos os cidadãos virem a tomar decisões que dessem origem à lei em âmbito nacional ${ }^{17}$. Tal eventual impossibilidade, contudo, não retira - ou não deveria retirar - do cidadão sua responsabilidade em relação à coletividade, já que o espaço público, entendido como espaço de todos, pressupõe não apenas o interesse de todos em relação a tal espaço público como também sua atuação em prol do mesmo devido ao pertencimento comum de todos àquela coletividade. Além disso, é importante destacar que o ideal democrático pressupõe cidadãos atentos à coisa pública para que, conscientes daquilo que se passa em sua comunidade, possam estar bem embasados no momento de tomar decisões vinculadas àquilo que é coletivo ${ }^{18}$.

Como definir o conceito de participação política? A expressão, nos dias atuais, pode ser entendida em ao menos três sentidos distintos. O primeiro deles vem a ser o sentido da presença: o cidadão é apenas passivo em relação aos fatos políticos de sua vida cotidiana ao estar presente em reuniões ou ser voluntariamente receptivo a mensagens políticas sem, contudo, realizar qualquer contribuição pessoal. O segundo sentido, chamado de ativação, pressupõe o cidadão realizando em alguns momentos alguma atividade política que lhe tenha sido designada por delegação, seja dentro ou fora de uma instituição eminentemente política, sendo exemplos da participação política no sentido da ativação o envolvimento em campanhas eleitorais ou em manifestações públicas de protesto. Por fim, o terceiro sentido da participação política se vincula à participação efetiva em sentido estrito, ou seja, ocorre naquelas situações em que o cidadão contribui direta ou indiretamente para uma decisão política ${ }^{19}$.

Quando se olha para as democracias ocidentais de maneira geral - e para os Estados em análise neste texto de maneira específica - percebe-se que a participação política se resume, na maioria das vezes, no máximo à etapa da ativação: poucos são os cidadãos que realmente participam no sentido de tomar decisões na esfera política, sendo inclusive razoável afirmar que a maioria dos cidadãos participa quando muito na forma da presença20. Verifica-se verdadeira apatia política a partir do momento em que para muitos cidadãos "tanto faz" quem será o candidato que virá a ser eleito, ou, ainda, quando se comprova que, em uma eleição, o cidadão vota no Partido A enquanto na eleição subsequente vota no Partido C e, por fim, na terceira eleição alterna, novamente, seu voto ao escolher o Partido B - é a chamada volatilidade eleitoral21. Além disso, em inúmeras pesquisas, comprova-se o fato de que os partidos políticos — que são as instituições representativas por

17 MIRANDA, Jorge. Manual de direito constitucional. Tomo III. Estrutura constitucional do Estado. Coimbra: Coimbra, 2014, p. 378. Canotilho, por sua vez, fala a respeito da democracia eletrônica, entendendo-se por tal termo não apenas o aspecto técnico - permitir votações e referendos por meios eletrônicos -, mas também, e talvez principalmente, a possibilidade de realização de debates deliberativos por outras formas - tais como videoconferências e debates televisivos - que não por meios tradicionais - no caso, o Parlamento. A esse respeito ver CANOTILHO, Joaquim José Gomes. Direito constitucional e teoria da Constituição. 7 ed., 16 reimp. Coimbra: Almedina, 2014, p. 1418-9.

18 Chama-se a atenção, no caso brasileiro, para a prerrogativa que o cidadão tem de questionar os atos da Administração Pública, conforme previsto no $\int 3^{\circ}$ (e incisos) do art. 37 da Constituição. Destaca-se que o cidadão pode fazer reclamações acerca da prestação dos serviços públicos, pode ter acesso aos registros administrativos e aos atos do governo e ainda fazer representações contra o exercício negligente ou abusivo do cargo, emprego ou função na administração pública. Contudo, infelizmente apenas o inciso II deste $\int 3^{\circ}$ (que trata do acesso à informação) foi regulamentado pela lei ordinária, de maneira que apenas esta prerrogativa está efetivamente disponível ao cidadão.

19 SANI, Giacomo. Verbete "participação política”. In: BOBBIO, Norberto; MATTEUCCI, Nicola; PASQUINO, Gianfranco. Dicionário de política. Trad. Carmen C. Varriale et al.; coord. trad. João Ferreira; rev. geral João Ferreira e Luís Guerreiro Pinto Cacais. 11 ed. Brasília: UnB, 1998, p. 888-9.

20 No mesmo sentido: "não basta a prescrição em leis estampando que a participação está garantida, mas é preciso um esforço para que tal participação tenha garantias efetivas em influenciar na agenda de um país e tenha qualidade para que seja reconhecida e praticada pela coletividade". SANTOS, Braulio de Magalhães; MAGALHÃES, José Luiz Quadros de. Notas para um debate principiológico sobre participação à luz de uma teoria democrática. Revista Brasileira de Políticas Públicas, Brasília, v. 1, n. 2, p. 1-30, jul./dez. 2011, pág. 12.

21 Mair traz dados que mostram que a volatilidade eleitoral na Europa ocidental é elevada, especialmente a partir da década de 1990. Ver MAIR, Peter. Ruling the void: the hollowing of Western democracy. Edição Kindle. Londres, Nova York: Verso, 2013 , p. $571-3$. 
excelência no sistema político-jurídico da atualidade ${ }^{22}$ - são pouco confiáveis e, portanto, pouco representativos da vontade do cidadão ${ }^{23}$.

A esse respeito é importante destacar um ponto que pode ser visto como falta de confiança do cidadão no sistema político-jurídico representativo como um todo, qual seja, o do crescente número de abstenções nas eleições. Pesquisas realizadas em países ocidentais revelam que o número de cidadãos que efetivamente votam nas eleições têm se reduzido, de maneira acentuada, a partir da década de 1990. Em tal década, os níveis mais baixos de participação em Portugal foram registrados em 1999, em 2002 e em 2005²4. Nas eleições subsequentes para a Assembleia da República Portuguesa, o número de abstenções continuou a aumentar: em 2009 houve 40,32\% de abstenções, com 1,74\% de votos em branco e 1,35\% de votos nulos ${ }^{25}$. Na eleição subsequente, em 2011, tais números aumentaram para 41,97\% de abstenções, para 2,66\% de votos em branco e para $1,42 \%$ de votos nulos ${ }^{26}$.

No caso brasileiro, a situação não é diferente. Apesar de o voto ser obrigatório, a eleição geral de 2014 teve, em seu primeiro turno, o nível mais alto de abstenção desde as eleições de 1998, com 19,4\% do eleitorado não comparecendo às urnas ${ }^{27}$. Os votos em branco e votos nulos - que, conforme a legislação eleitoral são chamados de votos inválidos, não servindo para qualquer cálculo eleitoral - corresponderam a 9,6\% daqueles que compareceram às urnas. Em síntese, tem-se que 27,1\% dos cidadãos aptos a votar se abstiveram de fazê-lo ou, se o fizeram, votaram em branco ou nulo ${ }^{28}$, o que, sem dúvida, é uma mostra do desinteresse do cidadão com o ato de $\operatorname{votar}^{29}$ - e isto, ressalte-se mais uma vez, em um regime político-jurídico em que o voto é obrigatório ${ }^{30}$.

22 No caso brasileiro, a representação partidária é explícita a partir da leitura do inciso V do parágrafo $3^{\circ}$ do artigo 14 da Constituição, já que tal dispositivo traz a exigência de filiação partidária para que um cidadão possa vir a ser eleito - isto sem falar de outros comandos constitucionais, como o próprio parágrafo único do artigo $1^{\circ}$, que fala de representantes eleitos, bem como da legislação infraconstitucional, sendo destacados o artigo 87 da Lei no 4.737/65, que traz que "somente podem concorrer às eleições candidatos registrados por partidos", ou ainda o artigo $9^{\circ}$ da Lei n ${ }^{\circ} 9.504 / 97$, quando se lê que "para concorrer às eleições, o candidato deverá [...] estar com a filiação deferida pelo partido no mínimo seis meses antes da data da eleição". O mesmo ocorre em Portugal, já que "os partidos são as únicas entidades que podem apresentar candidatos à Assembleia da República", conforme BELCHIOR, Ana Maria. Confiança nas instituições politicas. Lisboa: Fundação Francisco Manuel dos Santos, 2015, p. 87.

23 Segundo Sani, a situação não é melhor junto a outras instituições que, ainda que não sejam nominalmente políticas, exercem influência na vida política dos cidadãos e são vistas como instrumentos subsidiários de participação política, tais como sindicatos, associações culturais, dentre outras. Além disso, a participação política propriamente dita, ou seja, com envolvimento direto do cidadão na tomada de decisão contínua a ser atividade de poucos cidadãos, os quais participam em instâncias distintas (por exemplo, em partidos políticos e também em sindicatos). Sobre o tema ver SANI, Giacomo. Verbete "participação política". In: BOBBIO, Norberto; MATTEUCCI, Nicola; PASQUINO, Gianfranco. Dicionário de política. Trad. Carmen C. Varriale et al.; coord. trad. João Ferreira; rev. geral João Ferreira e Luís Guerreiro Pinto Cacais. 11 ed. Brasília: UnB, 1998, p. 889.

24 MAIR, Peter. Ruling the void: the hollowing of Western democracy. Edição Kindle. Londres, Nova York: Verso, 2013 , p. 497. 25 PORTUGAL. Comissão Nacional de Eleições. Diário da República, de 12 de outubro de 2009. № 197. Mapa oficial nº 2-A/2009. Relação dos deputados eleitos e mapa oficial das eleições para a Assembleia da República realizadas em 27 de setembro de 2009 , p. 6.

26 PORTUGAL. Comissão Nacional de Eleições. Diário da República, de 17 de junho de 2011. No 116. Mapa oficial nº 6-A/2011. Relação dos deputados eleitos e mapa oficial das eleições para a Assembleia da República realizadas em 5 de junho de 2011 , p. 6.

27 VELASCO, Clara. Nível de abstenção nas eleições é o mais alto desde 1998. G1 - eleição em números. 06 de outubro de 2014.

28 BRASIL. Tribunal Superior Eleitoral. Estatísticas eleitorais 2014. Critério de pesquisa: eleições gerais de 2014, $1^{\circ}$ turno, cargo de Presidente da República. Última atualização dos dados: 28/06/2015.

29 Existem diferenças político-jurídicas entre uma abstenção, um voto em branco e um voto nulo. A despeito de tais diferenças - as quais não serão apresentadas neste espaço -, tais manifestações do eleitorado servem, em conjunto, para demonstrar o desinteresse do eleitor brasileiro em relação ao mecanismo eleitoral atualmente vigente.

30 É possível afirmar que a obrigatoriedade do voto no Brasil se vincula apenas ao dever cívico do voto e, ainda, às sanções decorrentes do ato de não se votar e não se justificar o voto - sanções estas que, além do pagamento de multa que varia entre R $\$ 1,05$ e $\mathrm{R} \$ 35,14$ - sendo o valor padrão de R \$3,51 - se sintetizam na impossibilidade de exercício de alguns atos da vida civil, tais como inscrição em provas para funções públicas, receber vencimentos, salários ou proventos de função ou emprego público, participar de concorrência pública ou administrativa e obter passaporte ou carteira de identidade, dentre outras. Pouco ou nada é falado acerca do caráter positivo da participação política do cidadão, seja no sentido de que a participação é importante para que efetivamente exista representação política, seja no sentido de que o ato de votar é um dever para com a coletividade. Desta maneira, é possível afirmar que os estímulos são insuficientes, muitas vezes levando até mesmo à abstenção e/ou ao chamado "voto de protesto", o qual é prejudicial quando se considera as funções da participação e da representação políticas. 


\section{Democracia local: ReVitalizando a representação política (?)}

Se, por um lado, há consenso a respeito do fato de que a participação dos cidadãos é elemento essencial para a governança do século XXI, por outro, existem poucos mecanismos juridicamente institucionalizados que permitam o exercício da participação cidadã para além do aspecto eleitoral, ou seja, para além do direito de votar e ser votado - mais especificamente, não há mecanismo que permita a participação efetiva dos cidadãos na definição de políticas públicas. Para que ocorra uma verdadeira revitalização da ideia de democracia de maneira a amenizar, ou até mesmo extirpar, os problemas anteriormente apresentados, torna-se necessária a definição de padrões, ou seja, de regras constitucional e infraconstitucionalmente estabelecidas para a atuação do cidadão ${ }^{31}$ de maneira que se configure a existência da chamada cidadania ativa32.

Um elemento fundamental para o desenvolvimento da ideia de cidadania ativa é sua constitucionalização. Mesmo que existam críticas a respeito da necessidade de se constitucionalizar tudo - como se a mera constitucionalização de algo tornasse este algo eficaz e garantido ${ }^{33}$-, é importante ter presente na Constituição a possibilidade de que o cidadão possa legitimamente exercer sua cidadania até mesmo para que estejam claras as possibilidades e as limitações, bem como as responsabilidades, dos atores envolvidos. Da mesma forma, o estabelecimento constitucional da cidadania no contexto defendido até o momento, permite a garantia aos cidadãos de que estes são efetivamente considerados como atores políticos fundamentais ao enriquecimento e fortalecimento da democracia ${ }^{34}$.

Reconhecer-se-ia, dessa forma, a possibilidade de os cidadãos atuarem na esfera pública, seja de maneira individual ou em conjunto e, inclusive, com outros atores sociais relevantes, não apenas por meio de sugestões ao poder político estabelecido - característica típica da cidadania "tradicional" - mas também por meio da participação direta no processo de tomada de decisão, contribuindo assim para a melhoria da vida em coletividade. O Estado passa, dessa forma, não a abrir mão de suas responsabilidades, mas sim a reconhecer que certas ações são melhor pensadas, planejadas, desenvolvidas e avaliadas pelos próprios cidadãos, que em última instância correspondem àqueles que são o público-alvo das políticas públicas ${ }^{35}$.

No caso dos Estados aqui analisados, a Constituição portuguesa traz, no artigo 9, alínea "c", que é tarefa fundamental do Estado a defesa da democracia política, assegurando e incentivando a participação democrática dos cidadãos na resolução dos problemas nacionais ${ }^{36}$, o mesmo se repetindo no $\mathrm{n}^{\circ} 2$ do artigo $225^{\circ}$, que trata das regiões autônomas ${ }^{37}$. Nesse sentido, a respeito de tais dispositivos constitucionais parece não haver nenhuma possibilidade explícita de ações cívicas por parte dos cidadãos.

31 "Neste contexto, vários temas poderiam ser tratados. Um deles é o sentido da ação cívica, indo do constitucional (subsidiariedade horizontal) para a operacional (governança participativa). Outra diz respeito às relações com os interlocutores de ação cívica, com foco no contínuo conflito-cooperação. A última se refere a impactos e repercussões de ação cívica”. MORO, Giovanni. Civic action. Entrada na Enciclopédia Internacional da Sociedade Civil, editada por Helmut Anheier, Regina List e Stephen Toepler. Springer: Nova Iorque, 2009, p. 7-8.

32 A expressão cidadania ativa deve ser entendida no contexto aqui desenvolvido como sendo a capacidade jurídica atribuída aos cidadãos para criar diretamente políticas públicas, o que implica não apenas na possibilidade de definição da política pública mas também, e principalmente, de assunção de responsabilidades por eventuais consequências negativas de tal política pública. É importante ter em mente que a proposta da cidadania ativa não exclui, antes complementa, o conceito de cidadania “tradicional". Desta maneira, a cidadania ativa reconhece que os cidadãos são livres e soberanos, da mesma maneira que a cidadania "tradicional” o faz, mas enfatiza a ideia de que os cidadãos têm um papel central e construtivo na esfera pública, especialmente por atribuir-lhes responsabilidades que na cidadania "tradicional" geralmente não existem. Da mesma maneira, a cidadania ativa se fundamenta na ideia de que os cidadãos precisam atuar com reciprocidade e interdependência, já que irão decidir a respeito de políticas públicas que interferem no dia a dia de todos os membros da coletividade. Ver MORO, Giovanni. Active citizenship as phenomenon and concept. Paper apresentado no Congresso do Instituto Internacional de Sociologia. Tel Aviv: 15 de julho de 1999, p. 5-6.

33 A este respeito ver, por todos, NEVES, Marcelo. A constitucionalização simbólica. São Paulo: Acadêmica, 1994.

34 MORO, Giovanni. The citizen's side of governance. The Journal of Corporate Citizenship. Edição 7, outono de 2002 , p. 19.

35 MORO, Giovanni. The citizen's side of governance. The Journal of Corporate Citizenship. Edição 7, outono de 2002, p. 20.

36 PORTUGAL. Assembleia da República. Constituição da República Portuguesa. VII Revisão Constitucional (2005), p. 3.

37 PORTUGAL. Assembleia da República. Constituição da República Portuguesa. VII Revisão Constitucional (2005), p. 72. 
Por outro lado, o artigo $267^{\circ}$, que trata da estrutura da Administração Pública, traz alguns itens nos quais é possível ter-se vislumbres sobre a existência da cidadania ativa na Constituição portuguesa. Nesse sentido, o no 1 deste artigo afirma que a Administração Pública será estruturada visando, dentre outros objetivos, à garantia da participação dos interessados na sua gestão efetiva. Tal participação é reforçada pela manifesta descentralização administrativa, conforme traz o no 2 do artigo. Por sua vez, o $n^{\circ} 5$ do artigo diz que o processamento da atividade administrativa será regulamentada por lei especial, de maneira a permitir a participação dos cidadãos na formação das decisões ou deliberações que lhes disserem respeito ${ }^{38}$.

Contudo, a despeito da existência de tais previsões, parece não haver, na Constituição Portuguesa, a possibilidade real da participação efetiva do cidadão fora dos canais tradicionais, ou seja, para além do momento eleitoral como criador indireto de leis. Ainda que exista a possibilidade de participação dos cidadãos "nos temas que lhes dizem respeito", não há previsão explícita de quais seriam esses temas, nem qual seria o mecanismo pelos quais tal participação ocorreria. Nesse contexto a abertura interpretativa que o texto constitucional permite pode ser vista de maneira negativa, já que a lei infraconstitucional à qual o texto se refere pode ampliar ou restringir, de acordo com a vontade do legislador do momento, os temas que (supostamente) sejam de interesse do cidadão. Percebe-se, dessa forma, não haver a necessária abertura constitucional para a participação dos cidadãos no processo de tomada de decisão no âmbito das políticas públicas no caso português ${ }^{39}$.

Porém, no caso português, é importante chamar a atenção para o direito de petição conforme previsto na Constituição. Esse direito não está vinculado apenas à tutela jurídica dos direitos fundamentais: mais que isto, o direito de petição existe como verdadeiro direito político, caracterizando-se por ser um "direito de representação stricto sensu perante os órgãos do poder público" ${ }^{40}$. Com base no direito de petição pode o cidadão - seja de maneira individual ou coletiva -, ou ainda as pessoas jurídicas, criticar ou contestar a maneira pela qual questões de interesse geral têm sido tratadas pelo poder público. Da mesma maneira, pode, ainda, o cidadão, por meio desse direito, sugerir soluções para os problemas que ele vislumbra com a coisa pública. O direito de petição pode ser exercido frente a autoridades políticas e também administrativas, mas não jurisdicionais (para estas tem-se o direito à ação) ${ }^{41}$.

Para além da Constituição, é necessário, também, analisar a legislação infraconstitucional portuguesa, especificamente aquela relacionada às autarquias locais, ou seja, às pessoas coletivas de direito público assim definidas pela Constituição portuguesa ${ }^{42}$. As autarquias locais são regulamentadas pela Lei n $n^{\circ}$ 169/99, de 18 de Setembro, que define as competências e o regime jurídico das autarquias locais, e pela Lei $n^{\circ}$ 75/2013, de 12 de Setembro, que complementa a anterior ao também definir o regime jurídico das autarquias locais.

A Lei $n^{\circ} 169 / 99$, de 18 de Setembro, traz no $n^{\circ} 1$ do seu artigo $21^{\circ}$ que nas freguesias com 150 eleitores ou menos a assembleia será substituída pelos próprios cidadãos eleitores, de maneira a ser competência destes a decisão direta a respeito dos assuntos relativos à sua freguesia ${ }^{43}$. Caso isto ocorra, o plenário de

38 PORTUGAL. Assembleia da República. Constituição da República Portuguesa. VII Revisão Constitucional (2005), p. 82.

39 Há que se considerar a previsão constitucional a respeito das "organizações de moradores", que engloba os artigos $263^{\circ}$, $264^{\circ}$ e $265^{\circ}$ da Constituição portuguesa. Contudo, mesmo tal elemento não concretiza a cidadania ativa, conforme fica explícito pelo previsto nas alíneas "a" e "b" do $\mathrm{n}^{\circ} 1$ do artigo $265^{\circ}$, que trata dos direitos e da competência das organizações de moradores. A alínea "a" traz que estas organizações têm direito de petição perante as autarquias locais, no que concerne a temas administrativos de interesse dos cidadãos, enquanto a alínea "b" informa que tais organizações têm direito de participação na assembleia de freguesia por meio de seus representantes - sendo, contudo, que esta participação é sem direito a voto. Ora, no contexto da cidadania ativa, participar sem votar é o mesmo que não participar, ou seja, é o mesmo que estar presente mas não decidir.

40 MIRANDA, Jorge. Manual de direito constitucional. Tomo VII. Estrutura constitucional da democracia. Coimbra: Coimbra, 2007 , p. 111. 41 MIRANDA, Jorge. Manual de direito constitucional. Tomo VII. Estrutura constitucional da democracia. Coimbra: Coimbra, 2007, p. 113.

42 MIRANDA, Jorge. Manual de direito constitucional. Tomo III. Estrutura constitucional do Estado. Coimbra: Coimbra, 2014 , p. 234. 43 Para fins de exemplo, considera-se que cerca de 70\% da população total de determinada região seja composta por eleitores. Neste sentido, significa dizer que o disposto no $\mathrm{n}^{\circ} 1$ do artigo $21^{\circ}$ aqui em análise aplicar-se-ia em freguesias com pelo menos 215 cidadãos eleitores $(215-30 \%=150,5)$. Neste sentido, conforme informação disponível no site do Instituto Nacional de Estatística de Portugal, apenas 129 das 3.091 freguesias atualmente existentes em Portugal (tanto Continental quanto em Açores e Madeira) 
cidadãos reger-se-á pelas mesmas regras relativas à assembleia de freguesia, com as devidas adaptações, conforme estabelece o artigo $22^{\circ}$ da lei. Não há nessa lei nenhuma outra referência a respeito da possibilidade de tomada de decisão de maneira direta por parte do cidadão, ficando claramente prejudicada qualquer iniciativa que este queira ter a respeito de sua localidade ${ }^{44}$.

Já em relação à Lei no 75/2013, de 12 de Setembro, que define o Regime jurídico das autarquias locais, seus artigos $111^{\circ}$ e $112^{\circ}$ trazem, respectivamente, que a descentralização administrativa é concretizada por meio da transferência, por via legislativa, de competências de órgãos do Estado para órgãos das autarquias locais e das entidades intermunicipais, sendo que o objetivo de tal descentralização é a aproximação das decisões aos cidadãos, a promoção da coesão territorial, o reforço da solidariedade inter-regional, a melhoria da qualidade dos serviços prestados às populações e a racionalização dos recursos disponíveis ${ }^{45}$.

No que concerne à participação do cidadão, a alínea "c" do no 1 do artigo $12^{\circ}$ permite a convocação de sessões extraordinárias da assembleia de freguesia por requerimento de um número mínimo de cidadãos (mecanismo semelhante está presente na alínea "c" do no 1 do artigo $28^{\circ}$, que trata das sessões extraordinárias das assembleias municipais) ${ }^{46}$. Nesse sentido, entende-se tal dispositivo como positivo em direção a permitir ao cidadão a tomada de decisão, já que permite que a organização autônoma de cidadãos formalize uma assembleia cujo objetivo é deliberar a respeito de algo relevante ao espaço público próximo a si.

A lei traz, em seu artigo $47^{\circ}$, a maneira em que se dará a participação dos eleitores, e aqui percebe-se que esta participação é meramente em termos de presença, não de decisão. $\mathrm{O} \mathrm{n}^{\circ} 1$ de tal artigo é explícito em dizer que sessões extraordinárias dos órgãos deliberativos podem ser convocadas por cidadãos eleitores, o que seria um ponto positivo em direção à cidadania ativa; contudo, a parte final deste mesmo $\mathrm{n}^{\circ} 1$ do artigo $47^{\circ}$ afirma que os representantes dos cidadãos que forem participantes de tais sessões extraordinárias não têm direito a voto ${ }^{47}$. Ou seja, os cidadãos têm o direito de convocar sessões extraordinárias e têm o direito de participar de tais sessões, mas não têm o direito de decidir.

Da mesma maneira, o no 2 deste mesmo artigo $47^{\circ}$ traz que "os representantes referidos no número anterior podem apresentar sugestões ou propostas, as quais são votadas se tal for deliberado"48. Ou seja, primeiramente é necessário haver deliberação para a existência de votação, o que significa que se tal deliberação não ocorrer não haverá votação; por sua vez, mesmo que haja deliberação, os representantes dos cidadãos não terão direito a voto, conforme explícito no $\mathrm{n}^{\circ} 1$ deste artigo. Em outras palavras, parece não haver a possibilidade de participação efetiva do cidadão na definição dos rumos de sua própria localidade, já que permite-se sua presença no ato público e até mesmo a sugestão de ações a serem desenvolvidas pelo poder público, mas não se permite a sua contribuição no processo efetivamente decisório.

Destaca-se, nesse contexto de ausência de participação cidadã - talvez seja possível até mesmo falar em impedimento, como se verá a seguir -, o no 4 do artigo $48^{\circ}$ da lei, que diz, textualmente, que "a nenhum cidadão é permitido intrometer-se nas discussões, aplaudir ou reprovar as opiniões emitidas, as votações feitas ou as deliberações tomadas" ${ }^{49}$. Por um lado, em uma interpretação positiva do dispositivo, há que se

possuem 215 ou menos habitantes. Em outras palavras, significa dizer que seria possível a aplicação de tal dispositivo legal a apenas 23.466 habitantes - ou $0,23 \%$ da população de um país com população total de 10.561.614 de habitantes. PORTUGAL. Instituto Nacional de Estatística. Censos 2011 - População residente por freguesia, CAOP 2013.

44 PORTUGAL. Ministério Público. Procuradoria-Geral Distrital de Lisboa. Lei ñ 169/99, de 18 de Setembro. Autarquias locais competências e regime jurídico.

45 PORTUGAL. Ministério Público. Procuradoria-Geral Distrital de Lisboa. Lei $n^{\circ}$ 75/2013, de 12 de Setembro. Regime jurídico das autarquias locais.

46 PORTUGAL. Ministério Público. Procuradoria-Geral Distrital de Lisboa. Lei ñ 75/2013, de 12 de Setembro. Regime jurídico das autarquias locais.

47 PORTUGAL. Ministério Público. Procuradoria-Geral Distrital de Lisboa. Lei nº 75/2013, de 12 de Setembro. Regime jurídico das autarquias locais.

48 PORTUGAL. Ministério Público. Procuradoria-Geral Distrital de Lisboa. Lei $n^{0}$ 75/2013, de 12 de Setembro. Regime jurídico das autarquias locais.

49 PORTUGAL. Ministério Público. Procuradoria-Geral Distrital de Lisboa. Lei nº 75/2013, de 12 de Setembro. Regime jurídico 
compreender a necessidade de manutenção da ordem, do urbanismo, em órgãos deliberativos, especialmente no sentido de se evitar que as deliberações sejam prejudicadas por manifestações constantes daqueles ali envolvidos. Contudo, por outro lado também se destaca que a própria lei, em uma interpretação literal do texto, impede qualquer participação do cidadão nas decisões, inclusive com punição do cidadão "infrator" com multas, conforme estabelece o $\mathrm{n}^{\circ} 5$ deste mesmo artigo. Impede-se, com isto, a manifestação propositiva, positiva, do cidadão que esteja interessado em contribuir com a melhoria de suas condições locais, afastando-o da esfera pública em vez de aproximá-lo. Fragiliza-se desta maneira a capacidade do cidadão em tomar decisões a respeito da definição dos rumos de sua própria localidade, o que não pode ser visto, de forma alguma, como mecanismo efetivo de participação cidadã.

Por sua vez, no caso brasileiro, também se percebe a ausência de possibilidade de exercício da cidadania ativa pelo cidadão. Ainda que existam 30 normas constitucionais que prevejam a participação política do cidadão na vida em sociedade ${ }^{50}$, nenhuma delas possibilita ao cidadão a participação direta na formulação de políticas públicas. As normas que mais se aproximam da ideia de cidadania ativa são aquelas presentes, na Constituição, no inciso XII do artigo 29 ("cooperação das associações representativas no planejamento municipal"51) e no inciso II do artigo 204 ("participação da população, por meio de organizações representativas, na formulação das políticas e no controle das ações [de assistência social] em todos os níveis" ${ }^{2} 2$ ). Os termos do inciso II do artigo 204 da Constituição brasileira também parecem levar em direção à participação efetiva do cidadão nos termos da cidadania ativa, mas se referem explicitamente a apenas uma das condições necessárias ao seu exercício (à participação em uma das etapas do processo de criação das políticas públicas), sem garantir as demais condições ${ }^{53}$.

Deve-se chamar a atenção, no âmbito infraconstitucional brasileiro, para a Lei no 10.257, de 10 de julho de 2001, conhecida por Estatuto da Cidade54. A lei, que regulamenta os artigos 182 e 183 da Constituição brasileira, estabelece diretrizes gerais da política urbana, com destaque para as normas de ordem pública e interesse social que regulam o uso da propriedade urbana em prol do bem coletivo, da segurança e do bem-estar dos cidadãos, bem como do equilíbrio ambiental.

Tendo-se tal objetivo em mente o Estatuto da Cidade estabelece, no inciso II de seu artigo $2^{\circ}$, que a política urbana será definida por meio de gestão democrática com a participação da população e de associações representativas dos vários segmentos da comunidade na formulação, execução e acompanhamento de planos, programas e projetos de desenvolvimento urbano. Da mesma forma, o inciso III do mesmo artigo traz que deverá haver cooperação entre os governos, a iniciativa privada e os demais setores da sociedade no processo de urbanização, em atendimento ao interesse social.

Chama a atenção, também, o inciso XVI, ainda no artigo $2^{\circ}$, que propõe a isonomia de condições para os agentes públicos e privados na promoção de empreendimentos e atividades relativos ao processo de urbanização, atendido o interesse social. Já a alínea "g" do inciso III do artigo $4^{\circ}$ do Estatuto da Cidade informa

das autarquias locais.

50 LOPES, Ana Maria D’Ávila. A cidadania na Constituição Federal brasileira de 1988: redefinindo a participação política. In: BONAVIDES, Paulo; LIMA, Francisco Gérson Marques de; BEDÊ, Fayga Silveira (coords.). Constituição e democracia. Estudos em homenagem ao Prof. J. J. Gomes Canotilho. São Paulo: Malheiros Editores, 2006, p. 25-7.

51 BRASIL. Senado Federal. Secretaria especial de informática. Constituição da República Federativa do Brasil. Texto consolidado até a Emenda Constitucional no 88 de 07 de maio de 2015. Brasília: Senado Federal, 2015, p. 12.

52 BRASIL. Senado Federal. Secretaria especial de informática. Constituição da República Federativa do Brasil. Texto consolidado até a Emenda Constitucional no 88 de 07 de maio de 2015. Brasília: Senado Federal, 2015, p. 43.

53 O parágrafo $1^{\circ}$ do artigo 216 da Constituição brasileira traz a seguinte redação: "O poder público, com a colaboração da comunidade, promoverá e protegerá o patrimônio cultural brasileiro [...]”.BRASIL. Senado Federal. Secretaria especial de informática. Constituição da República Federativa do Brasil. Texto consolidado até a Emenda Constitucional no 88 de 07 de maio de 2015. Brasília: Senado Federal, 2015, p. 44. Contudo, também não está explícito que o cidadão poderá participar do processo completo de formulação das políticas públicas no que concerne à proteção do patrimônio cultural, não vindo este a ser, portanto, um mecanismo de cidadania ativa.

54 BRASIL. Presidência da República. Casa Civil. Subchefia para Assuntos Jurídicos. Lei n 10.257, de 10 de julho de 2001. Regulamenta os arts. 182 e 183 da Constituição Federal, estabelece diretrizes gerais da política urbana e dá outras providências. 
que a gestão orçamentária dos municípios será feita de maneira participativa, entendendo-se por "maneira participativa" a realização de debates, audiências e consultas públicas sobre as propostas do plano plurianual, da lei de diretrizes orçamentárias e do orçamento anual como condição obrigatória para sua aprovação pela Câmara Municipal.

A lei exige, também, que, no processo de elaboração do plano diretor - que é o instrumento básico da política de desenvolvimento e expansão urbana - e na fiscalização de sua implementação, os poderes Legislativo e Executivo municipais garantam a promoção de audiências públicas e de debates com a participação da população e de associações representativas dos vários segmentos da comunidade.

O Capítulo IV da lei traz, ainda, mecanismos que buscam garantir a gestão democrática da cidade. Assim, a lei estabelece que tal gestão deve se valer de órgãos colegiados de política urbana, de debates, audiências e consultas públicas e de conferências sobre assuntos de interesse urbano, permitindo-se ainda, quando for o caso, a iniciativa popular de projeto de lei e de planos, programas e projetos de desenvolvimento urbano.

Em um primeiro momento, poder-se-ia afirmar que o Estatuto da Cidade trouxe inovações no que diz respeito à participação popular, especialmente quando se está a considerar as questões orçamentárias, que exigem audiências públicas para sua análise. Nesse sentido, é inegável que o Estatuto da Cidade contribuiu para a democratização da administração dos municípios e, especialmente, para a divulgação de informações a respeito desta mesma administração. Assim, é plausível acreditar que a lei tem papel importante em termos de publicitação dos atos públicos.

Contudo, no que concerne ao exercício da cidadania ativa por parte do cidadão, mais uma vez fica-se sem sua concretização. O Estatuto da Cidade não traz, em nenhum momento, a possibilidade de responsabilização do cidadão no que concerne à sua participação em tais audiências públicas, de maneira a transparecer que a participação do cidadão é muito mais em termos consultivos do que deliberativos. Da mesma maneira, pode-se pressupor que tais audiências públicas tenham caráter apenas formal, ou seja, de presença dos cidadãos nas audiências sendo estas muito mais para expor as propostas dos órgãos públicos do que para ouvir e considerar as propostas dos cidadãos, de maneira a não haver nenhum tipo de "valor agregado" originado do cidadão à política pública.

Em síntese, percebe-se que tanto no caso português quanto no brasileiro existem normas constitucionais e infraconstitucionais que caminham em direção a permitir certo envolvimento do cidadão com a esfera pública, notadamente no âmbito das políticas públicas. Nos dois casos, verifica-se a predisposição, ao menos no aspecto formal, de garantir ao cidadão formas diferenciadas de participação política que vão além do aspecto eleitoral.

Contudo, nota-se, também, que tal abertura é tímida. Tendo-se o caso brasileiro como exemplo, percebe-se que o Estatuto da Cidade permite inegável contribuição do cidadão para a administração municipal, correspondendo à ideia de descentralização anteriormente apresentada. Entretanto, percebe-se, também, a necessidade de uma maior abertura da possibilidade de interferência direta do cidadão nos assuntos do Estado, especialmente no que concerne às políticas públicas locais, já que não há nenhuma responsabilização do cidadão pela sua participação em audiências públicas, o que leva ao não reconhecimento da importância de sua presença nestas mesmas audiências, de maneira que estas se tornem muito mais mecanismos para a mera "prestação de contas" por parte do governo que são legitimadas pelo cidadão - sem, contudo, haver efetivo envolvimento deste com o processo como um todo.

É necessária, portanto, a garantia de maior abertura, tanto constitucional quanto infraconstitucional, ao envolvimento direto dos cidadãos nos assuntos de sua vida cotidiana, o que pode ser feito, ao menos, em âmbito local - já que não há ninguém melhor para conhecer as necessidades de um bairro, por exemplo, do que o próprio cidadão ${ }^{55}$. Não se pode considerar como válidas, em um Estado democrático de direito, as

55 Como afirma Suxberger, "o papel da chamada 'grande política', portanto, desce aos planos de funcionamento efetivo e op- 
suposições, dentre outras, de que o cidadão é incapaz de participar - no sentido de não ter conhecimento e, portanto, de ter de ser excluído do processo decisório - ou de que o cidadão é desinteressado pela esfera pública e, consequentemente, não precisa ter a possibilidade de interferir. Tais suposições parecem não ser mais do que verdadeira desconfiança frente à capacidade do cidadão de se autodeterminar, o que justificaria um pretenso domínio exclusivo por aqueles que fazem parte das "elites dominantes"

\section{Considerações finais}

A democracia se apresenta como um dos pilares do atual Estado democrático de direito, sendo este o modelo estatal dominante no mundo ocidental pelo menos desde o final da Segunda Guerra Mundial. Nesse modelo de organização do Estado a prioridade é dada ao cidadão, ou seja, o cidadão é tomado como ponto de referência para a definição das ações estatais, já que se considera que tais ações devem, em última instância, concretizar a própria cidadania.

Por sua vez, não se pode pressupor que o cidadão seja um ente abstrato e passivo frente às ações do Estado. Por outras palavras, o modelo de estrutura constitucional-democrática existente, atualmente, não pode pressupor que o cidadão irá apenas participar esporadicamente em eleições para, por meio delas, expressar sua vontade acerca dos rumos que a coletividade deve seguir, como se incumbisse ao cidadão apenas passar um cheque em branco às lideranças que são por ele escolhidas. É necessário, isto sim, que o cidadão assuma responsabilidades pelas suas ações na esfera coletiva, já que se pressupõe que seja este o espírito de uma verdadeira república.

Tal perspectiva, entretanto, encontra-se ausente no ordenamento jurídico dos dois países que são objeto deste estudo, quais sejam, Brasil e Portugal. Ambos os países indicam, em seus respectivos textos constitucionais, a importância da participação do cidadão na definição dos rumos da polis, por um lado, mas por outro não concretizam a necessária abertura para que uma efetiva participação ocorra. Em síntese, há a previsão da participação do cidadão, mas não há indicação de como tal participação pode ocorrer.

O mesmo ocorre com a legislação infraconstitucional. Em ambos os países, no que se refere à instância administrativa mais próxima dos cidadãos existe a previsão legal de abertura à participação política do cidadão. Entretanto, uma análise mais detalhada dessa legislação mostrou que na prática tal participação acaba por não se concretizar, o que reforça o caráter meramente eleitoral do sistema democrático instalado no Brasil e em Portugal.

Ainda, é necessário que se considere o fato de que não há nos dois países nenhuma perspectiva de responsabilização do cidadão. Em suma, tem-se que o cidadão "participa” politicamente por meio do voto, mas, uma vez que tal participação ocorra o único responsável pelo sucesso ou fracasso da administração, é o representante eleito. Tal ideia precisa ser desconstruída e substituída por uma que considere o dever fundamental do cidadão de se preocupar com a coletividade, especialmente se se considera que a perspectiva atual permite que a não participação política do cidadão seja compreendida como o exercício da sua cidadania - o que se apresenta, no mínimo, como contraditório com o próprio conceito de cidadania.

Com base nessa perspectiva, defendeu-se neste artigo a ideia de cidadania ativa, entendendo-se esta como a possibilidade constitucionalmente garantida ao cidadão para que este possa participar, ao menos em âm-

eracional do Estado e do governo. Trata-se, verdadeiramente de (re)localizar o papel da Política, para que ela seja compreendida do plano macro para o plano microinstitucional, ou seja, da excessiva abstração do Estado para sua visualização a partir dos sujeitos nela envolvidos". SUXBERGER, Antonio Henrique Graciano. Políticas públicas e processo eleitoral: reflexão a partir da democracia como projeto político. Revista Brasileira de Políticas Públicas, Brasília, v. 5, Número Especial, 2015, p. 257, grifo nosso.

56 CANOTILHO, Joaquim José Gomes. Direito constitucional e teoria da Constituição. 7 ed., 16 reimp. Coimbra: Almedina, 2014, p. 1412. 
bito local, do processo de criação de políticas públicas. Acredita-se que desta forma será possível redefinir o conceito de democracia, de maneira que este deixe de ser compreendido como a mera participação eleitoral em momentos específicos e passe a ser vista como um real envolvimento do cidadão com os temas da coletividade que lhe digam respeito, recebendo o cidadão não apenas os benefícios - ou seja, o "bônus" - de ações positivas mas também arcando com as consequências - ou seja, com o "ônus" - pelos eventuais erros de suas decisões. Acredita-se que desta forma poderá o cidadão não apenas revitalizar o ambiente democrático por meio de sua presença na deliberação de temas que dizem respeito à sua vida em coletividade, mas também cumprir o seu dever fundamental de participação política efetiva, o qual se apresenta como primordial em um verdadeiro Estado democrático de direito.

\section{REFERÊNCIAS BIBLIOGRÁFICAS}

BELCHIOR, Ana Maria. Confiança nas instituições políticas. Lisboa: Fundação Francisco Manuel dos Santos, 2015.

BOBBIO, Norberto. Verbete "democracia”. In: BOBBIO, Norberto; MATTEUCCI, Nicola; PASQUINO, Gianfranco. Dicionário de política. Trad. Carmen C. Varriale et al.; coord. trad. João Ferreira; rev. geral João Ferreira e Luís Guerreiro Pinto Cacais. 11 ed. Brasilia: UnB, 1998.

BRASIL. Senado Federal. Secretaria especial de informática. Constituição da República Federativa do Brasil. Texto consolidado até a Emenda Constitucional no 88 de 07 de maio de 2015. Brasília: Senado Federal, 2015. Disponível em <http://www.senado.gov.br/legislacao/const/con1988/CON1988_07.05.2015/CON1988. pdf $>$. Acesso em 29 de agosto de 2016.

Tribunal Superior Eleitoral. Estatísticas eleitorais 2014. Comparecimento e votação. Critério de pesquisa: eleições gerais de 2014, $1^{\circ}$ turno, cargo de Presidente da República. Última atualização dos dados: 28/06/2015. Disponível em <http://www.tse.jus.br/eleicoes/estatisticas/estatisticas-eleitorais-2014-resultado $>$. Acesso em 29 de agosto de 2016.

Lei no 10.257, de 10 de julho de 2001. Regulamenta os arts. 182 e 183 da Constituição Federal, estabelece diretrizes gerais da política urbana e dá outras providências. Regulamenta os arts. 182 e 183 da Constituição Federal, estabelece diretrizes gerais da política urbana e dá outras providências. Disponível em <http://www.planalto.gov.br/CCivil_03/leis/LEIS_2001/L10257.htm>. Acesso em 29 de agosto de 2016.

CANOTILHO, Joaquim José Gomes. Direito constitucional e teoria da Constituição. 7 ed., 16 reimp. Coimbra: Almedina, 2014.

FIORAVANTI, Maurizio. Constitución: de la Antigüedad a nuestros días. Trad. Manuel Martínez Neira. Madrid: Editorial Trotta, 2001.

GOMES, José Jairo. Direito eleitoral. 11 ed. rev. atual. e ampl. São Paulo: Atlas, 2015.

LOPES, Ana Maria D’Ávila. A cidadania na Constituição Federal brasileira de 1988: redefinindo a participação política. In: BONAVIDES, Paulo; LIMA, Francisco Gérson Marques de; BEDÊ, Fayga Silveira (coords.). Constituição e democracia. Estudos em homenagem ao Prof. J. J. Gomes Canotilho. São Paulo: Malheiros Editores, 2006.

MAIR, Peter. Ruling the void: the hollowing of Western democracy. Edição Kindle. Londres, Nova York: Verso, 2013.

MENDES, Gilmar Ferreira; STRECK, Lenio Luiz; SARLET, Ingo Wolfgang; LEONCY, Léo Ferreira; CANOTILHO, J. J. Gomes. Comentários à Constituição do Brasil. Série IDP. São Paulo: Saraiva/Almedina, 2013. Recurso digital. 
MIRANDA, Jorge. Manual de direito constitucional. Tomo III. Estrutura constitucional do Estado. Coimbra: Coimbra, 2014.

. Manual de direito constitucional. Tomo VII. Estrutura constitucional da democracia. Coimbra: Coimbra, 2007.

MORO, Giovanni. Active citizenship as phenomenon and concept. Paper apresentado no Congresso do Instituto Internacional de Sociologia. Tel Aviv: 15 de julho de 1999. Disponível em <http://www.giovannimoro. info/documenti/g.moro\%20IIS\%2099.pdf>. Acesso em 2 de junho de 2015.

Civic action. Entrada na Enciclopédia Internacional da Sociedade Civil, editada por Helmut Anheier, Regina List e Stephen Toepler. Springer: Nova Iorque, 2009. Disponível em <http://www.giovannimoro. info/documenti/civic\%20action\%20IECS.pdf>. Acesso em 2 de junho de 2015.

The citizen's side of governance. The Journal of Corporate Citizenship. Edição 7, outono de 2002. Disponível em <http://www.giovannimoro.info/documenti/the $\% 20$ citizen $\% 27 \mathrm{~s} \% 20$ side $\% 20$ of $\% 20$ governance.pdf $>$. Acesso em 2 de junho de 2015.

NEVES, Marcelo. A constitucionalização simbólica. São Paulo: Acadêmica, 1994.

PORTUGAL. Assembleia da República. Constituição da República Portuguesa. VII Revisão Constitucional (2005). Disponível em <http://www.parlamento.pt/Legislacao/Documents/constpt2005.pdf>. Acesso em 29 de agosto de 2016.

Instituto Nacional de Estatística. Censos 2011 - População residente por freguesia, CAOP 2013. Disponível em <http://censos.ine.pt/xportal/xmain?xpid=CENSOS\&xpgid=censos_quadros $>$. Acesso em 29 de agosto de 2016.

Comissão Nacional de Eleições. Diário da República, de 12 de outubro de 2009. No 197. Mapa oficial no 2-A/2009. Relação dos deputados eleitos e mapa oficial das eleições para a Assembleia da República realizadas em 27 de setembro de 2009. Disponível em < http://www.cne.pt/sites/default/files/dl/resultados_ar_2009.pdf>. Acesso em 29 de agosto de 2016.

. Diário da República, de 17 de junho de 2011. No 116. Mapa oficial nº 6-A/2011. Relação dos deputados eleitos e mapa oficial das eleições para a Assembleia da República realizadas em 5 de junho de 2011. Disponível em < http://www.cne.pt/sites/default/files/dl/resultados_ar2011.pdf>. Acesso em 29 de agosto de 2016.

Ministério Público. Procuradoria-Geral Distrital de Lisboa. Lei no 75/2013, de 12 de Setembro. Regime jurídico das autarquias locais. Disponível em <http://www.pgdlisboa.pt/leis/lei_print_articulado. php?tabela=leis\&artigo_id=\&nid=1990\&nversao=\&tabela=leis $>$. Acesso em 29 de agosto de 2016.

. Ministério Público. Procuradoria-Geral Distrital de Lisboa. Lei n 169/99, de 18 de Setembro. Autarquias locais - competências e regime jurídico. Disponível em <http://www.pgdlisboa.pt/leis/lei_print_articulado.php?tabela=leis\&artigo_id=\&nid=592\&nversao=\&tabela=leis $>$. Acesso em 29 de agosto de 2016.

SANI, Giacomo. Verbete "participação política”. In: BOBBIO, Norberto; MATTEUCCI, Nicola; PASQUINO, Gianfranco. Dicionário de política. Trad. Carmen C. Varriale et al.; coord. trad. João Ferreira; rev. geral João Ferreira e Luís Guerreiro Pinto Cacais. 11 ed. Brasília: UnB, 1998.

SANTOS, Braulio de Magalhães; MAGALHÃES, JoséLuiz Quadros de. Notas para um debate principiológico sobre participação à luz de uma teoria democrática. Revista Brasileira de Políticas Públicas, Brasília, v. 1, n. 2, p. 1-30, jul./dez. 2011.

SUXBERGER, Antonio Henrique Graciano. Políticas públicas e processo eleitoral: reflexão a partir da democracia como projeto político. Revista Brasileira de Políticas Públicas, Brasília, v. 5, Número Especial, 2015, p. 252-263. 
VELASCO, Clara. Nível de abstenção nas eleições é o mais alto desde 1998. G1 - eleição em números. 06 de outubro de 2014. Disponível em <http://g1.globo.com/politica/eleicoes/2014/blog/eleicao-em-numeros/ post/nivel-de-abstencao-nas-eleicoes-e-o-mais-alto-desde-1998.html>. Acesso em 29 de agosto de 2016. 


\section{A "atividade-ação" punitivo-disciplinar. Interatividade e complexidade entre ato, procedimento e processo administrativo*}

* Recebido em 07/04/2016 Aprovado em 27/08/2016

** Doutorando em Direitos e Políticas Públicas, pelo Centro Universitário de Brasília - UniCEUB e Mestre em Direitos e Garantias Fundamentais, pela Faculdade de Direito de Vitória - FDV. Professor de direito administrativo, processo e direitos fundamentais, em faculdades e cursos preparatórios para concursos públicos. Professor Visitante (Investigador Não Permanente) do Mestrado em Ciências Policiais do Instituto Superior de Ciências Policiais e Segurança Interna - ISCPSI, Lisboa, Portugal. Delegado de Polícia Federal, ex-Coordenador da Escola Superior da Polícia Federal. Centro Universitário de Brasília - UniCEUB - Aluno do Doutorado.E-mail:dezann@ig.com.br

*** Juiz de Direito do Tribunal de Justiça do Distrito Federal e Territórios TJDFT. Mestre em Direito Urbanístico pela Pontifícia Universidade Católica de São Paulo - PUC/SP (2006) e Doutor em Direito Urbanístico pela Pontifícia Universidade Católica de São Paulo - PUC/SP (2012). Professor de Direito Administrativo e Urbanístico da Fundação Escola Superior do Ministério Público do Distrito Federal e Territórios - FESMPDFT. Professor de Direito Administrativo e Urbanístico do Doutorado, Mestrado e Pós-Graduação Lato Sensu do Centro Universitário de Brasília - UNICEUB. E-mail:paccarmona@hotmail.com.

\section{The "action- activity" punitive disciplinary. Interactivity and complexity of the act, procedure and administrative process}

\author{
Sandro Lucio Dezan** \\ Paulo Afonso Cavichioli Carmona***
}

\section{Resumo}

O presente texto tem por finalidade demonstrar a inter-relação entre as normas do direito penal e do direito administrativo disciplinar e, nesse contexto, a funcionalidade complexa entre direito material e direito processual, extensível ao ato administrativo, ao procedimento e ao processo da Administração Pública, para a concreção de direitos fundamentais, como expressão de ação e de justiça estatal, por meio do processo punitivo. Indaga-se se há influências mútuas entre os ramos jurídico-punitivos estatais e em que medida esse fenômeno se faz relevante para o intérprete e aplicador do Direito. Com a concepção de identidade finalística entre o direito penal e o direito disciplinar, busca-se lançar luzes sobre a sistêmica dialogicidade sancionadora do Estado, para concluir que direito processual e direito material se complementam, sem sobreposições, para garantir a justiça das decisões administrativas, como essência da "atividade-ação" punitivo-disciplinar da Administração Pública.

Palavras-chave: Direito administrativo. Ato administrativo. Relação jurídica. Processo administrativo disciplinar. Ação sancionadora da Administração Pública.

\section{Abstract}

This paper aims to demonstrate the interrelationship between the rules of criminal law and disciplinary administrative law and in this context, the complex functionality of substantive law and procedural law, extended to the administrative act, the procedure and the Public Administration process for the concretion of fundamental rights as an expression of action and state justice through the punitive process. It asks whether there is mutual influence between state legal and punitive branches and to what extent this phenomenon is relevant to interpreters and appliers of Law. With the concept of purposive identity between criminal law and disciplinary law, this paper seeks to shed light on the punitive dialogical systemic of the State, to conclude that procedural law and substantive law are complementary, not 
overlapping, to ensure the fairness of administrative decisions, as the essence of "action- activity" punitive-disciplinary Public Administration.

Keywords: Administrative law. Administrative act. Legal relationship. Disciplinary administrative proceedings. Punitive action of the public administration.

\section{INTRODUÇÃO}

Para o exercício da atividade de controle das condutas ilícito-administrativas interna corporis, assim compreendidas as ações ou omissões submetidas à regulação da disciplina interna do pessoal dos quadros do serviço público, a Administração conduz-se de modo distintamente peculiar do "obrar" atribuível aos sujeitos e atores dos demais ramos do direto punitivo estatal (as partes autora e ré e, ainda, o magistrado, como ator processual imparcial), e.g., do direito sancionador em sentido estrito (direito administrativo não disciplinar) e do direito penal ${ }^{1}$.

Exerce, nesses moldes vazados, uma espécie de autotutela ${ }^{2}$ dos próprios e qualificados interesses - e aqui envoltos ao interesse público e coletivo ${ }^{3}$-, por meio de vários instrumentos, característicos da função gestora, permeados pela matriz de ser a Administração "não proprietária"4 da coisa pública 5 .

Nesse plexo de coisas, sem embargo das tipificações postas à previsão de infrações, inserem-se as categorias (i) dos atos administrativos (materiais e ambientalmente processuais) ${ }^{6}$, (ii) dos procedimentos e (iii) dos processos disciplinares ${ }^{7}$, em uma relação complexa ${ }^{8}$ de instrumentalidade, de correlação e de finalidade constitucional ${ }^{9}$, destinada ao esclarecimento de fatos, com aporte da verdade processual possível à luz dos direitos fundamentais constitucionais dos acusados em geral, e, sobre esse vértice, dedicada à aplicação de

1 LOBREGAT, José Garberí. Derecho administrativo sancionador prático. Barcelona: Editorial Boch, 2012. v. 1; LLOBREGAT, José Garberí. Derecho administrativo sancionador prático. Barcelona: Editorial Boch, 2012. v. 2; NIETO, Alejandro. Derecho administrativo sancionador. 5. ed. Madrid: Tecnos, 2012.

2 MEDAUAR, Odete. A processualidade no direito administrativo. 2. ed. São Paulo: Revista dos Tribunais, 2003.

3 CRETELLA JUNIOR, José. Tratado de direito administrativo: teoria do direito administrativo. Rio de Janeiro: Forense, 1966. v. 1.

4 MELLO, Oswaldo Aranha Bandeira de. Principios gerais de direito administrativo. Rio de Janeiro: Forense, 1979. v. 2; MELLO, Oswaldo Aranha Bandeira de. Princípios de direito administrativo. 3. ed. São Paulo: Malheiros, 2007. v. 1. Nesse mesmo sentido, Ruy Cirne Lima esclarece que "a palavra administração, nos quadros do direito privado, designa a atividade do que não é proprietário - do que não é senhor absoluto. [...] opõe-se a noção de administração à de propriedade nisto que, sob administração, o bem se não entende vinculado à vontade ou personalidade do administrador, porém à finalidade impessoal a que essa vontade deve servir”. LIMA, Ruy Cirne. Princípios de Direito Administrativo. São Paulo: Malheiros, 2007. p. 36-37.

5 Nessa acepção, também: GARCÍA ENTERRÍA, Eduardo; FERNÁNDEZ, Tomás-Ramón. Curso de derecho administrativo. 16. ed. Madrid: Civitas, 2013. v. 1. p. 535 e ss.

6 Os atos administrativos desempenham imprescindível papel na ação administrativa, quer seja ela de natureza processual e em contraditório, ou, por outro lado, diretamente material. Consoante assinala Carlos Bastide Horbach, "a Teoria da Ação Administrativa, ao longo de aproximadamente 200 anos de dogmática administrativista, aprofundou o estudo de duas formas centrais de estruturação jurídica do agir administrativo: os atos administrativos, tradicionalmente apresentados como o principal meio de expressão da função administrativa do Estado e os contratos administrativos" HORBACH, Carlos Bastide. Contratos administrativos: conceito e critérios distintivos. Rev. Bras. Polít. Públicas, Brasília, v. 6, n. 1, p. 52-68, 2016.

7 Anote-se que o processo administrativo, disciplinar ou comum, compreende uma relação bilateral, formada pela Administração Pública e o administrado, agente público ou particular, mas, todavia, não se confunde com o contrato adminsitrativo, na medida em que ambos, processo adminsitrativo e contrato administrativo, são espécies de relação administrativa bilateral, em oposição à relação unilateral e, nessa medida, "en la actividad administrativa, junto con las manifestaciones de carácter unilateral se desarrollan acciones bilaterales en las que la Administración Pública entabla relaciones con otros sujetos [...]”REZZOAGLI, Bruno Ariel. Contratos públicos y mercado global: un abordaje desde el derecho administrativo del siglo XXI. Rev. Bras. Polit. Públicas (Online), Brasília, v. 6, n. 1, p. 28-41, 2016. p. 29-30.

8 A complexidade aqui investigada como fenômeno jurídico pode ser identificada com a teoria da complexidade, estudada por Edgar Morin MORIN, Edgar. Introdução ao pensamento complexo. Tradução de Eliane Lisboa. 5. ed. Porto Alegre: Sulina, 2015; MORIN, Edgar. O método 6: Ética. Tradução de Juremir Machado da Silva. 4. ed. Porto Alegre: Sulina, 2011.

9 Sobre a natureza e os fins constitucionais do processo administrativo disciplinar na ordem jurídica brasileira, $c$, por todos, BACELLAR FILHO, Romeu Felipe. Processo administrativo disciplinar. 4. ed. São Paulo: Saraiva, 2013. 
normas tipificadoras de ilícitos, normas processuais e normas sancionadoras ao caso concreto, submetidas a exame do Estado-administração ${ }^{10}$.

Essas categorias, a verterem-se na essência dos conceitos jurídicos de "ilícito administrativo", "processo" e "pena", são elementares ao regime jurídico estatutário-disciplinar, na medida em que se encontram estampadas em textos normativos diversos, todavia sistemicamente interdependentes, e, não obstante, submetidos à interpretação e à aplicação, sob o amparo das teorias do Direito, mormente as teorias (i) geral do processo e (ii) das nulidades do ato administrativo.

O sistema de direito disciplinar é jurídico e se submete à lei e ao direito - a ciências jurídicas e aos aportes teóricos corolários: em especial à teoria geral do processo e à teoria das nulidades materiais e processuais dos atos administrativos.

Atos prescritores de ilícitos disciplinares, atos descritores de sanções disciplinares e atos administrativos materiais que, em ambiente processual, transformam-se em atos administrativos processuais, dependem, mutuamente, da Teoria Geral do Processo e da Teoria Geral das Nulidades dos Atos Administrativos, para, de modo hígido e, destarte, existente e válido, chegarem ao objetivo final da persecução disciplinar com caráter eficiente e eficaz. Isso se dá, entretanto, não com o objetivo mecânico e incondicionado de aplicação da pena à situação fática diante de eventual notícia de infração à lei, mas sim de apuração da verdade processual, suficiente ao aperfeiçoamento, por corolário e, se for o caso, de constatação de responsabilidades, do direito de punir do Estado, com a aplicação concreta da sanção.

A sanção, no entanto, não é em si o fim do plexo de atos cronologicamente encadeados, mas a consequência do procedimento dialético que caracteriza o processo administrativo. Com efeito, em primeiro lugar, o processo administrativo busca reparar a ordem normativa desrespeitada, por intermédio da elucidação dos fatos com o aclarar da verdade processual; por consequência desse propósito, chega-se, também, no caso de constatação de responsabilidades, à estipulação e aplicação de sanção disciplinar.

Esse propósito, na essência, é o mesmo para os diversos ramos do direito punitivo em geral, afigura-se ora mais instrumentalizado, por meio do exercício da jurisdição, ora menos aparelhado, por institutos investigativos, mas, seja como for, não compreendem infração disciplinar e processo fins em si mesmos, mas meios de tutelas de direitos constitucionais fundamentais, garantias de limitação de uma aplicação da pena por força de uma medida direta e sem processo, sem averiguação, sem apuração e, com efeito, sem os corolários de garantias fundamentais, carreados ao procedimento por meio do processo, como relação jurídica em contraditório.

À vista da abordagem dos meandros epistemológicos do direito estatal punitivo e da relação intrínseca entre função pública e dever-poder disciplinar, busca-se demonstrar a inter-relação de complexidade e de interdependência entre as categorias jurídicas que formam a base e, paradoxalmente, a irradiação de essência da persecução sancionadora disciplinar da Administração Pública, mormente com base nas identidades categóricas que pervagam pelo direito penal e pelo direito disciplinar.

\section{DistinçÃo ePISTEMOlógica POR DEPENDÊnCIA dOS OBJetos MATERIAL E PROCESSUAL do DIREITO PUNITIVO ESTATAL}

A instrumentalidade e a correlação entre ato, procedimento e processo situam-se - em que pese a isso se dar sutilmente - na dependência do peculiar objeto de cada ramo do Direito ${ }^{11}$. As unidades de repartição epis-

10 COSTA, José Armando da. Teoria e prática do processo administrativo disciplinar. 3. ed. Brasília: Brasília Jurídica, 1999; COSTA, José Armando da. Incidência aparente de infrações disciplinares. Belo Horizonte: Fórum, 2004; COSTA, José Armando da. Direito disciplinar: temas substantivos e processuais. Belo Horizonte: Fórum, 2008; COSTA, José Armando da. Direito administrativo disciplinar. 2. ed. São Paulo: Método, 2009.

11 Sobre o regime jurídico administrativo, em sentido lato, $c$, por todos: MELLO, Celso Antônio Bandeira de. Curso de direito 
temológica possuem objetos sensivelmente distintos uns dos outros, o que se lhes atribuem diferenciadas autonomias científicas. Por exemplo, o processo civil e o processo penal, jurisdicionalizados e dotados, por isso e em tese, de uma maior certeza de concreção do Direito e de pacificação social, instrumentalizam os seus processamentos de modo deveras distinto dos processos administrativos, mormente no caso brasileiro, em que a legislação não prevê o clássico contencioso administrativo nos moldes, por exemplo, dos países europeus $^{12}$. Não há o exercício da jurisdição por meio da realização de qualquer procedimento administrativo, incluindo-se neste artigo também os processos disciplinares, que, nisso, malgrado dotados de carga punitiva, distinguem-se do congênere processo jurisdicional penal ${ }^{13} /{ }^{14}$.

De tudo, a distinção é explicável. As ciências jurídicas possuem seus objetos de estudo delimitados pela dogmática a definir as nuances epistemológicas de cada ramo do Direito ${ }^{15}$, a dotarem-se de estudos detalhados e delimitativos dos princípios informativos, dos postulados e regras essenciais e dos métodos, assim como dos resultados, com base no conhecimento científico de teorias do Direito ${ }^{16}$.

Formam-se, sob esse olhar, a divisão dicotômica entre o direito público e o direito privado e os ramos a vinculados, e.g., do direito constitucional, do direito civil, tributário, administrativo, penal, processual civil e processual penal, dentre tantos outros ${ }^{17}$. Cite-se o direto constitucional, que apresenta como objeto de estudo a organização político-jurídica fundamental a representar-se pela constituição política do Estado, com o fim de estruturação de uma ordem nacional e geral de segurança e paz jurídicas e sociais ${ }^{18}$.

Por exemplo, o direito penal, assim como qualquer outro ramo do Direito (inclui-se aqui também o direito administrativo disciplinar), considera-se, indistintamente, direito positivo e ciência. Esta, a ciência do direito penal, incide sobre aquele, o direito positivo, fazendo vezes de instrumento metalinguístico, para o seu estudo, de modo a abarcar no âmbito de investigação, as normatizações sancionatórias de natureza criminal, editadas pelo Estado, para a proteção, sem embargo da imprescindível e efetiva observância dos direitos e garantias dos acusados, de bens jurídicos socialmente relevantes ${ }^{19}$.

O direito disciplinar levado a efeito pelo Estado-administração também, a exemplo do direito penal, visa proteger bens jurídicos, bens relevantes para o convívio social, porém, em menor medida, uma vez que se quedam adstritos aos meandros de espaço e de interesse dos afazeres funcionais administrativos. Compreen-

administrativo. 32. ed. São Paulo: Malheiros, 2015.

12 Sem embargo da possibilidade, na experiência brasileira, de relação direta entre a Administração Pública e o particular administrado, a exemplo do direito de petição aos poderes públicos e da previsão do devido processo legal (respectivamente, art. $5^{\circ}$, XXXIV, "a", e LV, da CF/88), o fato é que não se permite falar em exercício de jurisdição no seio do processo adminsitrativo. A jurisdição, em matéria administrativa, deve ser objetivada em sede de Poder Judiciário, e, para tanto, a Constituição Federal brasileira estipula o princípio da ubiquidade ou da inafastabilidade da jurisdição (art. $5^{\circ}$, XXXV, da CF/88). Por outro lado, em realidade distinta se afigura a jurisdição contenciosa, e.g, europeia, em que se percebem características jurisdicionais no âmbito da própria ação administrativa. Para aprofundamento do tema "jurisdição contencioso-adminsitrativa", cf: GARCÍA ENTERRÍA, Eduardo; FERNÁNDEZ, Tomás-Ramón. Curso de derecho administrativo. 16. ed. Madrid: Civitas, 2013. v. 1. p. 582 e ss., em que o autor desenvolve o tema "La jurisdcción contencioso-administrativa: naturaleza, extensión, límites".

13 CORREIA, Sérvulo. Direito do contencioso administrativo. Lisboa: Lex, 2005.

14 Maurice Hauriou resalta que existe uma dualidade para os casos de soluções administrativas, em que as não judicializadas, decididas pela própria Administração Pública, seriam levadas a efeito por meio de atos administrativos, ao passo que as soluções judicializadas, no caso da experiência francesa por via do contencioso administrativo, haveria de fato uma solução em forma de decisão, no caso de real natureza jurisdicional. Desse modo, dois seriam os campos de resolução dos processos: o primeiro, no seio da própria Administração; o segundo no bojo do processo jurisdicional de Contencioso Administrativo. CfHAURIOU. Maurice. La gestion administrative. Étude théorique de droit administratif. Paris: Éditions Dalloz, 2010, páginas do “avant-propos”, especialmente a que se refere a "la dialité des décisions administratives".

15 DUTRA, Luiz Henrique de Araújo. Introdução à epistemologia. São Paulo: UNESP, 2010.

16 BERGEL, Jean-Louis. Théorie générale du droit. Paris: Dalloz, 2003. p. 21.

17 "Para fazer esse seccionamento na unidade da Ordem Jurídica, de modo a decompô-la em Direito Civil, em Direito Comercial, Direito Criminal, Direito Constitucional, Direito Administrativo etc., é preciso começar por fixar as características de cada setor e os seus elementos diferenciais, aquilo que vai ser a pedra de toque para se poder dizer: esta norma é civil, esta norma é criminal, esta é administrativa...". CAETANO, Marcelo. Princípios fundamentais do direito administrativo. Rio de Janeiro: Forense, 1977. p. 21-22.

18 CANOTILHO, J. J. Gomes. Direito constitucional. 7. ed. Lisboa: Almedina, 2000.

19 Cf SIQUEIRA, Galdino. Tratado de Direito penal: parte geral. Rio de Janeiro: J. Konfino Editor, 1947. v. 1. 
de o matiz de estudo de uma face do direito administrativo, que, por seu turno, incide sobre a Administração Pública e as normatizações jurídicas constitucionais, legais e infralegais produzidas com base na atividade administrativa para a gestão da coisa pública ${ }^{20}$.

Por essa óptica, o direito disciplinar há de se desenvolver sobre esses dois pilares: (i) observância da necessidade de proteção, por meio de sanção, a bens jurídicos relevantes em um ambiente de caráter geral de direito sancionador, (ii) sem perder de vista a sua origem em ramo jurídico dedicado à gestão pública, na busca da concreção do interesse público, e não na busca de normatização geral e abstrata a todo o coletivo social. Daí a noção de relação especial de sujeição ${ }^{21}$ a ditar os limites do dever-poder disciplinar, assim como a delimitar todo e qualquer ramo do direito administrativo sancionador.

Esse método é comum ao direito comparado, na medida em que, também, no direito estrangeiro, a normatização se sustenta como objeto científico, dedicado a servir de via a identificar as relações jurídicas sistêmicas e, por corolário, as unidades orgânicas atinentes às mais diversas disciplinas do Direito, enquanto expressas como texto e norma ${ }^{22}$. Com efeito, dentro desse viés epistemológico, seja como for, a Administração Pública decide processos disciplinares, com o emprego do livre convencimento motivado, à luz da lei e do Direito (princípio a juridicidade administrativa, estipulado no art. $2^{\circ}$, Parágrafo Único, I, da Lei 9.784/99), a exemplo do método de decisão judicial, mas, ao Poder Judiciário submetido, no que se reporta à possibilidade de revisão das decisões processuais (art. $5^{\circ}, \mathrm{XXXV}$, da $\mathrm{CF} / 88$ ).

Sob a óptica ora expressa, por mais que o direito disciplinar apresente um importante papel de aplicação de faceta do direito punitivo a determinado grupo de indivíduos submetidos ao Estado por relação de sujeição especial, para a experiência brasileira não se encontra absolutamente alheio ao controle jurisdicional de seus atos, na medida em que, por opção de ideal epistemológico, caracteriza-se pela ausência de uma jurisdição administrativa.

\section{Administração Pública, processo punitivo "interna Corporis" e fUnÇão ADMINISTRATIVA}

Como deixado implícito nas verbalizações alhures, o conceito comum do vocábulo "administração", derivado da ação de "administrar", envolve a noção de organizar, de gerir, de curar, patrimônio alheio e, na sua concepção publicística esposada pela doutrina tradicional, demanda a busca finalística do bem comum do corpo sociall ${ }^{23}$, da coletividade organizada, por meio do Estado, que se afigura pretender também por intermédio de medidas administrativas a concretização de um Estado Democrático e Social e de Direito ${ }^{24}$. Busca, assim, prover o interesse público, com emprego de recursos também públicos e, excepcionalmente particulares, à sua satisfação eficaz e eficiente ${ }^{25}$.

20 Por todos: CRETELLA JUNIOR, José. Tratado de direito administrativo: teoria do direito administrativo. Rio de Janeiro: Forense, 1966. v. 1.

21 Cf WIMMER, Miriam. As relações de sujeição especial na administração pública. Direito Público, n. 18, p. 31-43, trimestral, 2007.

22 Cf RIVERO, Jean. Curso de direito administrativo comparado. São Paulo: Revista dos tribunais, 2004; RIVERO, Jean. Droit administratif. Paris: Éditions Dallos, 2011.

23 Sobre o conceito de "administração pública”, of GARCÍA ENTERRÍA, Eduardo; FERNÁNDEZ, Tomás-Ramón. Curso de derecho administrativo. 16. ed. Madrid: Civitas, 2013. v. 1; SANDULLI, Aldo M. Manuale di direitto amministrativo. 15. ed. Napoli: Casa Editrice Dott. Eugenio Joveni, 1989. v. 1; CRETELLA JUNIOR, José. Tratado de direito administrativo: teoria do direito administrativo. Rio de Janeiro: Forense, 1966. v. 1.

24 Sobre a superação do Estado Liberal pelo Estado Social e deste pelo Estado Democrático de Direito, cf CRUZ, Álvaro Ricardo de Souza. Habermas e o direito brasileiro. 2. ed. Rio de Janeiro: Lumen Juris, 2008; HABERMAS, Jürgen. Direito e democracia: entre facticidade e validade. Tradução de Flávio Beno Siebeneichiler. Rio de Janeiro: Tempo Brasileiro, 2003. v. 2; FIORAVANTI, Maurizio. Constituición. De la antigüedad a nuestros días. Traducción de Manuel Martínez Neira. Madrid: editorial Trotta, 2001. Cf ainda FIORAVANTI, Maurizio. Stato di diritto e Stato amministrativo nell'opera giuridica di Santi Romano. I giuristi e la crisi dello Stato liberale in Italia. Napoli: Liguori, 1986. p. 309-346.

25 SERNA, Pedro Gomez de la. Instituciones del derecho administrativo español. Madrid: Imprenta de D. Vicente de Lalama, 1843. p. 13, 
A palavra "administração", em que pese a também ser empregada na seara privada para se reportar às atividades e às organizações submetidas ao direito privado, em âmbito público designa a atividade de administrar fatos e de gerir afazeres de interesse público, assim como os de organizar e regular os entes e órgãos que se dedicam a esses encargos, ou seja, pelo viés subjetivo, os atores que exercem essas atividades, assentando os conceitos material e orgânico, respectivamente, de Administração Pública ${ }^{26}$.

A partir da premissa distinta do que se pensou até meados do século XIX, que a personalidade jurídica de direito público se direcionava a cada função de repartição de poderes a entender os Poderes Legislativo, Executivo e Judiciário como pessoas jurídicas distintas, atualmente a personalidade jurídica pertence, integralmente e sem secção, ao Estado, a assinalar que a atividade administrativa e, destarte, a Administração Pública encontram-se presentes nas três esferas de repartições de funções dos Poderes. É encontrada, desse modo, nos Poderes referidos Legislativo, Executivo e Judiciário, não mais um instituto exclusivo do Poder Executivo ${ }^{27}$.

Nesse contexto, é de interesse dos três Poderes da República administrar o patrimônio social por meio do exercício de suas funções típica e atípicas, em que se insere o exercício da atividade de controle das condutas ilícito-administrativas interna corporis.

Assim, o processo administrativo disciplinar, embora não jurisdicional, não é instituto exclusivo dos regimes jurídicos do Poder Executivo. Encontra-se previsto na ordem reguladora de todas as pessoas políticas nacionais - União, Estados e Municípios - e nos três Poderes da República - o legislativo, o executivo e o judiciário -, no exercício de funções típicas e atípicas de controle da disciplina interna dos que ocupam cargos e funções públicas.

\section{INTERAÇÃo COMPLEXA ENTRE OS SUB-RAMOS DO DIREITO PUNITIVO ESTATAL E ENTRE O ATO, O PROCEDIMENTO E O PROCESSO, NO ÂMBITO DA FUNÇÃO PUNITIVA DISCIPLINAR}

A ação de administração pública, sob os aspectos material e orgânico, compreende as tarefas gerais, ativas ou omissivas, de tutela e de emprego de recursos e de métodos, pelos três Poderes da República. E, dentro desses pressupostos, a ação estatal se posta também a abarcar a utilização de procedimentos administrativos, em maior ou em menor grau, para todo e qualquer fim a cargo do Estado em sua função executiva. O gestor público vale-se de instrumentos jurídicos, lançados como meios aptos à obtenção dos resultados pretendidos, nos quais se inserem, na qualidade instrumental em uma primeira mirada, os procedimentos sancionadores comuns da Administração e, no que tange ao controle da disciplina e à persecução apuratória, os atos administrativos disciplinares e os procedimentos disciplinares. Estes são institutos constitucionalmente qualificados, destinados à prevenção, à reparação e à manutenção da ordem interna dos serviços públicos, que, por vias do exercício instrumental do sistema de poder administrativo sancionador ${ }^{28}$, exaurem efeitos nos moldes de uma "autotutela ativa ou agressiva" 2 . Para o controle da disciplina interna, a Administração não se comporta de modo omissivo, passivo, no âmbito da apatia de a situação se conformar por si ou por conta de particulares interessados. Apresenta-se, assim, o dever de agir com oficiosidade, ou seja, de ação de ofício, independentemente de provocação de qualquer interessado.

já afirmava em meados do século XIX que o significado de administração "se limita al poder ejecutivo, y es la accion de sus diversas partes, ó lo que es ló mismo, el conjunto de medios por los cuales las leyes se ejecutan”. SERNA, Pedro Gomez de la. Instituciones del derecho administrativo español. Madrid: Imprenta de D. Vicente de Lalama, 1843. Hoje tal conceito está afeto não somente ao poder executivo, mas também aos demais, legislativo e judiciário, abarcando a noção de funções típicas e atípicas dos poderes da república.

26 Cf RIVERO, Jean. Droit administratif. Paris: Éditions Dallos, 2011.

27 GARCÍA ENTERRÍA, Eduardo; FERNÁNDEZ, Tomás-Ramón. Curso de derecho administrativo. 16. ed. Madrid: Civitas, 2013. v. 1. p. $50-51$.

28 LLOBREGAT, José Garberí. Derecho administrativo sancionador prático. Barcelona: Editorial Boch, 2012. v. 1.

29 Sobre o termo "autotutela agressiva", como ação administrativa ex officio, of GARCÍA ENTERRÍA, Eduardo; FERNÁNDEZ, Tomás-Ramón. Curso de derecho administrativo. 16. ed. Madrid: Civitas, 2013. v. 1. 
Sob esse cariz de gestão de uma finalidade intermediária de controle para a regularidade, eficiência e eficácia da garantia de, ao menos, buscar-se o bem comum da coletividade administrada, com o manejo de atos e de procedimentos, à Administração Pública, com o uso dos textos normativos, do ordenamento jurídico e do princípio da legalidade ${ }^{30}$, apresenta-se o dever-poder disciplinar, faceta do dever-poder de persecução correcional e sancionatória - persecução pré-processual e persecução processual -, com a incumbência de elucidação das condutas administrativas ilícitas, praticadas por servidores a ela ligados por relação jurídica de direito material estatutário. Constatam-se a complexidade de inter-relação entre os aspectos subjetivo, orgânico, e objetivo, material, rizomaticamente ${ }^{31}$ intrincados e interdependentes, a envolverem regimes normativos (i) dos sujeitos processuais e (ii) dos efeitos jurídicos produzidos pelos atores processuais.

Atos e procedimentos administrativos viabilizam a atuação disciplinar da Administração Pública. São instrumentos aplicados à concretização desse múnus, sem se esquecer da relação jurídica processual, a formar-se entre os sujeitos do processo e dos direitos e deveres constitucionais fundamentais a eles atinentes.

Por via reflexa, a par da apuração da infração e por força do princípio da responsabilização, vislumbra-se a busca de aplicação da reprimenda legalmente definida como apropriada a cada situação e, assim, a atuação do escopo tutelar da Administração Pública na manutenção do bem comum coletivo. Para tanto, no desencadeamento do processo, o Estado age com base nas noções dos princípios da obrigatoriedade, da oficiosidade e da oficialidade, como faceta da indisponibilidade do interesse público. Logo, atos administrativos e procedimentos administrativos, no campo da atuação disciplinar, submetem-se a regime jurídico apropriado aos fins específicos do instrumento sancionador estatutário. Atos e procedimentos administrativos, harmonizados à ordem jurídica, impulsionam o Estado à operacionalização do poder de controle da disciplina interna, ao amparo do devido processo legal sancionador.

A subsunção da prescrição da conduta do agente público à descrição de sanção estatutária e a sua consequente execução constituem exercício desse poder disciplinar, autotutela sancionadora ${ }^{32}$, a que nos referimos como potestade formada pela composição entre o direito de apurar, de processar e de punir e que, a somar-se à competência jurisdicional dos órgãos do Poder Judiciário, integra, em sua totalidade, o jus persequendi e o jus puniendi de caráter penal geral do Estado, vertida a confirmar, sob essa óptica, a unicidade ou indivisibilidade do direito punitivo estatal. A persecução disciplinar e a persecução administrativa geral, assim como a persecução penal, são apenas manifestações concretas desse perfil publicístico de imperatividade e coercibilidade do Estado, na tarefa de manutenção, em um sentido macro, da ordem social. Apresenta-se, assim, como poder geral de persecução e punição do Estado ${ }^{33}$.

O direito administrativo disciplinar, destarte, sem embargo de sua específica processualidade, perfaz ramo do direito sancionador geral ${ }^{34} / 35$ e o seu exercício envolve claramente ${ }^{36}$ a operacionalização do dever- poder disciplinar, em sua conotação de aplicação de sanções, no caso as sanções administrativas, em suas subespécies disciplinares, aos agentes públicos que se encontram inseridos em ambiente formado por rela-

30 GARCÍA ENTERRÍA, Eduardo; FERNÁNDEZ, Tomás-Ramón. Curso de derecho administrativo. 16. ed. Madrid: Civitas, 2013. v. 1. p. $475-531$.

31 Sobre o uso da expressão "rizoma” em filosofia, cf: DELEUZE, Gilles; GUATTARI Félix. Mil Platôs: capitalismo e Esquizofrenia. Tradução de Aurélio Guerra Neto e Célia Pinto Costa. Rio de Janeiro: Editora 34, 1995, v. 1.

32 NIETO, Alejandro. Derecho administrativo sancionador. 5. ed. Madrid: Tecnos, 2012.

33 NIETO, Alejandro. Derecho administrativo sancionador. 5. ed. Madrid: Tecnos, 2012. p. 24.

34 DELLIS, Georges. Droitpenal et droit administratif: L'influense des príncipes du droit pénal sur droit administratif répressif. Paris: Librarie Générale de Droit et Jurisprudence, E.J.A, 1997.

35 Nesse sentido, "al respecto, con apoyo en la dogmática como ciencia del Derecho que tiene como fundamento la identificación de las instituciones a partir de un trabajo conceptual fundado en las diferencias y semejanzas, así como en las nociones de género a especie o de especie a especie, Carlos Arturo Gómez Pavajeau, sostiene que el Derecho penal y el Derecho disciplinario son dos especies, junto a otras, del Derecho sancionador o ius puniendi del Estado.” CASTILLO, Jaime Alonso Zetién et al. El injusto en el derecho disciplinário. Revista Derecho Penaly Criminología, v. 34, n. 97, p. 159-174, jul./dic. 2013. p. 162.

36 A par da interpretação de suas normas de modo a observar, sem perder de vista as suas origens de direito administrativo empregado na realização do bem comum, do bem coletivo, os direitos de garantias dos particulares e agentes públicos envolvidos nas questões examinadas - a exemplo do direito penal geral. 
ção estatutária, funcional de serviço público com o Estado e, após o devido processo legal, sejam considerados responsáveis por infrações administrativas.

Como ramo do direito sancionador e do direito administrativo, o direito disciplinar equilibra a busca do bem comum, representado pelo dever de elucidação de infrações e de reestruturação da ordem no serviço, com os direitos e as garantias dos agentes públicos envolvidos na relação processual, de modo a não suplantar a dignidade normativa (prevista pela ordem jurídica) de todo e qualquer acusado à supremacia do interesse público ${ }^{37}$, o que já se afere pacífico em sede de direito penal e se estende ao direito administrativo em seu vértice punitivo.

Isso caracteriza, de modo pormenorizado, a tese da unicidade do poder punitivo do Estado, malgrado epistemologicamente subpartida em suas duas manifestações, quais sejam a penal e a administrativa, como ressaltado por Alejandro Nieto, ao afirmar que "la potestad administrativa sancionadora, al igual que la potestad penal de los Jueces y Tribunales, forma parte de un genérico ius puniendi del Estado, que és único aunque luego se subdivide en estas dos manifestaciones" ${ }^{\prime 3}$.

O sistema jurídico formado em decorrência do conjunto de normas de direitos e de garantias fundamentais atinentes aos acusados em geral, limitativos - ou, mais precisamente, balizadores - do jus persequendi e do jus puniendi estatal, perfaz subsistema de um mais abrangente direito penal estatal, como poder de controle, organização, proteção e responsabilização, entregue ao Estado e direcionado a envolver e englobar o direito penal de sanções privativas de liberdade e, não obstante, o direito penal de aplicação de sanções gerais administrativas $^{39}$. Todo esse sistema geral encontra-se limitado em seus contornos de coerção por princípios e regras de garantia, em um feixe de normas jurídicas dedicadas à observância da dignidade humana do administrado, ora o particular, ora, no caso em que nos detemos, o agente público submetido a processo disciplinar. Apesar dos limites e dos contornos postos pela epistemologia, a necessidade de dialogicidade e de recursividade afeta ao plexo sistemático punitivo, de contornos abalizados ao Estado Democrático de Direito, irradia normatividade também ao sub-ramo do Direito que ora nos detemos à investigação, submetendo, sem perder de vista o sistema de direito administrativo, toda a sua análise, interpretação e aplicação, aos parâmetros de um direito sancionador geral. Se o direito penal e o direito disciplinar perfazem sub-ramos de um direito punitivo maior e geral do Estado, suas teorias de base necessariamente se comunicam, para atrair a incidência de direitos fundamentais de garantia aos acusados e processados, mormente quanto aos institutos já desenvolvidos em sede de direito penal, como ramo punitivo estatal por excelência. A "recursividade" ou "referenciações mútuas" desses ramos punitivos e de seus sub-ramos material e processual se encontram na ação e na retroação, ambas reflexivas, postas em influências de efeitos recíprocos. A esse fenômeno, Edgar Morin - sem se reportar à seara do Direito, mas a ele plenamente aplicável - refere-se como "causalidade recursiva", caracterizada pela codependência sinalagmática entre a parte e o todo, à vista do que "no processo recursivo, os efeitos e produtos são necessários para o processo que os gera. O produto é produtor do que o produz" ${ }^{40}$. Esse comportamento mútuo-referencial se apresenta, também, intrassistêmico, no âmbito de cada ordem normativa sancionadora, como no caso do direito disciplinar na qualidade de disciplina epistemológica autônoma, à vista da relação complexa entre ato processual e processo, como produtor e produto do direito sancionador.

O fenômeno de "recursividade" atrai, assim, regulações diversas de garantias na concepção e formação das normas e nas suas execuções, a exemplo das obrigações (i) ao legislador, quanto à edição das normas de natureza

37 NIETO, Alejandro. Derecho administrativo sancionador. 5. ed. Madrid: Tecnos, 2012. p. 25.

38 NIETO, Alejandro. Derecho administrativo sancionador. 5. ed. Madrid: Tecnos, 2012. p. 46.

39 Nesse sentido, of DELLIS, Georges. Droit penal et droit administratif: L'influense des príncipes du droit pénal sur droit administratif répressif. Paris: Librarie Générale de Droit et Jurisprudence, E.J.A, 1997; FENOUILLET, Cécile Chainais Dominique et al. Les sanctions en droit contemporain: la sanction, entre techinique et politique. Paris: Dallos, 2012. v. 1; FENOUILLET, Cécile Chainais Dominique et al. Les sanctions en droit contemporain: La motivation des sanctions prononcées en justice. Paris: Dallos, 2013. v. 2; BENESSIANO, William. Légalité pénale et droits fondamentaux. Marseille: Universitaires D’aix-Marseille, 2011.

40 MORIN, Edgar. Introdução ao pensamento complexo. Tradução de Eliane Lisboa. 5. ed. Porto Alegre: Sulina, 2015. p. 87. 
sancionatória disciplinar, e (ii) às autoridades administrativas encarregadas da interpretação e aplicação da norma, para a observância, e. g., da atuação conforme a lei e o Direito, da utilização de método de valoração de provas coerente e harmônicos com outros ramos do Direito, da proibição de retroatividade da lei não interpretativa, da proibição de definição aberta de ilícitos ou sanções, da proibição da previsão de responsabilidade objetiva, do devido processo legal etc. ${ }^{41} \mathrm{O}$ direito punitivo geral do Estado, em uma espécie de "romance em cadeias" coadjuvantes comportam o legislativo e o executivo -, passa a ser regulado por suas normatividades sistêmicas preexistentes, orientando de modo teleológico o campo das possibilidades de validades normativas, vinculativas, tanto dos seus intérpretes e aplicadores, quanto dos autorizados à produção das leis, as inovações legislativas.

Nesse arcabouço, aferem-se importantes identidades de categorias entre o direito penal e o direito administrativo, mormente o direito disciplinar. Por uma rápida mirada, muito se diz que o direito administrativo e o direito penal se apresentam notadamente como ramos epistemologicamente autônomos das ciências jurídicas $^{43}$ e isso se afigura de plena constatação e ao ponto de a doutrina e o direito positivo somente de modo escasso se importarem com as inter-relações que por ventura se venham a formar entre eles, salvo para os casos de definição de competências e de atribuições, que, todavia, mesmo assim, permitem a possibilidade de uma análise menos atenta, para atrair a aceitação de incidência de bis in idem punitivo, sem que isso seja tachado de ilegítimo e ofensor dos padrões de justiça, buscada pelo processo e, com efeito, pelo Direito.

Isto nos faz assinalar a necessidade de desconstrução das ideias preconcebidas de rígidas autonomias ente os diversos ramos do direito sancionador. O Estado se vale de instrumentos normativos semelhantes para a repressão e controle, quer seja da ordem pública e geral, quer seja da ordem interna das corporações e dos órgãos dos serviços públicos. "A repressão penal tem de fato uma natureza pública; ela é uma manifestação do poder público, assim como a maior parte das ações administrativas" publicística do Direito a se estender ao âmbito do direito administrativo e administrativo disciplinar, "segundo a teoria positiva prevalecente, o direito, ordem social de conduta humana, é um fenômeno homogêneo que não deve ser um objeto fragmentado" 45 .

Hão de se conceber normas semelhantes (ou mesmo idênticas e interdisciplinares) para a obtenção de efeitos semelhantes. Entre os ramos do direito punitivo geral, os princípios exercem esse importante papel de uniformidade do exercício do poder do Estado e da certeza jurídica de suas ações na atividade de persecução apuratória e punitiva.

Os ramos do direito sancionador geral, a exemplo, como referidos, do direito penal e do direito administrativo punitivo - e aqui, o direito disciplinar -, possuem o mesmo "esquema de coerção" ou de ameaça de sanção para a imperatividade de seus preceitos. A norma proibitiva, assim, pode ser entendida como 'ordem

41 Mister reparar que, ao lado do legislador, o intérprete e aplicador da norma também possui certa função na construção do direito e, nesse viés, "não é nova nem esdrúxula a ideia de se admitir a presença de alguma carga de normatividade ou de um poder normativo em toda a interpretação/aplicação judicial do direito, seja ao nível inicial da jurisdição, nas decisões monocráticas, seja no topo da hierarquia judiciária, nos veredictos dos colegiados judicantes, especialmente das cortes constitucionais, cujas decisões, sobre serem irrecorríveis, têm efeito irradiante por todo o sistema jurídico de que fazem parte" COELHO, Inocêncio Mártires. Poder normativo das cortes constitucionais: o caso brasileiro. Revista Brasileira de Políticas Públicas, Brasília, v. 5, n. 2, p.15-27, 2015. p. 21.

42 Em uma espécie de vinculações angariadas nas normas postas e a ditar as normas futuras, conforme método idealizado por Ronald Dworkin em sua obra "O Império do Direito” DWORKIN, Ronald. O império do direito. São Paulo: M. fontes, 2007.

43 MORÓN, Miguel Sánchez. Derecho de la función pública. 8. ed. Madrid: Tecnos, 1996; DORD, Olivier. Droit de la fonction publique. 2. ed. Paris: Thémis droit - Puf, 2007; SOUSA, Rui Correia de. Lei geral do trabalho em funções públicas. Porto: VidaEconómica, 2014; CHAINAIS, Cécile; FENOUILLET, Dominique; GUERLIN, Gaëtan. Les sanctions en droit contemporain. Paris: Éditions Dalloz, 2013. v. 1; CHAINAIS, Cécile; FENOUILLET, Dominique; GUERLIN, Gaëtan. Les sanctions en droit contemporain. Paris: Éditions Dalloz, 2013. v. 2; SANDULLI, Aldo M. Manuale di direitto amministrativo. 15. ed. Napoli: Casa Editrice Dott. Eugenio Joveni, 1989. v. 1; SANDULLI, Aldo M. Manuale di direitto amministrativo. 15. ed. Napoli: Casa Editrice Dott. Eugenio Joveni, 1989. v. 2; MOURA, Paulo Veiga. Estatuto disciplinar dos trabalhadores da administração pública. 2. ed. Coimbra: Coimbra Editora, 2012.

44 DELLIS, Georges. Droit penal et droit administratif: L’influense des príncipes du droit pénal sur droit administratif répressif. Paris: Librarie Générale de Droit et Jurisprudence, E.J.A, 1997. p. 1-2.

45 DELLIS, Georges. Droitpenal et droit administratif: L'influense des príncipes du droit pénal sur droit administratif répressif. Paris: Librarie Générale de Droit et Jurisprudence, E.J.A, 1997. p. 1-2. 
de constrangimento que reage a um ato de constrangimento em algumas circunstâncias consideradas indesejáveis ${ }^{46}$, e, sob esse olhar, "a norma jurídica é uma prescrição de conduta caracterizada não pelo conteúdo da prescrição ordenada, mas pelo fato de uma ameaça de restrição que a acompanha. Portanto, as regras dos diferentes ramos do direito são materialmente idênticas" ${ }^{\prime 7}$.

Isto declina que, ao controle da disciplina do serviço público realizado pelo direito administrativo disciplinar, conquanto reconhecida essa vinculação teleológica ao ramo geral de direito sancionador, não se lhe apresenta a possibilidade de inovar em suas normas e teorias a ponto de provocar inobservância de princípios informativos e basilares que aloque a temática da persecução administrativa distintamente fora da delimitação de um Direito que visa à aplicação da sanção pelo Estado. Com efeito, ato administrativo processual e procedimentos disciplinares, para além de se interligarem para a formação do devido processo legal disciplinar, de persecução interna corporis, encontram-se vinculados a teorias afetas à estrutura da norma jurídica, mormente à norma proibitiva de condutas, e, do mesmo modo, ao método de persecução, de investigação, processo e sanção, já, de longa data, experimentados pelos ramos jurídicos de direito punitivo jurisdicionais. Sob essa óptica, não há possibilidades de inovações: as tipificações proibitivas prescrevem o proibido, com a pertinente cominação de sanção, e o arquétipo do "devido processo legal" é oferecido pelo regime jurídico apropriado e isso se dá quer seja para o direito penal, quer, por exemplo, para o direito tributário ou para o direito administrativo, mormente para o direito disciplinar.

Com isso, exempli gratia, a imputação e a sanção pelo emprego da "verdade sabida"48, outrora fartamente utilizada, ou a não tipificação das infrações disciplinares, ou mesmo a utilização de métodos inquisitórios de valoração das provas (a exemplo da aplicação do método da íntima convicção), assim como a atribuição de natureza testemunhal à pessoa que noticia o ilícito disciplinar (confusão entre "denunciante" e testemunha conflito entre a faculdade e o dever de dizer a verdade nas informações prestadas à Administração Pública), compreendem técnicas de concreção jurídica que devem ser abolidas por obra do legislador. E, por outro lado, em casos de omissão dos agentes legiferantes, essas técnicas devem ser contornadas, com o emprego do princípio da juridicidade, por ação do administrador público, intérprete e aplicador do direito disciplinar, para a manutenção da coerência interna do sistema, tendo em mira a segurança jurídica, a certeza e a justiça do Direito (aprimoramento das relações sociais, apresentando à ordem jurídica regras justas, a serem aplicadas de modo equitativo $)^{49}$, como expressão da ética e da moral a sustentarem todas as produções normativas

46 DELLIS, Georges. Droit penal et droit administratif. L'influense des príncipes du droit pénal sur droit administratif répressif. Paris: Librarie Générale de Droit et Jurisprudence, E.J.A, 1997. p. 1-2.

47 DELLIS, Georges. Droitpenal et droit administratif. L'influense des príncipes du droit pénal sur droit administratif répressif. Paris: Librarie Générale de Droit et Jurisprudence, E.J.A, 1997. p. 1-2.

48 Por "verdade sabida" entenda-se a aplicação da penal ou sanção sem o devido processo legal, à vista, apenas, do conhecimento do fato ilícito pela autoridade pública dotada de poderes punitivos. Nessa óptica afirma Miguel Sánchez Morón, ao comentar o regime disciplinar dos agentes públicos da Espanha, "como sanciones administrativas que son, las disciplinarias no pueden imponerse de plano, sino en virtude de un procedimento ad hoc" MORÓN, Miguel Sánchez. Derecho de la función pública. 8. ed. Madrid: Tecnos, 2014. p. 339. Sobre o tema, ente os autores brasileiros, conferir: COSTA, José Armando da. Processo administrativo disciplinar: teoria e prática. 6. ed. Rio de Janeiro: Forense, 2010. p. 90 e ss.

49 BERGEL, Jean-Louis. Théorie générale du droit. Paris: Dalloz, 2003. p. 22. 
abstratas e as suas concreções ${ }^{50} /{ }^{51}$.

O direito penal geral e o direito administrativo sancionador, do qual o direito disciplinar se faz parcela, tende a formar, com base no aporte sistemático da Constituição Federal brasileira de 1988, um macrorrepressivo estatal singularmente complexo, completo e harmonioso, posto à superação de antigas contradições entre normas e princípios existentes ora em um, ora em outro ramo do Direito, e capaz de operar a resolução, em seus limites e meandros, das dificuldades teóricas e práticas ${ }^{52}$.

Em que pese o interesse público ser teleologicamente dosado pelo legislador em harmonioso equilíbrio com os direitos e garantias fundamentais dos agentes públicos acusados de infração, não se pode dizer que nesse tema opera uma tendência à disposição desse interesse público e, com efeito, para o Estatuto Geral Federal instituído pela Lei 8.112/1990, e para os entes e órgãos por ele regidos, não há mera faculdade de desencadeamento da persecução disciplinar, mas sim uma imposição legal de apuração, consoante a determinação de que "a autoridade que tiver ciência de irregularidade no serviço público é obrigada a promover a sua apuração imediata, mediante sindicância ou processo administrativo disciplinar, assegurando ao acusado ampla defesa" (art. 143, Lei $8.112 / 90)$.

Nesses termos, afere-se a obrigatoriedade delimitada pelos contornos da oficialidade e da oficiosidade. O primeiro instituto, a oficialidade, a declinar a natureza oficial, pública, do processo, o segundo, a sua essência de tratar-se de uma "marcha" a mover-se por impulso ex offício, para o deslinde das questões apuradas. Todavia, isso se deve apresentar sem se descurar o intérprete e aplicador do direito sancionador da concepção multissistêmica, para transitar pelas normatividades dos diversos ramos do direito punitivo geral, de modo a obter a essência dos fins de garantia do direito punitivo, impondo um caráter equilibrado entre o direito processual e o direito material e, assim, entre as formalidades e a matéria de fundo a ser sopesada pelo processo.

\section{Considerações finais}

Por fim, como nos ramos dos direitos penal e processual penal, o jus puniendi levado a efeito pelo direito disciplinar pertence ao Estado, no caso em voga o Estado em sua função executiva, administrativa, o que podemos denominar de Estado-administração, que, partindo de atos de ofício, após o conhecimento da notícia do ilícito, desencadeia uma série de atos administrativos stricto e lato sensu, correlacionados, com finalidades específicas, a envolver compulsoriamente por força de império e em razão de seu poder disciplinar eventual servidor público acusado de ser autor de infração no âmbito administrativo.

A persecução disciplinar, nesses moldes, é desenvolvida inteiramente pela Administração, em seu ciclo completo, compreendendo o exercício do jus persequendi e do jus puniendi - a investigação e o processo, segui-

50 Sobre o conceito e as características aplicadas da ética moral e da ética jurídica, of ADEODATO, João Maurício. Filosofia do direito. Uma crítica à verdade na ética e na ciência. 5. ed. São Paulo: Saraiva, 2013, em que o autor se reporta à não distinção entre ética e moral, mas sim a uma ética que permeia a moral e o direito, para se apresentar como ética da moral e ética do direito. Estas se afiguram como espécie do gênero "Ética". Em similar sentido, of também: ARNALD, André-Jean. Critique de la raison juridique. Governants sans frontières. Entre mondialisation et post-mondialisation. Paris: Librarie Générale de Droit et de Jurisprudence, 2003; ATIENZA, Manuel. El derecho como argumentación. Concepciones de la argumentación. Barcelona: Ariel, 2006; DASCAL, Marcelo. Interpretação e compreensão. Tradução Marcia Heloisa Lima Rocha. São Leopoldo: Unisinos, 2006; FERNANDEZ-LARGO, Antonio Osuna. El debate filosófico sobre hermenêutica jurídica. Valladolid: Secretariado de Publicaciones, Universidad, 1995; FICHTE, Johann Gottlieb. Fundamentos do direito natural. Segundo os princípios da doutrina da ciência. Lisboa: Fundação Calouste Gulbenkian, 2012; LECLERC, Bruno; LÉTOURNEAU, Alain. Validité et Limites Du consensus em éthique. Paris: L’Harmattan, 2007; MORCHÓN, Gregorio Robles. El derecho como texto: cuatro estúdios de teoria comunicacional del derecho. 2. ed. Madrid: Civitas, 2006; ROSS, Alf. Direito e justiça. São Paulo: EDIPRO, 2003; VETÖ, M. La synthèse a priori kantienne comme l'essence commune de la liberte et du temps. In: RICCCEUR, Paul; PHILONENKO, Alexis. Revue de Métaphysique et de Morale, Paris: Librarie Armand Colin, p. 70-91, 1979.

51 Cf também: BEÇAK, Rubens. A dimensão ético-moral e o direito. Revista Brasileira de Direito Constitucional: RBDC, n. 9, p. $307-$ 320, jan/jun. 2007.

52 NIETO, Alejandro. Derecho administrativo sancionador. 5. ed. Madrid: Tecnos, 2012. p. 24. 
do de eventual aplicação de sanção punitiva, malgrado sem o exercício de jurisdição e, destarte, sob o manto da inafastabilidade do controle judicial.

Com efeito, diferentemente do processual penal (em que o jus puniendi encontra-se a cargo do Estado-juiz e o jus persequendi a cargo do Estado-administração), constata-se que não só o jus persequendi está a cargo da Administração Pública, mas também o jus puniendi, precedido do necessário ato de decisão, o julgamento do processo, pois a ela também cabe, com base no princípio da oficiosidade, dar início e andamento de ofício aos procedimentos previstos em lei e, ao final, sendo o caso, aplicar o direito ao caso concreto, culminando na sanção ou na absolvição do acusado. A Administração Pública instaura, instrui e decide o processo apuratório e, com base no teor do ato de decisão, aplica a sanção ou, sendo o caso, promove o arquivamento do processo, sem punição.

De toda forma, o direito de a Administração apurar e punir os agentes públicos infratores submetidos ao seu poder de império, de hierarquia e de disciplinar é veiculado por meio de instrumentos jurídicos apropriados para esse fim específico e legalmente previstos nos regimes disciplinares estatutários, consubstanciando, dentro do plexo do regime disciplinar dos servidores públicos, os procedimentos disciplinares - formados por um encadear finalístico de atos administrativos e, para o processo, também de atos particulares [atos dos agentes públicos acuados no processo], o que, no exemplo do Direito português se denomina concertação53-, dos quais o processo é espécie caracterizada pela existência prima facie, quanto à ocorrência do ilícito (direito material disciplinar), de indícios de autoria e de materialidade, sendo patente, destarte, por essa constatação, a formação de um litígio entre Administração e agente público, desenvolvido em um ambiente processual público, propício à acusação e ao exercício do contraditório e da ampla defesa ao acusado ${ }^{54} /{ }^{55}$.

Afere-se, assim, identidade de método de aplicação da sanção ao caso concreto entre os processos punitivos jurisdicionais e os processos punitivos administrativos, como facetas de um todo maior, o jus puniendi estatal. Por esse olhar, com um enfoque de unicidade do direito sancionador geral e de "recursividade" ou "referenciações mútuas", direito penal e direito disciplinar se autocompletam em teorias, com o fim de concreção de valores constitucionais, mormente quanto à realização de direitos fundamentais de todo e qualquer acusado e, nesses mesmos moldes, direito material e direito processual - e as suas unidades intrínsecas mínimas: atos das partes e atos administrativos - se dedicam, também, não somente à conclusão do processo, mas sim à sua conclusão em harmonia com o rol de direitos fundamentais estampados na Constituição Federal.

Ato administrativo e procedimento administrativo espelham-se nos atos congêneres dos demais ramos do direito punitivo e, assim, há de se verificar a interconexão entre a imprescindibilidade de apontamentos dos contornos da infração administrativa, para a higidez diante da ordem jurídica da relação processual e aqui se demonstra a necessidade de o processo servir à concreção do direito material, no caso o direito de defesa do acusado à vista do direito de punir do Estado, em que a instrumentalidade do processo e de seus procedimentos se aclara, para levar a relação jurídica formal (processual) a um patamar de busca da efetivi-

53 MONCADA, Luís S. Cabral de. A relação jurídica administrativa: para um novo paradigma de compreensão da atividade, da organização e do contencioso administrativo. Coimbra: Coimbra, 2009. p. 143.

54 COSTA, José Armando da. Teoria e prática do processo administrativo disciplinar. 3. ed. Brasília: Brasília Jurídica, 1999; COSTA, José Armando da. Incidência aparente de infraçôes disciplinares. Belo Horizonte: Fórum, 2004; COSTA, José Armando da. Direito disciplinar. temas substantivos e processuais. Belo Horizonte: Fórum, 2008; COSTA, José Armando da. Direito administrativo disciplinar. 2. ed. São Paulo: Método, 2009; COSTA, José Armando da. Processo administrativo disciplinar: teoria e prática. 6. ed. Rio de Janeiro: Forense, 2010; CRETELLA JUNIOR, José. Direito administrativo do Brasil: processo administrativo. São Paulo: Revista dos Tribunais, 1962.

55 Anote-se que mesmo conceito que parecem simples se mostram complexos em sua aplicação no cotidiano da Administração Pública e, por exemplo, "o direito à ampla defesa com todos os meios e recursos a ela inerentes apresenta conteúdo jurídico bastante abrangente e possui uma série de desdobramentos, os quais encontram-se previstos explícita e implicitamente na Constituição, na legislação ordinária e em tratados internacionais de direitos humanos" HACHEM, Daniel Wunder; PETHECHUST, Eloi. O direito humano à comunicação prévia e pormenorizada das acusações nos processos administrativos: $\mathrm{O}$ desprezo do Superior Tribunal de Justiça ao Pacto de San José da Costa Rica e à Corte Interamericana de Direitos Humanos. Revista de Direito Internacional, Brasília, v. 12, n. 2, p. 589-610, 2015. p. 597. 
dade, como instrumento de ética e de justiça ${ }^{56} /{ }^{57}$. O processo sancionador, caracterizado pela interatividade complexa entre ato, procedimento e processo concebido como relação jurídica em contraditório, apresenta-se como instrumento de justiça e essência da "atividade-ação" punitivo-disciplinar da Administração Pública.

\section{REFERÊNCIAS BIBLIOGRÁFICAS}

ADEODATO, João Maurício. Filosofia do direito: uma crítica à verdade na ética e na ciência. 5. ed. São Paulo: Saraiva, 2013.

ARNALD, André-Jean. Critique de la raison juridique: Governants sans frontières: Entre mondialisation et post-mondialisation. Paris: Librarie Générale de Droit et de Jurisprudence, 2003.

ATIENZA, Manuel. El derecho como argumentación. Concepciones de la argumentación. Barcelona: Ariel, 2006.

BACELLAR FILHO, Romeu Felipe. Processo administrativo disciplinar. 4. ed. São Paulo: Saraiva, 2013.

BEÇAK, Rubens. A dimensão ético-moral e o direito. Revista Brasileira de Direito Constitucional: RBDC, n. 9, p. 307-320, jan/jun. 2007.

BEDAQUE, José Roberto dos Santos. Direito e processo: influência do direito material sobre o processo. São Paulo: Malheiros, 2003.

BENESSIANO, William. Légalité pénale et droits fondamentaux. Marseille: Universitaires D’aix-Marseille, 2011.

BERGEL, Jean-Louis. Théorie générale du droit. Paris: Dalloz, 2003.

CAETANO, Marcelo. Princípios fundamentais do direito administrativo. Rio de Janeiro: Forense, 1977.

CANOTILHO, J. J. Gomes. Direito constitucional. 7. ed. Lisboa: Almedina, 2000.

CASTILLO, Jaime Alonso Zetién et al. El injusto en el derecho disciplinário. Revista Derecho Penal y Criminologia, v. 34, n. 97, p. 159-174, jul./dic. 2013.

CHAINAIS, Cécile; FENOUILLET, Dominique; GUERLIN, Gaëtan. Les sanctions en droit contemporain. Paris: Éditions Dalloz, 2013. v. 1

CHAINAIS, Cécile ; FENOUILLET, Dominique ; GUERLIN, Gaëtan. Les sanctions en droit contemporain. Paris: Éditions Dalloz, 2013. V. 2.

COELHO, Inocêncio Mártires. Poder normativo das cortes constitucionais: o caso brasileiro. Revista Brasileira de Políticas Públicas, Brasília, v. 5, n. 2, p.15-27, 2015.

CORREIA, Sérvulo. Direito do contencioso administrativo. Lisboa: Lex, 2005.

COSTA, José Armando da. Direito administrativo disciplinar. 2. ed. São Paulo: Método, 2009.

COSTA, José Armando da. Direito disciplinar: temas substantivos e processuais. Belo Horizonte: Fórum, 2008.

COSTA, José Armando da. Incidência aparente de infrações disciplinares. Belo Horizonte: Fórum, 2004.

56 BEDAQUE, José Roberto dos Santos. Direito e processo. Influência do direito material sobre o processo. São Paulo: Malheiros, 2003.

57 "O processo administrativo oferece possibilidade de atuação administrativa com justiça. Encontra-se mesmo a afirmação de que 'o núcleo de todas as teorias clássicas do procedimento é a relação com a verdade ou com a verdadeira justiça como objetivo'. O processo administrativo direciona-se à realização da justiça não só pelo contraditório e ampla defesa vistos do ângulo do indivíduo, mas também por propiciar o sopesamento dos vários interesses que envolvem a situação”, MEDAUAR, Odete. A processualidade no direito administrativo. 2. ed. São Paulo: Revista dos Tribunais, 2003. p. 38. 
COSTA, José Armando da. Processo administrativo disciplinar: teoria e prática. 6. ed. Rio de Janeiro: Forense, 2010.

COSTA, José Armando da. Teoria e prática do processo administrativo disciplinar. 3. ed. Brasília: Brasília Jurídica, 1999.

CRETELLA JUNIOR, José. Direito administrativo do Brasil: Processo administrativo. São Paulo: Revista dos Tribunais, 1962.

CRETELLA JUNIOR, José. Tratado de direito administrativo: teoria do direito administrativo. Rio de Janeiro: Forense, 1966. v. 1.

CRUZ, Álvaro Ricardo de Souza. Habermas e o direito brasileiro. 2. ed. Rio de Janeiro: Lumen Juris, 2008.

DASCAL, Marcelo. Interpretação e compreensão. Tradução Marcia Heloisa Lima Rocha. São Leopoldo: Unisinos, 2006.

DELEUZE, Gilles; GUATTARI Félix. Mil Platôs: capitalismo e esquizofrenia. Tradução de Aurélio Guerra Neto e Célia Pinto Costa. Rio de Janeiro: Editora 34, 1995, v. 1.

DELLIS, Georges. Droit penal et droit administratif: L'influense des príncipes du droit pénal sur droit administratif répressif. Paris: Librarie Générale de Droit et Jurisprudence, E.J.A, 1997.

DORD, Olivier. Droit de la fonction publique. 2. ed. Paris: Thémis droit - Puf, 2007.

DUTRA, Luiz Henrique de Araújo. Introdução à epistemologia. São Paulo: UNESP, 2010.

DWORKIN, Ronald. O império do direito. São Paulo: M. fontes, 2007.

FENOUILLET, Cécile Chainais Dominique et al. Les sanctions en droit contemporain: La sanction, entre techinique et politique. Paris: Dallos, 2012.v. 1.

FENOUILLET, Cécile Chainais Dominique et al. Les sanctions en droit contemporain: La motivation des sanctions prononcées en justice. Paris: Dallos, 2013. v. 2.

FERNANDEZ-LARGO, Antonio Osuna. El debate filosófico sobre hermenêutica jurídica. Valladolid: Secretariado de Publicaciones, Universidad, 1995.

FICHTE, Johann Gottlieb. Fundamentos do direito natural. Segundo os princípios da doutrina da ciência. Lisboa: Fundação Calouste Gulbenkian, 2012.

FIORAVANTI, Maurizio. Constituición. De la antigüedad a nuestros días. Traducción de Manuel Martínez Neira. Madrid: editorial Trotta, 2001.

FIORAVANTI, Maurizio. Stato di diritto e Stato amministrativo nell'opera giuridica di Santi Romano. I giuristi e la crisi dello Stato liberale in Italia. Napoli: Liguori, 1986.

GARCÍA ENTERRÍA, Eduardo; FERNÁNDEZ, Tomás-Ramón. Curso de derecho administrativo. 16. ed. Madrid: Civitas, 2013. v. 1.

HABERMAS, Jürgen. Direito e democracia: Entre facticidade e validade. Tradução de Flávio Beno Siebeneichiler. Rio de Janeiro: Tempo Brasileiro, 2003. v. 2.

HACHEM, Daniel Wunder; PETHECHUST, Eloi. O direito humano à comunicação prévia e pormenorizada das acusações nos processos administrativos: O desprezo do Superior Tribunal de Justiça ao Pacto de San José da Costa Rica e à Corte Interamericana de Direitos Humanos. Revista de Direito Internacional, Brasília, v. 12, n. 2, p. 589-610, 2015.

HAURIOU. Maurice. La gestion administrative. Étude théorique de droit administratif. Paris: Éditions Dalloz, 2010. 
HORBACH, Carlos Bastide. Contratos administrativos: conceito e critérios distintivos. Rev. Bras. Polít. Públicas, Brasília, v. 6, n. 1, p. 52-68, 2016.

LECLERC, Bruno; LÉTOURNEAU, Alain. Validité et Limites Du consensus em éthique. Paris: L'Harmattan, 2007.

LIMA, Ruy Cirne. Princípios de Direito Administrativo. São Paulo: Malheiros, 2007.

LLOBREGAT, José Garberí. Derecho administrativo sancionador prático. Barcelona: Editorial Boch, 2012. v. 1.

LLOBREGAT, José Garberí. Derecho administrativo sancionador prático. Barcelona: Editorial Boch, 2012. v. 2.

MEDAUAR, Odete. A processualidade no direito administrativo. 2. ed. São Paulo: Revista dos Tribunais, 2003.

MELLO, Celso Antônio Bandeira de. Curso de direito administrativo. 32. ed. São Paulo: Malheiros, 2015.

MELLO, Oswaldo Aranha Bandeira de. Princípios de direito administrativo. 3. ed. São Paulo: Malheiros, 2007. v. 1.

MELLO, Oswaldo Aranha Bandeira de. Princípios gerais de direito administrativo. Rio de Janeiro: Forense, 1979. v. 2.

MONCADA, Luís S. Cabral de. A relação jurídica administrativa: para um novo paradigma de compreensão da atividade, da organização e do contencioso administrativo. Coimbra: Coimbra, 2009.

MORCHÓN, Gregorio Robles. El derecho como texto: cuatro estúdios de teoria comunicacional del derecho. 2. ed. Madrid: Civitas, 2006.

MORIN, Edgar. Introdução ao pensamento complexo. Tradução de Eliane Lisboa. 5. ed. Porto Alegre: Sulina, 2015.

MORIN, Edgar. O método 6: ética. Tradução de Juremir Machado da Silva. 4. ed. Porto Alegre: Sulina, 2011.

MORÓN, Miguel Sánchez. Derecho de la función pública. 8. ed. Madrid: Tecnos, 1996.

MOURA, Paulo Veiga. Estatuto disciplinar dos trabalhadores da administração pública. 2. ed. Coimbra: Coimbra, 2012.

NIETO, Alejandro. Derecho administrativo sancionador. 5. ed. Madrid: Tecnos, 2012.

REZZOAGLI, Bruno Ariel. Contratos públicos y mercado global: un abordaje desde el derecho administrativo del siglo XXI. Rev. Bras. Polít. Públicas (Online), Brasilia, v. 6, n. 1, p. 28-41, 2016.

RIVERO, Jean. Curso de direito administrativo comparado. São Paulo: Revista dos tribunais, 2004.

RIVERO, Jean. Droit administratif. Paris: Éditions Dallos, 2011.

ROSS, Alf. Direito e justiça. São Paulo: EDIPRO, 2003.

SANDULLI, Aldo M. Manuale di direitto amministrativo. 15. ed. Napoli: Casa Editrice Dott. Eugenio Joveni, 1989. v. 1.

SANDULLI, Aldo M. Manuale di direitto amministrativo. 15. ed. Napoli: Casa Editrice Dott. Eugenio Joveni, 1989. v. 2.

SERNA, Pedro Gomez de la. Instituciones del derecho administrativo español. Madrid: Imprenta de D. Vicente de Lalama, 1843.

SIQUEIRA, Galdino. Tratado de Direito penal: parte geral. Rio de Janeiro: J. Konfino Editor, 1947. v. 1.

SOUSA, Rui Correia de. Lei geral do trabalbo em funções públicas. Porto: VidaEconómica, 2014.

VETÖ, M. La synthèse a priori kantienne comme l'essence commune de la liberte et du temps. In : RICCCEUR, Paul; PHILONENKO, Alexis. Revue de Métaphysique et de Morale. Paris: Librarie Armand Colin, 1979.

WIMMER, Miriam. As relações de sujeição especial na administração pública. Direito Público, n. 18, p. 31-43, trimestral, 2007. 


\section{REVISTA BRASILEIRA DE POLÍTICAS PÚBLICAS BRAZILIAN JOURNAL OF PUBLIC POLICY}
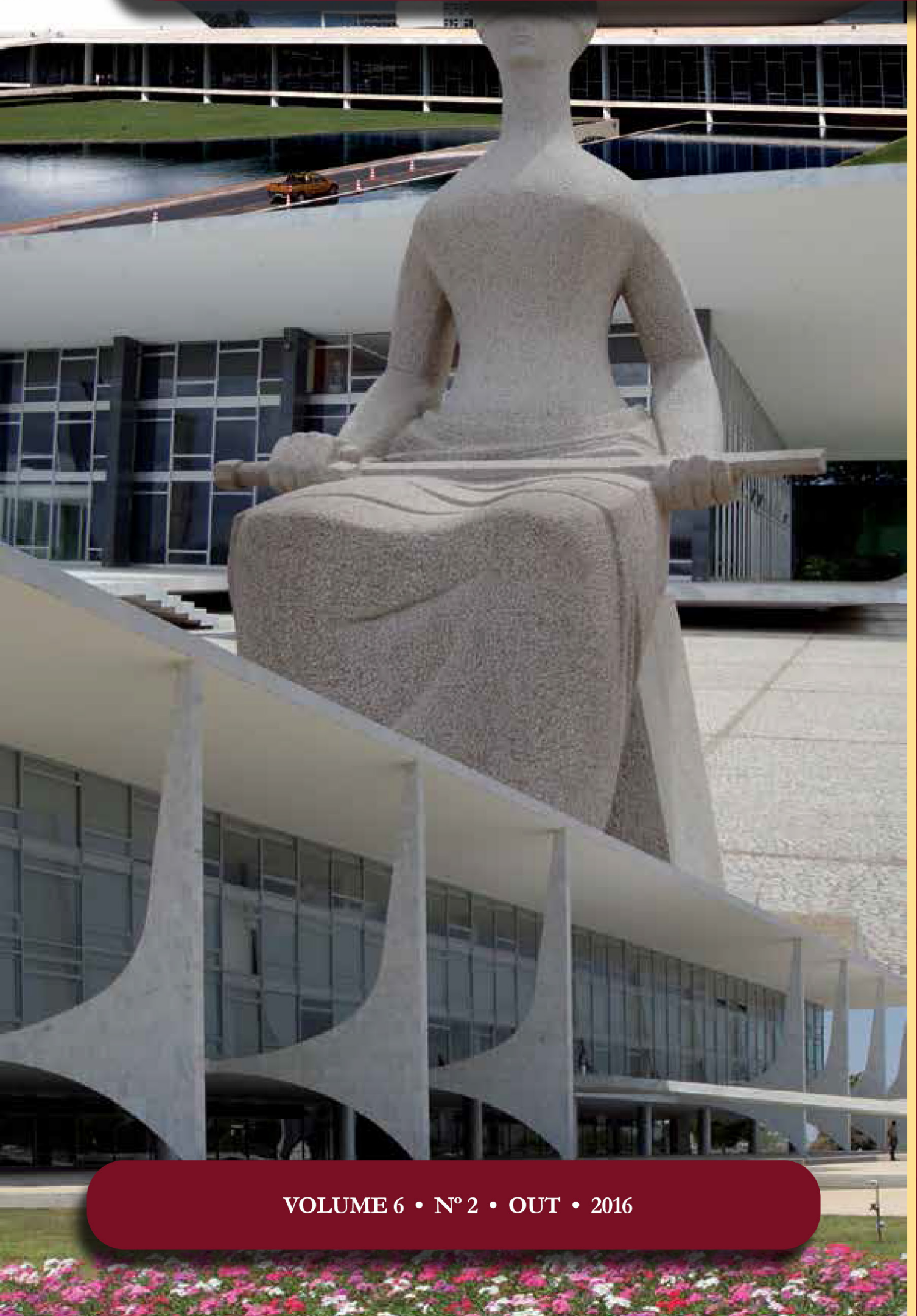

Transparência administrativa, lei federal $n^{\circ}$ 12.527/2011 e sigilo dos documentos públicos: A inconstitucionalidade das restrições ao acesso à informação Administrative transparency, federal act $n^{\circ} 12.527 / 2011$ and the confidentiality of public documents: the unconstitutionality of restrictions on access to information.

Emerson Affonso da Costa Moura 


\title{
Transparência administrativa, lei federal no 12.527/2011 e sigilo dos documentos públicos: A inconstitucionalidade das restrições ao acesso à informação*
}

\author{
Administrative transparency, federal act \\ $n^{\circ} 12.527 / 2011$ and the confidentiality of \\ public documents: the unconstitutionality of \\ restrictions on access to information.
}

Emerson Affonso da Costa Moura**

\section{Resumo}

A análise crítica da constitucionalidade das restrições impostos pela lei federal no 12.527/2011 ao acesso amplo à informação em razão da necessidade de proteção pelo interesse público é o tema posto em debate. Pretende-se verificar que o sigilo aos dados e informações administrativas impostas pela lei de acesso à informação importa em restrição legal desproporcional a regulação da norma constitucional que viola o dever de transparência administrativa. Para tanto, verifica-se, inicialmente, o controle social administrativo como instrumento de garantia da conformação da gestão pública aos fins constitucionais, no âmbito de uma Administração Pública marcada ainda pelos resquícios de patrimonialismo, autoritarismo e nepotismo. Após, analisa-se o dever de transparência administrativa imposta pela Constituição Federal e a sua regulação pela lei como um instrumento de controle social e concretização do princípio democrático e direito fundamental à informação. Por fim, analisam-se as hipóteses de sigilo impostas pela lei $\mathrm{n}^{\mathrm{o}} 12.527$ de 2011 ao acesso à informação dos documentos públicos e os fundamentos de sua inconstitucionalidade.

Palavras-chaves: Controle da Administração; Transparência Administrativa; Lei de Acesso a Informação; Sigilo; Inconstitucionalidade.

\section{Abstract}

The review of the constitutionality of restrictions imposed by Federal

* Recebido em 06/07/2016 Aprovado em 21/09/2016

** Professor Assistente da UFJF. Doutorando em Direito pela UERJ. Mestre em Direito Constitucional e Especialista em Direito da Administração Pública pela UFF. E-mail: emersonacmoura@yahoo.com.br.
Law No. 12,527 / 2011 to wide access to information because of the need to protect the public interest is the theme put into discussion. It is intended to verify that the confidentiality of data and administrative information imposed by law on access to information matter disproportionate legal restrictions regulating the constitutional provision that violates the duty of administrative transparency. Therefore, there is initially the administrative social control to guarantee the conformity of public management instrument for constitutional purposes as part of a Public Administration still ma- 
rked by traces of paternalism, authoritarianism and nepotism. After, it analyzes the duty of administrative transparency imposed by the Constitution and its regulation by the law as an instrument of social control and implementation of the democratic principle and fundamental right to information. Finally, we analyze the chances of secrecy imposed by law n ${ }^{\circ} 12.5272011$ access to information of public documents and the grounds of unconstitutionality.

Keywords: Administration Control; Administrative Transparency, Access to Information Act; Supremo Tribunal Federal. Secret; Unconstitutionality.

\section{INTRODUÇÃo}

Marcada pela persistência dos resquícios do autoritarismo, patrimonialismo e nepotismo advindo da formação das instituições políticas pátrias, a Administração Pública Brasileira encontra com o fim da ditadura militar e a ascensão do Estado Democrático de Direito e a promulgação da Constituição Cidadã uma nova configuração capaz de realizar os bens e valores democráticos e constitucionais.

Sujeita-se, portanto, a uma disciplina constitucional que prevê não apenas o regime fundamental de seus bens, serviços e servidores, mas impõe a observância a princípios fundamentais, gerais e setoriais que orientam a atividade administrativa, bem como programas e objetivos sociais e econômicos, que impõe deveres à Administração Pública na atividade de persecução de interesse público.

Consagra a Constituição Federal de 1988 uma cláusula geral de transparência na gestão administrativa que demanda, além da publicidade dos atos administrativos, com o respectivo direito de certidão e petição dos cidadãos, o dever de garantia de amplo acesso e, de forma inteligível, a atuação estatal, permitindo a participação da sociedade na condução da coisa pública.

Sob tal diretiva, erige-se a importância do controle social da Administração Pública de forma a garantir, por mecanismos jurídicos ou não, no âmbito administrativo ou jurisdicional, o cumprimento do dever constitucional de transparência, permitindo ao cidadão o acesso as informações não apenas individuais, mas de interesse coletivo e difuso.

Nesse tocante, em regulamentação à Constituição Federal, foi editada a lei de acesso à informação, que tem por objetivo não apenas disciplinar o procedimento e conteúdo do direito do cidadão do acesso à informação, mas, igualmente, a pretensão de formação de uma cultura administrativa de transparência nas atividades Administração Pública.

Todavia, sua aplicação corresponde, ainda, sob um desafio em razão da persistência do trato da informação pública como estatal e não coletiva, em que a Administração Pública não permite acesso aos dados sob alegação de interesses privados como de intimidade dos sujeitos envolvidos na relação pública ou de imperativos do interesse público.

Nesse giro, a lei vigente que disciplina o acesso à informação - a lei federal no 12.527 de 2011 - consagra as hipóteses em que garante uma suposta proteção da informação pública, permitindo a sua classificação, de forma sigilosa, em razão do interesse público, vedando, em prazos máximos, sua restrição em período de até cinquenta anos.

Há, portanto, uma tensão entre a conformação legislativa restritiva da norma constitucional do acesso de informação com o dever de transparência administrativa imposta pela Constituição Federal como forma de garantir mediante o conhecimento dos dados públicos, a concretização do princípio democrático e o direito fundamental à informação nas relações do cidadão com o poder público. 
Busca-se, no presente trabalho, investigar, em que medida as restrições de sigilo impostas aos dados e informações administrativas pela Lei de Acesso à Informação, em razão do interesse público, implicam ou não em restrição desproporcional e, portanto, inconstitucional, ao dever de transparência administrativa imposto pela Lei Fundamental.

Inicialmente, o objeto de pesquisa são os traços dominantes da Administração Pública Brasileira de forma a extrair dos seus resquícios de patrimonialismo, autoritarismo e nepotismo a importância do controle social e de seus mecanismos como forma de garantir a conformação da gestão pública aos fins constitucionais trazendo maior legitimidade e racionalidade à atuação administrativa.

Após, verifica-se o dever de transparência administrativa imposto pela Constituição Federal como instrumento que permite o processo do controle social ao garantir o acesso às informações necessárias aos sujeitos para participarem e fiscalizarem o processo de tomada de decisão administrativa, em realização ao princípio democrático e o direito fundamental à informação.

Por fim, analisam-se as hipóteses de sigilo impostas pela lei nº12.527 de 2011 ao acesso à informação dos documentos públicos, de forma a confirmar a inconstitucionalidade das restrições legais em razão da sua violação ao princípio da proporcionalidade, bem como ao dever de transparência administrativa no âmbito da Constituição Federal.

Para tanto, utiliza-se na pesquisa o método dedutivo partindo-se do controle social em geral para sua inserção dentre as formas de controle da Administração Pública, por meio da revisão bibliográfica dos principais expoentes do direito pátrio e estudo legislativo quando pertinente para a demonstração e fundamentação das proposições.

\section{A ADMINISTRAÇÃo PÚbLICA BRASILEIRA E O CONTROLE SOCIAL}

A Administração Pública Brasileira, desde sua formação, tem sido marcada por um modelo oligárquico e patrimonialista, com o predomínio da corrupção, do nepotismo e da ineficiência na gestão estatal, em uma economia com baixo grau de competitividade e concentração da função pública em uma sociedade eminentemente aristocrática ${ }^{1}$.

A Administração Colonial se assentava, apenas, na monarquia portuguesa que abrangia desde o rei - enquanto supremo chefe representante de Deus que regulava todas as atividades, inclusive, administrativas até o último de seus súditos e vassalos que exercem um papel, mesmo que modesto, no organismo político da monarquia ${ }^{2}$.

Assim, a nobreza assumia o monopólio dos cargos públicos e se imiscuía nas decisões políticas por meio dos Conselhos da Coroa $^{3}$ gozando de privilégios econômicos e políticos que marcavam uma confusão entre o público e o privado, em que o nobre era colono e governador administrava as mesmas terras como fazenda e província com privilégios e competências.

A falta de organização eficiência e presteza da sua ação, a adoção de processos autoritários como o recrutamento, a confusão entre competências dos agentes, o excesso de burocracia nas suas atuações tornava a "monstruosa, emperrada e ineficiente a máquina burocrática que é a 'administração colonial.".4

1 Tanto no Brasil Império quanto no primeiro período da República, enquanto os senhores de Terra e os grandes comerciantes se ocupavam da economia, ao Estamento burocrático ligado por laços de família ao patriarcado rural cabia dominar com relativa autonomia o Estado e a Política. BRESSER-PEREIRA, 2001, 222.

2 PRADO JUNIOR, Caio. Formação do Brasil Contemporâneo. São Paulo: Companhia das Letras, 2011. p. 318.

3 ABREU, J. Capistrano de. Capítulos de História Colonial: 1500-1800. Brasília: Conselho Editorial do Senado Federal, 1998. p. 27.

4 PRADO JUNIOR, Caio. Op cit. p. 353-354. 
As autoridades administrativas eram "organismo à parte" da Colônia com interesses particulares "e até radicalmente opostos aos interesses das novas sociedades", fazendo valer, por meio de suas prerrogativas, a imposição da vontade absoluta e soberana do governo, garantindo a realização dos interesses da metrópole sobre os da colônia. ${ }^{5}$

A imoralidade e corrupção dominava a Administração Pública: os cargos públicos eram "obtidos e vendidos como a mais vulgar mercadoria" e, para agravar com "métodos aceitos e reconhecidos" e o peculato, o suborno e todas as demais formas de corrupção administrativa eram práticas gerais e universalizadas. ${ }^{6}$

Ademais, se infundia, ainda, um caráter despótico: a impessoalidade nas relações entre autoridade e súdito. O sistema é aberto ao acesso pelo rei, apenas, aos poderosos em um modelo em que "manda quem pode e obedece quem tem juízo"?

A função pública torna-se "instrumento regalista da classe dominante", que forma um "patriciado administrativo", que "congrega, reúne e domina a economia". O cargo público é título que confere ao seu portador uma autoridade ou "marca de nobreza", pois é concedido, apenas, ao homem tido como de "limpo sangue" ou de "boa linhagem". 8

Durante o chamado Estado Patrimonial, houve as reformas de Pombal que com seu depotismo esclarecido e com a chamada "lei da boa razão" tentou trazer critérios objetivos para extração de regras de direito e preencher omissões nas leis vigentes gerando mais do que mera reforma na burocracia, mas a manifestação de uma nova perspectiva racionalista. ${ }^{?}$

Como contribuição de Pombal na Administração Pública, teve-se a consolidação de uma organização administrativa centralizada com a criação e a transformação de comarcas e vilas e distribuição de suas atribuições entre os agentes estatais mediante instruções e normas, dentre outras. ${ }^{10}$

Porém, suas reformas apenas demonstram a mudança do patrimonialismo tradicional - originário e patriarcal com o estereótipo do cargo como título de nobreza - para o estamental - com a racionalização dos negócios públicos, assumindo a camada dirigente um caráter burocrático permitindo o Estado absolutista se preparar para tutelar a economia. ${ }^{11}$

A Administração Pública Brasileira inicia o século XX com um modelo oligárquico e patrimonialista, marcado pelo predomínio da corrupção, do nepotismo e da ineficiência na gestão estatal, em uma economia com baixo grau de competitividade e concentração da função pública em uma sociedade eminentemente aristocrática $^{12}$.

Nas instituições administrativas, a burocracia estamental formada por agentes selecionados por critérios de confiança pessoal exercia o munus publico finalisticamente direcionado aos seus interesses privados, de forma autoritária e desvinculada de qualquer preocupação com a prestação eficiente dos serviços públicos ${ }^{13}$.

5 BOMFIM, Manoel. A América Latina: Males de Origem. Rio de Janeiro: Centro Edelstein de Pesquisas Sociais, 2008. p. 143-144.

6 PRADO JUNIOR, Caio. Op cit. p. 356-357.

7 FAORO, Raymundo. Os Donos do Poder. 3 ed. Rio de Janeiro: Globo, 2001. p. 200.

8 FAORO, Raymundo. Op. cit. p. 203-205.

9 SALDANHA, Nelson Nogueira. História das Ideias Políticas no Brasil. Brasília: Senado Federal, 2001. p. 58.

10 VIANNA, Hélio. História do Brasil: Período Colonial, Monarquia e República. 12ed. São Paulo: Universidade de São Paulo, 1975. p. 307-310.

11 AVELLAR, Hélio de Alcântara. História Administrativa do Brasil. Vol. 5. Brasília: DASP, 1970. p. 98.

12 Tanto no Brasil Império quanto no primeiro período da República, enquanto os senhores de Terra e os grandes comerciantes se ocupavam da economia, ao Estamento burocrático ligado por laços de família ao patriarcado rural cabia dominar com relativa autonomia o Estado e a Política. BRESSER-PEREIRA, Luiz Carlos. Do Estado Patrimonial ao Gerencial in: Pinheiro, Wilheim e Sachs (orgs.), Brasil: Um Século de Transformações. São Paulo: Cia. das Letras, 2001. p. 222.

13 Necessário ressaltar, que apenas excepcionalmente tivemos um sistema administrativo e um corpo de funcionários puramente dedicados ao interesse coletivo. Ao contrário, desde aquela época é possível acompanhar, ao longo de nossa história, o predomínio constante das vontades particulares que encontram seu ambiente próprio em círculos fechados e pouco acessíveis ai uma ordenação 
Na República, a partir da década de 1930, propôs-se um modelo organizacional burocrático ${ }^{14}$, que buscou, por meio de competências previamente definidas, relações estáticas baseadas na autoridade e atividade especializada pela divisão racional ampliar o grau de legitimidade e de eficiência da atividade administrativa através do controle do processo.

Não obstante, a persistência das concessões patrimonialistas transvertidas na forma de clientelismo e eventuais limites do formalismo burocrático impediu a construção de um modelo de gestão pública capaz de atender as demandas da transformação econômica, ampliando o grau de déficit de legitimidade e operacionalidade na Administração Pública ${ }^{15}$.

Nas décadas seguintes, foram utilizadas sucessivas tentativas de modernização da atividade administrativa, que abrangem desde a implantação de modelos de descentralização ${ }^{16}$ até a propositura um modelo gerencial, que buscou trazer maior legitimidade à atuação da burocracia através da eficiência dos resultados e a flexibilidade dos processos $^{17}$.

Todavia, a busca por implementação de modelos institucionais de outras tradições administrativas ${ }^{18}$, em um ambiente dotado de cultura própria ${ }^{19}$ tem resultado em descolamento entre a teoria e a práxis, resultando em pouco acréscimo de legitimidade e efetividade na atividade administrativa brasileira e concretização efetiva das reformas administrativas.

O patrimonialismo, ainda, permanece atuante embaixo de uma ordem burocrática-racional na Administração Pública e se desenvolvendo no quadro administrativo como resquício do caráter político assumido pela economia colonial, mascarando a herança que permanece nas instituições político-administrativa brasileiras. $^{20}$

Neste sentido, erige-se a importância dos mecanismos de controle da Administração Pública, como formas de corrigir os desvios de conduta pelos agentes públicos, garantindo a conformação da atividade administrativa à persecução do interesse público e, portanto, atribuindo maior grau de legitimidade à ação estatal.

Compreende o controle social, o conjunto de instrumentos empregados pela sociedade, capaz de induzir a conformação dos Poderes Públicos às determinadas diretrizes, ordenando a atuação institucional

impessoal. HOLANDA, Sérgio Buarque de. Raízes do Brasil. Rio de Janeiro: Olympio. 1984. p. 105-107.

14 O movimento se inicia com a reforma burocrática do Brasil em 1936 e se materializa com a criação de diversos diplomas reguladores e a criação do Departamento de Administração Pública do Serviço Público (DASP) que acabou se reproduzindo nos Estados. Sobre o tema consulte-se: WAHRLICH, 1983.

15 Observa-se, até atualmente, os perniciosos resquícios do patrimonialismo, a corrupção persistente, as políticas paternalistas e a ineficiência na gestão estatal, que produzem a crise de legitimidade das instituições estatais. Sobre o histórico, vide: FAORO, 2001. FREYRE, 2000 e NUNES, 1997.

16 A reforma desenvolvimentista se consubstancia na edição do Decreto 200-67 e foi conduzida pela Subsecretaria de Modernização e Reforma Administrativa, do Ministério do Planejamento. A partir de 1979, volta-se a desburocratização, visando à simplificação e à racionalização da burocracia e com forte orientação para o usuário do serviço público, e a desestatização. LIMA JUNIOR, 2008, 12-14.

17 Todavia, a nova configuração da própria atividade administrativa, com a profusão de novos entes e centros de decisão no interior da própria Administração e contexto de crise das instituições da democracia representativa, denuncia o problema da falta de legitimidade democrática da Administração Pública e a recondução ao chefe do Poder Executivo a direção da atividade administrativa. BAPTISTA, 2003, 125-126.

18 Os países da América Latina tendem a buscarem copiar as estratégias modernizadoras dos países anglo-saxões em uma tentativa de isomorfismo mimético. Todavia, instrumentos que funcionam bem no modelo anglo-saxão podem ter impactos negativos no nosso modelo continental de Administração, uma vez que os contextos institucionais e sociais são distintos. Além disso, quando duplicamos os modelos anglo-saxões nos países latinos não somo capazes de incorporar os "matizes ocultos" que são a chave do êxito desses modelos e estratégias nos países de origem. MATAS, 2001, 14-15.

19 Forma-se na Administração Pública Brasileira desde sua origem uma cultura organizacional, marcada pela praxe patrimonialista e clientelista, com uso da autoridade e paternalismo, supervalorização da hierarquia e apego ao formalismo, além da permeabilidade excessiva a pressões externas, que cria o campo propício para a falta de efetividade, corrupção e afastamento da sociedade. CARBONE, 2000, 21-22.

20 FAORO, Raymundo. A Aventura Liberal numa Ordem Patrimonialista in: Revista da USP. São Paulo, n. 17, p. 16, mar/abr/ mai 1993. 
no ambiente social e estabelecendo as condições necessárias para que sejam alcançados os fins e objetivos almejados pelo grupo social ${ }^{21}$.

O controle social pode ser exercido de forma direta pelo grupo social, através de instrumentos formais de natureza política, financeira ou administrativa concedidos pela ordem jurídica e exercidos exclusivamente na esfera pública estatal - ou informais - não institucionalizados e promovidos no campo privado ou público não estatal ${ }^{22}$.

O controle social administrativo erige-se no Estado Democrático de Direito como importante instrumento de concretização dos valores constitucionais, a saber, a releitura das categorias administrativas à luz dos direitos fundamentais chamado de constitucionalização23 e de reconduzir a atribuir legitimidade da atuação administrativa pela participação do cidadão na Administração Pública ${ }^{24}$.

Abrange os instrumentos administrativos de controle social, aqueles que permitem a intervenção da sociedade na persecução dos interesses públicos e o controle da atuação dos agentes, em um espectro que envolve desde a participação até a colaboração e a avaliação atividade administrativa contribuindo com a maximização do grau de legitimidade ${ }^{25}$.

Envolve, portanto, a consulta popular, variadas formas que distinguem-se quanto ao grau de influência que produzem na formação da discricionariedade administrativa, abrangendo desde a indireta - coleta de opinião e debate público - até a direta - audiência pública - no processo de escolha da conveniência e oportunidade pelo administrador.

A coleta de opinião busca mediante a utilização de canais de informação recolher as tendências e interesses dos grupos sociais e o debate público, aferir na dialética dos grupos sociais as distintas posições acerca de uma proposta, sendo atos preparatórios, facultativos e, em regra, não-vinculativos da decisão administrativa ${ }^{26}$.

A audiência pública abrange a deliberação pública convocada em ambiente institucional acerca de decisão administrativa que permite mediante a dialética, a exposição dos interesses, preferências e opções dos grupos sociais e atores envolvidos no processo, vinculando a ação pública pelos seus resultados ${ }^{27}$.

Compreende a participação as deliberações coletivas promovidas no âmbito dos órgãos estatais permanentes ou transitórios, com fins de consulta ou de decisão, que formados por representantes de diversos setores da sociedade, permitem a participação da coletividade na formação da decisão pública ${ }^{28}$.

21 Envolve, portanto, a capacidade de autorregulação de um grupo social para alcançar seus objetivos globais, obtidos mediante o consenso ou coerção dos indivíduos. BOBBIO; MATTEUCCI; PASQUINO, 1986, 283-284.

22 Para aprofundamento sobre o tema, com estudo sobre as modalidades, instrumentos e efeitos vide: MOURA, Emerson Affonso da Costa.. Do Controle Jurídico ao Controle Social: Parâmetros a Efetividade dos Direitos Sociais. Revista de Direito Constitucional e Internacional, v. 77, p. 131-184, 2011.

23 Com a promulgação da Constituição de 1988 observa-se um processo de deslocamento da Constituição para o eixo central do sistema jurídico e reconhecimento da sua supremacia axiológica, potencializada pela erradicação de seus preceitos pelo ordenamento jurídico, o que produz uma releitura das normas, categorias e institutos do direito infraconstitucional, inclusive, administrativo, à luz da lei fundamental. Sobre o tema, vide: MOURA, Emerson Affonso da Costa. A Constitucionalização do Direito e o Regime Jurídico-Administrativo. Revista IOB de Direito Administrativo, v. 87, p. 100-127, 2013.

24 A democratização é marcada pela abertura e fomento à participação dos administrados nos processos decisórios da Administração Pública, não apenas na formação final, mas nos procedimentos formativos da vontade administrativa. Sobre o tema, vide:BINENBOJM, 2010.

25 Compreende, portanto, o exercício da cidadania no processo de promoção dos direitos sociais nos níveis de distribuição dos bens materiais e imateriais indispensáveis a sociedade, de forma a atribuir racionalidade, legitimidade e eficiência à gestão dos interesses sociais. MARTINS JUNIOR, 2004. 298.

26 Sendo a consensualidade na Administração Pública uma exigência do Estado Democrático Brasileiro, a coleta de opinião prevista no artigo 31 da Lei 9.784 de 1999 permite a pluralização do debate público e contribui como mecanismo de legitimação social da decisão administrativa. MELLO, 2012. 11.

27 É consentâneo ao próprio Estado Democrático de Direito que a manifestação da sociedade em ambiente de deliberação pública e participação plural, vincule a Administração Pública. Em igual conclusão: MOREIRA NETO, 1992, 125-129.

28 Não obstante, a participação popular nos órgãos de consulta e decisão represente importante instrumento de controle social, observa-se na prática uma falta de real representatividade dos membros escolhidos, uma vez que não são eleitos pela sociedade e 
Perfaz-se, também, pela utilização de instrumentos administrativos que permitem a provocação dos órgãos de controle interno e externo, como os processos e recursos administrativos interpostos perante órgãos de revisão ou fiscalização da Administração Pública, as denúncias promovidas no âmbito do Ministério Público e outros órgãos ${ }^{29}$.

Com esses instrumentos de controle social da Administração Pública, é possível garantir a correção do deficit de legitimidade e a ampliação do grau de eficiência da ação administrativa, assim como um maior grau de neutralidade e de racionalidade nas decisões administrativas ${ }^{30}$.

Não obstante, uma gestão administrativa com participação da sociedade pressupõe o preenchimento de condições mínimas necessárias para participação dos atores sociais ${ }^{31}$ e o diálogo pelas instituições com a sociedade quanto à decisão administrativa ${ }^{32}$ o que envolve a maximização do direito à informação como pressuposto indispensável ao controle.

Por isso, para a sociedade exercer um controle da Administração Pública, torna-se necessário garantir, primariamente, o acesso às informações necessárias acerca da atividade e da estrutura administrativa, de forma a permita a mobilização dos cidadãos, a delimitação dos fins e objetivos almejados e a almejada influência na ação estatal.

O tema será tratado a seguir.

\section{A tRANSPARÊNCIA ADMINISTRATIVA E A LEI DE ACESSO À INFORMAÇÃO}

Compreende o regime jurídico-administrativo, o ponto nuclear de convergência e articulação das regras e princípios que regem a persecução do interesse público pela Administração Pública, que, no Estado Democrático de Direito, deve se adequar à Supremacia axiológica da Constituição, à centralidade dos direitos do homem e ao princípio democrático ${ }^{33}$.

O princípio da publicidade abrange o dever de ampla divulgação dos atos emanados pela Administração Pública pelos diversos meios de comunicação disponíveis de modo a garantir aos cidadãos o exercício do controle do grau de legitimidade dos agentes administrativos e de eficiência da promoção dos bens e serviços essenciais à sociedade ${ }^{34}$.

geralmente integram o próprio poder público. DI PIETRO, 2003, p. 35.

29 O controle social abrange, ainda, outros instrumentos administrativos como o direito de petição (artigo $5^{\circ}$ inciso XXXIV alínea "a" da Constituição), de informação (artigo 5 inciso XIV e XXXIII da Constituição e Artigo 14 \$6 $6^{\circ}$ da Lei 11.079/04), de fiscalização e reclamação dos serviços públicos (Artigo 58 \$2 $2^{\circ}$ inciso IV da Constituição, Artigo $3^{\circ}$, 29 inciso XII e 30 \único da Lei 8.987/95 e Artigo 33 da Lei 9.074/95), a assessoria externa, delegação atípica dentre outros. Sobre o tema, vide: SCHIER, 2002.

30 A participação de sujeitos que possam trazer diferentes perspectivas de resolução, por vezes, com conhecimentos específicos sobre o tema, melhora a qualidade das decisões administrativas pela melhor compreensão da dimensão e possíveis soluções do problema, além de permitir com a abertura do processo decisório aos vários atores sociais, maior facilidade de aceitação pelos seus destinatários. SILVA, 1998.402.

31 Como visto, no item anterior, a existência de um contexto aberto, livre e igualitário, onde cada cidadão possa ter a possibilidade de participar e igual capacidade de influenciar e persuadir na deliberação pública depende não apenas de garantias políticas, como eleições livres ou sufrágio universal, mas de condições que permitam uma existência digna e o efetivo exercício da cidadania.

32 Ainda há uma concepção fragmentada e exclusiva do espaço público, com a Administração Pública por um lado gerenciando o conteúdo das demandas sociais, de forma paternalista e fechada, como a única capaz de demarcar prioridades e políticas sociais e a sociedade civil com grande apatia política, ignorando a necessidade de mobilização e sua capacidade de influenciar nas questões políticas. Sobre o tema vide: LEAL, 2003, 831.

33 Com a promulgação da Constituição de 1988, observa-se um processo de deslocamento da Constituição para o eixo central do sistema jurídico e reconhecimento da sua supremacia axiológica, potencializada pela erradicação de seus preceitos pelo ordenamento jurídico, o que produz uma releitura das normas, categorias e institutos do direito infraconstitucional, inclusive, administrativo, à luz da lei fundamental. Sobre o tema, vide: MOURA, 2013.

34 Corresponde a um dever que vincula não apenas as pessoas administrativas, mas qualquer outra que realize a gestão dos interesses públicos, exceto nas hipóteses de sigilo em que a eventual excepcionalidade da situação e os riscos de eventual divulgação podem acarretar, permitindo que, na ponderação constitucional entre a informação e o direito do sigilo e intimidade, preservem-se 
Sob a irradiação do Princípio Democrático, a transparência administrativa erige-se como um dever que transcende a mera informação, mas conduz a visibilidade da atuação estatal e a viabilização da efetividade participação popular na deliberação pública acerca dos interesses socialmente almejados. ${ }^{35}$

Torna-se, portanto, o princípio da transparência instrumental para a realização dos princípios da participação e da impessoalidade, bem como garantindo que a efetiva aplicação do controle da Administração Pública seja estatal — autotutela e judicial review — ou social — cidadãos e entidades da sociedade civil ${ }^{36}$.

Propicia, em virtude da otimização da publicização, uma ampliada aplicação da sanatória para superar meras irregularidades, que importariam em declarações de nulidade após longos processos administrativos e judiciais, resultando em prejuízo à própria Administração Pública e aos administrados ${ }^{37}$.

Nesse tocante, erige-se a transparência atos estatais como instrumento capaz de viabilizar, mediante a visibilidade na gestão pública, o debate político ${ }^{38}$, o fortalecimento sociocultural da cidadania e fomento da participação popular, bem como o aperfeiçoamento da gestão estatal e dos instrumentos jurídicos de controle social.

O dever de transparência é consentâneo do direito humano à informação ${ }^{39}$, que compreende o direito de ser informado - ter acesso às informações de caráter público ou pessoal obtidas, produzidas ou armazenadas pelos poderes públicos e particulares ${ }^{40}$ - e de informar -a oportunidade de manifestar e comunicar fatos, vedada a censura e o anonimato ${ }^{41}$.

Embora tutelado pela Constituição de 1988, o direito à informação teve um ciclo de regulamentação voltado à proteção do segredo governamental ${ }^{42}$, interrompido apenas em 2011 quando foi editada a Lei de Acesso a Informação, que garantiu a transparência administrativa e o controle social como princípios norteadores da publicidade em geral ${ }^{43}$.

os últimos valores. CARVALHO FILHO, 2007. 21-22.

35 Corresponde, portanto, a princípio intimamente ligado à própria concepção de Estado Democrático de Direito, que busca trazer a efetividade ao exercício dos direitos políticos mediante a visibilidade dos atos praticados pelos poderes estatais. MARTINS JÚNIOR, 2011. p. 3.

36 Nesse tocante, os controles sociais, em um ambiente em que predomina a transparência administrativa e aberto instrumentos de participação, tornam-se eficientes, pois multiplicam o número de fiscais sem ônus para os contribuintes e têm ponderável efeito pedagógico, no sentido de desenvolver um sadio espírito cívico. MOREIRA NETO, 2010. 25.

37 Isto porque permite que a própria sociedade proceda o imediato controle da decisão administrativa verificando a irregularidade divulgada por meio da transparência, de tal sorte que esta substitui com vantagem o formalismo que se centra em um controle posterior. GORDILLO, 1996.

38 Apenas com o conhecimento das informações referentes à elaboração e execução dos planos governamentais, bem como da estrutura e modo de atuação dos órgãos político-administrativos envolvidos é capaz de ser realizado o controle social permitindo que os cidadãos possam influir na ação estatal. MILESKI, 2006. 87.

39 O Pacto de San José da Costa Rica prevê, no artigo 13, que toda pessoa tem direito à liberdade de pensamento e de expressão que compreende a liberdade de buscar, receber e difundir informações e ideias de toda natureza, sem consideração de fronteiras, verbalmente ou por escrito, ou em forma impressa ou artística, ou por qualquer outro processo de sua escolha.

40 A Constituição Federal de 1988 prevê, no artigo 5, incisos XIV, XXXIII e XXXIV, respectivamente: ser assegurado a todos o acesso à informação e resguardado o sigilo da fonte, quando necessário ao exercício profissional; o direito a receber dos órgãos públicos informações de seu interesse particular, ou de interesse coletivo ou geral, que serão prestadas no prazo da lei, sob pena de responsabilidade, ressalvadas aquelas cujo sigilo seja imprescindível à segurança da sociedade e do Estado; bem como, o direito de petição aos Poderes Públicos em defesa de direitos ou contra ilegalidade ou abuso de poder e de obtenção de certidões em repartições públicas, para defesa de direitos e esclarecimento de situações de interesse pessoal.

41 A Constituição Federal de 1988 elenca, no artigo $5^{\circ}$ inciso IV e IX e artigo 220, respectivamente: a liberdade de manifestação do pensamento, sendo vedado o anonimato; a liberdade de expressão da atividade intelectual, artística, científica e de comunicação, independentemente de censura ou licença; que a manifestação do pensamento, a criação, a expressão e a informação, sob qualquer forma, processo ou veículo não sofrerão qualquer restrição, observado o disposto na Constituição.

42 Embora o direito à informação tenha sido garantido pela Constituição de 1988, desde a sua promulgação foi frustrado em razão da ressalva do sigilo, em razão de parecer da Consultoria-Geral da República (n ${ }^{\circ}$ SR-71) que deixava a cargo do antigo Serviço Nacional de Informações a avaliação de quais dados poderiam ser divulgado. A promulgação da Lei 8.159 de 1991 que buscava regulamentar a norma constitucional acabou assegurando o direito ao sigilo dos documentos com prazos de 30 e 100 anos. Nas últimas décadas, avançou-se mais no segredo governamental e dos procedimentos de segurança de informação principalmente com os decretos 2.134 de 1997 e 2.910 de 1998, do que na regulamentação do direito à informação e do acesso aos registros governamentais. CEPIK, 2000. 43 Dispõe no artigo $3^{\circ}$ que busca a lei assegurar o direito fundamental de acesso à informação mediante dentre outros o fomento 
A referida Lei 12.527 prevê a gestão transparente da informação propiciando acesso amplo e regulamentando ao processo de acesso, vedando a negação do acesso à informação necessária à tutela judicial ou administrativa de direitos fundamentais, bem como que versem sobre condutas que implicam violação aos direitos humanos.

Em 2012, foi regulamentada a lei 12.527 pelo Decreto 7.724 que previu o dever de transparência ativa de promover, independente de requerimento, a divulgação em site de Internet de informações de interesse coletivo ou geral por eles produzidas ou custodiadas - e passiva - criando Serviço de Informações ao Cidadão e regulamentando o procedimento de acesso.

Todavia, a permanência da classificação e manutenção do sigilo de dados em razão da soberania nacional ${ }^{44}$, a burocracia ${ }^{45}$ e a cultura ${ }^{46}$ da Administração Pública, ainda são empecilhos para utilização do potencial da Lei de Acesso a Informação como instrumento capaz de auxiliar no aperfeiçoamento do Controle Social da Administração Pública.

O tema será tratado a seguir.

\section{A InCONStitucionalidade das ReStrições da leI 12.527/11 aO ACESSO À INFORMAÇÃo}

No Estado Democrático de Direito com epicentro em uma Constituição Cidadã, assumem os direitos fundamentais o papel de centralidade na ordem jurídica imponto limites na restrição e deveres de atuação pelo Estado ${ }^{47}$ e assumindo o papel de elementos integrantes de identidade e continuidade da lei fundamental, razão pelo qual, vedou qualquer reforma constitucional tendente a suprimí-los ${ }^{48}$.

Todavia, não significa que os direitos fundamentais não estão sujeito à restrição, seja em virtude dos outros bens e valores tutelados pela Constituição ou as limitações recíprocas que os direitos fundamentais se impõem, de forma que na sua colisão, deve haver uma conciliação entre os mesmos, sem esvaziá-los, objetivando a máxima efetivação de cada direito.

Por efeito, a própria Constituição Federal de 1988 ao veicular o direito fundamental de acesso à informação pública prevê a restrição constitucional para determinar vedação aquelas informações de interesse particular, coletivo ou difuso cujo sigilo seja imprescindível à segurança da sociedade e do Estado, embora a rigor determine caber ao legislador apenas regular o prazo legal. ${ }^{49}$

ao desenvolvimento da cultura de transparência e do controle social na Administração Pública.

44 Segundo a Lei no artigo 23 a restrição de acesso público as informações supostamente imprescindíveis para a segurança da sociedade e do Estado, com prazos que variam de 5, 15 ou 25 anos. Conforme o artigo $35 \$ 1^{\circ}$ inciso III os prazos são prorrogáveis por uma renovação, sendo garantindo por mais 50 anos o sigilo de alguns documentos.

45 Segundo pesquisa da Controladoria-Geral da União realizada em 2011, 74,8\% dos servidores públicos federais consideravam distante a relação entre sociedade e Estado, 32,9\% não conseguiam definir a cargo de quem estava a solicitação de acesso-2025151853 à informação pública e 53,2\% afirmavam não possuir em seus locais de trabalho unidades preparadas para atender aos pedidos de informações de acesso a documentos por parte dos cidadãos. Disponível em: -2025151853 http://download.uol. com.br/fernandorodrigues/pesquisa-diagnostico-cultura-acesso-a-informacao-dez2011.pdf-2025151853 Acesso em 08.04.2013.

46 Não se pode cair na ilusão de que uma nova lei mudará, por si só, a cultura política do segredo com que a Administração Pública no Brasil sempre esteve acostumada. Para que esse avanço legislativo torne-se efetivo, far-se-á necessária uma intensa mobilização dos atores sociais. AMORIM, Bianca Rihan Pinheiro. O Direito à Memória e à Informação nos Arquivos Brasileiros, 2012 , p. 10. 47 BARROSO, Luís Roberto. Neoconstitucionalismo e constitucionalização do direito: $\mathbf{O}$ triunfo tardio do direito constitucional no Brasil. In: SOUZA NETO, Cláudio Pereira de; SARMENTO, Daniel (orgs.). A constitucionalização do direito: fundamentos teóricos e aplicações específicas. Rio de Janeiro: Lumen Juris, 2007. p. 203-250.

48 A própria colocação do catálogo dos direitos fundamentais no início do texto constitucional, bem como a amplitude do rol do artigo $5^{\circ}$ denotam a intenção do constituinte de emprestar significado especial e a posição de destaque concedida aos direitos fundamentais pela Constituição Federal. MENDES, Gilma Ferreira. Direitos fundamentais e controle de constitucionalidade.

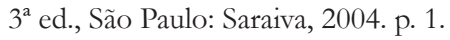

49 BRASIL, Constituição da República Federativa do Brasil de 05 de Outubro de 1988. Art. 5 XXXIII - "todos têm direito a receber dos órgãos públicos informações de seu interesse particular, ou de interesse coletivo ou geral, que serão prestadas no prazo 
Porém, isso não significa negar no âmbito infraconstitucional seja admitida limitações aos direitos fundamentais constitucionais dentro do espaço legítimo de atuação legislativa seja na conformação - precisão ou densinficação dos seus conteúdos ${ }^{50}$ - quanto de restrição - limitação da eficácia ${ }^{51}$, porém, desde que se sujeitem a um limite que não atinja a integridade de tais direitos.

De tal sorte, que ainda divirja a doutrina, da existência de um conteúdo básico na restrição dos direitos fundamentais admite-se a existência de um núcleo essencial que não pode ser atingido pelo legislador ${ }^{52}$, pode ser identificado justamente com as condições mínimas para uma existência humana digna e pressupostos iniciais para a participação democrática ${ }^{53}$.

Por efeito, pode-se sustentar nos direitos fundamentais a existência de um núcleo interno - que abrange o conteúdo jurídico protegido usualmente identificado como núcleo essencial - e a de um núcleo externoque se sujeita ao princípio da ponderação de interesses no caso concreto com os outros direitos envolvidos no conflito. ${ }^{54}$

Nesse sentido, inconteste que, na regulação da referida norma constitucional pela lei federal $n^{\circ} 12.527$ de 2011, embora determine o enunciado que o sigilo atingiria, apenas, as informações imprescindíveis à segurança da sociedade do Estado foi ampliado o objeto da limitação constitucional, com a criação de restrições legislativas inconstitucionais.

Determina lei como imprescindíveis à segurança da sociedade ou do Estado e, portanto, classificadas como informações de divulgação e acesso irrestrito, aquelas relativas à segurança e à soberania nacional, relações internacionais, segurança on saúde pública, forças armadas, pesquisa cientifica ou tecnológica, instituições e autoridades, atividades de inteligência e de investigação. ${ }^{55}$

Por um lado, a pretensão do legislador de esgotar as hipóteses restritivas com a criação de um rol taxativo impede que situações ou atividades não contempladas na regra jurídica, porém, que tenham a efetiva potencialidade de gerar dano efetivo ou potencial à segurança pública ou nacional, não se sujeitem ao sigilo que em ponderação com o direito de acesso à informação pode se demonstrar necessário.

Por outro, a previsão pelo legislador de um rol numerus clausus não se traduz maior segurança jurídica, uma vez que se refere a amplo rol de bens jurídicos - de "soberania nacional à "saúde da população" - com a utilização de conceitos jurídicos indeterminados - "planos" das forças armadas, "bens, instalações ou áreas de interesse estratégico nacional” - que amplia o campo das hipóteses de sigilo.

Com fundamento em tal norma restritiva, a Secretaria da Segurança Pública, por exemplo, editou resolu-

da lei, sob pena de responsabilidade, ressalvadas aquelas cujo sigilo seja imprescindível à segurança da sociedade e do Estado".

50 Mendes, Gilmar Ferreira. Op. cit. p. 25.

51 ALEXY, Robert. Teoria dos Direitos Fundamentais. São Paulo: Malheiros, 2008. p. 276-277

52 ALEXY, Robert. Op. cit. p. 279-281.

53 Como ilustração, no que tange ao direito de educação, são prestações passíveis de exigibilidade perante o Poder Judiciário, aquelas referentes à educação fundamental e o ensino médio, essenciais como condições iniciais para o exercício das liberdades, em especial, de ação, expressão e de associação, permitindo que o indivíduo possa buscar um projeto razoável para a sua vida e seja capaz de participar da deliberação sobre os bens e interesses almejados para a vida em sociedade.

54 BARCELLOS, Ana Paula de. Ponderação, racionalidade e atividade jurisdicional, p. 180

55 BRASIL, Lei Federal no 12.527 de 18 de Novembro de 2011: Art. 23. São consideradas imprescindíveis à segurança da sociedade ou do Estado e, portanto, passíveis de classificação as informações cuja divulgação ou acesso irrestrito possam: I - pôr em risco a defesa e a soberania nacionais ou a integridade do território nacional; II - prejudicar ou pôr em risco a condução de negociações ou as relações internacionais do País, ou as que tenham sido fornecidas em caráter sigiloso por outros Estados e organismos internacionais; III - pôr em risco a vida, a segurança ou a saúde da população; IV - oferecer elevado risco à estabilidade financeira, econômica ou monetária do País; V - prejudicar ou causar risco a planos ou operações estratégicos das Forças Armadas; VI - prejudicar ou causar risco a projetos de pesquisa e desenvolvimento científico ou tecnológico, assim como a sistemas, bens, instalações ou áreas de interesse estratégico nacional; VII - pôr em risco a segurança de instituições ou de altas autoridades nacionais ou estrangeiras e seus familiares; ou VIII - comprometer atividades de inteligência, bem como de investigação ou fiscalização em andamento, relacionadas com a prevenção ou repressão de infrações. 
ção que gerou sigilo de 50 anos sob os boletins de ocorrência registrados pela polícia ${ }^{56}$ impedindo na prática o controle social sob a implementação e execução das políticas de segurança pública por parte dos cidadãos.

De igual sorte, o Governo Federal ainda mantém documentos relativos à ditadura militar classificados como ultrassecretos ${ }^{57}$ em razão de suposta segurança nacional, o que foi um dos fundamentos da condenação do Brasil pela Corte Interamericana dos Direitos Humanos por violar o direito de acesso à informação necessário a formação de uma cultura democrática ${ }^{58}$.

Note, portanto, que a lei federal $\mathrm{n}^{\circ} 12.527$ de 2011 ao regulamentar a regra constitucional determinando como informações imprescindiveis à segurança da população e do Estado, quaisquer uma relativa àqueles bens jurídicos, com base nos conceitos jurídicos indeterminados que veicula, gerou uma restrição inconstitucional ao direito fundamental de acesso à informação.

Ao ampliar a excepcionalidade da limitação constitucional da segurança da sociedade e do Estado a qualquer informações, relativas àquelas amplas hipóteses, atenta contra o princípio da proporcionalidade, uma vez que, embora as medidas sejam adequadas ao resultado, se demonstram gravosas e desproporcionais, já que não delimitam critérios objetivos e adota sanção mais grave.

Isto porque deixa a lei de acesso à informação a classificação dos dados e informações estatais em reservados, secretos ou ultrassecreto ${ }^{59}$ sem a determinação de critério objetivo capaz de justificar a restrição e ser controlado $^{60}$ e tornando restrito o acesso à própria decisão que gerou a classificação restritiva da informação ${ }^{61}$, o que impede o controle social administrativo.

Ademais, determina, no caso da proteção da informação pública sigilosa, apenas a medida de restrição ao seu acesso ${ }^{62}$ e por prazos que chegam a vinte e cinco anos podendo ser prorrogado, enquanto, nas legislações modernas, tende-se a prever, apenas, prazos menores ${ }^{63}$, outras medidas, bem como o acesso à lista de documentos existentes e classificados como restrito com suas fundamentações. ${ }^{64}$

Por efeito, o legislador, ao efetuar a ponderação entre os valores em colisão - entre o interesse público constitucionalmente qualificado como o direito de segurança da sociedade e do Estado e o direito fundamental de

56 BRASIL, Governo de São Paulo, Secretaria de Segurança Pública DOSP, Resolução 7 Publicada em 04.02.2016. Disponível em: http://www.jusbrasil.com.br/diarios/108493300/dosp-executivo-caderno-1-04-02-2016-pg-11 Acesso em 10.03.2016.

57 BRASIL, Decreto n ${ }^{\circ}$ 7.845, de 14 de Novembro de 2012 regulamenta procedimentos para credenciamento de segurança e tratamento de informação classificada em qualquer grau de sigilo, e dispõe sobre o Núcleo de Segurança e Credenciamento.

58 Sobre o tema, vide: MOURA, Emerson Affonso da Costa.. Direitos Fundamentais, Anistia Política e Supremo Tribunal Federal: A Justiça de Transição Não Concluída. In: PFLUG, Samantha Ribeiro Meyer; ANDREUCCI, Álvaro Gonçalves Antunes; CAPANO, Evandro Fabini. (Org.). Memória, Verdade e Justiça de Transição. 1ed.Santa Catarina: FUNJAB, 2014, v. 1, p. 209-238. Disponível em: http://www.publicadireito.com.br/artigos/?cod=f65854da4622c1f1 Acesso em 10.03.2016.

59 BRASIL, Lei Federal ñ 12.527 de 18 de Novembro de 2011: Art. 28. A classificação de informação em qualquer grau de sigilo deverá ser formalizada em decisão que conterá, no mínimo, os seguintes elementos: I - assunto sobre o qual versa a informação; II - fundamento da classificação, observados os critérios estabelecidos no art. 24; III - indicação do pražo de sigilo, contado em anos, meses ou dias, ou do evento que defina o seu termo final, conforme limites previstos no art. 24; e IV - identificação da autoridade que a classificou."

60 BRASIL, Lei Federal no 12.527 de 18 de Novembro de 2011. Art. 24. "A informação em poder dos órgãos e entidades públicas, observado o seu teor e em rąão de sua imprescindibilidade à segurança da sociedade ou do Estado, poderá ser classificada como ultrassecreta, secreta ou reservada. \5 Para a classificação da informação em determinado grau de sigilo, deverá ser observado o interesse público da informação e utilizado o critério menos restritivo possível, considerados: I - a gravidade do risco ou dano à segurança da sociedade e do Estado; e II - o prazo máximo de restrição de acesso ou o evento que defina seu termo final."

61 BRASIL, Lei Federal no 12.527 de 18 de Novembro de 2011. Art. 28. Parágrafo único. "A decisão referida no caput será mantida no mesmo grau de sigilo da informação classificada."

62 BRASIL, Lei Federal no 12.527 de 18 de Novembro de 2011. "Art. 25. É dever do Estado controlar o acesso e a divulgação de informações sigilosas produzidas por seus órgãos e entidades, assegurando a sua proteção. $\$ 1 \mathrm{O}$ acesso, a divulgação e o tratamento de informação classificada como sigilosa ficarão restritos a pessoas que tenham necessidade de conhecê-la e que sejam devidamente credenciadas na forma do regulamento, sem prejuízo das atribuições dos agentes públicos autorizados por lei."

63 A Lei Federal de Transparência e Acesso a Informações Públicas do México prevê o prazo de 12 anos para informações sigilosas.

64 A Lei de Liberdade de Imprensa da Suécia prevê como garantia procedimental uma obrigação imposta aos órgãos públicos de criar um cadastro público de todos os documentos em posse da administração 
acesso à informação -, ao determinar maior peso ao primeiro, aplicou medida restritiva ao segundo que viola o princípio da proporcionalidade e atinge o seu núcleo essencial.

Não há de se invocar uma supremacia do interesse público sobre o privado como um princípio que prevalece in abstracto e, de forma absoluta, em todos os casos, não se adéqua a sua natureza, uma vez que não se sujeita à ponderação no caso concreto e não se compatibiliza com outros postulados normativos, como a proporcionalidade e concordância prática ${ }^{65}$.

Em uma ordem constitucional com pluralidade de bens e valores constitucionais tutelados - como a proteção dos direitos fundamentais e a consagração do princípio democrático -, o regime administrativo não pode ter como fundamento ou pedra basilar apenas um princípio, que impõe uma "supremacia" ou prevalência em qualquer juízo de ponderação. ${ }^{66}$

A restrição baseada em qualquer outro bem, inclusive, interesse público, deve se sujeitar à noção de núcleo essencial do direito fundamental, de maneira que, a título de realização do bem ou interesse coletivo, não pode ser capaz de alcançar a essencialidade do direito subjetivo, sob pena da restrição importar anulação, o que configura desrespeito à ordem jurídico-constitucional e abuso pelo agente público ${ }^{67}$.

Se, por um lado a restrição ao direito fundamental de acesso à informação pela lei federal $\mathrm{n}^{\circ} 12.527$ de 2011 é inconstitucional por não observar o parâmetro de proporcionalidade na determinação do limite da redução do campo de aplicação deste ${ }^{68}$, por outro se demonstra clara afronta ao princípio da transparência administrativa, que impõe o dever ao amplo acesso as informações públicas.

Embora inexista hierarquia formal ou axiológica entre os princípios e regras constitucionais em razão da própria unidade da constituição $0^{69}$ inegável o papel dos princípios como valores fundamentais que exercem o papel de normas em toda a sua extensão, substancialidade, plenitude e abrangência e demonstram o consenso social sobre os valores básicos daquele Estado. ${ }^{70}$

A Constituição Federal de 1988, enquanto estatuto fundamental do Estado Democrático de Direito, se erige sob a dialética entre constitucionalismo - enquanto técnica de limitação do poder como forma de garantia dos direitos básicos do cidadão ${ }^{71}$ - e democracia - enquanto soberania popular e vontade da maioria ${ }^{72}-\mathrm{e}$, portanto, sob uma tensão imanente entre os direitos fundamentais e democracia.

De um lado, portanto, cabe à Constituição garantir as condições necessárias ao processo democrático, mediante a garantia das condições procedimentais e minimamente substanciais e da reserva do espaço próprio do pluralismo, assegurando um ambiente para o adequado funcionamento da formação e deliberação pública.

Isto envolve, portanto, a garantia pelos poderes públicos das liberdades fundamentais essenciais ao exercício democrático, que abrange tanto as condições minimas para uma existência humana digna quanto as

65 ÁVILA, Humberto. Repensando o "Princípio da Supremacia do Interesse Público Sobre o Particular" in SARMENTO, Daniel (Org). Interesses Públicos vs. Interesses Privados: Desconstruindo o Princípio de Supremacia do Interesse Público. Rio de Janeiro: Lumen Juris, 2005. p. 186-190.

66 A desconstrução da Supremacia do Interesse Público sobre o Privado como princípio basilar ou fundamental do regime administrativo no Estado Democrático de Direito, mas a assunção que o interesse público é um dos bens e valores perseguidos pela Constituição Federal, junto aos direitos fundamentais e a democracia é tratado amplamente em: MOURA, Emerson Affonso da Costa. Um Fundamento do Regime Administrativo: O Princípio da Prossecução do Interesse Público. Rio de Janeiro: Lumen Juris, 2014.

67 DIEZ, Manuel Maria. Manual de Derecho Administrativo. Tomo 2. Buenos Aires: Plus Ultra, 1997. p. 187.

68 BUECHELE, Paulo Armínio Tavares. O Princípio da Proporcionalidade e a Interpretação da Constituição. São Paulo: Renovar, 1999. p. 15.

69 BARROSO, Luís Roberto. Fundamentos Teóricos e Filosóficos do Novo Direito Constitucional Brasileiro (Pós-modernidade, teoria crítica e pós-positivismo) in: BARROSO, Luís Roberto. Org. A nova interpretação constitucional: ponderação, direitos fundamentais e relações privadas. Rio de Janeiro: Renovar, 2003. p. 338

70 BONAVIDES, Paulo. Curso de Direito Constitucional. 7. ed. 2. tir. São Paulo: Malheiros, 1998. p. 260 e 265.

71 CANOTILHO, José Joaquim Gomes. Direito constitucional e teoria da constituição. 3. ed. Coimbra: Almedina, 2000 , p. 47.

72 BOBBIO, Norberto Bobbio; MATTEUCCI, Nicola; PASQUINO, Gianfranco. Op. cit. p. 320. 
condições que são necessárias para que cada indivíduo possa exercer substancialmente a sua autonomia pública e privada ${ }^{73}$.

Nesse tocante, relaciona-se o direito de acesso à informação como corolário do próprio Estado Democrático de Direito, uma vez que se liga a um dos princípios fundamentais da Federação Brasileira, de pluralismo em seus aspectos sociais, políticos, religiosos, filosóficos e políticos ${ }^{74}$ ligando, portanto, transparência administrativa com princípio democrático no âmbito da relação administrativa.

Nesse ponto, o acesso à informação constitui elemento essencial para o exercício da autonomia pública e privada, uma vez que permite a igualdade de possibilidade da participação do processo de deliberação e formação de vontade, tanto de assuntos na esfera política quanto privada e, portanto, necessário ao controle da administração pública.

De tal sorte, enquanto ligado ao princípio democrático, o princípio do acesso à informação pública demanda que as restrições devem ocorrer somente de forma excepcional e na medida em que não importe no esvaziamento do substrato necessário para exercício da cidadania e do controle social sob pena de sua respectiva inconstitucionalidade.

Por efeito, o controle social da Administração Pública demanda acesso à informações públicas, acesso a dados e a documentos relativos à gestão dos interesses públicos, de forma a permitir a participação e a fiscalização na atividade administrativa trazendo maior grau de racionalidade e legitimidade à própria gestão da coisa pública.

Não obstante, com o intuito de conformar a norma constitucional, a Lei de Acesso à Informação acabou por abranger, dentre as vedações determinadas atividades administrativas - como segurança ou saúde da população - ao qual o cidadão precisa ter acesso para efetuar o controle social e exercer sua cidadania em concretização ao princípio democrático.

Por essa razão, ainda que se sustente ou não uma precedência axiológica do acesso à informação sobre o sigilo ou anonimato ${ }^{75}$, uma vez que se liga ao princípio democrático, como pressuposto ao seu exercício, na ponderação normativa parece ter mais peso o acesso em algumas hipóteses das restrições da lei federal $n^{\circ}$ 12.527 de 2011 o que aponta a sua inconstitucionalidade.

\section{Estudo de caso: O sigilo na Casa Civil da Presidência da República e o controle SOCIAL DAS INFORMAÇÕES PÚBLICAS}

Compreende o controle social, um conjunto de instrumentos empregados pela sociedade, capaz de induzir a conformação das pessoas às normas de comportamento que a caracteriza, ordenando a sua atuação no ambiente social e estabelecendo as condições necessárias para que sejam alcançados os fins e objetivos almejados pelo grupo social ${ }^{76}$.

Mediante o controle social do poder, se garante a cooperação entre os atores estatais e não estatais na coordenação dos múltiplos e complexos interesses, auxiliando na formação de um espaço público que,

73 SOUZA NETO, Cláudio Pereira de. A justiciabilidade dos direitos sociais: críticas e parâmetros. In: ; Sarmento, Daniel. Direitos sociais: fundamentos, judicialização e direitos sociais em espécie. Rio de Janeiro: Lumen Juris, 2008. p. 535-538.

74 BRASIL, Constituição da República Federativa do Brasil, de 05 de Outubro de 1998. Artigo $1^{\circ}$ inciso V.

75 No julgamento da ADI 4815 o Supremo Tribunal Federal o Ministro Luís Roberto Barroso apontou uma posição preferencial dentro do sistema constitucional, tanto da liberdade de expressão quanto do direito de informação, que decorreria não apenas da tutela do texto constitucional como do histórico brasileiro de censura e do contexto da promulgação da Constituição Federal de 1988. -2025151826 Disponível em: -2025151826 http://www.stf.jus.br/arquivo/cms/noticiaNoticiaStf/anexo/ADI4815LRB.pdf2025151826 Acesso em: 10.03.2016.

76 Trata-se o controle social, portanto, da capacidade de autorregulação de um grupo social baseada na reiteração dos comportamentos necessários ou úteis para alcançar seus objetivos globais, obtidos mediante o consenso ou coerção dos indivíduos. BOBBIO, Noberto, MATTTEUCCI, Nicola e PASQUINO, Gianfranco. Op. cit. p. 283-284. 
baseado na negociação e consenso, atribui maior grau de legitimidade, transparência, racionalidade e eficiência à persecução dos fins sociais ${ }^{77}$.

Importa na construção entre a sociedade e os poderes públicos de um vínculo de compromisso e responsabilidade acerca das decisões estatais, que contribui para o aprimoramento dos mecanismos de exercício da cidadania, além de coibir os desvios de legalidade, garantindo previsibilidade e segurança nas relações jurídico-públicas.

Certamente, não se ignoram as dificuldades na efetivação da participação dos cidadãos na gestão pública. Observam-se, atualmente, dificuldades no controle social em razão do persistente desinteresse e apatia da sociedade pelo debate político ${ }^{78}$, bem como, da atuação burocrática, autoritária e hierarquizada dos poderes estatais na gestão político-administrativa dos interesses públicos ${ }^{79}$.

Neste tocante, erige-se a necessidade de uma otimização da publicidade dos atos estatais, de modo a viabilizar com a transparência na gestão pública o debate político ${ }^{80}$, a utilização de mecanismos de fortalecimento sociocultural da cidadania e fomento da participação popular ${ }^{81}$, bem como, o aperfeiçoamento da gestão estatal $^{82}$ e dos instrumentos jurídicos de controle social ${ }^{83}$.

Por efeito, para um funcionamento otimizado do sistema democrático, devem ser garantido mecanismos que permitam o controle da sociedade mediante acesso aos dados públicos, de forma a poder exercer a responsabilização dos agentes públicos pela tomada da decisão.

Todavia, com o sigilo dos documentos limita-se o controle social e para demonstrar a importância da hipótese levantada na pesquisa opta-se por estudo empírico acerca do acesso à informação no âmbito do Poder Executivo da União, em específico, da Casa Civil da Presidência da República no período de maio de 2012 a agosto de $2016^{84}$.

77 Demonstra-se, por meio da participação dos destinatários da atuação estatal no processo de deliberação pública e de fiscalização (legitimidade); nos argumentos e informações obtidos com a dialética promovida pelos atores envolvidos (racionalidade), do conhecimento das razões utilizadas como fundamentos da decisão estatal (transparência) e da escolha por consenso das medidas mais eficazes para alcançar os resultados almejados (eficiência).

78 Trata-se de fenômeno com fundamentos diversos, que variam desde a impossibilidade de participação devido às condições de pobreza extrema e baixo nível de educação de grande parte da população, da dificuldade de acesso às informações sobre as questões políticas e a falta de tempo para debater e manifestar sobre tais assuntos, até mesmo a descrença de que sua participação seja capaz de influenciar na ação pública. BARCELLOS, Ana Paula de. Papéis do Direito Constitucional no Fomento do Controle Social Democrático: Algumas Propostas Sobre o Tema da Informação in RDE ano 3. N. 12. Out/dez 2008. p. 82-84.

79 O comportamento autoritário e endógeno dos poderes instituídos, que consideram existir uma autossuficiência gerencial e política em relação à sociedade, dificulta o exercício do controle social, criando uma relação artificial e de distanciamento entre os poderes constituídos e a comunidade que deveriam servir. LEAL, Rogério. O Controle social dos serviços públicos no Brasil como condição de sua possibilidade. Revista de Direito Administrativo e Constitucional, Belo Horizonte, n. 13, jul/set 2003 . p. 158.

80 Apenas com o conhecimento das informações referentes à elaboração e execução dos planos governamentais, bem como da estrutura e modo de atuação dos órgãos político-administrativos envolvidos é capaz de ser realizado o controle social permitindo que os cidadãos possam influir na ação estatal. MILESKI, Helio Saul. Controle Social: Um Aliado do Controle Oficial. Interesse Público n. 36 mai/abr 2006. p. 87.

81 Trata-se de medidas que busquem um exercício pleno da cidadania ativa necessária para o controle social, por meio de investimentos na educação que permitam a conscientização política e social dos cidadãos, na ampliação dos espaços públicos de atuação participativa e o desenvolvimento de uma cultura política baseada na ética. SILVA, Francisco Carlos da Cruz. Controle Social: Reformando a Administração Para a Sociedade in: Perspectivas para o Controle Social e a Transparência da Administração Pública. Brasília: Tribunal de Contas da União, Instituto Serzedello Corrêa, 2002. p. 51-55

82 Pressupõe o controle social a superação do perfil burocrático Estatal, que permita, mediante a descentralização e profissionalização da gestão administrativo-financeira, um efetivo espaço de participação da sociedade na gestão dos interesses públicos e controle da atuação estatal. COELHO NETO, Milton. A Transparência e o Controle Social como Paradigmas para a Gestão Pública no Estado Moderno in: FIGUEIREDO, Carlos Maurício e NÓBREGA, Marcos. Administração Pública: Direito Administrativo, Financeiro e Gestão Pública: Prática, Inovações e Polêmicas. São Paulo: Revista dos Tribunais, 2002. p. 316-321.

83 Torna-se necessária a construção de instrumentos jurídicos de controle social que permitam a vinculação da atuação estatal às decisões promovidas no âmbito da deliberação pública - definidas no processo eletivo e na participação na gestão estatal - e a atribuição de responsabilidade pelos desvios de eficiência e legitimidade promovidos pelos agentes públicos na persecução dos interesses públicos.

84 Disponível-2025151821 em -2025151821 http://esic.cgu.gov.br/sistema/Relatorios/Anual/RelatorioAnualPedidos.aspx2025151821 Acesso em 10.09.2016 
No período foram realizados 1.847 pedidos de acesso à informação, sendo respondidas 1.844 solicitações $(99,84 \%)$ permanecendo apenas 3 em tramitação $(0,16 \%)$ sendo que destas 1.091 demandas (59.07\%) foram acerca de acesso aos dados relativo a atuação do Governo e 353 pedidos (19,11\%) foram acerca de Justiça e Legislação.

Foram concedidos acesso de forma integral a 1.244 demandas $(67,35 \%)$ um número abaixo do esperado, sendo negados 268 pedidos (14,51\%) sendo os demais 335 não obtidos acessos (18,41\%) em razão de serem pedidos duplicados, não haver a competência do órgão para a informação, a informação ser inexistente e outros.

Destes 268 pedidos negados, importante ressaltar que cerca de 20 se referiam a Informação sigilosa de acordo com legislação específica (7,463\%), 17 (6,343\%) classificada pela Lei 12.527/2011, 19 (7,09\%) considerada como pedido desproporcional e $40(14,925 \%)$ de um processo decisório em curso como forma de manter o sigilo dos dados.

Note, portanto, que, dentre os pedidos negados de acesso à informação, uma expressiva quantidade se refere à informações tidas como sigilosas em curso ou em finalização, que, na práxis, inviabiliza a já existente dificuldade de construção de um modelo de democrático de gestão pública ${ }^{85}$ e o aperfeiçoamento do controle social pela própria limitação de acesso a estes dados. ${ }^{86}$

Interessante notar que a necessidade de aperfeiçoamento do controle social já tem sido apontado como algo premente as pessoas jurídicas de direito privado em razão dos efeitos sociais e ambientais produzidos pela tomada de decisão das corporações e dos seus investidores. ${ }^{87}$

Igualmente, no que tange ao meio ambiente, exerce função capital ao permitir o acesso sobre a existência de informações, inclusive, aquelas relativas à concessão e à manutenção de licenciamento de empreendimentos, que, embora, em tese, tenham atendido aos estudos de impacto exigidos, podem estar ocasionando lesão a coletividade $^{88}$

Porém, sustenta-se a manutenção dentro da Administração Pública de um conjunto de informações ao qual não são garantidos acesso ao cidadão, que, além de dotada de patente inconstitucionalidade, não corrobora a construção de um modelo transparente e democrático de gestão estatal e ampliação do controle social.

\section{Considerações finais}

Em uma Administração Pública Brasileira marcada, ainda, pela persistência dos resquícios do autoritarismo, patrimonialismo e nepotismo, erige-se o controle pela sociedade da atividade administrativa como forma de garantir a correição ao interesse público e maior grau de racionalidade, eficiência e legitimidade na atuação dos poderes públicos.

Nesse viés, em um Estado Democrático de Direito pautado por uma ordem constitucional garantista, são atribuídos instrumentos para permitir a conformação da atuação da Administração Pública aos bens e valores democráticos e constitucionais tutelados, dentre os quais se destaca a consagração do dever de transparência administrativa na gestão pública.

85 Não foi objetivo deste trabalho problematizar o acesso à informação, mas o modelo demonstra-se, ainda, insuficiente já que, em relação ao universo de pedidos, a maior parte já foi realizada por cidadãos com nível superior $(76,8 \%)$ com alta concentração por servidores públicos federais (23,11\%) e por pessoas na região sudeste $(38,48 \%)$ sendo seguida pelo Distrito Federal (27,55\%). 86 Inclusive, não foi permitido acesso à natureza dos pedidos tampouco ao relatório de recursos e reclamações decorrentes. Disponível em http://esic.cgu.gov.br/sistema/Relatorios/Anual/RelatorioAnualRecursos.aspx Acesso em 10.09.2016.

87 ZANITELLI, Leandro Martins. Empresas, Responsabilidade Social e Politicas de Informacao Obrigatoria no Brasil. Revista Brasileira de Politicas Públicas. volume 3. N. 2. Jul-Dez 2013. p. 336-340.

88 PAES, Luciano Marcos Paes. Participação popular e acesso à informação ambiental para preservação do meio ambiente ecologicamente equilibrado. Revista Brasileira de Politicas Públicas. Vol. 5. n. 3. Jul-dez 2015. p. 280-282. 
Destaca-se o direito fundamental de acesso à informação que impõe o dever de prestação dos dados, documentos e elementos administrativos necessários ao conhecimento das situações individuais, coletivas e difusas, exceto nas hipóteses restritivas constitucionais, em caso da segurança dos indivíduos, da coletividade e do próprio Estado.

Sob tal viés, a lei de acesso à informação regulou o direito fundamental previsto na Constituição Federal estabelecendo normas procedimentais e substanciais para seu exercício, porém, ampliando as limitações constitucionais ao trazer um amplo rol de bens jurídicos com conceitos jurídicos indeterminados, o que gerou uma restrição legal inconstitucional.

A previsão do rol amplo de hipóteses e a imposição da restrição pelos prazos definidos pela lei não se adéqua ao juízo de proporcionalidade se demonstrando medida desnecessária e desproporcional, bem como atenta contra o dever de transparência administrativa, que, ao se ligar ao princípio democrático, impõe um peso maior em algumas de suas hipóteses no confronto com interesse público.

Sustentar uma supremacia do interesse público para manter as hipóteses de restrição ao direito fundamental do acesso à informação pública com a aplicação de conceitos já usados de forma autoritária como "segurança pública" ou que abrangem atividades de interesse coletivo na informação como "saúde da população" é dar azo ao autoritarismo que persiste na Administração Pública Brasileira.

O direito fundamental de acesso à informação pública não se refere a dados, documentos e afins que sejam de domínio do Estado, mas àqueles relativos à gestão dos interesses, bens e serviços que são da própria coletividade, cuja a titularidade dos poderes públicos impõe a restrição, apenas, na medida em que será necessária à preservação da própria sociedade organizada.

Por essa razão, a regulação promovida pela lei de acesso à informação, no que tange aos documentos públicos com a ampliação das hipóteses restritivas prevista na Constituição Federal de 1988, demonstra-se inconstitucional e impede o desenvolvimento do controle social da Administração Pública necessário para a plena realização do princípio democrático.

\section{REFERÊNCIAS BIBLIOGRÁFICAS}

ABREU, J. Capistrano de. Capitulos de História Colonial: 1500-1800. Brasilia: Conselho Editorial do Senado Federal, 1998.

ALEXY, Robert. Teoria dos Direitos Fundamentais. São Paulo: Malheiros, 2008,

AMORIM, Bianca Rihan Pinheiro. O Direito à Memória e à Informação nos Arquivos Brasileiros. VI Simpósio Nacional de História Cultural Escritas da História: Ver - Sentir - Narrar, Universidade Federal do Piauí, Teresina.

AVELLAR, Hélio de Alcântara. História Administrativa do Brasil. Vol. 5. Brasília: DASP, 1970.

ÁVILA, Humberto. Repensando o "Princípio da Supremacia do Interesse Público Sobre o Particular" in SARMENTO, Daniel (Org). Interesses Públicos vs. Interesses Privados: Desconstruindo o Princípio de Supremacia do Interesse Público. Rio de Janeiro: Lumen Juris, 2005.

BAPTISTA, Patrícia. Transformações do Direito Administrativo. Rio de Janeiro: Renovar, 2003.

BALLEIRO, Aliomar. Uma Introdução a Ciência das Finanças. 16 ed. Rio de Janeiro: Forense, 2004.

BARCELLOS, Ana Paula de. Papéis do direito constitucional no fomento do controle social democrático: algumas propostas sobre o tema da informação. Revista de Direito do Estado. a. 3. n. 12. Rio de Janeiro, out.dez. 2008. 
BARROSO, Luís Roberto. O direito constitucional e a efetividade de suas normas: Limites e possibilidades da Constituição brasileira. 7. ed. Rio de Janeiro: Renovar, 2003.

. Neoconstitucionalismo e constitucionalização do direito: O triunfo tardio do direito constitucional no Brasil.

In: SOUZA NETO, Cláudio Pereira de; SARMENTO, Daniel (orgs.). A constitucionalização do direito: fundamentos teóricos e aplicações específicas. Rio de Janeiro: Lumen Juris, 2007.

. Fundamentos Teóricos e Filosóficos do Novo Direito Constitucional Brasileiro (Pós-modernidade, teoria crítica e pós-positivismo) in: BARROSO, Luís Roberto. Org. A nova interpretação constitucional: ponderação, direitos fundamentais e relações privadas. Rio de Janeiro: Renovar, 2003.

BERGALLI, Roberto. Controle Social: Suas Origens Conceituais e Usos Instrumentais in: Revista Brasileira de Ciências Instrumentais. n 3. Jul/set 1993.

BINENBOJM, Gustavo. A constitucionalização do direito administrativo no Brasil: Direitos humanos e democracia como fundamentos de legitimidade e elementos estruturantes da dogmática administrativa in: NALINI, Jose Renato (Coord.). Direitos humanos e formação jurídica. Rio de Janeiro: Forense, 2010.

BOBBIO, Noberto, MATTEUCCI, Nicola e PASQUINO, Gianfranco. Dicionário de Política. Brasília: Editora UNB, 1986.

BRESSER-PEREIRA, Luiz Carlos. Do Estado Patrimonial ao Gerencial in: Pinheiro, Wilheim e Sachs (orgs.), Brasil: Um Século de Transformações. São Paulo: Cia. das Letras, 2001.

BOMFIM, Manoel. A América Latina: Males de Origem. Rio de Janeiro: Centro Edelstein de Pesquisas Sociais, 2008.

BONAVIDES, Paulo. Curso de Direito Constitucional. 7. ed. 2. tir. São Paulo: Malheiros, 1998.

BUECHELE, Paulo Armínio Tavares. O Princípio da Proporcionalidade e a Interpretação da Constituição. São Paulo: Renovar, 1999.

CARBONE, Pedro Paulo. Cultura organizacional do setor público brasileiro: desenvolvendo uma metodologia de gerenciamento da cultura. Revista de Administração Pública. Vol 34. n. 2. 2000.

CANOTILHO, José Joaquim Gomes. Direito constitucional e teoria da constituição. 3. ed. Coimbra: Almedina, 2000 .

CARVALHO FILHO, José dos Santos. Direito Administrativo e Administração Pública. 17 ed. rev., atual e ampla. Rio de Janeiro: Lumen Juris, 2007.

CEPIK, Marco. Direito à Informação: situação legal e desafios. Revista de. Informática Pública, Belo horizonte, v.2, n.2, maio/ 2000.

CUNHA, André Luiz Nogueira da. Direitos Políticos. 1 ed. São Paulo: Juarez de Oliveira, 2004.

DIEZ, Manuel Maria. Manual de Derecho Administrativo. Tomo 2. Buenos Aires: Plus Ultra, 1997.

DI PIETRO, Maria Sylvia Zanella. Participação Popular na Administração Pública. Revista de Direito Administrativo n. 191 jan/mar 2003.

FAORO, Raymundo. Os Donos do Poder. 15 ed. São Paulo: Editora Globo, 2000.

. A Aventura Liberal numa Ordem Patrimonialista in: Revista da USP. São Paulo, n. 17, p. 16, $\mathrm{mar} / \mathrm{abr} / \mathrm{mai} 1993$.

FREYRE, Gilberto. Casa-grande e Senzala. 39 ed. Rio de Janeiro: Record, 2000.

HOLANDA, Sérgio Buarque de. Raízes do Brasil. Rio de Janeiro: Olympio. 1984. 
GORDILLO, Agustín. Despúes de La Reforma Del Estado. Buenos Aires: Fundación de Derecho Administrativo, 1996.

LEAL, Rogério Gesta. Os pressupostos epistemológicos e filosóficos das políticas públicas no Estado Democrático de Direito. In: ___ A Araujo, Luiz Ernani Boresso. Direitos sociais e políticas públicas: desafios contemporâneos. Santa Cruz do Sul: Edunisc, 2003.

LEAL, Rogério. O Controle social dos serviços públicos no Brasil como condição de sua possibilidade. Revista de Direito Administrativo e Constitucional, Belo Horizonte, n. 13, jul/set 2003.

LIMA JUNIOR, Olavo Brasil. As reformas administrativas no Brasil: modelos, sucessos e fracassos. Revista de Serviço Público. Ano 49. N. 2. Abr-Jun 2008.

MARTINS JUNIOR, Wallace Paiva. Transparência Administrativa, Publicidade, Motivação e Participação Popular. São Paulo: Saraiva, 2004.

MATAS, Carles Ramió. Los problemas de la implantación de la nueva gestión pública en las administraciones públicas latinas: modelo de Estado y Cultura Institucional. Revista del CLAD Reforma y Democracia $\mathrm{n}^{\circ} 21$, Caracas, Venezuela 2001.

MENDES, Gilma Ferreira. Direitos fundamentais e controle de constitucionalidade. $3^{a}$ ed., São Paulo: Saraiva, 2004.

MELLO, Shirlei Silmara de Freitas. Consulta Popular e Audiência Pública: Por um Processo Administrativo Federal Dialogado in Anais do XXI Encontro Nacional do CONPEDI/UFU Sistema Jurídico e Direitos Fundamentais Individuais e Coletivos. 2012. Uberlândia. Minas Gerais.

MILESKI, Helio Saul. Controle Social: Um Aliado do Controle Oficial. Interesse Público n. 36 mai/abr 2006.

MONT'ALVERNE, Marcelo de Miranda. Vigência e eficácia da Lei de Responsabilidade Fiscal no âmbito Federal. Anais do XIV Congresso Nacional do Conselho Nacional de Pesquisa e de Pós-Graduação em Direito. Fortaleza. 2005.

MOREIRA NETO, Diogo de Figueiredo. Direito da Participação Política. Rio de Janeiro: Renovar, 1992 Mutacões de Direito Administrativo. Rio de Janeiro: Renovar, 2001.

MOURA, Emerson Affonso da Costa. Um Fundamento do Regime Administrativo: O Princípio da Prossecusão do Interesse Público. Rio de Janeiro: Lumen Juris, 2014.

- A Constitucionalização do Direito e o Regime Jurídico-Administrativo. Revista IOB de Direito Administrativo, v. 87, 2013.

Agências, Expertise e Profissionalismo. O Paradigma da Técnica na Administração Pública. Revista de Direito Administrativo, v. 254, 2011.

Do Controle Jurídico ao Controle Social: Parâmetros a Efetividade dos Direitos Sociais. Revista de Direito Constitucional e Internacional, v. 77, 2011.

Do Controle Jurídico ao Controle Social: Parâmetros a Efetividade dos Direitos Sociais. Revista de Direito Constitucional e Internacional, v. 77, p. 131-184, 2011.

Poder, Função e Prerrogativas Públicas. Revista de Direito Público, v. 48, p. 170-194, 2012.

Politicas Públicas, Controle Social e Orçamento Participativo. Revista de Direito Tributário (São

Paulo), v. 114, 2011.

Direitos Fundamentais, Anistia Politica e Supremo Tribunal Federal: A Justiça de Transição Não Concluida. In: PFLUG, Samantha Ribeiro Meyer; ANDREUCCI, Álvaro Gonçalves Antunes; CAPANO, Evandro Fabini. (Org.). Memória, Verdade e Justiça de Transição. 1ed.Santa Catarina: FUNJAB, 2014, v. 1. 
NUNES, Edson. A gramática política do Brasil - clientelismo e insulamento burocrático. Rio de Janeiro: Jorge Zahar Editor, 1997.

PAES, Luciano Marcos Paes. Participação popular e acesso à informação ambiental para preservação do meio ambiente ecologicamente equilibrado. Revista Brasileira de Politicas Publicas. Vol. 5. n. 3. Jul-dez 2015.

PRADO JUNIOR, Caio. Formação do Brasil Contemporâneo. São Paulo: Companhia das Letras, 2011.

SALDANHA, Nelson Nogueira. História das Idéias Políticas no Brasil. Brasília: Senado Federal, 2001.

SCHIER, Adriana da Costa R. A Participação popular na administração pública: o direito de reclamação. São Paulo: Renovar, 2002.

SCHMIDT, João Pedro. Capital social e políticas públicas in: LEAL, Rogerio Gesta e ARAUJO, Luiz Ernane Boresso de. Direitos sociais e politicas públicas: Desafios contemporâneos. Tomo II. Santa Cruz do Sul: Edunisc, 2003.

SPINK, Peter; TEIXEIRA, Marco Antonio. A Disponibilidade de Ser Controlado: O Controle Social da Administração Pública in: GUEDES, Álvaro Martins; Fonseca Francisco (Org.) Controle Social da Administração Pública: Cenário, Avanços e Dilemas no Brasil. Rio de Janeiro: FGV, 2007.

SILVA, Francisco Carlos da Cruz. Controle Social: Reformando a Administração Para a Sociedade in: Perspectivas para o Controle Social e a Transparência da Administração Pública. Brasília: Tribunal de Contas da União, Instituto Serzedello Corrêa, 2002.

SILVA, Vasco Manuel Pascoal Pereira da. Em busca do Acto Administrativo Permitido. Coimbra: Almedina, 1998.

SOUZA NETO, Cláudio Pereira de. Teoria Constitucional e Democracia Deliberativa. Renovar: Rio de Janeiro, 2006.

A justiciabilidade dos direitos sociais: críticas e parâmetros. In: ; Sarmento, Daniel.

Direitos sociais: fundamentos, judicialização e direitos sociais em espécie. Rio de Janeiro: Lumen Juris, 2008.

TORRES, Ricardo Lobo. O Princípio da Transparência e o Direito Financeiro. Mundo Jurídico. Disponível em: http://www.mundojuridico.adv.br/sis_artigos/artigos.asp?codigo=162. Acesso em: 25 de Julho de 2013.

VIANNA, Hélio. História do Brasil: Período Colonial, Monarquia e República. 12ed. São Paulo: Universidade de São Paulo, 1975.

WAHRLICH, Beatriz. A Reforma Administrativa da Era de Vargas. Rio de Janeiro: Editora FGV, 1983.

ZANITELLI, Leandro Martins. Empresas, Responsabilidade Social e Politicas de Informacao Obrigatoria no Brasil. Revista Brasileira de Politicas Publicas. Volume 3. N. 2. Jul-Dez 2013. 


\section{REVISTA BRASILEIRA DE POLÍTICAS PÚBLICAS BRAZILIAN JOURNAL OF PUBLIC POLICY}
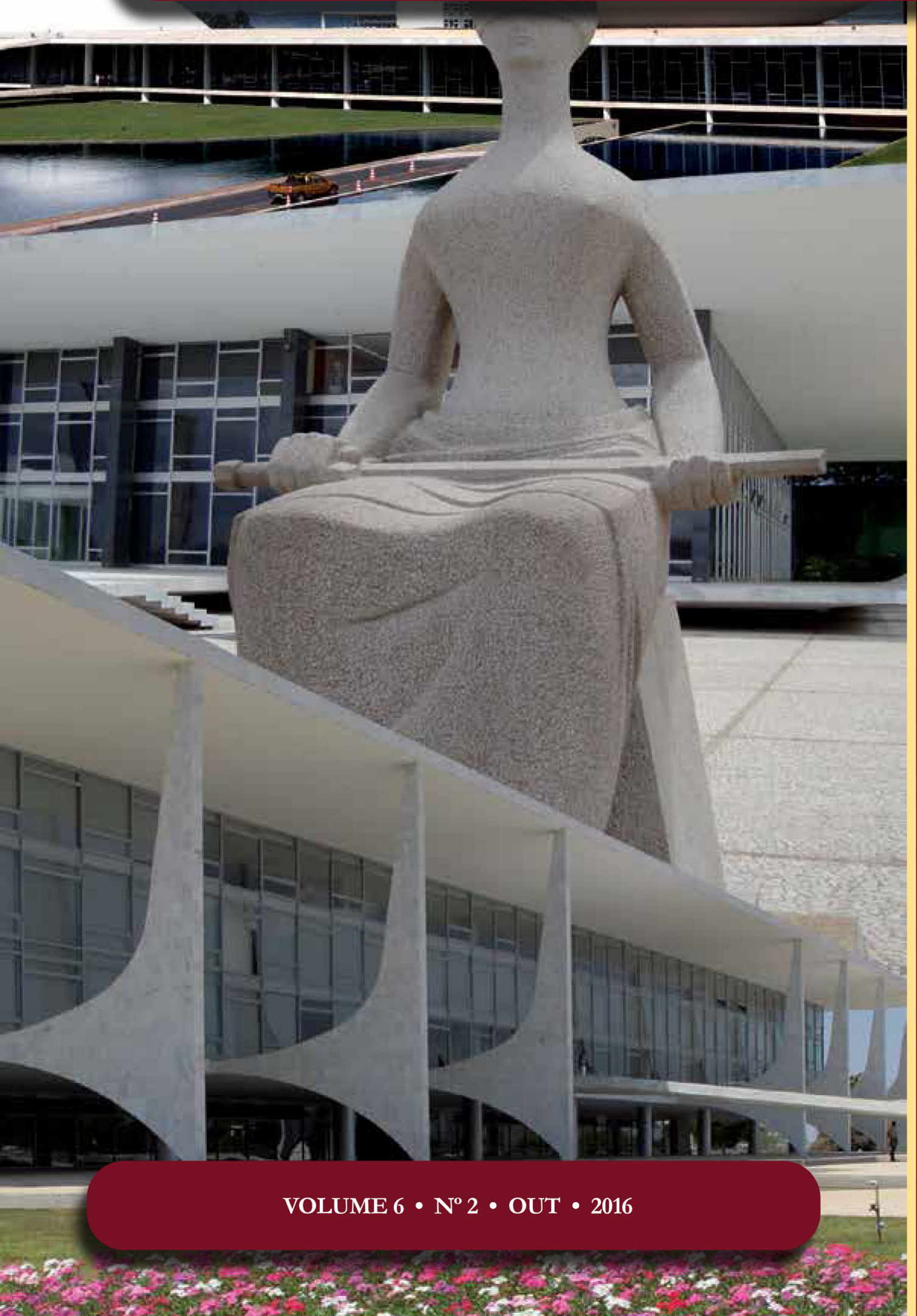

A influência do Direito Administrativo Global no processo brasileiro de Contratação Pública à luz do Princípio da Transparência The influence of the Global Administrative Law in the Brazilian process of public procurement in the light of transparency principle

Alice Rocha da Silva Ruth Maria Pereira dos Santos 


\title{
A influência do Direito Administrativo Global no processo brasileiro de Contratação Pública à luz do Princípio da Transparência*
}

\author{
The influence of the Global Administrative \\ Law in the Brazilian process of public \\ procurement in the light of transparency \\ principle
}

\author{
Alice Rocha da Silva** \\ Ruth Maria Pereira dos Santos***
}

\section{Resumo}

O trabalho tem por objetivo a apreciação da influência do Direito Administrativo Global no processo de contratação pública à luz do Princípio da Transparência a partir do direito internacional e europeu. Para tanto apresenta-se o direito administrativo sob a ótica internacional, uma vez que há diversos atores supra ou paraestatais que modificam a estrutura das relações administrativas do Estado. Por essa razão e em decorrência da internacionalização do direito, a contratação pública tem sido objeto de modificações em diversos ordenamentos jurídicos, devendo ser objeto de análise no contexto brasileiro, que ainda orienta o Direito Administrativo com base em uma visão monista. Posto essa razão, propõe-se a inserção do Princípio da Transparência, atribuído como um valor global, oriundo do Direito Administrativo Global (DAG) e inserido nas normas europeias e internacionais de contratação pública, a fim de que possa melhorar a transparência no processo brasileiro, uma vez que o atual cenário brasileiro se orienta mais na gestão do gasto público do que no acompanhamento do processo licitatório. Desse modo, se vislumbra o aumento da accoutability, com a maior eficiência do gasto público, bem como a proteção dos direitos e implementação dos ideais democráticos por meio da informação e participação do cidadão na esfera pública.

Palavras chaves: Contratação Pública. Direito Administrativo Global. Princípio da Transparência. Regulação Top-Down. Doutorado em Direito do UniCEUB. Doutora em Direito pela Université d'Aix-Marseille III. Mestre em Direito pelo UniCEUB. Graduada em Direito pelo UniCEUB e em Ciência Política e Relações Internacionais pela UnB. E-mail: rochaalice@yahoo.com.br

\section{Abstract}

The work aims to study the influence of Global Administrative Law in the procurement process at the light of the principle of transparency from the perspective of International and European law. In order to achieve this aim it's presented an analysis of the Administrative Law from an international point of view, since there are several above-state or parastatal actors that modify the structure of the administrative affairs of the state. For this 
reason and due to the internationalization of Law, public procurement has been the subject of changes in various legal systems and should be the object of analysis in the Brazilian context, which still guides the Administrative Law based on a monistic view. Having said that, it is proposed the insertion of the Principle of Transparency, understood as a global value from the so-called Global Administrative Law which is already inserted in the European and International standards of public procurement, in order to improve transparency in the Brazilian process, once the current Brazilian scenario is oriented more on management of public spending than in monitoring the bidding process. In this way, one can increase the accountability, with the greater efficiency of public spending, as well as the protection of the rights and the implementation of democratic ideals through information and citizen participation in the public sphere.

Keyword: Public Procurement; Global Administrative Law; Principle of Transparency; Regulation TopDown.

\section{INTRODUÇÃO}

A inserção de mecanismos de direito europeu e internacional no processo de contratação pública revela possibilidades jurídicas importantes para o desenvolvimento brasileiro, da esfera pública, sobretudo, no aumento da accountabilty dos agentes públicos, com base na adoção do Princípio da Transparência como um valor a ser atribuído nas legislações nacionais. Nesse sentido, o tema revela interesse em virtude da emergência do Direito Administrativo Global, que exerce um papel de regulador global, podendo influenciar positivamente no processo de accountability, promovendo a proteção dos direitos e a implementação da democracia.

Cabe ressaltar que o processo de contratação pública já não pode ser entendido como o mesmo de anos atrás, houve a alteração desse direito em virtude da globalização/internacionalização do direito. Isto quer dizer que a visão monista que se tem do direito administrativo não se coaduna mais com as novas relações transfronteiriças que o Estado passou a ter. Nota-se, portanto, a influência do Direito Internacional na óptica da Administração Pública, bem como, na contratação pública, como se verifica no direito europeu, que traça padrões normativos por meio das diretivas europeias a serem incorporadas na ordem interna dos Estados membros do bloco.

Verifica-se, portanto, a aproximação da contratação publica no contexto do direito administrativo global, isto porque o critério da transnacionalidade transpõe o tema para além das barreiras do Estado, justificando a expansão da regulação global, transposta na Teoria do Direito Administrativo Global, pois há a criação de novas relações estatais que estão além da fronteira da Administração interna, e que, consequentemente, necessitará de padrões normativos para tornar possível essa regulação, que agora não se restringe a um ou outro país.

Importa destacar que a defesa teórica do Direito Administrativo Global está pautada na ideia de uma construção de governança global, formada por normas internacionais e com base em princípios de direito administrativo. Isto tem por objetivo a reorganização do novo espaço internacional, que agora tem em conta não apenas os Estados, mas também as organizações internacionais e atores privados, além das relações intergovernamentais, que ensejam na formação de mecanismos comuns pautados na cooperação.

É nesse sentido que o direito administrativo global traz consigo mecanismos, princípios, práticas e acordos sociais que respaldam e que promovem e/ou afetam a accountability dos órgãos globais administrativos, a fim de assegurar que se cumpra padrões de transparência, participação, tomada de decisões fundamentadas e dentro da legalidade, promovendo a efetiva avaliação das normas e decisões que aprovam.

Diante dessa característica do direito administrativo global, com a construção de entendimentos globais acerca de diferentes temas, bem como a participação das organizações internacionais, Estados e atores privados, dentro de uma mesma esfera, surge a necessidade de averiguar o processo de contratação pública 
à luz da criação de valores, regras e princípios comuns, oriundas do direito internacional e do direito comunitário europeu, que serão reguladas pelo direito administrativo global, a fim de coordenar as relações administrativas, podendo levar a melhora do procedimento administrativo de contratação pública no plano do direito nacional.

Por essa razão, o presente trabalho dedicou-se a analise do Princípio da Transparência como um valor do Direito Administrativo Global, em virtude de seu reconhecimento pelas instâncias global e europeia como indispensável ao processo de contratação pública, seja por se tratar de uma ferramenta de governança global, seja por ser um mecanismo de aumento da responsabilidade (accountability) da Administração Pública. Além disso, em análise comparada, no Brasil, o Princípio da Transparência está direcionado, quase que inteiramente, para a gestão do gasto público, excluindo o controle das licitações, que geram um alto índice de irregularidades e corrupção.

É necessário alterar o direito administrativo, sobretudo o processo licitatório, que ainda possui a óptica inteiramente nacional, a fim de inserir com mais afinco o Princípio da Transparência nas relações adjudicatórias, a fim de criar maior responsabilidade dos administradores públicos, bem como diminuir os casos de corrupção oriundas das licitações. Posto isto, sugere-se que o princípio da transparência, sendo observado como um valor global e inserido no processo licitatório europeu e global, sirva de parâmetro para a alteração do sistema brasileiro de contratos públicos, que pouco preza pela transparência, muito embora existam mecanismos normativos que possibilitam a verificação da atuação da Administração Pública.

Em virtude disso, propõe-se a atuação do Direito Administrativo Global, por meio da regulação global "top down", que se origina da administração internacional e das normas internacionais, ante a deficiência de accountability, com a ampliação da eficiência e a garantia aos cidadãos da promoção dos direitos individuais e da implementação dos ideais democráticos, de modo que o cidadão esteja plenamente informado, sendo capaz de contribuir para a responsabilização dos agentes públicas ante a sua participação nas ações em prol da coletividade, melhorando o funcionamento do Estado.

\section{O PrincíPio da Transparência como Valor global no processo de Contratação PÚBLICA}

O princípio da transparência será o ponto de partida para a análise da regulação global dos contratos públicos, por ser um princípio basilar de direito administrativo nacional e que o direito administrativo global toma como sendo um mecanismo importante para a realização da accountability porque expõe, publicamente, as decisões administrativas, permitindo o exercício eficaz dos direitos. Nessa perspectiva, o objetivo do presente trabalho é utilizar o princípio da transparência como instrumento do direito administrativo global aplicável ao processo de contratação pública e, não, simplesmente, como um princípio de direito administrativo nacional, mas sim como mecanismo de accountability nos contratos públicos.

A transparência é uma das ferramentas adequada para realizar a governança global e aumentar o nível de responsabilidade (accountability) da Administração Pública. A escolha do princípio da transparência se justifica por se traduzir num pressuposto básico de governabilidade em respeito ao cidadão e às próprias instituições do Estado, pois permite que as informações sejam mais difundidas e, ao mesmo tempo, o cidadão tem a possibilidade de exercer a sua cidadania tornando o Estado mais eficaz ante a melhoria da sua governança frente aos nacionais e aos demais países.

A transparência pode ser entendida como um dos princípios gerais de direito, fundamental para Administração na consecução dos ideais democráticos, uma vez que se pretende a abertura dos procedimentos administrativos e da própria Administração, partindo, inicialmente, de uma ideia de publicidade do ato administrativo, a fim de legitimar o poder do Estado em prol do cumprimento das regras estabelecidas por 
ele. Ao conceber a transparência como um princípio basilar e moral do Estado Democrático de Direito, é possível inserir o cidadão como parte integrante dessa administração, com o direito à informação, à participação pública e às garantias judiciais ${ }^{1}$.

O princípio da transparência estabelece o diálogo entre a Administração e o cidadão, a fim de que este participe das decisões administrativas, expresso de três formas distintas: o direito de saber, o direito de controle e direito de participação dos mecanismos administrativos. O primeiro, o direito de saber, refere-se ao direito do cidadão de ter em conta o funcionamento da Administração, uma vez que ela está atuando a serviço destes. Já o direito de controle, que se refere ao segundo aspecto, está ligado ao "poder" que é dado ao cidadão, ao conhecer a Administração, com a possibilidade de verificar a legalidade do ato administrativo e a gestão do dinheiro público. Isto, consequentemente, leva ao terceiro ponto, que se refere à participação do cidadão nos mecanismos administrativos, ou seja, ele deixa de ser um expectador² .

Ainda em relação ao conceito de transparência, Fuentes afirma que não há uma definição universal, mas denota um dever de promover a disseminação de informações relevantes e precisas e acessível a todas as partes interessadas. Além disso, a transparência está associada à accountability, gerando um dever moral ou legal para os atores envolvidos, que necessita estar inserido em uma sociedade civil forte, para que os mecanismos de prestação de contas/responsabilização possam ser exigidos ${ }^{3}$.

Para a transparência atingir o seu objetivo, a informação deve abranger os aspectos econômicos, sociais e políticos, sendo realizada de forma oportuna, de maneira confiável e de boa qualidade, com amplo acesso às partes interessadas. Isto permite o desenvolvimento humano porque aumenta a eficiência da alocação dos recursos, além de garantir os benefícios sociais sejam melhor distribuídos, não se restringindo apenas a uma parcela da sociedade ${ }^{4}$.

Nessa perspectiva, se faz necessário destacar os posicionamentos de Joseph Stiglitz e Amartya Sen. O primeiro faz uma análise a partir de uma vertente econômica, enquanto o segundo verifica o princípio da transparência como um direito humano em favor da liberdade. Essa análise se faz interessante para o trabalho, porque os dois pontos são cruciais para o desenvolvimento dos princípios norteadores do direito administrativo global, uma vez que, com base nos direitos econômicos e dos direitos humanos, se vislumbra a universalização dos direitos com a devida harmonização entre eles.

A transparência para Stiglitz representa uma diminuição das desigualdades de informações entre os agentes públicos e os cidadãos, a fim de melhorar a gestão no setor público, de modo a minimizar os erros da gestão pública, permitindo maior controle da ação estatal. Portanto, é necessário informar para que o indivíduo possa valorar a prestação do serviço público, bem como o acesso amplo à informação permite maior abertura do mercado econômico, em virtude da diminuição das incertezas de investimento, trazendo maior eficiência do dinheiro pública, pois aloca melhor o resultado dos investimentos. De outra banda, manter o sigilo da informação leva, consequentemente, a ausência de responsabilidade e a defesa de interesses pessoais ou especiais em detrimento da esfera pública ${ }^{5}$.

No que se refere à Amartya Sen, não se pretende fazer uma explanação de sua teoria "desenvolvimento como liberdade", no entanto, se faz necessário explicar os seus pilares, para chegar ao tópico da transpa-

1 FUENTES, Carlos Iván. Transparency as a Global Goal: towards an unity of principles in Global Administrative Law. 2008. Disponível em: <http://ssrn.com/abstract=1134122>. Acesso em: 22 jul. 2015.

2 TABORDA, Maren Guimarães. O princípio da transparência e o aprofundamento dos caracteres fundamentais do direito administrativo. Revista de Direito Administrativo, Rio de Janeiro, p. 251-279, out./dez. 2002.

3 FUENTES, Carlos Iván. Transparency as a Global Goal: towards an unity of principles in Global Administrative Law. 2008. Disponível em: <http://ssrn.com/abstract=1134122>. Acesso em: 22 jul. 2015.

4 BELLVER, Ana; KAUFMANN, Daniel. Transparenting Transparency: Initial Empirics and Policy Applications. Preliminary draft, August, 2005 for discussion and comments. Local: Editora, 2005. Disponível em:http://siteresources. worldbank.org/INTWBIGOVANTCOR/ Resources/Transparenting_Transparency171005.pdf Acesso em: 27 de julho 2015.

5 STIGLITZ, Joseph. On liberty, the right to know, and public discourse: the role of transparency in public life. Oxford: Oxford Amnesty Lectures, 1999. 
rência. Assim, Sen entende que a globalização contribuiu, significativamente, para expandir os direitos e liberdades do homem, porém, com esse mesmo avanço econômico, político, social e cultural, há problemas que persistem, tais como a fome, a pobreza, a violação de liberdades políticas e liberdades básicas, a falta de atenção aos interesses e as ameaças ao meio ambiente. A superação desses problemas pode ocorrer por meio da expansão das liberdades, o que permitirá o desenvolvimento.

A liberdade funciona como um instrumento primordial para o desenvolvimento, que é o meio principal. Para tanto, são enumeradas cinco liberdades instrumentais indispensáveis para o desenvolvimento: oportunidade econômica, liberdades políticas, serviços sociais, garantia de transparência e segurança protetora. Para os fins do trabalho, interessa a garantia de transparência, que Sen define como a necessidade de franqueza que os indivíduos podem esperar um dos outros, ou seja, é a liberdade para se relacionar com a certeza de divulgação de informação e clareza. Consequentemente, quando há a violação da transparência, ou da confiança, com a ausência de franqueza, isto afetará a sociedade, sejam as partes diretamente envolvidas ou terceiros. A liberdade de garantia de transparência é um instrumento para a prevenção da corrupção, da irresponsabilidade financeira e das transações ilícitas ${ }^{6}$.

$\mathrm{Na}$ esfera do direito administrativo global, o princípio da transparência é um dos princípios, entre o corpo de princípios que tem origem no direito nacional, que dão legitimidade à norma global. Assim, a transparência atua no direito administrativo global como instrumento para a boa governança e construção do processo de accountability, em favor da democracia dentro da nova ordem mundial que requer a participação do cidadão, que ocorrerá por meio do princípio da transparência, entendido como um direito democrático de cidadania ${ }^{7}$, posto que é dever do Estado dar publicidade seja nas suas decisões administrativas ou judiciais. Cabe ressaltar a importância do princípio da transparência se justifica por ser considerado um direito humano, porque favorece o desenvolvimento, por meio de incentivos, redistribuição e inclusão dos benefícios, bem como um direito de o cidadão ter conhecimento do comportamento, tanto dos governos locais quanto organizações internacionais ${ }^{8}$.

Muito embora o princípio da transparência já tenha previsão normativa no direito brasileiro, o processo de contratação pública exige um grau máximo de transparência, seja para manter a legalidade do procedimento, seja para ampliar a participação dos interessados no processo licitatório, ou, sobretudo, para evitar fraudes e corrupção no decorrer da adjudicação. Todavia, os gestores públicos e o próprio cidadão brasileiro pouco se atentam para o critério da transparência ou para buscar se informar sobre os atos administrativos, ainda que recaia diretamente na vida cotidiana do indivíduo no que se refere aos serviços públicos.

Consequentemente, o nível de accountability no processo brasileiro de contratação pública é muito baixo ou inexistente. Por essa razão, é necessário buscar na Teoria do Direito Administrativo Global e nas normas internacionais a maximização da responsabilidade/prestação de contas dos agentes públicos. Isto porque é por meio da transparência, entendida como um direito humano, e indispensável para a consecução do objetivo proposto pelo DAG (a proteção dos direitos e a promoção dos ideais democráticos) que são restringidos pela corrupção, pela imoralidade política e pela não publicidade das contas públicas.

Nessa linha, verificar-se-á a inclusão do princípio da transparência nos órgãos regulatórios globais, direcionando a análise para a contratação pública, sobretudo, a previsão normativa no contexto europeu e global, no que se refere à ONU, OMC e FMI. Para, então, passar à apreciação do princípio da transparência no direito brasileiro.

6 SEN, Amartya. Desarrollo y libertad. Trad. Esther Rabasco e Luís Toharia. Buenos Aires: Planeta, 2000. p. 59.

7 HARLOW, Carol. Global administrative law: the quest for principles and values. EJIL, v. 17, p. 187-214, 2006.

8 FUENTES, Carlos Iván. Transparency as a Global Goal: towards an unity of principles in Global Administrative Law. 2008. Disponível em: <http://ssrn.com/abstract=1134122>. Acesso em: 22 jul. 2015. 


\section{O PRINCÍPIO DA TRANSPARÊNCIA COMO BASE DO PROCESSO DE CONTRATAÇÃO PÚBLICA NO}

CONTEXTO DA UNIÃO EUROPEIA E GLOBAL

A contratação pública é um tema que tem ganhado amplitude mundial, não se restringindo aos limites territoriais do Estado, no que se refere às normas e à dimensão dos contratos públicos, como explicitado na primeira parte do trabalho. Na esfera global, os princípios da não discriminação, da publicidade, da livre concorrência e transparência, garantem que os entes públicos atuem com clareza para com o interesse público, bem como frente a países terceiros. Além disso, os princípios de direito administrativo que fundamentam o Estado de Direito são essenciais para legitimar os ordenamentos jurídico global.

O princípio da transparência juntamente ao conceito de accountability constituem um dos focos de estudo do direito administrativo global, quais serão aplicados ao processo de contratação pública, a fim de proteger os direitos dos cidadãos e promover os ideais democráticos, com base em uma adjudicação transparente e mais eficiente. Desse modo, o princípio da transparência deve atuar de forma complementar e sincronizada com a vertente nacional e global, a fim de realizar o controle e a accountability nas compras públicas por meio dos órgãos de controle internos que adotarão, ou já adotaram, padrões normativos de transparência que tem origem na ordem global.

Assim, o princípio da transparência está previsto pela ONU, na Convenção das Nações Unidas contra a Corrupção (UNCAC), qual foi ratificada em dezembro de 2005, após ser ratificada por um número mínimo de países, incluindo o Brasil e a União Europeia. Em relação aos 71 artigos da convenção, quatro chamam a atenção para o trabalho, que são: art. $5^{\circ}$, sobre medidas preventivas; art. $7^{\circ 10}$, sobre setor público; art. $9^{\circ}$ sobre contratação pública; e art. 10, sobre informação pública.

No que se refere à contratação pública, a Convenção determina que cada parte signatária, nos moldes dos princípios vigentes em seu direito interno, adote medidas necessárias para estabelecer um sistema apropriado de contratação pública com base na transparência, na concorrência e em critérios objetivos de decisão, que sejam capazes de prevenir a corrupção, pautado, sobretudo, na difusão pública de informação e nos mecanismos de controle. A promoção da transparência e da accountability é um dever de cada Estado Parte, que deve inserir na legislação interna referente à Administração Pública medidas como a instauração de procedimentos ou regulamentos que facilitem o acesso do público aos atos praticados pela Administração Pública ${ }^{11}$.

Ainda na esfera global, destaca-se, também, o princípio da transparência na OMC, que configura, juntamente ao princípio da Nação Mais Favorecida e do Tratamento Nacional, um dos pilares do sistema multilateral de comércio. A transparência, no comércio internacional significa impedir obstáculos ao comércio, de modo que os países membros adotem mecanismos e políticas comerciais transparentes, dando maior previsibilidade e estabilidade ao comércio internacional.

9 Art. $5^{\circ}, \$ 1$. Cada Estado-Parte, em conformidade com os princípios fundamentais de seu ordenamento jurídico, formulará e aplicará ou manterá em vigor políticas coordenadas e eficazes contra a corrupção que promovam a participação da sociedade e reflitam os princípios do Estado de Direito, a devida gestão dos assuntos e bens públicos, a integridade, a transparência e a obrigação de render contas. NAÇÕES UNIDAS. Convenção das Nações Unidas contra Corrup̣cão. Escritório Drogas e Crime - UNODOC. 2007. Disponível em: <http://www.unodc.org/documents/lpo-brazil//Topics_corruption/Publicacoes/2007_UNCAC_Port.pdf>. Acesso em: 27 jul. 2015.

10 Cada Estado Parte, quando for apropriado e de conformidade com os princípios fundamentais de seu ordenamento jurídico, procurará adotar sistemas de convocação, contratação, retenção, promoção e aposentadoria de funcionários públicos e, quando proceder, de outros funcionários públicos não empossados, ou manter e fortalecer tais sistemas. Estes: a) estarão baseados em princípios de eficiência e transparência e em critérios objetivos como o mérito, a equidade e a aptidão. ORGANIZAÇÃO DAS NAÇÕES UNIDAS. Convenção das Nações Unidas contra Corrup̣cão. Geneva: UNODOC, 2007. Disponível em: <http://www.unodc. org/documents/lpo-brazil//Topics_corruption/Publicacoes/2007_UNCAC_Port.pdf>. Acesso em: 27 jul. 2015.

11 ORGANIZAÇÃO DAS NAÇÕES UNIDAS. Convenção das Nações Unidas contra Corrupção. Geneva: UNODOC, 2007. Disponível em: <http://www.unodc.org/documents/lpo-brazil//Topics_corruption/Publicacoes/2007_UNCAC_Port.pdf>. Acesso em: 27 jul. 2015. 
Além dos acordos trazerem disposições específicas acerca da transparência, a OMC adota o Mecanismo de Exame das Políticas Comerciais que tem por objetivo promover o cumprimento por todos os membros das normas e disposições da OMC, juntamente aos compromissos assumidos. Isso ocorre por meio da verificação coletiva das políticas comerciais adotadas pelos Membros não para fazer cumprir as obrigações ou procedimentos, tampouco para impor novos compromisso, mas para aumentar a transparência e compreender as políticas e práticas comerciais ${ }^{12}$.

No que se refere à contratação pública, a OMC trabalha com a sua promoção desde 1996, quando institui um grupo de trabalho sobre transparência nos contratos públicos que valorizou a inserção desse valor nas políticas nacionais. Quanto ao ACP, o princípio da transparência vem expresso em diversas partes do texto normativo, desde o preâmbulo que reconhece a importância de os países signatários disporem de medidas transparentes no que se refere aos contratos públicos, de modo que as contratações sejam transparentes e imparcial, a fim de evitar conflitos de interesses e práticas corruptivas, em consonância com a Convenção das ONU contra corrupção, outrora mencionada ${ }^{13}$.

De igual modo, estabelece que a execução da contratação deve ser realizada de maneira transparente e imparcial, adotando os métodos de licitação pública, de modo a evitar o conflito de interesses e que impeça a corrupção. Além disso, prevê a transparência da informação sobre a contratação e procedimentos internos de revisão, em que as partes possam apresentar recurso de modo eficaz, transparente e não discriminatório, com o intuito de impugnar o concurso público ${ }^{14}$.

A Organização para a Cooperação e Desenvolvimento Econômico (OCDE) também traça standards de transparência e de troca de informações, bem como a sua implementação. Sobretudo, com base no contexto da crise econômica europeia, houve um esforço em fazer cumprir com as recomendações da OCDE, permitindo maior circulação das informação e aumento da transparência nos mercados econômicos, a fim de evitar as fraudes, a evasão fiscal e o branqueamento de capitais. No contexto europeu, a transparência e a ampliação das informações em redes de cooperação são essenciais, devido ao alargamento do espaço comunitário com a abolição de fronteiras e a livre circulação de pessoas, mercadorias e capitais, tornando-se uma questão crucial para o desenvolvimento do mercado comum europeu ${ }^{15}$.

O princípio da transparência permeia todo o processo de padronização (criação de standards) na União Europeia, desde o Tratado de Maastrich, a partir da Declaração relativa ao direito de acesso à informação. Tal documento considerou que "a transparência do processo decisório reforça o caráter democrático das Instituições e a confiança do público na administração", determinando que, até o ano de 1993, deveria ser apresentado um relatório com as medidas direcionadas à facilitação do acesso à informação ${ }^{16}$.

A ideia transcrita na Declaração vem disposta no preâmbulo do Tratado de Lisboa, ao tratar sobre o desejo de aprofundar o caráter democrático e transparente da sua vida pública. Isto revela o intuito de aproximar a Comunidade Europeia dos cidadãos, posto que não se pode desenvolver as atividades comunitárias sem o conhecimento do cidadão, pressuposto democrático para reforçar os direitos fundamentais, sobretudo, a partir do direito à informação. Portanto, a transparência tornou um imperativo democrático para a

12 WORLD TRADE ORGANIZATION. WTO Annual Report 2015. Disponível em: < https://www.wto.org/english/res_e/ booksp_e/anrep_e/anrep15_e.pdf>. Acesso em: 27 jul. 2015. p. 78.

13 WORLD TRADE ORGANIZATION. Acuerdo revisado sobre contratación pública. 2014. Disponível em: <https://www.wto.org/ spanish/docs_s/legal_s/rev-gpr-94_01_s.pdf>. Acesso em: 27 jul. 2015.

14 WORLD TRADE ORGANIZATION. Acuerdo revisado sobre contratación pública. 2014. Disponível em: < https://www.wto.org/ spanish/docs_s/legal_s/rev-gpr-94_01_s.pdf>. Acesso em: 27 jul. 2015.

15 AZEVEDO, Patrícia Anjos. O princípio da transparência e a troca de informações entre administrações fiscais. Tese (Doutorado). Porto, 2010. Disponível em:<www.cije.up.pt/download-file/878>. Acesso em: 27 jul. 2015. p. 13-15.

16 UNIÃO EUROPEIA. Tratado da União Europeia. Luxemburgo: Serviço das Publicações Oficiais das Comunidades Europeias, 1992. Disponível em: < http://europa.eu/eu-law/decision-making/treaties/pdf/treaty_on_european_union/treaty_on_european_ union_pt.pdf>. Acesso em: 28 jul. 2015. p. 229. 
integração europeia e necessário para a construção da confiança nas instituições públicas ${ }^{17}$.

No que se refere aos contratos públicos, as normas europeias, incluindo as diretivas acerca do assunto, trazem consigo a obrigação de transparência, que está associado ao Princípio da igualdade de tratamento. A jurisprudência do $\mathrm{TJUE}^{18}$ entendeu que a obrigação de transparência se refere à garantia no processo adjudicatório que não existirá favoritismo ou arbitrariedade por parte da entidade adjudicante, que deve garantir a todos os proponentes um certo grau de publicidade, permitindo a abertura da concorrência e do controle da imparcialidade do processo. Além disso, todas as condições e as modalidades do processo de adjudicação devem atingir a todos os participantes de uma mesma maneira, de modo que as informações sejam claras, precisas e unívocas, a fim de permitir a todos os proponentes compreendam as condições as modalidades do processo de adjudicação ${ }^{19}$.

Corroborando com o entendimento da Advocacia-Geral, o Tribunal de Justiça da União Europeia (TJUE), no processo T-165/12, entendeu que o Princípio da igualdade de tratamento implica numa obrigação de transparência, bem como o princípio da transparência, nos contratos públicos, deve garantir que nenhum proponente seja favorecido em detrimento dos demais, tampouco existam práticas arbitrárias por parte da Administração Pública, representada pela entidade adjudicante. O TJUE considera que o princípio da transparência cria a obrigação de que todas as informações referentes à adjudicação estejam disponíveis, de modo que as empresas participantes possam compreender o alcance exato da proposta, sem qualquer ambiguidade, facilitando, inclusive, a verificação dos cumprimentos dos critérios por parte do adjudicante ${ }^{20}$.

Por fim, porém, não menos importante, a Organização dos Estados Americanos (OEA), por meio da Comissão Interamericana de Direitos Humanos, na sua Carta Democrática Interamericana, de setembro de 2001, entende que a transparência é indispensável para o exercício da democracia e das atividades governamentais, bem como a probidade e a responsabilidade dos agentes públicos na gestão administrativa, com o devido respeito aos direitos sociais. Insere a transparência no contexto das organizações políticas, posto que as campanhas eleitorais devem obedecer um regime equilibrado e transparente de financiamento de suas atividades ${ }^{21}$.

Muito embora a Carta Democrática não trate propriamente da contratação pública, ao estabelecer o princípio da transparência como um princípio do Estado de Direito e como um mecanismo necessário para a democracia, reflete, diretamente, nos contratos públicos. Principalmente, quando se trata do aumento da accountability na Administração Pública, pois, no caso brasileiro, o nível de responsabilização dos agentes públicos é baixo, bem como a valorização da transparência ainda caminha a passos lentos, como se demonstrará a seguir.

\section{A APLICABILIDADE dO PRINCÍPIO DA TRANSPARÊNCIA ÀS REGRAS BRASILEIRAS DE CONTRATAÇÃO PÚBLICA}

No presente tópico, a proposta é apresentar o princípio da transparência no contexto brasileiro de contratação pública, tendo em vista a sua pouca adesão nas normas nacionais, isto porque o princípio não se encontra expresso no texto da lei de licitação. Tampouco os princípios regentes do direito administrativo e,

17 GRARD, Loïc. La transparence un príncipe ascendant de la réalisation de l'Union Européenne. Communication et organisation, 17/2000. 2012. Disponível em: <http://communicationorganisation.revues.org/2351>. Acesso em: 28 jul. 2015. p. 2-6.

18 Telaustria, Telefonadress e Parking Brixen.

19 OBSERVATÓRIO DE CONTRATAÇÃO PÚBLICA. Conclusões do Advogado-Geral Yves Bot, no processo C-91/08. 2009. Disponível em: <http://www.contratacaopublica.com.pt/jurisprudencia/comunitaria/Conclusoes-do-Advogado-Geral-no-processoC-9108-27-de-Outubro-de-2009/712/>. Acesso em: 28 jul. 2015.

20 TRIBUNAL DE JUSTIÇA DA UNIÃO EUROPEIA. Processo T-165/12. Acórdão ECLI: EU: T:2013:646. Data do Julgado 13.12.2013. Disponível em: <http:/ / curia.europa.eu/juris/celex.jsf?celex=62012TJ0165\&lang $1=$ pt\&type=TXT\&ancre=> . Acesso em: 28 jul. 2015.

21 COMISSÃO INTERAMERICANA DE DIREITOS HUMANOS. Carta Democrática Interamericana. 2001. Disponível em: <http://www.cidh.oas.org/basicos/portugues/r.Carta.Democr\%C3\%A1tica.htm>. Acesso em: 27 jul. 2015. 
especificamente, do processo licitatório não inserem a transparência diretamente, chegando mais próximos do previsto na esfera global, a associação dos Princípios da publicidade e da igualdade, sendo tratada como um desdobramento destes.

$\mathrm{Na}$ esfera jurídica brasileira, a transparência foi, normativamente, concebida em 2011 por meio da Lei n. 12.527, que regula o acesso à informação, porém não direcionado à contratação pública. A proposta da lei era ampliar e facilitar o acesso às informações do poder público para o cidadão, dando publicidade aos seus atos. Todavia, a norma já nasceu pendente de regulamentação acerca dos prazos para a sua concretização, sendo necessário a elaboração do Decreto n. 7724/12, que regulamentou a referida lei, somente no âmbito do Poder Executivo Federal22.

Anteriormente, a Constituição Federal Brasileira de 1988 trouxe a previsibilidade do acesso à informação no art. $5^{\circ}$, XXXIII, art. $37, \S 3^{\circ}$ e art. $216, \mathbb{2} 2^{\circ}$, que dispõe sobre o direito de receber dos órgãos públicos informações, no interesse particular ou coletivo, sob pena de responsabilização, bem como deixando a cargo de lei específica a regulamentação da participação do usuário na Administração Pública. Complementa-se, também, o art. $37, \$ 1^{\circ}$, que traz o Princípio da publicidade dos "atos, programas, obras, serviços e campanhas dos órgãos públicos deverá ter caráter educativo, informativo ou de orientação social".

A lei n. 9.784/99, que trata do processo administrativo, consolidou a transparência administrativa, ao exigir a participação dos cidadãos no procedimento administrativo e a motivação de suas decisões ${ }^{23}$. Destaca-se, também, a Lei de Responsabilidade de Fiscal (LRF) ${ }^{24}$ que busca a criação da responsabilidade na gestão fiscal por meio da ação planejada e transparente, a fim de evitar riscos ou corrigir os desvios nas contas públicas. Ademais, determina que a transparência deverá ser realizada por meio do incentivo à participação popular, acompanhamento pelo cidadão em tempo real da execução orçamentária e financeira e adoção de um sistema de administração e controle.

No que se refere aos contratos públicos, a Lei n. 8.666/94, que disciplina licitações e contratos, prevê a publicidade em relação ao procedimento para o conhecimento de todos os interessados, como também os atos praticados durante as fases da licitação, sendo aberto aos interessados. No entanto, a publicidade varia conforme a modalidade de licitação, torna-se mais ampla na concorrência, pois o interesse da Administração é atrair um grande número de licitantes e é reduzido na modalidade de convite, em que o valor do contrato dispensa maior divulgação ${ }^{25}$.

Além disso, o Decreto n. 5.482/2005, que instituiu o Portal da Transparência, gerido pela Controladoria-Geral da União (CGU) e criou páginas de transparência pública no âmbito federal, estadual e municipal, a fim de assegurar boa gestão e aplicação dos recursos, a partir do aumento da transparência, permitindo que o cidadão acompanhe a utilização do dinheiro público e ajude na fiscalização. Nesse sentido a CGU instituiu o programa Brasil Transparente, por meio da Portaria n. 277/2013, que tem por objetivo promover a transparência na administração pública, aberta à participação social, com a capacitação e conscientização dos servidores públicos na valorização da transparência, bem como do cidadão ${ }^{26}$.

Nesse sentido, destaca-se duas pesquisas realizadas acerca do Portal da Transparência Federal e estaduais. No primeiro ${ }^{27} 72 \%$ (setenta e dois por cento) responderam que o Portal é eficaz na divulgação dos gastos

22 FERNANDES, Claudio Roberto et al. A transparência como desdobramento do princípio constitucional da publicidade na atual Administração Pública brasileira. 2012. Disponível em: < http://www.egov.ufsc.br/portal/conteudo/transpar\%C3\%AAncia-como-desdobramento-do-princ\%C3\%ADpio-constitucional-da-publicidade-na-atual-admini>. Acesso em: 28 jul. 2015.

23 TABORDA, Maren Guimarães. O princípio da transparência e o aprofundamento dos caracteres fundamentais do direito administrativo. Revista de Direito Administrativo, Rio de Janeiro, p. 251-279, out./dez. 2002. p. 261.

24 Lei Complementar n. 101/2000.

25 DI PIETRO, Maria Sylvia Zanella.Direito Administrativo. 27. ed. São Paulo: Atlas, 2014. p. 375.

26 BRASIL. Controladoria Geral da União. Brasil Transparente. Disponível em: < http://www.cgu.gov.br/assuntos/transparenciapublica/brasil-transparente/o-programa>.

27 A pesquisa foi realizada pela Universidade de Brasília no período de 10/2/2014 a 11/4/2014, foram obtidas 1.649 respostas válidas e $98 \%$ delas partiram de usuários do Brasil. 
do governo federal, sendo considerado por $72 \%$ (setenta e dois por cento) do perfil profissional e 65\% (sessenta e cinco por cento) do cidadão considera navegação no portal muito fácil ou fácil. No entanto, as informações mais difíceis de serem encontradas e entendidas são as que se relacionam aos tópicos de "quanto e em que o governo gasta", "como e o que o governo compra" e "quanto e quais empresas ou entidades recebem do governo" ${ }^{\prime 28}$ (grifo nosso).

No que se refere aos portais estaduais, realizou-se uma pesquisa ${ }^{29}$ acerca de quão transparente estes portais são. Concluiu-se que os portais do Ceará e do Rio Grande do Sul são os mais transparentes. O portal da transparência do Ceará apresentou todos os itens considerados na pesquisa, de forma integral e compreensível, enquanto o do Rio Grande do Sul apresentou mecanismos de acompanhamento externo. Porém, as informações fornecidas não estavam na íntegra ou inteligível; além das informações sobre os processos licitatórios entre outras informações foram consideradas incompletas ${ }^{30}$ (grifo nosso).

Os demais portais dos diversos estados mostraram-se negligentes no que se refere aos itens essenciais, como Lei Orçamentária Anual, Lei de Diretrizes Orçamentárias e sobre Plano Plurianual, não sendo possível o download dos dados informativos. Ademais, dez portais não forneciam nenhum tipo de informação sobre convênios firmados pelo governo, tampouco ofereciam informações sobre os processos de licitação (grifo nosso). Por fim, tanto o PIB quanto o IDH não influenciaram na qualidade das informações contidas nos portais ${ }^{31}$.

Desse modo, a simples divulgação da informação não é suficiente para se alcançar a transparência dos atos administrativos, se torna necessário observar três elementos fundamentais: a publicidade, a compreensibilidade das informações e utilidade para as decisões. O primeiro refere-se à ampla divulgação da informação à população, proporcionando o acesso por diferentes meios, de modo oportuno e tempestivo. Quanto ao segundo aspecto, trata da forma como a informação é apresentada ao público, que deve ser uma linguagem compreensível e orientada ao perfil dos usuários, no sentido de aumentar o entendimento da informação. Por fim, a informação tem de ser relevante e confiável, não direcionada, unicamente, aos interesses dos usuários ${ }^{32}$.

Muito embora a transparência tenha previsão normativa no ordenamento jurídico brasileiro, bem como o esforço da CGU para adotar práticas mais transparentes, a fim de diminuir a corrupção, pode-se observar que a preocupação principal nos portais da transparência é na gestão orçamentária e fiscal, em relação ao gasto realizado pelo governo, tanto por parte do Estado quanto pelo indivíduo. Esquece-se, portanto, que antes de se analisar os gastos, há um processo licitatório anterior, que deve ser pautado, sobretudo, no princípio da transparência, desde a intenção da Administração Pública em contratar até a gestão do gasto público, pois no Brasil as licitações lideram as irregularidades e são inseridas em práticas corruptivas, decorrente de "troca de favores", oriundos da campanha eleitoral. Portanto, realiza-se o direcionamento de licitação ou licitações fictícias para que os recursos públicos se mantenham com os fraudadores, acarretando, inclusive

28 UNIVERSIDADE DE BRASÍLIA. Relatório: Pesquisa de Avaliação do Portal da Transparência do Governo Federal. Brasília, 2014. Disponível em: <http://www.portaldatransparencia.gov.br/sobre/Boletim/Especial_Pesquisa-de-Avaliacao2014.pdf>. Acesso em: 29 jul. 2015.

29 Foi levando em consideração relação prática na internet, por meio da análise quantitativa e qualitativa, que buscou avaliar os aspectos informativos e a inteligibilidade no conteúdo oferecido pelos portais, além disso, utilizou o critério de índices econômicos e sociais (PIB e IDH) para explicar o grau de transparência encontrado. Assim, foram verificados 25 portais de transparência estaduais e do Distrito Federal, pois, o do Estado do Rio de Janeiro estava fora do ar.

30 ALMADA, Maria Paula. Ranking da qualidade dos portais de transparência dos estados brasileiros: análise da informação pública disponível ao cidadão. 2013. Disponível em: <http://www.ceadd.com.br/ranking-da-qualidade-dos-portais-de-transparencia-dos-estados-brasileiros-analise-da-qualidade-da-informacao-disponivel-ao-cidadao/>. Acesso em: 29 Jul. 2015.

31 ALMADA, Maria Paula. Ranking da qualidade dos portais de transparência dos estados brasileiros: análise da informação pública disponível ao cidadão. 2013. Disponível em: <http://www.ceadd.com.br/ranking-da-qualidade-dos-portais-de-transparencia-dos-estados-brasileiros-analise-da-qualidade-da-informacao-disponivel-ao-cidadao/>. Acesso em: 29 jul. 2015.

32 PLATT NETO, Orion Augusto et al. Publicidade e transparência das contas públicas: obrigatoriedade e abrangência. Contabilidade Vista e Revista, Belo Horizonte, v.18, n.1, p.75-94, jan./mar. 2007. p. 85-86. 
em carteis e práticas conclusivas impedindo a concorrência, bem como diminuindo a eficiência da contratação pública ${ }^{33}$.

Corroborando com isso, destaca o Programa de Fiscalização por Sorteio a CGU fiscaliza os municípios brasileiros anualmente e constatou, de forma seguida, que as irregularidades mais constantes são nos processos licitatórios. Dentre as anomalias, destaca-se a dispensa indevida de licitação, uso da mesma licitação para contratar diversas obras, montagem irregular dos processos licitatórios e vínculos familiares entre os licitantes e o prefeito municipal ${ }^{34}$. Além do uso de notas fiscais falsas, de empresas ou em nome de "laranjas" e direcionamento dos processos licitatórios ${ }^{35}$. Houve, ainda, desvio de recursos e de equipamentos, prática de superfaturamento do contrato e pagamento por serviços não realizados ${ }^{36}$.

Como exemplo destacam-se alguns casos em que a CGU encontrou irregularidades, como a ausência de numeração de páginas, na contratação na modalidade convite, no valor de $\mathrm{R}$ \$2,5 milhões, podendo incluir ou retirar páginas do documento, bem como a inexistência de empresas convidadas para a referida licitação. Outra situação foi a existência de vínculo familiar entre os sócios da empresa vencedora de várias licitações ocorridas no município e a aquisição de compra de merenda escolar acima da quantidade necessária. No caso em tela, o município de Pimenta Bueno, em Rondônia, adquiriu seis mil quilos de frango, para serem utilizados em uma escola, no período de três semanas. A quantidade é equivalente para o ano inteiro e para todas as escolas do município.

Além desses casos, salienta-se a aquisição de um veículo para a prefeitura, no valor de R $\$ 87.5$ mil, porém, jamais foi localizado, pois não foi comprado. Verificou-se, também, que a prefeitura contrata empresas para realizar as obras, mas na verdade são realizadas pelos moradores ou por operários sem vínculo com a empresa contratada. Por fim, constatou-se que há inclusão de moradores dos municípios como proprietários de empresas que irão participar da licitação, no entanto, esses moradores são agricultores ou empregadas domésticas, que não tem nenhuma relação com a contratação, servindo apenas de laranjas para as licitações irregulares.

Nota-se, portanto, que, apesar dos mecanismos de transparência acima mencionados, os processos licitatórios não refletem a transparência necessária para se garantir a idoneidade da contratação, fazendo surgir inúmeras irregularidades. Por essa razão, não basta, simplesmente, dispor a informação sobre a gestão do gasto público, deve-se ponderar que o princípio da transparência é mais amplo que a publicidade, isto porque não basta publicitar os atos administrativos, a informação deve ser relevante, dispor de confiança e ser inteligível, bem como permear todo o processo de contratação pública.

É por meio da transparência que se realiza a accountability, sendo a publicidade e o acesso à informação um instrumento de concretização da transparência, indispensável e necessária para o processo licitatório brasileiro, que se encontra em um momento de crise, em virtude das inúmeras denúncias de corrupção. Por essa razão, propõe-se a realização da regulação de cima para baixo (top down), ou seja, tomar o princípio da transparência como valor do direito administrativo global e inserir na contratação pública brasileira com a criação da accountability e ampliação da eficiência, com a garantia da proteção dos direitos e a implementação da democracia.

33 OLA OLAYA, Dr. Juanita; WIEHEN, Michael. How to reduce corruption in public procurement: the fundamentals. In: Handbook for curbing corruption in public procurement. 2006. Part I, p. 13-105. Disponível em: $<$ http://ssrn.com/abstract=1313787>. Acesso em: 17 ago. 2015.

34 BRASIL. Controladoria Geral da União. Licitações fraudadas continuam liderando as irregularidades encontradas pela CGU em municípios. Disponível em: < http://www.cgu.gov.br/noticias/2010/07/licitacoes-fraudadas-continuam-liderando-as-irregularidades-encontradas-pela-cgu-em-municipios>. Acesso em: 10 ago. 2015.

35 BRASIL. Controladoria Geral da União. Licitacões lideram indícios de fraude em municípios. Disponível em: <http://www.cgu.gov. br/noticias/2004/09/licitacoes-lideram-indicios-de-fraude-em-municipios>. Acesso em: 10 ago. 2015.

36 BRASIL. Controladoria Geral da União. Licitações fraudadas continuam liderando as irregularidades encontradas pela CGU em municípios. Disponível em: <http://www.cgu.gov.br/noticias/2010/07/licitacoes-fraudadas-continuam-liderando-as-irregularidades-encontradas-pela-cgu-em-municipios>. Acesso em: 10 ago. 2015. 


\section{A ATUAL AUSÊNCIA DE ACCOUNTABILITY NO PROCESSO BRASILEIRO DE CONTRATAÇÃO PÚBLICA}

Nota-se que no Brasil, principalmente, no processo de contratação pública, há uma ausência de accountability dos agentes públicos. São inúmeros os casos de corrupção que envolvem fraudes e cartéis em licitações, dentre outras irregularidades, como exemplo a atual investigação do Ministério Público Federal (MPF), juntamente à Polícia Federal brasileira, chamada de "Operação Lava-Jato". A investigação teve início em março/2014, envolvendo diversas empresas, políticos, servidores públicos e setores públicos como petróleo e energia, sendo considerada como o maior caso de corrupção brasileira, levando o Brasil a uma grave crise institucional e financeira que se encontra em seu ápice.

Para que se entenda o caso e a sua relação com o trabalho, é necessário fazer uma breve explanação acerca das investigações do MPF, que foi iniciada em março de 2014, ainda perante à Justiça Federal de Curitiba, quando quatro organizações criminosas, dirigidas por doleiros ${ }^{37}$, foram investigadas e processadas. Isto desembocou em um esquema criminoso de corrupção que teve início, há, pelo menos, dez anos, e envolveu a Petrobras, a maior empresa petrolífera do Brasil, bem como grandes empreiteiras, que estão organizadas em um esquema de cartel e pagavam suborno para agentes públicos e altos executivos do governo em contratos superfaturados ${ }^{38}$.

O suborno ocorria para garantir que as empreiteiras, que estavam associadas em cartel, simulassem uma concorrência aparente, mas na verdade concorriam entre si, em sistema de rodízio ou sorteio e a empreiteira que, supostamente, oferecia o preço mais baixo era contratada pela Petrobras. No entanto, os preços dos contratos eram calculados e ajustados previamente em reuniões secretas. Além da restrição de entrada de outras empresas pelos funcionários da Petrobras, restringiam a entrada de outras empresas que estivessem fora da relação do cartel e privilegiavam aquelas já predeterminadas, com negociações diretas injustificadas, celebração de termos aditivos desnecessários, supressão de etapas relevantes do procedimento licitatório e divulgação de informações sigilosas ${ }^{39}$.

Após diversas fases de investigação da "Operação Lava Jato", na última semana de julho/2015, verificou-se que o esquema criminoso se irradiou para outros setores, além da Petrobras, envolveu, também, o setor energético. As empreiteiras envolvidas, Engevix, Andrade Gutierrez, Odebrecht e Camargo Correia, dentre outras, participavam de licitações combinadas, sobretudo, para a construção da Usina Nuclear Angra 3. Houve o acordo para que somente dois consórcios participassem do concurso adjudicatório, fazendo com que as empresas ficassem cada uma em um bloco, garantindo o cartel. Por um lado, concorreu a Odebrecht, Camargo Corrêa, UTC e Andrade Gutierrez, representando o consórcio UMA 3; de outro lado Angra 3, representado pela Grupo MPE (Techint e EBE) e Queiroz Galvão. Importa ressaltar que ambos ganharam a concorrência e formaram um único consórcio, o Agramon ${ }^{40}$.

As práticas frustraram e fraudaram as licitações, por meio de combinações, retirando a competitividade dos diversos procedimentos licitatórios, tanto da Petrobras quanto de Angra 3, com o fito de obter para as empresas ou para outras diversas vantagens decorrentes do objeto do contrato. Verifica-se, portanto, um baixo controle e fiscalização nos processos adjudicatórios devido à ausência de transparência durante todo o procedimento licitatório, bem como a falta de responsabilização dos agentes públicos. Por essa razão, se propõe a regulação global top down, com base em princípios globais, com ênfase na transparência de procedimentos.

37 Atuação ilegal de câmbio.

38 BRASIL. Ministério Público Federal. Caso Lava Jato. Disponível em: <http://lavajato.mpf.mp.br/entenda-o-caso >. Acesso em: 30 jul. 2015.

39 BRASIL. Ministério Público Federal. Caso Lava Jato. Disponível em: <http:/ /lavajato.mpf.mp.br/entenda-o-caso >. Acesso em: 30 jul. 2015.

40 LAVA Jato: investigação chega a Eletronuclear. Carta Capital, São Paulo, 28 jul. 2015. Disponível em: < http://www.cartacapital. com.br/blogs/parlatorio/lava-jato-a-investigacao-chega-a-eletronuclear-6751.html>. Acesso em: 30 jul. 2015. 
Nessa perspectiva, não se vislumbra como o possível o aumento da accountability nos processos de contratação sem que haja uma ampliação da transparência nos procedimentos adjudicatórios, caso contrário a responsabilização/prestação de contas dos agentes públicos se tornam inócuas. É preciso esclarecer que uma maior transparência invariavelmente diminuirá a corrupção. No entanto, destaca-se que a transparência deve estar presente não apenas na publicitação dos gastos do governo, mas também nos atos praticados por seus agentes. $\mathrm{O}$ caso apresentado acima demonstra que há condescendência, em várias esferas do poder público, com os arranjos licitatórios, sendo, nesse ponto, que o Princípio da transparência, tido como valor global, deve incidir, uma vez que é um meio de superar o défice de responsabilização de maneira a aumentar a $a c$ countability e a segurança nas instituições do Estado, consequentemente levando à sua maior democratização.

Tal afirmação se corrobora por meio do Índice de Percepção do Cumprimento da Lei (IPCLBrasil) ${ }^{41}$, ano de 2015, em que se constatou que apenas $19 \%$ da população confia no Governo Federal, 15\% no Congresso Nacional e 5\% nos Partidos Políticos. Isso reflete diretamente na confiança no Ministério Público, que alcança o montante de $45 \%$ e no Poder Judiciário em $25 \% \%^{42}$.

Nesse sentido, a accoutability não se restringe a uma pessoa ou partido político, pois envolve tanto instituições quanto entidades privadas. O problema que se vislumbra com a ausência de responsabilização é a deficiência dos mecanismos de prestação de contas, que necessitam de uma melhoria ou de um reforço ${ }^{43}$. Verifica-se que há legislação e instrumentos de fiscalização e controle do gasto público, especialmente o realizado por meio da CGU, que foram demonstrados anteriormente, mas nestes não se inserem, ou se omitem, os procedimentos licitatórios, fazendo com que as irregularidades cometidas nas contratações reflitam, negativamente, na própria figura do Estado. Por conseguinte, isso reflete no cotidiano do cidadão - com a baixa qualidade dos serviços públicos e com aumento de preços, por exemplo - em virtude das repercussões econômicas da crise institucional e política e da má prestação dos serviços do Estado, ambos decorrentes de eventuais casos de corrupção.

Diante disso, torna-se imprescindível a adoção de uma política transparente que permita submeter o Estado e seus agentes ao controle da cidadania. Além disso, para o aumento da accountability, o cidadão deve saber a quem responsabilizar pelo desempenho do governo ${ }^{44}$. Para tanto é necessário um maior exercício da cidadania, ou uma ação cidadã, em favor da diminuição da corrupção e para controle do Estado. Isto quer

41 Trata-se de um índice de percepção que procura retratar o sentimento da população em relação às leis, bem como analisar a percepção dos brasileiros sobre o respeito às leis e o respeito às autoridades que devem fazer cumprir a lei. O subíndice de percepção é construído a partir de quatro indicadores, quais sejam: (i) indicador de instrumentalidade, que mede a percepção das perdas associadas ao descumprimento da lei - sanções; (ii) indicador de moralidade, que mede a percepção dos entrevistados sobre o quanto é certo ou errado realizar determinada conduta que esteja em desconformidade com a lei; (iii) indicador de controle social, que mede a percepção de reprovação social a determinados tipos de comportamento de descumprimento da lei; e (iv) indicador de legitimidade, que mede a percepção sobre a obediência à lei e às ordens de autoridades que devem fazer com que a lei seja cumprida. A população-alvo da pesquisa é composta de habitantes, com 18 anos ou mais, de oito unidades federativas (UF) brasileiras: Amazonas, Pernambuco, Bahia, Minas Gerais, Rio de Janeiro, São Paulo, Rio Grande do Sul e Distrito Federal, que juntos constituem aproximadamente $55 \%$ da população do país com 18 anos ou mais, segundo dados do Censo 2010. Essa população foi estratificada por UF e a amostra foi alocada de forma a ter um mínimo de 150 entrevistas por UF, procurando-se ao mesmo tempo manter minimamente a proporcionalidade com relação ao número de habitantes dentro desta faixa etária. Nos meses de janeiro, fevereiro e março de 2015, foram entrevistadas 1.650 pessoas distribuídas por 8 Unidades da Federação (UF): Amazonas (150), Pernambuco (150), Bahia (200), Minas Gerais (300), Rio de Janeiro (200), São Paulo (350), Rio Grande do Sul (150) e Distrito Federal (150). FUNDAÇÃO GETÚlIO VARGAS. Relatório IPCLBRASIL: $1^{\circ}$ Trimestre/2015. São Paulo: FGV Direito, 2015. Disponível em: <http://bibliotecadigital.fgv.br/dspace/bitstream/handle/10438/13729/Relat\%C3\%B3rio_IPCLBrasil_1\%C2\%BA\%20Trimestre\%202015.pdf?sequence $=1$ \&is Allowed $=y>$. Acesso em: 30 jul. 2015. p. 3-5.

42 FUNDAÇÃO GETÚlIO VARGAS. Relatório IPCLBRASIL: 1º Trimestre/2015. São Paulo: FGV Direito, 2015. Disponível em: < http://bibliotecadigital.fgv.br/dspace/bitstream/handle/10438/13729/Relat\%C3\%B3rio_IPCLBrasil_1\%C2\%BA\%20Trimestre $\% 202015$.pdf? sequence $=1 \&$ is Allowed $=y$ > . Acesso em: 30 jul. 2015. p. 16-32.

43 KRISCH, Nico. The Pluralism of Global Administrative Law. The European Journal of International Law, v. 17, n. 1, p. 249-250, 2006.

44 FILGUEIRAS, Fernando. Transparência, publicidade e accountability. Belo Horizonte: Centro de Referência do Interesse Público, 2011. Disponível em: <http://democraciaejustica.org/cienciapolitica3/sites/default/files/transparencia_publicidade_e_accountability.pdf>. Acesso em: 17 ago. 2015. p. 5. 
dizer que, quanto mais próximo o cidadão estiver da esfera política/pública, menores serão as chances de surgir uma representação política imperfeita, com a consequente ausência de responsabilidade ${ }^{45}$.

Assim, é preciso construir uma accountability por meio da transparência, permitindo que o cidadão tenha acesso aos atos administrativos. De igual modo, o cidadão precisa buscar se informar sobre a atuação do Estado desde o processo licitatório, não apenas na gestão do gasto público. Desse modo os procedimentos de accountability devem garantir que governos, instituições, empresas privadas, funcionários individuais, executivos de empresas, agentes públicos e pessoas que atuem em nome das empresas sejam responsabilizados em qualquer situação em que ocorram violações de obrigações legais ou contratuais, por sanções disciplinares, contratuais, civis e/ou penais ${ }^{46}$.

Ao estabelecer um procedimento adjudicatório pouco transparente, a consequência direta que se tem é a falta de eficiência dos contratos públicos. Isto porque não se vislumbra o best value, ou seja, a premissa de que o menor preço é o melhor para o Estado inexiste, pois há a dissimulação dos preços e a conluio de empresas em favor de interesses pessoais. Posto isto, defende-se maior transparência para o aumento da eficiência, uma vez que haverá a ampliação da concorrência.

\section{A INSERÇÃo dOS VALORES GLOBAIS DE TRANSPARÊNCIA NO PROCESSO DE CONTRATAÇÃo PÚBLICA: PROTEÇÃO DOS DIREITOS INDIVIDUAIS E IMPLEMENTAÇÃO DOS IDEAIS DEMOCRÁTICOS}

Ao longo do trabalho, demonstrou-se a necessidade de prezar pelo Princípio da Transparência nos contratos públicos, o que já tem sido uma preocupação das Organizações Internacionais, tais como a ONU e a OMC, e de sistemas regulatórios globais, como a União Europeia, que inseriu tal princípio não apenas nas normas de contratação pública também como um mecanismo para a proteção e promoção do mercado interno europeu. De maneira análoga, defende-se que, por meio da inclusão do princípio da transparência na legislação brasileira, será possível aumentar o nível de accoutability no processo brasileiro de contratação pública. Propõe-se tal inserção uma vez que os atuais instrumentos de transparência, bem como as atuais normas brasileiras, não são capazes de evitar os problemas de ilicitude nas licitações.

A transparência se torna necessária para garantir um processo licitatório fidedigno, pois o risco de corrupção está relacionado com leis de má qualidade e falta de mecanismos de transparência ${ }^{47}$. Sendo impossível estabelecer uma lei mundial sobre contratos públicos, pela obviedade da questão, torna-se imperioso trabalhar com o valor que a transparência denota no âmbito global. Ora, se a Convenção da ONU contra corrupção, a qual o Brasil é signatário, estabelece um nível global mínimo de transparência, porque os princípios e regras contidas nesta não podem se tornar um valor e um padrão na óptica interna brasileira?

O princípio da transparência é um objetivo a ser perseguido pelo direito administrativo global, não apenas para se tornar uma referência da boa governação, mas também para dar transparência às decisões e para ampliar o acesso à informação, uma vez que são bases importantes para o exercício do direito de participação, do direito de revisão e, ainda, para a promoção da accountability, expondo as decisões administrativas e

45 SILVA, Matheus Passos. A cidadania ativa como mecanismos de combate à corrupção. In: BRANCO, Paulo Gustavo Gonete; VICTOR, Sérgio Antônio Ferreira. (Org.). Estado de direito, direitos fundamentais e combate à corrupção: interfaces Portugal/Brasil. Brasília: IDP, 2015. Disponível em: <Disponível em: http://www.idp.edu.br/publicacoes/portal-de-ebooks>. Acesso em: 30 jul. 2015. p. $20-21$

46 OLAYA, Dr. Juanita; WIEHEN, Michael. How to reduce corruption in public procurement: the fundamentals. In: Handbook for curbing corruption in public procurement. 2006. Part I, p. 13-105. Disponível em: $<$ http://ssrn.com/abstract=1313787>. Acesso em: 17 ago. 2015. p. 51

47 Em pesquisa realizada em 18 países, que o risco de corrupção aumenta para 65\% quando há a de mecanismos de transparência e a má qualidade das leis, em contraposição que o risco cai para 35\%, quando os mecanismos são efetivamente implementados. 
os documentos relevantes ao escrutínio público ${ }^{48}$. Tal raciocínio se mostra relevante especialmente quando se considera que é por meio da transparência nas leis, regulamentos, instituições e decisões - que devem ser acessíveis ao público em geral - que se pode alcançar a responsabilização dos agentes públicos, das partes interessadas e dos tomadores de decisão, evitando-se que as práticas ilícitas se prosperem no escuro da legislação.

É indispensável que mecanismos de transparência sejam criados desde o início do processo de adjudicação e que estejam presentes em todas as fases, desde a tomada de decisão até a auditoria, de modo que a Administração Pública forneça voluntariamente e de maneira proativa informações públicas por meio da mídia impressa e eletrônica, bem como todas as partes interessadas sejam plenamente informadas e consultadas sobre todo o processo. Assim, a utilização do dinheiro público com transparência denota a melhoria da eficiência na contratação de bens e serviços, pois diminui-se o emprego do patrimônio público para o favorecimento ou favores a pessoas ou empresas específicas, tratando todos interessados de maneira igualitária e concorrencial ${ }^{49}$.

Ademais, o reforço da transparência - principalmente no sistema europeu e que deve ser levado também para ordenamento jurídico brasileiro -, bem como dos instrumentos de controle da atividade administrativa, que pode partir de qualquer cidadão ou dos participantes no procedimento adjudicatório, tem como pretensão aceder à informação administrativa, inexistindo motivos para limitar o acesso, especialmente quando se analisa a situação da perspectiva do cidadão. Por meio dos mecanismos de transparência se alcança a accountability dos agentes públicos e, eventualmente, sua responsabilização pelos seus atos administrativos, além de contribuir, positivamente, para a prevenção da corrupção ${ }^{50}$.

Não se está aqui afirmando que o aumento da transparência extinguirá, automaticamente, a corrupção. No entanto, defende-se que tal aumento levará à ampliação da responsabilidade dos administradores públicos e dos demais envolvidos no processo adjudicatório uma vez que se demonstrou que a transparência nos contratos públicos se funda, primordialmente, nas publicações dos atos administrativos. Defende-se, também, a ampliação do grau de transparência porque aqueles atualmente disponíveis no ordenamento jurídico brasileiro não abarcam a contratação pública, espaço em que se encontra o maior número de ilicitudes. Diante disso, faz-se necessário buscar no direito administrativo global o padrão de transparência concebido como padrão internacional e que possa ser aplicável ao direito administrativo interno, realizando uma abordagem ou uma regulação de cima para baixo (top-down).

É necessária a compreensão de que o direito administrativo se desenvolve em duas vertentes: bottom-up (de baixo para cima) e top-down (de cima para baixo). A primeira vertente se verifica a partir dos instrumentos do direito administrativo nacional, que são ampliados para a esfera global, buscando-se assegurar a accountability e a participação na administração global por meio do direito nacional. Todavia, para o presente trabalho, interessa a orientação top-down, a qual se realiza com base em padrões de direito internacional contemporâneo ${ }^{51}$. Isto quer dizer que seria a aplicação, ou ainda a influência, dos padrões e dos instrumentos internacionais referentes ao Princípio da Transparência - e de igual modo dos mecanismos previstos na norma global - no processo brasileiro de contratação pública. Isto permitiria a aplicação de mecanismos de accountability de nível global no âmbito interno brasileiro, de maneira que indivíduos, grupos e até mesmo o Estado brasileiro

48 KINGSBURY, Benedict; KRISCH, Nico; STEWART, Richard B. Anexxe: l'emergence du droit administratif global. In: BORIS, Clementine. Un droit administratif global? Cahiers Internationaux - CEDIN, Naterre: Pedone, 2012. p. 345.

49 OLAYA, Dr. Juanita; WIEHEN, Michael. How to reduce corruption in public procurement: the fundamentals. In:

Handbook for curbing corruption in public procurement. 2006. Part I, p. 13-105. Disponível em: $<$ http://ssrn.com/abstract=1313787>. Acesso em: 17 ago. 2015. p. 55

50 RAIMUNDO, Miguel Assis. A formação dos contratos públicos: Uma concorrência ajustada ao interesse público. Lisboa: AAFDL, 2013. p. 358-368.

51 KINGSBURY, Benedict; KRISCH, Nico; STEWART, Richard B. The emergence of global administrative law. Law and Contemporary Problems, v. 68, p. 15. Disponível em: <http://scholarship.law.duke.edu/cgi/viewcontent.cgi?article=1361\&context=lcp $>$. Acesso em: 10 jul. 2015. p. 57. 
estariam inseridos nos processos administrativos globais e no de revisão das decisões, as quais poderiam ser realizadas por meio de órgãos internacionais ${ }^{52}$ a partir de um tratado ou rede de cooperação, que adotaria procedimentos para a promoção da transparência, de informações a todos os interessados e ampliação de participação e da responsabilização dos envolvidos ${ }^{53}$.

É necessário, portanto, a existência de mecanismos que garantam a prestação de contas, ou seja, a accountability, no processo brasileiro de contratação pública. A accoutability, na definição de Grant e Keohane, é o direito que determinados atores têm de julgar outros a respeito de sua conduta e de seu cumprimento das normas, bem como impor sanções no caso de descumprimento das responsabilidades. Nesse caso, pressupõe-se a relação de poder entre aquele que analisa a conduta e determina a sanção e aquele que deve cumprir a norma ou ser responsabilizado, especialmente quando se considera que a legitimidade decorre das normas operacionais para a prestação de contas e do consentimento na autoridade daquele que emana o poder ${ }^{54}$.

A função da accountability é expor e punir os abusos no exercício de poder não autorizado ou ilegítimo e decisões que são imprudentes ou injustas, sendo necessário que as instituições forneçam informações para controlar a responsabilidade, seja por ação ou omissão na esfera pública, permitindo impor sanções. A publicitação das informações é indispensável para a realização o processo de accountability. Por essa razão, o mecanismo de transparência é um componente funcional para a responsabilização democrática, facilitando a avaliação pública do desempenho no exercício do processo de tomada decisão pública, realizando uma transparência democrática ${ }^{55}$.

Além disso, para ampliar o campo de responsabilização dos agentes públicos, é necessário delimitar o papel público e facilitar a avaliação pública do desempenho dos representantes. O primeiro refere-se à identificação, por parte dos cidadãos, de quais são os poderes exercidos pelos agentes públicos e o papel que cada um exerce dentro do processo de decisão administrativa. Quanto ao segundo, refere-se à necessidade de divulgação dos resultados do processo de tomada de decisão.

Quando se delimita qual é o papel tanto do agente quanto do cidadão nos mecanismos de transparência, é possível atribuir, diretamente, a responsabilidade para quem deveria alcançar o resultado pretendido na ação da Administração Pública e não o fez, bem como torna-se possível para o cidadão identificar o responsável para cobrar o cumprimento do serviço público. De igual modo, tal controle por parte do cidadão é reforçado quando se coloca a atividade do agente público ao crivo da avaliação pública por meio da divulgação completa das informações como o fundamento para a tomada da decisão, os meios utilizados para sanções, fontes de financiamento, detalhes de orçamento, dentre outros ${ }^{56}$. Ou seja, não basta publicitar o interesse da Administração Pública em abrir um processo licitatório; torna-se indispensável, para garantir uma política pública transparente, que os agentes públicos deem detalhes dos resultados e das razões que levaram à escolha daquela empresa em específico, não apenas com base no menor preço, além de demonstrar de maneira fática os resultados de determinada adjudicação.

Dessa maneira, a partir do momento em que a Administração Pública expõe a fundamentação das decisões, aumenta-se a transparência, garantindo que o processo de tomada de decisões esteja aberto ao escrutínio das partes interessadas. Ademais, os custos para ampliação do acesso à informação não deve ser

52 KINGSBURY, Benedict; KRISCH, Nico; STEWART, Richard B. The emergence of global administrative law. Law and Contemporary Problems, v. 68, p. 15. Disponível em: <http://scholarship.law.duke.edu/cgi/viewcontent.cgi?article=1361\&context=lcp $>$. Acesso em: 10 jul. 2015. p. 57.

53 STEWART, Richard B. U.S. Administrative law: a model for global administrative law? Law and contemporary problems, v. 68, p. 63, Summer/Autumn 2005. p. 72.

54 GRANT, Ruth; Keohane, Robert O. Accountability and Abuses of Power in World Politics. American Political Science Review, v. 99 , n. 1, Feb, 2005. p. 20.

55 MACDONALD, Terry; MACDONALD, Kate. Non-electoral accountability in global politics: strengthening democratic control within the global garment industry. The European Journal of International Law, v. 17, n. 1, 2006. p. 90

56 MACDONALD, Terry; MACDONALD, Kate. Non-electoral accountability in global politics: strengthening democratic control within the global garment industry. The European Journal of International Law, v. 17, n. 1, 2006. p. 93. 
um impeditivo de realizar uma política pública transparente, pois deve-se garantir as informações sejam disponibilizadas de forma acessível e a baixo custo, em termos de tempo, dinheiro, educação, tecnologia e mobilidade, para que a transparência ultrapasse a perspectiva do valor comum global ${ }^{57}$ e se transforme em prática cotidiana nas contratações públicas brasileiras.

Nessa linha, propõe-se que se realize a administração internacional (Explicar) que se refere à regulação global por parte das organizações internacionais formais, o que significa dizer que a regulação global é feita por meio das organizações internacionais, estabelecidas por meio de um tratado ou acordo executivo. No caso em tela, é o Escritório das Nações Unidas contra droga e crime (UNODOC), que estabeleceu a Convenção da ONU contra corrupção, da qual o Brasil é signatário.

Assim, ao torna-se signatário da convenção, o Brasil assumiu o compromisso de promover e fortalecer medidas que previnam e combatam à corrupção por meio da criação de agências anticorrupção, maior transparência no setor público, participação da sociedade, criação de códigos de conduta para os funcionários públicos e regras para a contratação pública, com a devida criminalização dos atos de corrupção.

Como apresentado anteriormente, a CGU tem assumido a responsabilidade acerca dos casos de corrupção, juntamente com o Ministério Público Federal e Estadual e Polícia Federal, com inúmeras investigações, auditorias, elaboração de normas, como já demonstrado. Todavia, com base no Índice de Percepção da Corrupção (IPC), realizado, anualmente, pela Transparência Internacional (TI), nota-se que a corrupção no Brasil, ao longo de dez anos, não modificou, em absolutamente nada, ao contrário, desde a adoção da Convenção da ONU contra corrupção, o Brasil manteve os mesmos resultados.

O Índice de Percepção de Corrupção (IPC) é o indicador de corrupção mais utilizado no mundo e refere-se às pontuações e classificações dos países/territórios com base em quão corrupto o setor público de um país pode ser. Esse índice é composto por uma combinação de levantamentos e avaliações de corrupção, recolhidos por institutos de pesquisa, considerando-se que a pontuação vai de uma escala crescente de 0 a 10, de um baixo nível de corrupção até altamente corrupto. As percepções são baseadas nas práticas corruptivas que surgem após a publicidade na mídia, investigações ou condenações, são analisados o número de procedimentos instaurados ou processos judiciais relacionados diretamente com a corrupção, bem como a eficácia do Ministério Público/Promotores, dos Tribunais e dos meios de comunicação em relação à investigação e exposição da corrupção no setor público, ou seja, administrativa e política ${ }^{58}$.

A partir da análise do IPC do ano de 2004 a 2014, o Brasil manteve-se no mesmo índice de corrupção, variando entre $60^{\mathrm{a}}$ e $80^{\mathrm{a}}$ posição, pontuando entre 3,3 e 4,3, conforme a seguir:

Quadro 1 - Índice de corrupção

\begin{tabular}{|cccccc} 
& Posição & Pontuação & & Posição & Pontuação \\
\hline 2004 & $59^{\mathrm{a}}$ & 3,9 & $\mathbf{2 0 1 0}$ & $69^{\mathrm{a}}$ & 3,7 \\
\hline 2005 & $62^{\mathrm{a}}$ & 3,7 & $\mathbf{2 0 1 1}$ & $73^{\mathrm{a}}$ & 3,8 \\
\hline 2006 & $70^{\mathrm{a}}$ & 3,3 & $\mathbf{2 0 1 2}$ & $69^{\mathrm{a}}$ & 4,3 \\
\hline 2007 & $72^{\mathrm{a}}$ & 3,5 & $\mathbf{2 0 1 3}$ & $72^{\mathrm{a}}$ & 4,2 \\
\hline $\mathbf{2 0 0 8}$ & $80^{\mathrm{a}}$ & 3,5 & $\mathbf{2 0 1 4}$ & $69^{\mathrm{a}}$ & 4,3 \\
\hline $\mathbf{2 0 0 9}$ & $75^{\mathrm{a}}$ & 3,7 & & &
\end{tabular}

Fonte: Transparency International ${ }^{59}$

57 MACDONALD, Terry; MACDONALD, Kate. Non-electoral accountability in global politics: strengthening democratic control within the global garment industry. The European Journal of International Law, v. 17, n. 1, 2006. p. 95.

58 TRANSPARENCY INTERNATIONAL. Corruption Perceptions Index 2014: indetail. 2014. Disponível em: <http://www.transparency.org/cpi2014/in_detail\#myAnchor3>. Acesso em: 04 ago. 2015.

59 Dados disponíveis no site da http://www.transparency.org. 
Verifica-se, portanto, que os mecanismos como a Lei de Acesso à Informação e os portais da transparência, bem como a atuação realizada pela CGU, pouco têm surtido efeito no combate à corrupção no Brasil, não alcançando o padrão mínimo de transparência como disposto na Convenção da ONU sobre a corrupção - já que, como se viu na pesquisa da TI, o índice de corrupção no Brasil tem se mantido o mesmo. Além disso, vale lembrar que o Relatório sobre Barômetro Global de Corrupção, também realizado pela TI, demonstrou que no Brasil as instituições nacionais mais corruptas e que geram preocupação são os partidos políticos, alcançado uma pontuação de $4,5^{60}$ no ano de 2004 , e mantendo a porcentagem de $81 \%$, considerando extremamente corrupto, no ano de 2013. O mesmo ocorre com o poder Legislativo que ficou com a pontuação de 4,3 em 2004, e em 2013, com 72\%, como corrupto.

Diante disso, nota-se que o controle da transparência no processo brasileiro de contratação pública deve ser realizado não apenas pelas instituições nacionais, papel este que atualmente está sob responsabilidade da CGU em conjunto com MP e PF, mas também dos reguladores internacionais, via UNODOC, por meio da administração internacional, prevista nos tipos de regulação do direito administrativo global. Isto se faz necessário porque os instrumentos normativos e funcionais de transparência não têm sido suficientes para controlar e responsabilizar os agentes públicos e privados envolvidos nos casos corrupção decorrentes dos contratos públicos, portanto, frente à deficiência da administração pública nacional, que se torna necessária a inserção dos valores e as normas globais para o aumento da accountability no ordenamento jurídico brasileiro de contratos públicos.

Ademais, torna-se imperiosa a regulação top-down, via administração por parte das organizações internacionais, pois há um défice democrático no Brasil com baixa implementação dos direitos decorrentes dos serviços públicos, o que, em última instância, leva à fragilização e à diminuição do exercício da cidadania no Brasil.

É importante que se destaque que a cidadania é um direito fundamental na ordem constitucional brasileira. Ainda que, formalmente, a cidadania não esteja presente no Título II da Constituição - que traz explicitamente os direitos e garantias fundamentais -, o conceito se reveste do caráter de verdadeiro direito fundamental não apenas por se apresentar como um fundamento do Estado brasileiro - já que está presente no inciso II do artigo $1^{\circ}$ da Constituição - mas também por refletir valores dos mais essenciais da sociedade brasileira.

Se a cidadania é um direito fundamental do cidadão, compete a este exercê-lo, por um lado, e ao Estado em dar as condições necessárias para seu exercício, por outro. No âmbito do tema tratado neste texto, torna-se necessário considerar que um dos aspectos que precisam ser concretizados pelo Estado brasileiro para que o cidadão possa exercer seu direito fundamental à cidadania diz respeito, sem dúvida, à transparência que deve haver em seus contratos públicos. Destaque-se que tal transparência se torna necessária não apenas pela sua presença formal no texto constitucional brasileiro - conforme o caput do artigo 37 da Constituição brasileira $^{61}$ - mas também, e principalmente, pelo aspecto material do exercício da cidadania, já que não se pode vislumbrar o exercício da cidadania pelo cidadão sem que a este sejam dadas condições materiais para fazê-lo.

No que concerne ao aspecto formal, o próprio texto constitucional já traz, no aludido artigo 37, a determinação explícita de que o Estado brasileiro, em todas as suas instâncias, obedecerá ao princípio da publicidade. Veja-se que o texto constitucional é taxativo ao deixar claro que é uma obrigação do Estado brasileiro garantir o máximo de publicidade às suas ações. Em uma interpretação tanto axiológica quanto teleológica

60 A pergunta da pesquisa era: "Em que medida considera que os seguintes setores se veem afetados pela corrupção em seu país? A resposta varia de 1 , para não corruptos, até 5 , para muito corrupto.

61 "Art. 37. A administração pública direta e indireta de qualquer dos Poderes da União, dos Estados, do Distrito Federal e dos Municípios obedecerá aos princípios de legalidade, impessoalidade, moralidade, publicidade e eficiência [...]”. BRASIL. Senado Federal. Constituição da República Federativa do Brasil: texto consolidado até a Emenda Constitucional no 88 de 07 de maio de 2015. Brasília: Senado Federal, 2015. p. 13. (Grifo nosso.) 
do texto constitucional brasileiro, percebe-se que o princípio da publicidade - utilizado como sinônimo do princípio da transparência ao qual se aludiu ao longo deste texto - se reveste de condição sine qua non no que diz respeito à possibilidade de ter o cidadão condições mínimas para exercer sua função de verdadeiro controlador do Estado. Além disso, destaca-se que, no caput do artigo 37, o princípio da publicidade vem associado, dentre outros, ao princípio da moralidade, o que significa dizer que o administrador público, premido pela publicidade e pela transparência dos seus atos, não poderá nem deverá realizar ações imorais - tais quais a prática da corrupção - no exercício de suas funções públicas.

Por sua vez, o aspecto material do princípio da publicidade está diretamente relacionado, como já se referiu, à necessidade que o cidadão tem de estar bem informado para que possa efetivamente exercer sua função de controlador do Estado. Nesse contexto, ainda que, por um lado, possa ser possível argumentar que um nível mínimo de conhecimento dependa da atuação do próprio cidadão ${ }^{62}$, por outro, parece ser inegável que o próprio cidadão, por mais que seja escolarizado e interessado na esfera coletiva, não poderá exercer o controle do aparelho do Estado se este não disponibilizar todas as informações necessárias ao cidadão - ou se eventualmente as disponibilizar de maneira incompleta ou mascarada. Portanto, torna-se extremamente relevante que o Estado brasileiro se guie pelo princípio da transparência para que o cidadão, uma vez empoderado acerca do que é realizado pelo Estado no âmbito dos contratos públicos, possa, de maneira consciente, realizar o seu papel em relação ao que ele pode fazer para auxiliar no combate à corrupção.

Um reflexo positivo que pode se originar a partir do exercício da cidadania por parte do cidadão empoderado com base no conhecimento adquirido surgido como reflexo da aplicação do princípio da transparência aos contratos públicos no Brasil é, sem dúvida alguma, o aprofundamento e o fortalecimento da democracia brasileira. Ao partir-se da concepção de que não se pode conceber a ideia de democracia como mera "concretização do ato eleitoral" realizado periodicamente, torna-se necessário compreender a democracia como verdadeira afirmação constante do valor humano do cidadão frente à atuação do Estado. Em outras palavras, entende-se que, em uma democracia, o indivíduo não é mero objeto do poder mas sim verdadeiro sujeito do poder ${ }^{63}$ : significa dizer que o indivíduo não mais se submete ao poder oriundo do Estado, mas sim que, ao contrário, o Estado apenas pode exercer o poder político porque o cidadão assim o permitiu - sendo o cidadão o titular do poder político.

Ora, em uma situação de (total) ausência de transparência o cidadão não pode exercer seu poder político para além do momento eleitoral ${ }^{64}$. Em uma situação na qual as informações são retidas - ou eventualmente disponibilizadas apenas a um "seleto" grupo de privilegiados - e não publicitadas, o cidadão perde sua capacidade de tomar decisões - basicamente, de fazer escolhas políticas - com base naquilo que efetivamente ocorre na realidade. É um verdadeiro círculo vicioso que, em longo prazo, contribui para a redução do nível de democracia no Brasil: o cidadão - fonte do poder político do Estado - não tem conhecimento acerca do que ocorre no âmbito estatal; por não ter conhecimento, não exerce sua cidadania para além do momento eleitoral; por não fazê-lo, aqueles que exercem funções públicas veem-se incentivados a continuarem a não concretizar, efetivamente, o princípio da transparência, eventualmente, encobrindo, inclusive, casos de corrupção. Nesse círculo vicioso, a accountability deixa de existir - consequentemente, deixando de existir até mesmo o vínculo de representação entre o cidadão e o Estado, fragilizando em última instância a própria democracia.

Por sua vez, em sentido oposto, o Estado poderia dar início ao verdadeiro círculo virtuoso se colocasse em

62 Já que, em última instância, o cidadão pode até mesmo abrir mão de sua função de controlador do Estado caso decida se utilizar da liberdade individual constitucionalmente garantida de se preocupar, apenas, com sua vida privada, sem intervir na esfera coletiva - ainda que, claramente, não se concorde com tal apatia por parte do cidadão já que a vida em coletividade é pressuposto da ação cívica.

63 MIRANDA, Jorge. Manual de direito constitucional. Estrutura constitucional do Estado. Coimbra: Coimbra, 2014. p. 366.

64 E mesmo se o fizer - ou seja, mesmo se o cidadão exercer seu poder político apenas no momento eleitoral -, fá-lo-á sem o embasamento necessário para tomar a decisão de escolher entre o candidato "A" ou o candidato "B", já que a falta de transparência - geradora de corrupção - impedirá que o indivíduo possa efetivamente tomar uma boa decisão. 
prática o princípio da transparência conforme os moldes aqui defendidos. Dessa maneira, estando o cidadão devidamente informado poderia exercer sua cidadania por meio, por exemplo, de uma ação popular ${ }^{65}$ ou, ainda, por meio de eventual denúncia de irregularidades ao Tribunal de Contas da União ${ }^{66}$. Nessa situação de transparência acerca dos contratos públicos, - o que, em última instância, significa transparência acerca dos gastos públicos, tema relevante a qualquer cidadão - este sentir-se-ia incentivado a realizar tais ações por ter conhecimento não apenas a respeito do tema, mas também a respeito daquilo que se passa no âmbito interno do Estado, bem como por saber que suas ações em prol da coletividade poderiam gerar a melhoria no funcionamento esperado do Estado. É nesse sentido que o maior envolvimento do cidadão com a res publica pode aprofundar a democracia, deixando esta de ser vista como o simples ato de votar e passando a ser vista como o mecanismo por excelência para a garantia da cidadania e, em última instância, de própria dignidade humana.

\section{Considerações finais}

O trabalho se propôs a analisar a viabilidade de inserir o Princípio da Transparência, observado como um padrão normativo global, no processo brasileiro de contratação pública, uma vez que a accountability tem sido ausente na legislação brasileira, dando espaço para que casos de corrupção e irregularidades permeie todo o processo licitatório tornando pouco eficiente o gasto publico, com a pouca proteção dos direitos e a baixa implementação dos ideais democráticos.

Dessa forma, na primeira parte do trabalho, verificou-se a contextualização do Direito Administrativo Global na contratação pública por meio da internacionalização do tema, a aproximação dos contratos públicos com o Direito Administrativo Global, tendo em vista as novas relações construídas pelo Estado que estão das fronteiras nacionais, bem como a importância do processo de globalização para o contexto do direito brasileiro sob o aspecto do princípio da transparência.

No capítulo 2, analisou-se o Princípio da Transparência como valor global a ser inserido no processo de contratação pública. Nesse sentido, foi necessário construir teoricamente o Princípio da Transparência a partir da regulação global, com base no direito internacional e europeu, para se alcançar a aplicabilidade desse princípio nas regras brasileiras de contratação pública, que estão muito mais direcionadas, unicamente, para a publicidade do ato administrativo, o que não é suficiente para tornar o processo adjudicatório plenamente transparente, como demonstrado com base nos dados apresentados.

No último capítulo, foi abordada a ausência de accountability no processo brasileiro de contratação pública, mostrando-se necessária a regulação top down realizada pelo Direito Administrativo Global, a fim de que se promova a proteção dos direitos e se implemente os ideais democráticos. Verificou-se que isso se torna possível por meio da ampliação da eficiência do gasto público a partir do aumento da transparência, bem como a inserção do cidadão na esfera pública, por meio da informação e dos meios de participação.

Conclui-se, portanto, que é necessário buscar no direito internacional e europeu, por meio do Direito Administrativo Global, mecanismos para a melhoria do processo licitatório brasileiro, haja vista que as

65 Artigo $5^{\circ}$, inciso LXXIII da Constituição brasileira: "Qualquer cidadão é parte legítima para propor ação popular que vise a anular ato lesivo ao patrimônio público ou de entidade de que o Estado participe, à moralidade administrativa, ao meio ambiente e ao patrimônio histórico e cultural, ficando o autor, salvo comprovada má-fé, isento de custas judiciais e do ônus da sucumbência". BRASIL. Senado Federal. Constituição da República Federativa do Brasil: texto consolidado até a Emenda Constitucional no 88 de 07 de maio de 2015. Brasília: Senado Federal, 2015. p. 6.

66 Artigo 74, \ $2^{\circ}$ da Constituição brasileira: “Qualquer cidadão, partido político, associação ou sindicato é parte legítima para, na forma da lei, denunciar irregularidades ou ilegalidades perante o Tribunal de Contas da União". BRASIL. Senado Federal. Constituição da República Federativa do Brasil: texto consolidado até a Emenda Constitucional no 88 de 07 de maio de 2015. Brasília: Senado Federal, 2015. p. 21. 
regras vigentes não são suficientes para impedir e punir as práticas ilícitas decorrentes dos procedimentos adjudicatórios. De igual modo, a transparência hoje difundida no Brasil deve permear toda a licitação não apenas parte de gestão do gasto público; de outro lado, deve haver a contrapartida do cidadão, que deverá estar plenamente informado, a fim de que possa contribuir para a melhoria da responsabilidade dos agentes públicos, exercendo o seu direito de participação, enquanto cidadão.

\section{REFERÊNCIAS BIBLIOGRÁFICAS}

ALMADA, Maria Paula. Ranking da qualidade dos portais de transparência dos estados brasileiros: análise da informação pública disponível ao cidadão. 2013. Disponível em: <http://www.ceadd.com.br/ranking-da-qualidade-dos-portais-de-transparencia-dos-estados-brasileiros-analise-da-qualidade-da-informacao-disponivelao-cidadao/>. Acesso em: 29 jun. 2015.

AZEVEDO, Patrícia Anjos. O princípio da transparência e a troca de informações entre administrações fiscais. Tese (Doutorado). Porto, 2010. Disponível em: <www.cije.up.pt/download-file/878>. Acesso em: 27 jul.015.

BELLVER, Ana; KAUFMANN, Daniel. Transparenting Transparency: Initial Empirics and Policy Applications. Preliminary draft, August, 2005 for discussion and comments. Local: Editora, 2005.

Disponível em: http://siteresources. worldbank.org/INTWBIGOVANTCOR/ Resources/Transparenting_ Transparency171005.pdf

Acesso em: 27 de julho 2015.

BRASIL. Ministério Público Federal. Caso Lava Jato. Disponível em: < http://lavajato.mpf.mp.br/entendao-caso >. Acesso em: 30 jul. 2015.

BRASIL. Senado Federal. Constituição da República Federativa do Brasil: texto consolidado até a Emenda Constitucional no 88 de 07 de maio de 2015. Brasília: Senado Federal, 2015.

LAVA Jato: investigação chega a Eletronuclear. Carta Capital, São Paulo, 28 jul. 2015. Disponível em: <http://www.cartacapital.com.br/blogs/parlatorio/lava-jato-a-investigacao-chega-a-eletronuclear-6751. html>. Acesso em: 30 jul. 2015.

COMISSÃO INTERAMERICANA DE DIREITOS HUMANOS. Carta Democrática Interamericana. 2001. Disponível em: <http://www.cidh.oas.org/basicos/portugues/r.Carta.Democr\%C3\%A1 tica.htm>. Acesso em: 27 jul. 2015.

BRASIL. Controladoria Geral da União. Brasil Transparente. Disponível em: < http://www.cgu.gov.br/assuntos/transparencia-publica/brasil-transparente/o-programa>.

BRASIL. Controladoria Geral da União. Licitações fraudadas continuam liderando as irregularidades encontradas pela CGU em municípios. Disponível em: <http://www.cgu.gov.br/noticias/2010/07/licitacoes-fraudadascontinuam-liderando-as-irregularidades-encontradas-pela-cgu-em-municipios > . Acesso em: 10 ago. 2015.

BRASIL. Controladoria Geral da União. Licitações lideram indícios de fraude em municípios. Disponível em: <http://www.cgu.gov.br/noticias/2004/09/licitacoes-lideram-indicios-de-fraude-em-municipios>. Acesso em: 10 ago. 2015.

DI PIETRO, Maria Sylvia Zanella. Direito Administrativo. 27. ed. São Paulo: Atlas, 2014.

FERNANDES, Claudio Roberto et al. A transparência como desdobramento do princípio constitucional da publicidade na atual Administração Pública brasileira. 2012. Disponível em: <http://www.egov.ufsc.br/portal/conteudo/ transpar $\%$ C3\%AAncia-como-desdobramento-do-princ $\%$ C3\%ADpio-constitucional-da-publicidade-naatual-admini>. Acesso em: 28 jul. 2015. 
FILGUEIRAS, Fernando. Transparência, publicidade e accountability. Belo Horizonte: Centro de Referência do Interesse Público, 2011. Disponível em: <http://democraciaejustica.org/cienciapolitica3/sites/default/files/transparencia_publicidade_e_accountability.pdf>. Acesso em: 17 ago. 2015.

FUENTES, Carlos Iván. Transparency as a Global Goal: towards an unity of principles in Global Administrative Law. 2008. Disponível em: <http://ssrn.com/abstract=1134122>. Acesso em: 22 jul. 2015.

FUNDAÇÃO GETÚlIO VARGAS. Relatório IPCLBRASIL: $1^{\circ}$ Trimestre/2015. São Paulo: FGV Direito, 2015. Disponível em: <http://bibliotecadigital.fgv.br/dspace/bitstream/handle/10438/13729/ Relat\%C3\%B3rio_IPCLBrasil_1\%C2\%BA\%20Trimestre\%202015.pdf? sequence=1\&isAllowed=y $>$. Acesso em: 30 jul. 2015.

GRANT, Ruth; Keohane, Robert O. Accountability and Abuses of Power in World Politics. American Political Science Review, v. 99, n. 1, Feb, 2005.

GRARD, Loïc. La transparence un príncipe ascendant de la réalisation de l'Union Européenne. Communication et organisation, 17/2000. 2012. Disponível em: < http://communicationorganisation.revues.org/2351>. Acesso em: 28 jul. 2015.

HARLOW, Carol. Global administrative law: the quest for principles and values. EJIL, v. 17, p. 187-214, 2006.

KINGSBURY, Benedict; KRISCH, Nico; STEWART, Richard B. Anexxe: l'emergence du droit administratif global. In: BORIS, Clementine. Un droit administratif global? Cahiers Internationaux - CEDIN, Naterre: Pedone, 2012. p. 335-389.

KINGSBURY, Benedict; KRISCH, Nico; STEWART, Richard B. The emergence of global administrative law. Law and Contemporary Problems, v. 68, p. 15. Disponível em: <http://scholarship.law.duke.edu/cgi/ viewcontent.cgi?article=1361\&context=lcp $>$. Acesso em: 10 jul. 2015.

KRISCH, Nico. The Pluralism of Global Administrative Law. The European Journal of International Law, v. 17, n. 1, p. 249-250, 2006.

MACDONALD, Terry; MACDONALD, Kate. Non-electoral accountability in global politics: strengthening democratic control within the global garment industry. The European Journal of International Law, v. 17, n. 1, 2006.

MIRANDA, Jorge. Manual de direito constitucional. Estrutura constitucional do Estado. Coimbra: Coimbra, 2014.

ORGANIZAÇÃO DAS NAÇÕES UNIDAS. Convenção das Nações Unidas contra Corrupção. Geneva: UNODOC, 2007. Disponível em: <http://www.unodc.org/documents/lpo-brazil//Topics_corruption/Publicacoes/2007_UNCAC_Port.pdf>. Acesso em: 27 jul. 2015.

OBSERVATÓRIO DE CONTRATAÇÃO PÚBLICA. Conclusões do Advogado-Geral Yves Bot, no processo C-91/08. 2009. Disponível em: <http://www.contratacaopublica.com.pt/jurisprudencia/comunitaria/ Conclusoes-do-Advogado-Geral-no-processo-C-9108-27-de-Outubro-de-2009/712/>. Acesso em: 28 jul. 2015.

OLAYA, Dr. Juanita; WIEHEN, Michael. How to reduce corruption in public procurement: the fundamentals. In: Handbook for curbing corruption in public procurement. 2006. Part I, p. 13-105. Disponível em: <http://ssrn.com/abstract=1313787>. Acesso em: 17 ago. 2015.

PLATT NETO, Orion Augusto et al. Publicidade e transparência das contas públicas: obrigatoriedade e abrangência. Contabilidade Vista e Revista, Belo Horizonte, v.18, n.1, p.75-94, jan./mar. 2007.

RAIMUNDO, Miguel Assis. A formação dos contratos públicos: Uma concorrência ajustada ao interesse público. Lisboa: AAFDL, 2013. 
SEN, Amartya. Desarrollo y libertad. Trad. Esther Rabasco e Luís Toharia. Buenos Aires: Planeta, 2000.

SILVA, Matheus Passos. A cidadania ativa como mecanismos de combate à corrupção. In: BRANCO, Paulo Gustavo Gonete; VICTOR, Sérgio Antônio Ferreira. (Org.). Estado de direito, direitos fundamentais e combate à corrup̣cão: interfaces Portugal/Brasil. Brasília: IDP, 2015. Disponível em: <Disponível em: http://www.idp. edu.br/publicacoes/portal-de-ebooks>. Acesso em: 30 jul. 2015.

STEWART, Richard B. U.S. Administrative law: a model for global administrative law? Law and contemporary problems, v. 68, p. 63, Summer/Autumn 2005.

STIGLITZ, Joseph. On liberty, the right to know, and public discourse: the role of transparency in public life. Oxford: Oxford Amnesty Lectures, 1999.

TABORDA, Maren Guimarães. O princípio da transparência e o aprofundamento dos caracteres fundamentais do direito administrativo. Revista de Direito Administrativo, Rio de Janeiro, p. 251-279, out./dez. 2002.

TRANSPARENCY INTERNATIONAL. Corruption Perceptions Index 2014: in detail. 2014. Disponível em: <http://www.transparency.org/cpi2014/in_detail\#myAnchor3>. Acesso em: 04 ago. 2015.

TRIBUNAL DE JUSTIÇA DA UNIÃO EUROPEIA. Processo T-165/12. Acórdão ECLI: EU: T:2013:646. Data do Julgado 13.12.2013. Disponível em: <http:/ / curia.europa.eu/juris/celex.jsf?celex=62012TJ0165\& lang1 $=$ pt\&type $=$ TXT\&ancre $=>$. Acesso em: 28 jul. 2015.

UNIÃO EUROPEIA. Tratado da União Europeia. Luxemburgo: Serviço das Publicações Oficiais das Comunidades Europeias, 1992. Disponível em: <http://europa.eu/eu-law/decision-making/treaties/pdf/treaty_on_european_union/treaty_on_european_union_pt.pdf>. Acesso em: 28 jul. 2015.

UNIVERSIDADE DE BRASÍLIA. Relatório: Pesquisa de avaliação do Portal da Transparência do Governo Federal. Brasília, 2014. Disponível em: < http://www.portaldatransparencia.gov.br/sobre/Boletim/Especial_Pesquisa-de-Avaliacao2014.pdf>. Acesso em: 29 jul. 2015.

WORLD TRADE ORGANIZATION. Acuerdo revisado sobre contratación pública. 2014. Disponível em: <https://www.wto.org/spanish/docs_s/legal_s/rev-gpr-94_01_s.pdf>. Acesso em: 27 jul. 2015.

WORLD TRADE ORGANIZATION. WTO Annual Report 2015. Disponível em: <https:/ www.wto.org/ english/res_e/booksp_e/anrep_e/anrep15_e.pdf>. Acesso em: 27 jul. 2015. 


\section{REVISTA BRASILEIRA DE POLÍTICAS PÚBLICAS BRAZILIAN JOURNAL OF PUBLIC POLICY}

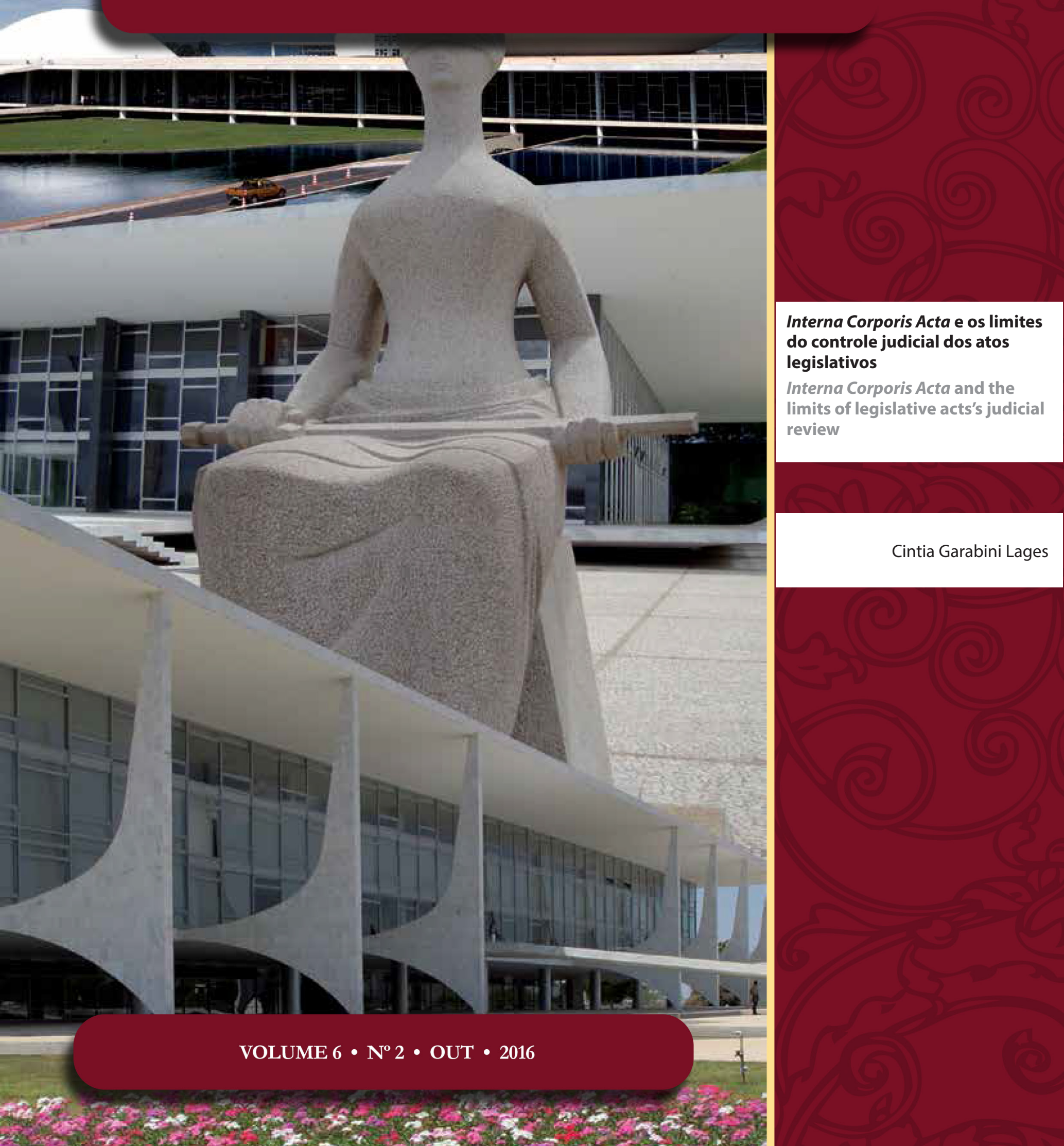




\section{Interna Corporis Acta e os limites do controle judicial dos atos legislativos*}

\author{
Interna Corporis Acta and the limits of \\ legislative acts's judicial review
}

Cintia Garabini Lages**

\section{Resumo}

O presente trabalho tem por objeto de análise crítica o entendimento segundo o qual a atuação das casas legislativas regulamentada por atos normativos internos (interna corporis acta)não se sujeitam a controle judicial relativo à sua legalidade, mas apenas com relação à sua constitucionalidade. Tal análise é realizada, introdutoriamente, com base na reconstrução dos pressupostos teóricos que possibilitaram a definição do conceito tradicional deinterna corporis acta e sua vinculação ao princípio da separação dos poderes. Em um segundo momento, analisou-se a natureza dos atos legislativos internos da perspectiva do modelo processual legislativo estruturado pela constituição brasileira, buscando-se definir sua natureza normativa e seu caráter cogente. Em um terceiro momento, passou-se à discussão acerca da possibilidade de controle judicial destes, utilizando-se, para tanto, dos pressupostos teóricos de uma concepção teórica procedimentalista de democracia e do Direito, cuja nota diferenciadora reside na compreensão do papel atribuído ao processo democrático na formação legítima do Direito. Conclui-se afirmando que, assumido o processo legislativo como a forma jurídica institucionalizada garantidora das condições de produção legítima do Direito nos discursos de justificação normativa, são passíveis de controle de legalidade todos os atos internos que disponham acerca do processo legislativo no âmbito das casas legislativas, uma vez que tais disposições normativas possuem caráter obrigatório, cogente. Tal conceito, apenas, abrange os argumentos apresentados pelos participantes ao longo de todo o processo legislativo, não o seu procedimento.

Palavras-chave: Interna corporis acta. Regimento interno. Processo legislativo.

* Recebido em 16/06/2016 Aprovado em 18/09/2016

** Doutora e Mestre em Direito pela Pontifícia Universidade Católica de Minas Gerais. Professora do Programa de Pós-graduação stricto sensu da Universidade de Itaúna. Professora de Direito Constitucional e Hermenêutica e Argumentação Jurídica da Faculdade Mineira de Direito da Pontifícia Universidade Católica de Minas Gerais. Coordenadora de Pesquisa da Faculdade Mineira de Direito em Betim. Email: cintiagarabini@gmail.com

\section{Abstract}

The presentpaperaimsdiscussthetheoryaccordingtowhichthelegislativebodiesactsruledbymanual procedures (interna corporis acta) maynotbeobjectof judicial reviewregarding its legality, butonly its constitutionality. The analyseisbuilt, initially, in the light oftheseparationofpowersprinciple, whichallowstheunderstandingthatinternalacts are notsubjectto a judicial reviewbasedon its legality, independentlyof its object. Then, it isdiscussedthemanual procedures naturefromthe perspective ofthelegislativedueprocessdefinedbybrazilianconstitution, intendingtoestabilishthenormativeasp 
ectandmandatory'scharacteroftheinternallegislativeacts. Next, thepossibilityof judicial reviewisdiscussedconcerningthelegalityoftheinterna corporis actabythejudiciarycourts, adoptingprimarilytheassumptionsof a proceduralistlegitimationtheoryofdemocracyandlaw, accordingtowhichthesucessofdeliberativepoliticsdependsontheinstitutionalizationofthecorresponding procedures and communication conditions. Finally, thearticleconcludesthat, consideringthelegislativeprocess as theinstitutionalizedmodernformthat garantes theconditionsoflegitimacyoflaw in thediscourseofjustification, actsbasedonmanual procedures are subjecttoa judicial reviewconcerning its legality. Theinterna corporis actaconceptonlyappliestotheargumentssubmittedbyparticipantsthroughoutthelegislativeprocess.

Keywords: Internacorporis acta. Manual procedure. Legislativedueprocess.

\section{INTRODUÇÃo}

A discussão acerca da adoção do princípio da separação dos poderes, aqui concebida como separação de funções ${ }^{1}$, desde cedo foi atrelada à necessidade da sua operacionalização. Não bastava que uma função política especializada fosse atribuída a um órgão estatal, este deveria ter condições de atuar de modo autônomo da mesma forma como seus membros, também, deveriam gozar de condições de atuação independente. Titulares de uma função política, a legislativa, parlamentos são objeto de proteção constitucional, que não apenas prevê, como regra geral, garantias de autonomia administrativa e financeira, mas também do poder de se auto-organizarem por meio da adoção de atos normativos editados sem a participação dos demais poderes.

Nesse contexto, o da teorização da separação dos poderes, é que se encontra a discussão acerca da (im) possibilidade de controle judicial da atuação dos órgãos parlamentares por meio de seus procedimentos e provimentos de caráter interno, os chamadosinterna corporisacta.

Pode-se afirmar que a insindicabilidade dos atos regulamentares editados pelos órgãos legislativos, ou seja, a impossibilidade de controle judicial dos interna corporis acta, tem origem nos internal proceedings previstos, pela primeira vez, no Bill ofRights, documento promulgado pelo Parlamento inglês em 1.689 e que impôs limites ao exercício da monarquia inglesa, inaugurando o fim do absolutismo monárquico na Europa.

Embora não sendo uma declaração de direitos humanos, nos moldes das que viram a ser aprovados cem anos depois nos Estados Unidos e na França, o Bill ofRights criava, com a divisão de poderes, aquilo que a doutrina constitucionalista alemã do século XX viria denominar, sugestivamente, uma garantia institucional, isto é, uma forma de organização do Estado cuja função, em última análise, é proteger os direitos fundamentais da pessoa humana².

Referido documento possibilitou a institucionalização das condições de estruturação do Estado Moderno na Inglaterra, ao estabelecer a prerrogativa da liberdade de expressão e de procedimentos para o exercício independente das função legislativa, estabeleceu as bases para eleições livres para a Câmara dos Comuns, definiu como ilegal a suspensão da vigência ou execução das leis sem o consentimento do parlamento, bem como considerou ilícita a dispensa real que autorizava o descumprimento da lei ${ }^{3}$.

A partir da experiência inglesa, desenvolveu-se a Toria dos Interna Corporis Acta, segundo a qual os procedimentos e atos internos do Parlamento configuram um limite material ao controle por parte de outros órgãos. Em 1863, Rudolf von Gneist, juspublicista alemão, ao ser perguntado em um congresso de juristas

1 Não obstante a Constituição brasileira adotar a expressão separação de poderes, como por exemplo, no texto do seu artigo $2^{\circ}$, entende-se, no presente trabalho, que a Constituição atribui a órgãos distintos e independentes (autônomos) o exercício de funções especializadas. Assim, entende-se que a separação diz respeito ao exercício das funções, não dos poderes do Estado, que se revela único.

2 COMPARATO, Fábio Konder. A afirmação histórica dos Direitos Humanos. São Paulo: Editora Saraiva, 2005 , p. 90.

3 COMPARATO, Fábio Konder. A afirmação histórica dos Direitos Humanos. São Paulo: Editora Saraiva, 2005 , p. 93. 
sobre a possibilidade de o juiz apreciar a regularidade constitucional de uma lei, respondeu positivamente, mas rejeitou a possibilidade de controle dos atos parlamentares durante o processo legislativo, por tratarem-se de atos internacorporis. Tornou-se a primeira vez que a expressão interna corporis acta foi utilizada referindo-se a um conjunto de matérias que se subtraem ao controle judicial ${ }^{4}$.

Por interna corporis entende-se, como afirma José Adércio de Leite Sampaio ${ }^{5}$, os atos e atividades realizados no interior das Casas Legislativas e dizem respeito à garantia da liberdade de expressão dos parlamentares, à definição de uma agenda deliberativa, à competência para a adoção de regulamentos definidores de procedimentos legislativos, e, sobretudo, diz respeito à liberdade para modificá-lo e interpretá-lo. Definem um amplo espaço de liberdade para a atuação das casas legislativas, englobando, inclusive, a possibilidade de fazer cumprir, ou não, os regulamentos que, livremente, adota e interpreta, além de representar a expressão máxima de atuação independente do Parlamento contra toda forma de ingerência de qualquer outra instância de poder, administrativa ou jurisdicional.

Os interna corporis acta consubstanciam a garantia de atuação independente dos parlamentos que se auto-organizam de modo independente, definindo, sobretudo, os processos legislativos que permitem a elaboração das espécies de leis previstas constitucionalmente. Não obstante a Constituição estabelecer normas sobre processo legislativo, tanto o ordinário quanto os de caráter especial ${ }^{6}$, ela o faz em linhas gerais. O devido processo legislativo é definido, com base na Constituição, pelas próprias casas legislativas, no âmbito do seu regimento interno, que prevê, para cada espécie legislativa, os atos legislativos que integram a sequência normativa do seu respectivo procedimento, estabelecendo o modo como se dá a participação dos parlamentares e demais sujeitos processuais no processo de produção normativa de caráter legislativo. Em uma analogia ao Direito Processual Civil, pode-se afirmar que o regimento interno das casas legislativas contempla, dentre outras matérias, o código de processo legislativo.

Dada a importância dos regimentos internos e seu caráter interno, a questão que se apresenta como objeto de discussão no presente trabalho diz respeito à possibilidade de controle judicial da atuação parlamentar no exercício da atividade legislativa não apenas com relação à constitucionalidade dos seus atos, mas também da sua legalidade, tomando como parâmetro as normas regimentais que disciplinam o processo legislativo.

Mas a discussão acerca da possibilidade de controle judicial dos atos internos das casas legislativas levanta uma questão preliminar: o caráter normativo destes. Estabelecer se os regimentos internos e demais atos parlamentares de caráter interno possuem natureza normativa e, portanto, caráter vinculante no que tange à ação daqueles que são os destinatários dos seus efeitos apresenta-se como um pressuposto para a discussão da possibilidade do próprio controle judicial dos atos legislativos.

\section{A NATUREZA NORMATIVA DOS INTERNA CORPORIS ACTA}

A Constituição Federal de 1988 é o marco a partir do qual pretendo discutir a natureza normativa dos chamados interna corporis acta. Ao dispor acerca do processo legislativo, a Constituição brasileira indicou, no artigo 59, as espécies de leis que podem ser editadas pelo Congresso Nacional diretamente, ou com sua aprovação anterior, como forma de exercício da função legislativa. Nesse sentido dispôs a Constituição brasileira que o processo legislativo compreende a elaboração de emendas a constituição, leis complementares,

4 ÁLVAREZ, Elviro Aranda. Los actos parlamentarios no normativos y su control jurisdiccional. Madrid: Centro de Estudios Políticos y Costitucionales, 1998, p. 67. SILVA FILHO, Derly Barreto. Controle dos atos parlamentares pelo poder judiciário. São Paulo: Malheiros Editores, 2003, p. 95.

5 (SAMPAIO, 2002, p. 294)

6 Como os processos de elaboração da lei complementar, a delegação legislativa, a conversão da medida provisória em lei e o processo sumário. 
leis ordinárias, leis delegadas, medidas provisórias, decretos legislativos e resoluções.

Inicialmente é possível perceber a ausência de rigor por parte do Constituinte originário ao incluir no supracitado dispositivo duas espécies normativas que não se encaixam no conceito de espécies legislativas, por não serem produto da atividade legislativa: as emendas constitucionais e as medidas provisórias.

Emendas constitucionais são produto do Poder Constituinte Derivado. Sua natureza constituinte a distingue das demais espécies elencadas ao longo do art. 59, já que, uma vez aprovadas, promovem alteração formal do texto constitucional e são, dessa forma, hierarquicamente superiores às espécies legislativas. Sua aprovação dá-se por meio de um processo constituinte derivado, que se diferencia do processo legislativo em função de uma iniciativa restrita, da exigência de um duplo turno de deliberação, pela definição de um quórum de aprovação especial, o de três quintos, por estabelecer limites circunstanciais e materiais (as chamadas cláusulas pétreas), por não se sujeitar à sanção ou à sua negativa (veto) por parte do Presidente da República, por atribuir às Mesas das Casas do Congresso Nacional sua promulgação e publicação.

Nesse sentido, não obstante serem as emendas à Constituição produto de um devido processo, esse processo tem natureza constituinte e diferencia-se do legislativo não apenas por adotar uma sequência de atos processuais distintos, mas por resultar na produção de um provimento de natureza constitucional.

Por sua vez, as medidas provisórias encontram-se "deslocadas" no artigo 59 da Constituição brasileira por não configurarem uma espécie legislativa, muito menos resultarem de um processo legislativo. Medidas provisórias configuram atos normativos dotados de generalidade e abstração, com eficácia de lei, editados pelo Presidente da República nas hipóteses expressamente autorizadas pela Constituição, ou melhor dizendo, nas hipóteses não proibidas constitucionalmente ${ }^{7}$. Uma vez editadas, tornam-se objeto de um processo legislativo de conversão em lei, nos termos do artigo 62 da Constituição brasileira ${ }^{8}$ e, se aprovadas, resultam na aprovação de um provimento do tipo lei ordinária.

As espécies legislativas são assim denominadas porque resultam da atuação dos órgãos titulares da função legislativa, Câmara dos Deputados e Senado Federal, e sua legitimidade decorre da adoção de um procedimento democrático que permite sua elaboração de modo participativo. Nesse sentido, são espécies legislativas a lei ordinária (tanto a que se origina de um projeto de lei ordinária quanto aquela originada da conversão de uma medida provisória), a lei complementar, a lei delegada, o decreto legislativo e a resolução.

Interessa para a presente discussão, em especial a resolução, uma vez que é por meio dessa espécie legislativa que as competências privativas das Casas do Congresso Nacional são veiculadas, como a de organizarem-se por meio da adoção de regimentos internos, a de criarem comissões parlamentares, a de autorizarem a instauração de processo de impeachment ou processo criminal contra o Presidente da República etc.

As resoluções são espécies legislativas constitucionalmente previstas, art. 59, inciso VII, às quais a Constituição dispõe sobre toda a competência privativa da Câmara dos Deputados (art. 51), do Senado Federal (art. 52) e do Congresso Nacional, desde que esta não esteja prevista no artigo 49, hipótese na qual a espécie legislativa a ser adotada é o decreto legislativo.

Nesse sentido, são veiculados, por meio de resolução, os Regimentos Internos de cada uma das Casas do Congresso Nacional, bem como o Regimento Comum do Congresso Nacional, os atos de criação de comissões parlamentares temporárias, como por exemplo, as comissões parlamentares de inquérito, os atos de cassação de mandato de parlamentares, os atos do Senado Federal que suspendem a execução de lei declarada inconstitucional por decisão definitiva do Supremo Tribunal Federal, entre outras.

As resoluções são atos legislativos que disciplinam a matéria privativa das casas legislativas e que recebem a designação de internos, aderindo ao conceito de interna corporis acta. Entretanto, seu processo de elaboração

7 Ver parágrafos $1^{\circ}$ e $2^{\circ}$ do artigo 62 da Constituição Federal de 1988.

8 Com a redação dada pela Emenda Constitucional n. 22/21001. 
não se encontra regulamentado pela Constituição Federal, que, ao contrário, estabelece normas acerca do processo legislativo das leis ordinárias (arts. 61, 64 a 67), das leis complementares (arts. 61 e 69), da delegação de competência delegada ao Presidente da República (art. 68), além de disciplinar o processo de conversão da medida provisória em lei (art. 62).

O processo legislativo das resoluções é definido, internamente, pelas Casas do Congresso Nacional e via de regra encontra-se previsto no regimento interno de cada uma delas. A Constituição tão somente indica as matérias que configuram objeto de resolução, definindo, para algumas, um quórum especial, como na hipótese de cassação de mandato de parlamentar. A Constituição estabelece o quórum da maioria absoluta, mas, para a hipótese de recebimento da acusação contra o Presidente da República pela prática de crime de responsabilidade, estabelece o quórum de dois terços. Para as demais matérias, às quais a Constituição não estabelece um quórum especial, aplica-se o quórum da maioria relativa, nos termos do seu artigo $47^{9}$.

Ao elencar as resoluções como espécies legislativas, produto de um devido processo legislativo, a Constituição Federal não apenas reconhece sua natureza legislativa, mas também estabelece que sua elaboração sujeita-se aos mesmos requisitos de produção democrática exigíveis do processo legislativo ordinário ou complementar.

Como espécie legislativa, a resolução possui caráter vinculante, residindo sua especificidade na matéria que lhe é reservada: a competência privativa atribuída às casas do Congresso Nacional, bem como a matéria privativa do Congresso Nacional não enunciada ao longo do artigo 49 da Constituição Federal. Esta é a única característica diferenciadora da resolução em face das demais espécies legislativas elencadas no artigo 59 da Constituição Federal, mas não seu caráter vinculante, uma vez que o possui como qualquer outra figura legislativa.

Reconhecido o caráter normativo-legislativo da resolução, faz-se relevante ressaltar que seu processo legislativo atende aos mesmos princípios constitucionais processuais que caracterizam o modelo constitucional processual brasileiro.

A Teoria do Modelo Constitucional do Processo foi elaborada, inicialmente, por Ítalo Andolina e Giuseppe Vignera ${ }^{10}$ e tem por fio condutor a relação do processo com a Constituição. Ainda muito influenciados pela nova prática constitucional inaugurada em 1948, na Itália, os autores apresentam uma preocupação atual: a necessidade de se afirmar um fundamento constitucional para o processo, não apenas processual ou formal, mas material, consubstanciador de um verdadeiro modelo processual de observância obrigatória ${ }^{11}$.

Segundo o que os autores denominam de "nova perspectiva constitucional", o problema do processo não pode estar vinculado, apenas, ao seu ser, ou seja, à sua concreta organização segundo as leis processuais ordinárias vigentes, como também não pode estar atrelado a uma concepção subjetivista da jurisdição, que a identifica com base no órgão que prolatou o provimento. O processo deve ser analisado com base em seu dever ser segundo o conjunto de normas constitucionais, que regulam a atividade jurisdicional. A jurisdição, ao originar-se de um procedimento, deve fundamentar-se constitucionalmente. Assim, distinguem os autores a jurisdição originária do procedimento e a jurisdição derivada da Constituição ${ }^{12}$.

Entretanto, para além do inicialmente proposto por Andolina e Vignera e que neste lugar podemos assumir como uma crítica à mera faticidade do processo na busca do respeito à sua normatividade, entende-se que o modelo constitucional processual, estabelecido pela Constituição Federal de 1988, aplica-se não apenas à

9 Art. 47. Salvo disposiçãoconstitucionalemcontrário, as deliberações de cada Casa e de suasComissõesserãotomadaspormaioria dos votos, presente a maioriaabsoluta de seusmembros.

10 ANDOLINA, Italo; VIGNERA, Giuseppe. Il fondamenticostituzionalidellagiustiziacivile: ilmodellocostituzionaledel processo civile italiano. Torino: G. Giappichelli Editore, 1997.

11 ANDOLINA, Italo; VIGNERA, Giuseppe. Il fondamenticostituzionalidellagiustiziacivile: ilmodellocostituzionaledel processo civile italiano. Torino: G. Giappichelli Editore, 1997, p. 07.

12 ANDOLINA, Italo; VIGNERA, Giuseppe. Il fondamenticostituzionalidellagiustiziacivile: ilmodellocostituzionaledel processo civile italiano. Torino: G. Giappichelli Editore, 1997, p. 06. 
configuração de novos procedimentos jurisdicionais, mas a todos os procedimentos adotados pelo Estado para a realização de suas funções e em todos os procedimentos privados regulados pelo Estado. Assim, não há que se falar, apenas, em modelo constitucional do processo jurisdicional, mas em modelo constitucional do processo, abarcando, também, o processo legislativo.

O modelo constitucional processual estruturado pela Constituição Federal de 1988 reconhece como princípios que o integram o contraditório, a ampla defesa, a fundamentação das decisões, entre outros. O processo legislativo, enquanto processo, por meio do qual dá-se o exercício de uma função política de modo democrático, a legislativa, deve atender aos mesmos princípios que conformam o modelo constitucional processual brasileiro e, nesse contexto, Este ocorre com a elaboração de resoluções.

A vinculação do processo legislativo das resoluções ao modelo constitucional do processo é uma exigência de coerência do sistema constitucional, que não concebe a democracia de modo compartimentalizado, mas íntegro e coerente.

\section{Controle Judicial dos interna CORPoris acta}

Assumidos esses pressupostos, o reconhecimento do caráter normativo das resoluções por meio das quais dá-se a elaboração dos atos de competência privativa das casas legislativas - interna corporis acta, e da sua sujeição ao modelo constitucional processual estruturado pela Constituição Federa de 1988, passa-se à discussão acerca da possibilidade de controle judicial destes.

Como afirmado anteriormente, os interna corporis acta surgiram como limites à atuação do Poder Executivo e tinham por finalidade resguardar a liberdade de atuação das casas parlamentares e dos seus membros. Seu fundamento reside no princípio da separação de poderes e o único controle admitido era o de constitucionalidade, dado o caráter hierarquicamente superior das normas constitucionais e que se estabelecem como parâmetro de legitimidade de todas as demais normas do ordenamento jurídico, inclusive aquelas que dispõe sobre matéria interna das casas legislativas.

Segundo Silva Filho ${ }^{13}$, Ruy Barbosa, Francisco Campos e Manuel Gonçalves Ferreira Filho, ao conferirem aos regimentos parlamentares, a condição de normas jurídicas pertencentes ao ordenamento jurídico e de fonte do Direito Parlamentar afirmavam que, na condição de normas infraconstitucionais, encontram-se as mesmas hierarquicamente subordinadas à Constituição, sujeitando-se ao controle de constitucionalidade por parte do Poder Judiciário.

No entanto, não discutiam os referidos teóricos acerca da possibilidade de controle da legalidade dos atos legislativos, com base no regimento interno, este concebido como ato interna corporis por excelência, já que, editado por meio de resolução, disciplinava o exercício da atuação das casas legislativas no desempenho das suas funções. A questão acerca da vinculação dos parlamentares às normas regimentais e a possibilidade de controle de legalidade dos atos realizados em desconformidade com o regimento permanecia inadmissível, sustentada com base no princípio da separação dos poderes.

Uma compreensão mais ampla da sindicabilidade dos atos legislativos foi apresentada por Meireles ${ }^{14}$, que afirmou a possibilidade do controle atuar não apenas na hipótese de violação de uma norma constitucional, mas também na hipótese de violação de normas regimentais. "Deparando infringência à Constituição, à lei ou ao regimento, compete ao Judiciário anular a deliberação ilegal do Legislativo, para que outra se produza

13 SILVA FILHO, Derly Barreto. Controle dos atos parlamentares pelo poder judiciário. São Paulo: Malheiros Editores, 2003 , p. 344.

14 MEIRELLES, Hely Lopes. Direito Administrativo Brasileiro. São Paulo: Editora Revista dos Tribunais, 1979. 
de forma legal"15.

Meirelles excluiu da apreciação do Poder Judiciário a decisão propriamente dita, o mérito, ou ainda as opções políticas que levaram as casas legislativas a adotar um ou outro posicionamento, e que não podem ser substituídas por uma decisão do Judiciário sob pena de violação da separação dos poderes. Todavia, afirma Meirelles, sempre, que houver violação de normas constitucionais, legais ou regimentais que estabeleçam condições, forma ou rito para a produção do ato legislativo, o controle se afigura devido.

Verifica-se neste ponto a estreita correlação que Meirelles estabelece entre os limites jurisdicionais de controle do ato legislativo e do ato administrativo. Segundo o referido administrativista, ainda quando se trate de ato administrativo discricionário, o realizado com liberdade de escolha da sua conveniência, oportunidade e/ou conteúdo, a liberdade de ação do administrador dá-se dentro dos limites postos pela lei, razão pela qual liberdade e arbitrariedade não se confundem.

O que a doutrina assinala é que o ato, embora resultante de poder discricionário da Administração, não pode prescindir de certos requisitos, tais como a competencia legal de quem o pratica, a forma prescrita em lei ou regulamento e o fim indicado no texto legal em que o administrador se apóia. Exemplifiquemos: se determinada lei prevê diversas penalidades administrativas para uma infração, o poder discricionário da Administração, manifesta-se na escolha da penalidade que entender adequada ao caso ocorrente, dentre as enumeradas no texto. Mas, se a lei indica o processo de apuração dessas infrações, não pode a autoridade utilizar de outro meio para sua verificação, nem modificar o que está indicado ${ }^{16}$.

Tal raciocínio aplica-se à consideração do caráter vinculante das normas regimentais que estabelecem a forma, ou seja, o processo por meio do qual a atividade legislativa se desenvolve. Ainda que o exercício da atividade legislativa seja atribuída às Casas do Congresso Nacional pela Constituição Federal, cuja liberdade de atuação é assegurada pelo princípio da separação de poderes, seu exercício não se pode dar legitimamente se desconsiderados os limites processuais impostos a este pelas normas regimentais. Ressalte-se, mais uma vez, que a discricionariedade do legislador restringe-se à conveniência de se editar a lei, ao momento de fazê-lo e ao seu conteúdo, observados os limites constitucionais.

Nessa mesma linha, entendem Russomano ${ }^{17}$, Figueiredo ${ }^{18}$, e Coelho ${ }^{19}$, para os quais o regimento interno, na qualidade de ato interno, integra o processo legislativo e vincula os parlamentares.

O interesse que se manifesta na correta elaboração das leis não é apenas o dos parlamentares que participam do processo legislativo. Por outro lado, as leis produzidas também não se limitam subjetivamente aos eventuais destinatários da conduta prevista. Ao contrário, dizem respeito a todos, pois expressam o interesse público. Por isso, a visão contrária ao controle reflete a ótica privada do direito, em especial a tutela dos interesses dos parlamentares, quando o correto é a defesa dos interesses públicos ${ }^{20}$.

O devido processo legislativo possui, assim como o processo jurisdicional, um duplo parâmetro de correção normativa, o constitucional e o legal. Este encontra sua fonte nas resoluções, sobretudo nos atos regimentais. Reconhecer a possiblidade de controle judicial da legalidade dos atos legislativos significa não apenas reafirmar o caráter vinculante das normas regimentais que dispõem acerca do processo legislativo e que encontram-se previstas nos regimentos internos, mas redefinir as possibilidades de controle judicial dos atos legislativos, para além do controle de sua constitucionalidade.

A atividade legislativa deve ser compreendida com base em sua perspectiva processual, o que significa conferir ao regimento interno o status de norma garantidora da produção legítima do Direito. O estudo da natureza processual da atividade legislativa e da possibilidade de controle de sua constitucionalidade e lega-

15 MEIRELLES, Hely Lopes. Direito Administrativo Brasileiro. São Paulo: Editora Revista dos Tribunais, 1979 , p. 687.

16 MEIRELLES, Hely Lopes. Direito Administrativo Brasileiro. São Paulo: Editora Revista dos Tribunais, 2008 , p. 173.

17 RUSSOMANO, Rosa. Dos poderes legislativo e executivo. Rio de Janeiro: Biblioteca Jurídica Freitas Bastos, 1976

18 FIGUEIREDO, Lúcia Valle. Curso de Direito Administrativo. São Paulo: Malheiros Editores, 2003.

19 COELHO, Fábio Alexandre. Processo Legislativo. São Paulo: Editora Juarez de Oliveira, 2007.

20 COELHO, Fábio Alexandre. Processo Legislativo. São Paulo: Editora Juarez de Oliveira, 2007, p. 350. 
lidade requer, necessariamente, a redefinição dos matérias interna corporis no contexto do paradigma procedimental de Estado, neste trabalho assumido como capaz de fornecer uma compreensão mais adequada do Direito e da democracia, como ver-se-á a seguir.

O reconhecimento do caráter fundamental das normas regimentais que disciplinam o processo legislativo (direitos de participação) e das liberdades de ação dos parlamentares e cidadãos no processo de produção das leis importa, necessariamente, a revisão da Teoria dos Interna Corporis Acta, ao mesmo tempo em que assegura a legitimidade da produção do Direito através do exercício das autonomias públicas dos cidadãos constantemente alimentada pelo exercício das liberdades subjetivas dos sujeitos de direito enquanto dotados de autonomia privada, conforme a dicotomia apresentada por Habermas ${ }^{21}$.

\section{Direito POSITIVO, LEGITIMIDADE E PROCESSO: O PAPEL DO PROCESSO LEGISLATIVO NA MODERNIDADE E O CARÁTER COGENTE DAS NORMAS REGIMENTAIS SOBRE PROCESSO LEGISLATIVO}

Pretende-se, nesse tópico, discutir, com base na Teoria Discursiva Habermasiana, o caráter cogente das normas regimentais que dispõem sobre processo legislativo. A Teoria Discursiva de Jürgen Habermas propõe, em substituição aos modelos liberal e republicano ${ }^{22}$, uma concepção procedimentalista de democracia e do Direito, cuja nota diferenciadora reside na compreensão do papel atribuído ao processo democrático na formação legítima do Direito.

A essa nova compreensão do exercício da democracia Habermas dá-se o nome de política deliberativa ${ }^{23}$, conceito que ganha expressão quando são consideradas as diversas formas comunicacionais que constroem a vontade geral.

A concepção deliberativa de democracia apropria-se tanto de elementos presentes na concepção liberal, preocupada em legitimar o exercício do poder político, quanto os presentes na concepção republicana, tomada como autodeterminação política da sociedade, integrando-os, como afirma Habermas, "no conceito de um procedimento ideal para deliberação e a tomada de decisão"24. Esse procedimento parte da intersubjetividade de uma ordem superior, representada pelos processos de entendimento realizados por meio de procedimentos democráticos ou que se encontram presentes na rede de comunicação dos espaços públicos políticos. Essas várias formas de comunicação não ocorrem, exclusivamente, no âmbito da estrutura administrativa (comissões, parlamento, tribunais, conselhos etc...), mas também ocorrem na esfera pública, espaços extrainstitucionais. O desenvolvimento e a consolidação de uma política deliberativa dependem da institucionalização de procedimentos e pressupostos comunicativos, bem como da interação entre deliberações institucionalizadas com opiniões públicas desenvolvidas informalmente.

A imagem que Habermas nos oferece para explicar os processos de comunicação e de decisão do sistema político é aquela que retrata uma relação do tipo centro-periferia. No centro, localiza-se a administração, o judiciário e a formação democrática da opinião e da vontade (parlamento, eleições políticas, partidos) que formam o núcleo do sistema político; e na periferia encontra-se a esfera púbica composta por

21 HABERMAS, Jürgen. A constelação pós-nacional: ensaios políticos. Trad. Márcio Seligmann-Silva. São Paulo: LitteraMundi, 2001, p. 146.

22 Segundo Habermas, o modelo liberal de democracia estrutura-se de modo semelhante ao mercado, sendo determinado pela concorrência entre agentes coletivos que atuam estrategicamente com a finalidade de manter ou conquistar posições de poder. Já o modelo de democracia republicano, a formação da opinião e da vontade política em meio à opinião pública e no parlamento obedece às estruturas de uma comunicação pública voltada para o entendimento mútuo. O paradigma aqui é o da interlocução. A concepção republicana de democracia peca ao adotar uma “condução estritamente ética dos discursos políticos” HABERMAS, Jürgen. A inclusão do outro. São Paulo: Edições Loyola, 2002, pp. 275/276.

23 HABERMAS, Jürgen. A inclusão do outro. São Paulo: Edições Loyola, 2002, p. 269.

24 HABERMAS, Jürgen. Direito e democracia: entre faticidade e validade. Trad. Flávio BenoSiebeneichler. Rio de Janeiro: Tempo Brasileiro, 1997, v. II, p. 19. 
associações formadoras de opinião, especializadas em tema e em exercer influência pública (grupos de interesse, sindicados, associações culturais, igrejas etc).

Tendo em mente tal imagem, Habermas define a política deliberativa por meio de duas vias: a formação da vontade democraticamente constituía em espaços institucionais e a construção da opinião informal em espaços extrainstitucionais. É a partir da inter-relação entre esses dois espaços que se encontra a possibilidade de um governo legítimo. (FARIA, 2000, p. 49).

O processo legislativo apresenta-se como um dos processos por meio do qual se dá a formação da opinião e da vontade e que institucionaliza as exigentes condições de comunicação do procedimento democrático por meio dos direitos fundamentais e dos princípios do Estado de Direito. Tal procedimento democrático gera um nexo interno entre negociações, discursos de autoentendimento e discursos sobre a justiça e supõe que, a possibilidade de se obter resultados racionais, legítimos ou válidos.

Com base no princípio do Discurso, Habermas explica o modo como, sob condições simétricas (pragmática universal) de reconhecimento de formas de vida estruturadas comunicativamente, é possível fundamentar, imparcialmente, normas de ação sem que seja necessário o recurso a uma ordem normativa superior, promovendo a distinção entre o Direito e a Moral, sem negar a relação de complementaridade e co-originalidade entre $\operatorname{ambos}^{25}$.

A fundamentação do Direito dá-se pelo recurso à estruturação de procedimentos de produção de modo legítimo. A aplicação do princípio do Discurso à forma jurídica, ao medium do Direito, resulta no princípio da democracia segundo o qual "podem pretender validade as normas que poderiam encontrar o assentimento de todos os potencialmente atingidos, na medida em que estes participam de discursos racionais" ${ }^{26}$ e cujo sentido é reconhecer um elemento de imparcialidade nos juízos que racional e discursivamente serão providos, sem o recurso a fórmulas prontas ou conteúdos pré-definidos, mas disciplinando o desenvolvimento de processos através dos quais as decisões são tomadas discursivamente ${ }^{27}$.

O princípio democrático, como especialização do princípio do discurso, determina a institucionalização de procedimentos que possibilitam a produção legítima, racional, do Direito por meio da garantia da igual participação de todos os sujeitos afetados pelo Direito produzido ${ }^{28}$. Mas a questão da legitimidade do Direito não se esgota na institucionalização de procedimentos, mas requer, como exigência do princípio democrático, o reconhecimento de direitos considerados indispensáveis para que se proceda a uma autorregulação racional do Direito.

Os procedimentos institucionalizados, segundo o princípio democrático, devem assegurar a cada um dos participantes iguais condições de participação em igualdade de condições em face da exigência de institucionalização de procedimentos.

Por isso devem ser simultaneamente reconhecidas liberdades subjetivas capazes de garantir a busca privada de projetos particulares e individuais de vida, na concretização das mais variáveis autorrealizações éticas, bem como também reconhecidas devem ser iguais liberdades comunicativas capazes de garantir um espaço discursivo aberto tanto à participação de quem quer que seja, quanto a mais diferenciada sorte de argumentos discursivamente criticáveis ${ }^{29}$.

25 HABERMAS, Jürgen. Direito e democracia: entre faticidade e validade. Trad. Flávio BenoSiebeneichler. Rio de Janeiro: Tempo Brasileiro, 1997, v. I, p. 159. CHAMON JÚNIOR, Lúcio Antônio. Filosofia do Direito na alta modernidade. Incursões teóricas em Kelsen, Luhmann e Habermas. 2a . edição. Rio de Janeiro: Lumen Juris Editora, 2010, p. 07.

26 HABERMAS, Jürgen. Direito e democracia: entre faticidade e validade. Trad. Flávio BenoSiebeneichler. Rio de Janeiro: Tempo Brasileiro, 1997, v. I, p. 164.

27 CHAMON JÚNIOR, Lúcio Antônio. Filosofia do Direito na alta modernidade. Incursões teóricas em Kelsen, Luhmann e Habermas. $2^{a}$. edição. Rio de Janeiro: Lumen Juris Editora, 2010, p. 09.

28 CHAMON JÚNIOR, Lúcio Antônio. Filosofia do Direito na alta modernidade. Incursões teóricas em Kelsen, Luhmann e Habermas. $2^{\text {a }}$. edição. Rio de Janeiro: Lumen Juris Editora, 2010, p. 09.

29 CHAMON JÚNIOR, Lúcio Antônio. Filosofia do Direito na alta modernidade. Incursões teóricas em Kelsen, Luhmann e Habermas. 2a . edição. Rio de Janeiro: Lumen Juris Editora, 2010, p. 10. 
A legitimidade do Direito não se encontra garantida na institucionalização de um processo de justificação normativa, por meio da sua previsão constitucional e regimental. Faz-se necessário assegurar condições de participação simétricas, iguais, o que exige o reconhecimento dos direitos de participação, de modo que o princípio democrático seja respeitado. Direitos processuais, enquanto asseguradores de liberdades comunicativas, devem ser compreendidos como direitos fundamentais de participação e de construção legítima do Direito positivo.

No quadro de uma democracia procedimental (deliberativa), o processo legislativo aparece como uma das formas de institucionalização das condições de comunicação por meio das quais as diversas esferas da sociedade civil participam diretamente ou por meio de representantes na tomada de decisões legislativas supostamente racionais, legítimas.

O processo legislativo deve, necessariamente, atender às exigências de uma comunicação aceitável, que possibilite a participação de todos os envolvidos de modo livre e igual, e, para tanto, faz-se necessária a garantia tanto da soberania popular, viabilizada pelo exercício da autonomia pública dos cidadãos por meio do asseguramento das liberdades de participação e de comunicação, quanto das liberdades subjetivas garantidas na autonomia privada dos sujeitos de direito (HABERMAS, 2001, p. 146).

O processo político-legislativo apresenta-se como a forma jurídica institucionalizada garantidora das condições de produção legítima do Direito nos discursos de justificação normativa. Com base nos pressupostos teóricos, que importam na assunção de uma compreensão discursiva do Direito, como desenvolvida por Habermas, em relação às normas institucionalizadoras do processo legislativo previstas tanto pela Constituição Federal de 1988, quanto pelos regimentos internos das Casas do Congresso Nacional, deve-se reconhecer caráter cogente, enquanto exigência do princípio democrático.

O processo legislativo brasileiro importa, nos termos do artigo 59 da Constituição Federal, na elaboração de emendas à Constituição, leis complementares, leis ordinárias, leis delegadas, conversão de medidas provisórias em leis ${ }^{30}$, decretos legislativos e resoluções. Todas essas espécies, com exceção da medida provisória, caracterizam-se por resultarem da atividade desenvolvida processualmente no âmbito das Casas legislativas, o que permite sua identificação como leis e não meros atos normativos.

Referidos processos não podem configurar-se de qualquer maneira, se se pretende garantir a legitimidade das normas por eles ao final produzidas, os processos e pressupostos de comunicação (pragmática universal) institucionalizados juridicamente enquanto princípios de processo constitucional. Tais princípios “[...] permitem levantar a suposição de que os processos de criação e de aplicação do direito levam a resultados racionais" e portanto, legítimos $^{31}$. Assim, a produção válida das leis depende da adoção de um processo legislativo discursivo e participativo, o que só se alcança com respeito a essa dimensão processual-normativa.

Dessa forma é inevitável reconhecer o caráter cogente e vinculante das normas que, enquanto juridicamente institucionalizadoras dos pressupostos da pragmática universal, criam condições legítimas de desenvolvimento e conclusão do próprio processo legislativo. Além disso, referidos pressupostos condensados nos princípios processuais constitucionais permitem-nos checar a legalidade dos atos legislativos.

Este é o motivo pelo qual não se pode assumir a posição segundo a qual atos interna corporis encontrar-se-iam fora da esfera de sindicabilidade do Poder Judiciário, como forma de garantir a atuação livre e independente dos órgãos legislativos e, dessa forma, realizar-se o princípio da separação dos poderes.

A discussão em torno da possibilidade do controle judicial do processo legislativo e de seus limites deve considerar um argumento importante: o de ser o processo legislativo a espécie processual que encontra

30 Ressalte-se que, apesar de a Constituição Federal de 1988 incluir as medidas provisórias no rol das espécies legislativas do artigo 59, não são as mesmas produto de um processo legislativo prévio, razão pela qual não podem ser consideradas como espécie legislativa, mas tão somente como ato normativo, editado pelo Chefe do Poder Executivo, com força de lei, nos termos do art. 62. 31 HABERMAS, Jürgen. Direito e democracia: entre faticidade e validade. Trad. Flávio BenoSiebeneichler. Rio de Janeiro: Tempo Brasileiro, 1997, v. II, p. 153. 
na Constituição disciplinamento próprio, estendendo-se para além do reconhecimento e positivação dos princípios constitucionais (aplicáveis a todos os ramos do Direito Processual), mas indo além ao estabelecer quais espécies legislativas são constitucionalmente reconhecidas (art. 59), a quem compete sua iniciação (art. 61), o quórum a ser observado (art. 47 e art. 69), o papel das comissões parlamentares (art. 58), de que modo se dá a apreciação das emendas a projetos de lei (art. 65), de que forma participa o Chefe do Poder Executivo (art. 66), qual prazo possuem as Casas legislativas para deliberar acerca do veto presidencial ( $\$ 6^{\circ}$. do art. 66), entre várias outras normas, todas insertas na Seção VIII do Capítulo I, Título IV da Constituição Federal, intitulada Do Processo Legislativo.

Por estabelecer a Constituição mais que um modelo constitucional processual conglobante da atividade legislativa, na medida em que disciplina atos processuais específicos, que encontram nos regimentos internos sua complementação natural, não há como negar o caráter vinculante das normas regimentais em matéria processual, como, embora com outros fundamentos, afirma SILVA FILHO ${ }^{32}$. Da mesma forma, não há como excluir do modelo constitucional do processo estabelecido pela Constituição Federal de 1988 a atividade legislativa, dado seu irrefutável caráter processual.

As normas regimentais de conteúdo processual legislativo, por tratarem de matéria atinente ao exercício racional, legítimo da atividade legislativa, são elaboradas sem a participação direta do Chefe do Poder Executivo por meio da possibilidade da sanção ou da sua negativa (veto), de forma a preservar a independência do Poder Legislativo e assumem a forma de resoluções, espécies legislativas previstas no inciso VII do art. 59 da Constituição Federal de 1988.

Enquanto resolução, o Regimento Interno, como o afirma Santos, é lei, não obstante tenha seu âmbito de incidência restrito à atividade da assembleia que o decretou. Sua produção ocorre por meio de um verdadeiro processo legislativo, que se desenvolve a partir da produção de uma sequência normativa de atos de observância obrigatória, garantida a participação de todos os membros da Casa respectiva.

Ao estabelecer a Constituição Federal de 1988 que a lei não excluirá da apreciação do Poder Judiciário lesão ou ameaça a direito (art. $5^{\circ}$, inciso XXXV), resta confirmada a competência do Poder Judiciário, em específico do Supremo Tribunal Federal, para conhecer de toda e qualquer violação a norma regimental decorrente do exercício da atividade legislativa pelo Congresso Nacional.

O exercício desse controle não importa em ruptura com o princípio da separação dos poderes. Ao contrário, fundado no sistema de freios e contrapesos que impede o abuso no exercício do poder confiado aos órgãos titulares da função estatal e, segundo o princípio democrático, o controle da legalidade possibilita assegurar a produção do Direito de modo legítimo, por meio da adoção de um processo discursivo e racional.

Nesse sentido, o conceito de matéria interna corporis reduz-se à discussão empreendida por via do processo e à decisão tomada pelo órgão legislativo, ou seja, ao discurso de justificação normativa, não ao seu procedimento.

\section{Considerações finais}

O desafio imposto pelo paradigma procedimental de Estado é o de compreender o processo legislativo como instituidor de um conjunto de direitos fundamentais de participação em igualdade de condições nos processos institucionalizados de formação da lei que se mantêm abertos à formação da opinião e a vontades públicas. Isso é o que uma compreensão deliberativa da democracia exige dos processos de formação do Direito que uma sociedade constituída por cidadãos livres e iguais reconhece a si mesma de modo legítimo.

32 SILVA FILHO, Derly Barreto. Controle dos atos parlamentares pelo poder judiciário. São Paulo: Malheiros Editores, 2003, 185. 
Segundo a Teoria do Discurso, a ideia de uma autolegislação se realiza por meio do Princípio do Discurso enquanto princípio democrático e requer o reconhecimento a iguais liberdades de ação a todos os membros da sociedade, que a participação de cada membro da sociedade ocorra de modo voluntário, autônomo e não imposto e o reconhecimento do direito fundamental de acesso à jurisdição, dentre outros pressupostos da pragmática universal ${ }^{33}$.

Essas categorias de direitos, com base em Habermas, permitem-nos concluir que a legitimidade do Direito e da democracia modernos está a depender das relações que se estabelecem entre os sujeitos livremente associados na adoção da organização político-objetiva e na organização jurídica do próprio Estado. Esse processo entrelaça-se ao reconhecimento dos direitos de participação, na qualidade de direitos fundamentais, os quais, segundo Habermas, caracterizam-se "como fundamentais à participação em igualdade de chances, em processos de formação da opinião e da vontade, nos quais os civis exercitam sua autonomia política e através dos quais eles criam direito legítimo ${ }^{34}$." A garantia da participação de modo livre e igual dos associados é decorrente do reconhecimento da autonomia política dos cidadãos e possibilita a criação do Direito de modo legítimo, o que permite afirmar o caráter fundamental dos direitos processuais, enquanto garantidores das condições de participação.

A compreensão do processo como medium do Direito, que permite aos cidadãos, sujeitos livres e iguais, avaliarem se o direito que estão criando é legítimo ${ }^{35}$, coloca para a Teoria do Processo novos desafios. A compreensão e a prática do processo não mais pode reduzir-se à tríade ação, processo e jurisdição, tão cara à Teoria do Processo desde a célebre preleção de Bologna ${ }^{36}$, mas deve abrir-se, com base na perspectiva aqui assumida, a todos os processos de formação do Direito, seja administrativo, legislativo ou jurisdicional, enquanto exercício de funções públicas ou no exercício de uma atividade privada, como a arbitragem.

Teorias processuais, no marco procedimentalista de Estado, devem discutir a natureza jurídica do processo e devem construir argumentos que possibilitam sua compatibilidade com o ideal subjacente ao princípio do discurso; caso contrário, colocam em risco a legitimidade da produção normativa, bem como a legitimidade do próprio direito produzido. Com base nessa longa premissa, apresentam-se as conclusões a seguir.

1. O exercício da atividade legislativa pelas Casas do Congresso Nacional deve atender aos princípios do contraditório, da ampla defesa e, sobretudo, do devido processo legal, princípios que, concretamente, se encontram no regimento interno das Casas do Congresso;

2. Os regimentos internos são normasjurídicas, dotadas de características próprias dos atos com força de lei — generalidade, abstração, obrigatoriedade e caráter inovador —, e encontramse integrados ao ordenamento jurídico do Estado. Seu processo de produção é definido constitucionalmente e adota a forma de resolução, espécie legislativa prevista no art. 59, inciso VII da Constituição Federal;

3. Possuem os regimentos internos, como expressão do poder autonormativo das Casas do Congresso Nacional, fundamento constitucional. O cumprimento das normas regimentais importa a garantia dos direitos fundamentais de participação neste processo institucionalizado, razão pela qual não mais se sustenta o argumento de soberania parlamentar como razão para o descumprimento de normas regimentais;

33 HABERMAS, Jürgen. Direito e democracia: entre faticidade e validade. Trad. Flávio BenoSiebeneichler. Rio de Janeiro: Tempo Brasileiro, 1997, v. I, p. 159.

34 HABERMAS, Jürgen. Direito e democracia: entre faticidade e validade. Trad. Flávio BenoSiebeneichler. Rio de Janeiro: Tempo Brasileiro, 1997, v. I, p. 159.

35 HABERMAS, Jürgen. Direito e democracia: entre faticidade e validade. Trad. Flávio BenoSiebeneichler. Rio de Janeiro: Tempo Brasileiro, 1997, v. I, p. 163.

36 O célebre estudo sobre a natureza da ação, intitulado "A ação no sistema dos direitos", apresentado por Chiovenda, é considerado um marco na construção da Teoria do Processo. 
4. A caracterização dos regulamentos parlamentares como atos dotados de força de lei permite a consideração do processo legislativo como verdadeiro processo, estrutura normativa de atos que prepara o provimento(a lei), realizado de modo a garantir o contraditório. Tem-se, assim, um verdadeiro processo, ao qual são aplicáveis todos os princípios processuais constitucionais, sobretudo o do devido processo, a permitir não apenas o controle de sua constitucionalidade mas da legalidade dos atos praticados;

5. Normas regimentais são válidas se compatíveis com o modelo processual legislativo que lhes serve de fundamento e, como normas válidas, vinculam todos aqueles que têm garantido o direito à participação no processo legislativo em simétrica paridade de armas (FAZZALARI). Negar o caráter cogente dos regimentos e a possibilidade de controle judicial dos atos do Legislativo fundados em normas regimentais significa desconsiderar o caráter processual da atividade legislativa, confundir o processo através do qual atua o Congresso Nacional com as decisões que o mesmo toma processualmente, bem como desconsiderar o próprio caráter procedimental e democrático do Estado de Direito;

6. Por matéria interna corporis, devem-se compreender os argumentos apresentados pelos participantes ao longo de todo o processo legislativo, os quais se encontram nas justificativas dos projetos de lei, nos pareceres das comissões parlamentares, nas manifestações dos parlamentares no exercício do direito à palavra e no fundamento a favor da manutenção ou derrubada do veto presidencial e que se decidem com argumentos éticos, morais e pragmáticos, além de argumentos acerca da coerência do próprio discurso de justificação normativa. Essa é a matéria insindicável, ou seja, imune a controle por parte de qualquer outro poder durante o exercício da atividade processual legislativa, que se finda com a promulgação da lei, a qual poderá ter sua constitucionalidade material aferida pelos órgãos do Poder Judiciário;

7. A análise do Regimento Interno da Câmara dos Deputados permite a constatação da conformação de um verdadeiro modelo constitucional do processo aplicável também à atividade legislativa. A adoção de iniciativa legislativa concorrente e de iniciativa legislativa popular, a previsão de realização de audiências públicas no interior das comissões parlamentares, a composição proporcional das comissões parlamentares, o direito de apresentar emendas a projetos de lei, o direito de participação no debate franqueado aos parlamentares, todos esses aspectos do processo legislativo possibilitam o exercício dos direitos de participação institucionalizada na formação da vontade coletiva do Estado. Por meio da elaboração de normas jurídicas, possibilitam o exercício tanto de uma autonomia pública quanto o exercício da autonomia privada dos cidadãos, de modo direto ou através de seus representantes eleitos.

\section{REFERÊNCIAS BIBLIOGRÁFICAS}

ÁLVAREZ, Elviro Aranda. Los actos parlamentarios no normativos y su control jurisdiccional. Madrid: Centro de Estudios Políticos y Costitucionales, 1998.

ANDOLINA, Italo; VIGNERA, Giuseppe. Il fondamenticostituzionalidellagiustiziacivile: ilmodellocostituzionaledel processo civile italiano. Torino: G. Giappichelli Editore, 1997. 
CHAMON JÚNIOR, Lúcio Antônio. Filosofia do Direito na alta modernidade. Incursões teóricas em Kelsen, Luhmann e Habermas. $2^{\text {a }}$. edição. Rio de Janeiro: Lumen Juris Editora, 2010.

COELHO, Fábio Alexandre. Processo Legislativo. São Paulo: Editora Juarez de Oliveira, 2007.

COMPARATO, Fábio Konder. A afirmação histórica dos Direitos Humanos. Sao Paulo: Editora Saraiva, 2005.

FARIA, Cláudia Feres. Democracia deliberativa: Habermas, Cohen e Boham. Revista Lua Nova. São Paulo, no. 49, pág. 47-68. Ano 2000.

FAZZALARI, Elio.Istituzioni de dirittoprocessuale. 8. ed., Padova: CEDAM - Casa EditriceDott. Antonio Milani, 1996.

FERREIRA FILHO, Manoel Gonçalves. Do processo legislativo. São Paulo: Saraiva, 2002.

FIGUEIREDO, Lúcia Valle. Curso de Direito Administrativo. São Paulo: Malheiros Editores, 2003.

HABERMAS, Jürgen. Direito e democracia: entre faticidade e validade. Trad. Flávio BenoSiebeneichler. Rio de Janeiro: Tempo Brasileiro, 1997, v. I.

HABERMAS, Jürgen. Direito e democracia: entre faticidade e validade. Trad. Flávio BenoSiebeneichler. Rio de Janeiro: Tempo Brasileiro, 1997, v. II.

HABERMAS, Jürgen. A constelação pós-nacional: ensaios políticos. Trad. Márcio Seligmann-Silva. São Paulo: LitteraMundi, 2001.

HABERMAS, Jürgen. A inclusão do outro. São Paulo: Edições Loyola, 2002.

MEIRELLES, Hely Lopes. Direito Administrativo Brasileiro. São Paulo: Editora Revista dos Tribunais, 1979.

MEIRELLES, Hely Lopes. Direito Administrativo Brasileiro. São Paulo: Malheiros Editores, 2008.

RUSSOMANO, Rosa. Dos poderes legislativo e executivo. Rio de Janeiro: Biblioteca Jurídica Freitas Bastos, 1976.

SAMPAIO, José Adércio Leite. A Constituição reinventada pela jurisdição constitucional. Belo Horizonte: Del Rey, 2002.

SANTOS, Carlos Maximiliano Pereira dos. Comentários à Constituição brasileira de 1891. Brasília: Senado Federal, 2005.

SILVA FILHO, Derly Barreto. Controle dos atos parlamentares pelo poder judiciário. São Paulo: Malheiros Editores, 2003. 


\section{REVISTA BRASILEIRA DE POLÍTICAS PÚBLICAS BRAZILIAN JOURNAL OF PUBLIC POLICY}

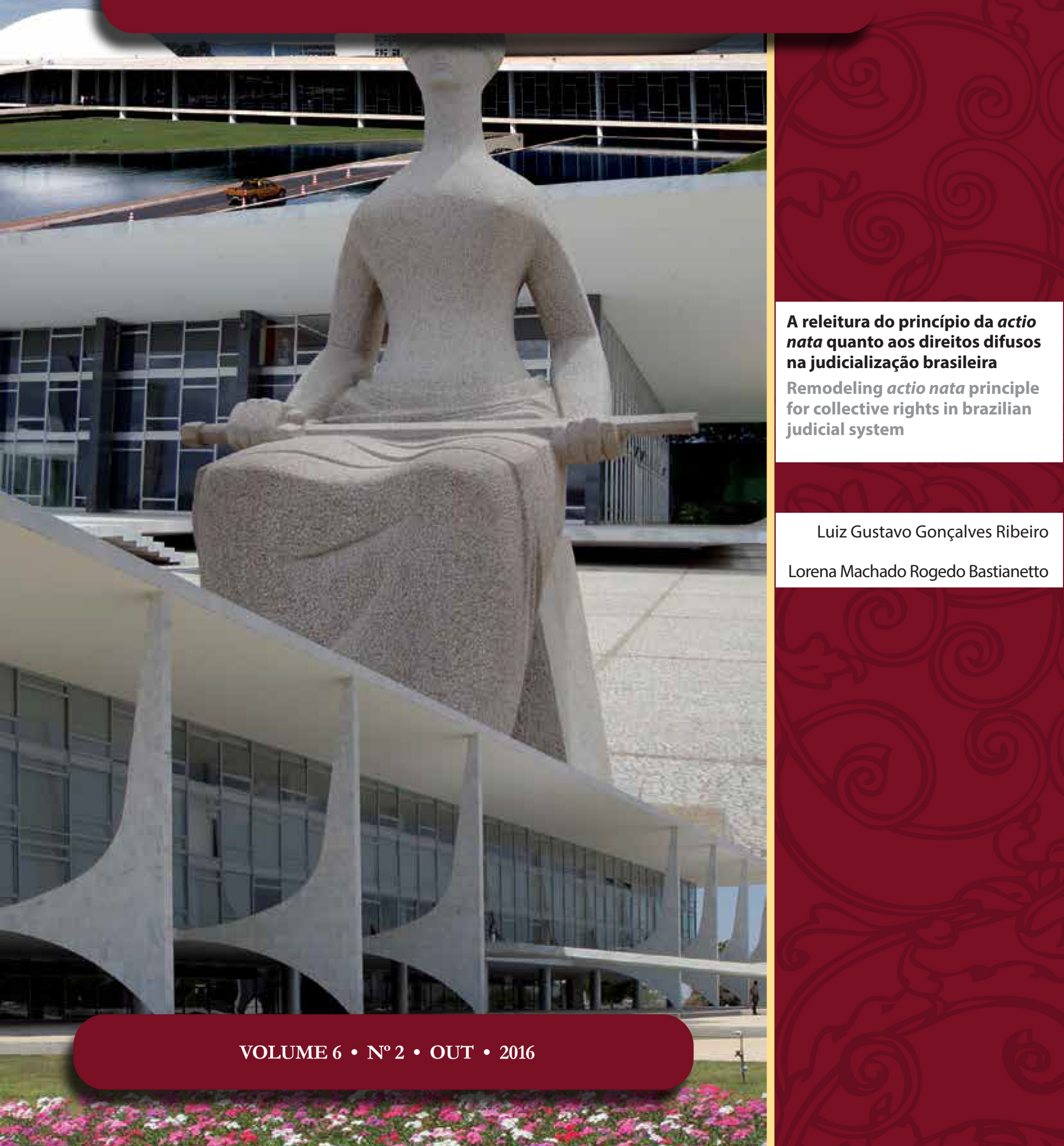




\section{A releitura do princípio da actio nata quanto aos direitos difusos na judicialização brasileira*}

\section{Remodeling actio nata principle for collective rights in brazilian judicial system}

\author{
Luiz Gustavo Gonçalves Ribeiro** \\ Lorena Machado Rogedo Bastianetto***
}

\section{Resumo}

Este artigo centra-se no estudo do princípio universal da Actio Nata ou do nascedouro do direito de ação regularmente válido na conjuntura pós-moderna de propalação dos direitos transindividuais e difusos, sendo o meio ambiente o de maior pujança. A análise tradicionalista da "pretensão", sustentáculo para o ingresso eficaz ao Poder Judiciário, revela-se, na doutrina e jurisprudência nacionais, matéria useira e vezeira para a aquilatação dos termos temporais de exigibilidade de direitos em Juízo. Todavia, a ideação precaucional que reveste os direitos comuns das gentes não encontra confluência com os institutos processuais preliminares para a formação de uma demanda legítima sub judice. $\mathrm{O}$ corpo do trabalho consiste na análise conceitual da "pretensão" em cotejo com as peculiaridades do bem ambiental sujeito à tutela de heterocomposição judicial e na protetividade do Poder Judiciário por meio dos instrumentos de sindicabilidade à disposição na ordem jurídica. Por meio do exame jurisprudencial e análise doutrinária e legislativa, bem como pelo realce da ponderação, evidencia-se a eminência de uma mutação principiológica, considerando-se, em igual modo, o influxo que essa virada conceitual acarretará no Devido Processo Legal brasileiro. No desfecho, em vista da premissa da propalação dos direitos transindividuais e difusos, abre-se, com o emprego do método lógico-dedutivo, a perspectiva para um direcionamento sustentável do tempo por vir.

Palavras-chave: Protagonismo judicial. Actio Nata. Bem ambiental. Processo Civil. Direitos Fundamentais.

\section{Abstract}

This article focuses on the study of the universal principle of Actio Nata i.e, the right to an efficient demand through a lawsuit. In post modern contextures, the Environment as a common good and a legal asset implies alterations and constant revisions of pleadings filed with courts on the grounds of causes of action. In Brazil, the pursue of a cause of action is firstly weighted by time barriers, fact that conducts to default judgements when noncompliance is verified by the court. However, collective goods nourish 
a diverse comprehension of torts and damages through ideas of risk management and preventive injunctions. These new concepts address essential matters to the juridical community pertaing to the origins and notion of a legal claim able to enforce the right sustained. The body text consists of the analysis of national jurisprudence and procedural instruments concerning the causes of action as well as their connection to the main goals of precautionary directives when collective rights are at stake. In the end, in view of the spread of diffuse premises and rights, new perspectives are arisen envisioning a sustainable development and life safeguarding, through the logical-deductive method.

Keywords: Judicial Activism. Actio Nata. Environment. Civil Procedure. Fundamental Rights.

\section{INTRODUÇÃO}

A judicialização das ocorrências sociais, sempre que um dano ou ameaça de dano ocorram, é corolário natural dos ditames constitucionais de $1988^{1}$, os quais fomentam, amplamente, a condução das desavenças e conflitos ao Poder Judiciário, fenômeno que promove a substitutividade e criatividade normativa de um ente que é compelido a manifestar-se a respeito da pretensão sub judice ${ }^{2}$.

No entanto, almeja-se, há muito, que a tutela substitutiva seja a ultima ratio na tentativa de desfecho conflitual, apesar dos contínuos avanços legislativos que alavancam a composição heterogênea das pretensões mediante o alargamento do alcance ao Poder Judiciário pela reestruturação das condicionantes de legitimação e interesse processuais, bem como pela sobrelevação do res communis omnium³.

Assim, os equivalentes jurisdicionais, principalmente a autocomposição bilateral, por meio da conciliação interpartes, têm tido, na pós-modernidade, considerável impulsionamento, episódio que caminha em paralelo ao incremento de vias de ingresso ao Juízo.

O meio ambiente, direito difuso de valia vultosa e imperiosa na estruturação social contemporânea, determina-se um bem público de uso comum do povo $^{4}$ e de natureza indisponível ${ }^{5}$, dado que aparta o influxo arbitral nas lides a ele relacionadas ${ }^{6}$.

Por essa razão, faz-se inegável a operacionalização de um protagonismo judicial intenso nas controvérsias que remetam à temática, já que a heterocomposição, em se tratando da tutela ecológica, detém um contorno eminentemente preventivo e não de composição expost, seja esta implementada por ações - obrigações de fazer ou não fazer que possibilitem a restauração ou recuperação da Biota - ou pela tradicional conversão em perdas e danos, obrigação de aspiração remanescente e acessória da responsabilidade civil em linhas gerais.

A salvaguarda normativa ecológica é bastante evoluída no direito pátrio, visto que se chegou a um consenso, na Assembleia Constituinte de 1987-1988, de que a biografia do país até aquele momento pautara-se

1 A respeito, consultar art. 5, Constituição da República de 1988 (CR/1988): “Todos são iguais perante a lei, sem distinção de qualquer natureza, garantindo-se aos brasileiros e aos estrangeiros residentes no País a inviolabilidade do direito à vida, à liberdade, à igualdade, à segurança e à propriedade, nos termos seguintes: 'XXXV - a lei não excluirá da apreciação do Poder Judiciário lesão ou ameaça a direito'; [...]" BRASIL Constituição (1988). Constituição da República Federativa do Brasil. Disponível em: <http://www. planalto.gov.br/ccivil_03/Constituicao/ConstituicaoCompilado.htm>. Acesso em: 01 nov. 2015.

2 A assertiva destaca os princípios da demanda e da inafastabilidade no processo civil.

3 Compreenda-se, pela expressão, os bens de novíssima dimensão de natureza difusa, transindividual.

4 A respeito, consultar art. 225 da CR/1988.

5 A respeito, ver: BRASIL. Superior Tribunal de Justiça. Agravo Regimental no Recurso Especial. AgRg no REsp 1412664 SP 2011/0305364-9. Quarta Turma. Relator: Ministro Raul Araújo. Brasília, 11 de fevereiro de 2014. Disponível em: <http://www.stj. jus.br>. Acesso em: 01 nov. 2015.

6 A Lei n ${ }^{\circ}$ 13.129/2015, a qual altera a Lei n 9.307/1996, dispõe, em seu art. 1: "A administração pública direta e indireta poderá utilizar-se da arbitragem para dirimir conflitos relativos a direitos patrimoniais disponíveis". BRASIL. Lei n. 13.129, de 26 de maio de 2015. Disponível em: <http://www.planalto.gov.br/ccivil_03/_Ato2015-2018/2015/Lei/L13129.htm>. Acesso em: 01 nov. 2015. 
pela depauperação ambiental, atributo explícito no gentílico dos seus naturais. Segundo Carlos Alberto Xavier $^{7}$, representante do CONAMA (Conselho Nacional do Meio Ambiente) nas audiências públicas atinentes à matéria por ocasião da Constituinte, a mercância e exploração econômica do pau-brasil foram o mote para a formação do nome étnico aos habitantes da sua região: brasileiros.

Esse cenário usurário, associado à mobilização vigorosa da comunidade internacional, especialmente com a elaboração, em 1987, do Relatório Brundtland - Our Common Future ${ }^{8}$-, levou a Subcomissão da Saúde, Seguridade e Meio Ambiente da Assembleia Nacional Constituinte à elaboração de diretivas verdes na Constituição da República de 1988 (CR/1988), as quais, em âmbito judicial, encapam-se de coercibilidade, mormente na conjuntura de responsabilidade aquiliana e de prevenção e precaução a lesões ao Ecossistema.

Desborda-se, desse modo, a premência do ativismo magistral, um dos matizes do protagonismo do Juízo na sociedade atual. O Poder Judiciário, por sua arquitetura constitucional genuína, já é personagem principal nas inquietudes comunitárias a ele postas, feitio que não infirma a utilidade de uma atuação ainda mais ambiciosa na aplicação do Direito ao caso concreto, performance que inova a letra legal, engrandecendo-a até encobrir a realidade em debate.

O Princípio da Actio Nata, orientador do surgimento da pretensão, isto é, da aptidão de exigir um direito em sede judicial ${ }^{9}$, revela-se uma construção civilista ligada aos direitos relativos, obrigacionais. Com o advento da CR/1988, a concepção de "pretensão" ganha qualidades que transcendem a clássica dicotomia entre direitos relativos e absolutos, entre descumprimento contratual e dever de abstenção, aterrisando na seara difusa dos direitos comuns e em terras de imprevisibilidade danosa e incertezas científicas.

Nesse enquadramento, o presente artigo abordará as novas acepções da "pretensão", seu nascedouro e a releitura do Princípio da Actio Nata para a proteção ambiental judicial, tendo como base as doutrinas e normatizações atinentes ao assunto, bem como a indispensabilidade de conformação pós-moderna dos institutos processuais para o atendimento às demandas coletivas e transindividuais.

A pesquisa, que se vale de dados primários (legislação) e secundários (doutrina e jurisprudência), tem por premisssa a natureza difusa do objeto da tutela e, por isso, o emprego do método lógico-dedutivo é adequado para a proposta de uma necessária e iminente releitura da Actio Nata em vista de futura e eventual judicialização primária das ocorrências sociais de instabilidade e de indefinição, em prol da sobrevivência humana.

\section{A NATUREZA REFLEXIVA DO DIREITO AO MEIO AMBIENTE EQUILIBRADO}

Como é cediço, os direitos fundamentais têm aplicação incisiva nas relações privadas, a cognominada "eficácia horizontal" ou "dimensão objetiva", assim como o indivíduo per si e coletivamente considerado demanda do Estado um preciso respeito aos direitos humanos positivados. Todavia, o ente estatal, no escólio de Alexy ${ }^{10}$, não é titular de direitos fundamentais.

Dessa armação, infere-se que o meio ambiente ecologicamente equilibrado contempla um viés bidimensional: a de "microbem" e a de "macrobem". Na acepção de microbem, sua relevância destaca-se na responsabilidade extracontratual ou aquiliana, ou seja, na lesão ao bem ambiental vivenciada e suportada por um ou mais cidadãos determinados. Já no sentido de macrobem, o dano, mesmo não coabitado e não padecido pelas pessoas in concreto, carrega, intrinsecamente, um abalo ecológico que ecoará de maneira sub-reptícia

7 BACKES, Ana Luiza; AZEVEDO Débora Bithiah de; ARAÚJO, José Cordeiro de (Org.). Audiências públicas na assembleia nacional constituinte: a sociedade na Tribuna. Brasília: Câmara dos Deputados, 2009. p. 495.

8 SUÍÇA. Relatório Brundtland: our common future. 1987. Available in: <http://www.un-documents.net/our-common-future. pdf $>$. Access in: 01 nov. 2015.

9 DONIZETTI, Elpídio; QUINTELLA, Felipe. Curso didático de direito civil. 2. ed. São Paulo: Atlas, 2013.

10 ALEXY, Robert. Teoria dos direitos fundamentais. 2. ed. São Paulo: Malheiros, 2011. 
no tempo até reverberar nas gerações futuras ou afetará cocidadãos contemporâneos espalhados por diferentes localidades do planeta. A esfera do macrobem envolve a compreensão de que a conta da degradação será cobrada de muitos, em algum lugar e em algum momento. Nos meandros de tanta inespecificidade, a Jurimetria faz seu papel estatístico e estima a perturbação e impregnância nociva do dano, do provável mal ou do risco de ambos.

Chama-se a atenção, porém, não para a percepção lata da ecologia, mas para sua variante diminuta. A literatura dominante alevanta a magnitude do ângulo macro - postura extremamente escorreita nos dias atuais, entretanto, o prisma micro, por evocar a posição tradicional e patrimonialista do Direito Civil, perpassa pelos textos muito timidamente. Acredita-se que esse posicionamento debilita a consciência do direito ao bem ambiental em sua integralidade e abandona a necessidade forçosa de revisitar o microbem ecológico.

Os instrumentos processuais de sindicabilidade protetiva do meio ambiente, como a ação popular e a ação civil pública, ocupam-se, sobretudo, da tutela difusa e apartada da Biota, dissociando a Natureza da pessoa humana, que vivencia as agruras dos impactos ambientais. Essa propensão deve ser relida.

A Conferência das Nações Unidas sobre Desenvolvimento Sustentável, conhecida como Rio+20, emitiu, em seu desfecho, um documento batizado de "The Future We Want"11, no qual as pessoas situam-se no centro do desenvolvimento sustentável, ou seja, os objetivos e metas traçados para a preservação da natureza devem considerar o ser humano em primeiro plano, a melhoria de sua qualidade de vida, de seu bem-estar e a erradicação da miséria, bem como a desmarginalização de categorias atavicamente esquecidas pela comunidade global.

Na esteira de Strapasson e Pamplona,

[...] a complexidade e a multidimensionalidade da pobreza geram implicações nos mais diversos âmbitos da esfera pessoal. As consequências psicológicas das privações e do não desenvolvimento das capacidades pessoais devem ser perspectivas contempladas no combate à pobreza. Essa dimensão exige o fortalecimento da identidade cultural, da visibilidade e da participação política, instrumentalizadas por políticas públicas voltadas à educação, principalmente em âmbito informal para a emancipação individual $^{12}$.

Desse contexto, extrai-se a ratio essendi do direito ao bem ambiental, direito humano positivado, cuja tarefa constitui o favorecimento inclusivo das pessoas, semeando a transmudação de uma "Economia Marron" para uma "Sociedade Verde", que incorpora em suas políticas o volumoso número do abandono, da cifra negra de multidões largadas à própria sorte ${ }^{13}$. Pragmaticamente, essa inteligência traduz que as ações afirmativas de resguardo ecológico, mormente ao meio ambiente natural, são obrigadas a computar o custo ambiental da melhoria de vida, da desmarginalização e da aquisição da dignidade de populações ignoradas ${ }^{14}$.

11 UNITED NATIONS. The future we want: outcome document of the United Nations conference on sustainable development. 2012. Available in: <https://sustainabledevelopment.un.org/content/documents/733FutureWeWant.pdf>. Access in: 01 nov. 2015.

12 STRAPASSON, Karoline; PAMPLONA, Danielle Anne. A escolha pública econômica para erradicar a pobreza extrema no Brasil. Revista Brasileira de Políticas Públicas, Brasília, v. 4, n. 2, p. 47-63, jul./dez. 2014. Disponível em: < http://www.publicacoesacademicas.uniceub.br/index.php/RBPP/article/view/2988/pdf>. Acesso em: 07 jul. 2016.

13 Essa ideação encontra-se evidente em: SINGSON-LEDESMA, Maitet. Rio+20: ¿una Victoria pírrica para los derechos humanos y el desarrollo? In: GUTIÉRREZ, Aitana Uria (Coord.). De la economía verde a las sociedades verdes: reflexiones para el futuro que queremos. Madrid: Catarata, 2013. p. 67-82.

14 Já se disse, em face da importância da agenda ambiental: "O preparo das populações do globo a respeito da significância de bens de titularidade propalada advirá do caminhar sem saltos pelos estágios de capacitação humana, exercendo a mídia papel medular na comoção coletiva de conscientização e internalização da crucialidade da agenda ambiental na vida de cada um, de todos e dos a nascer, seja hoje ou no futuro, aqui, ali ou acolá”. RIBEIRO, Luiz Gustavo; BASTIANETTO, Lorena Machado Rogedo. Direito penal ambiental como tutela de sustentação à atuação administrativa e civil nos Estados Unidos da América e no Japão. Revista Brasileira de Políticas Públicas, Brasília, v. 6, n. 1, p. 213-228, jan./jun. 2016. Disponível em: < http://www.publicacoesacademicas.uniceub. br/index.php/RBPP/article/view/2988/pdf>. Acesso em: 17 ago. 2016. 
Os fundos de Defesa de Direitos Difusos ${ }^{15}$, corolário pecuniário da sindicabilidade ao bem ambiental no direito pátrio, oriundos da LACP (Lei da Ação Civil Pública), Lei no $7.347 / 1985$, propõem-se a ações educativas, preventivas e à recomposição dos bens lesados em plano prioritário à remição voltada às pessoas e a todas as esferas de suas vidas que sofreram prejuízo. Essa ideação disjuntiva da recomposição do bem ambiental e da reparação aos cidadãos enfraquece os propósitos maiores das "sociedades verdes", as quais propõem a asserção do Direito Protetivo ou Schutzgesetž como prevalecente. Essa construção volta-se, energeticamente, à tutela da pessoa humana em primazia à custódia coletiva, essa última de eminência inatacável, dado que não pode ofuscar, no entanto, o microdano ou o drama individual de cada sujeito, como célula básica da comunidade.

Nessa esteira, a evolução do Direito deve elaborar o expediente de que a responsabilidade ambiental, tanto para a restauração, recuperação ou conservação da Biota quanto para o ser humano afetado per si e agregado, surge com a infringência de qualquer prescrição jurídica normatizada, seja em forma de princípios, regras ou em disposições legais complementares e minudentes da lei, isto é, regulamentos, portarias, resoluções etc. A responsabilidade nasce de qualquer proscrição legislativa, bem como de todas as diretrizes comissivas e omissivas erga omnes, estabelecidas em diplomas legais. Esse é o real sentido do direito protetivo lato e stricto.

Neste artigo, ousa-se almejar pela configuração da responsabilidade ambiental nacional advinda de atitudes de defiance ou noncompliance aos documentos persuasivos transnacionais, especialmente os emanados da Organização das Nações Unidas (ONU), inferência válida e legítima quando se trata de bens difusos, ocorrência que acoberta o Ecossistema e os cidadãos que dele dependem.

\section{A ORIGEM DA "PRETENSÃo"}

Uma vez abordados os aspectos micro e macro do meio ambiente, bem como a inserção da pessoa humana em seu cerne, passemos a uma digressão atinente à "pretensão".

Como versado acima, a "pretensão" rege o interesse das partes em Juízo, melhor dizendo, adjetiva o pedido com a qualidade de imperatividade, de cumprimento forçado. E é justamente a qualidade de compulsão de direitos que legitima o pedido em Juízo.

Em uma visão simplista, o peticionamento de direito prescrito não é judicialmente eficaz, isto é, esvazia a qualidade legítima de intrusão do Poder Judiciário. Todavia, não deixa de ser direito válido. O devedor de dívida prescrita que, voluntariamente, assinta quanto ao pagamento em autocomposição bilateral com seu credor, nada mais faz do que adimplir sua obrigação contratual ou aquiliana.

No entanto, para que o ingresso do conflito possa ser efetivamente tutelado pelo magistrado investido em jurisdição, o constrangimento ao implemento do Direito deve determinar-se pleno, ou seja, a aptidão para exigir judicialmente tem de se agasalhar por todas as condicionantes procedimentais do processo.

A “decadência" e a "prescrição", por exemplo, são fatos jurídicos ensecantes da "pretensão". Contudo, não se pretende, neste artigo, empenhar-se na "eficácia pretensional", mas em sua gênese e sua constituição exordial.

Se a "pretensão" é o primeiro atributo para a entrada no Poder Judiciário, urge saber quando e como esta se dá. Por essa razão, o propósito do Princípio da Actio Nata, ou nascimento do direito de ação regularmente

15 A respeito, ver: BRASIL. Decreto n. 1.306, de 09 de novembro de 1994. Disponível em: < http://www.planalto.gov.br/ccivil_03/ decreto/1990-1994/D1306.htm>. Acesso em: 01 nov. 2015.

16 A respeito do Schutzgesetz, consultar: HINTEREGGER, Monika. Environmental liability and ecological damage in European law. Cambridge, NY: Cambridge University Press, 2008. p. 68. 
válido em concordância com a Teoria Eclética ${ }^{17}$ do direito de ação, perpetuada no Novo Código de Processo Civil Brasileiro.

Esse princípio, de interpelação breve e perfunctória em âmbito doutrinário e jurisprudencial, mostra sua importância para o Juízo na contagem do tempo, na aferição do termo inicial e final de plenitude da pretensão, isto é, à margem das consequências que a prescrição e a decadência acarretam ao pedido em contraditório.

No entanto, a Actio Nata, em se tratando de direitos difusos e transindividuais, urge por mudanças. A CR/1988, em seu art. $5^{\circ}$, inciso XXXV, reza:

Todos são iguais perante a lei, sem distinção de qualquer natureza, garantindo-se aos brasileiros e aos estrangeiros residentes no País a inviolabilidade do direito à vida, à liberdade, à igualdade, à segurança e à propriedade, nos termos seguintes: XXXV - a lei não excluirá da apreciação do Poder Judiciário lesão ou ameaça a direito. ${ }^{18}$. (grifo nosso).

Em relação ao texto excerto supracitado, depreende-se que somente o dano ou a ameaça comprovada a direito seriam justificantes do direito de ação válido ou pleno, entendido este não como direito a um pronunciamento jurisdicional, mas como o direito à análise meritória, à tutela do Juízo.

O inciso LXXIII, também do art. 5, CR/1988, exprime:

[...] qualquer cidadão é parte legítima para propor ação popular que vise a anular ato lesivo ao patrimônio público ou de entidade de que o Estado participe, à moralidade administrativa, ao meio ambiente e ao patrimônio histórico e cultural, ficando o autor, salvo comprovada má-fé, isento de custas judiciais e do ônus da sucumbência; [... $]^{19}$. (grifo nosso).

De igual maneira, propala-se, uma vez mais, a estruturação da Actio Nata na disposição constitucional em tela. $\mathrm{Na}$ realidade normativa da ação popular, porém, trata-se de direitos difusos, patrimônio jurídico da coletividade, o qual, considerando-se o tradicional nascedouro do direito de ação, tem a lesão como imprescindível para sua instrução protetiva.

Nesse mesmo sentido, a Lei da Ação Civil Pública, Lei no $7.347 / 1985$, em seus artigos $1^{\circ}$ e $2^{\circ}$, consagra o dano patrimonial e moral ao meio ambiente como bandeira para sua proposição. A norma realça, ainda, que a ação a ser deflagrada para se evitar o dano seria a cautelar, cenário que avulta, vigorosamente, o prisma danoso da Actio Nata e não precaucional.

A natureza assecuratória e não satisfativa do processo cautelar, existente para curar um direito a ser analisado a posteriori, geralmente inserto em um procedimento de maior morosidade, ganhou nova roupagem com a entrada em vigor do Novo Código de Processo Civil sob o nome de "tutela provisória"20, não se distanciando em nada; entretanto, em termos substanciais do processo cautelar do Código de Processo Civil ainda vigente ${ }^{21}$.

Nesse eco, seguem os demais textos normativos, especialmente os mais recentes, como o Código de Defesa

17 A respeito, consultar art. 17. BRASIL. Lei n. 13.105, de 16 março de 2015. Código de Processo Civil. Disponível em: <http:// www.planalto.gov.br/ccivil_03/_ato2015-2018/2015/lei/113105.htm>. Acesso em: 01 nov. 2015.

18 BRASIL Constituição (1988). Constituição da República Federativa do Brasil. Disponível em: <http://www.planalto.gov.br/ccivil_03/Constituicao/ConstituicaoCompilado.htm>. Acesso em: 01 nov. 2015.

19 BRASIL Constituição (1988). Constituição da República Federativa do Brasil. Disponível em: <http://www.planalto.gov.br/ccivil_03/Constituicao/ConstituicaoCompilado.htm>. Acesso em: 01 nov. 2015.

20 A respeito, ver art. 294, NCPC (Novo Código de Processo Civil). BRASIL. Lei n. 13.105, de 16 março de 2015. Código de Processo Civil. Disponível em: <http://www.planalto.gov.br/ccivil_03/_ato2015-2018/2015/lei/113105.htm>. Acesso em: 01 nov. 2015

21 A respeito, ver: art. 796 e seguintes do Código de Processo Civil. BRASIL. Lei n. 5.869, de 11 de janeiro de 1973. Institui o Código de Processo Civil. Disponível em: <http://www.planalto.gov.br/ccivil_03/leis/L5869.htm>. Acesso em: 01 nov. 2015. 
do Consumidor, o qual, apesar de enfatizar que a prevenção do dano ao consumidor é um direito ${ }^{22}$, assevera que a inauguração da pretensão conta-se a partir do conhecimento do dano e de sua autoria ${ }^{23}$. A Lei do Mandado de Segurança Individual e Coletivo, Lei no 12.016/2009, batiza o dano como violação, e, em seu art. $1^{\circ}$, notabiliza que seu propósito é a salvaguarda de direitos violados ou ameaçados de maneira hábil a gerar justo temor da parte ${ }^{24}$.

Igualmente, também se valida a Lei de Improbidade Administrativa, ao exigir da comissão processante em âmbito administrativo que procedimentos cautelares específicos como o sequestro sejam pedidos em Juízo em desfavor daquele que causou dano ${ }^{25}$.

Enfim, a "tutela precaucional”26 é reconhecida não só como direito, mas como metadireito pela CR/1988 e pelas leis a ela subordinadas, máxime da natureza tutelar difusa. Todavia, se precaver é um direito, a pretensão, como instrumento de garantia e efetividade dessa prerrogativa, não nasce da precaução, mas do seu corolário mais temível: o dano.

A jurisprudência pátria, em consenso com a doutrina, conceitua, incindenter tantum, o princípio universal da Actio Nata, essencial para a verificação da plenitude petitória das partes e da obrigatoriedade, em contrapartida, do Juízo em aprovisionar a questão meritória.

O nascimento da ação é sempre o enfoque inicial examinado pelo Poder Judiciário, a fim de desmembrar as "ações ajuizáveis ou plenas" das "ações vazias ou de pretensão ineficaz", com o propósito maior de decrescer o copioso volume de reclamações penetrantes na Justiça brasileira. Por essa razão, a Actio Nata está presente fertilmente em toda análise magistral preliminar, em todas as áreas da Ciência Jurídica e em qualquer matéria conflituosa da vida em sociedade. O esclarecimento do princípio, o qual, nas decisões magistrais, apresenta-se, majoritariamente, em forma de aposto, profere continuamente o pensamento de que a lesão ou a violação ou o conhecimento desses estreiam o direito de ação pleno ${ }^{27}$.

Não obstante, se a precaução e a prevenção ao dano, sobretudo alusivos aos direitos difusos, são, inegavelmente, parte do patrimônio jurídico da comunidade mundial e de cada cidadão isoladamente considerado para a factual proteção e preservação da Biota e evasão dos efeitos danosos que afligem e causam perene inquietude na população brasileira, somente o preenchimento da pretensão ou da Actio Nata com ambos os predicados refletiria a concreta aptidão para a provocação regular do Juízo e a decorrente tutela eficaz ex ante ao dano, ou ao perigo de dano, ou até mesmo ao risco prejudicial.

A mutação da Actio Nata ou da pretensão prescindem de reforma ou elaboração de demais textos normativos; faz-se capital, apenas, sua transformação hermenêutica, uma virada interpretativa pós-modernista,

22 A respeito, ver: art. 6, inciso VI do CDC (Código Defesa do Consumidor). BRASIL. Lei n. 8.078, de 11 de setembro de 1990. Disponível em: <http://www.planalto.gov.br/ccivil_03/leis/L8078compilado.htm>. Acesso em: 01 nov. 2015.

23 Conferir: art. 27 do CDC. BRASIL. Lei n. 8.078, de 11 de setembro de 1990. Dispõe sobre a proteção do consumidor e dá outras providências. Disponível em: <http://www.planalto.gov.br/ccivil_03/leis/L8078compilado.htm>. Acesso em: 01 nov. 2015.

24 A respeito, consultar: art. 1, BRASIL. Lei n. 12.016, de 07 de agosto de 2009. Disponível em: <http://www.planalto.gov.br/ ccivil_03/_ato2007-2010/2009/lei/112016.htm>. Acesso em: 01 nov. 2015.

25 A respeito, ver: art. 16, BRASIL. Lei n. 8.429, de 02 de junho de 1992. Disponível em: <http://www.planalto.gov.br/ccivil_03/ leis/L8429.htm>. Acesso em: 01 nov. 2015.

26 A respeito, ver: art. 225, incisos I, II, IV e V, CR/1988. BRASIL Constituição (1988). Constituição da República Federativa do Brasil. Disponível em: <http://www.planalto.gov.br/ccivil_03/Constituicao/ConstituicaoCompilado.htm>. Acesso em: 01 nov. 2015. 27 A respeito, consultar: BRASIL. Supremo Tribunal Federal. Agravo de Instrumento. AI 534006 AgR/MG. Primeira Turma. Relator(a): Min. Carlos Britto. Brasília, 29 de abril de 2008. Disponível em: < http://stf.jusbrasil.com.br/jurisprudencia/14721396/ agregno-agravo-de-instrumento-ai-534006-mg>. Acesso em: 01 nov. 2015.; BRASIL. Supremo Tribunal Federal. Agravo Regimental no Agravo de Instrumento. AI-AgR 580793 RJ. Primeira Turma. Relator(a): Sepúlveda Pertence Brasília, 21 de junho de 2007. Disponível em: <http://stf.jusbrasil.com.br/jurisprudencia/756642/agregno-agravo-de-instrumento-ai-agr-580793-rj>. Acesso em: 01 nov. 2015.; BRASIL. Superior Tribunal de Justiça. Agravo Regimental no Recurso Especial. AgRg no REsp 1324764/ PB. Quarta Turma. Relator: Ministro Luís Felipe Salomão. Brasília, 15 de outubro de 2015. Disponível em: <http://www.lexml. gov.br/urn/urn:lex:br:superior.tribunal.justica;turma.4:acordao;resp:2015-10-15;1324764-1477373>. Acesso em: 01 nov. 2015.; BRASIL. Superior Tribunal de Justiça. Recurso Especial. REsp 1372227 SE 2013/0061614-9. Relator(a): Ministra Marga Tessler. Brasília, 27 de maio de 2015. Disponível em: <http://stj.jusbrasil.com.br/jurisprudencia/195437665/recurso-especial-resp1372227-se-2013-0061614-9>. Acesso em: 01 nov. 2015. 
a qual exaltaria que as incertezas, indefinições, os limites do conhecimento científico e a flutuação vaga e imprecisa das evidências do pensamento elaborado são convicções bastantes para que a pretensão alcance um olhar pregresso, prenunciativo de sintomas sociais.

Poder-se-ia, nesse desiderato, obter um alastramento gravoso das pretensões temerárias e vulneráveis ao Poder Judiciário, assoberbando um ofício decisório que já se apresenta, nos dias atuais, por demais congestionado. No entanto, se esse atulhamento pode ser confiavelmente previsto pela sabedoria humana e forense, a reverência precaucional apregoa justamente o oposto: a inespecificidade e liquidez de garantias do que se espera e do que possa vir a ocorrer.

Assim, entre um corolário certo de conturbação e empilhamento processual, gerador de sequelas graves, mas aferíveis, e um resultado ambiental integralmente desconhecido, proveniente de uma tutela da violação e não do gerenciamento do risco, há que sopesar com muita detença e cautela.

O Estado da Ponderação (Abwägungstaat) é um eixo de escora muito útil para a elucidação de impasses que transcendem a mera releitura da pretensão ou da Actio Nata quanto aos direitos difusos e transindividuais, e tem sido uma premissa muito empregada, tanto na inovação da ordem jurídica quanto nas técnicas de integração e interpretação do direito já posto.

O Código de Processo Civil de 2015 consolida a natureza jurídica da figura do amicus curiae como modalidade de intervenção de terceiros ${ }^{28}$, dado que revela a busca pelo Poder Judiciário de maior legitimação e de formação de um palco de construção da decisão concernente ao caso concreto com a manifestação da sociedade civil organizada, a qual traz ao processo dados e percepções que o Juízo não possui apenas com a contribuição das normas, doutrina e jurisprudência.

Ademais, o "pensamento jurídico do possível” ou "teoria constitucional das alternativas"22, de Peter Häberle ${ }^{30}$ já foi, obter dictum, instrumento utilizado para a integração e interpretação do Direito, conjuntura que promove a percepção de que a Actio Nata pode ser matéria de debate sub judice pela sociedade em ações que versem sobre direitos coletivos e difusos; e, mesmo na carência de normas delimitadoras de seu conceito e de sua gênese, a aferição de sua estrutura e tomo, em cada demanda levada a Juízo, pode ser, segundo os seus parâmetros clássicos, ampliada ou conservada, em consonância com a aquilatação da magnitude e valor do objeto da demanda.

O pensamento jurídico do possível, juntamente ao poder ampliado de intervenção da sociedade civil nas demandas, inaugurado pelo Código de Processo Civil de 2015, Lei $\mathrm{n}^{\mathrm{o}}$ 13.105/2015, permite que o Princípio da Actio Nata seja revisto em concerto com o caso concreto, e não de maneira abstrata e anterior à propositura da ação de natureza difusa, fato que favorece tanto a protetividade precaucional ambiental quanto o resguardo da utilização temerária do Poder

28 A respeito, consultar: art. 138. BRASIL. Lei n. 13.105, de 16 março de 2015. Código de Processo Civil. Disponível em: <http:// www.planalto.gov.br/ccivil_03/_ato2015-2018/2015/lei/113105.htm>. Acesso em: 01 nov. 2015.

29 A respeito, ver: BRASIL. Supremo Tribunal Federal. Ação Direta de Inconstitucionalidade. ADI n. 1289 EI/DF. Tribunal Pleno. Relator: Ministro Gilmar Mendes. Brasília, 3 de abril de 2003. Disponível em: <http://redir.stf.jus.br/paginadorpub/paginador.jsp?docTP=AC\&docID=324427>. Acesso em: 01 mar. 2016.

30 HÄBERLE, Peter. Demokratische Verfassungstheorie im Lichte des Möglichkeitsdenken. In: DIE verfassung des pluralismus. Königstein, 1980. 
Judiciário por ações insipientes.

\section{Considerações finais}

O direito subjetivo de ação regularmente válido com fincas em probabilidades ou possibilidades remotas, ou mesmo em receios exacerbados não comprovados, impõe à Justiça um papel excepcionalmente ativista. Muito mais do que judicializar questões, o protagonismo judicial é a atividade criativa ultra lex do Juízo. Em outras palavras, é uma inovação disruptiva que incrementa e amplia o espectro ordenatório a dilemas anteriormente não aventados ou não enfrentados ou encarados de maneira tradicional.

Escancarar as portas do Poder Judiciário para a tutela precaucional lastreada em provas equívocas seria, para muitos, um retrocesso do ponto de vista procedimental e processual dos pedidos em Juízo, derrubando fases fulcrais do caminhar procedimental até a decisão final, as quais asseguram muitos outros direitos fundamentais, como a ampla defesa, o contraditório, a eficiência e o próprio devido processo legal.

O saneamento processual, a preclusão, o direito de regresso, a legitimidade e o interesse, o prequestionamento, a repercussão geral, enfim, institutos processuais vários, sofreriam o influxo da releitura da pretensão para um viés precaucional.

Por outro lado, ao Estado da Ponderação incumbe o munus de mensurar se o nascimento prematuro do direito de ação sob os alicerces da providência, vigilância e presciência, mesmo que inexatas, superaria e suplantaria os fundamentos já constituídos da Actio Nata e dos demais institutos que movimentam a máquina judicial.

Ademais, sabe-se que muitos estudos ambientais, talvez o mais conhecido deles seja o de 1972, Limites do crescimento, elaborado pelo Clube de Roma, traçam apenas dois cenários futuros para a humanidade: o primeiro, o esgotamento dos recursos do planeta pelo crescimento da população, industrialização, contaminação ambiental, consumerismo, produção de refugo; já o último, o alcance de estabilidade ecológica e econômica sustentáveis que propiciem uma total ruptura com os parâmetros político-econômicos dos dias atuais, especialmente os referentes às políticas públicas ${ }^{31}$.

Talvez uma grande esperança para o futuro da sobrevivência humana seja a judicialização primária das ocorrências sociais de instabilidade e de indefinição. O primeiro passo seria a releitura da Actio Nata em consenso com a manifestação e inteligência sociais.

\section{REFERÊNCIAS BIBLIOGRÁFICAS}

ALEXY, Robert. Teoria dos direitos fundamentais. 2. ed. São Paulo: Malheiros, 2011.

BACKES, Ana Luiza; AZEVEDO Débora Bithiah de; ARAÚJO, José Cordeiro de (Org.). Audiências públicas na assembleia nacional constituinte: a sociedade na Tribuna. Brasília: Câmara dos Deputados, 2009.

BRASIL Constituição (1988). Constituição da República Federativa do Brasil. Disponível em: < http://www.planalto.gov.br/ccivil_03/Constituicao/ConstituicaoCompilado.htm>. Acesso em: 01 nov. 2015.

BRASIL. Decreto n. 1.306, de 09 de novembro de 1994. Disponível em: < http:/ /www.planalto.gov.br/ccivil_03/ decreto/1990-1994/D1306.htm>. Acesso em: 01 nov. 2015.

BRASIL. Lei n. 12.016, de 07 de agosto de 2009. Disponível em: <http://www.planalto.gov.br/ccivil_03/_

31 Consultar: MEADOWS, Dennis L.; MEADOWS Daniela; RANDERS, Jorgen. Limites do crescimento. Rio de Janeiro: Qualitymark, 2007. 
ato2007-2010/2009/lei/112016.htm>. Acesso em: 01 nov. 2015.

BRASIL. Lei n. 13.105, de 16 março de 2015. Código de Processo Civil. Disponível em: <http://www.planalto.gov.br/ccivil_03/_ato2015-2018/2015/lei/113105.htm>. Acesso em: 01 nov. 2015.

BRASIL. Lei n. 13.129, de 26 de maio de 2015. Disponível em: <http://www.planalto.gov.br/ccivil_03/_ Ato2015-2018/2015/Lei/L13129.htm>. Acesso em: 01 nov. 2015.

BRASIL. Lei n. 5.869, de 11 de janeiro de 1973. Institui o Código de Processo Civil. Disponível em: <http:// www.planalto.gov.br/ccivil_03/leis/L5869.htm>. Acesso em: 01 nov. 2015.

BRASIL. Lei n. 7.347, de 24 de julho de 1985. Disciplina a ação civil pública de responsabilidade por danos causados ao meio-ambiente, ao consumidor, a bens e direitos de valor artístico, estético, histórico, turístico e paisagístico e dá outras providências. Disponível em: < http://www.planalto.gov.br/ccivil_03/leis/L7347orig.htm>. Acesso em: 01 nov. 2015.

BRASIL. Lei n. 8.078, de 11 de setembro de 1990. Disponível em: <http://www.planalto.gov.br/ccivil_03/leis/ 18078.htm>. Acesso em: 01 nov. 2015.

BRASIL. Lei n. 8.429, de 02 de junho de 1992. Disponível em: <http://www.planalto.gov.br/ccivil_03/leis/ L8429.htm>. Acesso em: 01 nov. 2015.

BRASIL. Superior Tribunal de Justiça. Agravo Regimental no Recurso Especial. AgRg no REsp 1412664 SP 2011/0305364-9. Quarta Turma. Relator: Ministro Raul Araújo. Brasília, 11 de fevereiro de 2014. Disponível em: <http://www.stj.jus.br>. Acesso em: 01 nov. 2015.

BRASIL. Superior Tribunal de Justiça. Agravo Regimental no Recurso Especial. AgRg no REsp 1324764/ PB. Quarta Turma. Relator: Ministro Luís Felipe Salomão. Brasilia, 15 de outubro de 2015. Disponível em: <http://www.lexml.gov.br/urn/urn:lex:br:superior.tribunal.justica;turma.4:acordao;re sp:2015-10-15;1324764-1477373>. Acesso em: 01 nov. 2015.

BRASIL. Superior Tribunal de Justiça. Recurso Especial. REsp 1372227 SE 2013/0061614-9. Relator: Ministra Marga Tessler. Brasilia, 27 de maio de 2015. Disponível em: <http://stj.jusbrasil.com.br/jurisprudencia/195437665/recurso-especial-resp-1372227-se-2013-0061614-9>. Acesso em: 01 nov. 2015.

BRASIL. Supremo Tribunal Federal. Ação Direta de Inconstitucionalidade. ADI n. 1289 EI/DF. Tribunal Pleno. Relator: Ministro Gilmar Mendes. Brasília, 3 de abril de 2003. Disponível em: < http://redir.stf.jus. br/paginadorpub/paginador.jsp?docTP=AC\&docID=324427>. Acesso em: 01 mar. 2016.

BRASIL. Supremo Tribunal Federal. Agravo de Instrumento. AI n. 534006 AgR/MG. Primeira Turma. Relator(a): Min. Carlos Britto. Brasília, 29 de abril de 2008. Disponível em: <http://stf.jusbrasil.com.br/ jurisprudencia/14721396/agregno-agravo-de-instrumento-ai-534006-mg>. Acesso em: 01 nov. 2015.

BRASIL. Supremo Tribunal Federal. Agravo Regimental no Agravo de Instrumento. AI-AgR 580793 RJ. Primeira Turma. Relator(a): Sepúlveda Pertence Brasília, 21 de junho de 2007. Disponível em: <http://stf. jusbrasil.com.br/jurisprudencia/756642/agregno-agravo-de-instrumento-ai-agr-580793-rj>. Acesso em: 01 nov. 2015.

COSTA, Beatriz Souza; RIBEIRO, Luiz Gustavo Gonçalves. Ballast water and bioinvasion: brazilian legislation and the protection of marine environmental risks. Revista Veredas do Direito, Belo Horizonte, v. 13, n. 25, p. 45-67, jan./abr. 2016. Disponível em: <http://www.domhelder.edu.br/revista/index.php/veredas/ article/view/644/475>. Acesso em: 22 ago. 2016.

DINAMARCO, Cândido Rangel. Instituições de direito processual civil. São Paulo: Malheiros, 2004. v.1.

DONIZETTI Elpídio; QUINTELLA, Felipe. Curso didático de direito civil. 2. ed. São Paulo: Atlas, 2013.

GUEDES, Jefferson Carús. Direito processual de grupos sociais atual: entre o ativismo judicial e o garanti- 
smo processual. Revista Brasileira de Políticas Públicas, Brasília, v. 6, n. 1, p. 124-149, jan./jun. 2016. Disponível em: <http://www.publicacoesacademicas.uniceub.br/index.php/RBPP/article/view/2988/pdf>. Acesso em: 21 ago. 2016.

HÄBERLE, Peter. Demokratische Verfassungstheorie im Lichte des Möglichkeitsdenken. In: DIE verfassung des pluralismus. Königstein, 1980.

HINTEREGGER, Monika. Environmental liability and ecological damage in European law. Cambridge, NY: Cambridge University Press, 2008.

MEADOWS, Dennis L.; MEADOWS Daniela; RANDERS, Jorgen. Limites do crescimento. Rio de Janeiro: Qualitymark, 2007.

RIBEIRO, Luiz Gustavo; BASTIANETTO, Lorena Machado Rogedo. Direito penal ambiental como tutela de sustentação à atuação administrativa e civil nos Estados Unidos da América e no Japão. Revista Brasileira de Políticas Públicas, Brasília, v. 6, n. 1, p. 213-228, jan./jun. 2016. Disponível em: <http:/ /www.publicacoesacademicas.uniceub.br/index.php/RBPP/article/view/2988/pdf>. Acesso em: 17 ago. 2016.

SINGSON-LEDESMA, Maitet. Rio+20: ¿una Victoria pírrica para los derechos humanos y el desarrollo? In: GUTIÉRREZ, Aitana Uria (Coord.). De la economía verde a las sociedades verdes: reflexiones para el futuro que queremos. Madrid: Catarata, 2013. p. 67-82.

STRAPASSON, Karoline; PAMPLONA, Danielle Anne. A escolha pública econômica para erradicar a pobreza extrema no Brasil. Revista Brasileira de Políticas Públicas, Brasília, v. 4, n. 2, p. 47-63, jul./dez. 2014. Disponível em: <http://www.publicacoesacademicas.uniceub.br/index.php/RBPP/article/view/2988/pdf>. Acesso em: 07 jul. 2016.

SUÍÇA. Relatório Brundtland: our common future. 1987. Disponível em: <http://www.un-documents.net/ our-common-future.pdf>. Available in: 01 nov. 2015.

UNITED NATIONS. The future we want: outcome document of the united nations conference on sustainable development. 2012. Available in: <https://sustainabledevelopment.un.org/content/ documents/733FutureWeWant.pdf>. Access: 01 nov. 2015. 


\section{REVISTA BRASILEIRA DE POLÍTICAS PÚBLICAS BRAZILIAN JOURNAL OF PUBLIC POLICY}
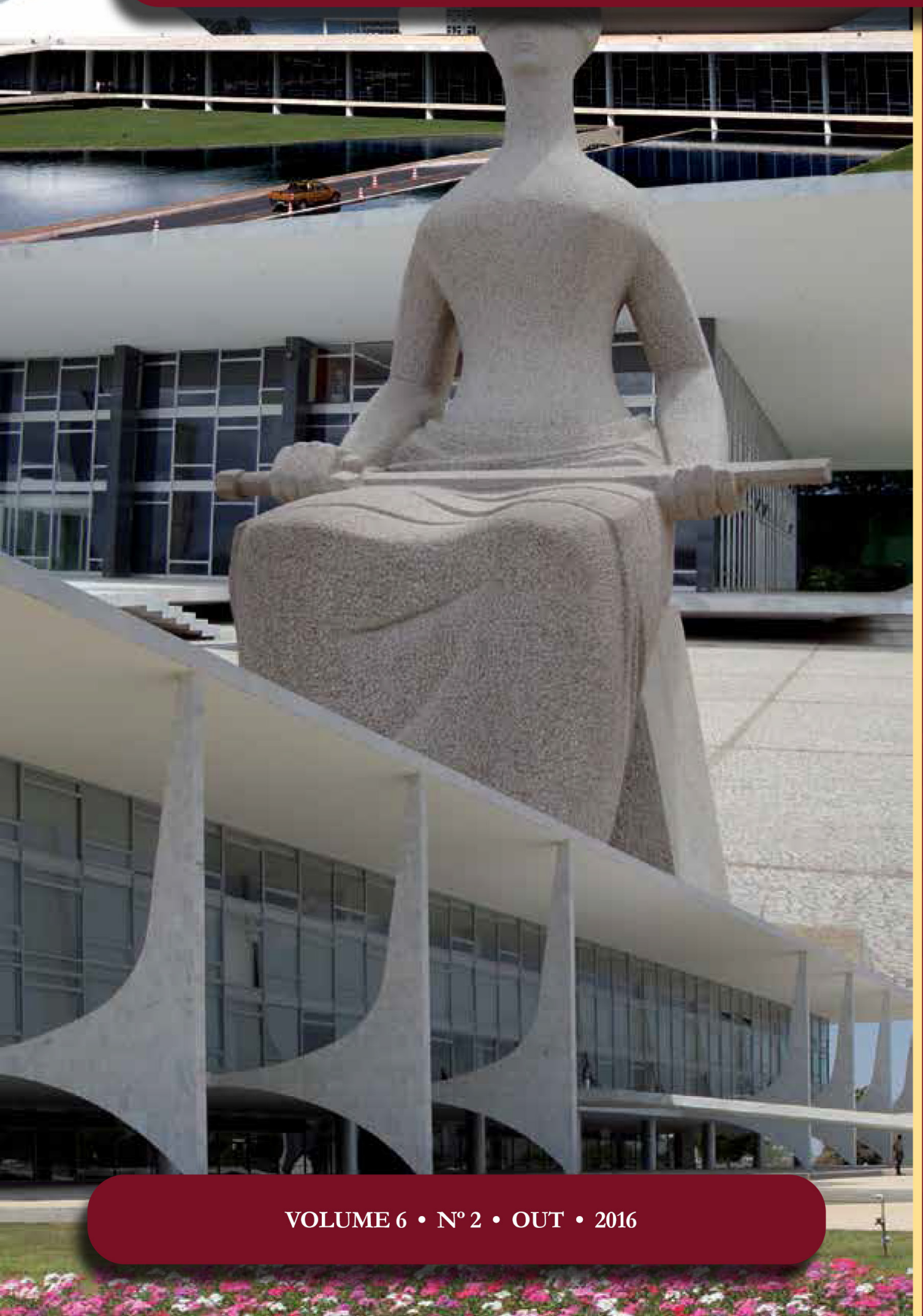

A defensoria pública como garantia constitucional processual de acesso à justiça na América do Sul

The public legal defense as a constitutional and procedural guarantee on the access to justice in South America

Antonio Henrique Graciano Suxberger Alberto Carvalho Amaral 


\section{A defensoria pública como garantia constitucional processual de acesso à justiça na América do Sul*}

\section{The public legal defense as a constitutional and procedural guarantee on the access to justice in South America}

\section{Resumo}

O artigo analisa a Defensoria Pública e sua conformação como garantia constitucional processual voltada para concretizar o acesso à Justiça. $\mathrm{O}$ estudo enquadra-se nos campos do Direito e das Políticas Públicas. Serão apreciadas a constitucionalização das garantias processuais, no contexto latino-americano, a sistemática do acesso à Justiça, com os modelos de concretização de acesso à justiça, e o delineamento institucional da Defensoria Pública na América do Sul. O objetivo consiste em demonstrar a importância da instituição como garantia constitucionalmente positivada de acesso à Justiça, especialmente no âmbito da América do Sul. Foi utilizado o método hipotético-dedutivo, em pesquisa do tipo qualitativa, explicativa, bibliográfica e documental, especialmente das Constituições sul-americanas e de outros textos normativos que preveem organização de finalidade idêntica ou assemelhada. A pesquisa constata forte influência do modelo brasileiro de Defensoria Pública em outros países da América do Sul, inclusive com a atribuição por alguns deles de status constitucional a essa garantia institucional.

Palavras-chave: Constitucionalização de garantias processuais. Acesso à Justiça. Contexto sul-americano. Defensoria Pública.

\section{Abstract}

The purpose of this paper is to evaluate the Public Legal Defense as a constitutional and procedural guarantee stated to enforce the access to justice. From an approach according to the Law and the Public Policies, the paper assays the consideration of procedural guarantees in Constitutions, especially in the Latin American context. It pursues to demonstrate the importance of the Public Legal Defense in Brazil as a constitutional guarantee statued to enforce the access to justice, especially in South America. Methodologically, the paper explores the hypothetical-deductive method, in a qualitative research, and explanatory literature and documents, especially the Constitutions from South America's countries and other normative acts involving similar organizations or resembling services. As a result, the paper

\footnotetext{
*** Mestre em Direito e Políticas Públicas pelo Centro Universitário de Brasília (2016). Especialista em Direito Processual pela Universidade do Sul de Santa Catarina (2008). Especialista em Ciências Penais pela Universidade do Sul de Santa Catarina (2007). Graduado em direito pelo Centro Universitário de Brasília (2005). Defensor Público do Distrito Federal. E-mail:prof.albertoamaral@gmail.com.

** Mestre e Doutor em Direito. Professor do ito do UniCEUB. E-mail: antonio.suxberger@ uniceub.br.
}

Recebido em 07/06/2016

Aprovado em 26/07/2016 
establishes a strong influence of the Public Legal Defense model adopted in Brazil towards other countries of South America, some of them including it as a constitutional guarantee stated to ensure equality and to enforce the access to justice.

Keywords: Procedural guarantees in Constitution. South America Context. Access to Justice. Public Legal Defense.

\section{INTRODUÇão}

O design constitucional adotado para a prestação de assistência jurídica aos necessitados, no Brasil, mostrou-se arrojado e guardou certo grau de ineditismo à época da edição da Constituição de 1988. A conformação constitucional do direito de assistência jurídica a ser prestada pelo Estado aos necessitados representou para parcela significativa da população um início de diálogo a respeito de acesso à Justiça.

O que poderia ser, à primeira vista, apenas, a previsão de novos papéis e funções jurídicas a um novo órgão, que ganhou visibilidade com sua inserção no texto constitucional, reflete muito mais que isso. $\mathrm{O}$ arranjo institucional positivado na Carta Maior é sinal característico de uma preocupação, presente em grande parte dos ordenamentos jurídicos, voltada a assegurar, no âmbito constitucional, princípios e garantias processuais. Não é de se estranhar, portanto, que, na Constituição sobrevinda após o término de período de exceção, fosse ela dotada de diversos mecanismos de proteção e salvaguarda dos hipossuficientes em face dos detentores de poder.

O fenômeno das garantias constitucionais processuais, que na Europa sobrevém especialmente após o término da Segunda Guerra Mundial, alastrou-se para outros países da América Latina e, nesse contexto, ganha relevância a previsão de conformação organizacional similar à brasileira, voltada para assegurar acesso à Justiça para os carentes e economicamente frágeis. Da mesma forma, é relevante que se verifique, a partir do início do século XX, mais precipuamente nos anos após 1950, significativa movimentação internacional no sentido de prever instrumentos para assegurar o acesso à Justiça, considerado questão relevante e fundamental para a concretização dos direitos enunciados e proclamados em diversos textos legais. O Pacto Internacional, sobre Direitos Civis e Políticos, de 1966, expressamente menciona em diversas passagens a preocupação de instrumentalizar meios para o acesso à Justiça por todos e, aos que reclamam intervenção material para tanto, aos hipossuficientes em especial.

Nesse contexto, a Defensoria Pública, no Brasil, e órgãos similares em outros países, auspiciam novas discussões, pois são instrumentos imprescindíveis para o aceso à Justiça e para a diminuição das dificuldades de considerável parcela populacional, que, apesar de sobreviver, não tem meios para proteger seus direitos e, em realidade, sequer tem conhecimento dos direitos que possui. A Constituição da República de 1988 inovou ao prever a Defensoria como órgão de Estado, com estatura semelhante ao Ministério Público e essencial à função jurisdicional, no que foi acompanhada por diversas cartas na América Latina. Alterações constitucionais posteriores reafirmaram a importância do órgão no Brasil e enfatizaram sua autonomia, prestigiando, sobremaneira, os direitos dos necessitados e grupos vulneráveis.

Busca-se, neste trabalho, analisar a concepção de Defensorias Públicas na América Latina, no contexto de progressiva inserção de garantias constitucionais processuais, como medida de assegurar, minimamente, o direito de os cidadãos acessarem o Poder Judiciário e, assim, disporem de instrumentos jurídicos aptos à promoção de seus direitos. O problema volta-se a verificar se, no contexto de constitucionalização de garantias processuais, a previsão nos textos constitucionais de países da América do Sul da Defensoria Pública com seu respectivo desenho organizacional revela-se como tendência decorrente da maior preocupação com o acesso ao Judiciário.

O fenômeno da constitucionalização das garantias fundamentais e suas notas primordiais será abordado no 
desenvolvimento do artigo. Em seguida, será apreciado o princípio do acesso à Justiça, como pleito presente e indelegável da processualística moderna, que ganha ares de essencialidade a partir da metade do século XX. A Defensoria Pública será apresentada como garantia constitucional processual, imprescindível para assegurar o acesso à Justiça, a qual foi paulatinamente prevista nos ordenamentos de outros países da América do Sul. Após esse caminho, acredita-se ser possível realizar o desenho do desenvolvimento da instituição da Defensoria Pública no âmbito da América do Sul, como garantia das garantias, imprescindível para promover e assegurar o acesso à Justiça, propiciando meios, formais e materiais, de concretizar a igualdade especialmente aos mais carentes.

\title{
2. Desenvolvimento
}

\subsection{A constitucionalização das garantias fundamentais: o contexto latino-americano}

\begin{abstract}
"Os juízes precisam, agora, reconhecer que as técnicas processuais servem a questões sociais, que as cortes não são a única forma de solução de conflitos a ser considerada e que qualquer regulamentação processual, inclusive a criação ou o encorajamento de alternativas ao sistema judiciário formal tem um efeito importante sobre a forma como opera a lei substantiva — com que frequência ela é executada, em beneficio de quem e com que impacto social. Uma tarefa básica dos processualistas modernos é expor o impacto substantivo dos vários mecanismos de processamento de litígios."
\end{abstract}

Decorrente dos aspectos usualmente correlacionados ao ativismo judicial, como nova opção política de enfrentamento das dificuldades de implementação de decisões pelo Poder Judiciárioº a constitucionalização das garantias processuais emerge e suscita diversas questões, teóricas e práticas, sobre fundamentos e limites dessa nova opção teórica.

Uma das características primordiais da previsão de garantias processuais no arcabouço de normas constitucionais é a intercorrelação estrita com o Direito Constitucional. A norma processual, como instrumento para alcance e proteção de direitos, não pode ser entendida como mero conjunto de procedimentos, mas sim como concretizadora de direitos. Todos os instrumentos processuais devem perseguir, como fim último e primordial, assegurar o bem da vida pretendido pelas partes.

A Constituição, como carta que positiva e prevê instrumentos de garantia aos direitos básicos dos cidadãos, deve imiscuir-se nessa matéria e assegurar que os postulados processuais básicos sejam respeitados pelos poderes públicos, conformando a atividade do Poder Legislativo à exigência democrática dos destinos processuais. Dessa feita, "la tutela del proceso se realiza por imperio de las previsiones constitucionales", sendo esses dispositivos constitucionais verdadeiras garantias de garantias.

Essa visão decorre da análise das Constituições democráticas do século vinte, as quais, em regra, teriam conjugado, juntamente aos direitos e garantias das pessoas, uma série de princípios de Direito Processual ${ }^{4}$, inaugurando, para determinada parcela da doutrina, o que se convencionou chamar por tutela jurídico-constitucional das liberdades. ${ }^{5}$ Essa forma de promoção das liberdades pelo Direito, em primeiro momento,

1 CAPPELletTi, Mauro; GARTH, Bryant. Acesso à justiça. Porto Alegre: Fabris, 1988. p. 5.

2 O neoconstitucionalismo poderia ser constatado, como aponta Miguel Carbonell, pela presença de três níveis de análise, quais sejam, (a) textos constitucionais, a partir dos anos 70 do século XX, que, além da tripartição de poderes e competência, tratam da atuação do Estado por seus fins e objetivos, descrevendo um rol de direitos fundamentais; (b) jurisprudência "intrometida e invasora", que adentra na vida social e consagra processos democráticos pela efetividade de dispositivos constitucionais; (c) desenvolvimento teórico inovador, que criam o fenômeno jurídico a partir da análise dos textos constitucionais, além de sua mera descrição CARBONELL, Miguel. El neoconstitucionalismo: significado y niveles de análises. In: CARBONELL, Miguel; JARAMILLO, Leonardo García. El canon neoconstitucional. Madrid: UNAM/Trotta, 2010. p. 153-164.

3 COUTURE, Eduardo J. Fundamentos del derecho procesal civil. Buenos Aires: Depalma, 1976. p. 148.

4 COUTURE, Eduardo J. Fundamentos del derecho procesal civil. Buenos Aires: Depalma, 1976. p. 151.

5 COUTURE, Eduardo J. Fundamentos del derecho procesal civil. Buenos Aires: Depalma, 1976. p. 153. 
orienta e limita a atuação do legislativo, que deverá seguir tais preceitos para a conformação dos instrumentos processuais. ${ }^{6}$

Como aponta Picó I Junoy ${ }^{7}$, após a Segunda Guerra Mundial, verifica-se, especialmente nos países que experimentaram regimes totalitários na primeira metade do século vinte, a constitucionalização dos direitos fundamentais das pessoas, aliada à previsão de tutela das garantias processuais mínimas.

Ultrapassando o marco teórico do positivismo, que, "por um lado, contribuiu para a sistematização do Direito, por outro, ao considerar a lei como fonte exclusiva do fenômeno jurídico, ignorou a complexidade ínsita no próprio 'mundo jurídico', isolando-o do fato e do juízo valorativo"s, houve uma nova adequação da atividade dos juízes, como intérpretes da norma, com decisão de vontade própria ou quando atuam para suprimir a celeuma legislativa, na integração do Direito?.

Tais previsões se configuraram em reviravoltas na hermenêutica e na produção do Direito em geral, pois, de acordo com os postulados do Estado Liberal, até então vigentes, não poderiam os juízes "criar" novos direitos. Atuariam eles limitados de modo estrito, isto é, sujeitos à dicção da lei e, por isso, impedidos de agirem para obrigar a implementação de políticas públicas ${ }^{10}$, tema tão caro na atualidade, pelas rígidas previsões do checks and balances. Acrescido a esse novo posicionamento institucional de parcela da judicatura, verifica-se que as Constituições dos países de civil law, além de possuírem previsões abstratas da interação entre os órgãos públicos, e entre estes e os cidadãos, passaram a prever direitos inerentes às pessoas, que deveriam ser conformados pelos juízes nos casos concretos. ${ }^{11}$ Essa nova conformação do modo pelo qual se assegura a concretização de direitos ganhou impulso, posteriormente, com a utilização dos direitos fundamentais como fonte para legitimação do discurso. ${ }^{12}$

Nesse contexto, a Constituição assume a função de definir as linhas processuais primordiais, com a estipulação da estrutura essencial dos órgãos jurisdicionais e alguns de seus postulados principiológicos básicos ${ }^{13}$ assegurando uma menor ingerência do poder constituído e assegurando, com maior certeza, que os ganhos democráticos e políticos possam alcançar certa consolidação com o transcurso temporal. ${ }^{14} \mathrm{O}$ dirigismo constitucional, já que as normas constitucionais são premissas materiais fundantes das políticas públicas assumidas por determinados Estados ${ }^{15}$, irradia seus efeitos sobre as normas constitucionais processuais, especialmente considerando que a finalidade última do fenômeno da constitucionalização dessas garantias é, justamente, uma pretensão de alcançar Justiça. ${ }^{16}$

6 "Se pretendia con ello evitar que el futuro legislador desconociese o violase tales derechos, protegiéndolos, en todo caso, mediante un sistema reforzado de reforma constitucional." PICÓ I JUNOY, Joan. Las garantías constitucionales del proceso. Barcelona: J. M. Bosch, 1997, p. 17.

7 PICÓ I JUNOY, Joan. Las garantías constitucionales del proceso. Barcelona: J. M. Bosch, 1997, p. 17.

8 PORTO, Gilberto Porto; USTÁRROZ, Daniel. Lições de direitos fundamentais no processo civil: conteúdo processual da Constituição Federal. Porto Alegre: Livraria do Advogado, 2009, p. 17.

9 PORTO, Gilberto Porto; USTÁRROZ, Daniel. Lições de direitos fundamentais no processo civil: conteúdo processual da Constituição Federal. Porto Alegre: Livraria do Advogado, 2009, p. 17.

10 CAMBI, Eduardo. Neoconstitucionalismo e neoprocessualismo: direitos fundamentais, políticas públicas e protagonismo judiciário. São Paulo: Revista dos Tribunais, 2009.

11 PORTO, Gilberto Porto; USTÁRROZ, Daniel. Lições de direitos fundamentais no processo civil: conteúdo processual da Constituição Federal. Porto Alegre: Livraria do Advogado, 2009, p. 18.

12 PORTO, Gilberto Porto; USTÁRROZ, Daniel. Lições de direitos fundamentais no processo civil: conteúdo processual da Constituição Federal. Porto Alegre: Livraria do Advogado, 2009, p. 23.

13 GRINOVER, Ada Pellegrini. Os princípios constitucionais e o código de processo civil. São Paulo: José Bushatski, 1975. p. 4-5.

14 Para Nelson Nery Jr., como ordem jurídica fundamental da coletividade, a Constituição deve realizar a integração - unificando o Estado e pacificando o conflito dos grupos que o formam -, a organiz̧ação dos órgãos estatais e competências, e a direção jurídica, dotando os direitos fundamentais de força vinculante para o ordenamento jurídico, o qual se pressupõe moralmente reto, legítimo e auferido historicamente. NERY JUNIOR, Nelson. Princípios do processo civil na Constituição Federal. 9. ed. São Paulo: Revista dos Tribunais, 2009. p. 38.

15 NERY JUNIOR, Nelson. Princípios do processo civil na Constituição Federal. 9. ed. São Paulo: Revista dos Tribunais, 2009 . p. 39.

16 "La finalidad última dei fenómeno de constitucionalización de Ias garantias procesales no es otro que lograr Ia tan pretendida Justici.” PICÓ I JUNOY, Joan. Las garantías constitucionales del proceso. Barcelona: J. M. Bosch, 1997. p. 21. 
O processo, como instrumento, é essencial à democracia e deve ser protegido com o instrumento jurídico mais notável no ordenamento, no caso, a própria Constituição, porque, presume-se, a partir das previsões constitucionais asseguradoras de direitos e da atuação incisiva do Poder Judiciário é possível fazer cessar ilegalidades e assegurar direitos fundamentais básicos. Não há espaços, doravante, para ritualísticas desnecessárias ou procedimentos que olvidem o relevante papel do aparato processual na busca dos fins de Justiça e harmonização das relações. As garantias constitucionais processuais, dessa feita,

Não servem apenas aos interesses das partes, [...] mas configuram, antes de mais nada, a salvaguarda do próprio processo, objetivamente considerado, como fator legitimante do exercício da jurisdição. ${ }^{17}$

A constitucionalização das garantais processuais alcançou os países latino-americanos em geral, especialmente aqueles da América do Sul, que sofreram - ou sofrem - com governos autoritários e que fazem tábula rasa dos dispositivos constitucionais e das deliberações populares. Como anota Fix-Zamudio, ${ }^{18}$ na América Latina da década de 1970, embora numerosas leis fundamentais tenham se inspirado na Constituição Norte Americana de 1787, a maior preocupação com garantias constitucionais processuais ocorre recentemente à época que escreve o mencionado texto. ${ }^{19}$ Atualmente, a análise comparativa das Constituições demonstra a existência de significativo avanço nas matérias processuais que, no texto constitucional, alcançaram a relevância de garantias constitucionais.

Da análise comparativa, podemos verificar que diversos preceitos processuais foram erigidos à natureza de garantias constitucionais em Constituições da América Latina, como, por exemplo, (a) a independência do Judiciário: Argentina (art. 114), Bolívia (art. 12 e 178), Chile (art. 73), Colômbia (art. 228), Equador (art. 168), México (art. 17), Paraguai (art. 248), Peru (art. 139, 2) e Venezuela (art. 254); (b) direito a recorrer: Argentina (art. 117), Bolívia (art. 180), Chile (art. 19, “e”, e art. 20), Colômbia (art. 31), Equador (art. 76, 7; 86, 3, 437, 1 e 2), México (art. 104), Peru (art. 141), Venezuela (art. 49); (c) vedação da prova ilícita: Argentina (art. 18), Equador (art. 76), Peru (art. 24), Venezuela (art. 49, 1 e 5); (d) julgamento justo: Bolívia (art. 120, 178, I, e 180, I), Colômbia (art. 29), Equador (art. 75 e 76, 7, k), México (art. 17 e 20, A, IV e VI); Paraguai (art. 16), Peru (art. 139, 14), Venezuela (art. 49, 3 e 4); (e) julgamento público: Bolívia (art. 178 e 180), Colômbia (art. 29), Equador (art. 76, 7, “d”), México (art. 20, II e IV), Paraguai (art. 17, 2), Peru (art. 139, 4); (f) julgamento célere: Bolívia (art. 178 e 180), Colômbia (art. 29), Cuba (art. 63), Equador (art. 75 e 169), México (art. 17), Venezuela (art. 49, 3); (g) devido processo legal: Argentina (art. 18), Bolívia (arts. 115, II, 117, I, 137 e 180), Chile (art. 19, \3.), Colômbia (art. 29), Equador (arts. 11, 76 e 169), Peru (art. 139, 3) e Venezuela (art. 49, 1).

Todos esses princípios têm previsão na Constituição brasileira de 1988 e a análise pormenorizada de cada um deles indica certa liquidez entre os conceitos adotados no Brasil e nas outras nações mencionadas. Essa noção será importante para que, fixada a ocorrência de constitucionalização de regras processuais, seja analisado o acesso à Justiça, como "o ponto central da moderna processualística" 20 e, em seguida, a disciplina dada à Defensoria Pública, como órgão e garantia constitucional processual, no Brasil e em outros países da América do Sul.

\subsection{A Defensoria Pública como órgão instrumentalizador da garantia constitucional processual de acesso à justiça}

O acesso à Justiça é, certamente, uma das garantias mais relevantes dos ordenamentos jurídicos modernos. Não seria suficiente previsão abstrata de um número indeterminado de direitos sem que, concretamente, seja possível acessar e utilizar tais direitos.

17 CINTRA, Antonio Carlos de Araújo; GRINOVER, Ada Pellegrini; DINAMARCO, Cândido Rangel. Teoria geral do processo. 20. ed. São Paulo: Malheiros, 2004. p. 82.

18 FIX-ZAMUDIO, Héctor. Constitución y proceso civil en Latinoamérica. Ciudad de México: UNAM, 1974. p. 10.

19 FIX-ZAMUDIO, Héctor. Constitución y proceso civil en Latinoamérica. Ciudad de México: UNAM, 1974. p. 10.

20 CAPPELlETTI, Mauro; GARTH, Bryant. Acesso à justiça. Porto Alegre: Fabris, 1988. p. 5. 
Para fins conceituais, pode-se afirmar que o acesso à Justiça se volta para duas finalidades primordiais do sistema jurídico, quais sejam, a reivindicação de direitos e/ou resolução de conflitos sob a tutela Estatal deve ser acessível a todos e, de outro lado, a produção de resultados deve ser individual e socialmente justos ${ }^{21}$. Jesús González Pérez ${ }^{22}$, por sua vez, define o "derecho a la tutela jurisdiccional” como o

Derecho de toda persona a que se le 'haga justicia', a que cuando pretenda algo de la outra, esta pretensión sea atendida por un órgano jurisdiccional, a través de um proceso con unas garantías mínimas.

A partir do momento em que o mero formalismo foi ultrapassado, a questão material relacionada ao acesso à Justiça ganhou contrastes fortes, já que era necessário concretizar direitos textualmente expressos. Meras ritualísticas e procedimentos inúteis eram desnecessários, quando ilegalidades estavam presentes e não justificam sua manutenção por auspícios meramente formais, desalojados da norma material que deveria estar subjacente.

Tecendo breves considerações históricas, Cappelletti e Garth ${ }^{23}$ apontam que, nos estados liberais burgueses, dos séculos XVIII e XIX, compartilhava-se uma visão individualista e formal, no sentido de garantir o acesso, apenas, pela propositura de ação ou contestação, sem preocupações com a pobreza e com políticas públicas para erradicá-la ou diminuir seus efeitos. Nos estados modernos, porém, há uma mudança temática sensível.

Com o reconhecimento dos direitos e deveres sociais nas Constituições, anota-se, como dever estatal, a diminuição da miséria e pobreza. A atuação do Estado seria, portanto, imprescindível para assegurar a eficácia dos direitos sociais, ${ }^{24}$ justamente porque o acesso à Justiça seria "requisito fundamental - o mais básico dos direitos humanos - de um sistema jurídico moderno e igualitário que pretenda garantir, e não apenas proclamar os direitos de todos". ${ }^{25}$ Com o objetivo de diminuir as dificuldades para acesso à Justiça, verificam-se movimentos prematuros, inicialmente na Alemanha (1919-1923), com a previsão de advogados pagos pelo Estado para que fornecessem assistência judiciária a todos que pleiteassem, e na Inglaterra (1949), com o Legal Aid and Advice Scherne, que previa a compensação de advogados pelo aconselhamento jurídico e pela assistência judiciária. ${ }^{26}$

Essa temática, porém, ganha força doze anos após, quando começam a surgir diversas normativas tratando do assunto, entendendo-o como a grande questão processual para a diminuição das desigualdades e buscando, efetivamente, propiciar meios de acesso à Justiça para aqueles que não tem condições, ${ }^{27}$ de onde sobrevém dois sistemas de enfrentamento.

De um lado, pelo sistema do judicare, a assistência judiciária seria um direito de todas as pessoas que se enquadrassem nos conceitos legais, relativos à baixa renda, e existia a previsão de advogados particulares serem pagos pelo Estado, os quais constariam numa lista, predeterminada, e a parte beneficiária, caso provasse a sua necessidade, poderia escolher livremente qual advogado iria patrocinar sua ação. Esse sistema foi

21 CAPPELlETTT, Mauro; GARTH, Bryant. Acesso à justiça. Porto Alegre: Fabris, 1988. p. 3.

22 FAVELA, José Ovalle. Garantias constitucionales del processo. 3. ed. México: Oxford, 2007. p. 224.

23 CAPPELLETTI, Mauro; GARTH, Bryant. Acesso à justiça. Porto Alegre: Fabris, 1988. p. 4.

24 CAPPELLETTI, Mauro; GARTH, Bryant. Acesso à justiça. Porto Alegre: Fabris, 1988. p. 4.

25 CAPPELLETTI, Mauro; GARTH, Bryant. Acesso à justiça. Porto Alegre: Fabris, 1988. p. 4.

26 CAPPELLETTT, Mauro; GARTH, Bryant. Acesso à justiça. Porto Alegre: Fabris, 1988. p. 12-13.

27 CAPPELLETTI, Mauro; GARTH, Bryant. Acesso à justiça. Porto Alegre: Fabris, 1988. p. 13. Indicam, em resumo, as principais alterações normativas, a seguir compiladas: EUA (1965- Office of economic opportunity [OEO]), que propalou para o mundo a partir de 1970: França (janeiro de 1972 - substituiu o serviço gratuito dos advogados por um modelo no qual o custo dos honorários é suportado pelo Estado), Suécia (maio de 1972 - novo e inovador programa), Inglaterra (julho de 1972 - Lei de aconselhamento e Assistência Judiciária aumentou o alcance do sistema) e Canadá/Quebec (julho de 1972 - primeiro programa de assistência judiciária financiada pelo governo), Alemanha (outubro de 1972 - aperfeiçoou o sistema, aumentou a remuneração paga aos advogados), EUA (julho de 1974 - Legal services Corporation - preservar e ampliar os progressos do OEO), Áustria e Holanda (reviveram programas de assistência judiciária, com melhor remuneração), Austrália (várias reformas), Itália (quase mudou seu sistema, que era semelhante ao Francês anterior a 1972). 
implementado na Áustria, Inglaterra, Holanda, França e Alemanha Ocidental2 ${ }^{28}$. De outro lado, pelo sistema do advogado remunerado pelos cofres públicos, que foi adotado nos Estados Unidos da América do Norte, com os "escritórios de vizinhança", os advogados eram pagos com recursos públicos e tinham o dever de promover os interesses dos pobres enquanto classe, com o objetivo de levar a efeito uma conscientização de direitos, atuando em escritórios pequenos, localizados em áreas marginalizadas. Buscava, sobremaneira, manejar ações coletivas, para tratar de temas, ao invés de discutir questões individuais ${ }^{29}$.

Os dois sistemas apresentavam falhas importantes. No judicare, houve apenas a superação da barreira de custo, permanecendo problemas estruturais sérios, como a ausência de conscientização em direitos, além da evidente perda de interesse, pelos advogados, das causas, em razão do valor baixo ofertado, quando dividiam espaço e atenção com suas outras causas remuneradas. ${ }^{30}$ No sistema do advogado remunerado pelos cofres públicos, por sua vez, a busca por ações coletivas entravam em detrimento das ações individuais e os altos gastos orçamentários exigiam uma atuação limitada, além de ataques políticos fortes pela opção de o Estado arcar com o ônus de auxiliar quem é financeiramente incapaz. ${ }^{31}$

Além desses dois modelos, surgiram modelos combinados, que confluíam com as ideias dos dois modelos, com uma preponderância de um sobre o outro, como ocorria na Suécia e em Quebec, no Canadá, em que se poderia optar por advogados particulares ou advogados servidores públicos. Na Austrália, Holanda e Grã-Bretanha, centros de atendimento jurídico de vizinhança suplementam os esquemas de advogados escolhidos pelo judicare. ${ }^{32}$

Atualizando esses modelos propostos por Cappelletti e Garth, é perceptível que, no Brasil, criou-se uma terceira via, que não pode ser considerada mera combinação dos modelos judicare e advogados remunerados pelo Estado. A Defensoria Pública é uma instituição de Estado autônoma, porém, na sua atuação, congrega servidores públicos devidamente habilitados, com remuneração paga pelo Estado independentemente do êxito nas lides que atuam, e que devem atuar em questões individuais ou coletivas, com anseios primordiais voltados para evitar o excessivo ajuizamento de demandas - ênfase, portanto, na resolução extrajudicial de conflitos -, e com exigências de atuação para conscientização de direitos, para promoção dos direitos humanos e para a maior atuação em relação às pessoas carentes e grupos vulneravelmente expostos.

A opção pela Defensoria Pública com desenho institucional, isto é, para além da simples assunção de sua atuação por órgãos integrantes do Poder Executivo, ganha contornos relevantes para um modelo de observância obrigatória na Federação brasileira. O desenho constitucional brasileiro não prevê o simples exercício das funções de Defensoria Pública. Vai muito além do simples desenho funcional, para estabelecer verdadeiro modelo organizacional. Ao afirmar a Defensoria Pública como instituição, a Constituição impõe que o exercício da promoção da assistência judiciária gratuita aos hipossuficientes seja assumido efetivamente pelo Estado. Ainda que de modo não exclusivo, certo é que o Estado não pode — porque afirmado o desenho institucional da Defensoria Pública - escusar-se de prevê-la, organizá-la e mantê-la de modo compatível a relevância de suas atribuições.

Desse modo, ultrapassam-se os óbices do judicare, pois a atividade do Defensor Público é de exclusividade com seus assistidos e com a promoção de isonomia. Não há, assim, preferências a outras causas. Suas questões não ficam restritas às questões individuais, pois o Defensor Público possui meios de acessar conflitos coletivos, inclusive com o manejo da ação civil pública para demandas que ultrapassem a individualidade das pessoas. Com relação ao sistema dos advogados pagos pelos cofres públicos, percebe-se ganho, também, pela visualização que, enquanto estruturada como carreira de Estado, os gastos orçamentários diminuem-se sensivelmente, em razão da essencialidade e da perenidade do serviço. Ademais, os números de processos atendidos ganham de forma exponencial, já que a atuação é desvinculada do êxito nas demandas.

28 CAPPELLETTT, Mauro; GARTH, Bryant. Acesso à justica. Porto Alegre: Fabris, 1988. p. 13-14.

29 CAPPELletTT, Mauro; GARTH, Bryant. Acesso à justiça. Porto Alegre: Fabris, 1988. p. 15-16.

30 CAPPELLETTT, Mauro; GARTH, Bryant. Acesso à justiça. Porto Alegre: Fabris, 1988. p. 14.

31 CAPPELLETTI, Mauro; GARTH, Bryant. Acesso à justiça. Porto Alegre: Fabris, 1988. p. 16.

32 CAPPELletTI, Mauro; GARTH, Bryant. Acesso à justiça. Porto Alegre: Fabris, 1988. p. 16-17. 
Não se trata, cabe ressaltar, de mera combinação dos modelos anteriores, mas sim de nova via, que aposta, essencialmente, no dever estatal para propiciar o acesso à Justiça e equipara a instituição a outras funções imprescindíveis ao sistema de justiça. A importância da estruturação da Defensoria Pública, nos moldes preconizados, é tamanha que esse efeito alastrou-se para outros países da América Latina e, atualmente, há discussões férteis sobre esse sistema de acesso à Justiça em países da Europa.

Para além da discussão sobre as opções de implementação do desenho organizacional da Defensoria Pública, há um dado fundamental no contexto brasileiro a recomendar que a garantia de promoção do acesso à justiça aos mais necessitados se dê por meio de uma instituição. O Brasil não é um país necessariamente marcado pela pobreza; trata-se de país marcado, de modo muito duro, por um contexto de desigualdades. O malferimento à dignidade encontra-se mais na distância entre a regra e as exceções de conformação socioeconômica de sua população, que efetivamente na presença de uma massa de pessoas desprovidas das condições básicas para sua subsistência.

Tal consideração assume importância na medida em que a Carta brasileira faz uma opção clara pelo desenho institucional de Defensoria Pública. Essa opção política de concreção da dignidade humana guarda importante aspecto de enfrentamento das desigualdades. Não é demais lembrar que o combate à pobreza e a redação das desigualdades sociais e regionais são objetivos fundamentais da República Federativa do Brasil, como destaca o inciso III do artigo 3. ${ }^{\circ}$ da Constituição. E, ao colocar-se o próprio Estado, por meio de essencial garantia institucional (a Defensoria Pública), para cumprir o dever autoimposto de prestar "jurídica integral e gratuita aos que comprovarem insuficiência de recursos", como afirma o inciso LXXIV do artigo 5..$^{\circ}$ da Constituição, essa tarefa só poderia ser desincumbida por uma estrutura organizacional estabelecida em respeito a uma instituição essencial à Justiça. É dizer: não bastaria a prestação do serviço de assistência. Para atuar em consonância com o dever imposto ao próprio Estado e com vista aos objetivos da própria República, foi preciso que a Constituição estabelecesse modelagem organizacional — vinculativa e de reprodução obrigatória em suas unidades federativas — que consagrou verdadeira garantia institucional de promoção dos direitos humanos e de efetivação do primado da igualdade perante a lei.

Cabe assinalar, ainda, a importância dessa temática nos dias de hoje, pois, em que pesem diversas reformas legislativas e estruturais, ainda há um distanciamento grande entre o direito de acessar a Justiça e o efetivo alcance de instrumentos de resolução de conflito. No cenário brasileiro, ainda há muito a ser realizado para diminuir as exclusões sociais.

De acordo com dados obtidos no Panorama do acesso à justiça no Brasil (2004 a 2009), do Conselho Nacional de Justiça, 12,6 milhões de pessoas maiores de idade afirmaram ter vivenciado situações de conflito. A maior parte desses conflitos dizia respeito a questões trabalhistas (23,3\%), familiares (22\%), prestação de serviços de água, luz, telefone e instituições bancárias $(17,1 \%)$ e criminal $(12,6 \%)^{33}$. Esse número é representativo, pois corresponde a $9,4 \%$ da população brasileira nessa faixa etária.

Das 12,6 milhões de pessoas que vivenciaram situações de conflitos, 92,7\% afirmaram ter procurado resolver os conflitos e, para os fins dessa pesquisa, "procurar resolver o conflito" poderia significar ingressar na Justiça, nos Juizados Especiais, sindicato, associações, Igrejas ou amigos, ou contatar órgãos do Estado, como polícia e órgãos estaduais de proteção ao consumidor (PROCON). Grande importância se observa, também, no campo relativo aos "principais responsáveis pela solução dos conflitos", surge, ao lado do poder judiciário, a função de advogados/defensores públicos.

Em que pesem eventuais incorreções técnicas e falhas metodológicas da pesquisa, ressalta-se a verificação, relativa a reclamações e queixas daqueles que não conseguiram acessar o Poder Judiciário, de uma correlação drástica entre renda e escolaridade. Em relação àqueles que afirmaram não ter procurado a Justiça por não saber o que poderia utilizar a Justiça, a renda seria a inferior das demais reclamações $(\mathrm{R} \$ 762,00)$, com

33 BRASIL. Conselho Nacional de Justiça. Panorama do acesso à justiça no Brasil, 2004 a 2009. Disponível em <http://www.cnj.jus. br/images/pesquisas-judiciarias/Publicacoes/relat_panorama_acesso_pnad2009.pdf>. Acesso em: 10 maio 2015. 
apenas 6,31 anos de escolaridade. Também se mostraram no cume da pirâmide as reclamações de não ter procurado a Justiça porque custaria muito caro (renda de $\mathrm{R} \$ 787,00$ e escolaridade de 6,45 anos de estudo) e ou porque era muito longe (renda de $\mathrm{R} \$ 885,00$ e escolaridade de 5,57 anos de estudo).

Extrai-se, daí, que há um grande óbice no acesso ao Poder Judiciário e à resolução de conflitos que fica agravado pela situação econômica das pessoas, o que resulta na dificuldade ou impossibilidade de instruir-se ou de utilizar serviços jurídicos de qualidade, que se mostra importante em razão da dificuldade de acesso à Defensoria Pública, inclusive pelo desconhecimento e falta de instrução de grande parcela da população mais miserável, pelo baixo número de profissionais e dificuldades políticas e orçamentárias que inviabilizam a interiorização do órgão ${ }^{34}$. Tais dificuldades, porém, não desvirtuam a importância da Defensoria Pública, ressaltada recentemente pela criação desse órgão em diversas Constituições e na quase totalidade da América Latina, como se verá a seguir.

\subsection{A Defensoria Pública como garantia constitucional processual de acesso à justiça}

Um dos grandes desafios do ordenamento brasileiro, ultrapassados consideráveis anos de estabilização democrática e retorno às práticas constitucionais como premissa básica, é propiciar, a todos os viventes, uma eficaz proteção de seus direitos contra ingerências e terceiros, que objetivassem a prática de atos ilícitos e/ ou contrários ao novel estado de direito.

Os regimes constitucionais anteriores a 1988 ocuparam-se relativamente pouco com processo, usualmente prendendo sua atenção no processo penal ${ }^{35}$. Com relação a acesso à justiça, sequer existia a previsão de um órgão estatal com essa função, mas garantia-se, tão-somente, a assistência judiciária integral e gratuita para os necessitados, compreendida como a isenção de custas e honorários para o ingresso, participação e acompanhamento de processo perante o Poder Judiciário, como previsto na Lei Federal n. 1.060/1950.

A previsão de garantias constitucionais processuais, no texto constitucional pátrio de 1988, além de refletir os movimentos de outros países da Europa e da América, como já visto no capítulo precedente, era uma salvaguarda contra o regime de exceção até então vigente e, na crença dos constituintes, uma medida eficaz para assentar os anseios democráticos populares. Além de prever diversas garantias no bojo do artigo 5. ${ }^{\circ}$, o qual, para dotar maior força, foi grafado como cláusula pétrea, com núcleo essencial que não pode ser excluído pelo poder constituinte reformador, era nítida a tentativa de instrumentalizar órgãos públicos para melhorar a atuação do Estado, inclusive o seu controle, como se observa na feição assumida pelo Ministério Público.

O acesso à Justiça, porém, permanecia como uma das preocupações gritantes para o constituinte originário. Este ampliou as fórmulas já previstas em Constituições anteriores a respeito da gratuidade de Justiça. ${ }^{36} \mathrm{~A}$ assistência aos mais necessitados passou a ser jurídica, não apenas judiciária. Operou-se, então, uma

34 De acordo com o Mapa da Defensoria Pública no Brasil, de 2.680 comarcas, apenas 755 são atendidas pela Defensoria Pública, existindo grande defasagem do número de defensores públicos inclusive quando comparado com o número de Juízes e promotores. Com efeito, as "análises sobre as taxas de pessoas com até três salários-mínimos por defensor público evidenciaram a insuficiência generalizada de defensores nos estados [...]. Apenas 124 comarcas não apresentam déficit de defensores, considerando como necessário um defensor público para cada 10.000 habitantes, de modo que $95,4 \%$ das comarcas brasileiras ou não possuem defensor público ou possuem em número insuficiente. Cerca de um terço do déficit de defensores públicos é referente a comarcas já atendidas pela Defensoria, pois 87,3\% das comarcas com Defensoria Pública ainda apresentam déficit de defensores.” MOURA, Tatiana Whately. Mapa da defensoria pública no Brasil. Brasília: ANADEP, 2013. p. 41-43.

35 MOREIRA, José Carlos Barbosa. A constitucionalização do processo no direito brasileiro. In: MACGREGOR, Eduardo Ferrer; LARREA, Arturo Zaldívar Lelo de (Coord.). Estudos de direito processual constitucional: homenagem brasileira a Héctor FixZamudio em seus 50 anos como pesquisador do direito. São Paulo: UNAM-Malheiros, 2009. p. inicial-final. p. 47.

36 A esse respeito, é importante considerar que a Constituição da República de 1988 inovou também nesse ponto, ao prever que a assistência jurídica, não apenas judicial, seria gratuita aos que comprovassem hipossuficiência de recursos. Dessa feita, estão englobados, além da atuação perante o Poder Judiciário com os seus gastos inerentes, atividades outras que, não necessariamente, implicarão acesso ao Judiciário, como, por exemplo, atuação cartorária, meios extrajudiciais de resolução de conflitos (conciliação, mediação e arbitragem). 
significativa ampliação do rol de atuação, não mais se limitando ao ingresso e acompanhamento de ações perante o Poder Judiciário. Essa conformação deu azo à disciplina e à criação, de forma inédita em textos constitucionais, de uma instituição, a ser minudenciada em diversos órgãos de atuação e de execução, encarregada de prestar assistência jurídica, integral e gratuita, aos que fossem carentes.

Até esse momento, as disposições que estipulavam órgãos estatais de assistência judiciária, como os núcleos de assistência que atuavam em Minas Gerais, São Paulo, Rio de Janeiro ou no Distrito Federal, de conformação infraconstitucional, eram restritos ao âmbito estadual ou municipal. A grande totalidade dos municípios brasileiros, porém, não tinham previsão, de forma sistematizada, de um serviço estatal de assistência jurídica.

Há grande dificuldade em assegurar, para pessoas sem patrimônio e alijadas dos avanços culturais, igualdades de participação, de desenvolvimento e de aferição de valor por suas condutas. A previsão abstrata de direitos não era suficiente para a resolução dos conflitos, pois se mostrava imprescindível a existência de arsenal fático e jurídico, propiciando, concretamente, acesso ao Judiciário e a outros meios de resolução de conflito. A normatividade formal clássica, ao declarar/proclamar direitos, pouco fez para atacar a injusta e desigual realidade, que mantinha os menos abastados afastados dos bens culturais e alijados dos avanços da modernidade.

Sem uma disciplina clara sobre o acesso à Justiça por instrumentos que propiciem auxílio jurídico, aconselhamento e atuação direta nas lides, inclusive naquelas de baixo valor remuneratório, indiscutivelmente seriam mantidas as desigualdades sociais no bojo do processo judicial. Tais preconceitos e diminuições tendem a reproduzir-se no contexto judicial, em face de exigências práticas que alijam aqueles que não tem recursos ou dificultam sobremaneira o exercício de seus direitos. A igualdade, no contexto de discriminação e de miséria, é uma medida dificilmente alcançada. ${ }^{37}$

Dessa forma, a sistematização da Defensoria Pública no texto da Constituição mostra-se extremamente relevante e vai ao anseio dos princípios constitucionais e os fins visados pelo Brasil, como a diminuição das mazelas sociais e a proteção da dignidade da pessoa humana. É indiscutível que a previsão e organização do órgão resultam em paridade de armas entre os litigantes, uma nítida feição do princípio da igualdade. ${ }^{38}$ Com esse objetivo, o artigo 134 da Constituição da República estabeleceu a Defensoria Pública como instituição essencial à função jurisdicional do Estado, com a incumbência de prestar orientação jurídica e defesa, em todos os graus, aos necessitados. No parágrafo único do mesmo dispositivo, constou a previsão de que Lei Complementar organizaria a Defensoria Pública da União, do Distrito Federal e dos Territórios, além de prescrever regras gerais para as Defensorias estaduais. ${ }^{39}$ Os cargos da carreira de Defensor Público — carreira de Estado - seriam providos, por expresso mandamento constitucional, por concurso público.

"Para a efetivação da garantia”, explicitam Cintra, Grinover e Dinamarco ${ }^{40}$, “a Constituição não apenas se preocupou com a assistência judiciária aos que comprovarem insuficiência de recursos, mas a estendeu à

37 "Para aferir essa igualdade, inclusive para concretizá-la, é preciso verificar que existem diversas circunstâncias que desequilibram as forças dos litigantes, como a econômica (carência de recursos financeiros para custear o processo), desníveis sociais e culturais (que asseguram maior acomodação a um habitat litigioso), custos processuais, meios de defesa em juízo (ineficiência das instituições públicas, impossibilidade de escolha pessoal do, então, advogado público, relação de confiança), depósito prévio para a prática de determinados atos processuais, atuação do advogado (não cumprimento de sua função social, atuação desidiosa ou descomprometida, não alcance da linguagem necessária para alcançar o cidadão), função assistencial do magistrado (no socorro da parte que se encontra mais fragilizada, de forma a corrigir o desequilíbrio das partes), disparidade de forças (grandes empresas e Administração Pública, por exemplo).” MOREIRA, José Carlos Barbosa. La igualdad de las partes en el proceso civil. Revista de Processo, São Paulo, n. 44, 1986.

38 CINTRA, Antonio Carlos de Araújo; GRINOVER, Ada Pellegrini; DINAMARCO, Cândido Rangel. Teoria geral do processo. 20. ed. São Paulo: Malheiros, 2004. p. 82.

39 A Lei Complementar Federal n. 80/1994 organizou a Defensoria Pública da União, do Distrito Federal e dos Territórios, bem como, em razão da competência concorrente entre União e Estados, prescreveu regras gerais para as Defensorias Públicas estaduais. Cada Estado, por sua vez, regulamentou suas regras específicas, as quais deveriam guardar consonância com as disposições gerais estabelecidas naquela norma.

40 CINTRA, Antonio Carlos de Araújo; GRINOVER, Ada Pellegrini; DINAMARCO, Cândido Rangel. Teoria geral do processo. 20. ed. São Paulo: Malheiros, 2004. p. 82. 
assistência jurídica pré-processual". Como deveres do Estado, caberia a este ente "organizar a carreira jurídica dos defensores públicos, cercada de muitas das garantias reconhecidas ao Ministério Público (art. 5. ${ }^{\circ}$, inc. LXXIV, c/c art. 134)".

Importante realçar, ainda, que, além da redação originária do texto constitucional de 1988, as Emendas à Constituição que posteriormente vieram a tratar do tema enfatizaram a relevância e a importância da Defensoria Pública, desvinculando-a do Poder Executivo, conferindo autonomia e importância no cenário jurídico nacional, além de definir, com maior exatidão, suas funções primordiais.

Com efeito, a Emenda Constitucional n. 45/2004 fez inserir, nos dispositivos constitucionais, assertivas para assegurar às Defensorias Públicas estaduais autonomia funcional e administrativa, bem como a iniciativa de sua proposta orçamentária, nos limites e moldes definidos na Constituição. A Emenda Constitucional n. 69/2012, por sua vez, adequou o texto constitucional à realidade fática, modificou a competência para tratar sobre a Defensoria Pública do Distrito Federal, transferindo-a da União para o Distrito Federal, bem como assegurou que a ela a incidência das mesmas previsões concernentes às Defensorias Públicas estaduais. ${ }^{41}$ A previsão de autonomia e administrativa, além da iniciativa orçamentária, foram estendidas às Defensorias Públicas da União e do Distrito Federal pela Emenda Constitucional n. 74/2013.

Por derradeiro, a Emenda Constitucional n. 80/2014 criou uma seção específica para a Defensoria Pública, retirando-a da seção da advocacia, como forma de assegurar, expressamente, a sua importância e relevância, evidenciando que a atuação do Defensor Público não se confunde com a dos advogados ou com a advocacia pública. Inseriu, no texto constitucional, também, os princípios institucionais (unidade, indivisibilidade e independência funcional), mandando-se aplicar, no que couber, as disposições do artigo 93 e 96, II, da Constituição, conferindo-lhe iniciativa de lei e outros aspectos imprescindíveis para sua atuação. Por derradeiro, determinou a progressiva interiorização dos serviços da Defensoria Pública, no prazo de 8 (oito) anos, preferencialmente nas regiões com maior exclusão social e adensamento populacional.

As recentes reformas constitucionais são significativas e sugerem que há esperanças, pelo poder constituinte reformador, quanto ao papel ainda a ser desempenhado pelas Defensorias Públicas, para que a instituição possa, efetivamente, atenuar as mazelas sociais pela atuação, judicial ou extrajudicial, em prol dos necessitados.

Esta é, portanto, uma das estratégias políticas que podem ser implementadas para que se tente obter igualdade entre as partes, na medida em que condições econômicas não serão óbices para que pessoas carentes tenham acesso a profissionais do Direito com capacidade e aptidão para bem representá-las. Além disso, destaque-se a nítida preocupação de assegurar um acesso igualitário à justiça, em que a sorte do direito deduzido perante o Judiciário não seja definida pelo melhor ou pior patrocínio da causa a depender das forças do causídico que a patrocina.

Desníveis sociais indicam que, enquanto houver grande desequilíbrio entre os detentores do poder ou de bens materiais, e aqueles que nada têm, será possível manter-se tais discriminações, inclusive pelos óbices aos direitos constitucionais, pela ausência de um serviço eficiente e atuante, tal como prestado pela Defensoria Pública. Além das discriminações derivadas do modelo econômico hegemônico e da parca distribuição de rendas, o sistema judicial pode servir como relevante barreira quando não há a estruturação essencial da Defensoria Pública para atuação e auxílio dos necessitados e dos grupos vulneráveis.

41 Em relação à mencionada adequação à realidade fática, "formalmente, a Defensoria Pública do Distrito Federal foi apenas 'criada' no ano de 2012. Desde 1987, o serviço de Defensoria Pública do DF é prestado, materialmente, pelo Centro de Assistência Judiciária do DF (CEAJUR). Muito embora o comando constitucional fosse claro, no sentido de que apenas a União poderia criar, organizar e manter a Defensoria Pública do DF, desse ônus a União nunca se desincumbiu [...] o objetivo era transformar o CEAJUR na Defensoria Pública do DF, concretizando uma situação fática em prol da coletividade e sem gastos orçamentários, já que existia um quadro competente e profissional de advogados voltados para a prestação de assistência à população carente. Assim, uma Defensoria Pública de fato, a qual, com a alteração da Carta Magna, juridicamente consolidou-se.” AMARAL, Alberto Carvalho. Nota de esclarecimento da associação dos defensores públicos do Distrito Federal. Disponível em: <http://s.conjur.com.br/dl/notaesclarecimento-adep-df-mapa.pdf>. Acesso em: 9 maio 2015. 
O modelo proposto no Brasil e que vem sendo exercitado diariamente pelas Defensorias Públicas possui capacidade para superar as limitações dos sistemas originariamente informados por Cappelletti, como visto anteriormente, sendo essa uma das prováveis razões de ele ter sido sistematicamente reprisado nos países da América Latina. A partir da experiência brasileira, já que a sistematização de um órgão de assistência judiciária, pago pelo Estado, é típica inovação brasileira, outros países da América do Sul, que também sofrem com miséria e desigualdade social, passaram a prever regras específicas para a criação e aparelhamento de um órgão, com nomenclatura e funcionamento semelhantes, em suas Constituições.

Assim sucedeu, portanto, com o Ministerio Público de la Defensa, previsto no art. 120 da Constituição da Argentina ${ }^{42}$ e regulamentado, infraconstitucionalmente, pela Ley Orgánica del Ministerio público (n. 24.946), de 1998, que disciplinou a Defensoria Pública Federal. E aquele país ainda não tinha disciplinado a contento, ainda, as Defensorias que atuariam nas províncias. ${ }^{43} \mathrm{Na}$ Colômbia, foi criada a Defensoría del Pueblo, que tinha previsão constitucional explícita nos artigos 281 a $284^{44}$, e foi regulamentada pela Lei 941, de 14.01.1995. A Defensoria Pública, do Equador, encontra previsão nos artigos constitucionais 76 e 19145, e foi instrumentalizada pelo artigo 286 do Código Orgánico de la Función Judicial. Na Venezuela, foi disciplinada a Defensa Pública, com explícita previsão no artigo 253 da Constituição desse país ${ }^{46}$, regulamentada pela Ley Organica de la Defensa Pública.

Com relação a esses países, Argentina, Colômbia, Equador e Venezuela, a partir da leitura dos dispositivos constitucionais indicados, verificou-se a existência de previsões constitucionais similares à brasileira - e muito possivelmente inspiradas por ela -, com a designação, pelo próprio Poder Constituinte, de um órgão

42 Articulo 120. El Ministerio Publico es un organo independiente con autonomia funcional y autarquia financiera, que tiene por funcion promover la actuacion de la justicia em defensa de la legalidad de los intereses generales de la sociedad, en coordinacion con las demas autoridades de la Republica. Esta integrado por un procurador general de la Nacion y um defensor general de la Nacion y los demas miembros que la ley establezca. Sus miembros gozan de inmunidades funcionales e intangibilidad de remuneraciones. La organizacion y el funcionamiento de esta institucion seran regulados por una ley.

43 BURGER, Adriana Fagundes; ROCHA, Amélia Soares da. Cartografía del acceso a la justicia en el Mercosur. Porto Alegre: ADPERGS, 2012. p. 40.

44 ARTICULO 281. El Defensor del Pueblo formará parte del Ministerio Público y ejercerá sus funciones bajo la suprema dirección del Procurador General de la Nación. Será elegido por la Cámara de Representantes para un período de cuatro años de terna elaborada por el Presidente de la República. ARTICULO 282. El Defensor del Pueblo velará por la promoción, el ejercicio y la divulgación de los derechos humanos, para lo cual ejercerá las siguientes funciones:1. Orientar e instruir a los habitantes del territorio nacional y a los colombianos en el exterior en el ejercicio y defensa de sus derechos ante las autoridades competentes o entidades de carácter privado. 2. Divulgar los derechos humanos y recomendar las políticas para su enseñanza. 3. Invocar el derecho de Habeas Corpus e interponer las acciones de tutela, sin perjuicio del derecho que asiste a los interesados. 4. Organizar y dirigir la defensoría pública en los términos que señale la ley. 5. Interponer acciones populares en asuntos relacionados con su competencia. 6. Presentar proyectos de ley sobre materias relativas a su competencia. 7. Rendir informes al Congreso sobre el cumplimiento de sus funciones. 8. Las demás que determine la ley. ARTICULO 283. La ley determinará lo relativo a la organización y funcionamiento de la Defensoría del Pueblo. ARTICULO 284. Salvo las excepciones previstas en la Constitución y la ley, el Procurador General de la Nación y el Defensor del Pueblo podrán requerir de las autoridades las informaciones necesarias para el ejercicio de sus funciones, sin que pueda oponérseles reserva alguna.

45 Art. 76. En todo proceso en el que se determinen derechos y obligaciones de cualquier orden, se asegurará el derecho al debido proceso que incluirá las siguientes garantías básicas: 7. El derecho de las personas a la defensa incluirá las siguientes garantías: g) En procedimientos judiciales, ser asistido por una abogada o abogado de su elección o por defensora o defensor público; no podrá restringirse el acceso ni la comunicación libre y privada con su defensora o defensor. Art. 191. La Defensoría Pública es un órgano autónomo de la Función Judicial cuyo fin es garantizar el pleno e igual acceso a la justicia de las personas que, por su estado de indefensión o condición económica, social o cultural, no puedan contratar los servicios de defensa legal para la protección de sus derechos. La Defensoría Pública prestará un servicio legal, técnico, oportuno, eficiente, eficaz y gratuito, en el patrocinio y asesoría jurídica de los derechos de las personas, en todas las materias e instancias. La Defensoría Pública es indivisible y funcionará de forma desconcentrada con autonomía administrativa, económica y financiera; estará representada por la Defensora Pública o el Defensor Público General y contará con recursos humanos, materiales y condiciones laborales equivalentes a las de la Fiscalía General del Estado.

46 Artículo 253. La potestad de administrar justicia emana de los ciudadanos y ciudadanas y se imparte en nombre de la República por autoridad de la ley.Corresponde a los órganos del Poder Judicial conocer de las causas y asuntos de su competencia mediante los procedimientos que determinen las leyes, y ejecutar o hacer ejecutar sus sentencias.El sistema de justicia está constituido por el Tribunal Supremo de Justicia, los demás tribunales que determine la ley, el Ministerio Público, la Defensoría Pública, los órganos de investigación penal, los o las auxiliares y funcionarios o funcionarias de justicia, el sistema penitenciario, los medios alternativos de justicia, los ciudadanos o ciudadanas que participan en la administración de justicia conforme a la ley y los abogados autorizados o abogadas autorizadas para el ejercicio. 
para propiciar assistência judiciária aos necessitados, com cargos providos por advogados habilitados e percebendo remuneração do próprio Estado.

Essa conformação é claramente influenciada pela necessidade de salvaguardar o direito dos carentes em acessar o Poder Judiciário e mostra-se relevante, na medida em que esse direito de acesso à Justiça, por ser um direito a ser exercitado em desfavor de detentores de poder, não foi de ganho fácil para a população pobre e carente. Tais Constituições, ao previrem essa formulação, foram muito além de prever, abstratamente, direitos e fórmulas de garantia, mas previram um sistema de assessoramento jurídico, por intermédio de um órgão, que pode concretamente fazer valer os direitos pelo acesso ao Judiciário. Em razão disso, há quem sustente o papel da Defensoria Pública como metagarantia ${ }^{47}$, de viés constitucional-processual, na medida em que ela é a garantia das garantias, ou o instrumento que propicia a plena efetivação dos direitos proclamados nos diversos textos vigentes.

Com relação aos demais países da América do Sul, com exceção apenas da Guiana e do Suriname, também funcionam serviços semelhantes à Defensoria Pública brasileira, com a ressalva, porém, de que esta garantia não foi explicitamente prevista em seus textos constitucionais.

Assim ocorre, por exemplo, com a Defensa Pública, na Bolívia, prevista na Lei n. 463, de 19.12.2013, e, com a mesma nomenclatura, no Peru, neste prevista na Lei n. 29.360, de 14.05.2009; com o Ministerio de la Defensa Pública, no Paraguai, regulamentado pela Ley Orgánica Nacional de la Defensa Pública (Lei n. 4423/11); com relação ao Chile, pela previsão do órgão pela Lei n. 19.718, que regulou a criação, natureza, objeto, organização, atribuições, funcionamento e sede da Defensoria Penal Pública, prestado em nível nacional; ${ }^{48}$ e, por último, no Uruguai, no qual a Lei Nacional n. 17.930, previu o serviço de Defensorías Públicas, que funciona no âmbito do Poder Judiciário, com submissão à Suprema Corte de Justiça. ${ }^{49}$

Portanto, é inegável a escolha, por diversos países da América Latina, da Defensoria Pública como órgão capaz de propiciar o acesso à Justiça, sendo interessante verificar que, em muitos deles, optou-se por fórmula semelhante à brasileira, grafando como garantia constitucional processual esse órgão, que se investe na função de proteção dos carentes e grupos vulneráveis.

\section{Considerações finais}

As economias de mercado, na medida em que criam benefícios para os detentores de poder, tendem por criar mecanismos que, invariavelmente, implicam diminuição de direitos de outras pessoas. No âmbito processual, quando há mecanismos que dependem de encargos remuneratórios, ocorrem limites grandes àqueles que não têm recursos, o que, invariavelmente, tende a obstar que acessem os seus direitos mais básicos, quando, evidentemente, tenham conhecimento mínimo sobre eles.

A Defensoria Pública é o órgão por excelência voltado para, no aspecto jurídico-processual, fazer cessar ilegalidades de acesso aos mais carentes e necessitados. Sua função primordial é garantir, para todos os que não têm condições, a possibilidade de defenderem seus direitos adequadamente, ainda que a resolução desse

47 A esse respeito, "buscou o constituinte mais do que criar um modelo de instituição que possibilitasse ao hipossuficiente bem poder exercer a defesa dos seus direitos em juízo ou se aconselhar para questões extraprocessuais, mas criou-se um modelo que em si é metagarantia, exatamente pela sua sólida base constitucional, sua roupagem integradora da própria função jurisdicional - o que revela que esta não ocorre plenamente sem aquela - e uma vocação absolutamente ampla e democrática, próprio deste nosso regime constitucional.” DEVISATE, Rogério. Categorização: o modelo constitucional, o defensor público e o seu atuar: ato de defensorar. In: DEFENSORIA pública: o reconhecimento constitucional de uma metagarantia. Brasília: ANADEP, 2015. p. inicial-final.

48 BURGER, Adriana Fagundes; ROCHA, Amélia Soares da. Cartografía del acceso a la justicia en el Mercosur. Porto Alegre: ADPERGS, 2012. p. 42.

49 BURGER, Adriana Fagundes; ROCHA, Amélia Soares da. Cartografía del acceso a la justicia en el Mercosur. Porto Alegre: ADPERGS, 2012. p. 44. 
conflito não dependa do ajuizamento de ações. E, em razão das funções que desempenha, representa uma evolução considerável no tipo de enfrentamento às disparidades econômicas e sociais no acesso à Justiça.

No presente estudo, analisamos, inicialmente, os movimentos de inserção, como preceitos constitucionais, de regras processuais, na tentativa de conferir certa estabilidade e proteção a esses comandos, entendendo-os como essenciais para a proteção e efetivação dos direitos que tutelam. A constitucionalização dos direitos processuais é um aspecto moderno e relevante na concepção das constituições, que irradia efeitos interessantes sobre o ordenamento jurídico e sobre as considerações teóricas correlatas, especialmente quanto ao papel e função do processo e de seus instrumentos para a perseguição da Justiça.

Vimos, também, que o acesso à Justiça, como direito à tutela jurisdicional, ultrapassa a formalidade dos sistemas clássicos da burguesia e, na modernidade, torna-se relevante, pois é apenas com o efetivo acesso à Justiça que se pode, concretamente, fazer valer os direitos previstos nos textos legais. Foram analisados os dois sistemas básicos de acesso à Justiça, judicare e o de advogado remunerado pelos cofres públicos, apontando-se, sinteticamente, benefícios e desvantagens, e, após, considerou-se que a Defensoria Pública, tal como estruturada e aparelhada, é uma terceira opção de acesso, cada vez mais presente nos ordenamentos internacionais.

Por derradeiro, foi discutida a Defensoria Pública como garantia constitucional processual de acesso à Justiça, constitucionalmente inaugurada no Brasil em 1988 e que irradia, com forte projeção, para cenários internacionais desde então. Foram frisadas as reformas constitucionais, que posicionaram o órgão com certa autonomia, com o objetivo de melhorar a prestação jurisdicional. E foram analisadas outras Defensorias Públicas, de países da América do Sul, que tinham previsão constitucional semelhante à nossa, ou seja, que também entenderam esse órgão como uma verdadeira garantia constitucional processual para acesso à Justiça, bem como outras que, apesar de não gravarem constitucionalmente, preveem em seus ordenamentos instituições semelhantes.

Restou evidenciada que a opção político-legislativa pela criação e aparelhamento da Defensoria Pública tem a ver, sobremaneira, com uma maior preocupação do legislador em dotar os mais carentes de meios necessários para acessarem o Poder Judiciário e outras formas de resolução de conflito, no bojo de uma constitucionalização voltada para assegurar direitos, em vez de meramente proclamá-los, e concretizá-los, pela existência de um órgão específico, com aptidão e capacidade para encerrar os conflitos e fornecer auxílio jurídico aos mais carentes e necessitados.

\section{REFERÊNCIAS BIBLIOGRÁFICAS}

AMARAL, Alberto Carvalho. Nota de esclarecimento da associação dos defensores públicos do Distrito Federal. Disponível em: <http://s.conjur.com.br/dl/nota-esclarecimento-adep-df-mapa.pdf>. Acesso em: 9 jan. 2016.

BRASIL. Conselho Nacional de Justiça. Panorama do acesso à justiça no Brasil, 2004 a 2009. Disponível em <http://www.cnj.jus.br/images/pesquisas-judiciarias/Publicacoes/relat_panorama_acesso__ pnad2009. pdf>. Acesso em: 15 jan. 2016.

BRASIL. Constituição (1988). Constituição da República Federativa do Brasil. Disponível em: < http://www.planalto.gov.br/ccivil_03/constituicao/constituicao.htm>. Acesso em: 10 jan. 2016.

BRASIL. Decreto n. 592, de 6 de julho de 1992. Atos Internacionais. Pacto Internacional sobre Direitos Civis e Políticos. Promulgação. Disponível em: <http://www2.camara.leg.br/legin/fed/decret/1992/decreto592-6-julho-1992-449004-publicacaooriginal-1-pe.html>. Acesso em: 10 jan. 2015.

BRASIL. Lei n. 1.060, de 5 de fevereiro de 1950. Estabelece normas para a concessão de assistência judiciária aos necessitados. Disponível em: <http://www.planalto.gov.br/ccivil_03/leis/L1060compilada.htm>. 
Acesso em: 10 jan. 2016.

BURGER, Adriana Fagundes; ROCHA, Amélia Soares da. Cartografía del acceso a la justicia en el Mercosur. Porto Alegre: ADPERGS, 2012.

CAMBI, Eduardo. Neoconstitucionalismo e neoprocessualismo: direitos fundamentais, políticas públicas e protagonismo judiciário. São Paulo: Revista dos Tribunais, 2009.

CAPPELLETTI, Mauro; GARTH, Bryant. Acesso à justiça. Porto Alegre: Fabris, 1988.

CARBONELL, Miguel. El neoconstitucionalismo: significado y niveles de análises. In: CARBONELL, Miguel; JARAMILLO, Leonardo García. El canon neoconstitucional. Madrid: UNAM/Trotta, 2010. p. 153-164.

CINTRA, Antonio Carlos de Araújo; GRINOVER, Ada Pellegrini; DINAMARCO, Cândido Rangel. Teoria geral do processo. 20. ed. São Paulo: Malheiros, 2004.

COUTURE, Eduardo J. Fundamentos del derecho procesal civil. Buenos Aires: Depalma, 1976.

DEVISATE, Rogério. Categorização: o modelo constitucional, o defensor público e o seu atuar: ato de defensorar. In: DEFENSORIA pública: o reconhecimento constitucional de uma metagarantia. Brasília: ANADEP, 2015.

FAVELA, José Ovalle. Garantias constitucionales del processo. 3. ed. México: Oxford, 2007.

FIX-ZAMUDIO, Héctor. Constitución y proceso civil en Latinoamérica. Ciudad de México: UNAM, 1974.

GRINOVER, Ada Pellegrini. Os princípios constitucionais e o código de processo civil. São Paulo: José Bushatski, 1975.

INSTITUTO DE PESQUISA ECONÔMICA APLICADA. Mapa da Defensoria Pública no Brasil. 2013. Disponível em: <http://www.ipea.gov.br/sites/images/downloads/mapa_defensoria_publica_no_brasil_19_03.pdf>. Acesso em: 10 maio 2016.

MOREIRA, José Carlos Barbosa. A constitucionalização do processo no direito brasileiro. In: MACGREGOR, Eduardo Ferrer; LARREA, Arturo Zaldívar Lelo de (Coord.). Estudos de direito processual constitucional: homenagem brasileira a Héctor Fix-Zamudio em seus 50 anos como pesquisador do direito. São Paulo: UNAM-Malheiros, 2009.

MOREIRA, José Carlos Barbosa. La igualdad de las partes en el proceso civil. Revista de Processo, São Paulo, n. 44, 1986.

MOURA, Tatiana Whately. Mapa da defensoria pública no Brasil. Brasília: ANADEP, 2013.

NERY JUNIOR, Nelson. Princípios do processo civil na Constituição Federal. 9. ed. São Paulo: Revista dos Tribunais, 2009.

PICÓ I JUNOY, Joan. Las garantías constitucionales del proceso. Barcelona: J. M. Bosch, 1997.

PORTO, Gilberto Porto; USTÁRROZ, Daniel. Lições de direitos fundamentais no processo civil: conteúdo processual da Constituição Federal. Porto Alegre: Livraria do Advogado, 2009. 


\section{REVISTA BRASILEIRA DE POLÍTICAS PÚBLICAS BRAZILIAN JOURNAL OF PUBLIC POLICY}
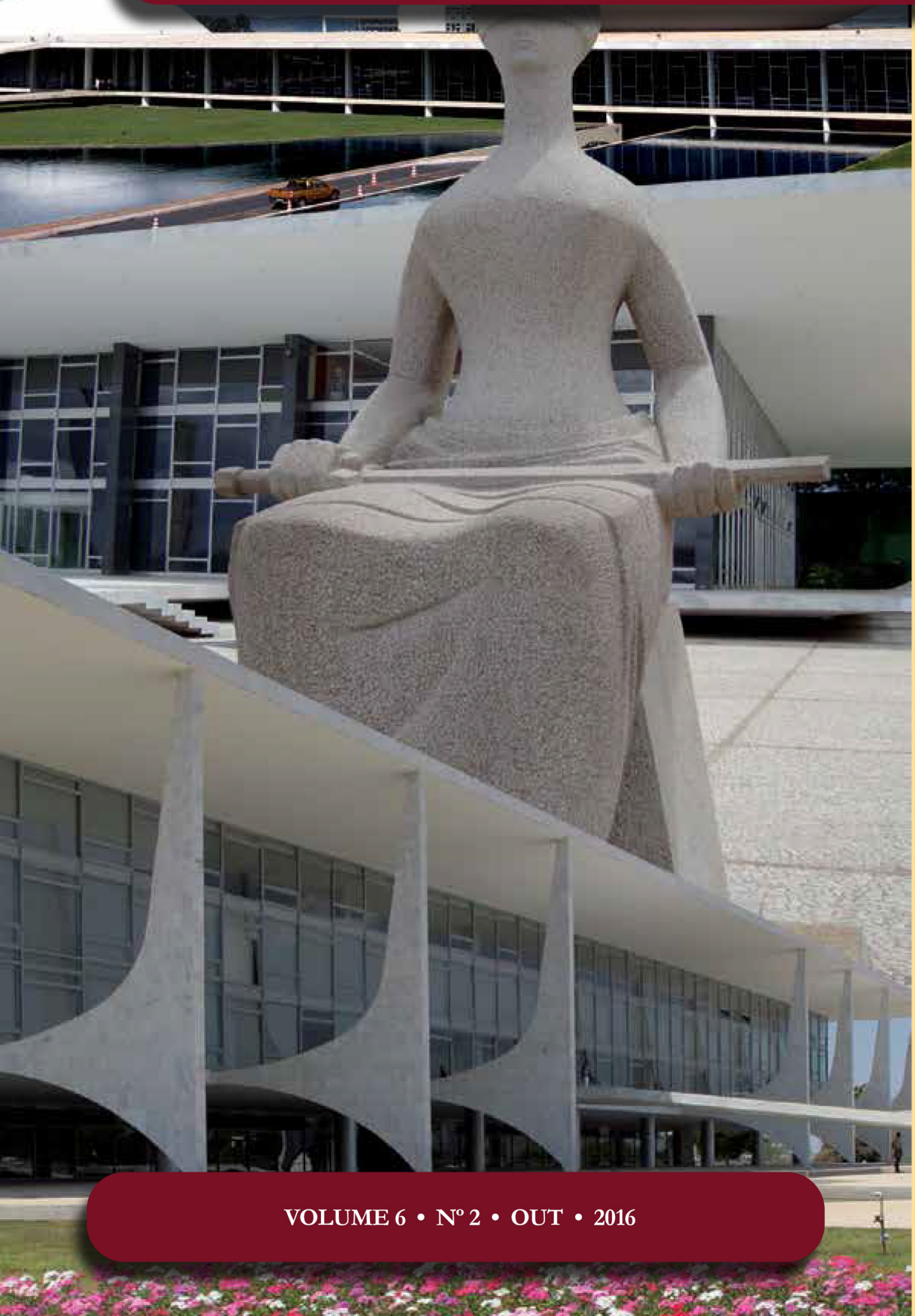

Judicialização da saúde pública brasileira

Judicialization of brazilian

public health

Maria Socorro de Araújo Dias

Diógenes Farias Gomes

Thaís Araújo Dias

Lielma Carla Chagas da Silva

Maria da Conceição Coelho Brito

Manoel de Castro Carneiro Neto 


\title{
Judicialização da saúde pública brasileira*
}

\section{Judicialization of brazilian public health}

\author{
Maria Socorro de Araújo Dias** \\ Diógenes Farias Gomes*** \\ Thaís Araújo Dias**** \\ Lielma Carla Chagas da Silva***** \\ Maria da Conceição Coelho Brito****** \\ Manoel de Castro Carneiro Neto*******
}

\section{Resumo}

Este estudo tem por objetivo descrever as evidências científicas sobre a judicialização da saúde no Brasil, enquanto estratégia para garantia do direito à saúde. Trata-se de uma revisão integrativa, que, após a adoção dos critérios de elegibilidade, analisou 25 artigos publicados na interface de dados da Bireme. Constatou-se que a judicialização da saúde no Brasil está presente em diferentes óticas, sendo, prioritariamente, utilizada para a aquisição de medicamentos e tratamentos médicos especiais para resolução de problemas individuais, o que tem gerado altos custos ao setor público. O conteúdo evidenciado pela análise dos artigos permite concluir a necessidade de redução, ou controle, da judicialização da saúde, e para isto faz-se necessário alinhar e (re)formular as políticas públicas de saúde, baseadas em conceitos e atitudes mais equânimes e fundamentadas a partir de evidências.

Palavras-chave: Direito a saúde. Direito sanitário. Acesso aos serviços de saúde. Saúde Pública.

* Recebido em 15/04/2016 Aprovado em 04/07/2016

** Departamento de Saúde da Universidade Estadual do Vale do Acaraú. Email: socorroad@gmail.com.

*** Universidade Federal do Ceará. Departamento de Pós-Graduação em Ciências da Saúde. Email: diogenesfariasgomes@gmail. com

**** Universidade Estadual do Vale do Acaraú. Centro de Ciências Sociais Aplicadas. Departamento de Direito. Email: thais_araujo_ dias@hotmail.com

***** Departamento de Ssaúde da Universidade Estadual do Vale do Acaraú. Email: marycey@hotmail.com

****** Universidade Estadual do Vale do Acaraú. Centro de Ciências Sociais Aplicadas. Departamento de Direito. Email: carneironet@ hotmail.com

\section{Abstract}

This study aims to describe scientific evidence on the judicialization of health in Brazil, as a strategy to guarantee the right to health. This is an integrative review, which after the adoption of eligibility criteria analyzed 25 articles published in the Bireme database. It was observed that the judicialization of health in Brazil is present in different perspectives, giving priority to the purchasing of drugs and special medical treatment to solve individual problems, which has generated high costs to the public sector. The contents seen through the analysis of these articles enabled us to conclude the need for reduction, or control, of the judicialization of health, and in order to do this it is necessary to align and re(formulate) public health policies, based on more impartial concepts and attitudes and substantiated on evidence.

Keywords: Right to health. Health law. Health services accessibility. Public health. 


\section{INTRODUÇÃO}

A saúde passou a ganhar destaque na agenda pública a partir do século XVI na Europa, quando os Estados começaram a se interessar pelas condições de saúde da população. Entretanto, foi no século XVIII, com a Revolução Industrial, que movimentos sociais envolvendo proletariados protagonizaram reivindicações contra as precárias condições de vida e trabalho, e o Estado atuou de forma sanitarista na higienização das cidades, iniciando a percepção da saúde como dever social ${ }^{1}$.

Direitos sociais são resultados das lutas históricas da sociedade, contrapondo-se à situação de profunda desigualdade provocada pelo sistema capitalista. Nessa ótica, o Estado assume a responsabilidade pelas demandas sociais geradas nesse contexto, visando redistribuir parte da riqueza produzida para as classes menos favorecidas por meio da garantia de serviços públicos ${ }^{2}$. No Brasil, a oferta dos direitos fundamentais perpassa diferentes conjunturas políticas e sociais, desde o estabelecimento da República, que não pretendia ser para todos, aos tempos de ditadura militar, marcada pela opressão dos direitos civis, e reivindicações de trabalhadores e estudantes por melhorias na educação, moradia, transporte e saúde 3 .

A Constituição Federal brasileira de 1988, atualmente vigente no País, representa um marco na democracia para o estabelecimento dos direitos fundamentais, ao mesmo tempo em que estabelece novos desafios para efetivar tais direitos. A partir desta, a saúde passa a ser um direito de todos e dever do Estado, conforme estabelece o art., 196:

A saúde é direito de todos e dever do Estado, garantido mediante políticas sociais e econômicas que visem à redução do risco de doença e de outros agravos e ao acesso universal e igualitário às ações e serviços para sua promoção, proteção e recuperação ${ }^{4}$.

Complementarmente, o caput do art. $2^{\circ}$ da Lei no 8.080, de 19 de setembro de 1990, dispõe que "A saúde é um direito fundamental do ser humano, devendo o Estado prover as condições indispensáveis ao seu pleno exercício". Essas condições devem ser garantidas por meio de políticas sociais e econômicas que visem à promoção da saúde e à redução do risco de adoecimento. Tal Lei implanta o Sistema Único de Saúde (SUS) no Brasil, na perspectiva de garantir o acesso à saúde como direito 5 .

O SUS parte das ações definidas pela Constituição Federal de 1988, que atribuiu ao setor público às atividades de regulamentação, fiscalização e controle das ações e serviços de saúde, sobre um aspecto universal ${ }^{6}$. Outros países da América Latina conversam com as propostas do SUS, ao adotar o princípio da universalidade como: Chile, Colômbia, Cuba, Ruanda, Sri Lanka, Costa Rica e Filipinas, os quais apresentam investimentos e modelos estruturais diferentes da realidade brasileira? ${ }^{7}$.

Indubitavelmente, a Constituição Cidadã trouxe consigo inúmeros adventos. Tal fato ocorreu devido a sua natureza de ser uma constituição dirigente. Esse caráter trouxe ao texto constitucional um foco que objetiva a mudança social demarcada por metas a serem alcançadas pela associação entre o Estado e a sociedade. Por conseguinte, a saúde passa a ser protegida estatalmente como bem de relevância pública no qual o cuidado deve ser endereçado ao Estado e à própria sociedade ${ }^{8}$.

1 PEREIRA, I. D. F.; LAGES, I. Diretrizes curriculares para a formação de profissionais de saúde: competências ou práxis? Trab. Educ. saúde, Rio de Janeiro, v. 11, n. 2, p. 319-338, 2013. Disponível em: <http://www.scielo.br/pdf/tes/v11n2/a04v11n2.pdf>. Acesso em: 02 jul. 2015.

2 SOUZA, A. M. C. Universalidade da saúde no Brasil e as contradições da sua negação como direito de todos. Katálysis, Florianópolis, v. 17, n. 2, p. 227-234, 2014. Disponível em: <https://periodicos.ufsc.br/index.php/katalysis/article/view/32679/28074>. Acesso em: 08 jul. 2015.

3 SOUZA, C. R.; BOTAZZO, C. Construção social da demanda em saúde. Physis, Rio de Janeiro, v. 23, n. 2, p. 393-413, 2013. Disponível em: <http://www.scielo.br/pdf/physis/v23n2/v23n2a05.pdf>. Acesso em: 17 jul. 2015.

4 BRASIL. Constituição (1988). Constituição da República Federativa do Brasil. Brasília: Senado Federal, 1988.

5 MORAES, A. Direitos Humanos Fundamentais. São Paulo: Atlas, 2002.

6 BRASIL. Conselho Nacional de Secretários de Saúde. Para entender a gestão do SUS. Brasília: CONASS, 2003.

7 BRASIL. Conselho Nacional de Secretários de Saúde. SUS: avanços e desafios. Brasília: CONASS, 2006.

8 TOJAL, S. B. B. A constituição dirigente e o direito regulatório do estado social: o direito sanitário. In: BRASIL. Ministério da 
O direito fundamental à saúde conferiu à sociedade brasileira o acesso aos serviços de saúde nos seus diferentes níveis de atenção: primária, secundária e terciária, de forma universal, integral e equânime. A busca pela efetivação desse direito tem implicado o uso de alternativas legais, nos termos da Constituição. Tal fato deve-se à complexidade da implementação do conceito ampliado de saúde (saúde como bem viver) e de uma equação ainda não resolvida entre financiamento do setor saúde e necessidades expressas pela população, que tem conduzido a um volume significativo de processos judiciais implicando na intervenção do poder judiciário junto ao poder executivo. Dessa forma, surge o fenômeno da judicialização da saúde, o qual vem tomando espaço no cenário jurídico brasileiro ${ }^{9,10}$.

Assim, vimos o fortalecimento das instituições jurisdicionais de defesa dos direitos coletivos e difusos, como o Ministério Público e a Defensoria Pública, as quais possuem a função de garantir a efetivação dos direitos fundamentais, quando estes não forem devidamente cumpridos pelo Estado.

O fato do SUS ter sido implantado em um momento de dificuldades econômicas, até hoje não superadas, certamente impossibilitou(a) a distribuição igualitária de serviços de qualidade e segurança da população no usufruto do direito à saúde. Desdobra-se em relação a essas premissas, a inferência que a judicialização da saúde decorre da ampliação de processos democráticos e da inclusão civil, representada pela positivação dos direitos sociais e pela difusão da informação e da consciência cidadã ${ }^{11}$.

Diante do exposto, objetiva-se com este estudo descrever as evidências científicas sobre a judicialização da saúde no SUS, enquanto estratégia para garantia do direito à saúde.

\section{Metodologia}

Realizou-se pesquisa do tipo revisão integrativa, que possibilita a síntese do estado da arte do conhecimento de um determinado assunto de modo sistemático, apontando lacunas do conhecimento que precisam ser preenchidas com a realização de novos estudos como suporte à tomada de decisão e à melhoria da prática clínica, além de permitir a realização de uma síntese de múltiplos estudos publicados, viabilizando conclusões gerais a respeito de uma particular área de estudo ${ }^{12}$. Com esta revisão, é ensejada a produção de evidências sobre a judicialização da saúde no Brasil.

Uma revisão integrativa exige os mesmos padrões de rigor, clareza e replicação utilizada nos estudos primários. Considerando-se isso, na operacionalização dessa revisão, foram percorridas as seguintes etapas: delimitação da questão de pesquisa; estabelecimento dos critérios de inclusão/exclusão para a seleção dos estudos a serem analisados; definição das informações a serem extraídas dos estudos selecionados; avaliação dos estudos incluídos na revisão integrativa; análise dos dados, interpretação dos resultados e apresentação da síntese da revisão.

Parte-se, então, do questionamento: quais evidências os periódicos científicos anunciam sobre a judicialização da saúde no SUS, enquanto estratégia para a garantia do direito à saúde?

Saúde. Direito sanitário e saúde pública: coletânea de textos. Brasília: Ministério da Saúde, 2003. v.1. 375p.

9 NUNES, C. F. O. Judicialização do direito à saúde no estado do Ceará, Brasil: cenários e desafios. 2014. 222f. Dissertação (Mestrado) Universidade Federal do Ceará, Fortaleza, 2014.

10 PEPE, V. L. E. et al. Judicialização da saúde e os novos desafios da gestão da assistência farmacêutica. Ciênc. saúde coletiva, Rio de Janeiro, v. 15, n. 5, p. 2405-2414, 2010. Disponível em: <http://www.scielo.br/pdf/csc/v15n5/v15n5a15.pdf>. Acesso em: 18 jul. 2015.

11 FLEURY, S. Judicialização pode salvar o SUS. Saúde debate, Rio de Janeiro, v. 36, n. 93, p. 159-162, 2012. Disponível em: <http://peep.ebape.fgv.br/sites/peep.ebape.fgv.br/files/A_judicializacao_pode_salvar_o_SUS_Saude_em_Debate.pdf>. Acesso em: 30 jun. 2015.

12 POLIT, D. F.; BECK, C. T. Fundamentos de pesquisa em enfermagem: avaliação de evidências para a prática de enfermagem. 7. ed. Porto Alegre: Artmed, 2011. 
O levantamento bibliográfico foi realizado por meio da interface Bireme. A busca para identificar os estudos iniciou-se, de forma mais ampla, com vistas a identificar descritores suficientemente sensíveis para localizar os artigos que se fizessem cumprir os objetivos do estudo. Para compor as estratégias de busca, foram identificados os Descritores em Ciências da Saúde (DeCS), direito sanitário e direito à saúde, utilizados simultaneamente nas referidas bases de dados, e a palavra-chave judicialização da saúde, com vistas a ampliar a busca.

Os descritores identificados foram aplicados isoladamente, com e sem técnicas de trucagem (optou-se pelas aspas, nesse caso), e combinados com o operador boleano and. Posterior ao teste de sensibilidade chegou-se a combinação: "direito sanitário" and "direito à saúde". Utilizou-se, ainda, a palavra-chave judicialização da saúde entre aspas para ampliar a busca.

Os critérios de elegibilidade dos artigos foram: (1) artigos completos, (2) disponíveis na forma de artigos científicos, (3) escritos na língua portuguesa/estudos brasileiros e (4) publicados em revistas científicas indexadas na Bireme. Foram excluídos dessa revisão anais, monografias, dissertações, teses, boletins informativos de gestores, artigo original não disponível eletronicamente e publicações repetidas em bases de dados diferentes. O levantamento ocorreu entre maio e julho de 2015.

Realizada a busca, foram identificados 74 documentos resultantes do cruzamento "direito sanitário" and "direito à saúde" e 40 documentos na busca imediata resultante da palavra-chave judicialização da saúde (utilizada com aspas). Submetidos aos critérios de inclusão e exclusão, foram selecionados 05 artigos do cruzamento entre os descritores e 21 da busca por meio da palavra-chave; destes houve 01 (um) artigo de publicação duplicada; resultou-se em um total de 25 artigos.

A coleta de informações foi orientada por meio de instrumento elaborado a partir do objetivo, pergunta de partida e leituras prévias sobre a temática, de modo a contemplar aspectos importantes para essa revisão. Assim, o roteiro foi estruturado em três dimensões: caracterização do periódico (título do artigo, periódico e classificação do periódico no Qualis Capes); caracterização do autor (formação e vinculação institucional); e caracterização do estudo (descritores ou palavras-chave, ano de publicação, objeto de estudo, desenho metodológico e evidências apontadas nos resultados).

A análise das informações utilizou a análise de conteúdo proposta por Bardin ${ }^{13}$, que identifica, de forma frequencial, os assuntos mais discutidos nos estudos, permitindo um agrupamento dos achados similares por temas. Ressalta-se que os artigos foram apresentados nos resultados por numeral ordinal conforme ordenamento cronológico das publicações.

\section{Resultados E discussão}

A análise da produção científica brasileira sobre o fenômeno da judicialização da saúde no Brasil permitiu a organização deste capítulo em três tópicos. Inicialmente, será apresentada a caracterização dos artigos, seguida da discussão sobre a origem e enfoques da judicialização no sistema de saúde brasileiro e os efeitos desta.

Considerando-se a proporção de artigos publicados por ano, identifica-se que a produção científica relacionada à judicialização da saúde é crescente nos últimos seis anos; embora registre-se que a primeira publicação é datada em 1988. O ano dessa primeira publicação foi o mesmo da promulgação da atual Constituição brasileira, a partir da qual a saúde passou a ser considerado um dever do Estado e direito do cidadão.

O Quadro 1 apresenta as publicações em ordem cronológica, permitindo identificar que, a partir de 2010, a ocorrência de publicações sobre a temática se manteve presente anualmente e que o intervalo entre 2010 e os anos após respondem por 23 dos 25 artigos selecionados.

13 BARDIN, L. Análise de conteúdo. São Paulo: Edições 70, 2011. 
Quadro 1 - Apresentação dos artigos científicos selecionados por meio da interface Bireme. Sobral-CE: 2015.

\begin{tabular}{|c|c|c|}
\hline $\mathrm{N}^{\mathrm{o}}$ & Título & Ano \\
\hline 1 & Uma nova disciplina: o direito sanitário & 1988 \\
\hline 2 & Normatização, o Estado e a saúde: questões sobre a formalização do direito & 2005 \\
\hline 3 & Medicina e direito: atuação na integralidade destes dois saberes & 2010 \\
\hline 4 & Judicialização ou juridicização? As instituições jurídicas e suas estratégias na saúde & 2010 \\
\hline 5 & A judicialização da saúde e os desafios da gestão da assistência farmacêutica & 2010 \\
\hline 6 & udicialização da saúde, acesso à justiça e a efetividade do direito à saúde & 2010 \\
\hline 7 & $\begin{array}{l}\text { Perspectivas do controle da infecção hospitalar e as novas forças sociais em defesa da } \\
\text { saúde }\end{array}$ & 2011 \\
\hline 8 & $\begin{array}{l}\text { Ligações perigosas: indústria farmacêutica, associações de pacientes e as batalhas judiciais } \\
\text { por acesso a medicamentos. }\end{array}$ & 2011 \\
\hline 9 & $\begin{array}{l}\text { Aspectos jurídicos e sanitários condicionantes para o uso da via judicial no acesso aos } \\
\text { medicamentos no Brasil }\end{array}$ & 2012 \\
\hline 10 & $\begin{array}{l}\text { Médicos, advogados e indústria farmacêutica na judicialização da saúde em Minas Gerais, } \\
\text { Brasil }\end{array}$ & 2012 \\
\hline 11 & Judicialização da Saúde, problema e solução: questões para a enfermagem & 2012 \\
\hline 12 & $\begin{array}{l}\text { Os centros de informação sobre medicamentos e o acesso e uso racional de } \\
\text { medicamentos à luz do direito sanitário }\end{array}$ & 2013 \\
\hline 13 & A tese da judicialização da saúde pelas elites: os medicamentos para mucopolissacaridose & 2013 \\
\hline 14 & Judicialização da saúde: um estudo de caso de três tribunais brasileiros & 2013 \\
\hline 15 & Saúde, poder, judiciário e sociedade: uma análise de Brasil e Portugal & 2013 \\
\hline 16 & Perfila das demandas judiciais por medicamentos em municípios do Es & 2013 \\
\hline 17 & A judicialização da saúde no Distrito Federal, Brasil & 2014 \\
\hline 18 & $\begin{array}{l}\text { Judicialização da saúde e a audiência pública convocada pelo Supremo Tribunal Federal } \\
\text { em 2009: o que mudou de lá para cá. }\end{array}$ & 2014 \\
\hline 19 & Sobre jovens drogaditos: as histórias de ninguém & 2014 \\
\hline 20 & $\begin{array}{l}\text { Os princípios da universalidade e integralidade do SUS sob a perspectiva da política de } \\
\text { doenças raras e da incorporação tecnológica. }\end{array}$ & 2014 \\
\hline 21 & Decisões Judiciais e Orçamento: um olhar sobre a saúde pública & 2014 \\
\hline 22 & $\begin{array}{l}\text { Os impactos da judicialização da saúde no município de São Paulo: gasto público e } \\
\text { organização federativa }\end{array}$ & 2014 \\
\hline 23 & Judicialização da saúde na garantia do acesso ao medicamento & 2014 \\
\hline 24 & Judicialização da Saúde: analisando a audiência pública no Supremo Tribunal Federal & 2014 \\
\hline 25 & $\begin{array}{l}\text { Os discursos na Audiência Pública da Saúde e seu impacto nas decisões do Supremo } \\
\text { Tribunal Federal: uma análise à luz da teoria dos sistemas sociais }\end{array}$ & 2015 \\
\hline
\end{tabular}

Fonte: Elaborado pelo autor.

No que concerne aos delineamentos dos artigos analisados, identifica-se a predominância de estudos teórico-reflexivos, documentais e bibliográficos. Evidencia-se ênfase nas discussões sobre a garantia de acesso a saúde incitada e aprofundada mediante a especificidade das questões de pesquisas.

Quando se fala das especificidades das pesquisas, ressalta-se as conexões entre os perfis de formação (graduações), linhas de pesquisas e vinculações institucionais dos autores com a delimitação dos objetos de estudo. Dessa forma investigou-se a graduação de cada um dos autores dos artigos. Os 25 artigos foram escritos por 79 autores. No que concerne as áreas de formação destes, identificou-se: Direito $(n=28)$, se- 
guido de Farmácia ( $n=17)$, Medicina ( $n=9)$, Odontologia ( $n=6)$, Saúde Coletiva $(n=4)$, Psicologia ( $n=3)$, Economia ( $\mathrm{n}=3)$, Enfermagem $(\mathrm{n}=2)$, Ciências Sociais $(\mathrm{n}=2)$, Administração $(\mathrm{n}=1)$, Linguística $(\mathrm{n}=1)$ e Jornalismo $(n=1)$.

Esse resultado permite inferir que a produção do conhecimento sobre a judicialização da saúde no Brasil concentrou-se mais em pesquisadores da área do Direito e da Farmácia; inferência que pode ser explicada por se constituírem duas categorias profissionais que estão mais diretamente relacionadas ao foco dos processos de judicialização: a busca pelo acesso a medicamentos ou garantia à saúde por meio de procedimentos médicos específicos.

No que tange às vinculações institucionais dos autores, estas se concentram nos grandes centros de pesquisas, prioritariamente situados nas regiões Centro-Oeste, Sudeste e Sul do Brasil. Situação que denota uma assimetria típica do Estado brasileiro no que concerne à produção do conhecimento. Foi da região Sudeste, via Universidade de São Paulo (USP), a autoria do primeiro estudo escrito pela pesquisadora e jurista Sueli Gondolfi Dallari, no ano 1988 (Artigo 1). Pesquisadora de expressiva produção na área de judicialização da saúde.

Além da USP, destaca-se a participação do Grupo Cochrane de Direito, do Centro Cochrane do Brasil, enquanto instituição de vínculo dos autores. O Centro Cochrane é uma organização sem fins lucrativos, que tem o objetivo de contribuir para a tomada de decisões na Saúde, com base em informações disponíveis. Dessa forma, essa organização manifesta a preocupação em construir e fornecer evidências científicas que estruturem a conversação com outros estudos brasileiros, associados às propostas de mudança do cenário conjuntural que se presencia na construção da saúde baseada em evidência no Brasil ${ }^{14}$.

Pelo exposto, verifica-se um movimento crescente de instituições e autores na sistematização e divulgação de estudos que denotem evidências sobre a judicialização da saúde no Brasil. Tal premissa ganha força quando se avalia a qualidade dos periódicos nos quais foram publicados os artigos selecionados. No Brasil, a Coordenação de Aperfeiçoamento de Pessoal de Nível Superior (CAPES) adota critérios parametrizados para classificação dos periódicos; denominado Qualis Capes. O Qualis Capes representa um esforço em avaliar e qualificar a produção científica brasileira. Os periódicos são enquadrados em estratos decrescentes indicativos de qualidade A1 (o mais elevado), A2, B1, B2, B3, B4, B5 e C (peso zero) ${ }^{15}$. Todos os artigos selecionados foram publicados em periódicos brasileiros classificados no Qualis Capes.

O Quadro 2 apresenta a avaliação dos periódicos que ancoraram os artigos selecionados neste estudo, segundo estratificação por áreas nas quais os periódicos são avaliados no Qualis Capes.

Quadro 2 - Classificação dos periódicos identificados no estudo a partir da estratificação do Qualis Capes. Sobral-CE: 2015.

\begin{tabular}{|c|c|c|c|c|c|}
\hline \multirow[b]{2}{*}{ Título do Periódico } & \multicolumn{4}{|c|}{ Área/Classificação } & \multirow{2}{*}{$\begin{array}{c}\mathrm{N}^{\circ} \text { de } \\
\text { artigos }\end{array}$} \\
\hline & Interdisciplinar & $\begin{array}{l}\text { Saúde } \\
\text { coletiva }\end{array}$ & Enfermagem & Direito & \\
\hline Revista de Salud Publica & B1 & B3 & B1 & A1 & 2 \\
\hline $\begin{array}{l}\text { Physis: revista de saúde } \\
\text { coletiva }\end{array}$ & B1 & B1 & B1 & $-*$ & 4 \\
\hline $\begin{array}{l}\text { Revista Baiana de Saúde } \\
\text { Publica }\end{array}$ & B2 & B4 & B3 & -* & 1 \\
\hline Revista Direito Sanitário & -* & B4 & B3 & B1 & 3 \\
\hline
\end{tabular}

14 CENTRO COCHRANE DO BRASIL. Quem somos. Disponível em: < http://www.centrocochranedobrasil.org.br/cms/index. php?option $=$ com_content\&view $=$ article\&id $=13 \&$ Itemid $=4>$.

15 BRASIL. COORDENAÇÃO DE APERFEIÇOAMENTO DE PESSOAL DE NÍVEL SUPERIOR. Diretoria de avaliação. Webqualis. 2012. Disponível em: <http://qualis.capes.gov.br/webqualis>. Acesso em: 05 jul. 2015. 


\begin{tabular}{|c|c|c|c|c|c|}
\hline \multirow[b]{2}{*}{ Título do Periódico } & \multicolumn{4}{|c|}{ Área/Classificação } & \multirow{2}{*}{$\begin{array}{c}\mathrm{N}^{\circ} \text { de } \\
\text { artigos }\end{array}$} \\
\hline & Interdisciplinar & $\begin{array}{l}\text { Saúde } \\
\text { coletiva }\end{array}$ & Enfermagem & Direito & \\
\hline $\begin{array}{l}\text { Revista administração } \\
\text { Pública }\end{array}$ & A2 & B3 & -* & A2 & 1 \\
\hline Ciência \& Saúde Coletiva & B1 & B1 & B1 & -* & 6 \\
\hline Diagnóstico e tratamento & B4 & B4 & & $\mathrm{B} 4$ & 1 \\
\hline Revista de Saúde Pública & $\mathrm{A} 2$ & A2 & A2 & A1 & 2 \\
\hline Saúde em Debate & B1 & $\mathrm{B} 2$ & $\mathrm{~B} 2$ & $\mathrm{C}$ & 1 \\
\hline Psicologia \& Saúde & A2 & $\mathrm{B} 2$ & -* & $-*$ & 1 \\
\hline Revista Bioética & B2 & B4 & B3 & $\mathrm{C}$ & 1 \\
\hline $\begin{array}{l}\text { Revista de Enfermagem } \\
\text { da UERJ }\end{array}$ & B1 & -* & B1 & B3 & 1 \\
\hline $\begin{array}{l}\text { Revista Saúde e } \\
\text { Sociedade }\end{array}$ & A2 & B2 & B1 & $\mathrm{C}$ & 1 \\
\hline \multicolumn{5}{|l|}{ TOTAL } & 25 \\
\hline
\end{tabular}

-*Não pontua nesta estratificação do Qualis Capes.

Verifica-se que os artigos selecionados para este estudo estão, predominantemente, publicados em periódicos bem avaliados no Qualis Capes em diferentes áreas de concentração (Interdisciplinar, Saúde Coletiva, Enfermagem e Direito); situação que denota, ao mesmo tempo, a qualidade do rigor metodológico e a contemporaneidade da temática que orientaram os estudos. Infere-se, ainda, a essência interdisciplinar do tema em voga.

Tendo apresentado uma descrição dos estudos selecionados, passa-se a discorrer sobre as evidências identificadas nessa revisão por meio das unidades temáticas: "Judicialização da saúde: origem e enfoques no sistema de saúde brasileiro", e "Efeitos da judicialização no Estado brasileiro".

\section{JudicializAÇÃo da SAÚde: ORIGEM E ENFOQUeS NO SISTEMA DE SAÚdE BRASILEIRO}

O fenômeno da judicialização da saúde parte do enfrentamento em conceituar a saúde enquanto direito social resguardado pelo Estado. Assim, conceituar a saúde é uma problemática discutida mundialmente, quando até mesmo a Organização Mundial de Saúde (OMS) historicamente altera suas visões sobre esse aspecto. Tão representativa é esta realidade que o Artigo 2 sinaliza os desafios epistemológicos na conceitualização da saúde enquanto ciência multidimensional.

Isso descende da década de 1990 com os portadores do Vírus da Imunodeficiência Humana ou no inglês Human Immunodeficiency Virus (HIV), quando o sistema de saúde pública brasileiro não dispunha dos medicamentos para esse público, que gerou a busca judicial por tratamentos com antirretrovirais ${ }^{16,17}$. Sem progresso, surge no decorrer dos anos uma demanda reprimida, que opta pela via judicial para a garantia da assistência farmacêutica pelo SUS.

16 PANDOLFO, M.; DELDUQUE, M. C.; AMARAL, R. Aspectos jurídicos e sanitários condicionantes para o uso via judicial no acesso aos da medicamentos no Brasil. Rev. salud pública, São Paulo, v. 14, n. 2, p. 340-349, 2012. Disponível em: <http://www. scielosp.org/pdf/rsap/v14n2/v14n2a14.pdf>. Acesso em: 20 jul. 2015.

17 BARRETO, J. L. Perfil das demandas judiciais por medicamentos em municípios do Estado da Bahia. Rev. baiana saúde pública, Bahia, v. 37, n. 3, p. 536-552, 2013. Disponível em: <http://inseer.ibict.br/rbsp/index.php/rbsp/article/viewFile/574/pdf_425>. Acesso em: 04 jun. 2015. 
Delimita-se a judicialização da saúde no Brasil a partir da primeira ação judicial neste campo no cenário jurídico brasileiro. Em relação a esse fato, questiona-se a aplicabilidade e resolução desse recurso jurídico no sistema de saúde, o qual poderia incitar a criação de regimentos legais que garantam de fato o direito à saúde em sua totalidade, sem a necessidade de petições judiciais que tomam tempo e gastos ao setor público ${ }^{18}$.

Nessa ótica, o direito sanitário constitui-se como uma área de estudo que merece destaque e que deve ganhar espaço no cenário das políticas públicas brasileiras, pois representa propostas para a garantia da saúde da população, com vistas a evitar processos jurídicos. Assim, ele deve ser encarado com uma garantia, frente à atuação do Estado em projetar o atendimento satisfatório a partir das necessidades de cada pessoa, fornecendo serviços de amplo espectro na saúde.

Contudo, cabe sinalizar que o direito sanitário não é tido como uma disciplina atual constitui temática que remota a estudos nos Estados da Comunidade Europeia em 1984, especialmente na Itália e França ${ }^{19}$. Aspecto que corrobora o apontado no Artigo 1, sobre a inserção da disciplina de direito sanitário no Brasil em 1988, em cursos da área das ciências sociais e aplicadas, em detrimento da área da saúde, com especial direcionamento para os cursos de graduação em Direito.

As discussões incitadas pela iniciação do direito sanitário nascem em um momento de profundas mudanças no cenário brasileiro. Em 1988 foi instituída a Constituição Federal, na qual se destaca a saúde enquanto direito fundamental. É dever do Estado a garantia desse direito, além do apoio a movimentos sanitaristas. Essas provocações foram incitatórias para a posterior criação do atual sistema de saúde público brasileiro ${ }^{20}$.

Com base nesse compromisso constitucional do Estado é que se resguardam os processos judiciais para garantia de acesso a saúde no Brasil, ou aos meios que a viabilize. Os artigos retratam situações em que se tornou necessário recorrer a meios jurídicos para fazer valer o compromisso firmado com a população. Isso é verificado em oito artigos dessa revisão, os quais versam sobre ações locais e nacionais de indivíduos na busca por assistência farmacêutica, além de ações que envolvem a solicitação de insumos, equipamentos ou cirurgias específicas, e que até então não eram acessíveis pelo SUS, até se tornarem objetos de disputas jurídicas, certas vezes de grande proporção.

O Artigo 18 pondera sobre uma grande problemática nas áreas da saúde e jurídica, ao identificar que a judicialização da saúde apresenta pretensões que afetam o coletivo em prol de necessidades individuais. Consonante, os Artigos 4 e 14 apresentam a utilização da via jurídica para a garantia da saúde de forma individual, o que conversa também com o Artigo 21 ao abordar que na análise dos seus documentos, o Supremo Tribunal Federal (STF) entende, em grande parte de seus julgamentos, que o direito à saúde é um direito individual e que pode ser gozado diretamente por cada indivíduo, influenciando na grande quantidade dessas ações.

O quantitativo crescente de ações se torna evidente no Artigo 16, ao apresentar a judicialização da saúde em municípios do estado da Bahia (estado de maior densidade populacional da Região Nordeste do País), entre os anos de 2006 a 2010; somente nesse período foram 228 ações solicitando 574 medicamentos em quatro municípios. Sobre o acesso ao uso de medicamentos, destaca que muitos processos judiciais se referem a pacientes que se encontram em tratamentos especiais e que demandam medicamentos não disponibilizados pelo SUS; enfoque mencionado no Artigo 12, no qual sinaliza que o primeiro caso de judicialização para medicamentos ocorreu no Estado do Rio Grande do Sul, Região Sul do País, no ano de 2002, continuando com números crescentes posteriormente.

18 BRAUNER, M. C. C.; CIGNACHI, J. C. B. O direito à saúde e o papel do poder judiciário: uma perspectiva acerca das dimensões constitucionais e das tutelas coletivas. Juris, Rio Grande, v. 16, p. 29-48, 2011. Disponível em: < http://www.seer.furg.br/juris/ article/view/3420/2042 >. Acesso em: 05 jun. 2015.

19 DALLARI, S. G. Direito sanitário. In: BRASIL. Ministério da Saúde. Direito sanitário e saúde pública: coletânea de textos. Brasília: Ministério da Saúde, 2003. v.1.375p.

20 PRIORI, A. et al. A ditadura militar e a violência contra os movimentos sociais, políticos e culturais. In: PRIORI, A. et al História do Paraná: séculos XIX e XX. Maringá: Eduem, 2012. p. 199-215. 
O exposto é corroborado pelo Artigo 4 ao abordar a intensidade das demandas judiciais por medicamentos para assistência farmacêutica de usuários do SUS e informa que $60 \%$ desses processos demandam por produtos não disponíveis no SUS, como já sinalizado no Artigo 8.

Nesse contexto, faz-se necessário articular setores da sociedade e conhecimentos que norteiem não somente o setor jurídico, mas que englobem as áreas médicas em etapas decisórias da judicialização da saúde. O Artigo 3 versa sobre os princípios da atenção à saúde com vistas ao fortalecimento da integralidade entre medicina e direito, enquanto aspectos estruturantes para a consolidação do SUS. Ressalta que a unificação desses conhecimentos é um mecanismo importante para reconstruir os aspectos da judicialização no País, visto que grande parte dos processos jurídicos é puramente ligada a princípios legislativos. Nessa perspectiva, vê-se a necessidade de embasar as decisões judiciais por meio da saúde baseada em evidências, o que confronta a forma de aplicação da lei que predomina atualmente nas análises jurídicas sobre saúde ${ }^{21}$.

O Artigo 7 traz a tona outra importante discussão, quando reflete sobre as repercussões das infecções hospitalares na saúde de pacientes e que estas, também, têm sido alvo dos processos judiciais para que serviços hospitalares sejam ofertados com qualidade no Brasil.

Outro importante aspecto sobre a judicialização da saúde é mencionado no Artigo 19, neste são apresentadas ações judiciais para o internamento psiquiátrico enquanto alternativa para evitar o uso abusivo de drogas ou como medida protetiva para adolescentes, o que aponta para o uso da via judicial direcionada a saúde mental.

As internações psiquiátricas no Brasil são encaradas como última alternativa no tratamento em saúde mental, quando todos os recursos nos diferentes níveis de atenção à saúde foram tentados para o tratamento ou manejo do problema, considerando os riscos do paciente para si e aos outros a partir da limitação de sua autonomia, agressões, risco de exposição social e incapacidade de autocuidado ${ }^{22}$.

Vale lembrar que, diferentemente dos casos sobre a judicialização da saúde para o uso de medicamentos, a internação psiquiátrica não foi apresentada em outros artigos, o que permite inferir que, no cenário da judicialização da saúde, há poucos processos direcionados ao tratamento para saúde mental, situação que pode ser compreendida se tomar em consideração a recente melhoria neste campo de assistência em saúde reforçada pela Lei 10.216/2001 ${ }^{23}$.

Destaca-se, portanto, que a garantia da saúde, antes ou após do fenômeno da judicialização, é obrigação dos entes gestores da saúde, pois devem assegurar a assistência à saúde orientada pelos princípios norteadores do SUS. Nesta direção, o Artigo 8 acusa que a judicialização da saúde é uma resposta imediata ao deficit orçamentário nos investimentos do SUS, e que isso repercute de forma severa no País.

Tendo exposto o percurso histórico e caracterização da judicialização da saúde no Brasil; passa-se a refletir sobre os efeitos destas.

\section{Efeitos da Judicialização no Estado brasileiro}

$\mathrm{Na}$ análise dos artigos, foram identificados diferentes efeitos ocasionados pela judicialização da saúde no Brasil que envolveram, principalmente, aspectos orçamentários e de gestão, salientado que o principal problema é direcionar recursos financeiros imprevistos no sistema público de saúde.

21 BARTOLOMEI, C. E. F. et al. Medicina e direito: atuação na integralidade destes dois saberes. Diagn. tratamento, Brasília, v.15, n. 1, p. 39-42, 2010. Disponível em:< http://files.bvs.br/upload/S/1413-9979/2010/v15n1/RDTv15n1a1146.pdf>. Acesso em: 05 jul. 2015.

22 CARDOSO, L; GALERA, S.A.F. Internação psiquiátrica e a manutenção do tratamento extra-hospitalar. Revista Esc. Enferm. USP, São Paulo, v. 46, n. 1, p. 87-94, 2011. Disponível em: <http://www.scielo.br/pdf/reeusp/v45n1/12.pdf >. Acesso em: 10 jul. 2015.

23 PITTA, A. M. F. Um balanço da reforma psiquiátrica brasileira: instituições, atores e políticas. Ciênc. saúde coletiva, Rio de Janeiro, v. 16, n. 12, p. 4579-4589, 2011. Disponível em: <http://www.scielo.br/pdf/csc/v16n12/02.pdf>. Acesso em: 20 jul. 2015 
Nessa perspectiva, discute-se, inicialmente, que as necessidades orçamentárias destinadas à saúde é uma realidade enfrentada, também, por países com grande poder econômico e altos níveis de investimento no setor público da saúde, que nem sempre são capazes de oferecer tudo para todos, o que converge com a situação do estado brasileiro ${ }^{24}$. O custeio do SUS, conforme Nove lino ${ }^{25}$, é feito com os recursos do orçamento da seguridade social, ou seja, com os recursos provenientes dos orçamentos dos entes federados oriundos das contribuições da seguridade social.

Em relação a esse aspecto orçamentário, cabe ressaltar um achado evidenciado pela literatura ao reforçar que os processos litigiosos para demanda de medicamentos são um dos principais processos judiciais do cenário brasileiro, que necessitam um menor tempo e investimento impreciso, já que não pode ser medida a quantidade esperada desses processos afetando diretamente nos recursos destinados ao setor saúde ${ }^{26}$.

Nesse contexto, o Artigo 21 versa sobre a criticidade da situação do sistema de saúde brasileiro ao sofrer com processos judiciais. O artigo aponta que, no estado de São Paulo, os processos de judicialização da saúde proporcionam um deficit orçamentário nas contas do Estado que chegou a aproximadamente a $\mathrm{R} \$ 7,2$ milhões, sem contar com os tratamentos de saúde já previamente licitados no orçamento estadual.

Em consonância, o Artigo 13 apresenta que os gastos por medicamentos somente para mucopolissacaridose chegaram a aproximadamente $\mathrm{R} \$ 219.664 .476,05$ no período de cinco anos (2006-2010) e que, certamente, não estava no orçamento do Ministério da Saúde. Enquanto o Artigo 8 afirma que, somente no ano de 2005, foram gastos cerca de dois milhões de reais para sentenças judiciais no Ministério da Saúde e mais de 68 milhões nos três anos posteriores.

O Artigo 21 garante, também, que foram identificados impactos orçamentários gerados pela realocação de recursos para que as decisões judiciais fossem cumpridas, prejudicando assim quem se beneficiaria desses recursos e também as políticas públicas da saúde de forma coletiva. Reflete-se que a judicialização da saúde e o comprometimento orçamentário, muitas vezes resulta da falta de conhecimentos técnicos por parte do Poder Judiciário, ao conceder as demandas que lhe são apresentadas, estando o problema longe de ser resolvido visto que a resolução dele será individual e não coletiva.

Um importante efeito das ações judiciais por medicamentos é o interesse das indústrias farmacêuticas nesse tipo de judicialização, aspecto referido nos Artigos 8 e13. Esse interesse está relacionado ao fornecimento de medicamentos de altos custos, inacessíveis e necessários para uma demanda populacional que opta pela via judicial como meio de garantir tal fármaco. ${ }^{27}$

Nesse interim, infere-se que a indústria farmacêutica no Brasil trabalha sobre os costumes e características do mercado consumidor, quando o Artigo 8 sinaliza que o País é um dos maiores consumidores de medicamentos do mundo e que diferentemente de países com sistema de saúde universal, o Brasil apresenta gastos crescentes com medicamentos desde o ano de 2002.

Assim, o ano de 2009, como aponta o Artigo 25, foi considerado um divisor das relações entre o sistema jurídico e o sistema político do SUS em função do excesso de ações jurídicas na saúde. Isso dialoga com o Artigo 8, no qual discute a necessidade de elaborar uma estratégia para reverter este fenômeno, bem como para monitoramento e resolução das demandas de assistência à saúde. É importante vislumbrar como isso reverbera no SUS, fazendo com que essas ações judiciais deixem de ser meros processos e passem a compor importantes meios de reflexão sobre as necessidades de saúde da população e o que é ofertado pelo sistema público.

24 SILVA, M. V. O processo decisório judicial e a assessoria técnica: a argumentação jurídica e médico-sanitária na garantia do direito à assistência terapêutica no Sistema Único de Saúde. 2012. 186 f. Tese (Doutorado) - Escola Nacional de Saúde Pública Sergio Arouca, Rio de Janeiro, 2012.

25 NOVELINO, M. Manual de direito constitucional. 8. ed. São Paulo: Método, 2013.

26 MACHADO, M. A. A. et al. Judicialização do acesso a medicamentos no Estado de Minas Gerais, Brasil. Rev. saúde pública, São Paulo, v. 45, n. 3, p. 590-598, 2011. Disponível em: <http://www.scielo.br/pdf/rsp/v45n3/2403.pdf>. Acesso em: 15 jul. 2015.

27 NETO, O. H. C. et al. Médicos, advogados e indústria farmacêutica na judicialização da saúde em Minas Gerais, Brasil. Rev. saúde pública, São Paulo, v. 46, n. 5, p. 784-790, 2012. Disponível em: <http://www.scielo.br/pdf/rsp/v46n5/04.pdf>. Acesso em: 12 jul. 2015. 
Cabe, então, compreender os efeitos da judicialização da saúde nas políticas públicas. Os Artigos 9 e 24 discutem que os processos judiciais afetam o orçamento gestor, e a própria ideologia das políticas de saúde quando a decisão judicial é abarrotar os órgãos públicos para de fato garantir um direito constitucional.

O cerne da questão está em não se confundir a defesa do direito à saúde com o direito à procedência do pedido judicial sanitário. Há que se buscar meios diversos, os menos onerosos possíveis para a satisfação do pedido do paciente/autor.

É necessário estabelecer critérios para a atuação judicial nas demandas sanitárias. Deve-se ter o cuidado de não se desigualar iguais. As pretensões individuais devem ser analisadas com prudência, pois é comum que a sua concessão faz de uns privilegiados em face de toda a coletividade.

As decisões judiciais sanitárias devem ter caráter subsidiário frente às políticas públicas de saúde, ou seja, só devem ser utilizadas quando esgotados os meios convencionais. Não se admite que a judicialização da saúde pública seja a regra.

No Brasil há inconcretude na formação das políticas públicas de saúde, em seus aspectos ideológicos, que certas vezes ferem os princípios da equidade e não estabelecem meios para que seja efetiva a sua implantação e implementação no SUS, como retrata o Artigo 24. Isso requer que nos inquietemos com os vazios assistenciais que existem no SUS, em que muitos dos objetos de processos judiciais são disponíveis no sistema público, mas não estão acessíveis a população, como apontado no Artigo 10.

Pondera-se que a criação de políticas públicas mais efetivas e sua implementação destinada especialmente à demanda farmacêutica e realização de procedimentos médicos específicos seriam uma alternativa para reduzir o fenômeno da judicialização da saúde (18).

Contudo, apesar de serem trazidas evidências de que a judicialização da saúde acusa um dano às políticas públicas, aponta-se uma visão contraditória que se considera pertinente: que a judicialização é um meio de acesso a saúde, talvez o mais pertinente ou legítimo para a promoção da igualdade ${ }^{28}$.

Enfim, tem o Judiciário uma difícil missão: buscar soluções para as crescentes demandas sanitárias, ponderando os valores da democracia, da dignidade da pessoa humana, da fundamentalidade do direito à saúde, da limitação orçamentária, da discricionariedade administrativa e da cautela. A judicialização da saúde pública é um processo necessário para o progresso das políticas públicas desta área, todavia há de se ter cautela e critérios racionais para lidar com o tema. É desproporcional impedir que uma criança que depende de um aparelho para respirar tenha este direito resguardado, assim como o é permitir que uma pessoa antecipe sua posição na fila de um transplante pelo fato de ter recorrido ao Judiciário, mesmo que outros necessitem deste transplante em caráter bem mais urgente. O juiz justo é o que decide nem pelo excesso nem pelo descaso, mas pelo equilíbrio. Afinal, in medio est virtus, a virtude está no meio-termo.

\section{Considerações finais}

Este estudo apresentou evidências científicas sobre o fenômeno da judicialização da saúde no Brasil, trazendo o processo histórico da implantação da Constituição Federal de 1988, atualmente vigente no País, e as dificuldades orçamentárias e organizacionais para a garantia do direito à saúde da população.

Constatou-se que a judicialização da saúde apresenta uma característica incomum, quando identificado o caráter individualista dos processos litigiosos que englobam pretensões por tratamentos específicos, atingindo

28 MEDEIROS, M.; DINIZ, D.; SCHWARTZ, I. V. D. A tese da judicialização da saúde pelas elites: os medicamentos para mucopolissacaridase. Ciênc. saúde coletiva, Rio de Janeiro, v. 18, n. 4, p. 1089-1098, 2013. Disponível em: <http://www.scielo.br/pdf/ csc/v18n4/22.pdf>. Acesso em: 08 jul. 2015. 
o interesse coletivo, ao destinar um recurso não previsto da saúde para contemplar uma demanda específica.

Contudo, visualizou-se que, embora haja um excesso de ações judiciais no setor saúde, crescente quantitativamente a cada ano, não são apresentadas propostas para reversão desse fenômeno ou reavaliação/ reformulação de políticas públicas assistenciais na saúde, o que denota um vício entre busca judicial, garantia do direito a saúde, deficit orçamentário e pouca resolutividade da judicialização da saúde.

Nesse trâmite, destaca-se a necessidade de alavancar a criação de políticas públicas que se destinem a minimizar a iniquidade existente na prestação da saúde no Brasil, salientadas e fundamentadas em evidências científicas que permitam uma descrição prévia da realidade em todas as unidades federativas.

\section{Agradecimentos}

Agradecemos o financiamento da Fundação Cearense de Apoio ao Desenvolvimento Científico e Tecnológico (FUNCAP) para a realização deste estudo.

\section{REFERÊNCIAS BIBLIOGRÁFICAS}

BARDIN, L. Análise de Conteúdo. São Paulo: Edições 70, 2011.

BARRETO, J. L. et al. Perfil das demandas judiciais por medicamentos em municípios do Estado da Bahia. Rev. baiana saúde pública, Bahia, v.37, n.3, p. 536-552, 2013. Disponível em: < http://inseer.ibict.br/rbsp/ index.php/rbsp/article/viewFile/574/pdf_425>. Acesso em: 04 jun. 2015.

BARTOLOMEI, C.E.F. et al. Medicina e direito: atuação na integralidade destes dois saberes. Diagn. tratamento, Brasília, v. 15, n. 1, p. 39-42, 2010. Disponível em:<http://files.bvs.br/upload/S/1413-9979/2010/ v15n1/RDTv15n1a1146.pdf>. Acesso em: 05 jul. 2015.

BRASIL. Coordenação De Aperfeiçoamento De Pessoal De Nível Superior. Diretoria de avaliação. Webqualis. 2012. Disponível em: <http://qualis.capes.gov.br/webqualis>. Acesso em: 05 jul. 2015.

BRASIL. Conselho Nacional de Secretários de Saúde. Para entender a gestão do SUS. Brasília: CONASS, 2003.

BRASIL. Conselho Nacional de Secretários de Saúde. SUS: avanços e desafios. Brasília: CONASS; 2006.

BRASIL. Constituição (1988). Constituição da República Federativa do Brasil. Brasília: Senado Federal, 1988.

BRAUNER, M.C.C.; CIGNACHI; J.C.B. O direito à saúde e o papel do poder judiciário: uma perspectiva acerca das dimensões constitucionais e das tutelas coletivas. Juris, Rio Grande, v. 16, p.29-48, 2011. Disponível em: <http://www.seer.furg.br/juris/article/view/3420/2042>. Acesso em: 05 jun. 2015.

CARDOSO, L.; GALERA, S. A. F. Internação psiquiátrica e a manutenção do tratamento extra-hospitalar. Revista Esc Enferm USP, São Paulo, v. 46, n.1, p. 87-94, 2011. Disponível em: < http://www.scielo.br/pdf/ reeusp/v45n1/12.pdf>. Acesso em: 10 jul. 2015.

CENTRO COCHRANE DO BRASIL. Quem somos. Disponível em: <http://www.centrocochranedobrasil. org.br $/ \mathrm{cms} /$ index.php?option $=$ com_content\&view $=$ article\&id $=13 \&$ Itemid $=4>$.

DALLARI, S.G. Direito sanitário. In: BRASIL. Ministério da Saúde. Direito Sanitário e Saúde Pública: coletânea de textos. Brasília: Ministério da Saúde, 2003. 375p.

PITTA, A. M. F. Um balanço da reforma psiquiátrica brasileira: instituições, atores e políticas. Ciênc. saúde coletiva, Rio de Janeiro, v. 16, n. 12, p. 4579-4589, 2011. Disponível em: < http://www.scielo.br/pdf/csc/ 
v16n12/02.pdf>. Acesso em: 20 jul. 2015.

FLEURY, S. Judicialização pode salvar o SUS. Saúde debate, Rio de Janeiro, v. 36, n. 93, p. 159-162, 2012. Disponível em: <http://peep.ebape.fgv.br/sites/peep.ebape.fgv.br/files/A_judicializacao_pode_salvar_o_ SUS_Saude_em_Debate.pdf>. Acesso em: 30 jun. 2015.

MACHADO, M. A. A. et al. Judicialização do acesso a medicamentos no Estado de Minas Gerais, Brasil. Rev. saúde pública, São Paulo, v. 45, n. 3, p. 590-598, 2011. Disponível em: <http://www.scielo.br/pdf/rsp/ v45n3/2403.pdf>. Acesso em: 15 jul. 2015.

MEDEIROS, M.; DINIZ, D.; SCHWARTZ, I. V. D. A tese da judicialização da saúde pelas elites: os medicamentos para mucopolissacaridase. Ciênc. saúde coletiva, Rio de Janeiro, v. 18, n. 4, p. 1089-1098, 2013. Disponível em: <http://www.scielo.br/pdf/csc/v18n4/22.pdf>. Acesso em: 08 jul. 2015.

MORAES, A. Direitos Humanos Fundamentais. São Paulo: Atlas, 2002.

NETO, O. H. C. et al. Médicos, advogados e indústria farmacêutica na judicialização da saúde em Minas Gerais, Brasil. Rev. saúde pública, São Paulo, v. 46, n. 5, p. 784-790, 2012. Disponível em: <http://www.scielo. br/pdf/rsp/v46n5/04.pdf>. Acesso em: 12 jul. 2015.

NOVELINO, M. Manual de direito constitucional. 8. ed. São Paulo: Método, 2013.

NUNES, C. F. O. Judicialização do direito à saúde no estado do Ceará, Brasil: cenários e desafios. 2014. 222f. Dissertação (Mestrado). Universidade Federal do Ceará, Fortaleza, 2014.

PANDOLFO, M.; DELDUQUE, M. C.; AMARAL, R.G. Aspectos jurídicos e sanitários condicionantes para o uso da via judicial no acesso aos medicamentos no Brasil. Rev. salud pública, São Paulo, v. 14, n. 2, p. 340-349, 2012. Disponível em: <http://www.scielosp.org/pdf/rsap/v14n2/v14n2a14.pdf>. Acesso em: 20 jul. 2015.

PEPE, V. L. E. et al. A judicialização da saúde e os novos desafios da gestão da assistência farmacêutica. Ciênc. saúde coletiva, Rio de Janeiro, v.15, n.5, p. 2405-2414, 2010. Disponível em: < http://www.scielo.br/pdf/ csc/v15n5/v15n5a15.pdf>. Acesso em: 18 jul. 2015.

PEREIRA, I. D. F; LAGES, I. Diretrizes curriculares para a formação de profissionais de saúde: competências ou práxis? Trab. Educ. saúde, Rio de Janeiro, v. 11, n. 2, p. 319-38, 2013. Disponível em: <http://www. scielo.br/pdf/tes/v11n2/a04v11n2.pdf>. Acesso em: 02 jul. 2015.

POLIT, D. F.; BECK, C. T. Fundamentos de pesquisa em enfermagem: avaliação de evidências para a prática de enfermagem. 7. ed. Porto Alegre: Artmed, 2011.

PRIORI, A. et al. A ditadura militar e a violência contra os movimentos sociais, políticos e culturais. In: PRIORI, A. et al. História do Paraná: séculos XIX e XX. Maringá: Eduem, 2012. p. 199-215.

SILVA, M.V. O processo decisório judicial e a assessoria técnica: a argumentação jurídica e médico-sanitária na garantia do direito à assistência terapêutica no Sistema Único de Saúde. 2012. 186 f. Tese (Doutorado) Escola Nacional de Saúde Pública Sergio Arouca, Rio de Janeiro, 2012.

SOUZA, A. M. C. Universalidade da saúde no Brasil e as contradições da sua negação como direito de todos. Katálysis, Florianópolis, v. 17, n. 2, p. 227-234, 2014. Disponível em: <https://periodicos.ufsc.br/index. php/katalysis/article/view/32679/28074>. Acesso em: 08 jul. 2015.

SOUZA, C. R.; BOTAZZO, C. Construção social da demanda em saúde. Physis, Rio de Janeiro, v. 23, n. 2, p. 393413, 2013. Disponível em: <http://www.scielo.br/pdf/physis/v23n2/v23n2a05.pdf>. Acesso em: 17 jul. 2015.

TOJAL, S. B. B. A constituição dirigente e o direito regulatório do estado social: o direito sanitário. In: BRASIL. Ministério da Saúde. Direito sanitário e saúde pública: coletânea de textos. Brasília: Ministério da Saúde, 2003. v.1. 375p. 


\section{REVISTA BRASILEIRA DE POLÍTICAS PÚBLICAS BRAZILIAN JOURNAL OF PUBLIC POLICY}

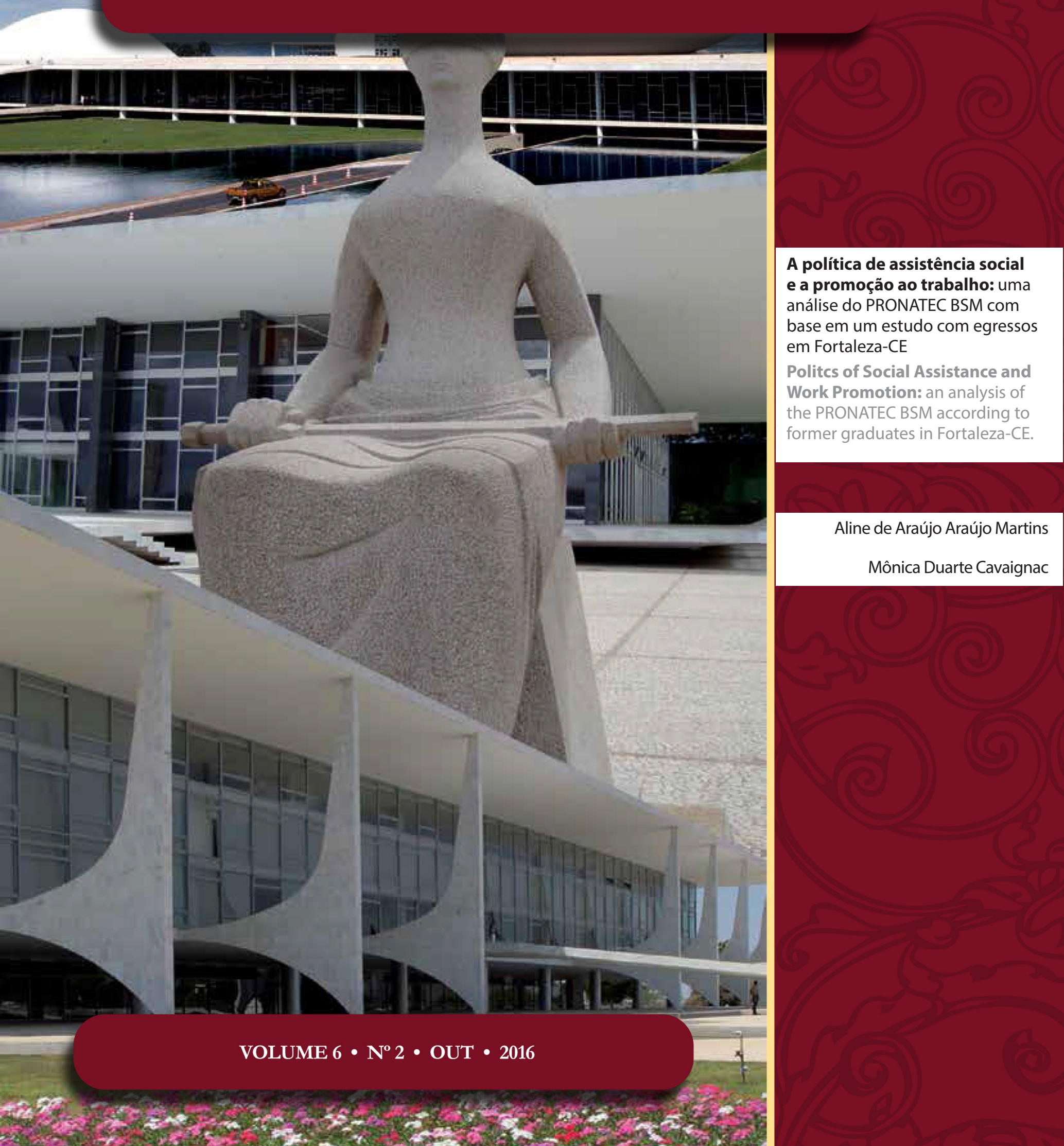




\title{
A política de assistência social e a promoção ao trabalho: uma análise do PRONATEC BSM com base em um estudo com egressos em Fortaleza-CE *
}

\author{
Politcs of Social Assistance and Work \\ Promotion: an analysis of the PRONATEC BSM \\ according to former graduates in Fortaleza-CE.
}

Aline de Araújo Araújo Martins **

Mônica Duarte Cavaignac***

\section{Resumo}

O presente artigo analisa o Programa Nacional de Acesso ao Ensino Técnico e Emprego (PRONATEC) Brasil Sem Miséria, com base em um estudo de dados obtidos numa pesquisa de mestrado. Discute-se, portanto, o PRONATEC BSM como uma estratégia de inserção e/ou reinserção da população pobre e extremamente pobre no mercado de trabalho via qualificação profissional. A metodologia utilizada pautou-se na pesquisa bibliográfica, documental e empírica, sendo de natureza qualitativa. O estudo foi realizado no município de Fortaleza-CE, tendo como sujeitos da pesquisa egressos encaminhados ao Programa por meio do Centro de Qualificação Profissional (Casa Brasil) do bairro Granja Portugal, além de profissionais da Secretaria Municipal de Trabalho, Desenvolvimento Social e Combate à Fome (SETRA). Conclui-se que o Programa não tem suprido, efetivamente, as deficiências de escolarização da população à qual se destina, nem garantido sua inserção ou reinserção no mercado formal de trabalho, devido à ausência de articulação com outras políticas públicas, especialmente as políticas de educação e de emprego e de renda. A relevância deste estudo está na análise tanto das configurações da política de assistência social quanto do trabalho no cenário contemporâneo, refletindo sobre as bases teórico-ideológicas que fundamentam as políticas de promoção ao trabalho na atual conjuntura política brasileira.

Palavras-chaves: Trabalho. Política de Assistência Social. PRONATEC BSM.

** Assistente social. Mestre em Serviço Social, Trabalho e Questão Social (MASS) pela Universidade Estadual do Ceará (UECE). Professora do curso de Serviço Social da Faculdade Ratio. E-mail: aline88_am@hotmail.com.

*** Mestre em Educação e Doutora em Sociologia pela Universidade Federal do Ceará (UFC). Professora do Curso de Serviço Social e do Mestrado Acadêmico em Serviço Social, Trabalho e Questão Social (MASS) da Universidade Estadual do Ceará (UECE). E-mail: monicacavaignac@bol.com.br.

\section{Abstract}

This article analyzes the Programa Nacional de Acesso ao Ensino Técnico e Emprego (PRONATEC) Brasil Sem Miséria, from a study of data obtained during research for a master's degree. It discusses PRONATEC BSM as a strategy of insertion and/or rehabilitation of poor and extremely poor people into the market, through professional qualification. The methodolo- 
gy used was based on bibliographic, documentary and empirical research of a qualitative nature. The study was conducted in the city of Fortaleza-CE, with the research subjects being PRONATEC-graduates, who were referred to the program through the Centro de Qualificação Profissional (Casa Brasil), from the neighborhood Granja Portugal, as well as professionals of the Secretaria Municipal de Trabalho, Desenvolvimento Social e Combate à Fome (SETRA). This study concluded that PRONATEC BSM has not alleviated the schooling deficiencies of the population for which it was intended, nor has it guaranteed their integration or reintegration into the formal labor market, especially since there is no effective coordination with other public policies, especially policies of education and of employment and income. The relevance of this study lies in its analysis of both the settings of social welfare policy, as in the work in the contemporary scenario, and its reflection upon the theoretical/ideological foundations that underlie the policies designed to increase employability in the current time period of Brazilian politics.

Keywords: Work. Social Welfare Policy. PRONATEC BSM.

\section{INTRODUÇÃo}

A partir da Constituição Federal (CF) de 1988, a assistência social no Brasil tramita para o campo das políticas públicas de seguridade social, passando o Estado a assumir a primazia na sua condução. Regulamentada pela Lei Orgânica da Assistência Social - LOAS (1993), alterada pela Lei no 12.435/2011, e pela Política Nacional de Assistência Social - PNAS (2004), "será prestada a quem dela necessitar" e tem como um de seus objetivos "a promoção da integração ao mercado de trabalho" (art. 203, caput e III, CF/1988). Atualmente, uma parcela, cada vez maior da população brasileira, tem se tornado alvo dessa política, sobretudo em decorrência dos efeitos do neoliberalismo e da reestruturação produtiva instaurados na década de 1990, tendo em vista a inserção do País na economia mundial e sua adequação às estratégias dos organismos transnacionais do capital diante da crise que se inicia nos anos $1970^{1}$.

Marcada pela crescente incorporação de tecnologias poupadoras de força de trabalho ao processo de produção de mercadorias e de serviços, entre as quais se destacam a automação, a informática e a microeletrônica, a reestruturação produtiva traz como principais consequências a flexibilização das relações de trabalho e o aumento do desemprego estrutural, levando uma enorme quantidade de pessoas, destituídas do trabalho associado a garantias e direitos, a dependerem do Estado para sobreviver, elevando, significativamente, a demanda por políticas sociais. Por outro lado, a adoção das diretrizes neoliberais estabelecidas pelo Consenso de Washington ${ }^{2}$, tais como abertura comercial, privatização das empresas estatais e focalização das políticas públicas, interfere, diretamente, nas relações do Estado com a sociedade, transferindo suas responsabilidades ora para o mercado, ora para o chamado Terceiro Setor, em amplo processo de mercantilização e de refilantropização do atendimento às necessidades sociais.

1 Esta crise se diferencia das crises anteriores do capital por seu caráter estrutural. Segundo Mészáros (2011, p. 100), “sob as condições de crise estrutural do capital, seus constituintes destrutivos avançam como força extrema, ativando o espectro da incontrolabilidade total numa forma que faz prever a autodestruição, tanto para este sistema reprodutivo social excepcional, em si, como para a humanidade em geral". Antunes (2001) aponta os principais traços que foram evidenciados com a crise estrutural do capital: esgotamento do padrão de acumulação taylorista/fordista; hipertrofia da esfera financeira em detrimento da esfera produtiva; crise fiscal do Estado, levando à necessidade de contenção de gastos públicos; acentuação das privatizações; desregulamentação e flexibilização do trabalho; aumento do desemprego, entre outros.

2 O Consenso de Washington, realizado em 1989 pelos Estados Unidos da América, Banco Mundial e Fundo Monetário Internacional (FMI), objetivou discutir medidas a serem adotadas pelos países da América Latina, a fim de que estes se adequassem aos interesses do capital internacionalizado. Uma das medidas foi a diminuição da intervenção do Estado nas relações econômicas e sociais, abrindo mais espaço para o mercado. "Assim, as políticas de ajuste estrutural propostas e aceitas pela maioria dos governos dos países periféricos, principalmente os latino-americanos, compreendem: estabilização fiscal e monetária (controle da inflação); liberalização do comércio e dos fluxos de capital; privatizações; reformas financeiras, tributárias, previdenciárias e administrativas; desregulamentação das relações trabalhistas e inflexões nas políticas sociais públicas” (CARDOZO, 2006, p. 205). 
Assim, para além dos idosos, crianças, adolescentes e pessoas com deficiência que não possuem os meios de prover a própria manutenção ou de tê-la provida pela família, o público-alvo da política de assistência social passa a abranger, cada vez mais, trabalhadores que vivenciam o desemprego, o subemprego e o trabalho precarizado, ou seja, sem proteção social, constituindo o que a PNAS (2004) classifica como pessoas em condição de vulnerabilidade social, em decorrência da ausência ou precarização de renda. Diante dessa realidade, faz-se necessário compreender como tem se efetivado o objetivo da "promoção da integração ao mercado de trabalho" no âmbito da referida política, conforme previsto no texto constitucional, bem como analisar os limites e desafios das principais frentes de atuação do Estado nessa perspectiva, entre as quais se destaca neste artigo o Programa Nacional de Acesso ao Ensino Técnico e Emprego (PRONATEC).

É fato que os governos petistas de Lula (2003-2010) e Dilma Rousseff (2011-2016) demonstraram uma maior preocupação com a assistência social, expressa, principalmente, nos programas de transferência de renda voltados para a erradicação da extrema pobreza ${ }^{3}$, tendo sido esta uma das maiores metas do primeiro mandato de Dilma Rousseff (2011-2014), com o seguinte lema de campanha: "Brasil: país rico é país sem pobreza". Como resposta ao fenômeno da extrema pobreza, o referido governo criou o Plano Brasil Sem Miséria (BSM), que agrega distribuição de renda, acesso a serviços sociais e inclusão produtiva. É nesse último eixo que o plano se vincula ao PRONATEC, constituindo o denominado PRONATEC BSM, propagado como o programa "carro-chefe" do governo Dilma no que diz respeito à qualificação profissional para o trabalho.

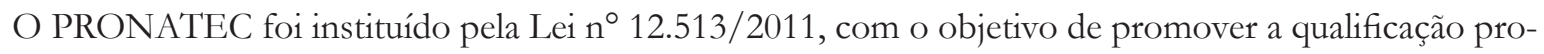
fissional e o emprego, tendo em vista capacitar 1 (um) milhão de brasileiros até o ano de 2014, ano em que ocorreu a Copa do Mundo no Brasil; e adquiriu relevância ainda maior no último mandato de Dilma Rousseff, iniciado em janeiro de 2015, com o novo lema: "Brasil, Pátria Educadora". Trata-se de um programa descentralizado, com alguns eixos, tais como: PRONATEC Bolsa-Formação Estudante e Bolsa-Formação Trabalhador, PRONATEC Jovem, PRONATEC Campo, PRONATEC Seguro-Desemprego, dentre outros. Este estudo tem como foco o PRONATEC Brasil Sem Miséria, voltado, especialmente, para o público da assistência social, isto é, pessoas inscritas no Cadastro Único ${ }^{4}$, beneficiárias ou não do programa de transferência de renda denominado Bolsa Família, com idade a partir de 16 anos e com escolaridade desde o letramento inicial ao ensino médio (BRASIL, MDS, 2014) 5 .

Nesse contexto, torna-se importante refletir sobre as bases ideológicas que sustentam o discurso da qualificação profissional, em especial de pessoas em situação de pobreza e de extrema pobreza, historicamente prejudicadas no que se refere ao acesso à educação pública de qualidade.

Pereira (2012) observa que hoje, no Brasil, ocorre uma mudança no confronto valorativo entre trabalho e assistência social, ou seja: não é mais o trabalho que dignifica o usuário da assistência social, mas é essa política que termina por se constituir em alternativa mais digna ao trabalhador, quando este se vê diante do trabalho precário. Assim, há uma equivocada valorização em torno da assistência social, tendo esta transita-

3 A extrema pobreza é definida pelo governo a partir do fator econômico. Até 2014 considerava-se família pobre aquela cuja renda per capta fosse de $\mathrm{R} \$ 140,00$ mensal e extremamente pobre aquela cuja renda per capta fosse igual ou inferior ao valor mensal de $\mathrm{R} \$$ 70,00 . No entanto, a partir de $1^{\circ}$ de junho de 2014 , o valor de definição da linha da pobreza e extrema pobreza no Brasil é reajustado para R \$ 154,00 e R \$77, 00 per capta, respectivamente. Dados extraídos do site do MDS: http://www.mds.gov.br/saladeimprensa/ noticias/2014/maio/beneficios-do-bolsa-familia-tem-reajuste-de-10. Acesso em: 10 jul. 2014.

4 O Cadastro Único para Programas Sociais do Governo Federal (Cadastro Único) é um instrumento de identificação e caracterização das famílias de baixa renda, permitindo que o governo conheça melhor a realidade socioeconômica dessa população. Nele são registradas informações como características da residência, identificação de cada pessoa, escolaridade, situação de trabalho e renda etc.. Constitui-se, portanto, no principal instrumento do Estado brasileiro para selecionar e incluir famílias de baixa renda em programas federais, sendo utilizado, obrigatoriamente, para a concessão dos benefícios do Programa Bolsa Família, da Tarifa Social de Energia Elétrica, do Programa Minha Casa Minha Vida, da Bolsa Verde, entre outros. Informações disponíveis em: http://mds. gov.br/assuntos/cadastro-unico/o-que-e-e-para-que-serve. Acesso em 30 ago.2016.

5 BRASIL. Cartilha Pronatec Brasil Sem Miséria. Disponível em: http://www.camacari.ifba.edu.br/attachments/article/20/2013_ PronatecCartilhaBSM_v2012.pdf. Acesso em 31 ago. 2014. 
do da condição de "gata borralheira" para a de "cinderela" entre as políticas públicas, sendo utilizada como uma estratégia imediata para aliviar a pobreza. Mota (2010) acrescenta que é um erro designar à assistência social papéis que não lhe são cabíveis, colocando-a como a política que combaterá a pobreza e a desigualdade social. Lopes (2012, p. 165), por sua vez, questiona: "Política de assistência social ou de trabalho?”.

O fato é que a questão do trabalho tem ganhado relevância na política de assistência social e isto é perceptível no município de Fortaleza, em que foi criada, em 2013, na gestão do prefeito Roberto Claudio, do Partido Democrático Trabalhista (PDT), a Secretaria Municipal de Trabalho, Desenvolvimento Social e Combate à Fome (SETRA), em substituição à Secretaria Municipal de Assistência Social (SEMAS), criada em 2005, no governo de Luiziane Lins, do Partido dos Trabalhadores (PT), para consolidar o Sistema Único de Assistência Social (SUAS) na capital do Ceará. Desenvolvido nesta capital desde 2011, o PRONATEC BSM conta com alguns equipamentos da Política de Assistência Social voltados para a qualificação profissional da população fortalezense, a exemplo dos Centros Integrados de Referência da Qualificação Profissional, mais conhecidos como Casa Brasil. Foi na Casa Brasil localizada no bairro Granja Portugal, um dos bairros de maior vulnerabilidade social do município de Fortaleza, que foram abordados os sujeitos do presente estudo, egressos de cursos ofertados pelo PRONATEC BSM, cujas percepções são importantes para análise dos limites e desafios desse Programa como estratégia de integração dos usuários da política de assistência social no mercado de trabalho.

\section{QUESTÃo SOCIAL, ASSISTÊNCIA SOCIAL E A ÊNFASE NA ERRADICAÇÃo DA POBREZA No BRASIL CONTEMPORÂNEO}

De acordo com Iamamoto (2014), a questão social compreende o conjunto de expressões das desigualdades sociais engendradas na e pela sociedade capitalista madura, impensáveis sem a intermediação do Estado. Tem sua gênese no caráter coletivo da produção, contraposto à apropriação privada da própria atividade humana — o trabalho —, das condições necessárias à sua realização, assim como de seus frutos. Ela é, pois, indissociável da emergência do "trabalhador livre", que depende da venda de sua força de trabalho como meio de satisfação de suas necessidades vitais.

Embora a raiz da questão social se encontre na própria lei geral de acumulação capitalista - que, ao substituir trabalho vivo por trabalho morto (incorporado aos meios materiais de produção) visando atingir níveis mais elevados de mais-valia, acaba constituindo uma população supérflua para as necessidades do capital, levada a viver sob o pauperismo -, alguns aspectos reconfiguram a questão social na contemporaneidade, atingindo as esferas da economia, da produção, da política e da cultura, em todos os países capitalistas ${ }^{6}$.

$\mathrm{Na}$ esfera econômica, a mundialização e a financeirização do capital trazem como principais consequências: a submissão dos países de capitalismo periférico à lógica dos organismos multilaterais; a subordinação da política social à política econômica; a primazia dos investimentos especulativos em detrimento dos investimentos na produção; e o aumento da concentração de riqueza e da desigualdade social.

$\mathrm{Na}$ esfera da produção, o modelo de acumulação flexível substitui o padrão produtivo taylorista/fordista num processo de reestruturação produtiva, com implicações diretas nos processos de trabalho, nas formas de consumo e de gestão da foça de trabalho, nos direitos trabalhistas e na organização política dos trabalhadores. Além do desemprego estrutural, decorrente da incorporação de tecnologias cada vez mais poupadoras de trabalho vivo, tem-se a flexibilização e a precarização das relações e das condições de trabalho, com rebaixamento salarial, desregulamentação de direitos e fragilização dos organismos de representação da classe trabalhadora, a qual, conforme afirma Antunes (1995), torna-se cada vez mais heterogênea, fragmentada e complexa.

6 IAMAMOTO, Marilda Villela. A questão social no capitalismo. In: Associação Brasileira de Ensino e Pesquisa em Serviço Social. Revista Temporalis. Ano 2, n.3 (jan/jul.2001). Brasília: ABEPSS, Grafline, 2001. 
Já na esfera política, há uma profunda mudança nas relações entre o Estado e a sociedade civil, em consequência do neoliberalismo. O Estado passa a priorizar os interesses mercantis em detrimento dos interesses sociais, reduzindo suas ações no enfrentamento da questão social, privatizando a coisa pública e restringindo os investimentos em políticas, programas e projetos sociais.

Por fim, há, também, mudanças significativas na esfera da cultura. A sociedade de mercado transforma as relações sociais em relações mercantis, baseadas no individualismo, na competitividade, na produtividade, na rentabilidade e na eficácia, ou seja, converte a mentalidade humana em uma mentalidade utilitarista, amarrando a sociabilidade às leis mercantis.

Nesse cenário, Iamamoto ressalta que:

A "velha questão social" metamorfoseia-se assumindo novas roupagens. Ela evidencia uma imensa fratura entre o desenvolvimento das forças produtivas do trabalho social e as relações que o sustentam. Crescem as desigualdades e afirmam-se as lutas do dia a dia contra as mesmas - na sua maioria silenciadas pelos meios de comunicação - no âmbito do trabalho, do acesso a direitos e serviços no atendimento às necessidades básicas dos cidadãos, das diferenças étnico-raciais, religiosas, de gênero, etc. A globalização do capital globaliza também a questão social, atingindo não apenas os países pobres que lideram o ranking mundial das desigualdades, mas espraiando-se aos recantos mais sagrados do capitalismo mundial, sob formas particulares e distintas segundo as características nacionais ${ }^{7}$.

No Brasil, atualmente, dois projetos societários distintos estão em constante tensão: um que visa à democratização dos direitos sociais conquistados com a Constituição Federal de 1988; e outro que visa à mercantilização desses direitos. Isto repercute, diretamente, nas respostas do Estado à questão social, que têm se dado, principalmente, por meio da política de assistência social, com base em ações focalizadas na população em situação de pobreza e de extrema pobreza.

Em contexto marcado pela reorganização do sistema econômico, político e ideológico de dominação do capital, os anos 1990 no Brasil são marcados pela adequação do País aos interesses do capitalismo mundial, a partir de reformas estruturais iniciadas pelo governo de Fernando Collor (1990-1992) e aprofundadas durante o governo de Fernando Henrique Cardoso - FHC (1995-2002), inclusive a chamada contrarreforma do Estado ${ }^{8}$.

Diante dessa realidade, a questão social passa a ser reduzida às manifestações da extrema pobreza, trazendo implicações para as políticas sociais, como a assistência social, que tem sido vista como aquela responsável por absorver e gerenciar as consequências do desemprego e da precarização do trabalho. É nesse sentido que ela ganha centralidade no sistema de seguridade social brasileiro.

Ao assumir o compromisso de conduzir o desenvolvimento social e o crescimento econômico do País, o governo Lula (2003-2010) parece resgatar a centralidade do Estado no atendimento às necessidades sociais. Entretanto, em vez de retomar os investimentos no e do setor público, sua proposta econômica se ancora nos mesmos pilares macroeconômicos do governo anterior, favorecendo as decisões e os investimentos privados ${ }^{9}$.

No que se refere às políticas sociais, a proposta do governo Lula é aumentar a renda e o consumo dos pobres, enfatizando a qualificação dos trabalhadores como meio de melhoria de distribuição de renda. Durante esse governo, a assistência social ganha maior visibilidade, avançando, especialmente, no âmbito legal, apesar dos limites à sua efetivação como política pública. Ela passa a ser direcionada pela Política Nacional de Assistência Social - PNAS (2004) e conduzida pelo Sistema Único de Assistência Social - SUAS (2005),

7 MARILDA, VILLELA. A questão social no capitalismo. In: Associação Brasileira de Ensino e Pesquisa em Serviço Social. Revista Temporalis. Ano 2, n.3 (jan/jul.2001). Brasília: ABEPSS, Grafline, 2001, p. 21.

8 BEHRING, Elaine Rosetti. Brasil em contrarreforma: desestruturação do Estado e perda de direitos. São Paulo: Cortez, 2008.

9 BEHRING, Elaine Rossetti. O Plano Plurianual do governo Lula: um Brasil de todos? In: FREIRE, Lúcia M.B. e CASTRO, Alba Tereza (orgs.). Serviço social, política social e trabalho: desafios e perspectivas para o século XXI. $3^{a}$ ed. São Paulo: Cortez; Rio de Janeiro: UERJ, 2010. 139-157 p. 
que regula e organiza as ações socioassistenciais em todo o território nacional. Embora tenha havido uma queda nos índices de extrema pobreza entre 2004-2009, no País milhões de pessoas ainda vivenciavam essa condição, de acordo com dados do Instituto de Pesquisa Econômica Aplicada (IPEA) ${ }^{10}$.

Com o lema "Brasil: país rico é país sem pobreza", o primeiro governo de Dilma Rousseff (20112014) estabelece como diretrizes "a garantia dos direitos humanos com redução das desigualdades sociais, regionais, étnico-raciais e de gênero", bem como "o estímulo e a valorização da educação, da ciência e da tecnologia" 11 . Em seu discurso, enfatiza o crescimento econômico com geração de emprego, estabilidade macroeconômica e diminuição da desigualdade e da pobreza.

Dando continuidade às ações desenvolvidas durante o governo de Lula, as principais estratégias de enfrentamento da pobreza pelo atual governo de Dilma Rousseff, iniciado em janeiro de 2015, têm sido: o Programa Bolsa Família, a Segurança Alimentar e Nutricional, o SUAS e o Plano Brasil Sem Miséria, constituindo-se esse último na novidade para a erradicação da extrema pobreza no Brasil, tendo sido criado em junho de 2011.

De acordo com pesquisa realizada pela Comissão Econômica para a América Latina (CEPAL) ${ }^{12}$, a pobreza no Brasil caiu de 18,6\%, em 2012, para 18\%, em 2013. Entretanto, a mesma pesquisa aponta que a extrema pobreza no País aumentou de 5,4\% para 5,9\% nesse mesmo período. De 34 (trinta e quatro) milhões de brasileiros em situação de pobreza, 11 (onze) milhões estão na extrema pobreza ${ }^{13}$. Segundo o estudo, desde o ano de 2012, a redução da extrema pobreza está estancada.

De fato, a pobreza é uma das principais expressões da questão social e um dos maiores problemas que a sociedade brasileira vem enfrentando, segundo informações publicadas pelo Ministério de Desenvolvimento Social e Combate à Fome - MDS ${ }^{14}$. Tal problemática, no entanto, não é recente no Brasil, mas se constitui como resultado da própria formação sócio-histórica do País, marcada pela colonização e exploração econômica, expressando-se atualmente na falta de estabilidade econômica, na dificuldade para com o trabalho formal e, consequentemente, para com a obtenção de renda e no alastramento do quadro de pobreza (STRAPASSON e PAMPLONA, 2014). Couto (et.al., 2012) assinala que tal fenômeno não se limita às privações materiais, mas alcança diversas outras dimensões da vida de um cidadão. Assim, a pobreza não deve ser compreendida numa perspectiva unidimensional, mas

como um fenômeno multidimensional e inter-relacionado aos elementos sociais, culturais, etários, de gênero em confluência com aspectos econômicos, de modo que decorre de um complexo sistema de carência de recursos múltiplos desembocando na fome e na privação física ${ }^{15}$.

Mesmo sendo a pobreza considerada um fenômeno multidimensional, nas publicações oficiais do governo federal, é o fator renda que define a linha da pobreza e da extrema pobreza no País, seguindo as orientações do Banco Mundial ${ }^{16}$.

10 BRASIL. INSTITUTO DE PESQUISA ECONÔMICA APLICADA (IPEA). Políticas sociais: acompanhamento e análise, v. 1 - Brasília: IPEA, 2012.

11 Lei n ${ }^{\circ}$ 12.593/2012, que lança o Plano plurianual (PPA) para os anos de 2012 a 2015, plano este que define diretrizes, objetivos e metas das ações do governo pelo período de quatro anos. O PPA do governo Dilma é intitulado "Plano Plurianual 2012-2015 Mais Brasil: mais desenvolvimento, mais igualdade, mais participação”, Disponível em: http://www.planalto.gov.br/ccivil_03/_Ato20112014/2012/Lei/L12593.htm\#anexo. Acesso em 23 ago. 2014.

12 Citação extraída do site do MDS: http://www.mds.gov.br/saladeimprensa/noticias/2014/maio/beneficios-do-bolsa-familiatem-reajuste-de-10. Acesso em 11 jul. 2014.

13 Dados disponíveis em: http://www.cepal.org/sites/default/files/pr/files/tabla_panoramasocial-2014_port.pdf e http:// agenciabrasil.ebc.com.br/internacional/noticia/2015-01/reducao-da-pobreza-na-americalatina-ficou-estavel-aponta-cepal. Acesso em 30 jul. 2015.

14 BRASIL. Ministério do Desenvolvimento Social e Combate à Fome. Caderno de Estudos do Curso de Indicadores para Diagnóstico do SUAS e do Plano Brasil sem Miséria. Brasília, DF: MDS, Secretaria de Avaliação e Gestão da Informação; Secretaria Nacional de Assistência Social, 2013. 210p.

15 STRAPASSON, Karoline; PAMPLONA, Danielle Anne. A escolha pública econômica para erradicar a pobreza extrema no Brasil. In: Revista Brasileira de Políticas Públicas. Volume 4. N. 2. Jul-Dez 2014, p. 55.

16 BRASIL. Ministério do Desenvolvimento Social e Combate à Fome. Caderno de Estudos do Curso de Indicadores para 
Em verdade, não há como compreender os fenômenos da pobreza e da extrema pobreza, isoladamente, sem situá-los na esfera das relações de produção capitalistas, tampouco combatê-lo com ações focalizadas. Mota (2010) observa que há uma tendência a reduzir a questão social às manifestações da pobreza, buscando enfrentá-la com políticas de inserção. Assim, o discurso que propaga a assistência social como o mais importante mecanismo de proteção social brasileiro no combate à desigualdade social constitui-se em um mito, uma vez que tal política não conseguirá, por si só, desempenhar tal papel.

Embora a erradicação da extrema pobreza passe, necessariamente, pela transferência de renda ${ }^{17}$, sendo esta um incentivo inicial para o processo de empoderamento da população vulnerabilizada, o verdadeiro fortalecimento da autonomia requer ir muito além, sendo fundamental a articulação política e a participação direta das pessoas assistidas na gestão das políticas públicas, via controle e aprimoramento (STRAPASSON e PAMPLONA, 2014).

As configurações assumidas pela política de assistência social no contexto contemporâneo brasileiro estão relacionadas à inserção do Brasil na economia internacional, em especial à sua adequação à mundialização do capital sob sua forma financeirizada, com base na qual se tem a intensificação da exploração do trabalho e a redução dos custos com sua reprodução, uma vez que o capital financeiro prioriza investimentos na esfera da especulação em detrimento da esfera produtiva, contribuindo, assim, para a supressão dos postos de trabalho e crescimento do desemprego ${ }^{18}$.

Diante desse contexto, o governo de Dilma Rousseff cria o Programa Nacional de Acesso ao Ensino Técnico e Emprego - PRONATEC, com o objetivo de promover qualificação profissional para a população, tendo em vista sua inserção no mercado de trabalho. Um dos eixos do Programa, o PRONATEC Brasil Sem Miséria, volta-se, especialmente, para a população pobre e extremamente pobre, público-alvo da política de assistência social, cuja tendência atual, conforme assinala Sitcovsky $(2010)^{19}$, é assumir a função, antes pertencente ao trabalho assalariado, de integrar os indivíduos à ordem social.

\section{O PRONATEC BSM NO MUNICÍPIO de ForTALEZA: PERCEPÇõeS DE PROFISSIONAIS E EGRESSOS DO PROGRAMA}

As informações que aqui se apresentam são frutos de uma pesquisa de mestrado realizada entre os anos de 2014 e 2016, em Fortaleza, em que foram entrevistados egressos do PRONATEC BSM, bem como profissionais que atuam na Secretaria Municipal de Desenvolvimento Social e Combate à Fome (SETRA), responsável pela gestão da política de assistência social nesse município - desde 2013, quando passou a substituir a Secretaria Municipal de Assistência Social (SEMAS) e, consequentemente, pela execução do referido Programa ${ }^{20}$.

Diagnóstico do SUAS e do Plano Brasil sem Miséria. Brasília, DF: MDS, Secretaria de Avaliação e Gestão da Informação; Secretaria Nacional de Assistência Social, 2013. 210p.

17 Em outros países, os programas de transferência de renda não visam, necessariamente, ao combate à pobreza, embora tenham caráter redistributivo. Todavia, no Brasil, devido aos índices de pobreza e de desigualdade historicamente muito elevados, o combate à pobreza se constitui como um dos principais objetivos de tais programas (ROCHA et.al., 2014, p. 140).

18 SILVA, Sheyla Suely de Souza. Contradição da Assistência Social no governo "neodesenvolvimentista" e suas funcionalidades ao capital. In: Serviço Social e Sociedade. São Paulo, n.113, p. 86-105, jan./mar.2013.

19 SITCOVSKY, Marcelo. Particularidades da expansão da assistência social no Brasil. In: MOTA, Ana Elizabete (org.). O Mito da Assistência Social: ensaios sobre Estado, política e sociedade. 4. ed. - São Paulo: Cortez, 2010. 147-179 p.

20 Foram entrevistados onze egressos, dos sexos feminino e masculino, com idade entre 18 a 50 anos. A amostra se deu por acessibilidade, primeiro tendo em vista que o Programa se destina a um público bastante diversificado, ou seja, pessoas inscritas no Cadastro Único com idade a partir de 16 anos; segundo, devido à dispersão dos egressos, pois muitos deles não residiam mais no bairro Granja Portugal e outros não se dispuseram a participar da pesquisa. Além dos egressos, foram entrevistadas três profissionais com formação em Serviço Social, que atuam na execução do PRONATEC BSM no município de Fortaleza. 
De acordo com o MDS (2015), foram registradas, no Cadastro Único, 351.239 (trezentos e cinquenta e uma mil, duzentos e trinta e nove) familias fortalezenses entre os meses de junho e outubro de 2015. Deste número, 198.615 (cento e noventa e oito mil, seiscentos e quinze) são beneficiárias do Programa Bolsa Família (PBF), o que significa 24,90\% da população municipal. De junho de 2011 a setembro de 2015, foram incluídas no PBF 14.153 (catorze mil, cento e cinquenta e três) famílias fortalezenses em situação de extrema pobreza. Em novembro do mesmo ano, foram transferidos para tais familias um total de $\mathrm{R} \$ 28.377 .589,00$ (vinte e oito milhões, trezentos e setenta e sete mil, quinhentos e oitenta e nove reais). Em síntese, de junho de 2011 a novembro de 2015, a partir da criação do Plano Brasil Sem Miséria, houve um aumento de 1,86\% no total de familias beneficiárias em Fortaleza ${ }^{21}$.

São as famílias cadastradas no Cadastro Único, independentemente de serem ou não usuárias do PBF, que constituem o público-alvo do PRONATEC BSM, cujos limites e desafios como programa de qualificação profissional voltado para inserção dos usuários da política de assistência social no mercado de trabalho já se fazem notar desde o processo de inscrição dos candidatos nos cursos ofertados pelo Programa.

Tal processo tem início com as pré-matrículas, que são realizadas em equipamentos da Política de Assistência Social, como os Centros de Referência da Assistência Social (CRAS), Centros de Referência Especializados da Assistência Social (CREAS), Centros Integrados de Referência de Qualificação Profissional (Casa Brasil), entre outros. Após essa etapa, as pré-matrículas são encaminhadas para a sede da SETRA, sendo registradas no Sistema Nacional de Informações da Educação Profissional e Tecnológica (SISTEC). Posteriormente, por meio de contato telefônico, os candidatos são chamados pela SETRA a comparecerem à unidade ofertante ${ }^{22}$ para confirmarem seu interesse pelo curso.

Segundo as profissionais da SETRA entrevistadas, uma das dificuldades no processo de inscrição se refere à burocracia e ao período entre a pré-matrícula dos candidatos e o início do curso, que costuma chegar até seis meses, tempo em que podem ocorrer situações que lhes impossibilitem de fazer o curso no local e/ou no horário para o qual se inscreveram, tais como mudança de endereço, surgimento de uma oportunidade de trabalho, ainda que temporário, entre outras. Assim,

Há dificuldade em relação ao tempo, ou seja, entre o tempo em que é feita a pré-matrícula no CRAS até que chegue a esta Secretaria, para que a gente possa entrar em contato com o candidato, inserir no sistema, para que depois a gente entre em contato novamente com o usuário, orientando que ele vá confirmar a matrícula. Muitas vezes esse tempo se torna longo para o usuário. A ficha chega aqui e a turma já tem sido fechada ou a vaga já tem sido preenchida, então não tem como a gente inserir mais ${ }^{23}$.

Desse modo, quando o usuário chega até o equipamento para realizar sua pré-matrícula no curso de sua preferência, não há certeza de que sua vaga será garantida; e, quando ocorre de não haver vaga para o curso pretendido, não há um cadastro de reserva para a próxima turma, devendo o candidato participar de novo processo de inscrição. Aqueles que chegam primeiro à unidade ofertante garantem sua vaga; os que chegam depois correm o risco de a turma já ter sido fechada.

Além disso, não há uma divulgação prévia por parte dos equipamentos da Política de Assistência Social sobre os cursos que serão ofertados à comunidade, assim como não há um percentual de vagas destinado exclusivamente aos candidatos da modalidade PRONATEC BSM, que concorrem às vagas juntamente com beneficiários do Seguro Desemprego ${ }^{24}$, por exemplo, entre outros. Se o Programa tem o objetivo de contribuir para que a população em situação de pobreza e extrema pobreza seja inserida no mercado de trabalho por meio da qualificação profissional e, assim, melhorar sua condição de vida, no mínimo deveria garantir

21 Informações disponíveis em: http://aplicacoes.mds.gov.br/sagi/RIv3/geral/index.php. Acesso em 02 set. 2015.

22 Os cursos podem ser ofertados pelas unidades do Sistema S (Serviço Nacional de Aprendizagem Industrial - SENAI, Serviço Nacional de Aprendizagem Comercial - SENAC, Serviço Social do Transporte - SEST, e Serviço Nacional de Aprendizagem do Transporte - SENAT), pela Secretaria de Educação do município (SEDUC), pelos institutos federais, entre outras.

23 Profissional entrevistada 1, SETRA.

24 O PRONATEC é um Programa amplo e, ao ser criado, englobou várias modalidades, como: PRONATEC Bolsa-Formação Estudante e Bolsa-Formação Trabalhador; PRONATEC Jovem, PRONATEC Campo, PRONATEC Copa para Empresa, PRONATEC Brasil Sem Miséria, PRONATEC Seguro-Desemprego, dentre outras. 
determinado número de vagas para esse público.

Outra limitação do Programa se refere aos cursos ofertados. Geralmente, a procura é bem maior do que a oferta, principalmente para aqueles cursos mais demandados pela população, como costureiro, modelista, auxiliar administrativo, auxiliar de recursos humanos, auxiliar de pessoal etc. De acordo com as profissionais entrevistadas, a solicitação dos cursos por parte da SETRA ao MDS é feita de acordo com as condições do mercado de trabalho. Dessa forma,

Não é interessante a gente pedir um curso se a pessoa vai realizá-lo e, após a qualificação, não ter para onde ser encaminhada, nem sequer possibilitando-lhe trabalhar para si própria, porque tem cursos que são ofertados que contribuem para o empreendedorismo, outros não ${ }^{25}$.

A cada semestre é realizada uma pactuação de vagas entre o município e o MDS. Nesse momento, o município indica o quantitativo de vagas necessárias e o Ministério responde à demanda apresentada, embora essa resposta não necessariamente atenda à solicitação tal como é feita. "Às vezes acontece de a gente pedir cem vagas para o curso de auxiliar administrativo e receber vinte vagas de auxiliar administrativo e quarenta vagas de outro curso que a gente desconhece. Aí a gente tem que começar do zero esse curso"26. Portanto, muitas vezes os cursos oferecidos não condizem com a demanda do município e dos usuários.

De acordo com relatório do MDS sobre o PRONATEC BSM $(2015)^{27}$ no município de Fortaleza, de janeiro de 2012 a dezembro de 2014, foram efetuadas 5.719 (cinco mil, setecentos e dezenove) matrículas no Programa e foi pactuada a oferta de 5.184 (cinco mil, cento e oitenta e quatro) vagas em 2014, e, no ano de 2015, não houve oferta de cursos devido à crise econômica e política vivenciada pelo País, chegando a repercutir no Programa, com o atraso de repasses financeiros às instituições promotoras dos cursos. O relatório, entretanto, traz informações referentes apenas ao número de matrículas efetuadas, não dispondo do quantitativo de pessoas que chegaram a concluir os cursos.

No que diz respeito às ações para a inserção no mercado de trabalho, existe na SETRA uma Célula de Emprego, Renda e Gestão, vinculada ao Sistema Nacional de Emprego (SINE), que faz a intermediação entre os egressos do Programa e algumas empresas/instituições, todavia trata-se de uma ação esporádica, e não permanente. Embora os egressos recebam orientação para se cadastrarem no SINE, isso não garante que eles sejam empregados ao concluírem o curso.

Não há articulação efetiva do PRONATEC com uma política de emprego e renda. Particularmente, no que se refere ao público do BSM, a situação é ainda mais difícil, já que as empresas fazem exigências que, na maioria das vezes, não condizem com a realidade da população em situação de pobreza e extrema pobreza, geralmente com baixa escolaridade e pouca ou nenhuma experiência profissional. Assim, além de privados do acesso a políticas públicas como saúde, moradia e educação, os usuários da política de assistência social estão privados do acesso ao trabalho, principal meio para a satisfação de suas necessidades.

Como observa Mota $(2010)^{28}$, a política de assistência social hoje tem se constituído no principal mecanismo de proteção social no Brasil, tornando-se, assim, um "fetiche de enfrentamento à desigualdade social"; em vez de ser uma política mediadora que possibilite aos seus usuários o acesso às demais políticas públicas, como a política de emprego e renda, tem se assumido como uma política estruturadora, tendo que absorver e gerenciar as consequências da precarização do trabalho e do desemprego estrutural.

Faltam, ainda, informações sistematizadas sobre o Programa e seus usuários, tais como dados pessoais

25 Profissional entrevistada 2, SETRA.

26 Profissional entrevistada 3, SETRA.

27 BRASIL. Ministério do Desenvolvimento Social e Combate à Fome. Caderno de Estudos do Curso de Indicadores para Diagnóstico do SUAS e do Plano Brasil sem Miséria. Brasília, DF: MDS, Secretaria de Avaliação e Gestão da Informação; Secretaria Nacional de Assistência Social, 2013. 210p.

28 MOTA, Ana Elisabete. O mito da assistência social: ensaios sobre Estado, política e sociedade. $4^{a}$ ed. São Paulo: Cortez, 2010 Mota, 2010, p. 134. 
dos cursistas, tempo de permanência no curso, quantidade de evasões etc. Isto está relacionado, entre outros aspectos, às condições de trabalho na SETRA e nos equipamentos da Política de Assistência Social, que dificultam a realização de estudos, pesquisas e relatórios que possam contribuir para a melhoria do Programa no município.

Outro achado da pesquisa tem a ver com a qualidade dos cursos ofertados, sobretudo no que diz respeito à preparação para o exercício de uma profissão, tendo em vista que, para muitos egressos, as aulas deixam a desejar.

Durante as entrevistas um elemento relevante apontado pelos egressos refere-se à bolsa oferecida para os cursistas, constituindo-se numa motivação para a inscrição e permanência de muitos no Programa, como se percebe nas falas abaixo:

Muitos vão só pelos cem reais, que é o auxílio que recebem $(. . .)^{29}$.

Começaram aqueles problemas relacionados ao fato de que as pessoas não ficavam na sala e recebiam a presença. Eu acho errado, porque tem gente que vai e fica até o final, não vai embora. Outra coisa: quem desistiu do curso não era para receber o benefício. A minha cunhada foi uma dessas pessoas. Ela se inscreveu, não foi mais às aulas e recebeu o dinheiro até o final do curso. Porque a gente recebe aquela ajuda, a passagem, e é um estímulo, porque o curso é caríssimo. Não é um curso barato, é um curso caro, e aí a pessoa vem e tira a oportunidade de outra pessoa $^{30}$.

Como se pode observar, o PRONATEC BSM está inserido na política de assistência social como estratégia de superação da condição de pobreza e extrema pobreza dos usuários desta política por meio de sua inserção ou reinserção no mercado de trabalho, via oferta de cursos profissionalizantes. Entretanto, a qualificação profissional e a geração de emprego e renda não são papeis da política de assistência social, uma vez que requerem políticas sociais complexas voltadas especialmente para sua promoção. Embora a integração ao mercado de trabalho seja um dos objetivos da referida política, esta não será capaz de responder, por si só, a questões mais amplas, como escolarização precária, falta de qualificação profissional e, principalmente, o desemprego, o qual faz parte do modo como se estrutura a sociedade capitalista, que, ao produzir riqueza, produz, concomitantemente, uma população supérflua às necessidades do capital, fazendo surgir o pauperismo.

Desse modo, de acordo com Kuenzer (2006), há uma ausência de efetividade social em programas de qualificação profissional, como é o caso do PRONATEC BSM, uma vez que vêm sendo desenvolvidos de modo fragmentado, assistencialista e compensatório. Um dos indicadores disso é o fato de que várias pessoas fizeram diversos cursos, geralmente motivadas pela bolsa-formação e, ainda assim, não conseguiram inserir-se no mercado formal de trabalho.

Dessa forma, a bolsa-formação acaba tornando-se uma fonte de renda temporária para os usuários da Política de Assistência Social, inscritos no Cadastro Único. De fato, o que era para ser uma política pública efetiva voltada para a inserção no mercado de trabalho passa a ser mais uma ação assistencialista, a qual acaba por reproduzir as condições de pobreza de uma população que, após concluir os cursos, permanece "cliente do Estado", não sendo capaz de suprir, pelo próprio trabalho, suas necessidades de sobrevivência, dada a falta de articulação do Programa com outras políticas públicas, sobretudo de educação e de geração de emprego e renda.

Com base nas entrevistas, verificou-se que muitos egressos tiveram dificuldades relacionadas ao seu baixo nível de escolaridade. Alguns, inclusive, não conseguiram concluir os cursos, como se pode apreender nas falas a seguir:

Teve gente que não fez o curso porque não tinha a sexta série concluída ${ }^{31}$.

29 Egressa do curso de modelagem, 56 anos.

30 Egressa do curso de figurinista, 31 anos.

31 Egressa do curso de modelagem, 56 anos. 
Eu acho que os cursos do PRONATEC eram para ser mais na prática e menos na caneta. Muita gente desistiu por isso, por não ter estudo para escrever e ler. Também teve espanhol e teve matemática. Mas eu escrevo direitinho, leio tudo, mas tinha gente com a quarta ou quinta série e não conseguiu. Muita gente desistiu. Eu passei trinta anos sem ir para o colégio e tinha gente que tinha parado os estudos há muitos anos e dizia que não ia conseguir. Tinha gente que tinha a sexta série, entendeu? Era difícil. Tínha gente que sabia mais, tinha gente que sabia menos, mas a prova era a mesma para todos ${ }^{32}$.

Assim, a falta de intersetorialidade e de articulação com a política de educação se constitui como um dos limites do Programa, uma vez que este é voltado para pessoas em situação de pobreza e de extrema pobreza, mas, ao mesmo tempo, exige dessa população certo nível de conhecimento. Muitas receberam uma educação precária ou sequer tiveram acesso à educação básica, como se percebe a partir do relato da entrevistada. Embora este seja um dos objetivos do Programa, o PRONATEC BSM ainda não tem contribuído para a elevação da escolaridade da população pobre e extremamente pobre, pois, ao se definir como um Programa de formação inicial e continuada, deve oferecer aos seus usuários mecanismos educacionais, tais como: continuidade dos estudos, elevação da escolaridade e reforço aos que apresentem maiores dificuldades, tendo em vista que um curso de três meses não é suficiente para reparar as dificuldades educacionais das pessoas prejudicadas com a ausência de uma educação básica de qualidade.

Kuenzer (2006) assinala que, embora os programas de qualificação se pautem no discurso da inclusão dos trabalhadores no mercado de trabalho, além de não sustentarem o efeito anunciado, ainda tornaram as ofertas educativas mais precarizadas. Portanto, parafraseando a autora, no âmbito do sistema educacional e, especialmente, da educação profissional, há um processo de inclusão que, devido a sua desqualificação, é excludente.

Em meio às limitações da maioria dos egressos, referentes ao nível de escolaridade, um deles relatou que, após ter passado muitos anos fora da sala de aula, o PRONATEC lhe despertou para retornar aos estudos, como é o caso de um egresso do curso de representante comercial:

Depois do curso tive interesse em voltar aos estudos, porque você está ali de novo numa sala de aula, vendo pessoas que estão com o seu nível de educação, aí você vê que o seu nível pode melhorar ainda mais. O relacionamento com o colega de sala de aula faz com que você cresça junto com ele. Se ele sabe, você vai tentar acompanhá-lo; se eu sei, vou tentar repassar aquilo que eu sei para aquela pessoa. Isso ajudou muito, o fato de eu voltar para sala de aula. Passar três meses na sala de aula com pessoas de n perfis é gostoso, aí voltei para a faculdade e voltei a estudar só por causa do empurrão que o PRONATEC me deu ${ }^{33}$.

O mesmo egresso relatou que o PRONATEC lhe serviu de incentivo para retornar à sala de aula, fazendo com que se matriculasse em um curso de nível superior. A maioria dos usuários, entretanto, não tem oportunidade e incentivo para continuar os estudos. Esta é uma das questões apontadas por alguns entrevistados, como foi o caso de um jovem de 23 anos, egresso do curso de operador de computador: "Acredito que o Programa pode melhorar dando sequência aos cursos, aprofundando". Além disso, o mesmo relata que falta clareza em relação aos cursos que são ofertados, pois muitos têm nomes parecidos, fazendo com que o usuário se inscreva em um determinado curso achando que é outro, com outras expectativas, contribuindo, assim, para a sua não permanência nos cursos.

Outro ponto interessante a ser destacado é que, de forma recorrente, os egressos entrevistados relataram sobre a relação entre teoria e prática no curso. Algumas falas expressaram satisfação quanto à parte teórica, porém, outras consideram a teoria desnecessária. Uma das egressas, que tem ensino médio completo e um curso técnico na área de contabilidade, considera que a teoria foi muito válida. Já duas outras egressas, uma com o ensino médio incompleto e outra, que embora tenha o ensino médio completo, estava há muito tempo sem estudar, consideram a teoria desnecessária. Por parte de muitos egressos entrevistados, há uma

32 Egressa do curso de auxiliar de cozinha, 54 anos.

33 Egresso do curso de representante comercial, 41 anos. 
desvalorização da teoria, uma incompreensão quanto à importância do conhecimento, como se a teoria não embasasse a prática. Portanto, pode-se perceber que a própria metodologia do Programa acaba contribuindo para a desarticulação entre a teoria e a prática, uma vez que, primeiramente, se tem a parte teórica para, posteriormente, se ter a parte prática, enquanto ambas deveriam ser articuladas no decorrer do curso. Essa metodologia colabora para o desconhecimento, por parte dos cursistas, da unidade entre as duas.

Nas entrevistas surgiram, também, falas sobre o pouco tempo dos cursos, demonstrando a insuficiência da carga-horária para dar conta do conteúdo abordado e atingir o objetivo do Programa, qual seja, a qualificação profissional.

Ao avaliarem o PRONATEC BSM, todos os egressos entrevistados responderam ser este um Programa importante em termos de oportunidade oferecida às pessoas de baixa renda e, apesar das críticas ao Programa, todos se consideram mais qualificados após a realização dos cursos, como apontam as falas a seguir:

Eu acho que é uma oportunidade muito boa, só não faz a pessoa que não quer (...). Se fosse pra mim mesma fazer eu faria outro, porque eu gostei da oportunidade. Se abrisse de novo, eu queria de novo, mas o negócio é que eu quero trabalhar. Mas se eu fosse nova eu faria todos os cursos pra eu poder ficar bem, pra eu poder arranjar um emprego melhor, se eu pudesse ter essa oportunidade. É uma oportunidade muito boa que o governo dá para as pessoas. E o pessoal joga fora. Não querem os cursos que eles dão. É muito bom: a gente recebe a passagem, a gente recebe a merenda, tudo direitinho, num tem burocracia e eu acho, assim, uma oportunidade muito boa e os jovens deviam aproveitar e agarrar, mas os jovens jogam fora, não querem"34.

Eu vejo que o PRONATEC é um incentivo (...). Eu creio que o PRONATEC é um programa muito bom, uma oportunidade muito boa porque as pessoas carentes, que não têm condições de pagar, já têm essa oportunidade para se profissionalizar numa área. Muito bom, maravilhoso! Foi o melhor curso que já fiz ${ }^{35}$.

Por meio das entrevistas, verificou-se que, após a conclusão dos cursos, a maior parte dos egressos não havia conseguido mudar a condição na qual se encontrava antes de realizar o curso. Para duas entrevistadas, que já trabalham com costura em uma cooperativa, o curso veio como um complemento, uma vez que pretendem continuar nesta profissão.

A maioria dos egressos entrevistados buscou o Programa a fim de conseguir uma qualificação para se inserir no mercado de trabalho. Uma egressa do curso de cozinheira, de 45 anos, informou que, após a conclusão do curso, surgiram oportunidades de trabalho na área em que se qualificou, mas afirmou ter sido por esforço próprio, ou seja, não foi por encaminhamento do Programa, como se vê abaixo:

Houve oportunidade para mim em um trabalho, mas eu não cheguei a trabalhar porque fui cuidar da minha filha que teve neném. Era de auxiliar de cozinha (...). Souberam que eu tinha o curso do SENAC e me procuraram, mas não foi o SENAC que encaminhou. Meu marido trabalha em um condomínio e souberam lá que eu fiz esse curso no SENAC, de auxiliar de cozinha, e se interessaram, já que iam abrir um restaurante. Eu queria trabalhar, mas eu queria trabalhar de carteira assinada. Não sei se a minha idade possibilita ainda. Quando eu terminar esse curso [curso de costura que realiza pelo SENAI] eu vou ver se consigo o de auxiliar ou de costureira.

Por outro lado, deve-se destacar que, embora as oportunidades não tenham sido frutos de encaminhamentos do Programa, foram decorrentes dos cursos realizados pelos egressos, o que demonstra que, de algum modo, as pessoas com alguma qualificação ainda têm mais chances de inserção no mercado de trabalho.

A citação acima mostra uma realidade perversa vivenciada por muitos trabalhadores, como denunciam Antunes e Alves (2004): "vem ocorrendo [...] a exclusão dos trabalhadores considerados "idosos" pelo capital, com idade próxima de 40 anos e que, uma vez excluídos do trabalho, dificilmente conseguem reingresso no mercado de trabalho" 36 .

34 Egressa do curso de cozinheira, 45 anos.

35 Egressa do curso de figurinista, 31 anos.

36 ANTUNES, Ricardo; ALVES, Giovanni. As mutações no mundo do trabalho na era da mundialização do capital. Educação 
De acordo com os autores, hoje, além dos idosos, vários jovens encontram-se fora do mercado de trabalho, "engrossando as fileiras dos trabalhos precários, dos desempregados, sem perspectivas de trabalho, dada a vigência da sociedade do desemprego estrutural" ${ }^{37}$. Em relação aos três jovens entrevistados com idade entre 18 a 23 anos, dois estão desempregados. Para eles, a principal dificuldade que enfrentam para ingressarem no mercado de trabalho é o fato de não terem experiência profissional, por isso sugerem que o PRONATEC ofereça, além dos cursos, oportunidades para o primeiro emprego.

O capital, por produzir o desemprego estrutural, cria uma população excedente, supérflua, que não será mais absorvida pelo mercado de trabalho. De acordo com dados de uma pesquisa recente realizada pela Organização Mundial do Trabalho $(\mathrm{OIT})^{38}$, a previsão em relação ao número de pessoas desempregadas para o ano de 2017 corresponde a 3,4 milhões e, em relação a esse número, estima-se que 700 mil brasileiros comporão o contingente de desempregados.

Bauman faz uma análise relevante sobre o desemprego na contemporaneidade. Em sua obra "Vidas Desperdiçadas" (2005), o autor observa que a modernização produz inevitavelmente o "refugo" ou seres humanos refugados, "excessivos", "redundantes". Segundo ele, um dos diagnósticos mais comuns vivenciados pela geração X, pessoas nascidas na década de 1970, é o desemprego. Se as pessoas que vivenciaram o período de desenvolvimento industrial que estavam sem emprego, o chamado exército industrial de reserva, teriam o destino do retorno ao trabalho, para o refugo o destino é o depósito de lixo. Bauman (2005) ${ }^{39}$ assim define a população redundante:

Ser "redundante" significa ser extranumerário, desnecessário, sem uso (...). Os outros não necessitam de você. Podem passar muito bem, e até melhor, sem você. Não há uma razão autoevidente para você existir nem qualquer justificativa óbvia para que você reivindique o direito à existência. Ser declarado redundante significa ter sido dispensado pelo fato de ser dispensável - tal como a garrafa de plástico vazia e não retornável, ou a seringa usada, uma mercadoria desprovida de atração e de compradores, ou um produto abaixo do padrão, ou o machado, sem utilidade, retirado da linha de montagem pelos inspetores de qualidade. "Redundância" compartilha o espaço semântico de "rejeitos", "dejetos", "restos", "lixo" - com refugo (grifos do autor).

Ao vivenciar o desemprego, a grande maioria dos egressos entrevistados vê no trabalho a possibilidade de melhoria de sua condição vida e sonha com um emprego em condições dignas. Um dos jovens entrevistados, com apenas dezoito anos, que nunca trabalhou e ainda não ingressou na faculdade, vê o trabalho como uma perspectiva para o futuro: "Eu quero fazer uma faculdade e conseguir um emprego bom na área da administração".

Outro entrevistado, egresso do curso de representante comercial, ao ser questionado sobre suas perspectivas para o futuro, relatou:

Em relação à aposentadoria, a gente não consegue viver só com ela, então é por isso que eu me vejo um empresário, porque o empresário é dono daquele negocinho dele. Por mais que ele ganhe pouco, mas vai ser um ganho constante, que vai aumentando se ele tiver uma boa orientação, uma boa administração do negócio dele. É o meu pé de meia, é o meu futuro. Eu penso nisso porque tenho meus filhos que estão crescendo e eu preciso melhorar o padrão de vida para oferecer para eles. Quando penso em abrir o meu próprio negócio, vejo os horizontes se abrindo. Eu estou pensando em fazer meu empreendimento crescer lá na frente. Quero me aposentar, mas não parar de trabalhar ${ }^{40}$.

Frente às precárias condições de trabalho na contemporaneidade, marcadas por baixos salários, incerteza e perda de direitos trabalhistas, muitos trabalhadores, por outro lado, passam a sonhar em terem seu próprio

\& Sociedade. Campinas, vol. 25, n. 87, p. 335-351, maio / ago., 2004, p. 339).

37 ANTUNES, Ricardo; ALVES, Giovanni. As mutações no mundo do trabalho na era da mundialização do capital. Educação \& Sociedade. Campinas, vol. 25, n. 87, p. 335-351, maio / ago., 2004, p. 339)

38 Dados extraídos da página eletrônica: http://g1.globo.com/economia/noticia/2016/01/brasil-pode-ter-quase-1-em-cada5-novos-desempregados-do-mundo-em-2017-diz-oit.html. 20 jan.2016.

39 BAUMAN, Zygmunt, 1925. Vidas desperdiçadas. Tradução de Carlos Alberto Medeiros. - Rio de Janeiro: Zahar, 2005, p. 20).

40 Egresso do curso de representante comercial, 41 anos. 
negócio, tornarem-se independentes, trabalharem por conta própria ou serem pequenos empresários. Alencar (2010) observa que esse sonho "não se revela como um desejo real (...), significando, na verdade, a única possibilidade diante do desemprego e dos baixos salários" $"$.

A partir do que foi exposto sobre o PRONATEC BSM, torna-se perceptível que o Programa apresenta contradições, como por exemplo, o fato de um programa de qualificação profissional para pessoas em extrema pobreza exigir do cursista certo nível de escolarização, sem, contudo, criar ações que garantam uma formação inicial e continuada. O IPEA (2012) salientou que as entidades que promovem os cursos de qualificação profissional, que são as escolas técnicas e do sistema $\mathrm{S}$, não atuam juntamente ao público com baixa escolaridade ou inserção precária no mercado de trabalho.

\section{Considerações finais}

Com este trabalho, conclui-se que a política de assistência social não pode dar conta de integrar seus usuários ao mercado de trabalho, por meio de um programa de qualificação profissional como o PRONATEC BSM. A questão social é muito mais complexa, encontrando suas raízes no modo de produção capitalista, e suas configurações e expressões atuais, entre as quais se destaca o desemprego, agravam-se na medida em que o capital encontra estratégias econômicas, políticas e ideológicas para superar sua própria crise, precarizando o trabalho e deteriorando as condições de vida da população planetária.

Se a qualificação profissional não garante a empregabilidade, para os usuários do PRONATEC BSM, essa realidade é ainda mais severa, pois o mercado está cada vez mais competitivo e seletivo, exigindo, além de qualificação e experiência profissional, conhecimentos, competências e habilidades que pessoas em situação de pobreza e de extrema pobreza geralmente não têm oportunidade de desenvolver, uma vez privadas do acesso a políticas públicas que atendam às suas necessidades de saúde, educação, moradia, trabalho, entre outras.

Pelo que apontam os resultados da pesquisa realizada juntamente a egressos do PRONATEC Brasil Sem Miséria no município de Fortaleza, o Programa não é capaz de promover grandes mudanças em suas condições de trabalho e de vida, que permanecem praticamente as mesmas em que eles se encontravam antes de realizarem os cursos. A maioria dos egressos entrevistados continuou na condição de desemprego ou subemprego, especialmente as mulheres com idade acima de 40 anos, que experimentam preconceitos de toda sorte, inclusive de gênero e geracional. Em um cenário socioeconômico fortemente marcado pelo desemprego estrutural e pela precarização do trabalho, o público-alvo do PRONATEC BSM parece sonhar mesmo é com a possibilidade de um trabalho digno, associado a garantias e direitos sociais, em vez de ficar a mercê da Política de Assistência Social para satisfazer suas necessidades de sobrevivência.

Ressalta-se, por outro lado, que a qualificação profissional ofertada aos trabalhadores que vivenciam a condição de pobreza e de extrema pobreza não é capaz de, por si só, suprir suas deficiências de escolarização, nem, muito menos, de garantir sua inserção ou reinserção no mercado formal de trabalho. Desse modo, enquanto suas possibilidades estiverem restritas ao trabalho incerto, instável e precário, sem a garantia sequer da aposentadoria, esses trabalhadores continuarão buscando alternativas de rendimentos, mesmo esporádicos (como a bolsa-auxílio do PRONATEC BSM), no âmbito de programas que, embora tenham objetivos mais amplos de inserção social, acabam configurando-se como programas assistenciais incapazes de combater as causas dos problemas que se propõem a enfrentar.

Por fim, por maior importância que os usuários atribuam ao PRONATEC BSM, o Programa, assim como outros, não os retira da condição de descartáveis para o capital e de dependentes do Estado, que tem

41 ALENCAR, Mônica Maria Torres. As políticas públicas de emprego e renda no Brasil: do "nacional-desenvolvimentismo" ao "nacional-empreendedorismo". In: BEHRING, Elaine Rosetti e ALMEIDA, Maria Helena Tenório de (orgs.). Trabalho e seguridade social: percursos e dilemas. 2ed. - São Paulo: Cortez; Rio de Janeiro: FSS / UERJ, 2010, p. 121. 
atribuído suas responsabilidades pelo atendimento às necessidades sociais ao mercado e às organizações da sociedade civil, transformando direitos sociais em mercadorias ou benesses, focalizando cada vez mais as políticas públicas na população extremamente pobre e nos mínimos sociais.

\section{REFERÊNCIAS BIBLIOGRÁFICAS}

ALENCAR, Mônica Maria Torres. As políticas públicas de emprego e renda no Brasil: do "nacional-desenvolvimentismo" ao "nacional-empreendedorismo". In: BEHRING, Elaine Rosetti e ALMEIDA, Maria Helena Tenório de (orgs.). Trabalho e seguridade social: percursos e dilemas. 2ed. - São Paulo: Cortez; Rio de Janeiro: FSS / UERJ, 2010.

ANTUNES, Os Sentidos do Trabalho: ensaios sobre a afirmação e a negação do trabalho. 6. ed. São Paulo: Boitempo Editorial, 2001.

Adeus ao trabalho? Ensaio sobre as metamorfoses do e a centralidade do mundo do trabalho. São Paulo; Cortez; Campinas, SP: Editora da Universidade Estadual de Campinas, 1995.

ANTUNES, Ricardo; ALVES, Giovanni. As mutações no mundo do trabalho na era da mundialização do capital. Educação \& Sociedade. Campinas, vol. 25, n. 87, p. 335-351, maio / ago., 2004.

BAUMAN, Zygmunt, 1925. Vidas desperdiçadas. Tradução de Carlos Alberto Medeiros. - Rio de Janeiro: Zahar, 2005.

BEHRING, Elaine Rosetti. Brasil em contrarreforma: desestruturação do Estado e perda de direitos. São Paulo: Cortez, 2008.

BRASIL. Cartilha Pronatec Brasil Sem Miséria. Disponível em: http://www.camacari.ifba.edu.br/attachments/article/20/2013_PronatecCartilhaBSM_v2012.pdf. 31 ago. 2014.

BRASIL, Ministério de Desenvolvimento Social e Combate a Fome. Política Nacional de Assistência Social. (PNAS). Brasília, nov. 2004.

BRASIL. Cartilha Pronatec Brasil Sem Miséria. Disponível em: http://www.camacari.ifba.edu.br/attachments/article/20/2013_PronatecCartilhaBSM_v2012.pdf. 31 ago. 2014.

BRASIL. INSTITUTO DE PESQUISA ECONÔMICA APLICADA (IPEA). Políticas sociais: acompanhamento e análise, v. 1 - Brasília: IPEA, 2012.

BRASIL. LEI $\mathrm{n}^{\circ}$ 12.513, de 26 de outubro de 2011. Disponível em: http://www.planalto.gov.br/ccivil_03/_ato2011-2014/2011/lei/112513.htm. Acesso em 29 set. 2014.

BRASIL. LEI $\mathbf{n}^{\circ}$ 8.742, de 07 de dezembro de 1993. Disponível em: http://www.planalto.gov.br/ccivil_03/leis/18742.htm. Acesso em 31ago. 2014.

BRASIL. Ministério do Desenvolvimento Social e Combate à Fome. Caderno de Estudos do Curso de Indicadores para Diagnóstico do SUAS e do Plano Brasil sem Miséria. Brasilia, DF: MDS, Secretaria de Avaliação e Gestão da Informação; Secretaria Nacional de Assistência Social, 2013. 210p.

BRASIL. Ministério do Planejamento, Orçamento e Gestão. Secretaria de Planejamento e Investimento Estratégico. Plano Plurianual 2012-2015: projeto de lei / Ministério do Planejamento, Orçamento e Gestão. Secretaria de Planejamento e Investimento Estratégico. Brasília: MP, 2011. 278p.

IAMAMOTO, Marilda Villela. Serviço Social em tempo de capital fetiche: capital financeiro, trabalho e questão social. $8^{a}$ ed. São Paulo: Cortez, 2014. 
A questão social no capitalismo. In: Associação Brasileira de Ensino e Pesquisa em Serviço Social. Revista Temporalis. Ano 2, n.3 (jan/jul.2001). Brasília: ABEPSS, Grafline, 2001.

KUENZER, Acácia Zeneida. A Educação profissional nos anos 2000: a dimensão subordinada das políticas de inclusão. Educação \& Sociedade. Campinas, vol. 27, n. 96 - especial, p. 877-910, out. 2006.

MÉSZÁROS, István. Para além do capital: rumo a uma teoria da transição. Tradução de Paulo Cézar Castanheiras, Sérgio Lessa. $1^{a}$ ed. revista. São Paulo: Boitempo, 2011.

MOTA, Ana Elisabete. O mito da assistência social: ensaios sobre Estado, política e sociedade. $4^{a}$ ed. São Paulo: Cortez, 2010.

PEREIRA, Potyara Amazoneida P. Prefácio à $3^{\circ}$ edição. In: O Sistema Único de Assistência Social no Brasil: uma realidade em movimento / (orgs.) Berenice Rojas Couto... [et al.]. - 3. ed rev. e atual. - São Paulo: Cortez, 2012. 15-20 p.

ROCHA, Mirian Aparecida [et.al.]. Programas sociais brasileiros e sua relação com a pobreza, a desigualdade e o desenvolvimento. In: Revista Brasileira de Políticas Públicas. Volume 4. N. 1. Jan-Jun 2014, 138-153 p.

SILVA, Sheyla Suely de Souza. Contradição da Assistência Social no governo "neodesenvolvimentista" e suas funcionalidades ao capital. In: Serviço Social e Sociedade, São Paulo, n.113, p. 86-105, jan./mar.2013.

SITCOVSKY, Marcelo. Particularidades da expansão da assistência social no Brasil. In: MOTA, Ana Elizabete (org.). O Mito da Assistência Social: ensaios sobre Estado, política e sociedade. 4. ed. - São Paulo: Cortez, 2010. 147-179 p.

STRAPASSON, Karline; PAMPLONA, Danielle Anne. A escolha pública econômica para erradicar a pobreza extrema no Brasil. In: Revista Brasileira de Políticas Públicas. Volume 4. N. 2. Jul-Dez 2014, 47-63 p. 


\section{Intervenção estatal na agricultura: a possibilidade de uma ação ética a fim de materializar a Constituição brasileira*}

\author{
State intervention in agriculture: the \\ possibility of ethical action in order to \\ materialize the Brazilian constitution
}

Davi Augusto Santana de Lelis**

Giovani Clark***

\section{Resumo}

O presente trabalho tem o objetivo de traçar breve histórico das políticas econômicas estatais no setor agrícola, entre os anos 1990 e 2012. Neste trabalho, pretende-se identificar a natureza da intervenção estatal na agricultura investigando em que eixos as ditas políticas públicas atuam. Para tanto, analisam-se os Planos Plurianuais dos governos Fernando Henrique Cardoso (PPA 2000-2003), Luís Inácio Lula da Silva (PPA 2004-2007 e PPA 20082011) e Dilma Roussef (PPA 2012-2015), questionando as intervenções em face da concretude aos comandos constitucionais. O articulado é fruto de uma pesquisa documental, versando sobre políticas econômicas planejadas a um setor especifico (agrícola) e em um espaço de tempo determinado, dentro do marco teórico do Direito Econômico, partindo dos ensinamentos do seu introdutor no Brasil, Prof. Washington Peluso Albino de Souza, inclusive de seu método analítico substancial. Utilizam-se, também, as significativas contribuições da sociologia rural, explanadas por Zander Navarro e Sergio Schneider.

Palavras-chave: Intervenção estatal no domínio econômico. Setor agrícola. Política setorial. Planejamento. Plano Plurianual.

* Recebido em 02/03/2016 Aprovado em 04/07/2016

** Professor adjunto de direito administrativo na Universidade Federal de Viçosa (UFV), doutorando em direito público na Pontifícia Universidade Católica de Minas Gerais. E-mail: davi.lelis@ufv.br.

*** Doutor em Direito Econômico, Professor do Programa de Pós-Graduação em Direito da PUC Minas e da Graduação da Faculdade de Direito da UFMG. E-mail: giovaniclark@gmail. com.

\section{Abstract}

This study aims to trace a brief history of state economic policies in the agricultural sector, between 1990 and 2012.This theoretical effort is intended to identify the nature of state intervention in agriculture. We will examine the Multi-Year Plan of Fernando Henrique Cardoso (PPA 20002003), Luis Inácio Lula da Silva (2004-2007 PPA and PPA 2008-2011) and Dilma Roussef (PPA 2012-2015), questioning the interventions face of concreteness to the constitutional commands. This paper is the result of an documentary research, dealing with economic policies designed to a specific sector (agriculture) and an expected time frame, within the theoretical framework of Economic Law, based on the teachings of his introducer in Brazil, Prof. Washington Peluso Albino de Souza, including its substantial 
analytical method. It is also used the significant contributions of rural sociology, explained by Zander Navarro and Sergio Schneider.

Keywords: State intervention in the economic domain. Agricultural sector. Sectoral policy. Planning. MultiYear Plan.

\section{INTRODUÇÃO}

Desde 1500 o setor agrícola tem sido um importante mecanismo de crescimento econômico no Brasil. Os primeiros invasores portugueses se dedicaram à atividade extrativa, em especial à da árvore que viria a nomear esta terra, o pau-brasil. Ao aprenderem em como lidar com a terra e o clima, bem como a subjugar os povos que já habitavam a floresta, (indígenas), ou que, coercitivamente, vieram a habitar (africanos), os portugueses e demais europeus realizaram outras atividades igualmente lucrativas: cana-de-açúcar, algodão, fumo, borracha, cacau, café. Os nativos deram ainda prosseguimento as culturas da soja, milho, feijão, mandioca, laranja etc. O setor agrícola, em seus diversos ciclos de expansão, transcendeu a sua natureza regional e impactou o Brasil, a América Latina e o Mundo.

Não obstante a importância da agricultura na economia nacional e existência, no setor, de uma aguda e secular intervenção estatal por intermédio de políticas públicas de alcance nacional e internacional, a Ciência do Direito pátria quase não versa sobre o tema em suas pesquisas e publicações. Constatação intrigante em face dos inúmeros instrumentos legais que versam sobre o setor agrícola, iniciando-se pela Constituição brasileira que impõe a reforma agrária, a função social das propriedades de produção e o planejamento da política agrícola, dentre outros comandos, passando, ainda, por criação de empresas estatais de pesquisa e apoio e terminando por decisões judiciais relevantes à agricultura.

Analisando-se as intervenções estatais no setor, nota-se que as políticas desenvolvidas têm, geralmente, fins meramente utilitaristas ${ }^{1}$ e, indo além dos textos legais planejadores, não é "claro" a quem o benefício da política pública é dirigido ou se estão comprometidas com a efetivação da nossa Constituição. Seria a política pública voltada para o mero trabalhador, desprovido de terra e recursos, procurando o controle dos meios de produção? Ou estaria aquele um passo atrás, em busca de um confronto que lhe dê reconhecimento perante o nosso Estado Democrático de Direito? Seria possível identificar alguma política pública capaz de conferir um aspecto moral à luta por reconhecimento no meio rural e, por consequência, em prol da materialização do texto constitucional?

O presente trabalho tem o objetivo de traçar um breve histórico das políticas econômicas estatais no setor agrícola, iniciando os apontamentos nos anos 1990 e findando a análise no ano de 2012. Pretende-se identificar a natureza da intervenção estatal na agricultura investigando em que eixos as ditas políticas públicas atuam. Para tanto, serão analisados os Planos Plurianuais dos governos Fernando Henrique Cardoso (PPA 2000-2003), Luís Inácio Lula da Silva (PPA 2004-2007 e PPA 2008-2011) e Dilma Roussef (PPA 20122015), questionando as intervenções em face da concretude aos comandos constitucionais.

É importante alertar que se trata de pesquisa eminentemente documental, versando sobre políticas econômicas planejadas a um setor especifico (agrícola) e em um espaço de tempo previsto acima, dentro do

1 O termo utilitarista é utilizado para designar as ações estatais pautadas pelo signo da eficiência econômica. Busca-se, assim, delimitar, por meio do uso do termo, o que é uma política pública utilitarista, aquela que se preocupa tão somente com o resultado positivo no balanço econômico, que quantifica e permite a barganha de direitos, que ignora questões que não podem ser matematizadas, como a emancipação da população, a liberdade do indivíduo, a preservação ambiental para as presentes e futuras gerações. Em contrapartida, a política púbica ética será aquela que demonstra preocupação com a alteridade, a emancipação popular, a preservação ambiental, a diversidade genética na produção do campo, com o pluralismo produtivo, com a ação estatal livre de ideologias puras advindas da economia, mas em busca da concretude da constituição. Assim, a política utilitarista busca a eficiência, apenas um primeiro critério de mínimo bem-estar e a certeza de que não está havendo desperdício de recurso. Entretanto, essa maneira de se elaborar políticas públicas pode não ser justa. 
marco teórico do Direito Econômico, partindo-se dos ensinamentos do seu introdutor no Brasil, Prof. Washington Peluso Albino de Souza, inclusive de seu método analítico substancial. Utiliza-se, também, as significativas contribuições da sociologia rural, explanadas por Zander Navarro e Sergio Schneider.

\section{Panorama do setor agrícola brasileiro nos anos 1990}

Durante muito tempo, por influência da revolução verde ${ }^{2}$, o progresso rural era associado ao conjunto de ações que o Estado e organismos internacionais destinadas à intervenção em regiões rurais atrasadas que não conseguiam se inserir no processo de modernização mundial. Somente na década de 1990, é que uma mudança de enfoque ocorreu ${ }^{3}$. Até essa década, como evidenciam Schneider, Shiki e Belik ${ }^{4}$, as políticas públicas brasileiras voltadas ao setor rural fundamentavam-se nos mesmos pressupostos: a busca pela modernização agrícola e o papel ativo do Estado.

Constata-se que o período entre meados da década de 1960 até 1990 compreende o processo de modernização agrícola brasileiro, chamado de Modernização Conservadora ${ }^{5}$. Segundo Delgado ${ }^{6}$, esse processo foi marcado por uma elevação significativa nos indicadores técnicos de modernização agropecuária, aumento da produção e diversificação desta, e, ainda, expressiva alteração no padrão técnico da agricultura. Essa dinâmica, de acordo com Lavinas e $\mathrm{Cobo}^{7}$, deixou à margem das políticas públicas a agricultura familiar, gerando grandes desequilíbrios econômicos e sociais na nação As novas configurações vigentes a partir do final da década de 1980, mais precisamente do início da década de 1990, entretanto, trazem importantes implicações sobre o assunto.

Um importante marco refere-se à promulgação da Constituição Federal de 1988, com um conjunto de direitos sociais que colocaram em voga a proteção social a grupos da população antes à margem do processo, como os residentes em áreas rurais ${ }^{8}$. As regulamentações estabelecidas surtiram efeitos sobre a descentralização política e financeira, com a responsabilização dos municípios pela implementação de boa parte das políticas públicas de saúde, educação e segurança ${ }^{9}$. Inserem-se como importantes nesse contexto a normatização das aposentadorias rurais, a demarcação de terras indígenas e territórios quilombolas, a regu-

2 A revolução verde significou a supremacia da techne: A transferência de tecnologia era o mote, e o objetivo era aumentar a produtividade agrícola e acabar com a fome por meio de melhoramento de sementes, uso de agrotóxicos, máquinas e tudo que a técnica (conhecimento alçado a finalidade humana) pudesse produzir. BECHARA, Miguel apud FONSECA, Maria Tereza Louza. Extensão rural: uma educação para o capital. São Paulo: Edições Loyola, 1985. p. 39-40. A produtividade aumentou, entretanto, isto não significou o fim da fome, mas sim a chegada dos transgênicos e dos agrotóxicos mais fortes para evitar as doenças resistentes à monogenia. A promessa da tecnologia moderna se transformou em ameaça: Talvez tenha faltado um norte ético, nos moldes de Jonas. JONAS, Hans. O princípio responsabilidade: ensaio de uma ética para a civilização tecnológica. Rio de Janeiro: Contraponto, 2006. 3 SCHNEIDER, Sergio. Situando o desenvolvimento rural no Brasil: o contexto e as questões em debate. Revista de Economia Política, São Paulo, v. 30. n. 3, p. 511-531, jul./set. 2010.

4 SCHNEIDER, Sergio; SHIKI, Shigeo; BELIK, Walter. Rural development in Brazil: overcoming inequalities and building new markets. Rivista di Economia Agraria, ano 65, n. 2, p. 225-259, giugno 2010.

5 MUELLER, Charles; MUELLER, Bernardo. The evolution of agriculture and land reform in Brazil: 1950-2006. In: CONFERENCE IN HONOR OF WERNER BAER, 2006, Illinois. Proceedings... Illinois: University of Illinois, 2006.

6 DELGADO, Guilherme da Costa; CONCEIÇÃO, Júnia da. Políticas de preços agrícolas e estoques de alimentos: Origens, situação atual e perspectivas. Revista Paranaense de Desenvolvimento, Curitiba, n. 108, p. 25-32, jan./jul. 2005.

7 LAVINAS, Lena; COBO, Barbara. Alcance e limite das políticas sociais para o combate à pobreza: desafios do mundo rural. In: MIRANDA, Carlos; TIBÚRCIO, Breno (Org.). A nova cara da pobreza rural: desafios para as políticas públicas. Brasília: IICA, 2012. p. 367-398. (Série Desenvolvimento Rural e Sustentável, v. 16).

8 MAIA, A. G. et al. Impacto dos rendimentos de aposentadoria e pensão na redução da pobreza rural. In: CONGRESSO DA SOCIEDADE BRASILEIRA DE ECONOMIA, 46., 2008, Rio Branco. Anais... Brasília: SOBER, 2008.

9 SCHNEIDER, Sergio. Situando o desenvolvimento rural no Brasil: o contexto e as questões em debate. Revista de Economia Política, São Paulo, v. 30. n. 3, p. 511-531, jul./set. 2010. 
lação de atividades extrativistas em áreas públicas e medidas contra o trabalho infantil ${ }^{10}$. Dedecca ${ }^{11}$ ressalta a relevância dessas ações públicas ao enfatizar a suas contribuições para que o problema da pobreza rural no Brasil não seja ainda mais expressivo nos dias atuais.

O início da década de 1990, ainda, assistiu ao quase total esgotamento do crédito rural, o principal indutor da política de modernização agrícola das décadas anteriores ${ }^{12}$. Além disso, a alteração da política de preços mínimos, quando o preço único foi eliminado, a decretação de uma maior abertura da economia e o lançamento do Plano Real foram importantes modeladores da política agrícola vigente. Segundo Mueller ${ }^{13}$, a partir desses anos, tem-se uma nova fase, marcada pela abertura da economia ao exterior e pelo "abandono" da postura intervencionista do governo na agricultura.

Desse modo, a década de 1990 marca o início de novas concepções sobre o desenvolvimento rural, com importantes mudanças no foco e entendimento do processo. Essas alterações desdobraram-se em políticas estatais direcionadas a assuntos até então pouco tratados: reforma agrária, crédito para agricultores familiares, apoio aos territórios rurais e ações de inclusão de mulheres, jovens, aposentados e negros ${ }^{14}$.

Três fatores associam-se, de maneira mais intrínseca, ao processo de mudanças de concepções quanto ao "desenvolvimento rural", conforme Schneider, Shiki e Belik ${ }^{15}$. A primeira alteração importante refere-se à mudança na própria visão do que se entendia por desenvolvimento rural, desatrelando-o da ideia de que se tratava, apenas, de uma questão de assistência social ou políticas pró-pobres em áreas marginalizadas. Segundo, o papel ativo dos agentes locais rurais passou a ser priorizado para o desenho, planejamento e implementação das políticas públicas. O terceiro aspecto relaciona-se à incorporação da noção de desenvolvimento rural sustentável.

Esses fatores foram responsáveis por iniciar um processo de mudança que continua a acontecer desde a década de 1990, com relevantes implicações sobre as políticas públicas do setor. Dessa forma, com base nos padrões de intervenção do Estado e no modo pelo qual esses se desenvolveram, podem-se distinguir três gerações ${ }^{16}$ de políticas brasileiras de "desenvolvimento rural" a partir desses anos ${ }^{17}$. A primeira geração corresponde ao período entre 1993 e 1998 e é caracterizada pelo delineamento de novas políticas públicas com o foco em assentamentos, reforma agrária e crédito para pequenos agricultores familiares. É nessa geração que se enquadra a política públicas dos anos 1990. A segunda geração de políticas para o desenvolvimento do meio rural é alocada no início da década de 2000 e tem como referência a política social e assistencialista. A terceira geração de meados de 2005 até o presente, tem referencial de construção de mercados para a segurança alimentar e sustentabilidade ambiental, conforme se mostrará no estudo dos PPAs. Logicamente, o grande capital rural não foi esquecido pala intervenção estatal.

Outro fator importante a ser considerado no período é a criação do Plano Real. Os anos que antecedem

10 SCHNEIDER, Sergio; SHIKI, Shigeo; BELIK, Walter. Rural development in Brazil: overcoming inequalities and building new markets. Rivista di Economia Agraria, ano 65, n. 2, p. 225-259, giugno 2010.

11 DEDECCA, Cláudio Salvadori. Contribuições para a agenda da política de combate à pobreza rural. In: MIRANDA, Carlos; TIBÚRCIO, Breno (Org.). A nova cara da pobreza rural: desafios para as políticas públicas. Brasília: IICA, 2012. v. 16. (Série Desenvolvimento Rural Sustentável). p. 107-120.

12 GONZALEZ, B. C. R.; COSTA, S. M. A. L. Agricultura brasileira: modernização e desempenho. Teoria Evidência Econômica, Passo Fundo, v. 5, n. 10, p. 7-35, maio 1998.

13 MUELLER, Charles C. A política agrícola no Brasil: uma visão de longo prazo. Revista de Política Agrícola, Brasília, v. 19, p. 9-23, jul. 2010. Edição Especial

14 SCHNEIDER, Sergio. Situando o desenvolvimento rural no Brasil: o contexto e as questões em debate. Revista de Economia Política, São Paulo, v. 30. n. 3, p. 511-531, jul./set. 2010.

15 SCHNEIDER, Sergio; SHIKI, Shigeo; BELIK, Walter. Rural development in Brazil: overcoming inequalities and building new markets. Rivista di Economia Agraria, ano 65, n. 2, p. 225-259, giugno 2010.

16 As gerações não encerram seu ciclo ao advento de seus termos, continuam funcionando e sofrem ajustes e/ou alterações em sua formulação e aplicação, conforme GRISA, Cátia; SCHNEIDER, Sergio. Três gerações de políticas públicas para a agricultura familiar e formas de interação entre sociedade e estado no Brasil. RESR, Piracicaba, v. 52, supl. 1, p. 125-146, fev. 2014. p. S128. 17 SCHNEIDER, Sergio; SHIKI, Shigeo; BELIK, Walter. Rural development in Braziil: overcoming inequalities and building new markets. Rivista di Economia Agraria, ano 65, n. 2, p. 225-259, giugno 2010. 
a maturidade do Plano Real e a nitidez de uma política de governo preocupada com o crescimento modernizante $^{18}$ são definidores do cenário atual do setor agrícola. O panorama dos anos 1990 retrata que o dito Plano, em um primeiro momento, desestabilizou a agricultura, com "desestímulo às operações em ativos financeiros, com consequente fuga em direção a ativos reais e estoques de produtos agrícolas" 19 . Entretanto, o "Plano Real" mostraria que o susto inicial era, apenas, medo de fantasmas -- permanente taxa de inflação e instabilidade macroeconômica. Em geral, o Plano Real teve um efeito estimulante ${ }^{20}$. Permitiu o redesenho da política agrícola, possibilitando a criação de instrumentos posteriores de combate à fome e à pobreza.

Em especial, pode-se relatar o Plano Safra 1995-1996, que: (i) Aboliu a Taxa Referencial2 ${ }^{21}$ (TR) e aderiu a taxa de juros fixa em 16\% ao ano; (ii) aboliu a equivalência-produto ${ }^{22}$; (iii) renegociou a dívida agrícola; (iv) aumentou a oferta do Programa Nacional de Fortalecimento da Agricultura Familiar (PRONAF); (v) criou a Modernização da Frota Máquinas e Equipamentos Agrícolas (MODERFROTA) e; (vi) promoveu o Prêmio de Escoamento do Produto ${ }^{23}$ (PEP), de modo que o Estado se dispôs a pagar a diferença entre o preço de mercado e o preço mínimo a quem adquirisse o produto do agricultor ${ }^{24}$.

O Plano Safra 1996-1997 também adotou medidas que fomentaram o setor: (i) A instituição do contrato de operações de venda para evitar a associação imediata de preços e recursos; (ii) a desregulação do mercado que criaram uma concorrência interna e externa tornando a estrutura do setor agrícola mais competitiva ${ }^{25}$.

O problema foi a supervalorização do dólar, política cambial que durou até 1999. Após esse ano, já inaugurando o século XXI, não havia mais pressão no câmbio e o setor agrícola passou a ter maiores taxas de crescimento. Em suma, a década de 1990 representou aumento de produção, queda dos preços e a continuidade do Estado como um dos principais compradores da produção agrícola. Por sinal, persistiu a intervenção estatal direta e indireta no setor.

18 BERCOVICI, Gilberto. Constituição econômica e desenvolvimento: uma leitura a partir da Constituição de 1988. São Paulo: Malheiros, 2005.

19 REZENDE, Gervásio; KRETER, Ana Cecília. Desafios para o setor agrícola no século XXI. In: DELFIM NETTO, Antônio (Coord.); GUILHOTO Joaquim; DUARTE, Pedro Garcia; SILBER, Simão Davi (Orgs.). O Brasil e a ciência econômica em debate: o Brasil do século XXI. São Paulo: Saraiva, 2011. v. 1. p. 193-196. p. 193.

20 REGO, José Márcio et al. Economia brasileira. São Paulo: Saraiva, 2006. p.238, apontam que o "Plano Real" é até então a melhor experiência de estabilidade da economia brasileira. Na fase pós Real a inflação caiu, o ambiente econômico se tornou estável e previsível, mas alguns problemas ainda se fazem presentes como a carência de poupança interna, baixo crescimento e necessidade de reformas macroeconômicas. Ademais, existem críticas severas, como do Prof. João Antônio de Paula, ao dito "Plano" por ele aprofundar a nossa dependência externa, desindustrializar a nação, aumentar a dívida interna e o desemprego PAULA, João Antonio de. A longa servidão: a trajetória do capitalismo no Brasil. In: PAULA, João Antonio de (Org.). Adeus ao desenvolvimento: a opção do governo Lula. Belo Horizonte: Autêntica, 2005. p. 17-35.

21 A TR foi instituída pela Medida Provisória nº. 294 de 31 de janeiro de 1991, convertida na Lei no .8 .177 de $1^{\circ}$ de março de 1991. O Banco Central determina que a TR seja calculada por aplicadores correspondentes à Taxa Básica Financeira (TBF), que por sua vez é calculada pela remuneração de certificados e recibos de depósito bancário. Todos os dias o BC calcula a TBF que por sua vez influência a TR. Informações disponíveis em: FRALETTI, Paulo Beltrão. Ensaios sobre taxas de juros em reais e sua aplicação na análise financeira. 2004. 160 f. Tese (Doutorado) - Universidade de São Paulo, São Paulo, 2004. p. 104-107. Por esta lógica não era possível saber quanto seria o índice a ser aplicado. Os juros fixos simplificaram a situação de negócios no setor agrícola.

22 A prática da equivalência-produto consistia em fazer, no ato da concessão do empréstimo um cálculo da quantidade equivalente do produto financiado, dividindo o valor total do financiamento, acrescido de despesas e juros, pelo preço mínimo vigente. "No vencimento do empréstimo seria facultada ao tomador a liquidação de seu débito mediante entrega de documento representativo da estocagem o produto na quantidade devida" REZENDE, Gervásio. Política de preços mínimos na década de 90: dos velhos aos novos instrumentos. Rio de Janeiro: IPEA, 2000. (Texto para discussão, n. 470). p. 03.

23 O PEP "tem o objetivo prioritário de garantir um preço referência ao produtor e às cooperativas e, ao mesmo tempo, contribuir para o abastecimento interno. O preço referência é definido pelo governo federa, com base no preço mínimo ou no preço de exercício das opções". DELGADO, Guilherme da Costa; CONCEIÇÃO, Júnia da. Políticas de preços agrícolas e estoques de alimentos: Origens, situação atual e perspectivas. Revista Paranaense de Desenvolvimento, Curitiba, n. 108, p. 25-32, jan./jul. 2005. p. 29. 24 REZENDE, Gervásio; KRETER, Ana Cecília. Desafios para o setor agrícola no século XXI. In: DELFIM NETTO, Antônio (Coord.); GUILHOTO Joaquim; DUARTE, Pedro Garcia; SILBER, Simão Davi (Orgs.). O Brasil e a ciência econômica em debate: o Brasil do século XXI. São Paulo: Saraiva, 2011. v. 1. p. 193-196. p. 194.

25 REZENDE, Gervásio; KRETER, Ana Cecília. Desafios para o setor agrícola no século XXI. In: DELFIM NETTO, Antônio (Coord.); GUILHOTO Joaquim; DUARTE, Pedro Garcia; SILBER, Simão Davi (Orgs.). O Brasil e a ciência econômica em debate: o Brasil do século XXI. São Paulo: Saraiva, 2011. v. 1. p. 193-196. p. 195. 
Nos anos seguintes, aponta-se a manutenção das políticas adotadas nos anos 1990, incluindo-se elementos novos. Segundo Rezende e $\mathrm{Kreter}^{26}$, o maior problema era o aumento do endividamento, mesmo com taxas de juros especiais a determinadas linhas de crédito. Isso porque, nos anos 2000, os recursos para financiamento do setor agrícola se tornaram abundantes. O Banco Central repassou recursos provenientes do Fundo de Amparo do Trabalhador (FAT), dos fundos regionais, do PIS-Pasep, do imposto de renda e do imposto sobre produtos industrializados e com isso aumentou os débitos agrícolas na nação.

O censo agrícola de 1995 revelou uma queda do número de pessoas empregadas na zona rural, eram 21,7 milhões no censo de 1985 e 17,9 milhões no censo de 1995. Segundo Baer ${ }^{27}$, a alteração ocorreu em face da mecanização agrícola. O uso de tratores aumentou $23,5 \%$ no período. $\mathrm{O}$ aumento de maquinário deveu-se tanto pelo MODERFROTA quanto pela participação dos bancos privados no setor.

Curioso notar que a maioria dos bancos privados investidores no setor agrícola, por meio de linhas de crédito, são bancos de montadoras de máquinas agrícolas, interessados tão somente em financiar a venda de seus próprios produtos por meio de repasses do Banco Nacional do Desenvolvimento Social (BNDES ${ }^{28}$. Dias ${ }^{29}$ informa que em 2005 o Conselho Administrativo de Defesa Econômica (CADE) aprovou a última fusão no setor, já bastante concentrado, fazendo com que existam, apenas, quatro produtores mundiais de tratores no Brasi ${ }^{30}$.

As dificuldades resultantes com os débitos agrícolas privados, sempre lucrativos aos bancos, segundo Rezende e $\operatorname{Kreter}^{31}$, não impõe medo ao setor financeiro, pois sabe-se que, em caso de crise, o Estado brasileiro vai agir salvadoramente ${ }^{32}$, conforme estabelecido, por exemplo, no Plano Safra 1995-1996. A socialização dos prejuízos/riscos não é somente estatal, os preços praticados pelos financiamentos são superiores aos de mercado, assim, os agricultores também arcam com o encargo. Trata-se de um oligopólio de venda difícil de ser revertido no cenário atual, dilatando a sucção de ganhos para os especuladores.

Desse modo, o agronegócio reclama das alterações estruturais causadora da elevação das taxas de juros após o Plano Real, do poder oligopolístico da indústria de insumos e da assimetria no poder de negociação ${ }^{33}$. Mas Baer ${ }^{34}$ aponta que o setor teve ganho de produtividade ${ }^{35}$, em especial na produção voltada para o mercado interno.

26 REZENDE, Gervásio; KRETER, Ana Cecília. Desafios para o setor agrícola no século XXI. In: DELFIM NETTO, Antônio (Coord.); GUILHOTO Joaquim; DUARTE, Pedro Garcia; SILBER, Simão Davi (Orgs.). O Brasil e a ciência econômica em debate: o Brasil do século XXI. São Paulo: Saraiva, 2011. v. 1. p. 193-196. p. 195.

27 BAER, Werner. A economia brasileira. 2. ed. São Paulo: Nobel, 2002. p. 392.

28 REZENDE, Gervásio; KRETER, Ana Cecília. Desafios para o setor agrícola no século XXI. In: DELFIM NETTO, Antônio (Coord.); GUILHOTO Joaquim; DUARTE, Pedro Garcia; SILBER, Simão Davi (Orgs.). O Brasil e a ciência econômica em debate: o Brasil do século XXI. São Paulo: Saraiva, 2011. v. 1. p. 193-196. p. 196.

29 DIAS, Guilherme Leite da Silva. Agronegócios: problemas de coordenação e regulação a superar. In: DELFIM NETTO, Antônio (Coord.); GUILHOTO Joaquim; DUARTE, Pedro Garcia; SILBER, Simão Davi (Org.). O Brasil e a ciência econômica em debate: Brasil do século XXI. São Paulo: Saraiva, 2011. v. 1. p. 179-188. p. 184.

30 A FIAT adquiriu as montadoras New Holland e Case, além de continuar produzindo tratores da linha FiatAllis. A fusão gerou a $\mathrm{CNH}$, empresa que mantém as três marcas no mercado. Além da $\mathrm{CNH}$, o mercado brasileiro conta ainda com as americanas Carterpillar e John Deere e a japonesa Komatsu.

31 REZENDE, Gervásio; KRETER, Ana Cecília. Desafios para o setor agrícola no século XXI. In: DELFIM NETTO, Antônio (Coord.); GUILHOTO Joaquim; DUARTE, Pedro Garcia; SILBER, Simão Davi (Orgs.). O Brasil e a ciência econômica em debate: o Brasil do século XXI. São Paulo: Saraiva, 2011. v. 1. p. 193-196.

32 CLARK, Giovani. O neoliberalismo de regulação como intervenção do Estado: a regulação e a Constituição de 1988. Economia \& Empresa, Lisboa, n. 9, p. 10-30, 2009.

33 Sobre o poder oligopolístico e assimetria no poder de negociação é possível apontar alguns exemplos dos anos 2000: A indústria do suco de laranja sofreu com um processo de concentração vertical e teve diversos contratos contestados na justiça entre 2000 e 2005. A indústria do couro para calçados reclama de uma intervenção do governo em 2001: aumento do imposto de exportação sobre o couro. Segundo o setor a medida reduziu a competitividade e a concorrência com a China enfraqueceu severamente a indústria nacional. A indústria têxtil e produtores de algodão entraram em conflito sobre o excesso de importações em 2000 segundo, DIAS, Guilherme Leite da Silva. Agronegócios: problemas de coordenação e regulação a superar. In: DELFIM NETTO, Antônio (Coord.); GUILHOTO Joaquim; DUARTE, Pedro Garcia; SILBER, Simão Davi (Org.). O Brasil e a ciência econômica em debate: Brasil do século XXI. São Paulo: Saraiva, 2011. v. 1. p. 179-188. p. 184-185.

34 BAER, Werner. A economia brasileira. 2. ed. São Paulo: Nobel, 2002. p. 395.

35 Baseados em dados do FIBGE, as culturas de algodão, soja, milho e feijão apresentaram significativo aumento nos índices de produtividade. O café e o cacau, voltados para exportação sofreram redução no índice de produtividade. Para BAER, Werner. $A$ 
Nota-se que as políticas econômicas executadas pelo Estado são, geralmente, utilitaristas, e beneficiam, de forma costumeira, os bancos privados, inseridos no setor agrícola, financiadores de seus próprios produtos. Não há risco, fator inerente ao capitalismo, pois, em caso de crise, o Estado está comprometido com intervenção salvadora. Novamente, os parâmetros constitucionais foram abandonados. A política da cadeia produtiva do setor não resultou em alimentos e produtos destinados à vida e à saúde, mas sim em concentração de renda, favorecendo banqueiros e grandes produtores rurais. Quanto à intervenção estatal na vida econômica ensina o Prof. Washington Peluso Albino de Souza:

Quando o Estado exerce poder no "domínio econômico", ou seja, na área da realidade econômica, caracteriza-se o Poder Econômico do Estado. O exercício desse poder implica medidas de política econômica, quer em relação à economia interna corporis, sua própria administração, quer no espaço econômico externo, ou atividade econômica fora da sua própria administração. Desta, deparamos com áreas antes reservadas à iniciativa privada, quando disciplina a atividade econômica do particular, ou mesmo a do Estado-Empresário, na medida em que os seus efeitos se fazem sentir, ou em que os seus interesses extrapolam o âmbito das relações privadas, e se projetam no todo social. [...]

A realidade histórica, como se sabe, jamais registrou alguma forma ideológica "pura". Daí a evolução da ideologia capitalista, com a absorção de elementos da socialista, configurando um modelo híbrido, com extremos opostos e que se concretiza num processo "pendular" de aproximações com tendências ora para um ora para outro extremo, ao qual podemos aplicar o raciocínio "marginalista". A esse "tipo" se costuma traduzir por "Estado Mínimo", com a mínima participação do poder econômico do Estado, seguindo "tendência" na direção negativa para a "margem" ou "limite", no Liberalismo "puro". Na posição oposta, estaria o "Estado Máximo", com "tendência" na direção positiva para as margens, ou o limite extremo, do Socialismo. Ao modelo composto e, por isso, com elementos de ambos, porque simbiótico, se passou a denominar Neoliberalismo. Sua estrutura é construída à base da anteposição Estado versus Mercado, com preferência para este, porém sem abolir aquele. Correspondendo a esse esquema, concentra o seu apoio na livre concorrência e na restrição às modalidades de ação econômica do Estado. Dentre estas, revela maior tolerância para a "Regulação", e maior restrição para a "Regulamentação" e para o "Planejamento"36.

Assim, nessa primeira geração de políticas públicas para o "desenvolvimento rural”, tem-se o início dos diálogos entre os movimentos sociais e as esferas de poder, destaca-se nesse período a criação do Programa Nacional de Agricultura Familiar (PRONAF) em 1995, importante iniciativa por constituir-se na primeira política agrícola a levar em consideração as características específicas da agricultura familiar ${ }^{37}$. A partir do cenário descrito, pode-se indagar como foi a intervenção estatal no setor agrícola nos anos 2000? A resposta virá da análise dos PPAs de 2000-2003; 2004-2007; 2008-2011 e 2012-2015, da segunda e terceira gerações de políticas públicas para o setor e das teorias da sociologia rural.

\section{O PLANejamento estatal NOS ANOS 2000}

Os anos 1990 marcaram uma mudança na intervenção estatal. Se durante a década de 1980 o enfoque era o da modernização da agricultura preconizado pela revolução verde, nos últimos 20 anos, o enfoque tem sido as "políticas governamentais direcionadas para a reforma agrária, o crédito para agricultura familiar, o apoio aos territórios rurais, o estímulo a ações afirmativas para mulheres, jovens, aposentados e negros" 38 . Todavia, os poderosos do setor não foram excluídos ou deixados de lado, o Estado regulador que estava a se formar demonstrava-se mais flexíveis às demandas da sociedade civil.

economia brasileira. 2. ed. São Paulo: Nobel, 2002. p. 395. Isso significa que as medidas adotadas pelo governo nos anos 1990 foram voltadas especialmente à agricultura voltada para o mercado doméstico.

36 SOUZA, Washington Peluso Albino de. Primeiras linhas de direito econômico. 6. ed. São Paulo: LTr, 2005. p. 314-315.

37 GRISA, Cátia; SCHNEIDER, Sergio. Três gerações de políticas públicas para a agricultura familiar e formas de interação entre sociedade e estado no Brasil. RESR, Piracicaba, v. 52, supl. 1, p. 125-146, fev. 2014.

38 SCHNEIDER, Sergio. Situando o desenvolvimento rural no Brasil: o contexto e as questões em debate. Revista de Economia Política, São Paulo, v. 30. n. 3, p. 511-531, jul./set. 2010. 
Acompanha essa mudança de atuação estatal o surgimento de um planejamento por parte do Estado. $\mathrm{Na}$ década de 1990, não havia um planejamento global, apenas políticas econômicas anti-inflacionárias, chamadas por Souza ${ }^{39}$ (2005) de antiplanos e, geralmente de alcance setorial ${ }^{40}$, exemplifica-se por meio dos planos Collor, Bresser, Real e Safra. O Estado brasileiro não estava interessado em planejar - método de intervir na economia - por meio de um plano - peça técnica, de iniciativa do poder executivo, a ser transformada em lei. Era a implantação do neoliberalismo de regulação ${ }^{41},{ }^{42}$, 3 . Todavia a legislação planejadora foi fixada no Brasil, por intermédio da Constituição de 1988, previstas em instrumentos como a lei do Plano Plurianual (PPA), da Diretrizes Orçamentárias (LDO) e a Lei Orçamentária (LO), bem como as Leis de Política Agrícola (Lei n. 8.171 de 17/01/1991 e alterações) e de Reforma Agrária (Lei n. 8.629 de 15/02/1993 e alterações). Assim, pelo disposto nos artigos 165, 174 e 182 da Constituição, não é por demais afirmar que a República Federativa do Brasil deve possuir um Estado planejador.

Planejar as ações públicas é definir, em longo, médio e curto prazo, como o Estado irá dar concretude aos ditames impositivos e dirigentes constitucionais, diante de uma realidade socioeconômica, ambiental e tecnológica injusta, excludente e concentradora. Nas palavras de Souza, "o Planejamento é uma técnica de intervenção do Estado no domínio econômico" 4 . Ressalte-se que: o planejamento não está refém de nenhuma ideologia, sendo adotado por diversos Estados na órbita terrestre, sejam eles capitalistas, socialistas, democráticos, autoritários, religiosos etc. Todavia, é importante alertar que pode existir intervenção estatal independentemente de qualquer planejamento público, como nos casos de medidas de política econômicas setoriais destinadas a mudança de moeda, redução da tributação para a indução do consumo, entre outras.

A intervenção deve existir, portanto, no domínio econômico e social, que, segundo os ditames constitucionais de 1988, obriga o Estado agir planejadamente na atividade econômica, sem que ocorra a eliminação do setor privado e dos seus meios de produção, mas a impondo a sua função social, a fim de efetivar as garantias e os direitos individuais e sociais.

Assim sendo, o Estado planejador brasileiro deve adotar técnicas e ações que abarquem, de maneira indissociável, o desenvolvimento, a justiça social e a proteção do meio ambiente.

Schneider ${ }^{45}$, identifica que a política agrícola passa por um estágio de ampliação em torno da agricultura familiar e de seu potencial como modelo social, econômico e produtivo na sociedade brasileira. Dilata-se, ainda, o aumento da presença do Estado no meio rural por meio de políticas para a agricultura familiar, segurança alimentar, PRONAF, entre outras. Quanto ao dito programa, formado em 1995, por força de representantes da agricultura familiar, de estudiosos do meio rural, políticos e gestores públicos, como uma política de crédito rural que contribuía para a capitalização e o acesso dos agricultores familiares a mercados, tem-se a sua constante ampliação, exemplifica-se com o Plano Safra da agricultura familiar 2014-2015, com previsão orçamentária de 24,1 bilhões de reais ${ }^{46}$. Apesar da importância do PRONAF, existe, ainda, uma resistência política e ideológica com a polarização entre a forma familiar e a patronal-empresarial. A produção familiar é comumente voltada para o mercado local ou o mercado interno, enquanto a patronal-empresarial dirigida essencialmente para a exportação.

39 SOUZA, Washington Peluso Albino de. Primeiras linhas de direito econômico. 6. ed. São Paulo: LTr, 2005.

40 Regredindo ainda mais no tempo é possível elencar também o Plano de Metas 1956-1961 de Juscelino Kubitscheck, o Plano Trienal - 1962-1963 -, de João Goulart e os Planos Nacionais de Desenvolvimento dos militares.

41 SOUZA, Washington Peluso Albino de. Primeiras linhas de direito econômico. 6. ed. São Paulo: LTr, 2005. p. 314-315.

42 CLARK, Giovani. O neoliberalismo de regulação como intervenção do Estado: a regulação e a Constituição de 1988. Economia \& Empresa, Lisboa, n. 9, p. 10-30, 2009.

43 CAMARgO, Ricardo Antônio Lucas. Curso elementar de direito econômico. Porte Alegre: Núria Fabris, 2014.

44 SOUZA, Washington Peluso Albino de. Primeiras linhas de direito econômico. 6. ed. São Paulo: LTr, 2005. p. 317.

45 SCHNEIDER, Sergio. Situando o desenvolvimento rural no Brasil: o contexto e as questões em debate. Revista de Economia Política, São Paulo, v. 30. n. 3, p. 511-531, jul./set. 2010.

46 GRISA, Cátia; SCHNEIDER, Sergio. Três gerações de políticas públicas para a agricultura familiar e formas de interação entre sociedade e estado no Brasil. RESR, Piracicaba, v. 52, supl. 1, p. 125-146, fev. 2014. 
A referida polarização na prática se traduz em uma acirrada disputa política e ideológica. De um lado, a agricultura familiar e os movimentos sociais, que tentam por meio de suas manifestações o reconhecimento de suas reivindicações (preços mínimos, reforma agrária, crédito justo) na agenda estatal (políticas públicas). De outro lado, o agronegócio - o grande agraciado dos recursos e ações estatais - e os construtores de políticas (policy-makers). Reforça tal dicotomia a própria organização do aparelho do Estado (União): existem, no Brasil, dois ministérios responsáveis pela agricultura e pelo meio rural, o Ministério do Desenvolvimento Agrário (MDA), criado em 1999, e o Ministério da Agricultura Pecuária e Abastecimento (MAPA), criado em 1860 com o nome de Ministério da Agricultura ${ }^{47}$. O MDA é comumente retratado como o ministério da agricultura familiar enquanto o MAPA é tido como o ministério do agronegócio ${ }^{48}$.

Dessa polarização surge o conflito da formulação da agenda da política agrícola, seria ela determinada pela demanda social, portanto fruto da pressão de movimentos, atores, instituições e organizações do meio rural ligadas ao MDA? Ou seria a agenda formulada ex ante, por estudiosos, pesquisadores e organizações do capital atuantes no MAPA que sobrevivem da elaboração de projetos e de sua interface com o Estado? Schneider ${ }^{49}$, acredita que a balança tende para o lado do agronegócio, sem ignorar eventuais movimentos sociais capaz de influenciar a formação daquela ${ }^{50}$. Necessário verificar, em face das principais correntes de desenvolvimento rural, como os planos plurianuais (PPAs), um dos instrumentos de planejamento global do Estado, tem tratado o setor agrícola.

A primeira corrente teórica tem como expoentes José Eli da Veiga e Ricardo Abramovay e como matrizes teóricas a ecologia, a sociologia econômica e a economia. Ambos valorizam a agricultura familiar por seu potencial dinamizador das economias locais. Os agricultores familiares são considerados como empreendedores com a capacidade de inovar e diversificar a produtividade dos territórios rurais em que vivem. Veiga foca seus estudos em empresas públicas e políticas governamentais, enquanto Abramovay trabalha a noção de capital social e seus fatores de cooperação, reciprocidade e solidariedade entre os agricultores familiares.

A segunda corrente possui como destaque José Graziano da Silva, que trabalha a sua matriz teórica no rurbano, ou o novo rural, que não é mais sinônimo de atraso. O meio rural tem uma nova formação com redução crescente das diferenças entre o urbano e o rural, especialmente em face do mercado de trabalho. O novo rural é composto por: (i) uma agropecuária moderna baseada em commodities; (ii) um conjunto de atividades não agrícolas, como moradia, lazer, indústria e prestação de serviços; (iii) uma série de novas atividades impulsionadas por nichos de mercado. Há, também, um grupo excluído, os sem-sem, desprovidos de terra, trabalho, educação, saúde e organização para reivindicar/demandar seus direitos. A solução para tais problemas, na visão da segunda corrente, seria gerar oportunidades não agrícolas, já que o setor agrícola moderno, mecanizado, poupa trabalho. E se isso não for possível, acionar políticas compensatórias como: a reforma agrária seletiva, ações de combate a fome, segurança alimentar, entre outras ${ }^{51}$.

A terceira corrente, comandada por José de Souza Martins e Zander Navarro, apresenta como matriz teórica a força da tradição histórica como limitadora do desenvolvimento rural, estudos sobre clientelismo

47 SCHNEIDER, Sergio. Situando o desenvolvimento rural no Brasil: o contexto e as questões em debate. Revista de Economia Política, São Paulo, v. 30. n. 3, p. 511-531, jul./set. 2010. p. 517.

48 O problema aqui pode ser meramente de uma arquitetura institucional. Bandeira de Mello (2009) informa que é livre a constituição dos ministérios, e de fato, a cada governo tem-se um novo arranjo institucional de forma tentar fazer o Executivo mais eficiente. Mas a discussão também pode tangenciar as capacidades institucionais, que investigam comparativamente como duas instituições podem responder aos problemas sociais. Informam ARGUELHES, Diego Werneck; LEAL, Fernando. O argumento das "capacidades institucionais" entre a banalidade, a redundância e o absurdo. Direito, Estado e Sociedade, Rio de Janeiro, n. 38, p. 6-50, jan./jun. 2011. 49 SCHNEIDER, Sergio. Situando o desenvolvimento rural no Brasil: o contexto e as questões em debate. Revista de Economia Política, São Paulo, v. 30. n. 3, p. 511-531, jul./set. 2010. p. 518.

50 Como exemplos de movimentos sociais tem-se o movimento sem terra e seu abril vermelho e o sindicato dos trabalhadores rurais, composto basicamente por agricultores familiares, que por meio do grito da terra buscam benefícios no Plano Safra. Tudo conforme, SCHNEIDER, Sergio. Situando o desenvolvimento rural no Brasil: o contexto e as questões em debate. Revista de Economia Política, São Paulo, v. 30. n. 3, p. 511-531, jul./set. 2010. p. 518.

51 SCHNEIDER, Sergio. Situando o desenvolvimento rural no Brasil: o contexto e as questões em debate. Revista de Economia Politica, São Paulo, v. 30. n. 3, p. 511-531, jul./set. 2010. p. 521-522. 
e patriarcalismo com bases weberianas de dominação carismática e tradicional. Assim, o desenvolvimento rural esbarra em mecanismos de dominação social e cultural construídos historicamente por elites locais para legitimar e manter o poder. Defendem a democratização capaz de libertar os indivíduos dos mediadores (igreja, partidos políticos, movimentos sociais). Os processos de desenvolvimento deveriam significar a emancipação social.

A quarta e última corrente teórica destaca-se como expoente Lima Wilkinson e a sua matriz teórica é pautada no agronegócio e nas cadeias alimentares. Analisa as formas de integração dos pequenos produtores nas cadeias agroindustriais ou agroalimentares. O desafio, para a agricultura familiar, consiste na melhoria da capacidade de inserção em mercados locais ou non-standards, como: merenda escolar, programas sociais. Para Wilkinson, é preciso desenvolver novas habilidades e ler as necessidades do consumidor. Aponta-se, ainda, como dificuldades: o baixo nível escolar dos agricultores, reduzida capacidade de absorção dos excedentes de produção pelos mercados locais da agricultura familiar, percalços no manejo de contratos de financiamento e das propriedades ${ }^{52}$.

Explicadas as principais vertentes teóricas, resta, agora, verificar se o planejamento estatal segue alguma dessas correntes. O PPA 2000-2003, ainda, vivenciava as políticas pertinentes aos anos 1990 - política com foco na revolução verde e na modernização conservadora. No relatório do Ministério do Planejamento ${ }^{53}$, apesar de não existir qualquer política estatal nítida para o setor agrícola, seja ela voltada para a agricultura familiar, seja ela voltada para o agronegócio, tem-se o início do diálogo entre a sociedade civil e as esferas políticas, com viés sociológico econômico aos moldes da teoria de José Eli da Veiga e Ricardo Abramovay (primeira corrente).

O PPA 2004-2007 deu continuidade à vertente sociológica-econômica, encarou os problemas sociais de maneira separada dos problemas rurais, mas previu, em suas ações, medidas prioritárias para a assistência social, a reforma agrária e para a agricultura e pecuária. No setor agrícola, por exemplo, foi projetado um reajuste de preços mínimos de produtos, reprogramação das dívidas e medidas indutivas via PRONAF. Tais medidas fortaleceram a agricultura familiar, que se beneficiou com uma maior demanda global por alimentos $^{54}$. Ainda quanto ao PRONAF, segundo o relatório do PPA 2004-2007, 3,7 milhões de famílias foram beneficiadas pelo programa ${ }^{55}$ sendo responsáveis por 38\% do valor bruto da produção agropecuária nacional ${ }^{56}$.

No tocante à reforma agrária, outra meta prioritária do PPA 2004-2007, foram realizados assentamentos sustentáveis de 265,4 mil famílias ${ }^{57}$, com preocupação de permitir o acesso à infraestrutura produtiva, à habitação, à saúde, à educação e à capacitação ${ }^{58}$.

As medidas voltadas ao setor agrícola familiar ainda refletem o combate à fome, devendo ser erradicada até $2015^{59}$. Para essa meta ser alcançada, as medidas incluem o programa Fome Zero, de 2003, com o acesso a

52 SCHNEIDER, Sergio. Situando o desenvolvimento rural no Brasil: o contexto e as questões em debate. Revista de Economia Politica, São Paulo, v. 30. n. 3, p. 511-531, jul./set. 2010. p. 525-526

53 BRASIL. Ministério do Planejamento, Orçamento e Gestão. Secretaria de Planejamento e Investimentos Estratégicos. Relatório de Avaliação do Plano Plurianual 2000-2003. Brasília: MPOG, 2001.

54 BRASIL. Ministério do Planejamento, Orçamento e Gestão. Secretaria de Planejamento e Investimentos Estratégicos. Relatório de Avaliação do Plano Plurianual 2004-2007: exercício 2008 - ano base 2007. Brasília: MP, 2008. p. 56.

55 BRASIL. Ministério do Planejamento, Orçamento e Gestão. Secretaria de Planejamento e Investimentos Estratégicos. Relatório de Avaliação do Plano Plurianual 2004-2007: exercício 2008 - ano base 2007. Brasília: MP, 2008. p. 81.

56 No período também foi criado o Programa de Aquisição de Alimentos da Agricultura Familiar, destinado a aquisição de "alimentos com isenção de licitação, por preços de referência que não podem ser superiores nem inferiores aos praticados nos mercados regionais, até o limite de $\mathrm{R} \$ 3.500,00$ ao ano por agricultor familiar que se enquadre no PRONAF” BRASIL. Ministério do Planejamento, Orçamento e Gestão. Secretaria de Planejamento e Investimentos Estratégicos. Relatório de Avaliação do Plano Plurianual 2004-2007: exercício 2008 - ano base 2007. Brasília: MP, 2008. p. 110.

57 BRASIL. Ministério do Planejamento, Orçamento e Gestão. Secretaria de Planejamento e Investimentos Estratégicos. Relatório de Avaliação do Plano Plurianual 2004-2007: exercício 2008 - ano base 2007. Brasília: MP, 2008. p. 82.

58 BRASIL. Ministério do Planejamento, Orçamento e Gestão. Secretaria de Planejamento e Investimentos Estratégicos. Relatório de Avaliação do Plano Plurianual 2004-2007: exercício 2008 - ano base 2007. Brasília: MP, 2008. p. 187.

59 BRASIL. Ministério do Planejamento, Orçamento e Gestão. Secretaria de Planejamento e Investimentos Estratégicos. Relatório 
alimentos, fortalecimento da agricultura familiar e geração de renda, e o Bolsa Família, que em 2007 atendeu 11 milhões de famílias e representou uma melhora nutricional em $62,3 \%$ das crianças entre 6 e 11 meses ${ }^{60}$.

Em uma dimensão mais pertinente ao agronegócio, o relatório informa que o aumento da safra de grãos não atingiu a meta - de 150 milhões - ficando no patamar de 131,73 milhões de sacas. A exportação de carne, também, não atingiu a meta - de 3 milhões de toneladas por ano - ficando em 1,6 milhões de toneladas por ano. A febre aftosa, também não atingiu a meta - de erradicação total - sendo cumprida apenas 59,2\% de controle.

Pode-se afirmar que o PPA 2004-2007 insere-se na chamada segunda geração de políticas públicas de desenvolvimento rural. Período marcado pela formulação e implementação de políticas sociais e compensatórias para as áreas rurais, da "preocupação" com a reforma agrária e com o crédito a agricultura familiar. Nesse período, um conjunto mais variado de medidas de bem-estar passou a ser considerado, foram criadas importantes políticas sociais (Bolsa Escola, Auxílio Gás e outros programas que em 2003 uniram-se para formar o Programa Bolsa Família) e o Programa de Aquisição de Alimentos (PAA), em 2004 ${ }^{61}$.

Em 2006 inicia-se a terceira geração de políticas públicas, momento compreendido tanto pelo PPA 20042007 quando pelo PPA 2008-2011. A terceira geração de políticas públicas para o desenvolvimento rural se estende até os dias atuais. Além do refinamento dos programas existentes, novas iniciativas foram criadas. Destaca-se nesse contexto o surgimento de políticas de apoio ao processamento dos produtos agrícolas, como as medidas de incentivo ao desenvolvimento de agroindústrias familiares ${ }^{62}$.

Percebe-se que a agricultura familiar tem sido alvo específico de políticas públicas há pouco mais de vinte anos. A despeito disso, sua importância para a economia brasileira é marcante. De acordo com IBGE, 84,4\% dos produtores rurais brasileiros são agricultores familiares, que, mesmo ocupando apenas $24,3 \%$ da área de estabelecimentos agropecuários brasileiros, são importantes fornecedores de alimentos para o mercado interno e responsáveis por boa parte da segurança alimentar da população. Em 2006, a agricultura familiar foi responsável por $87 \%$ da produção nacional de mandioca, $70 \%$ da produção de feijão, $46 \%$ do milho, $38 \%$ do café, $34 \%$ do arroz, $21 \%$ do trigo e, na pecuária, $58 \%$ do leite, $59 \%$ do plantel de suínos, $50 \%$ das aves e $30 \%$ dos bovinos.

Nesse cenário, O PPA 2008-2011 destaca a nítida distinção entre as ações do MAPA e da MDA. O MAPA estabelece os seguintes programas: (i) o abastecimento agroalimentar; (ii) de desenvolvimento da economia cafeeira; (iii) o desenvolvimento do agronegócio no comércio internacional; (iv) o desenvolvimento sustentável das regiões produtoras de cacau; (v) o desenvolvimento sustentável do agronegócio; (vi) a gestão política da agropecuária; (vii) a minimização dos riscos do agronegócio; (viii) a pesquisa e desenvolvimento agropecuário e agroindustrial para a inserção social; (ix) a qualidade de insumos e serviços agropecuários; (x) a segurança da sanidade na agropecuária; (xi) a segurança e qualidade de alimentos e bebidas ${ }^{63}$.

Já o MDA fixa os programas de: (i) agricultura familiar - PRONAF; (ii) o assentamento de trabalhadores rurais; (iii) a assistência técnica e extensão rural na agricultura familiar; (iv) o crédito fundiário; (v) o desenvolvimento sustentável de projetos de assentamento; (vi) o desenvolvimento sustentável de territórios rurais; (v) a educação no campo - PRONERA; (vi) o gerenciamento da estrutura fundiária e destinação de terras públicas; (vii) a gestão política do desenvolvimento agrário; (viii) a paz no campo ${ }^{64}$.

de Avaliação do Plano Plurianual 2004-2007: exercício 2008 - ano base 2007. Brasília: MP, 2008. p. 105.

60 BRASIL. Ministério do Planejamento, Orçamento e Gestão. Secretaria de Planejamento e Investimentos Estratégicos. Relatório de Avaliação do Plano Plurianual 2004-2007: exercício 2008 - ano base 2007. Brasília: MP, 2008. p. 108.

61 SCHNEIDER, Sergio; SHIKI, Shigeo; BELIK, Walter. Rural development in Brazil: overcoming inequalities and building new markets. Rivista di Economia Agraria, ano 65, n. 2, p. 225-259, giugno 2010.

62 SCHNEIDER, Sergio; SHIKI, Shigeo; BELIK, Walter. Rural development in Brazil: overcoming inequalities and building new markets. Rivista di Economia Agraria, ano 65, n. 2, p. 225-259, giugno 2010.

63 BRASIL. Ministério do Planejamento, Orçamento e Gestão. Secretaria de Planejamento e Investimentos Estratégicos. Relatório de Avaliação do Plano Plurianual 2008-2011: exercício 2011 - ano base 2010. Brasília: MP, 2011.

64 BRASIL. Ministério do Planejamento, Orçamento e Gestão. Secretaria de Planejamento e Investimentos Estratégicos. Relatório de Avaliação do Plano Plurianual 2008-2011: exercício 2011 - ano base 2010. Brasília: MP, 2011. 
O PPA 2012-2015 define as metas para o setor, reconhecendo especial importância para a agricultura familiar, já que o modelo econômico e agrícola implantado na nação desde 1930, e que perdura até os dias atuais, não reconheceu nem possibilitou a agricultura familiar, responsável pelo abastecimento dos grandes centros urbanos, se desenvolvesse a contento. Para corrigir tal distorção, o PPA 2012-2015 estabelece:

A prioridade do governo federal nos últimos anos tem sido a de criar um conjunto de políticas públicas diferenciadas, simultâneas e continuadas de garantia do direito à terra e de democratização da estrutura fundiária, de fortalecimento da agricultura familiar, de segurança alimentar, de promoção da igualdade de gênero, de raça e de etnia, de desenvolvimento territorial e de integração regional, além da educação e da cultura ${ }^{65}$.

As bases das ações se encontram no Censo Agropecuário 2006 do IBGE; na Lei nº 11.326/06, que estabeleceu as diretrizes da Política Nacional da Agricultura Familiar e Empreendimentos Familiares Rurais, definindo, também, o público da agricultura familiar; na Lei nº.12.188/10 instituidora da Política Nacional de Assistência Técnica e Extensão Rural para a Agricultura Familiar e Reforma Agrária (PNATER) e o Programa Nacional de Assistência Técnica e Extensão Rural na Agricultura Familiar e na Reforma Agrária (PRONATER), estabelecendo um novo modelo de Extensão Rural.

Segundo os dados do Censo de 2006, são 4,37 milhões de estabelecimentos de agricultura familiar, representando $84 \%$ do total de empreendimentos rurais no país. Nesses estabelecimentos trabalham 12,3 milhões de pessoas. O correspondente a $74,4 \%$ da mão de obra do campo, respondendo a $10 \%$ do PIB nacional ${ }^{66}$.

As políticas implantadas desde 2006, segundo o PPA de 2011-2015 geraram resultados, pois,

Entre 2002 a 2009, as áreas rurais receberam quase um milhão de novos domicílios. A pobreza rural teve uma queda expressiva, com redução da taxa de pobreza rural de 48,6\%, em 2002, para 32\%, em 2008 , indicando a saída da pobreza de mais de quatro milhões de pessoas, bem como a redução da taxa da pobreza extrema de $19,9 \%$ para $11,7 \%{ }^{67}$.

Apesar da melhora, ainda há muito por fazer. Em valores globais, serão mais de 93 bilhões de reais destinados para a agricultura familiar no período $2012-2015^{68}$. Incluindo, entre outras metas, as de: i) aquisição de 2,7 milhões de toneladas de alimentos produzidos pela agricultura familiar; ii) ampliar o crédito para 5 mil pessoas jurídicas da agricultura familiar; iii) distribuir sementes para 220 mil famílias (Plano Brasil Sem Miséria); iv) expandir a garantia de safra para 1 milhão de famílias; v) financiar equipamentos (Plano Mais Alimentos).

$\mathrm{Na}$ atual conjectura de economias de mercado supostamente abertos, em que se enquadram a grande maioria das nações, o crescimento econômico nacional modernizante ${ }^{69}$ depende sobremaneira da taxa de exportação. Assim, se considerarmos a existência de um mercado limitado, tem-se a concorrência entre as nações na busca dos mercados consumidores. Analisando o caso brasileiro, é possível notar uma generosa expansão da economia até 2010, a partir de então, seja por reflexos da crise mundial, seja pelo enfrentamento da China como concorrente, com seu baixo custo de produção, o crescimento nacional estagnou ${ }^{70}$.

O setor agrário é fundamental para a economia brasileira. Apenas a agricultura familiar, como visto,

65 BRASIL. Ministério do Planejamento, Orçamento e Gestão. Plano Mais Brasil: PPA 2012-2015: relatório anual de avaliação: ano base 2012. Brasília: MPOG, 2013. v. 1. p. 164-165.

66 BRASIL. Ministério do Planejamento, Orçamento e Gestão. Plano Mais Brasil: PPA 2012-2015: relatório anual de avaliação: ano base 2012. Brasília: MPOG, 2013. v. 1. p. 165.

67 BRASIL. Ministério do Planejamento, Orçamento e Gestão. Plano Mais Brasil: PPA 2012-2015: relatório anual de avaliação: ano base 2012. Brasília: MPOG, 2013. v. 1. p. 165.

68 BRASIL. Anexo da Lei n. 12.593, de 18 de janeiro de 2012. Institui o Plano Plurianual da União para o período de 2012 a 2015. Disponível em: <http://www.planalto.gov.br/ccivil_03/_Ato2011-2014/2012/Lei/L12593.htm>. Acesso em: 10 set. 2012.

69 BERCOVICI, Gilberto. Constituição econômica e desenvolvimento: uma leitura a partir da Constituição de 1988. São Paulo: Malheiros, 2005.

70 MEDEIROS, Carlos Aguiar. Industrialização e distribuição de renda, dilemas e desafios para uma estratégia de desenvolvimento. In: SEMINÁRIO DE DESENVOLVIMENTO E POLÍTICAS PÚBLICAS, 3., 2012, Viçosa. Anais... Viçosa: Universidade Federal de Viçosa, 2012. 
é responsável por $84 \%$ da produção nacional. O setor conta, ainda, com o grande produtor, comumente chamado de agronegócio, que merece especial atenção do PPA 2012-2015. Note-se que não há no texto qualquer divisão entre as duas formas, pois qualquer um dos programas específicos pode ser desfrutado (teoricamente) pelo grupo da agricultura familiar que se enquadre nos requisitos mínimos.

A importância dos programas específicos está na necessidade de manter a segurança alimentar da população brasileira, que hoje é de 190,73 milhões de pessoas, e deve chegar a 216,41 milhões em 2030. As alternativas, segundo o Ministério do Planejamento são, aumento da produção, redução das perdas; otimização da distribuição e processamento ${ }^{71}$, medidas que trabalham tão somente sob o signo da eficiência.

A agropecuária é projetada para ser sustentável e permitir que o produto brasileiro seja competitivo nos mercados externos, não servindo apenas para o abastecimento interno. A agropecuária representou em 2010 22,4\% do PIB e 37,9\% das exportações nacionais. No programa específico da agropecuária, pretende-se: i) fomentar a produção por meio de crédito rural; ii) aprimorar a gestão do risco agrícola; iii) garantia de preço mínimo ao produtor; iv) aumento da capacidade de armazenagem; v) promoção internacional do produto brasileiro; vi) sustentabilidade; vii) redução da emissão de carbono (Plano $\mathrm{ABC}$ ); viii) promoção do associativismo e cooperativismo na agropecuária; ix) geração de agroenergia; x) política de modernização da gestão institucional ${ }^{72}$.

Para atingir esses objetivos, o PPA de 2012-2015 deseja: i) ampliar a área de seguro rural de 6,7 para 30 milhões de hectares; ii) aumentar a capacidade de armazenagem de 2,148 milhões de toneladas para 2,792 milhões de toneladas; iii) implantar 900 unidades de baixo carbono (Plano ABC); iv) mapear áreas para a produção sustentável; v) capacitar 40 mil produtores e 20 mil técnicos; vi) ampliar de 26 para 90 os núcleos de agroecologia na rede federal ${ }^{73}$.

Além dos objetivos acima, o PPA de 2012-2015 pretende aumentar o desenvolvimento de ciência e tecnologia no setor, voltando suas atenções, não apenas para a produtividade, mas também para redução da miséria, sustentabilidade e proteção do patrimônio genético. Apoiando-se no uso de defesas agropecuária, por meio do Sistema Unificado de Atenção à Sanidade Agropecuária (SUASA) ${ }^{74}$.

Para a agricultura, a intenção é aumentar a fronteira agrícola, regulamentando as áreas já devastadas como áreas aptas para a produção. Não é de se espantar o conteúdo do novo Código Florestal, promulgado via Medida Provisória em meados de $2011^{75}$, bem permissivo com os desmatamentos ilegais já realizados ${ }^{76}$.

Essa ampliação contará com as intenções do aumento da área agrícola irrigada em 100\% nos próximos quatro anos, pois a irrigação, de acordo com dados da ONU é capaz de aumentar a produtividade. Os incentivos virão no mote de $\mathrm{R} \$ 4$ bilhões para linhas de crédito destinadas a agricultura irrigada; a disponibilização de assistência técnica (ATER) para 25.000 pequenos produtores; e desenvolvimento de projetos públicos de irrigação. Em valores globais serão mais de 6 bilhões para a irrigação ${ }^{77}$.

A pesca e aquicultura, também, são contempladas, afinal, o Brasil é $21^{\circ}$ nação no ranking mundial de produtores de pescado, com uma produção de 1,2 milhão de tonelada por ano ${ }^{78}$. Mas, na balança comercial,

71 BRASIL. Ministério do Planejamento, Orçamento e Gestão. Plano Mais Brasil: PPA 2012-2015: relatório anual de avaliação: ano base 2012. Brasília: MPOG, 2013. v. 1. p. 243.

72 BRASIL. Ministério do Planejamento, Orçamento e Gestão. Plano Mais Brasil: PPA 2012-2015: relatório anual de avaliação: ano base 2012. Brasília: MPOG, 2013. v. 1. p. 165; 239.

73 BRASIL. Ministério do Planejamento, Orçamento e Gestão. Plano Mais Brasil: PPA 2012-2015: relatório anual de avaliação: ano base 2012. Brasília: MPOG, 2013. v. 1. p. 165; 240.

74 BRASIL. Ministério do Planejamento, Orçamento e Gestão. Plano Mais Brasil: PPA 2012-2015: relatório anual de avaliação: ano base 2012. Brasília: MPOG, 2013. v. 1. p. 165; 248.

75 O novo código florestal foi posteriormente transformado em lei. Trata-se da lei número 12.651 de 25 de março de 2012.

76 LELIS, Davi Augusto Santana de. Entre o fato e a norma: uma análise sobre o procedimento legiferante em torno do novo código florestal. Saarbrücken: Novas Edições Acadêmicas, 2014.

77 BRASIL. Anexo da Lei n. 12.593, de 18 de janeiro de 2012. Institui o Plano Plurianual da União para o período de 2012 a 2015. Disponível em: <http://www.planalto.gov.br/ccivil_03/_Ato2011-2014/2012/Lei/L12593.htm>. Acesso em: 10 set. 2012.

78 BRASIL. Ministério do Planejamento, Orçamento e Gestão. Plano Mais Brasil: PPA 2012-2015: relatório anual de avaliação: ano 
há déficit. Em 2009, foram exportados U\$ 169 milhões, e importados U\$ 688 milhões ${ }^{79}$. Portanto, é preciso fazer com que o pescado atenda de maneira satisfatória o mercado interno e seja capaz de gerar excedente para exportação. O programa inclui implantação 9 terminais pesqueiros; atender 65 regiões com equipamento e infraestrutura para a pesca; alfabetização de 80.000 pescadores; concessão de bolsa para os pescadores; implantação de 6 escolas nacionais de pesca.

Percebe-se, desde o PPA 2000-2003 até o PPA 2012-2015, as três gerações de políticas públicas para o “desenvolvimento rural" se estruturando. No PPA 2000-2003, tem-se a primeira e segunda gerações, em matrizes teóricas que remetem à todas as correntes teóricas da sociologia rural com enfoque no viés social no início dos anos 2000. Em relação ao PPA 2004-2007 em diante, tem-se presente a terceira geração de políticas públicas para o desenvolvimento rural, com enfoque na corrente teórica do Rurbano, do agronegócio e suas cadeias produtivas. Entretanto, em todos os momentos as ideias de Navarro (2002) se apresentando, há um constante horizonte histórico como limitador do almejado "desenvolvimento"- na realidade visto como crescimento modernizante ${ }^{80}$. Há uma insistência em políticas que não promovem a emancipação da população rural, nem respeitam suas individualidades. Assim, questiona-se: seria possível encontrar, no emaranhado de políticas públicas caminhos possíveis para uma ação ética a fim de materializar a Constituição brasileira?

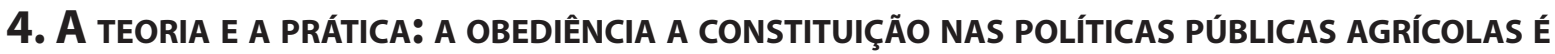 POSSÍVEL?}

Scheinder ${ }^{81}$, já havia alertado sobre a polarização das políticas agrícolas e que elas seriam incluídas na agenda estatal por força dos movimentos sociais, sendo executadas pelo Ministério do Desenvolvimento Agrário (MDA), ou seriam produzidas ex ante, por mediadores, estudiosos, empresários rurais e formuladores de políticas, tendendo a serem executadas pelo o Ministério da Agricultura Pecuária e Abastecimento (MAPA). Entretanto, a política agrícola, pendendo para um lado ou para o outro, executada pelo MDA ou pelo MAPA tem comumente um víeis utilitarista ${ }^{82}$.

Em relação à leitura dos PPAs e das políticas isoladas da década de 1990, percebe-se uma crescente importância e atenção com a agricultura familiar ${ }^{83}$, mas os resultados apresentados são apenas números. A cada ano, a cada política executada, o ministério em questão comemora a inclusão de milhares de brasileiros, o aumento nas metas de produtividade - ou lamentam a redução destas -, e celebram as porcentagens nos indicadores

base 2012. Brasília: MPOG, 2013. v. 1. p. 245.

79 BRASIL. Ministério do Planejamento, Orçamento e Gestão. Plano Mais Brasil: PPA 2012-2015: relatório anual de avaliação: ano base 2012. Brasília: MPOG, 2013. v. 1. p. 246.

80 BERCOVICI, Gilberto. Constituição econômica e desenvolvimento: uma Leitura a partir da Constituição de 1988. São Paulo: Malheiros, 2005.

81 SCHNEIDER, Sergio. Situando o desenvolvimento rural no Brasil: o contexto e as questões em debate. Revista de Economia Política, São Paulo, v. 30. n. 3, p. 511-531, jul./set. 2010.

82 JONAS, Hans. O princípio responsabilidade: ensaio de uma ética para a civilização tecnológica. Rio de Janeiro: Contraponto, 2006. Identifica a necessidade de uma ética que rompa com o modelo tradicional. Segundo o autor a ética tradicional é voltada para a atividade privada, tem fins meramente antropocêntricos e se preocupa apenas com o presente. Em sua proposta a ética deve ser praticada, em especial, pelo poder público, pois não está presa ao tempo presente e tão pouco se preocupa apenas com as questões antropocêntricas. Jonas argumenta que "se a esfera do produzir invadiu o espaço do agir essencial, então a moralidade deve invadir a esfera do produzir, da qual ela se mantinha afastada anteriormente, e deve fazê-lo na forma de política pública". Poderia ser este o caminho para um planejamento e execução de políticas públicas menos utilitário e mais moral?

83 No fiel da balança entre os movimentos sociais e os formuladores de políticas públicas pode estar um caminho que leva a ética para com o outro nas políticas públicas. Lévinas discorre sobre a condição de outro frente ao Estado: "Estado liberal - categoria constitutiva do Estado - e não possibilidade empírica contingente; Estado que admite, para além de suas instituições, a legitimidade, mesmo que transpolítica, da busca e da defesa dos direitos do homem. Para além da justiça, lembrança imperiosa de tudo o que, em seus rigores necessários, deve ser acrescido proveniente da unidade humana em cada um dos seus cidadãos reunidos em nação" em LÉVINAS, Emmanuel. Entre nós: ensaios sobre a alteridade. Petrópolis: Vozes, 2004. p. 270. 
sociais. Entretanto, as políticas se resumem a racionalidade iluminista. A população, beneficiada ou não pelos programas, permanece sem voz sendo tratada como uma massa com características únicas. Prevalece na prática, a matriz teórica de Navarro ${ }^{84}$ com projetos que não significam uma emancipação da população rural: A população do meio rural segue desconhecida do centro do sistema político, e em especial dos estudos jurídicos sobre a questão ${ }^{85}$. A democracia participativa da Constituição brasileira é deixada de lado.

A Teoria Crítica de Navarro ${ }^{86}$ é acompanhada por Santos ${ }^{87}$, para quem a "teoria crítica foi desenvolvida para lutar contra o consenso, como forma de questionar a dominação e criar o impulso de lutar contra ela". Mas a Teoria Crítica tem-se perdido pelo caminho das políticas utilitaristas. Recorrendo ao principal movimento rural, o Movimento dos Sem Terra (MST), constata-se que ele acaba sendo um movimento incapaz de viabilizar a autonomia e nova significação dos grupos sociais representados, segundo Navarro,

o resultado final, em todas as regiões agrárias brasileiras, tem sido a significativa materialização de uma capacidade de mobilização empreendida pelo MST [que tem a incapacidade de] produzir sujeitos locais portadores de real autonomia organizativa, comandantes de seus próprios destinos, assim impossibilitados de inscrever a emancipação social e política entre seus objetivos de vida ${ }^{88}$.

Mas haveria algum movimento social livre da influência política e econômica capaz de levar a efeito a emancipação buscada por Navarro? Os líderes dos movimentos sociais e dos partidos são frutos de seus interesses e de lutas/pressões populares. Um estudo do Instituto de Justiça Fiscal chamado Os donos do congresso apontam que 157.315 doadores privados forneceram aos congressistas mais de 2 bilhões de reais em doações $^{89}$. Obviamente os doadores esperam que os donatários devolvam a gentileza de alguma forma. Se a teoria de Luhmann ${ }^{90}$ estiver correta, a forma de comunicação precípua que o congresso tem é a formação de políticas, portanto, não é de se estranhar que as medidas por ventura favoreçam este ou aquele grupo privado, entenda-se o grande capital investidor na política institucional.

Alternativa ao sistema político representativo poderia ser uma democracia radical ${ }^{11}$ : A possibilidade de emancipação poderia se dar ao entender desnecessária a representação para influir na esfera política? As respostas para tais questões não estão em políticas agrícolas propriamente ditas, mas em políticas socioeconômicas que buscam efetivar o texto constitucional.

84 NAVARRO, Zander. Mobilização sem emancipação: as lutas sociais dos sem-terra no Brasil. In: SANTOS, Boaventura de Sousa (Org.). Produح̨ir para viver. Rio de Janeiro: Civilização brasileira, 2002. p. 189-232.

85 O reconhecimento que aqui se busca é o estabelecido por HONNETH, Axel. Luta por reconhecimento: a gramática moral dos conflitos sociais. São Paulo: Editora 34, 2003: Em uma primeira esfera, afeita a intimidade e as relações de pequeno círculo, como a família e a amizade, o reconhecimento produz autoconfiança no indivíduo. Entende-se que os moradores do meio rural possuem, ou tem condições de possuir, essa espécie de reconhecimento. Em uma segunda esfera o reconhecimento ocorre por meio do direito, gerando autorrespeito. A violação dessa forma de reconhecimento ocorre pela violação de direitos, e pelo que se demonstra ocorrer no campo, os movimentos sociais rurais clamam por essa forma de reconhecimento. Por fim uma terceira forma de reconhecimento, que geraria autoestima aos indivíduos que se reconhecem como iguais. Entende-se, a princípio, que não essa forma de reconhecimento, basta ver a polarização entre agronegócio e agricultura familiar, que se confrontam de maneira assimétrica em busca das políticas públicas para o setor agrário.

86 NAVARRO, Zander. Mobilização sem emancipação: as lutas sociais dos sem-terra no Brasil. In: SANTOS, Boaventura de Sousa (Org.). Produح̨ir para viver. Rio de Janeiro: Civilização brasileira, 2002. p. 189-232.

87 SANTOS, Boaventura de Sousa. A crítica da razão indolente: contra o desperdício da experiência. São Paulo: Cortez Editora, 2000. v. 1. p. 35.

88 NAVARRO, Zander. Mobilização sem emancipação: as lutas sociais dos sem-terra no Brasil. In: SANTOS, Boaventura de Sousa (Org.). Produzir para viver. Rio de Janeiro: Civilização brasileira, 2002. p. 189-232. p. 25-26.

89 Os dados completos podem ser acessados em: <http://www.donosdocongresso.com.br>.

90 Luhman identifica sistemas autopoiéticos com comunicações binárias próprias. A função do sistema é reduzir a complexidade da realidade conforme a função que desempenham. Assim o sistema do direito se reproduz por meio dos comandos lícito/ilícito; o sistema político pelo voto sim/não para as políticas públicas KUNZLER, Caroline de Morais. A teoria dos sistemas de Niklas Luhmann. Estudos de sociologia, Araraquara, v. 16, n. 16, p.123-136, 2004.

91 O termo democracia radical remonta ao significado dado por Restrepo, em sua ontologia mais radical: Democracia (demos, significando povo e kratos, poder) representa o governo do povo; um governo que tem por pressuposto que o sujeito político é tanto o governante quanto o governado, afinal a democracia não pressupõe nenhuma pré-condição para se autogovernar, é, na verdade, o governo daqueles que carecem de qualidades para governar. SANÍN RESTREPO, Ricardo. Teoria crítica constitucional: rescatando la democracia del liberalismo. Quito, Ecuador: Corte Constitucional para el Período de Transición, 2011. (Crítica y Derecho, 3). p. 105. 
Em todo o período analisado percebe-se que o setor agrícola é comumente tratado de forma separada das atuações estatais sociais, mais um indício de que a balança das ações estatais políticas pendem para o lado dos formuladores de políticas públicas. Entretanto, pesquisas já começam a apontar uma sinergia entre as políticas sociais e o "desenvolvimento rural", em especial o da agricultura familiar.

Sabates-Wheeler, Devereux e Guenther ${ }^{92}$, em estudo sobre sinergia de políticas estatais identificaram as atuações estatais no campo social e no setor agrícola interagem criando sinergias positivas ${ }^{93}$. $\mathrm{O}$ estudo se baseou em dados de diversas nações da África, da América Central e Latina, no Brasil com destaque para o Bolsa Família ${ }^{94}$, que tem sido aplicado paralelamente ao PRONAF. Como resultado da sinergia, os autores concluem: (i) a proteção social promove segurança alimentar e produção agrícola. Quando a transferência é feita em dinheiro, os resultados são mais proveitosos do que as transferências em alimentos; (ii) o ministério da agricultura -- no caso do Brasil o MDA e o MAPA -, "need to learn about social protection, whilr the social protection experts need to learn about the particular complexity of agriculture and seasonality of rural livelihoods"9"; (iii) é preciso ter atenção quanto aos preços praticados no mercado, preços baixos são bons para os consumidores pobres, mas preços justos são necessários para estimular o investimento agrícola e aumentar a renda dos agricultores familiares; (iv) uma sinergia significante entre as políticas sociais e as políticas agrárias podem ser conseguidas por meio de ações que garantam seguro contra intempéries, garantias de mercado futuro, e câmbio de commodities.

Winters e Davies ${ }^{96}$, em estudo de dois programas no México, o PROCAMPO ${ }^{97}$ e o OPORTUNIDA$\mathrm{DES}^{98}$ também perceberam a sinergia entre políticas sociais e "desenvolvimento rural": a maioria dos programas destinados à agricultura acabam beneficiando apenas as famílias mais abastadas do México, o que não ocorre com o PROCAMPO e OPORTUNIDADES, que beneficiam as famílias pobres e geram benefícios indiretos na agricultura99.

No Brasil, no mesmo sentido, Rego e Pinzani ${ }^{100}$ desenvolveram pesquisa sobre o programa Bolsa Família e na linha adotada não foi a das políticas utilitárias. Os pesquisadores, por meio do domínio da teoria crítica, literalmente deram voz aos beneficiários do programa Bolsa Família e puderam constatar no programa o germe para uma política pública que se comprometa tanto com o desenvolvimento econômico ${ }^{101}$, quanto com a emancipação e cidadania, afinal o "Estado ainda é o instrumento primário de organização e gestão

92 SABATES-WHEELER, Rachel; DEVEREUX, Stephen; GUENTHER, Bruce. Building synergies between social protection and smallholder agricultural policies. Future Agricultures, n. 6, 2009. Available: <http://www.future-agricultures.org/publications/ research-and-analysis/849-building-synergies-between-social-protection-and-smallholder-agricultural-policies/file>. Access on: 18 May 2014.

93 Reducing risk in smallholder farming requires agricultural development policies, and policies that create a conducive enabling environment for agriculture, while managing risk in smallholder farming requires social protection policies that can also contribute to reduce risk WINTERS, Paul; DAVIES, Benjamin. Designing a new PROCAMPO program: lessons from OPORTUNIDADES, 2007. p. 3. 94 REGO, Walquiria Leão; PINZANI, Alessandro. Vožes do Bolsa Família: autonomia, dinheiro e cidadania. São Paulo: Unesp, 2013. Afirmam que o Bolsa Família, mesmo em seu minimalismo pode ser visto como uma política de urgência moral com capacidade de estabelecer condições mínimas para o desenvolvimento ético e político da população.

95 O ministério da agricultura precisa aprender sobre políticas sociais, enquanto os especialistas em políticas sociais precisam aprender sobre a complexidade da agricultura e a sazonalidade da vida dos agricultores. (Tradução livre).

96 WINTERS, Paul; DAVIES, Benjamin. Designing a new PROCAMPO program: lessons from OPORTUNIDADES, 2007.

97 O PROCAMPO é um programa criado em 1994 destinado a todos os produtores rurais mexicanos para equilibrar a produtividade do setor agrícola mexicano e o do NAFTA WINTERS, Paul; DAVIES, Benjamin. Designing a new PROCAMPO program: lessons from OPORTUNIDADES, 2007. p. 06.

98 O OPORTUNIDADES é um programa criado em 1997, originalmente com o nome PROGRESA, para combater a pobreza, tanto no meio rural quanto no meio urbano. WINTERS, Paul; DAVIES, Benjamin. Designing a new PROCAMPO program: lessons from OPORTUNIDADES, 2007. p. 07.

99 WINTERS, Paul; DAVIES, Benjamin. Designing a new PROCAMPO program: lessons from OPORTUNIDADES, 2007. p. 10. 100 REGO, Walquiria Leão; PINZANI, Alessandro. Vozes do Bolsa Família: autonomia, dinheiro e cidadania. São Paulo: Unesp, 2013.

101 CLARK, Giovani; CÔRREA, Leonardo; NASCIMENTO, Samuel Pontes do. Ideologia constitucional e pluralismo produtivo. Revista da Faculdade de Direito da UFMG, Minas Gerais, n. especial, p. 265-300, 2013. 
da vida em sociedade - inclusive do mercado, que nunca foi e nunca poderá ser autorregulamentado" 102 .

Tal posição não destoa do exposto por Clark, Corrêa e Nascimento ${ }^{103}$ : A ideologia, constitucionalmente adotada para a economia, deve ser uma forma de interpretar o direito econômico [e as atuações do aparelho do Estado], independentemente de valores e visões de mundo particularistas. Assim o "intérprete, ao analisar a judicialização da política econômica, deve condicionar-se aos fundamentos normativos-axiológicos positivados na constituição" 104 .

É possível, portanto, visualizar um embate construtivo e dialético nas políticas públicas planejadas, mesmo em tempos do neoliberalismo regulador em crise. É essencial exigir que o Estado deixe de lado a sua intervenção utilitarista na economia rural e adote políticas publica com conteúdo ético materializando do texto constitucional e logicamente o desenvolvimento ${ }^{105}$. Em matéria agrícola os recentes estudos demonstram que as atuações ortodoxas acabam favorecendo um pequeno grupo, que se beneficia com empréstimos e financiamentos para os próprios produtos e aumenta a dívida daqueles que literalmente trabalham o campo. Por outro lado, políticas públicas sociais, como a Bolsa Família e PRONAF têm gerado bons resultados, não apenas para os beneficiários, mas para todos aqueles que de forma direta ou indireta entram em contato com a distribuição condicionada de renda, bem como para a sociedade. Apoiar as ações em programas sociais é uma da maneira lógica de gerar a concretude da Constituição brasileira de 1988.

\section{Considerações finais}

A partir do contexto de intervenção estatal no setor agrícola, dos anos 1990 até o início da década de 2010, o artigo procurou demonstrar quais foram as principais políticas estatais para o setor. Constatou-se que todas elas se fundamentam em uma linha de pensamento "racional", institucional e utilitarista. Em comum, as políticas tentam reduzir as divergências e edificar instituições justas para um "desenvolvimento rural" que ainda é tardio.

As ações estatais dependem de políticas que são tomadas em processos decisórios pautados muito mais nos formuladores de políticas públicas (técnicos e grande capital agrícola) do que nos movimentos sociais, sendo na prática uma "norma unificadora" voltada ao "desenvolvimento" significando na realidade o crescimento modernizante.

$\mathrm{Na}$ contracorrente desse cenário, existe uma teoria crítica, fazendo a negação do direito positivado e das políticas de intervenção estatal adotadas até então. Não se tratou aqui de estruturar por completo um novo panorama da atuação estatal no setor econômico, mas de destacar os caminhos trilhados. Como legado para trabalhos futuros, acredita-se ser possível investigar a fundo as teorias de "desenvolvimento dominante" ou de crescimento modernizante e como elas influenciam a formação da agenda estatal; se é possível, ainda, uma única instituição (ministério) dar melhores respostas a atual bipartição do meio rural em dois ministérios; se é viável, por meio de uma teoria crítica, apontar caminhos que não necessitam de representações, eliminando, assim, eventuais influências políticas e econômicas; se é possível conjugar políticas públicas sociais com políticas econômicas estatais que permitam além de um mero consequencialismo uma atuação ética do Estado e implementadora da Constituição.

102 REGO, Walquiria Leão; PINZANI, Alessandro. Vozes do Bolsa Família: autonomia, dinheiro e cidadania. São Paulo: Editora Unesp, 2013. p. 224.

103 CLARK, Giovani; CÔRREA, Leonardo; NASCIMENTO, Samuel Pontes do. Ideologia constitucional e pluralismo produtivo. Revista da Faculdade de Direito da UFMG, Minas Gerais, n. especial, p. 265-300, 2013.

104 CLARK, Giovani; CÔRREA, Leonardo; NASCIMENTO, Samuel Pontes do. Ideologia constitucional e pluralismo produtivo. Revista da Faculdade de Direito da UFMG, Minas Gerais, n. especial, p. 265-300, 2013. p. 269.

105 CORRÊA, Leonardo Alves. Direito econômico e desenvolvimento: uma interpretação a partir da Constituição de 1988. Rio de Janeiro: Publit, 2011. 
Em notas finais, tem-se que o Estado (corpos políticos e burocráticos) já percebeu a importância da política socioeconômica, e tem, desde os anos de 1990, dado significativa importância para a agricultura familiar. Todavia, o agronegócio não perdeu espaço na esfera nacional e, quando possível, ampliou-se, lançando-se nas políticas produtivas realizados no nível local e estadual. Em alguns casos, o avanço do mercado agrícola foi pautado na certeza de intervenção estatal e significou lucro para bancos privados e aumento da dívida para os produtores, sinal de que a política econômica publica intervencionista ainda tem consequências as avessas da efetivação do texto constitucional; por outro lado, representou um aumento da participação do setor na balança comercial brasileira.

Mas, invariavelmente, as políticas públicas parecem não se importarem com as relações rurais mais caras. Não é possível dizer, portanto, apesar da provável resposta a ser descortinada inicialmente para ser negativa, se pelos caminhos escolhidos haverá melhora de vida duradora as populações rurais e, também, urbana, fazendo, enfim, que o real desenvolvimento leve à emancipação e reconhecimento de todos em nosso Estado Democrático de Direito.

\section{REFERÊNCIAS BIBLIOGRÁFICAS}

ARGUELHES, Diego Werneck; LEAL, Fernando. O argumento das "capacidades institucionais" entre a banalidade, a redundância e o absurdo. Direito, Estado e Sociedade, Rio de Janeiro, n. 38, p. 6-50, jan./jun. 2011.

BAER, Werner. A economia brasileira. 2. ed. São Paulo: Nobel, 2002.

BERCOVICI, Gilberto. Constituição econômica e desenvolvimento: uma leitura a partir da Constituição de 1988. São Paulo: Malheiros, 2005.

BRASIL. Anexo da Lei n. 12.593, de 18 de janeiro de 2012. Institui o Plano Plurianual da União para o período de 2012 a 2015. Disponível em: <http://www.planalto.gov.br/ccivil_03/_Ato2011-2014/2012/Lei/ L12593.htm>. Acesso em: 10 set. 2012.

BRASIL. Ministério do Planejamento, Orçamento e Gestão. Plano Mais Brasil: PPA 2012-2015: relatório anual de avaliação: ano base 2012. Brasília: MPOG, 2013. v. 1.

BRASIL. Ministério do Planejamento, Orçamento e Gestão. Secretaria de Planejamento e Investimentos Estratégicos. Relatório de Avaliação do Plano Plurianual 2000-2003. Brasília: MPOG, 2001.

BRASIL. Ministério do Planejamento, Orçamento e Gestão. Secretaria de Planejamento e Investimentos Estratégicos. Relatório de Avaliação do Plano Plurianual 2004-2007: exercício 2008 - ano base 2007. Brasília: MP, 2008.

BRASIL. Ministério do Planejamento, Orçamento e Gestão. Secretaria de Planejamento e Investimentos Estratégicos. Relatório de Avaliação do Plano Plurianual 2008-2011: exercício 2011 - ano base 2010. Brasília: MP, 2011.

CAMARGO, Ricardo Antônio Lucas. Curso elementar de direito econômico. Porte Alegre: Núria Fabris, 2014.

CLARK, Giovani. O neoliberalismo de regulação como intervenção do Estado: a regulação e a Constituição de 1988. Economia \& Empresa, Lisboa, n. 9, p. 10-30, 2009.

CLARK, Giovani; CÔRREA, Leonardo; NASCIMENTO, Samuel Pontes do. Ideologia constitucional e pluralismo produtivo. Revista da Faculdade de Direito da UFMG, Minas Gerais, n. especial, p. 265-300, 2013.

CORRÊA, Leonardo Alves. Direito econômico e desenvolvimento: uma interpretação a partir da Constituição de 1988. Rio de Janeiro: Publit, 2011.

DEDECCA, Cláudio Salvadori. Contribuições para a agenda da política de combate à pobreza rural. In: MI- 
RANDA, Carlos; TIBÚRCIO, Breno (Org.). A nova cara da pobreza rural: desafios para as políticas públicas. Brasília: IICA, 2012. v. 16. (Série Desenvolvimento Rural Sustentável). p. 107-120.

DELGADO, Guilherme da Costa; CONCEIÇÃO, Júnia da. Políticas de preços agrícolas e estoques de alimentos: Origens, situação atual e perspectivas. Revista Paranaense de Desenvolvimento, Curitiba, n. 108, p. 25-32, jan./jul. 2005.

DIAS, Guilherme Leite da Silva. Agronegócios: problemas de coordenação e regulação a superar. In: DELFIM NETTO, Antônio (Coord.); GUILHOTO Joaquim; DUARTE, Pedro Garcia; SILBER, Simão Davi (Org.). O Brasil e a ciência econômica em debate: Brasil do século XXI. São Paulo: Saraiva, 2011. v. 1. p. 179-188.

FONSECA, Maria Tereza Louza. Extensão rural: uma educação para o capital. São Paulo: Edições Loyola, 1985.

FRALETTTI, Paulo Beltrão. Ensaios sobre taxas de juros em reais e sua aplicação na análise financeira. 2004. $160 \mathrm{f}$. Tese (Doutorado) - Universidade de São Paulo, São Paulo, 2004.

GONZALEZ, B. C. R.; COSTA, S. M. A. L. Agricultura brasileira: modernização e desempenho. Teoria Evidência Econômica, Passo Fundo, v. 5, n. 10, p. 7-35, maio 1998.

GRAU, Eros Roberto. A ordem econômica na Constituição de 1988. 14. ed. São Paulo: Malheiros, 2010.

GRISA, Cátia; SCHNEIDER, Sergio. Três gerações de políticas públicas para a agricultura familiar e formas de interação entre sociedade e estado no Brasil. RESR, Piracicaba, v. 52, supl. 1, p. 125-146, fev. 2014.

HONNETH, Axel. Luta por reconhecimento: a gramática moral dos conflitos sociais. São Paulo: Editora 34, 2003.

JONAS, Hans. O princípio responsabilidade: ensaio de uma ética para a civilização tecnológica. Rio de Janeiro: Contraponto, 2006.

KUNZLER, Caroline de Morais. A teoria dos sistemas de Niklas Luhmann. Estudos de sociologia, Araraquara, v. 16, n. 16, p.123-136, 2004.

LAVINAS, Lena; COBO, Barbara. Alcance e limite das políticas sociais para o combate à pobreza: desafios do mundo rural. In: MIRANDA, Carlos; TIBÚRCIO, Breno (Org.). A nova cara da pobreza rural: desafios para as políticas públicas. Brasília: IICA, 2012. p. 367-398. (Série Desenvolvimento Rural e Sustentável, v. 16).

LELIS, Davi Augusto Santana de. Entre o fato e a norma: uma análise sobre o procedimento legiferante em torno do novo código florestal. Saarbrücken: Novas Edições Acadêmicas, 2014.

LÉVINAS, Emmanuel. Entre nós: ensaios sobre a alteridade. Petrópolis: Vozes, 2004.

MAIA, A. G. et al. Impacto dos rendimentos de aposentadoria e pensão na redução da pobreza rural. In: CONGRESSO DA SOCIEDADE BRASILEIRA DE ECONOMIA, 46., 2008, Rio Branco. Anais... Brasília: SOBER, 2008.

MEDEIROS, Carlos Aguiar. Industrialização e distribuição de renda, dilemas e desafios para uma estratégia de desenvolvimento. In: SEMINÁRIO DE DESENVOLVIMENTO E POLÍTICAS PÚBLICAS, 3., 2012, Viçosa. Anais... Viçosa: Universidade Federal de Viçosa, 2012.

MELLO, Celso Antônio Bandeira de. Curso de direito administrativo. 26. ed. São Paulo: Malheiros, 2009.

MUELLER, Charles C. A política agrícola no Brasil: uma visão de longo prazo. Revista de Política Agrícola, Brasília, v. 19, p. 9-23, jul. 2010. Edição Especial.

MUELLER, Charles; MUELLER, Bernardo. The evolution of agriculture and land reform in Brazil: 19502006. In: CONFERENCE IN HONOR OF WERNER BAER, 2006, Illinois. Proceedings... Illinois: University of Illinois, 2006. 
NAVARRO, Zander. Mobilização sem emancipação: as lutas sociais dos sem-terra no Brasil. In: SANTOS, Boaventura de Sousa (Org.). Produžir para viver. Rio de Janeiro: Civilização brasileira, 2002. p. 189-232.

PAULA, João Antonio de. A longa servidão: a trajetória do capitalismo no Brasil. In: PAULA, João Antonio de (Org.). Adeus ao desenvolvimento: a opção do governo Lula. Belo Horizonte: Autêntica, 2005. p. 17-35.

RAVALION, Martin. Targeted transfers in poor countries: revisting the trade-offs and policy options. CPRC Working Paper, n. 26, p. 1-37, Apr. 2003.

REGO, José Márcio et al. Economia brasileira. São Paulo: Saraiva, 2006.

REGO, Walquiria Leão; PINZANI, Alessandro. Vozes do Bolsa Família: autonomia, dinheiro e cidadania. São Paulo: Unesp, 2013.

REZENDE, Gervásio. Política de preşos mínimos na década de 90: dos velhos aos novos instrumentos. Rio de Janeiro: IPEA, 2000. (Texto para discussão, n. 470).

REZENDE, Gervásio; KRETER, Ana Cecília. Desafios para o setor agrícola no século XXI. In: DELFIM NETTO, Antônio (Coord.); GUILHOTO Joaquim; DUARTE, Pedro Garcia; SILBER, Simão Davi (Orgs.). O Brasil e a ciência econômica em debate: o Brasil do século XXI. São Paulo: Saraiva, 2011. v. 1. p. 193-196.

SABATES-WHEELER, Rachel; DEVEREUX, Stephen; GUENTHER, Bruce. Building synergies between social protection and smallholder agricultural policies. Future Agricultures, n. 6, 2009. Available: <http:// www.future-agricultures.org/publications/research-and-analysis/849-building-synergies-between-socialprotection-and-smallholder-agricultural-policies/file>. Access on: 18 May 2014.

SANÍN RESTREPO, Ricardo. Teoria crítica constitucional: rescatando la democracia del liberalismo. Quito, Ecuador: Corte Constitucional para el Período de Transición, 2011. (Crítica y Derecho, 3).

SANTOS, Boaventura de Sousa. A crítica da razão indolente: contra o desperdício da experiência. São Paulo: Cortez, 2000. v. 1.

SCHNEIDER, Sergio. Situando o desenvolvimento rural no Brasil: o contexto e as questões em debate. Revista de Economia Politica, São Paulo, v. 30. n. 3, p. 511-531, jul./set. 2010.

SCHNEIDER, Sergio; SHIKI, Shigeo; BELIK, Walter. Rural development in Brazil: overcoming inequalities and building new markets. Rivista di Economia Agraria, ano 65, n. 2, p. 225-259, giugno 2010.

SOUZA, Washington Peluso Albino de. Primeiras linhas de direito econômico. 6. ed. São Paulo: LTr, 2005.

WINTERS, Paul; DAVIES, Benjamin. Designing a new PROCAMPO program: lessons from OPORTUNIDADES, 2007. 


\section{REVISTA BRASILEIRA DE POLÍTICAS PÚBLICAS BRAZILIAN JOURNAL OF PUBLIC POLICY}
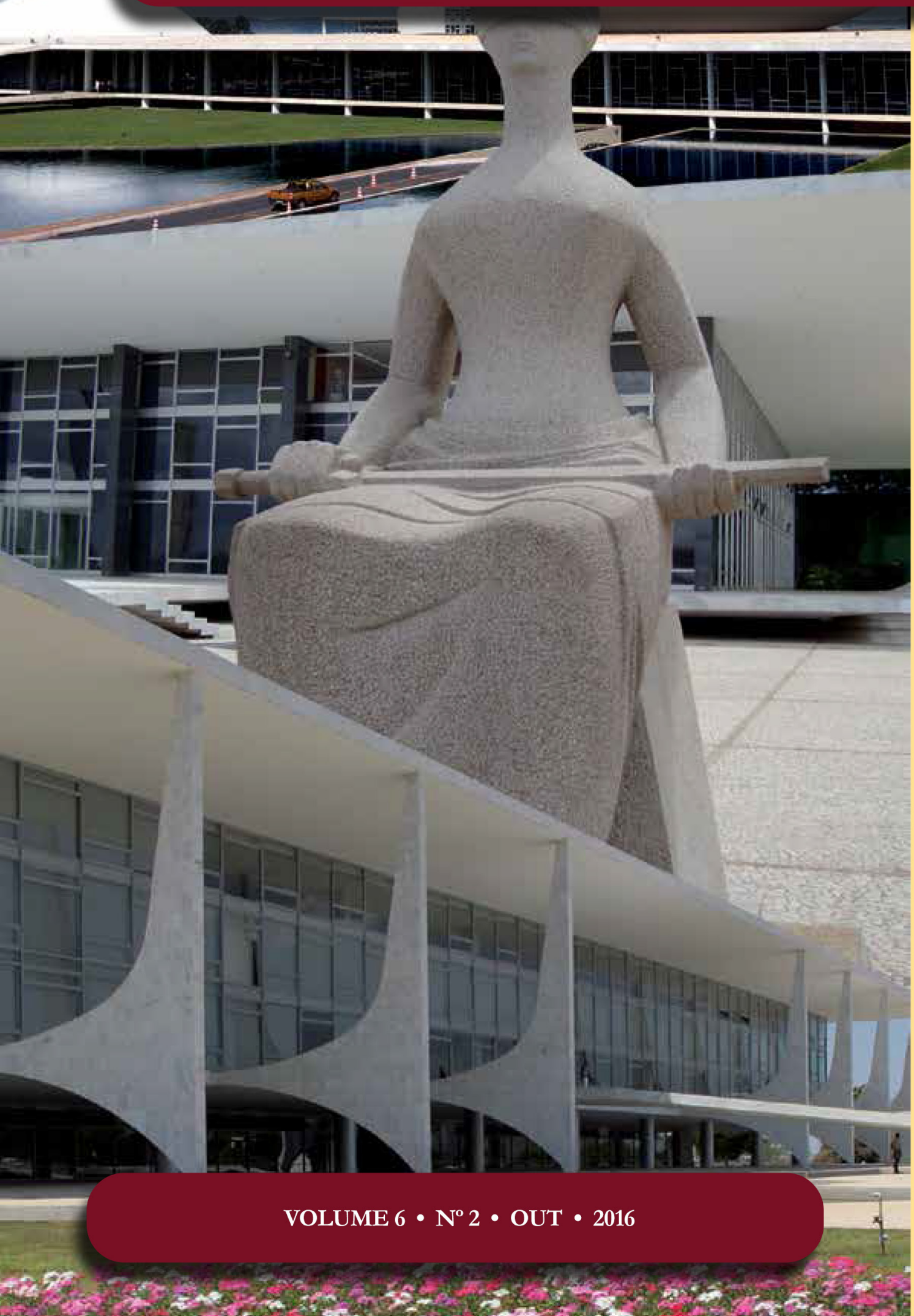

Agricultura orgânica: solução para o século XXI?

Organic farming: solution for the

XXI century?

Eloir Trindade Vasques Vieira

Denilson de Oliveira Guilherme

Luis Carlos Vinhas Itavo

Lucelia da Costa Nogueira Tashima 


\title{
Agricultura orgânica: solução para o século XXI?*
}

\section{Organic farming: solution for the XXI century?}

\author{
Eloir Trindade Vasques Vieira** \\ Denilson de Oliveira Guilherme*** \\ Luis Carlos Vinhas Itavo ${ }^{* * * *}$ \\ Lucelia da Costa Nogueira Tashima*****
}

\section{Resumo}

Este trabalho buscou compreender a contextualização da agricultura orgânica, por meio de conceitos, de sua cadeia produtiva, o papel desta na agricultura familiar e os perfis de consumo. A metodologia utilizada no estudo foi a revisão bibliográfica, retratando a inserção da agricultura orgânica na sociedade, por meio da evolução tecnológica da agricultura no século XIX e tendo como foco principal o pequeno e médio agricultor. A agricultura orgânica tem por princípios a melhoria da qualidade dos alimentos, a preservação dos ecossistemas, fortalecimento do associativismo e a prática do comércio justo. A tecnologia, inserida em alguns núcleos de agricultura orgânica, baseia-se em sistemas de produção que se limita a excluir o uso de fertilizantes sintéticos, pesticidas, reguladores de crescimento e aditivos para a alimentação animal. Ressalta-se que a agricultura orgânica não se baseia, apenas, em seu sistema produtivo e sim, também, na inserção da agricultura familiar. Conclui-se que a pratica da agricultura orgânica não se restringe, apenas, a um nicho de mercado e sim a um sistema justo solido que busca melhorar todos aspectos da qualidade de vida do ser humano respeitando as interações sociais, econômicas e biológicas entre o homem e meio ambiente.

* Recebido em 02/04/2016 Aprovado em 27/08/2016

** Doutora em Ciências Ambientais e Sustentabilidade Agropecuária, Mestre em Desenvolvimento Local. Universidade Católica Dom Bosco.E-mail:eloir@ucdb.br.

*** Professor Doutor do Programa de Pós Graduação em Ciências Ambientais e Sustentabilidade Agropecuária. UCDB. E-mail: denilsond@gmail.com.

**** Professor Doutor do Programa de Pós Graduação em Ciências Ambientais e Sustentabilidade Agropecuária. UFMS. E-mail: itavo@ ufms.br.

***** Doutoranda em Desenvolvimento Local. Mestre em Desenvolvimento Local. Universidade Católica Dom Bosco. E-mail: luceliatashima@gmail.com.
Palavras-chave: Agricultura convencional. Produtividade agrícola. Produtos orgânicos.

\section{Abstract}

This study aimed to understand the context of organic farming through concepts related to its production chain, its role in family farming and its consumption profiles. The methodology used in the study was based on literature review of the inclusion of organic agriculture in society through technological development of agriculture in the nineteenth century, focusing mainly on small and medium farmers. Organic agriculture principles' are to improve the quality of food, the preservation of ecosystems, the strengthening of associations and the practice of fair trade. The technology, set in some organic farming, is based on production systems that limit the use of synthetic fertilizers, pesticides, growth regulators and additives for ani- 
mal feed. It is noteworthy that organic farming is not based only on its productive system but also on the insertion of family farming. It is concluded that the practice of organic farming is not restricted to a niche market, but to a fair system that seeks the best in all aspects of human life quality respecting social, economic and biological interactions, between man and environment.

Keywords: Conventional agriculture. Agricultural productivity. Organic products.

\section{INTRODUÇão}

Desde a previsão Malthusiana no século XIX, há uma preocupação se haverá falta de alimentos no mundo. A Teoria de Malthus ${ }^{1}$ reportou "que se a população crescesse em progressão geométrica, enquanto a produção de alimentos crescesse em progressão aritmética", faltariam alimentos no mundo. Segundo dados da Organização das Nações Unidas, há previsão de que até 2050 a população mundial chegue a 9 bilhões

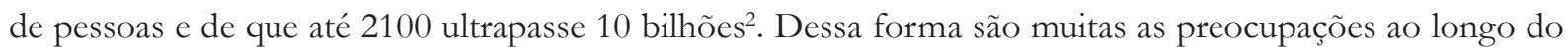
tempo com a produção de alimentos. Mas a preocupação não se restringe, apenas, à obtenção de alimentos, mas também a sua qualidade e ao bem-estar e saúde dos produtores.

No passado, por volta de 1950 a quantidade de alimentos era a grande preocupação. Inclusive, vale ressaltar que, nos anos de 1960 e 1970, a chamada revolução verde foi um marco na produção agrícola brasileira. Esse movimento marcou para sempre as interações entre o homem e sua relação com os ecossistemas nos quais estava inserido. Em um primeiro momento, saltou aos olhos as lavouras com uniformes, as altas produtividades, o extermínio de pragas que reduziam a produtividade das lavouras, além de outras práticas que facilitaram a vida do homem do campo. O que se pensava nesse momento é que todos os problemas iriam ser resolvidos, apenas, com o aumento da produção de alimentos.

Entretanto, esse crescimento gerou ações positivas e negativas. Alguns autores relatam que a revolução verde trouxe como ação positiva a mecanização da agricultura, o uso de adubos de alta solubilidade, a inserção de híbridos extremamente produtivos, alterações genéticas em plantas e animais visando à produção de alimentos em menor espaço de tempo. Outros autores reportam como pontos negativos o uso excessivo de fertilizantes de alta solubilidade, que tornam as plantas enfraquecidas e suscetíveis a patógenos, contaminação de rios, lagos e aguas subterrâneas, doenças e mortes provocadas pelo uso sem proteção e excessivo de defensivos químicos.

Pesquisas demonstraram que a previsão de Malthus não se concretizou por razões diversas entre elas, o não crescimento populacional conforme as expectativas, ou previsões e, em contrapartida, ocorreram grandes avanços nas técnicas agrícolas, crescimento em virtude dos avanços tecnológicos na produção agrícola. A produção de alimento superou as expectativas, levando as suas previsões a um fracasso.

Nesse contexto, também, surgem preocupações quanto ao desenvolvimento sustentável e à construção de práticas sustentáveis buscando ações que promovam a preservação dos ecossistemas e a biodiversidade, mas também que melhorem as condições socioeconômicas das comunidades. Dessa forma surge a agricultura orgânica como possibilidade a essa prerrogativa.

O estudo foi realizado com levantamento bibliográfico e de dados. Tratou-se de uma pesquisa descritiva. Portanto, no trabalho foi contextualizado à agroecologia, conceitos de agricultura orgânica, princípios, retratando os impactos ambientais, bem como mercado mundial, nacional, perfil de consumidores e a cadeia produtiva do produto orgânico.

1 MALTHUS, T. An essay on the principle of population: or a view of its past and present effects on human happiness: with an inquiry into our prospects respecting the future removal or mitigation of the evils which it occasions. 6. ed. Londres: John Murray, 1826.

2 UNFPA. Relatório sobre a situação da população mundial: pessoas e possibilidades em um mundo de 7 bilhões. Tradução: Eleny Corina Heller. New York, 2011. Disponível em: <http://www.un.cv/files/PT-SWOP11-WEB.pdf>. Acesso em: 19 set. 2016. 


\section{Agricultura familiar}

Grandes transformações ocorreram nas últimas décadas, esta é uma conclusão possível quando se analisa o meio rural, essa leitura pode ser feita por meio das paisagens alteradas pelas culturas, da configuração do território e da dinâmica social das famílias que vivem da agricultura ${ }^{3}$. Os conflitos e lutas pelo território não são recentes e, diversas vezes, elas ocorrerem dentro dos diferentes estados brasileiros onde a terra sempre foi alvo de disputa e transformações, em grande medida, provocadas pela expansão e intensificação do chamado agronegócio no país.

O agronegócio passava por uma série de mudanças, entre elas a modernização do aparato tecnológico no campo, essa transformação ocorreu por meio de um novo modelo, ou seja, um sistema produtivo baseado no uso intensivo de técnicas e maquinário de alto custo para o agricultor. O problema gerado por essa transformação no campo foi entender que esse novo modelo não se adequava às necessidades da pequena produção ${ }^{4}$ :

[...] o padrão tecnológico adotado e difundido não se adequa às necessidades da pequena produção e as razões para isto são simples: as características estruturais da agricultura familiar são simples: as características estruturais da agricultura familiar brasileira não se adequam ao padrão tecnológico disponível; o processo não foi feito para pequenos. De um lado, características como limitada disponibilidade de terras para uso de máquinas, condições ecológicas adversas - piores terras policultura, insuficiência de recursos para investimentos e mão-de-obra numerosa dificultam o acesso à moderna tecnologia.

Por um lado, a modernização para os grandes produtores que "tinham o enquadramento do agronegócio" e, do outro, pequenos produtores que começavam a se tornar invisíveis por não acompanhar essa mudança na estrutura de produção. O discurso do autor remete a uma crítica de que, talvez, o termo agronegócio esteja ligado a uma nova "classe social" do campo, em que, pessoas com grandes extensões de terra e recursos para investir em tecnologia e produção em larga escala quisesse se distinguir dos pequenos produtores. O grande engano dessa divisão é que toda e qualquer economia local é abastecida por pessoas que possuem pequenas propriedades, recursos limitados e trabalho familiar, os quais não fazem parte da classe burguesa rural ${ }^{5}$.

Nessa perspectiva de múltiplos interesses, não se pode confundir agronegócio com agricultura, afinal "cultura está associado à distribuição de riqueza no sentido forte da palavra e não necessariamente ao negócio. Eis o contraste entre a agricultura e o agronegócio".

Diante desse contraste, o agronegócio passa ter uma "dependência” às classes dominantes nas diferentes escalas da economia, entre eles, os grupos empresariais, os latifúndios, governo, políticos, indústrias, sendo todos os citados de caráter elitista que estão na contramão da necessidade de reforma agrária para direcionar ações de desenvolvimento sustentável ao pequeno produtor ${ }^{7}$.

3 TASHIMA, Lucelia da Costa Nogueira. A construção da visibilidade da agricultura familiar: estudo de caso na comunidade negra quilombola de São Miguel - MS. 2016. 118 f. Dissertação (Mestrado) - Programa de Pós-graduação em Desenvolvimento Local, Universidade Católica Dom Bosco, Campo Grande, 2016. Disponível em: <http://site.ucdb.br/public/md-dissertacoes/18973dissertacao-lucelia-da-costa-nogueira-tashima.pdf>. Acesso em: 15 jun. 2016.

4 CAMPOS, Christiane Senhorinha Soares. A face feminina da pobreza em meio à riqueza do agronegócio: o caso de Cruz Alta/RS. Bueno Aires: CLACSO, 2011.

5 TASHIMA, Lucelia da Costa Nogueira. A construção da visibilidade da agricultura familiar: estudo de caso na comunidade negra quilombola de São Miguel - MS. 2016. 118 f. Dissertação (Mestrado) - Programa de Pós-graduação em Desenvolvimento Local, Universidade Católica Dom Bosco, Campo Grande, 2016. Disponível em: <http://site.ucdb.br/public/md-dissertacoes/18973dissertacao-lucelia-da-costa-nogueira-tashima.pdf>. Acesso em: 15 jun. 2016.

6 GONÇALVES, Carlos Walter Porto. Geografia da riqueza, fome e meio ambiente: pequena contribuição crítica ao atual modelo agrário/agrícola de uso dos recursos naturais. Interthesis, Florianópolis, v. 1, n. 1, p. 1-55, 2004.

7 TASHIMA, Lucelia da Costa Nogueira. A construção da visibilidade da agricultura familiar: estudo de caso na comunidade negra quilombola de São Miguel - MS. 2016. 118 f. Dissertação (Mestrado) - Programa de Pós-graduação em Desenvolvimento Local, Universidade Católica Dom Bosco, Campo Grande, 2016. Disponível em: <http://site.ucdb.br/public/md-dissertacoes/18973- 
Marcuse ${ }^{8}$ explica que a tecnologia no meio rural é uma forma de organizar e modificar as relações sociais. Com essas relações modificadas, Sauer ${ }^{9}$ descreve que, em meados de 1990, na contramão do um setor rural altamente tecnificado, surge outra expressão trazida do modelo norte-americano, a agricultura familiar ${ }^{10}$. Esse termo tinha por objetivo desvincular a pequena produção ou mesmo a noção de produção camponesa do setor ligado ao agronegócio, em razão da pequena produção que carregava pré-noções de "ineficiência", baixa produtividade, ou ainda, produção apenas para o autoconsumo ou subsistência ${ }^{11}$.

Essa definição não é unânime, mas perfeitamente aplicável aos diferentes grupos sociais e suas representações por meio da agricultura familiar. $\mathrm{O}$ autor descreve a existência de uma dinâmica em relação a agricultura familiar, que tem em seu aporte três atributos básicos: propriedade, trabalho e familiares, estão presentes em todas elas.

Dernardi ${ }^{12}$ descreve que toda a existência humana, história e cultura dependem do espaço de terra que ele ocupa ou não lhe é permitido ocupar. No estudo histórico das civilizações, o homem primitivo aprendeu na terra, nas margens dos rios, que era possível produzir e criar animais com maior eficiência e o trabalhador do campo conhece de maneira muito profunda o quanto é importante a propriedade como forma de vida (sobrevivência) no meio rural.

O trabalho aparece em um segundo momento quando o trabalhador possui a posse ou mesmo o direito de propriedade, seja qual for a forma: comodato, arrendamento, parceria e outras. $\mathrm{O}$ trabalho fornece a liberdade necessária para a inserção a todo e qualquer processo produtivo com a função de não exclusão social e sim parte integrante de uma sociedade que produz e fornece o sustento para sua família.

O último atributo, família, onde tudo começa e, ao mesmo tempo tem fim, é a partir dela que se estabelece como e quando trabalhar. Com o apoio do grupo familiar são definidos o tempo em que se permanecerá no território. Porque, nesse caso específico de vida no campo, criam-se relações de pertencimento e permanência e que se faz presente por meio do trabalho.

De acordo com Schneider ${ }^{13}$ "[...] a agricultura familiar passou a ser reconhecida nos meios acadêmicos principalmente para as ciências sociais a partir de 1990, através do estudo realizado por Kageame e Bergamasco". O que foi percebido é que o estudo da agricultura familiar no Brasil é "recente", entretanto, as categorias sociais que ela pretende identificar não são novas (propriedade, trabalho e família). Porto e Siqueira discutem o conceito por meio de conteúdo político e ideológico, mas essa discussão já era debatida desde a década de 1970, em torno da pequena produção ou produtores de baixa renda, tendo em razão das transformações políticas do Estado brasileiro.

Nesse contexto (propriedade, trabalho e família), o próprio trabalhador rural foi objeto central do debate, em que se discutia a vida e modo de trabalho do ponto de vista da produção ou do aumento da produção e não em quais condições se encontravam o trabalhador.

Para Schneider ${ }^{14}$

dissertacao-lucelia-da-costa-nogueira-tashima.pdf>. Acesso em: 15 jun. 2016.

8 MARCUSE, H. de. Tecnologia, guerra e fascismo: coletânea de artigos. São Paulo: Unesp, 1999.

9 SAUER, Sérgio Reforma Agrária e geração de emprego e renda no meio rural. São Paulo: ABET, 1998.

10 Esse processo de consolidação da noção de "agricultura familiar" ganhou espaço no movimento sindical e nos espaços governamentais e acadêmicos a partir de pesquisas realizadas por equipes da Organização das Nações Unidas para a Agricultura e Alimentação (FAO) e do Programa das Nações Unidas para o Desenvolvimento (Pnud), em convenio com o então Ministério da Agricultura e de colonização e reforma Agrária (INCRA), que iniciou com avaliação e indicadores socioeconômicos de assentamentos de reforma agrária, posteriormente ampliada para outros segmentos da agricultura familiar.

11 SAUER, Sérgio Reforma Agrária e geração de emprego e renda no meio rural. São Paulo: ABET, 1998.

12 DENARDI, R. A. Agricultura familiar e políticas públicas: alguns dilemas e desafios para o desenvolvimento rural sustentável. Agroecologia e desenvolvimento rural sustentável, Porto Alegre, v. 2, n. 3, p. 56-62, jul./set. 2001.

13 SCHNEIDER, Sérgio Teoria social, agricultura familiar e pluriatividade. Revista Brasileira de Ciências Sociais, v. 18, n. 51, p. 99121, fev. 2003.

14 SCHNEIDER, Sérgio Teoria social, agricultura familiar e pluriatividade. Revista Brasileira de Ciências Sociais, v. 18, n. 51, p. 99- 
[...] a Agricultura Familiar desempenha vários papéis, entre os quais, de produzir e fornecer alimentos básicos de preço acessível e de boa qualidade para a sociedade e, ainda, reproduzir-se como uma forma social diferenciada no mundo capitalista.

Entretanto, dizer que estas são as características essenciais dessa forma de produção agrícola é desconhecer os traços mais importantes do desenvolvimento agrário tanto no Brasil como em países capitalistas avançados nos últimos anos.

Em estudos desenvolvidos pelo Ministério da Agricultura, faltava ao pequeno agricultor brasileiro um elemento que pudesse ajudar a melhor as perspectivas da família rural e adentrar no processo competitivo, uma política pública que fosse específica para a agricultura familiar do estado brasileiro. O que, de fato, foi uma alternativa muito viável economicamente, falando ao governo, trouxe uma minimização das massas que reivindicavam um posicionamento em relação à reforma agrária.

Com a percepção de fornecer mais acesso ao pequeno produtor rural, nasceu o Programa Nacional de Fortalecimento da Agricultura Familiar (PRONAF) como um "incentivo" do Governo Federal para subsidiar a produção das pequenas propriedades, bem como incentivar as diferentes articulações entre associações, cooperativas resultando de diferentes modos de interação da cadeia de produção de alimentos e sistemas de produção favoráveis ao pequeno produtor.

\subsection{Agroecologia}

De acordo com Hecht ${ }^{15}$ agroecologia está voltada a aplicação da ciência ecológica para a concepção e "gestão de agroecossistemas sustentáveis".

Altieri ${ }^{16}$ trata a agroecologia como uma corrente que preconiza que, para que aconteça a sustentabilidade, deve-se trabalhar a integração de quatro máximas em suas respectivas dimensões: ecologicamente correto, socialmente justo, economicamente viável e culturalmente aceitável.

Por meio de uma abordagem holística para o desenvolvimento agrícola, a agroecologia é baseada na pequena agricultura tradicional, alternativa e local. Isto significa trabalhar com a terra para o cultivo que são mais adequados para esse ambiente particular.

Guzmán e Molina ${ }^{17}$ apontam a agroecologia como:

campo de estudos que pretende um manejo ecológico dos recursos naturais, com ação social coletiva de caráter participativo, enfoque holístico, estratégia sistêmica, mediante controle de forças produtivas que estanque seletivamente formas degradantes e exploradoras da natureza e da sociedade.

Dessa forma, este método aproveita o conhecimento local da área e utiliza o consenso do grupo, do agricultor, na decisão do que plantar. Vários autores reforçam a importância de ouvir a necessidade da comunidade local, na qual não deve incorrer em influência de nenhum mercado global.

\subsection{Escolas agroecológicas}

Estudos da Embrapa ${ }^{18}$ apontam que a agricultura orgânica teve iniciou na década de 20, com as pesquisas

121, fev. 2003.

15 HECHT, S. B. A evolução do pensamento agroecológico. In: ALTIERI, M. A. (Ed.). Agroecologia: as bases científicas da agricultura alternativa. Rio de Janeiro: PTA/FASE, 1989. p. 25-41.

16 ALTIERI, M. Agroecologia: as bases científicas da agricultura alternativa. Rio de Janeiro: PTA-FASE, 1989. p. 25-41.

17 CAPORAL, Francisco Roberto. Em defesa de um plano nacional de transição ecológica: compromisso com as atuais e nosso legado para as futuras gerações. In: SAUER, S.; BALESTRO, M. V. (Org.) Agroecologia e os desafios da transição agroecológica. São Paulo: Expressão Popular, 2009.

18 BRASIL. Empresa Brasileira de Pesquisa Agropecuária. Evolução e cadeia produtiva da agricultura orgânica. Brasília, 2006. Dis- 
de Howard, que, em sua viagem à Índia, passou a observar as práticas agrícolas de sua região, de compostagens e adubação orgânica dos camponeses.

Howard defendia a não utilização de adubos artificiais, principalmente adubos de alta solubilidade. Em seus estudos, destacava a importância da utilização da matéria orgânica na melhoria da fertilização e vida do solo. Ele desenvolveu o método de compostagem, que foi chamado de Indor buscando a eliminação de pragas e doenças, melhoria dos rendimentos, e qualidade dos produtos agrícolas. É apontado por vários autores como o "pai da agricultura orgânica".

Bases históricas apresentam, também, que o método de Howard foi aprimorado por Lady Eve Balfour, que transformou uma propriedade rural, em uma estação de experimentos, fundando em 1946 uma entidade chamada "Soil Agricultura Orgânica Association", em que fez comparações entre qualidade do solo em parcelas orgânicas, mistas e químicas. Seus estudos reforçaram a importância de processos biológicos, fazendo relação solo, planta, animal e a saúde humana.

$\mathrm{Na}$ França, ainda segundo o documento Embrapa, nessa mesma década de XX, Aubert iniciou os estudos com práticas da agricultura biológica cujos produtos eram oriundos de rotação de culturas, adubos verdes, estercos, restos de culturas palhas e outros resíduos vegetais e animais, bem como o controle natural de pragas e doenças, suprimindo o uso de fertilizantes, adubos e defensivos sintéticos nas lavouras.

Na Alemanha em 1924, de acordo Willer ${ }^{19}$, iniciaram se os trabalhos com bases da agricultura biodinâmica no qual trabalhou se a junção "(terra, plantas, animais, homem) e o equilíbrio da unidade produtiva, através da influência do sol e da lua”.

No Japão, em 1935, Okada iniciou pesquisa com a filosofia a respeito de o que seria uma agricultura natural, a qual preconiza que existem espírito e sentimento em todos os seres vivos (vegetal e animal).

Na Austrália, em 1971, Mollison trabalhou o conceito de permacultura modelo de agricultura integrada com o meio ambiente, diferenciando essa corrente das demais pela utilização das informações sobre direção do sol e dos ventos.

Na década de 70, começaram a surgir, no comércio da Europa, os primeiros produtos orgânicos, no qual se consolidou em 1990 com o programa council regulation. Nessa mesma década, no Brasil, iniciaram-se produções agrícolas relacionadas a movimentos filosóficos, que traziam em sua essência o contato com a terra. Nesse período, também nasceram os hippies, que traziam uma forma alternativa de viver, uma forma natural de alimentação, bem como em oposição aos meios consumistas da sociedade.

\section{Agricultura orgânica}

A agricultura orgânica surgiu na década de 60 quando consumidores e produtores começaram a reconhecer que os defensivos agrícolas poderiam estar causando problemas à saúde da população e problemas ao meio ambiente.

Quando se busca conceitos em agricultura orgânica, são vários os autores que falam sobre o assunto, que pode como um modelo que propõe o cultivo da terra para a produção de alimentos sadios sem o uso de produtos químicos tóxicos à saúde humana e dos animais, bem como sem contaminar a água, o solo e o ar, assim, ela deve ser ecologicamente sustentável, e economicamente viável, com relações sociais justas e

ponível em: <https://www.embrapa.br/busca-de-publicacoes/-/publicacao/779849/evolucao-e-cadeia-produtiva-da-agriculturaorganica>. Acesso em: 16 set. 2016.

19 WILLER, H.; YUSSEFI, M. Organic agriculture worldwide 2001: statistics and future prospects. Bad Dürkheim: SÖL, 2001. (SÖL Publication, 74). 
culturalmente aceitáveis" ${ }^{20}$.

Dessa forma, se apresenta como mecanismo no qual se utiliza de conhecimentos e processos ecológicos, buscando, assim, mudanças tanto sociais quanto econômicas com o intuito de promoção da sustentabilidade de todo o processo agroalimentar.

Campanhola e Valarini ${ }^{21}$ alegam que a agricultura orgânica faz parte do "conceito de agricultura alternativa, e envolve outras correntes como: agricultura natural, agricultura biodinâmica, agricultura biológica, agricultura ecológica e permacultura (agricultura permanente)".

Pode-se ressaltar a Teoria da Trofobiose ou da planta equilibrada, na qual "todo organismo vegetal fica vulnerável à infestação de pragas e doenças quando excessos de aminoácidos livres e açúcares redutores estão presentes no sistema metabólico"22.

A agricultura orgânica tem por princípios encorajar prática, sugerir ciclos biológicos, que mantenham a fertilidade do solo, buscando minimizar possíveis contaminações do solo, buscando minimizar os impactos, sociais, ambientais e ecológicos, outra preocupação se refere à produtividade dos produtos agrícolas.

\subsection{Produtividade dos produtos agrícolas}

De acordo com a revista NATURE ${ }^{23}$, um grupo de cientistas da McGill University desenvolveu 66 estudos comparando mais de 300 resultados de produtividade entre produtos orgânicos e produtos convencionais. Em média, a produtividade dos produtos orgânicos é entre $20 \%$ a $25 \%$ inferior aos produtos convencionais produzidos com a utilização de produtos químicos e afins. A menor diferença percebida foi em torno de 10\%. Em alguns casos, a diferença de produtividade chegou a 30\%. Em nenhum caso estudado, a produtividade dos produtos orgânicos foi superior aos produtos convencionais.

Contudo, esses resultados são animadores de certo modo, já que se estimava, no passado, que sua produtividade fosse de $50 \%$ dos produtos convencionais padronizados.

Segundo o mesmo instituto, atualmente, no mundo, $1 \%$ das terras cultiváveis são utilizadas para a produção orgânica, sendo 99\% para o cultivo convencional. Em raciocínio lógico, para aumentar as áreas dos produtos orgânicos, teríamos que diminuir o cultivo convencional.

Já para Paschoal, a produtividade da agricultura orgânica é tão alta ou até mais alta de que a da agricultura convencional. "O produto orgânico é capaz de produzir alimentos, tanto quanto ou mais do que o convencional, a custos mais baixos" 24 .

O estudo realizado pela McGill University ${ }^{25}$ revelou que o rendimento das culturas da agricultura biológica geralmente está associado à produções menores em comparação com a agricultura convencional, mas, dependendo dos cuidados, essa produção pode ser alterada. Reforçam que a produção menor pode ser ver-

20 MOMESSO, Cristiane Maria Vendramini; ROEL, Antonia Railda; FAVARO, Simone Palma. Levantamento do potencial de comercialização de produtos orgânicos para o estado de Mato Grosso do Sul. Interações, Campo Grande, v. 10, n. 1, p. 55-62, jan./ jun. 2009.

21 CAMPANHOLA, Clayton; VALARINI, Pedro José. A Agricultura orgânica e seu potencial para o pequeno agricultor. Cadernos de Ciência \& Tecnologia, Brasília, v. 18, n. 3, p. 69-101, set./dez. 2001.

22 POLITO, Wagner L. The Trofobiose Theory and organic agriculture: the active mobilization of nutrients and the use of rock powder as a tool for sustainability. Anais da Academia Brasileira de Ciências, Rio de Janeiro, v. 78, n. 4, p. 765-779, dez. 2006.

23 SEUFERT, Verena; RAMANKUTTY, Navin; FOLEY, Jonathan A. Comparing the yields of organic and conventional agriculture. Nature, n. 485, p. 229-232, 10 May 2012. Available at: <http://www.nature.com/nature/journal/v485/n7397/full/nature11069.html>. Accessed on: 15 Sept. 2016.

24 PASCHOAL, A. D. Produção orgânica de alimentos: agricultura sustentável para os séculos XX e XXI; guia técnico e normativo para o produtor, o comerciante e o industrial de alimentos orgânicos e insumos naturais. Piracicaba: ESALQ, 1994.

25 CAN ORGANIC food feed the world? New study sheds light on debate over organic vs. conventional agriculture. ScienceDaily, 25 Apr. 2012. Available at: <www.sciencedaily.com/releases/2012/04/120425140114.htm>. Accessed on: 19 Sept. 2016. 
dadeiro para os cereais, que são a base da alimentação humana, mas que a diferença de rendimento é muito menos significativa para determinadas culturas e em determinadas condições de crescimento.

Outra preocupação se refere às práticas orgânicos, e aos impactos ambientais por ela provocados.

\subsection{Impactos ambientais}

Algumas pesquisas apontam que a agricultura orgânica em larga escala iria ocupar mais terra e tornar os alimentos inacessíveis para a maioria dos pobres do mundo e com fome ${ }^{26}$.

A tecnologia inserida no contexto da agricultura orgânica baseia-se nos sistemas de produção que se limita a evitar, ou excluir, o uso de fertilizantes sintéticos, pesticidas, reguladores de crescimento e aditivos para a alimentação animal. Para o solo, a tecnologia aplicada está voltada a recuperação e manutenção do equilíbrio biológico, influenciando nas suas características físicas e químicas. Além disso, há o desenvolvimento de técnicas que diminuem o uso de insumos industrializados e aumentem o uso dos recursos naturais, controlando, assim, a erosão e conservação da do sistema solo/planta.

Uma das maneiras de atender essa necessidade pode ser utilização da tecnologia de bioprospecção de produtos naturais, que visa, também, à utilização de recursos biológicos disponíveis na natureza que gera um produto renovável e de utilidades múltiplas (controle de doenças, pragas, novos fármacos fitoterápicos). Como produto, pode ser citado, também, o bioinseticida, produzido por meio de vegetais que possuem biomoléculas ativas contra as pragas nas plantações, por exemplo, a cigarrinha de pastagem, mosca branca ou até o cartucho do milho, que inviabilizam as plantações para alimentação animal quanto humano ${ }^{27}$.

O aproveitamento de resíduos orgânicos urbanos, como adubo para a produção agrícola, também é considerado no contexto da tecnologia. A crítica que alguns autores fazem é que falta, ainda, gerar conhecimento que possibilite a forma correta de prepará-los, garantindo um produto de boa qualidade, fornecendo nutrientes ao solo.

Outros estudos, como de Campanhola e Valarini ${ }^{28}$, já apontam efeitos ambientais negativos, devido o uso excessivo de matéria orgânica no solo. Para os autores, com o tempo, pode ocorrer risco de acumulação de nitratos nas águas subterrâneas, os efeitos dos estercos de aves e suínos adicionados ao solo: o de aves pode apresentar inconvenientes do ponto de vista da sanidade das plantas, da perda de nutrientes minerais e dos danos, em médio prazo, às condições físicas e biológicas do solo, enquanto o esterco de suínos pode conter gordura e transmitir doenças ao homem.

Em relação ao quesito impacto ambiental, a agricultura orgânica em comparação com a convencional, os autores entram em contradição quanto à questão se os impactos são negativos ou positivos, o que pode se verificar é que está ocorrendo crescimento constante na produção de produtos agrícolas no mundo. Como podemos identificar na figura 1 :

26 SEUFERT, Verena; RAMANKUTTY, Navin; FOLEY, Jonathan A. Comparing the yields of organic and conventional agriculture. Nature, n. 485, p. 229-232, 10 May 2012. Available at: <http://www.nature.com/nature/journal/v485/n7397/full/nature11069.html>. Accessed on: 15 Sept. 2016.

27 CANUTO, João Carlos. Agricultura ecológica en Brasil: perspectivas socioecológicas. 1998. 256 f. Tese (Doutorado) - Instituto de Sociología y Estudios Campesinos (ISEC), Escuela Superior de Ingenieros Agrónomos y Montes (ETSIAM), Universidad de Córdoba, Córdoba, 1998.

28 CAMPANHOLA, Clayton; VALARINI, Pedro José. A Agricultura orgânica e seu potencial para o pequeno agricultor. Cadernos de Ciência \& Tecnologia, Brasília, v. 18, n. 3, p. 69-101, set./dez. 2001. 
Figura 1- World: Growth of the organic agricultural land 1999-2012

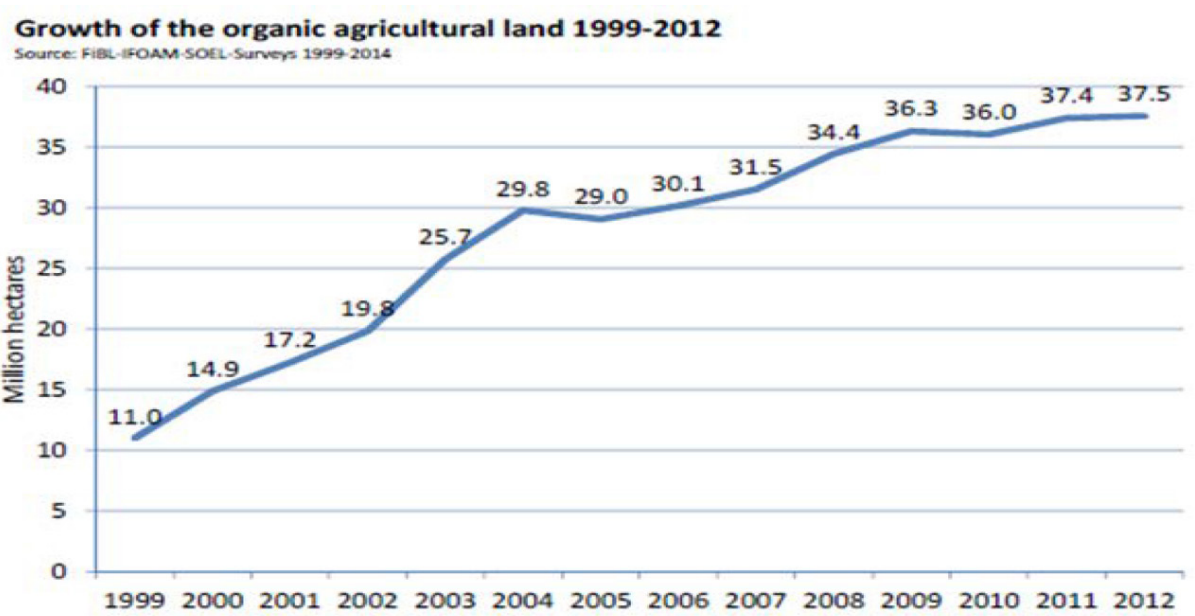

Fonte: LERNOUD; WILLER, 2014.

Evidencia-se o crescimento da terra agrícola orgânica em constante crescimento de 1999 a 2012. Dessa forma observa-se a busca em atender o mercado. Assim, também aumenta a exigência de regulamentação de procedimentos para sua produção e comercialização.

\subsection{Certificação}

No exterior o órgão internacional que credencia as certificadoras é a Internacional Federation of Organic Agriculture Movements (IFOAM). No Brasil, as normas de regulação, processamento, como produtos devem ser envasados, distribuídos, identificação e certificação são regulamentados pelo Ministério da Agricultura, Pecuária e Abastecimento (MAPA).

Certificação de produtos agrícolas é o procedimento pelo qual uma certificadora, devidamente credenciada ao órgão regulador é "acreditada". No Brasil o credenciamento ocorre pelo Instituto Nacional de Metrologia, e Qualidade e Tecnologia (INMETRO). Uma vez certificado evidencia se que determinado produto, obedece às normas e práticas de produção orgânica.

A certificação apresenta-se sobre a forma de um selo, fixado ou impressiono rótulo ou na embalagem do produto.

Figura 2- Produto orgânico

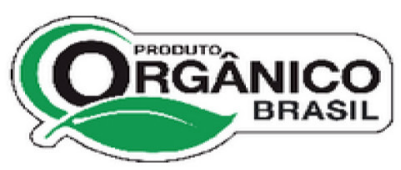

Figura 3- Outros selos utilizados

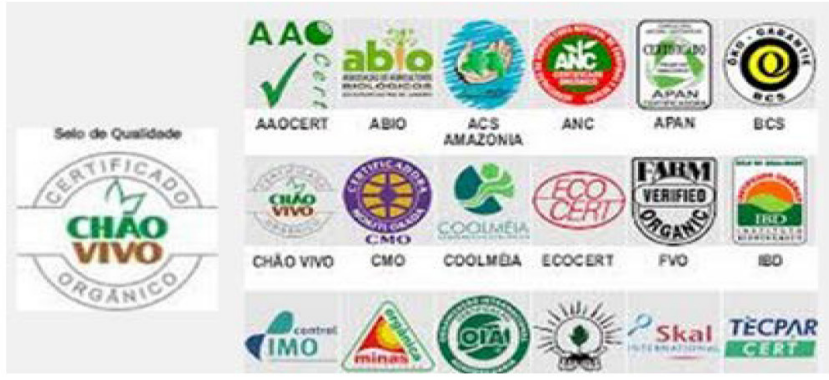

Fonte: IBD CERTIFICAÇÕES, 2014.

Os produtos orgânicos certificados têm como prerrogativa garantir uma proteção à saúde humana, pois foram passados por controles. 
Segundo o levantamento realizado pelo Ministério da Agricultura, Pecuária e Abastecimento (MAPA) sobre a produção de orgânicos no país, em 2012 o Brasil possuía uma área de 1,5 milhões de hectares e 11,5 mil unidades de produção ligadas ao sistema produtivo de orgânicos, como fazendas e estabelecimentos de processamento. Nesse cenário a região norte destaca-se com a maior área dedicada a agricultura orgânica com 778,8 mil hectares e 3,8 mil unidades de produção seguida pela região centro-oeste com 650,9 mil hectares e 1,1 mil unidades de produção, a região nordeste 79,8 mil hectares e 2,9 mil unidades de produção, a região Sul com 24,8 mil hectares e 2,3 mil unidades de produção e a região sudeste com 19,1 mil hectares e 1,2 mil unidades de produção.

\subsection{Mercado}

Em estudo realizado por FIBL-AMI ${ }^{29}$, são retratados 10 países maiores produtores de orgânicos no mundo, os Estados Unidos lideram com maior mercado de produtos agrícolas, seguidos de Alemanha, França, Canadá, Reino Unido, Itália, Suíça, Áustria, Japão e Espanha. Pesquisas, também, demonstraram que a taxa de alimentos orgânicos tem crescido a taxa de 25\% ao ano nos Estados Unidos, Europa e Japão.

A figura 5 evidencia o crescimento nos países em relação ao consumo principalmente na África, Ásia, Europa, América Latina, América do Norte e Oceania.

Figura 4- Growth of the organic agricultural land by continent 2004 to 2012

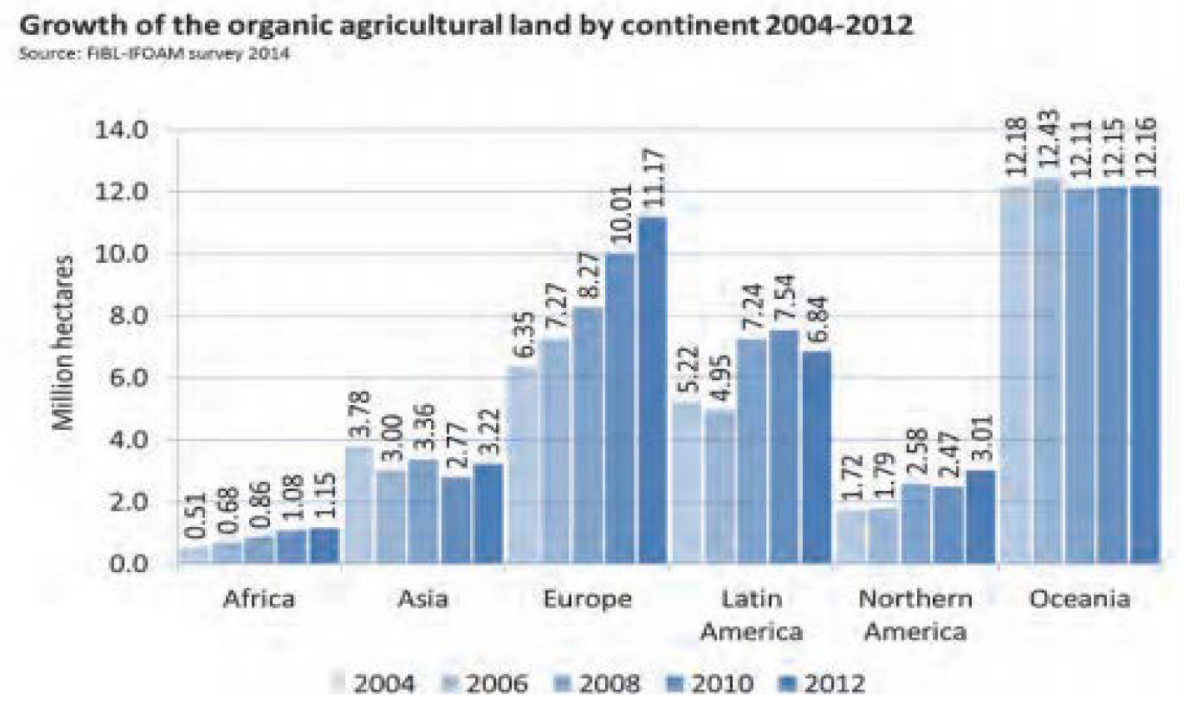

Fonte: LERNOUD; WILLER, 2014.

Considerando-se a agricultura orgânica dos continentes África, Ásia, Europa, América Latina, América do Norte e Oceania, observa-se crescimento superior no período de 2011 a 2012, totalizando 1,9 milhões de produtores com base na pesquisa The World of Organic Agriculture realizada por FIBL e IFOAM.

Consta-se o crescimento da preocupação com os preços destes produtos em relação a produtos advindos da agricultura convencional.

29 FIBL- AMI. Reserarch Institute of Organic Agriculture. Disponível em: < http://www.organic-world.net/fileadmin/documents/ yearbook/2014/fibl-ifoam-2014-regions-2012.pdf>. Acesso em: 19 set. 2016. 


\subsubsection{Preço}

O Banco Nacional de Desenvolvimento Econômico e Social (BNDES) ${ }^{30}$ divulgou uma pesquisa da Organic Europe, apontando os percentuais de diferença dos preços em relação aos produtos convencionais.

Tabela 1- Diferencial de preços na Europa entre produtos orgânicos e convencionais

\begin{tabular}{lc}
\hline & Preços de orgânicos/convencionais $(\%)$ \\
\hline Áustria & $20-30$ \\
França & $25-25$ \\
Holanda & $15-50$ \\
Irlanda & $30-50$ \\
Itália & $30-40$ \\
Suécia & $14-90$ \\
\hline
\end{tabular}

Fonte: SÖL - www.organic-europe.net. BNDES ${ }^{31}$

Dessa forma o Quadro 1 identifica que há diferenças significativas em nível mundial na comparação dos produtos convencionais e orgânicos inclusive em países como Holanda e Irlanda chegando a 50\% a mais.

No Brasil, segundo o Instituto Brasileiro de Defesa do Consumidor (IDEC), em supermercados, os preços de orgânicos podem ter uma diferença de até $463 \%$ a mais em relação aos mesmos produtos nas feiras orgânicas, que reúnem produtores locais.

A esse ponto, alguns autores apontam o aumento do custo do produto e a produção em menor escala. Ou seja, sua produção não tem um crescimento exponencial para satisfazer à crescente demanda por alimentos no mundo. Devido ao seu custo, somente uma parte restrita da população, com melhores condições financeiras têm acesso ao produto.

Júnior $^{32}$ define esse modelo como agricultura sustentável e de baixo uso de insumos externos (Low External Input and Sustainable Agriculture (LEISA)), sendo suas características e funções agroecológicas observadas na exploração dos recursos naturais e da produção de alimentos e riqueza. Nesse modelo, há o aproveitamento dos recursos orgânicos e naturais nos métodos e manejo da produção e, somente em caso de necessidade, utilizam-se produtos químicos e externos ao local, mas de forma controlada.

Em pesquisa realizada pelo Instituto de Planejamento e Economia Agrícola de Santa Catarina (Cepa/ SC) ${ }^{33}$ na região da Grande Florianópolis, conclui que a preocupação com a saúde pessoal (mais de 66\%), que o principal produto orgânico consumido é a hortaliça (mais de $77 \%$ das compras de orgânicos). Alegaram como principal problema preço alto (58\% dos clientes de pequenos estabelecimentos, $53 \%$ dos clientes de supermercados e $45 \%$ dos clientes de feiras).

Em outra pesquisa realizada na cidade do o Rio de Janeiro ${ }^{34}$, e na cidade Curitiba, a diferença entre o pre-

30 ORMOND, José Geraldo Pacheco et al. Agricultura orgânica: quando o passado é futuro. BNDES Setorial, Rio de Janeiro, n. 15, p. 3-34, mar. 2002. Disponível em: <https://web.bndes.gov.br/bib/jspui/bitstream/1408/2479/1/BS\%2015\%20Agricultura\%20 org\%C3\%A2ncia_P.pdf >. Acesso em: 18 set. 2016.

31 ORMOND, José Geraldo Pacheco et al. Agricultura orgânica: quando o passado é futuro. BNDES Setorial, Rio de Janeiro, n. 15, p. 3-34, mar. 2002. Disponível em: <https://web.bndes.gov.br/bib/jspui/bitstream/1408/2479/1/BS\%2015\%20Agricultura\%20 org\%C3\%A2ncia_P.pdf >. Acesso em: 18 set. 2016.

32 ALBERTO JUNIOR. Agricultura e sustentabilidade, 10 out. 2005. Disponível em: < http://www.administradores.com.br/artigos/carreira/agricultura-e-sustentabilidade/11413>. Acesso em: 19 set. 2016.

33 SANTA CATARINA. Secretaria de Estado da Agricultura e Política Rural. Instituto de Planejamento e Economia Agrícola de Santa Catarina. Agricultura orgânica em Santa Catarina, maio 2003. Disponível em: < http://docweb.epagri.sc.gov.br/website_cepa/ publicacoes/organicos.pdf>. Acesso em: 15 set. 2016.

34 FONSECA, M. F. de A C.; CAMPOS, F. F. O cenário da comercialização dos orgânicos no Estado do Rio de Janeiro: I - perspectivas na visão do agricultor, II - feiras, III - processadoras/distribuidoras, IV - grandes varejistas, V - pequenos varejistas. In: 
ço pago pelos consumidores e o que recebem os produtores pode chegar a $760 \%$, sendo a média de $250 \%$.

Para o autor, os preços dos produtos orgânicos são maiores,

[...] porque a demanda por esses produtos tem sido maior do que a oferta, como também porque a qualidade dos alimentos produzidos organicamente é superior em termos nutricionais ${ }^{35}$.

Pesquisas demonstram, também, que o fator preço mais alto é o diferencial de que algumas pessoas não utilizam o produto orgânico. Dessa forma é preciso identificar a cadeia produtiva e o reflexo que esta cadeia também pode alterar o preço.

\subsection{Cadeia produtiva}

A cadeia produtiva do orgânico estabelece a relação entre diversos agentes envolvidos ${ }^{36}$. O que a diferencia da cadeia de produtos convencionais é a questão da certificação, a inexistência da figura do atravessador, ou intermediário, bem como a baixa produção, em que não há, também, a figura do atacadista.

De acordo com o BNDES ${ }^{37}$, a cadeia produtiva do orgânico segue pela produção de insumos, onde há produção de mudas, sementes, adubos, fertilizantes, e, na produção agropecuária, formados por produtores, cooperativas, ou empresas responsáveis pela comercialização.

Em relação ao processamento primário, as empresas cooperadas ou associações atuam na seleção e higienização dos produtos, bem como são responsáveis pelo transporte e comercialização. Quanto ao processamento secundário, ocorre a distribuição, geralmente, por meio de lojas de produtos naturais, lojas especializadas e em supermercados. E, por fim a certificação onde ocorre a ação de credibilidade, onde através da mesma se obtém a confiança dos distribuidores e consumidores.

Figura 5- Cadeia produtiva dos orgânicos

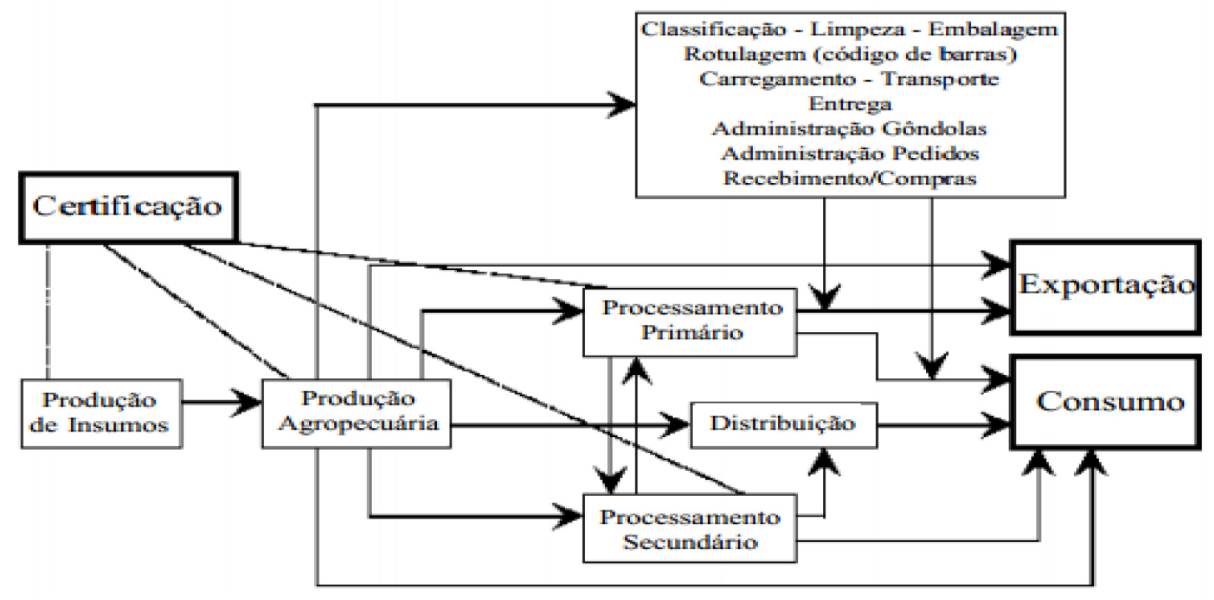

Fonte: Ormond, $2002^{38}$.

AMBROSANO, E. (Coord.). Agricultura ecológica. São Paulo: Livraria Editora Agropecuária, IAC, AAO, 1999.

35 PASCHOAL, A. D. Produção orgânica de alimentos: agricultura sustentável para os séculos XX e XXI; guia técnico e normativo para o produtor, o comerciante e o industrial de alimentos orgânicos e insumos naturais. Piracicaba: ESALQ, 1994.

36 ORMOND, José Geraldo Pacheco et al. Agricultura orgânica: quando o passado é futuro. BNDES Setorial, Rio de Janeiro, n. 15 , p. 3-34, mar. 2002. Disponível em: <https://web.bndes.gov.br/bib/jspui/bitstream/1408/2479/1/BS\%2015\%20Agricultura $\% 20$ org $\%$ C3\%A2ncia_P.pdf >. Acesso em: 18 set. 2016.

37 ORMOND, José Geraldo Pacheco et al. Agricultura orgânica: quando o passado é futuro. BNDES Setorial, Rio de Janeiro, n. 15 , p. 3-34, mar. 2002. Disponível em: <https://web.bndes.gov.br/bib/jspui/bitstream/1408/2479/1/BS\%2015\%20Agricultura\%20 org\%C3\%A2ncia_P.pdf >. Acesso em: 18 set. 2016.

38 ORMOND, José Geraldo Pacheco et al. Agricultura orgânica: quando o passado é futuro. BNDES Setorial, Rio de Janeiro, n. 15, p. 3-34, mar. 2002. Disponível em: <https://web.bndes.gov.br/bib/jspui/bitstream/1408/2479/1/BS\%2015\%20Agricultura\%20 
Faz-se necessário, também, apresentar como acontece a comercialização, bem como o perfil destes potenciais consumidores.

\subsection{Comercialização}

Quando se efetua análise do mercado desses produtos, muitos são as variáveis para análise, pois os consumidores desses produtos possuem particularidades, diferenciais, em face aos clientes que consomem produtos convencionais, onde o preço não é um fator primordial.

Em relação à comercialização do produto agrícola, há um fator de compra a ser considerado, o conceito de fair trade.

\subsubsection{Fair trade (comércio justo)}

Esse conceito Fair Trade (comércio justo) se baseia no fato de que as práticas, geralmente utilizadas no mercado global, são injustas no que se refere à distribuição de renda e afetam o subdesenvolvimento. Suas origens se baseiam no "consumo ético". Esse conceito teve início na Europa com a emergência de Organizações de Comércio Alternativo (ATOs, na sigla em Inglês), como Ten Thousand Villages, Fair Trade Organisatie e Global Exchange.

Dessa forma, é estabelecido um preço mínimo o qual deve cobrir os custos de produção ou de fabricação oferecendo uma margem de lucro para investimento. Evidencia-se, também, um prêmio que deve ser investido para melhoria das condições da comunidade ${ }^{39}$.

Nesse tipo de comércio, o consumidor se dispõe a pagar não o estipulado pela costumeira oferta de mercado, pela demanda, ou pelo preço de mercado e, sim, se dispõe a pagar um preço justo que remunere o produtor. A premissa é que o consumidor tem a certeza de que o preço que está pagando está sendo distribuído de forma justa dentro da cadeia produtiva. Nesse caso acredita-se que valor é reduzido também, pois não há a figura do atravessador.

Inclusive, há alguns slogans “do produtor para a mesa do consumidor”. Esse perfil de consumidor orgânico é diferenciado e possui algumas particularidades.

\subsubsection{Perfil dos consumidores}

Pesquisas realizadas no exterior e no Brasil, em vários pontos, apontam o perfil dos consumidores. Em pesquisa ${ }^{40}$ realizada nos Estados Unidos, constataram que a maioria dos entrevistados alegaram que compram alimentos rotulados como orgânicos e gostariam de comprar mais se houvesse uma maior disponibilidade. Uma menor parcela dos consumidores estaria disposta a pagar um valor a mais por produtos orgânicos, mas o fator preço também aparece como restrição.

Pesquisa realizada em São Paulo em 2002 apontou que o perfil dos consumidores é de 55,1\% entre 31 e 50 anos, e 17,4\% acima de 51\% anos, 27,5\% idade até 30 anos. Grande maioria do sexo masculino 55,1\%, cuja escolaridade era de 65,2\% com nível superior. Destes $97,8 \%$ consideravam a importância da rotulagem de produtos, identificando sua origem. Ao alegarem os itens que influenciaram a compra, 55,7\% alegaram a origem dos produtos, a apresentação do rótulo $26,7 \%$, e $36,6 \%$ o preço. Destes $88,4 \%$ acreditava que os produtos orgânicos eram benéficos a saúde ${ }^{41}$.

org $\%$ C3\%A2ncia_P.pdf >. Acesso em: 18 set. 2016.

39 FAIRTRADE BRASIL. Home. Disponível em: <http://www.fairtradebrasil.com.br/home>. Acesso em: 10 set. 2016.

40 SOUZA, Maria Célia Martins de. Produtos orgânicos. In: ZYLBERSZTAJN, Decio; NEVES, Marcos Fava (Org.). Economia e gestão dos negócios agroalimentares. São Paulo: Pioneira, 2000. p. 385-401.

41 LOMBARDI, M. S.; MOORI, R. G.; SATO, G. S. Um estudo exploratório dos fatores relevantes na decisão de compra de 
Verificou-se, nas regiões consumidoras de São Paulo, um alto nível de instrução e educação, o que pode ser fator de influência na decisão de consumo dos produtos orgânicos.

O Mercado consumidor de alimentos orgânicos em Belo Horizonte (MG) apontou que a maioria dos consumidores era do gênero feminino (76,0\%), com idade superior a 30 anos $(90,3 \%)$, graduados $(81,5 \%)$ e com renda familiar (acima de 12 S.M./mês) (78,7\%). A isenção de resíduos de agrotóxicos $(69,7 \%)$ foi o diferencial pela procura pelo produto. Alimentos orgânicos foram mencionados conter maiores níveis de nutrientes do que os convencionais (82,0\%). Pesquisa apresentou que 98,8\% acreditam que os produtos orgânicos traziam benefícios a saúde ${ }^{42}$.

Na região de Minas Gerais, observou se que o nível de instrução superior continua sendo a maioria dos consumidores de produtos orgânicos. Pesquisa ${ }^{43}$ realizada aponta que em 7 cidades, sendo: São Paulo, Curitiba, Rio de Janeiro, Brasília, Goiânia, Belo Horizonte e Belém demonstraram que os hábitos de consumo são de que $72 \%$ dos entrevistados compram em supermercados, $41 \%$ em lojas de orgânicos, e 35\% em feiras livres. Destes 29\% estão dispostos a pagar mais por um produto orgânico. O tempo de consumo também foi de fidelidade. A pesquisa demonstrou que 41\% consomem há mais de 5 anos. Muitos destes alegaram que, em relação à preocupação com a saúde, $72 \%$ foi o motivo de sua utilização. A grande maioria, 94\%, consome mais frutas verduras e legumes orgânicos.

Evidencia-se que há público específico para esse segmento, pessoas que estão buscando produtos diferenciados, um consumidor ecologicamente correto ou, ainda, que deseja produtos diferenciados propostos pelo mercado.

No tocante ao nome, "consumidor ecológico", este é definido como aquele indivíduo que busca para consumo apenas produtos que minimizem prejuízo ao meio ambiente, isto é, aqueles que buscam conscientemente produzir, por meio do seu comportamento de consumo, algum efeito favorável sobre o meio ambiente e à sociedade como um todo ${ }^{44}$.

\subsubsection{Qualidade dos produtos}

A preocupação com a saúde aliados a produtos livres de agrotóxicos são fatores que fazem com que as expectativas quanto aos produtos agrícolas sejam superiores.

De acordo com Souza ${ }^{45}$, "os produtos orgânicos classificam-se como bens de crença, pois apresentam atributos de qualidade altamente específicos não identificáveis mediante simples observação". Qualidade, para o autor, relaciona-se não apenas com o aspecto visual como a aparência ou salubridade, mas a isenção de produtos químicos.

Pesquisas apontaram, também, a preocupação com a saúde, fatores nutricionais superiores com fatores que fazem com que mais pessoas busquem produtos agrícolas, mesmo sabendo que seu custo por ser superior.

Quando verificada a questão da qualidade, são várias as premissas a serem aplicadas, devem atender a um padrão, atender a expectativa do cliente e propiciarem retorno ao preço aplicado no produto ou serviço.

produtos orgânicos. Revista de Administração Mackenz̨ie, v. 5, n. 1, p. 13-34, 2004.

42 ANDRADE, L. M. S, BERTOLDI, M. C. Atitudes e motivações em relação ao consumo de alimentos orgânicos em Belo Horizonte - MG. Brazilian Journal of Food Technology, v. 15, n. special, May 2012. Available at: <http://www.scielo.br/scielo. php?pid=S1981-67232012000500006\&script=sci_arttext>. Accessed on: 18 Sept. 2016.

43 KLUTH, B.; BOCCHI JUNIOR, U.; CENSKOWSKY, U. Pesquisa sobre o comportamento e a percepcão do consumidor de alimentos orgânicos no Brasil. Munchen: Organic Services; Jundaiai: Vitalfood, 2010.

44 PEREIRA, Severino Joaquim Nunes. O impacto do argumento ecológico nas atitudes dos consumidores: um estudo experimental. 2003.91 f. Dissertação (Mestrado) - Escola Brasileira de Administração Pública e de Empresas, Fundação Getúlio Vargas, São Paulo, 2003. 45 SOUZA, Maria Célia Martins de. Produtos orgânicos. In: ZYLBERSZTAJN, Decio; NEVES, Marcos Fava (Org.). Economia e gestão dos negócios agroalimentares. São Paulo: Pioneira, 2000. p. 385-401. 


\section{Considerações finais}

No passado, a grande preocupação era com a quantidade de produtos a ser produzido, hoje, esse item ainda permanece, porém com atenção ao meio ambiente e produzindo mais em um mesmo espaço de terra.

Nesse contexto, cresce, também, a análise dos impactos dessa produção exponencial de alimentos na saúde humana, dos malefícios causados muitas vezes da utilização de agrotóxicos ou com a falta de cuidados no acompanhamento da aplicação na terra, refletindo na saúde dos consumidores.

Dessa forma, surgem os produtos orgânicos com possibilidade de atender um cultivo ecologicamente correto por meio de cultivo em pequena escala, utilizando insumos de baixo impacto ambiental utilizando o aproveitamento e realização de compostagem no manejo, respeitando o tempo que se faz necessário de cada produto e com benefício a saúde humana.

Evidencia-se que o consumidor desse produto orgânico não está especificamente preocupado com preço, mas com fatores que estão agregados ao produto, que nesse caso é qualidade no cultivo diferenciada em relação ao produto convencional e à procedência da sua alimentação.

A procura por alimentos considerados mais saudável vem sendo orientada por conhecimento cientifico relacionados à saúde do homem e à preocupação com meio ambiente que foi produzido.

Finalizando, a conclusão do estudo a produção e consumo de alimentos orgânicos estão inseridos em uma mudança comportamental, de um consumidor mais preocupado com a saúde e de questões ambientais que permeiam o processo de produção.

\section{REFERÊNCIAS BIBLIOGRÁFICAS}

ALBERTO JUNIOR. Agricultura e sustentabilidade, 10 out. 2005. Disponível em: < http://www.administradores.com.br/artigos/carreira/agricultura-e-sustentabilidade/11413>. Acesso em: 19 set. 2016.

ALTIERI, M. Agroecologia: as bases científicas da agricultura alternativa. Rio de Janeiro: PTA-FASE, 1989.

ANDRADE, L. M. S, BERTOLDI, M. C. Atitudes e motivações em relação ao consumo de alimentos orgânicos em Belo Horizonte - MG. Brazilian Journal of Food Technology, v. 15, n. special, May 2012. Available at: <http://www.scielo.br/scielo.php?pid=S1981-67232012000500006\&script=sci_arttext>. Accessed on: 18 Sept. 2016.

BRASIL. Empresa Brasileira de Pesquisa Agropecuária. Evolução e cadeia produtiva da agricultura orgânica. Brasília, 2006. Disponível em: <https://www.embrapa.br/busca-de-publicacoes/-/publicacao/779849/ evolucao-e-cadeia-produtiva-da-agricultura-organica >. Acesso em: 16 set. 2016.

BRASIL. Instituto Brasileiro de Defesa do Consumidor. Rota dos orgânicos. Revista do Idec, n. 162, fev. 2012. Disponível em: <http://www.idec.org.br/em-acao/revista/diferenca-que-incomoda/materia/na-rota-dosorganicos>. Acesso em: 15 set. 2016.

BRASIL. Instituto Nacional de Metrologia, Qualidade e Tecnologia. [Homepage]. Rio de Janeiro, 2012. Disponível em: <http://www.inmetro.gov.br/>. Acesso em: 19 set. 2016.

BRASIL. Ministério da Agricultura, Pecuária e Abastecimento. Mato Grosso e Pará têm as maiores áreas de orgânicos do país, 30 maio 2012. Disponível em: < http://www.agricultura.gov.br/comunicacao/noticias/2012/05/ mato-grosso-e-para-tem-as-maiores-areas-de-organicos-do-pais>. Acesso em: 19 set. 2016.

BRASIL. Ministério do Desenvolvimento, Indústria e Comércio Exterior. Secretaria de Comércio Exterior. Exportações brasileiras de produtos orgânicos: agosto de 2006 a janeiro de 2010. Disponível em: <http://www. 
mdic.gov.br>. Acesso em: 19 set. 2016.

CAMPANHOLA, Clayton; VALARINI, Pedro José. A Agricultura orgânica e seu potencial para o pequeno agricultor. Cadernos de Ciência \& Tecnologia, Brasília, v. 18, n. 3, p. 69-101, set./dez. 2001.

CAMPOS, Christiane Senhorinha Soares. A face feminina da pobreza em meio à riqueza do agronegócio: o caso de Cruz Alta/RS. Bueno Aires: CLACSO, 2011.

CAN ORGANIC food feed the world? New study sheds light on debate over organic vs. conventional agriculture. ScienceDaily, 25 Apr. 2012. Available at: <www.sciencedaily.com/releases/2012/04/120425140114.htm>. Accessed on: 19 Sept. 2016.

CANUTO, João Carlos. Agricultura ecológica en Brasil: perspectivas socioecológicas. 1998. 256 f. Tese (Doutorado) - Instituto de Sociología y Estudios Campesinos (ISEC), Escuela Superior de Ingenieros Agrónomos y Montes (ETSIAM), Universidad de Córdoba, Córdoba, 1998.

CAPORAL, Francisco Roberto. Em defesa de um plano nacional de transição ecológica: compromisso com as atuais e nosso legado para as futuras gerações. In: SAUER, S.; BALESTRO, M. V. (Org.) Agroecologia e os desafios da transição agroecológica. São Paulo: Expressão Popular, 2009.

DAROLT, Moacir Roberto. Alimentos orgânicos: um guia para o consumidor consciente. 2. ed. rev. e ampl. Londrina: IAPAR, 2007. Disponível em: <http://www.iapar.br/arquivos/File/zip_pdf/publi_alimentos. pdf>. Acesso em: 19 set. 2016.

DENARDI, R. A. Agricultura familiar e políticas públicas: alguns dilemas e desafios para o desenvolvimento rural sustentável. Agroecologia e desenvolvimento rural sustentável, Porto Alegre, v. 2, n. 3, p. 56-62, jul./set. 2001.

FAIRTRADE BRASIL. Home. Disponível em: <http://www.fairtradebrasil.com.br/home>. Acesso em: 10 set. 2016.

FONSECA, M. F. de A C.; CAMPOS, F. F. O cenário da comercialização dos orgânicos no Estado do Rio de Janeiro: I - perspectivas na visão do agricultor, II - feiras, III - processadoras/distribuidoras, IV - grandes varejistas, V - pequenos varejistas. In: AMBROSANO, E. (Coord.). Agricultura ecológica. São Paulo: Livraria Editora Agropecuária, IAC, AAO, 1999.

GAZZONI, Décio Luiz. As razões da escalada de preços das commodities agrícolas. In: SIMPÓSIO INTERNACIONAL DE BIOCOMBUSTÍVEIS E SEGURANÇA ALIMENTAR, 2008, Salvador. Anais... Salvador: Goethe-Institut, 2008.

GONÇALVES, Carlos Walter Porto. Geografia da riqueza, fome e meio ambiente: pequena contribuição crítica ao atual modelo agrário/agrícola de uso dos recursos naturais. Interthesis, Florianópolis, v. 1, n. 1, p. $1-55,2004$.

HECHT, S. B. A evolução do pensamento agroecológico. In: ALTIERI, M. A. (Ed.). Agroecologia: as bases científicas da agricultura alternativa. Rio de Janeiro: PTA/FASE, 1989. p. 25-41.

IBD CERTIFICAÇÕES. Certificações: orgânico: IBD orgânico e orgânico Brasil, 2014. Disponível em: <http://ibd.com.br/pt/IbdOrganico.aspx>. Acesso em: 19 set. 2016.

KLUTH, B.; BOCCHI JUNIOR, U.; CENSKOWSKY, U. Pesquisa sobre o comportamento e a percepcão do consumidor de alimentos orgânicos no Brasil. Munchen: Organic Services; Jundaiai: Vitalfood, 2010.

LERNOUD, Julia; WILLER, Helga. Organic agriculture worldwide: key results from the FiBL-IFOAM surveyon organic agriculture worldwide 2014: part 3: organic agriculture in the regions 2012. Frick, Switzerland, Apr. 2014. Available at: <http://www.organic-world.net/fileadmin/documents/yearbook/2014/fiblifoam-2014-regions-2012.pdf>. Accessed on: 19 Sept. 2016.

LEVI, M.; LINTON, A. Fair trade: a cup at a time? Politics \& Society, v. 31, n. 3, Sept. 2003. 
LOMBARDI, M. S.; MOORI, R. G.; SATO, G. S. Um estudo exploratório dos fatores relevantes na decisão de compra de produtos orgânicos. Revista de Administraşão Mackeñie, v. 5, n. 1, p. 13-34, 2004.

MALTHUS, T. An essay on the principle of population: or a view of its past and present effects on human happiness: with an inquiry into our prospects respecting the future removal or mitigation of the evils which it occasions. 6. ed. Londres: John Murray, 1826.

MARCUSE, H. de. Tecnologia, guerra e fascismo: coletânea de artigos. São Paulo: Unesp, 1999.

MATIAS, Adalberto Borges; FREITAS, Zípora de Campos. Commodities ambientais: uma análise acerca da comercialização em bolsa de valores no mercado financeiro brasileiro, 2003. Disponível em: <http://www. cepefin.org.br/mapa.htm>. Acesso em: 18 set. 2016.

MAZZOLENI, Eduardo Mello; NOGUEIRA, Jorge Madeira. Agricultura orgânica: características básicas do seu produtor. Revista de Economia e Sociologia Rural, Rio de Janeiro, v. 44, n. 2, p. 263-293, abr./jun. 2006.

MOMESSO, Cristiane Maria Vendramini; ROEL, Antonia Railda; FAVARO, Simone Palma. Levantamento do potencial de comercialização de produtos orgânicos para o estado de Mato Grosso do Sul. Interações, Campo Grande, v. 10, n. 1, p. 55-62, jan./jun. 2009.

ORMOND, José Geraldo Pacheco et al. Agricultura orgânica: quando o passado é futuro. BNDES Setorial, Rio de Janeiro, n. 15, p. 3-34, mar. 2002. Disponível em: <https://web.bndes.gov.br/bib/jspui/bitstream/1408/2479/1/BS\%2015\%20Agricultura\%20org\%C3\%A2ncia_P.pdf >. Acesso em: 18 set. 2016.

PASCHOAL, A. D. Produção orgânica de alimentos: agricultura sustentável para os séculos XX e XXI; guia técnico e normativo para o produtor, o comerciante e o industrial de alimentos orgânicos e insumos naturais. Piracicaba: ESALQ, 1994.

PEREIRA, Severino Joaquim Nunes. O impacto do argumento ecológico nas atitudes dos consumidores: um estudo experimental. 2003. 91 f. Dissertação (Mestrado) - Escola Brasileira de Administração Pública e de Empresas, Fundação Getúlio Vargas, São Paulo, 2003.

POLITO, Wagner L. The Trofobiose Theory and organic agriculture: the active mobilization of nutrients and the use of rock powder as a tool for sustainability. Anais da Academia Brasileira de Ciências, Rio de Janeiro, v. 78, n. 4, p. 765-779, dez. 2006.

PRATES, Daniela Magalhães. A alta recente dos preços das commodities. Revista de Economia Política, v. 27, n. 3, p. 323-344, jul./set. 2007.

SANTA CATARINA. Secretaria de Estado da Agricultura e Política Rural. Instituto de Planejamento e Economia Agrícola de Santa Catarina. Agricultura orgânica em Santa Catarina, maio 2003. Disponível em: < http:/ / docweb.epagri.sc.gov.br/website_cepa/publicacoes/organicos.pdf>. Acesso em: 15 set. 2016.

SAUER, Sérgio Reforma Agrária e geração de emprego e renda no meio rural. São Paulo: ABET, 1998.

SCHNEIDER, Sérgio Teoria social, agricultura familiar e pluriatividade. Revista Brasileira de Ciências Sociais, v. 18, n. 51, p. 99-121, fev. 2003.

SEUFERT, Verena; RAMANKUTTY, Navin; FOLEY, Jonathan A. Comparing the yields of organic and conventional agriculture. Nature, n. 485, p. 229-232, 10 May 2012. Available at: <http://www.nature.com/ nature/journal/v485/n7397/full/nature11069.html>. Accessed on: 15 Sept. 2016.

SOUZA, Maria Célia Martins de. Algodão orgânico: o papel das organizações na coordenação e diferenciação do sistema agroindustrial do algodão. 1998. 187 f. Dissertação (Mestrado) - Departamento de Administração, Faculdade de Economia, Administração e Contabilidade, Universidade de São Paulo, São Paulo, 1998.

SOUZA, Maria Célia Martins de. Produtos orgânicos. In: ZYLBERSZTAJN, Decio; NEVES, Marcos Fava (Org.). Economia e gestão dos negócios agroalimentares. São Paulo: Pioneira, 2000. p. 385-401. 
TASHIMA, Lucelia da Costa Nogueira. A construção da visibilidade da agricultura familiar: estudo de caso na comunidade negra quilombola de São Miguel - MS. 2016. 118 f. Dissertação (Mestrado) - Programa de Pós-graduação em Desenvolvimento Local, Universidade Católica Dom Bosco, Campo Grande, 2016. Disponível em: <http://site.ucdb.br/public/md-dissertacoes/18973-dissertacao-lucelia-da-costa-nogueira-tashima.pdf>. Acesso em: 15 jun. 2016.

UNFPA. Relatório sobre a situação da população mundial: pessoas e possibilidades em um mundo de 7 bilhões. Tradução: Eleny Corina Heller. New York, 2011. Disponível em: <http://www.un.cv/files/PT-SWOP11WEB.pdf>. Acesso em: 19 set. 2016.

UNITED STATES. Food and Agriculture Organization. FAO FactFile: majoraty of people live in cities by 2005, 1998. Available at: <http://www.fao.org/NEWS/FACTFILE/ff9811-e.htm>. Accessed on: 19 Sept. 2016.

WILLER, H.; YUSSEFI, M. Organic agriculture worldwide 2001: statistics and future prospects. Bad Dürkheim: SÖL, 2001. (SÖL Publication, 74). 


\title{
Os desafios jurídicos e econômicos da aviação regional no Brasil*
}

\section{The legal and economic challenges to the regional aviation in Brazil}

\author{
Pablo Leurquin** \\ Mariana Magalhães Avelar***
}

\section{Resumo}

Dada a capacidade de viabilizar a integração entre as regiões do país, o mercado de aviação civil é um setor da economia que tem relevante importância para o desenvolvimento brasileiro. A popularização do acesso ao serviço aéreo, desencadeada a partir dos anos 1990, contrastou com uma redução da quantidade de cidades abrangidas, o que revela uma deficiência de políticas econômicas voltadas ao desenvolvimento da aviação regional. $\mathrm{O}$ objetivo do presente estudo é apresentar uma síntese dos desafios jurídicos e econômicos da aviação regional no Brasil. Trata-se de pesquisa de cunho interdisciplinar, envolvendo reflexões, pesquisas e conceitos do Direito e da Economia. O artigo foi dividido em três seções. Na primeira, apresentam-se os motivos pelos quais a aviação regional deve ser considerada como um setor estratégico para o desenvolvimento econômico. Na segunda, apontam-se as possibilidades de intervenção do Estado nessa área. Na terceira, abordam-se os contornos políticos, jurídicos e econômicos do Programa Nacional de Aviação Regional.

Palavras-chave: Programa Nacional de Aviação Regional. Regulação do mercado de aviação civil. Desenvolvimento econômico.

* Recebido em 05/04/2016 Aprovado em 27/08/2016

** Doutorando em Direito Econômico pela Universidade Federal de Minas Gerais e em Direito Internacional e Europeu na Université Paris I, Panthéon-Sorbonne, com bolsa do CNPq e da CAPES/PSDE. Mestre em Direito Econômico pela Universidade Federal de Minas Gerais, financiado pelo CNPq. Bacharel em Direito pela Universidade Federal do Rio Grande do Norte. Pesquisador do Grupo de Pesquisa em Direito Econômico (GPDE) da FDUFMG. E-mail: pabloleurquin@yahoo.com.br

*** Mestranda em Direito e Administração Pública pela Universidade Federal de Minas Gerais. Especialista em Gestão e Finanças pela UFMG. Bacharel em Direito pela Universidade Federal de Minas Gerais. Advogada associada à sociedade de advogados Manesco, Ramires, Perez, Azevedo Marques. E-mail: mmagalhaesavelar@gmail.com.

\section{Abstract}

The airline market is very relevant to Brazilian economic development because of its ability to integrate several locations of the country. The increasing access to national airline services, build on the 1990's, contrasted with a major reduction on the cities covered by this kind of services and revealed that Brazilian regional aviation public policy is deficient. This study aims to present the legal and economic challenges to regional aviation in Brazil. The research reaches law and economic concepts, being divided in three sections. In the first one, it presents the reasons to considerate regional aviation as a strategic field to economic development. In the second section, it emphasizes the possibilities of state - mandated regulation on regional aviation. The third and last section presents the political, economic and legal aspects of the National Program of Regional Aviation, analyzing its effectiveness. 
Keywords: National Program of Regional Aviation. Airline market regulation. Economic development.

\section{INTRODUÇÃo}

A partir da década de 1990, a reorganização do modelo de intervenção do Estado no setor aéreo permitiu importantes benefícios, que giram em torno da popularização do serviço, ou seja, maior quantidade de pessoas sendo transportadas, menores preços das passagens aéreas e aumento na quantidade de voos. Entretanto, o principal aspecto negativo foi a redução substancial do número de cidades abrangidas com o serviço de aviação civil ${ }^{1}$.

No Brasil, bem como em outros países, o impulso desregulamentador do serviço aéreo redimensionou a estratégia das empresas prestadoras do serviço na medida em que induziu, por uma questão de economia de densidade, a concentração de suas atividades em menos cidades. Entretanto, apesar de algumas experiências de desregulamentação no exterior terem sido conjugadas com a valorização, por intermédio do Estado, da aviação regional, o Brasil não reproduziu esses exemplos e não realizou os devidos investimentos no setor da infraestrutura, muito menos na aviação regional.

Diante desse contexto, o presente trabalho tem como objetivo a apresentar os desafios jurídicos e econômicos para a expansão da aviação regional no Brasil. Para tanto, ele foi dividido em três seções. Na primeira serão apresentados o conceito de aviação regional e os pormenores de sua relevância para a universalização do serviço. Na segunda serão explorados os detalhes da contração da aviação regional brasileira, especialmente após o fim do Sistema Integrado de Transporte Aéreo Regional (SITAR), além disso, serão abordadas algumas propostas encontradas na literatura especializada sobre intervenções estatais para resolver o gargalo no setor. Por fim, serão apresentados os debates contemporâneos para a substancial implementação do Programa Nacional de Aviação Regional.

\section{RELEVÂNCIA dA AVIAÇão REGIONAL NA UNIVERSALIZAÇÃo do SERVIÇo}

Ao tratar da definição da aviação regional, costuma-se retomar a explicação de Humberto Bettini de atividade explorada de maneira regular, que realiza ligações entre cidades de baixa densidade de tráfego, utilizando-se de aeronaves de capacidade inferior a cem passageiros. Entretanto, trata-se de conceito difuso, pois suas fronteiras nem sempre são tão claras. O autor resgata, por exemplo, o fato de muitas vezes as empresas aéreas regionais operarem aeronaves com capacidade superior a cem lugares, como era o caso da TAM e Rio Sul, que utilizavam aviões Fokker F100 e Boeing 737-500, bem como a TABA, que contava com dois F100 em sua frota. Ainda sobre o aspecto difuso do conceito, destaca-se que as empresas regionais podem voar em cidades de elevada densidade de tráfego ou mesmo serem de porte nacional, servindo cidades de baixa densidade de tráfego, como ocorria em 2007 com a GOL, TAM e VARIG ou mesmo da Transbrasil e VASP, antes de encerrarem suas atividades. ${ }^{2}$

Nas palavras de Alessandro Oliveira e Lucia Helena Salgado, a característica mais marcante para definir a aviação regional é a avaliação do setor da incidência das economias de densidade. ${ }^{3} \mathrm{O}$ artigo "Economies of Density versus Economies of Scale: Why Trunk and Local Airline Costs Differ?” de Douglas Caves, Laurits

1 LEURQUIN, Pablo. Os impactos da regulação da aviação civil na integração inter-regional do Brasil. 2013. Dissertação (Mestrado) - Universidade Federal de Minas Gerais, Belo Horizonte, 2013. p. 68 e ss.

2 BETTINI, Humberto. Um retrato da aviação regional no Brasil. Journal of Transport Literature, v. 1, n. 1, p. 46-65, jan. 2007. Disponível em: <http://pesquisaemtransportes.net.br/relit/index.php/relit/article/viewFile/11/70>. Acesso em: 1 set. 2015 . p. 48.

3 OLIVEIRA, Alessandro; SALGADO, Lúcia Helena. Constituição do marco regulatório para o mercado brasileiro de aviação regional. abr. 2008. Disponível em: <http://pantanalbraziltourism.com/fotos/arquivos/96.pdf>. Acesso em: 1 set. 2015. p. 35. 
Christensen e Michael Tretheway, publicado em 1984, é considerado pela literatura da economia dos transportes como precursor na constatação de que, na aviação civil, a economia de densidade é mais relevante que a de escala. Em apertada síntese, os autores identificam que os custos médios são decrescentes conforme a etapa média ou o tamanho médio das aeronaves é maior. ${ }^{4}$

Portanto, de acordo com Humberto Bettini e Alessandro Oliveira, a partir dessa pesquisa, passou-se a entender que o maior custo dessas empresas não decorre de seu menor tamanho, mas de sua menor densidade de operações. Além disso, ficaram claros, também, os estímulos que esse tipo de empresa tem para adquirir aeronaves maiores, o que acaba diminuindo o custo do assento; e para voar trechos mais longos, o que reduz o custo por quilômetro. ${ }^{5}$

Dito isso, a partir da visão de Alessandro Oliveira e Lucia Helena Salgado, pode-se fazer quatro demarcações para delinear na prática o mercado de linhas regionais: a) com base na companhia aérea; b) com base na aeronave, que pode ser do tamanho normalmente menor de cem assentos; c) com base nos aeroportos, definidos a partir da movimentação de passageiros ou aeronaves ou das características do município, definição frequentemente empregada na legislação brasileira; e por fim d) com base na ligação aérea, na qual se leva em consideração a densidade do tráfego (até 15 mil passageiros por ano, por exemplo), trecho percorrido (até 1.000 quilômetros, por exemplo) e número de participantes. Todavia, os autores alertam que existe a possibilidade de ser adotado algum critério arbitrário no momento de segregar os mercados. Isso porque essa separação fica, ainda, mais complicada em um ambiente competitivo, calcado na liberdade, no momento de definir as trajetórias e a não regulamentação impedindo a entrada e saída de outras empresas. ${ }^{6}$

Apresentado o conceito de aviação regional, passa-se à análise da relevância desse setor do mercado para o desenvolvimento econômico. Para Frederico Turolla, Maria Fernanda Lima e Thelma Ohira, o transporte aéreo regional mitiga o isolamento territorial e inclui cidades em eixos de desenvolvimento econômico. Os autores destacam dois aspectos específicos: a) possibilidade de criação de concorrência no setor aéreo por meio do reforço da aviação regional; e b) geração de empregos e sustentação das diversas economias regionais. $^{7}$

Sobre o primeiro aspecto, sabe-se que a estrutura de mercado do setor aéreo brasileiro é caracterizada como oligopólio, o que não significa dizer que há obrigatoriamente baixa competição entre as empresas. ${ }^{8}$

Apesar disso, a literatura econômica identifica a possibilidade de surgimento, em um ambiente concentrado, de comportamentos colusivos, inclusive tácitos, ou até mesmo um processo de cartelização. A partir

4 Para mais informações sobre a pesquisa econométrica que permitiu a constatação que, quando se trata de aviação regional, a economia de densidade tem mais relevância que a de escala, ver: CAVES, Douglas; CHRISTENSEN, Laurits; TRETHEWAY, Michael. Economies of density versus economies of scale: why trunk and local airline costs differ? Rand Journal of Economics, v. 15, p. 471-489, 1984. Disponível em: <http://econpapers.repec.org/scripts/redir.pf?u=http\%3A\%2F\%2Flinks.jstor. org\%2Fsici\%3Fsici\%3D0741-6261\%2528198424\%252915\%253A4\%253C471\%253AEODVEO\%253E2.0.CO \%253B2-S\%26ori gin\%3Drepec;h=repec:rje:randje:v:15:y:1984:i:winter:p:471-489>. Acesso em: 1 set. 2015.

5 BETTINI, Humberto Filipe; OLIVEIRA, Alessandro V. M. Transporte aéreo regional: entre economias de escala e custos de transação. Journal of Transport Literature, v. 5, n. 4, p. 171-187, Oct. 2011. Disponível em: <https://www.google.com.br/url?sa-

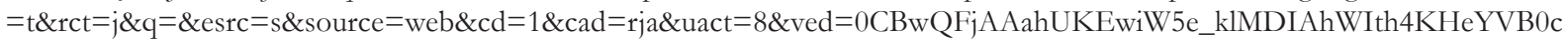
\&url $=\mathrm{http} \% 3 \mathrm{~A} \% 2 \mathrm{~F} \% 2 \mathrm{Fwww}$.pesquisaemtransportes.net.br $\% 2$ Frelit $\% 2$ Findex.php $\% 2 \mathrm{Frelit} \% 2 \mathrm{Farticle} \% 2 \mathrm{Fdownload} \% 2 \mathrm{Fjv} 5 \mathrm{n} 4 \mathrm{p}$ 10\%2F135\&usg=AFQjCNG1IqNxCI-1hoekrUSxBNxUymmI8Q\&sig2=ZPwA68Bu_OzMku67dsOwyg\&bvm=bv.104819420,d. dmo>. Acesso em: 1 set. 2015. p. 174.

6 OLIVEIRA, Alessandro; SALGADO, Lúcia Helena. Constituição do marco regulatório para o mercado brasileiro de aviação regional. abr. 2008. Disponível em: <http://pantanalbraziltourism.com/fotos/arquivos/96.pdf>. Acesso em: 1 set. 2015. p. 35.

7 TUROLLA, Frederico Araujo; LIMA, Maria Fernanda Freire; OHIRA, Thelma Harumi. Políticas públicas para a melhoria da competitividade da aviação regional brasileira. Journal of Transport Literature, v. 5, n. 4, p. 188-231, Oct. 2011. Disponível em: <http:// www.pesquisaemtransportes.net.br/relit/index.php/relit/article/view/jv5n4p11/pdf_57>. Acesso em: 1 set. 2015. p. 204.

8 Para mais detalhes sobre as concentrações mais recentes do setor, retomar: RUIZ, Ricardo Machado; HECKTHEUER, Leticiá Monteiro; BARROS, Gabriel Gil Barreto. Concentração e rivalidade em transporte aéreo de passageiros: reflexões a partir de casos recentes. In: SILVA, Leandro Novais (Org.) Regulação e concorrência no setor aéreo no Brasil: alternativas possíveis. São Paulo: Singular, 2014. p. 201-230. 
dessa visão, o fomento à entrada ou à redução das barreiras é estratégica para manter a competitividade no setor.

Portanto, tendo em vista que as companhias estabelecidas na aviação regional, por terem mais experiência na indústria específica, são entrantes mais prováveis dos mercados relevantes não regionais, elas têm importância inquestionável para a concorrência no setor. Diante disso, as possíveis desvantagens da aviação regional são minoradas dada essa importância na manutenção de possíveis entrantes nos mercados principais. ${ }^{9}$

Outro aspecto que Frederico Turolla, Maria Fernanda Lima e Thelma Ohira apresentam é a possibilidade da aviação regional de gerar empregos nas economias regionais. Essa perspectiva está ligada à possibilidade de evidenciar vocações regionais para negócios, que acabam ganhando maior espaço com um transporte que permita agilidade na locomoção de sujeitos e de cargas, em menor escala. ${ }^{10}$

Além desses pontos, questão que se mostra pertinente nesse contexto é a importância da aviação regional para a região amazônica. Nessa parte do território brasileiro, devido a suas caraterísticas geográficas, o sistema hidroviário é a principal rede física de transporte de cargas e de passageiros. Entretanto, as condições dessa locomoção, especialmente para os indivíduos, são precárias, além disso, determinados rios não são navegáveis durante todo o ano, devido às cheias e aos impedimentos decorrentes de bancos de areia, pedrais e travessões. Essas poucas condições de acessibilidade reforçam a necessidade de se consolidar o transporte aéreo como o principal na integração da própria região, bem como da mesma com as demais. ${ }^{11}$

Sobre a preocupação do desenvolvimento da aviação regional no Norte, em 2009, ainda durante o Governo do Presidente Lula, o Ministro Mangabeira Unger, da Secretaria de Assuntos Estratégicos, inseriu a intensificação da aviação regional na Amazônia, ao lado da construção de estradas vicinais e rodovias como uma das quatro etapas do Programa Amazônia Sustentável (PAS). ${ }^{12}$ Os outros eram a regularização ambiental, o surgimento do extrativismo madeireiro e não madeireiro, e a recuperação de áreas degradadas na Amazônia e no Cerrado. ${ }^{13}$

Isto posto, quando se pensa em investimento estatal no setor, o conceito de mercados de linhas essenciais chama atenção na temática da aviação regional. De acordo com Alessandro Oliveira e Lucia Helena Salgado, eles são caracterizados pela necessidade estratégica de garantir que esse serviço seja prestado. Como exemplo os autores citam localidades em área de fronteira, regiões inacessíveis sem outros meios de transportes, em zona rural ou turística, quando considerada serviço pioneiro. Às vezes essas linhas têm demanda futura suficiente para garantir seu sustento, entretanto, nos casos em que isso não se faz possível, o Estado costuma intervir. ${ }^{14}$

9 TUROLLA, Frederico Araujo; LIMA, Maria Fernanda Freire; OHIRA, Thelma Harumi. Políticas públicas para a melhoria da competitividade da aviação regional brasileira. Journal of Transport Literature, v. 5, n. 4, p. 188-231, Oct. 2011. Disponível em: < http:// www.pesquisaemtransportes.net.br/relit/index.php/relit/article/view/jv5n4p11/pdf_57>. Acesso em: 1 set. 2015 . p. 204.

10 TUROLLA, Frederico Araujo; LIMA, Maria Fernanda Freire; OHIRA, Thelma Harumi. Políticas públicas para a melhoria da competitividade da aviação regional brasileira. Journal of Transport Literature, v. 5, n. 4, p. 188-231, Oct. 2011. Disponível em: < http:// www.pesquisaemtransportes.net.br/relit/index.php/relit/article/view/jv5n4p11/pdf_57>. Acesso em: 1 set. 2015. p. 204 e ss.

11 BANCO NACIONAL DO DESENVOLVIMENTO. Aviação regional brasileira: modal aéreo IV. Informe infra-estrutura, n. 50, p. 7, 2002. Disponível em: <http://www.bndes.gov.br/SiteBNDES/export/sites/default/bndes_pt/Galerias/Arquivos/conhecimento/infra/Inf02-50.pdf>. Acesso em: 28 de ago. 2015.

12 Para ilustrar a importância que o Ministro Mangabeira Unger teve para fomentar o debate da aviação regional no Brasil, destacase que, na sua segunda posse como Ministro da Secretaria de Assuntos Estratégicos, em 2015, a Presidenta Dilma falou: "Todos os que integravam os ministérios ou órgão públicos naquela época sabem da contribuição do professor Mangabeira Unger. Destaco duas delas: o Plano Nacional de Defesa e a instigante determinação de que deveríamos investir em aeroportos regionais". INSTITUTO DE PESQUISA ECONÔMICA APLICADA. Mangabeira Unger toma posse como novo ministro da SAE. Brasília, 2 fev. 2015. Disponível em: <http://www.ipea.gov.br/portal/index.php?option=com_content\&view=article\&id=24432>. Acesso em: 2 set. 2015.

13 RÁDIO CÂMARA. Mangabeira Unger explica ações do governo para Amazônia e desenvolvimento regional. Câmara dos Deputados, Brasília, 10 mar. 2009. (3’57”). Disponível em: <http://www2.camara.leg.br/camaranoticias/radio/materias/ULTIMAS-NOTICIAS /364792-MANGABEIRA-UNGER-EXPLICA-A\%C3\%87\%C3\%95ES-DO-GOVERNO-PARAAMAZ\%C3\%94NIA-E-DESENVOLVIMENTO-REGIONAL-(03’57\%22).html>. Acesso em: 2 de set. 2015.

14 OLIVEIRA, Alessandro; SALGADO, Lúcia Helena. Constituição do marco regulatório para o mercado brasileiro de aviação regional. abr. 
Apesar da constatada necessidade de crescimento da aviação regional no Brasil, há deficiência histórica na formulação de políticas públicas para o setor. Esse comportamento é completamente diferente de outros países, em especial dos que possuem grandes extensões territoriais. Carlos Ragazzo e Cristiane Albuquerque, em seu texto "Concorrência e universalização: incentivos regulatórios à aviação regional", expõem algumas experiências internacionais de investimento estatal na aviação regional. Dentre elas merecem destaque duas nos EUA: o Programa de serviço aéreo essencial (Essential air service program), que passou a ser mais restrito após recentes reformulações; e o Programa de desenvolvimento de serviço aéreo de pequenas comunidades (Small community air service development program), criado em 2000, que concede linhas de crédito passíveis de financiar programas de marketing, contratação de pessoal e estudos em aeroportos. Em relação à União Europeia, por sua vez, no caso de nenhuma empresa ter interesse em atuar em uma rota considerada essencial para o desenvolvimento econômico da região (Regulação 1008/2008), o Estado-Membro pode restringir o acesso a apenas uma empresa no mercado específico por um período de no máximo quatro anos, ressarcindo seus prejuízos operacionais. ${ }^{15}$

No Brasil, frisa-se que a primeira política sistemática de investimento na aviação regional foi a Rede de Integração Nacional (RIN), instaurada em 1963. Tendo como objetivo subsidiar as empresas que trafegassem em rotas de baixo e médio potencial de tráfego e utilizassem aeronaves DC-3, Catalina ou C-46, com até 31 assentos, ela só durou até $1972 .{ }^{16}$ Em seguida, conforme visto na seção do capítulo 2 destinada ao histórico da regulação da aviação civil no Brasil, veio o SITAR. Após a extinção dele, a única medida que influenciava a aviação regional era o Programa Federal de Auxílio a Aeroportos (PROFAA), e que destinava $20 \%$ (percentual que subiu para 25,24\% em 2013) dos recursos originados do Adicional de Tarifas Aeroportuária (ATAERO) a aeroportos e aeródromos de interesse regional e estadual, conforme determinado pela Lei $n^{\circ} 8.399$, de 7 de janeiro de 1992.

Os recursos do programa eram frequentemente aplicados em razão de convênios, celebrados entre o Ministério da Defesa e entes gestores de aeródromos de interesse regional ou estadual. Apesar disso, conforme elucida Carlos Ragazzo e Cristiane Albuquerque, esse programa teve pouco efeito na manutenção da quantidade de cidades abrangidas pelo serviço aéreo. ${ }^{17}$

Ressalta-se em adendo a possível revogação da legislação que estabelece a destinação dos recursos acima mencionados ao PROFAA. Fala-se em possível revogação em vista da edição da Medida Provisória n ${ }^{\circ}$ 714, de $1^{\circ}$ de março de 2016, cujo art. $5^{\circ}$, II b) que estabelece a revogação, a partir de $1^{\circ}$ de janeiro de 2017 , da Lei no 8.399, de 7 de janeiro de 1992. Ao que tudo indica se agravará o quadro de ausência de investimentos intensivos na aviação regional ${ }^{18}$,

Esse quadro é especialmente gravoso ante o fato de que vários outros países cumularam a política de desregulamentação do setor aéreo com o investimento na aviação civil regional. Nesse cenário merece atenção a ausência desse tipo de postura do Estado brasileiro, que acabou por estagnar demasiadamente essa parte do mercado. Compreendida a importância da aviação regional para o desenvolvimento econômico do país, em especial para a universalização do serviço, passa-se à análise mais precisa da dimensão da contração desse mercado nos últimos anos.

2008. Disponível em: <http://pantanalbraziltourism.com/fotos/arquivos/96.pdf>. Acesso em: 1 set. 2015. p. 52.

15 Não se pretende com esse trabalho exaurir os pormenores das experiências estrangeiras de investimento Estatal no mercado de aviação regional, mas apenas dar notícia que se trata de realidade comum em outros países, como é o caso também da Austrália e Canadá, por exemplo. Para mais informações sobre o assunto, ver: RAGAZZO, Carlos Emmanuel Joppert; ALBUQUERQUE, Cristiane Landerdahl de. Concorrência e universalização: incentivos regulatórios à aviação regional. In: SILVA, Leandro Novais (Org.). Regulação e concorrência no setor aéreo no Brasil: alternativas possíveis. São Paulo: Singular, 2014. p. 238 e ss.

16 PINTO, Victor Carvalho. Dirigismo versus livre-iniciativa na regulação econômica do transporte aéreo. In: SILVA, Leandro Novais (Org.). Regulação e concorrência no setor aéreo no Brasil: alternativas possíveis. São Paulo: Singular, 2014. p. 37.

17 RAGAZZO, Carlos Emmanuel Joppert; ALBUQUERQUE, Cristiane Landerdahl de. Concorrência e universalização: incentivos regulatórios à aviação regional. In: SILVA, Leandro Novais (Org.). Regulação e concorrência no setor aéreo no Brasil: alternativas possíveis. São Paulo: Singular, 2014. p. 235.

18 Ao que tudo indica crescerá a importância do Fundo Nacional de Aviação Civil na realização de investimentos dependerá na atuação de investimento. A atuação do referido fundo será discriminada adiante. 


\section{A CONTRAÇÃo DA AVIAÇÃo REGIONAL BRASILEIRA E A NECESSIDADE DA INTERVENÇÃo ESTATAL}

Alessandro Oliveira e Lucia Helena Salgado retomam os dados do Anuário Estatístico da ANAC para afirmar que o crescimento no número de passageiros-quilômetros pagos foi de 22,5\% somente em 2010. Segundo eles, trata-se de "taxas chinesas" de crescimento, ${ }^{19}$ que colocam o Brasil como um dos países em que a aviação civil mais cresceu. Entretanto, esses indicadores não ressoam nas análises da aviação regional. Na realidade, de acordo com os mesmos, ela vem apresentando claros sinais de contração. ${ }^{20}$

Além disso, os autores apontam que houve crescimento de 6\% no número de ligações, o que pode ser considerado abaixo do esperado se for levado em consideração o rápido crescimento do setor na última década. Atrelado a isso, praticamente um terço das ligações não alcançou sustentabilidade e isso pode ilustrar o tamanho da vulnerabilidade do setor. Assim, para Alessandro Oliveira e Lucia Helena Salgado, pode-se concluir que há um "importante gargalo aeroportuário concentrado não apenas nos grandes centros, mas também ao longo do território nacional, nos pequenos e médios aeroportos que deixaram de ser servidos". ${ }^{21}$

Dados de 2012 fornecidos pela Associação Brasileira das Empresas Aéreas (ABEAR) reforçam a má distribuição do transporte aéreo, pois informam que dos 98 aeroportos brasileiros (administrados pela INFRAERO ou DAESP) 18 estão localizados em regiões com mais de 5 milhões de passageiros; 24 em regiões com 1 a 5 milhões de passageiros; e 56 em regiões com até 1 milhão de passageiros. Entretanto, a maior parte dos passageiros se concentra em regiões com mais de 5 milhões de passageiros. Além disso, esse estudo mostrou que dos doze maiores aeroportos do país, oito já estão com utilização igual ou acima da capacidade reportada, que é o caso de Guarulhos, Congonhas, Brasília, Rio de Janeiro, Belo Horizonte, Rio de Janeiro, Salvador, Porto Alegre, Campinas, Recife e Fortaleza. ${ }^{22}$

Humberto Bettini e Alessandro Oliveira destacam que, entre 1998 e 2008, houve redução de 199 para 155 cidades abrangidas pelo transporte aéreo regular. Os autores afirmam também que, na primeira metade da década de 2000, as empresas aéreas regionais transportaram uma parcela muito restrita dos passageiros domésticos totais (volumes entre 2,5\% e 4,5\%), sem contar que a situação financeira era extremamente instável, como pode ser visto na quantidade de encerramento de operações de empresas que se mantiveram durante muito tempo equilibradas, como a AirMinas, Penta, Rico e TAF. Os indicadores de lucratividade, por sua vez, não deixaram de se mostrar menores até mesmo para a Trip Linhas Aéreas, que era a líder da aviação regional em 2011.23

No que tange à instabilidade das empresas aéreas regionais, pode-se identificar o processo de incorporação desse tipo de empresa por outras como um sintoma da fragilidade do setor. A compra da Pantanal pela TAM Linhas Aéreas, em 2009, ilustra bem esse processo. Essa aquisição ganha especial relevância se for levado em consideração que a TAM já havia realizado pelo menos cinco movimentos progressivos de abandono da exploração do negócio da aviação regional por conta própria. Desperta atenção, também, por

19 A metáfora torna-se, no mínimo, curiosa se forem levados em consideração os dados da economia chinesa em 2015.

20 Cf. OLIVEIRA, Alessandro; SALGADO, Lúcia Helena. Popularização do transporte aéreo no Brasil: onde falta avançar nas políticas públicas? In: SILVA, Leandro Novais (Org.). Regulação e concorrência no setor aéreo no Brasil: alternativas possíveis. São Paulo: Singular, 2014. p. 298.

21 OLIVEIRA, Alessandro; SALGADO, Lúcia Helena. Popularização do transporte aéreo no Brasil: onde falta avançar nas políticas públicas? In: SILVA, Leandro Novais (Org.). Regulação e concorrência no setor aéreo no Brasil: alternativas possíveis. São Paulo: Singular, 2014. p. 299.

22 ASSOCIAÇÃO BRASILEIRA DAS EMPRESAS AÉREAS. Aviação brasileira: Agenda 2020, Brasília: ABEAR, 2014. Disponível em: <http://www.abear.com.br/uploads/pdf/releases/agenda2020.pdf>. Acesso em: 2 set. 2015. p. 29-30.

23 BETTINI, Humberto Filipe; OLIVEIRA, Alessandro V. M. Transporte aéreo regional: entre economias de escala e custos de transação. Journal of Transport Literature, v. 5, n. 4, p. 171-187, Oct. 2011. Disponível em: <https://www.google.com.br/url?sa$=\mathrm{t} \& \mathrm{rct}=\mathrm{j} \& \mathrm{q}=\& \mathrm{esrc}=\mathrm{s} \&$ source $={ }_{\mathrm{web}} \& \mathrm{~cd}=1 \& \mathrm{cad}=\mathrm{rja} \& u a c t=8 \& \mathrm{ved}=0 \mathrm{CBwQFjAAahUKEwiW5e \_ klMDIAhWIth4KHeYVB0c}$ \&url $=\mathrm{http} \% 3 \mathrm{~A} \% 2 \mathrm{~F} \% 2 \mathrm{Fwww}$.pesquisaemtransportes.net.br $\% 2$ Frelit $\% 2$ Findex.php $\% 2 \mathrm{Frelit} \% 2 \mathrm{Farticle} \% 2 \mathrm{Fdownload} \% 2 \mathrm{Fjv} 5 \mathrm{n} 4 \mathrm{p}$ 10\%2F135\&usg=AFQjCNG1IqNxCI-1 hoekrUSxBNxUymmI8Q\&sig2=ZPwA68Bu_OzMku67dsOwyg\&bvm=bv.104819420,d. dmo>. Acesso em: 1 set. 2015. p. 174. 
ter sido a primeira vez que uma empresa aérea de porte nacional voltou a ser proprietária de uma de natureza regional. ${ }^{24}$

A preocupação concorrencial com esse tipo de comportamento é informada por Frederico Turolla, Maria Fernanda Lima e Thelma Ohira, ao sustentar que apesar da alimentação das empresas regionais interessar às principais, o fato de estas serem potenciais concorrentes pode instigá-las a assumirem comportamentos de predação do tipo bit-and-run. ${ }^{25}$

Uma possibilidade levantada por Humberto Bettini e Alessandro Oliveira para justificar esse movimento foi fundada na necessidade de aquisição de novos slots no aeroporto já congestionado de Congonhas. Entretanto, o fato de a TAM ter mantido a unidade de negócios Pantanal e que até mesmo a sua frota seria renovada e expandida foi interpretado com estranheza pelos pesquisadores. De toda sorte, os autores consideraram esse movimento da TAM como um sinal mais forte da erosão do sistema bub-and-spoke $e^{26}$, aliado à interiorização do transporte aéreo e a necessidade de reforço da marca junto aos consumidores. ${ }^{27}$

Os desafios para as empresas são de diversas naturezas, como apontam vários estudos. Dentre eles, pode-se destacar o realizado por Frederico Turolla, Maria Fernanda Lima e Thelma Ohira, que identificam sete problemas mais relevantes: o preço dos combustíveis; a infraestrutura aeroportuária; os custos com pessoal; o regime de recolhimento da tributação; as taxas regulatórias; os seguros, os custos de capital e financiamento; e a manutenção das aeronaves. A partir desse momento, cada um desses gargalos será brevemente apresentado em conjunto com possíveis soluções são apresentadas por teóricos dessa temática.

O primeiro deles é o combustível, que é apontado na segunda posição entre os maiores custos para as empresas, pois representa de $20 \%$ a $40 \%$ dos custos diretos operacionais das companhias aéreas. Essa situação se agrava na aviação regional porque sua malha é planejada com um número menor de revendedores e distribuidores de combustível, o que leva a uma redução do espaço para este usufruir da concorrência decorrente dos diferentes ICMS existentes entre fornecedores localizados em estados diferentes. Além disso, os equipamentos utilizados na aviação regional normalmente consomem mais combustível.

Os principais tributos que incidem no preço do combustível de aviação são ICMS (estadual), PIS/ PASEP (federal) e COFINS (federal). Na tentativa de favorecer a aviação regional, os autores sugerem desoneração adicional ao PIS/PASEP e COFINS, no sentido de zerar o coeficiente de 0,7405. Além disso, se poderiam reduzir para zero os valores por metro cúbico da COFINS e do PIS/PASEP no caso da alíquota específica. Outra possibilidade apresentada é reduzir a alíquota do ICMS a 4\% para voos de linhas regionais ou para aeroportos que não sejam de capitais. ${ }^{28}$

24 BETTINI, Humberto Filipe; OLIVEIRA, Alessandro V. M. Transporte aéreo regional: entre economias de escala e custos de transação. Journal of Transport Literature, v. 5, n. 4, p. 171-187, Oct. 2011. Disponível em: <https://www.google.com.br/url?sa-

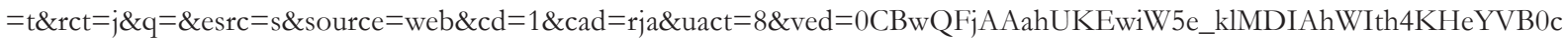
\&url $=$ http $\% 3 \mathrm{~A} \% 2 \mathrm{~F} \% 2 \mathrm{Fwww}$.pesquisaemtransportes.net.br $\% 2$ Frelit $\% 2$ Findex.php $\% 2$ Frelit $\% 2$ Farticle $\% 2 \mathrm{Fdownload} \% 2 \mathrm{Fjv} 5 \mathrm{n} 4 \mathrm{p}$ 10\%2F135\&usg=AFQjCNG1IqNxCI-1hoekrUSxBNxUymmI8Q\&sig2=ZPwA68Bu_OzMku67dsOwyg\&bvm=bv.104819420,d. dmo>. Acesso em: 1 set. 2015. p. 176.

25 TUROLLA, Frederico Araujo; LIMA, Maria Fernanda Freire; OHIRA, Thelma Harumi. Políticas públicas para a melhoria da competitividade da aviação regional brasileira. Journal of Transport Literature, v. 5, n. 4, p. 188-231, Oct. 2011. Disponível em: <http:// www.pesquisaemtransportes.net.br/relit/index.php/relit/article/view/jv5n4p11/pdf_57>. Acesso em: 1 set. 2015 . p. 204.

26 O sistema centro-raio (bub-and-spoke system) se fundamenta na existência de um aeroporto bem localizado e com importante ponto de geração de tráfego, conectado aos demais aeroportos, que concentram os voos e distribuem as ligações para aeroportos menores.

27 BETTINI, Humberto Filipe; OLIVEIRA, Alessandro V. M. Transporte aéreo regional: entre economias de escala e custos de transação. Journal of Transport Literature, v. 5, n. 4, p. 171-187, Oct. 2011. Disponível em: <https://www.google.com.br/url?sa-

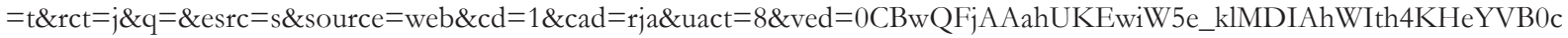
\&url=http $\% 3 \mathrm{~A} \% 2 \mathrm{~F} \% 2 \mathrm{Fwww}$.pesquisaemtransportes.net.br $\% 2$ Frelit $\% 2$ Findex.php $\% 2$ Frelit $\% 2$ Farticle $\% 2 \mathrm{Fdownload} \% 2 \mathrm{Fjv} 5 \mathrm{n} 4 \mathrm{p}$ 10\%2F135\&usg=AFQjCNG1IqNxCI-1hoekrUSxBNxUymmI8Q\&sig2=ZPwA68Bu_OzMku67dsOwyg\&bvm=bv.104819420,d. dmo>. Acesso em: 1 set. 2015. p. 174.

28 TUROLLA, Frederico Araujo; LIMA, Maria Fernanda Freire; OHIRA, Thelma Harumi. Políticas públicas para a melhoria da competitividade da aviação regional brasileira. Journal of Transport Literature, v. 5, n. 4, p. 188-231, Oct. 2011. Disponível em: <http:// 
O segundo gargalo para a aviação regional identificado pelos autores é a infraestrutura aeroportuária, que também é preocupação de Marcos Demant. Ele argumenta no sentido de que se trata de uma barreira à entrada de empresas regionais e constrói a hipótese de que cidades com melhores infraestrutura tendem a apresentar maior tráfego. ${ }^{29} \mathrm{O}$ autor identifica que o estrangulamento da infraestrutura também impede o desenvolvimento da aviação regional e que se faz necessária uma política pública voltada à solução desse problema. Carlos Ragazzo critica o modelo centralizado da INFRAERO e sugere que haja mais concessões para a iniciativa privada ou mesmo parcerias com os estados e municípios. ${ }^{30}$

Frederico Turolla, Maria Fernanda Lima e Thelma Ohira avaliam que a legislação trabalhista é um custo que tem impacto diferente de acordo com o tamanho da empresa. Além disso, existe um padrão que se repete na referida indústria, que é o fato de as empresas regionais terem baixo incentivo para qualificar a tripulação técnica, pois estes, após formados, tendem a ir trabalhar nas empresas principais. Os autores citam, também, o suposto alto custo das diárias, sugerindo que haja uma diminuição de custos com o pessoal. ${ }^{31}$ Apesar de reconhecer a importância dos argumentos dos autores, acredita-se que esse tipo de argumento pode colocar em piores condições o trabalhador, já submetido a atividade que, devido a seu alto risco, é extremamente estressante; isso pode significar, em última instância, um retrocesso dos direitos sociais. $^{32}$

Os referidos autores sugerem, também, a criação de um sistema análogo ao SIMPLES (regime especial unificado de arrecadação de tributos e contribuições devidos pelas microempresas e empresas de pequeno porte, instituído pela Lei Complementar n ${ }^{\circ} 123$, de 2006). Eles sugerem que as empresas de aviação regional paguem o conjunto de tributos por intermédio de uma alíquota única de 4,5\% sobre o faturamento. ${ }^{33}$

Embora inexistam grandes ações de simplificação tributária, existem algumas medidas de incentivo, como a estabelecida pela Lei $\mathrm{n}^{\circ}$ 11.488, de 15 de junho de 2007, que cria o Regime Especial de Incentivos para o Desenvolvimento da Infraestrutura - REIDI, regulamentada pelo Decreto no 6.144 de 3 de julho de 2007. No que tangencia os projetos de infraestrutura em aviação, referida legislação foi regulamentada pela Portaria SAC n ${ }^{\circ}$ 18, de 23 de janeiro de 2012, que disciplina os requisitos mínimos para a aprovação de projetos de investimento na área de infraestrutura, considerados prioritários no setor de Aviação Civil, bem como pela Portaria SAC no 93, de 6 de julho de 2012, que estabelece o procedimento de aprovação dos projetos de implantação de obras de infraestrutura nos sistemas aeroportuários e de proteção ao voo, instalados em aeródromos públicos, para fins de habilitação ao REIDE.

www.pesquisaemtransportes.net.br/relit/index.php/relit/article/view/jv5n4p11/pdf_57>. Acesso em: 1 set. 2015 . p. 204.

29 Cf. DEMANT, Marcos Alexandre. Infraestrutura aeroportuária e o desenvolvimento do tráfego aéreo regional no Brasil. Journal of Transport Literature, v. 5, n. 1, p. 124-160, Jan. 2011. Disponível em: <https:/ /www.google.com.br/url?sa=t\&rct=j\&q=\&e $\mathrm{src}=\mathrm{s} \&$ source $=$ web\&cd $=1 \& \mathrm{cad}=$ rja\&uact $=8 \& \mathrm{ved}=0 \mathrm{CBwQFjAAahUKEwiCkceZn8DIAhWIVh} 4 \mathrm{KHa} 1 \mathrm{XAQs} \& \mathrm{rrl}=\mathrm{http} \% 3 \mathrm{~A} \%$ $2 \mathrm{~F} \% 2 \mathrm{Fwww}$.pesquisaemtransportes.net.br $\% 2 \mathrm{Frelit} \% 2 \mathrm{Findex} \cdot \mathrm{php} \% 2 \mathrm{Frelit} \% 2 \mathrm{Farticle} \% 2 \mathrm{Fdownload} \% 2 \mathrm{Fj} v 5 \mathrm{n} 1 \mathrm{p} 7 \% 2 \mathrm{~F} 83 \& \mathrm{usg}=\mathrm{AF}$ QjCNEodE0Mg9BV9erZMWira_tijZVSjw\&sig2=FuuWkoz1LyJhSso3xW4bOw\&bvm=bv.104819420,d.dmo>. Acesso em: 1 set. 2015. p. 154.

30 RAGAZZO, Carlos Emmanuel Joppert; ALBUQUERQUE, Cristiane Landerdahl de. Concorrência e universalização: incentivos regulatórios à aviação regional. In: SILVA, Leandro Novais (Org.). Regulação e concorrência no setor aéreo no Brasil: alternativas possíveis. São Paulo: Singular, 2014. p. 249.

31 TUROLLA, Frederico Araujo; LIMA, Maria Fernanda Freire; OHIRA, Thelma Harumi. Políticas públicas para a melhoria da competitividade da aviação regional brasileira. Journal of Transport Literature, v. 5, n. 4, p. 188-231, Oct. 2011. Disponível em: < http:// www.pesquisaemtransportes.net.br/relit/index.php/relit/article/view/jv5n4p11/pdf_57>. Acesso em: 1 set. 2015 . p. 204.

32 Esse ponto ganha destaque com as últimas manifestações contra as demissões em massa anunciadas pela Air France. De acordo com a mesma 300 pilotos, 900 comissários e 1,7 mil funcionários de apoio em terra poderão ter seus cargos cortados. Essa decisão decorreu do fato dos sindicatos representantes da tripulação não aceitarem aumentar a quantidade de hora de trabalho sem a devida remuneração. ROSEMAIN, Mathieu. Grevistas agridem executivos da Air France. Valor Econômico, São Paulo, 6 out. 2015. Disponível em: <http://www.valor.com.br/empresas/4257122/grevistas-agridem-executivos-da-air-france>. Acesso em: 8 out. 2015.

33 TUROLLA, Frederico Araujo; LIMA, Maria Fernanda Freire; OHIRA, Thelma Harumi. Políticas públicas para a melhoria da competitividade da aviação regional brasileira. Journal of Transport Literature, v. 5, n. 4, p. 188-231, Oct. 2011. Disponível em: <http:// www.pesquisaemtransportes.net.br/relit/index.php/relit/article/view/jv5n4p11/pdf_57>. Acesso em: 1 set. 2015. p. 218 . p. 204. 
Outro ponto importante é a necessidade de redução ou isenção de taxas aeroportuárias em aeroportos regionais. De acordo com Carlos Ragazzo, até mesmo reduções e isenções de impostos aplicados às tarifas de passagens aéreas poderiam ser um possível incentivo a ser feito pelo Estado. Trata-se de uma estratégia adotada pelos EUA para os aeroportos rurais. Já a Austrália congelou as tarifas do aeroporto de Sidney para empresas regionais. ${ }^{34}$

Consta da agenda regulatória da ANAC, instituída pela Portaria no 160 de 26 de janeiro de 2016, uma tímida mudança na forma de cobrança de taxas em aeroportos regionais, a partir na sinalização da descentralização da regulação tarifária aplicável aos aeroportos conveniados nos Estados e Municípios. A agência objetiva com tal meta propor normatização que estabeleça regime tarifário diferenciado aplicável aos aeroportos administrados, por meio de convênio, por estados e municípios. O objetivo é permitir que administradores/reguladores locais (estados e municípios) busquem formas mais eficientes de remuneração das infraestruturas delegadas.

Outro problema comum é o manejo de riscos da atividade em aeroportos regionais e a adoção de medidas de prevenção e mitigação, em especial dos seguros. Costuma-se considerar os seguros do setor aeronáutico e do setor de energia nuclear como uma das carteiras de seguro mais desequilibradas, tanto que os custos normalmente não são suportados apenas por uma única empresa de seguros. Uma possível solução apresentada é, além da possibilidade de resseguro, diminuir o valor dos prêmios de seguro aeronáutico. ${ }^{35}$

A respeito dos custos de capital e financiamentos, destaca-se que existe uma grande assimetria de informações na concessão de financiamentos e a defesa daqueles que financiam vêm como exigências de garantias. Alcançar as referidas garantias pode impedir que empresas com boas condições e disposição para realizar o repagamento dos financiamentos possam ter acesso aos mesmos. Dessa maneira, a dificuldade em ter acesso aos recursos do BNDES é um exemplo de motivo para elevar o custo de capital das companhias. Segundo os autores, essa situação acaba inibindo a competição na aviação regional brasileira. ${ }^{36}$

O último custo apresentado por Frederico Turolla, Maria Fernanda Lima e Thelma Ohira é o de manutenção das aeronaves, que estão relacionados aos elevados custos na importação de peças para reposição. ${ }^{37}$ Após visitar os principais custos apontados por alguns autores da economia dos transportes para a aviação regional, importa, nesse momento, apresentar o Programa de Aviação Regional e suas propostas para investimento nesse mercado específico.

\section{O PROGRAMA NACIONAL DE AVIAÇÃo REGIONAL: ENTRE A URGÊNCIA E A FICÇão}

No intuito de realizar investimentos no setor de infraestrutura, em agosto de 2012, o Governo Federal lançou o Programa de Investimento em Logística: Rodovias e Ferrovias. Ainda no mesmo ano, foi apresentado, também, um conjunto de políticas para o setor portuário e aeroportuário. Para esse último, três objetivos foram estabelecidos como principais: melhorar a qualidade dos serviços e a infraestrutura para os

34 RAGAZZO, Carlos Emmanuel Joppert; ALBUQUERQUE, Cristiane Landerdahl de. Concorrência e universalização: incentivos regulatórios à aviação regional. In: SILVA, Leandro Novais (Org.). Regulação e Concorrência no Setor Aéreo no Brasil: Alternativas Possíveis. São Paulo: Singular, 2014. p. 251.

35 TUROLLA, Frederico Araujo; LIMA, Maria Fernanda Freire; OHIRA, Thelma Harumi. Políticas públicas para a melhoria da competitividade da aviação regional brasileira. Journal of Transport Literature, v. 5, n. 4, p. 188-231, Oct. 2011. Disponível em: < http:// www.pesquisaemtransportes.net.br/relit/index.php/relit/article/view/jv5n4p11/pdf_57>. Acesso em: 1 set. 2015 . p. 218.

36 TUROLLA, Frederico Araujo; LIMA, Maria Fernanda Freire; OHIRA, Thelma Harumi. Políticas públicas para a melhoria da competitividade da aviação regional brasileira. Journal of Transport Literature, v. 5, n. 4, p. 188-231, Oct. 2011. Disponível em: <http:// www.pesquisaemtransportes.net.br/relit/index.php/relit/article/view/jv5n4p11/pdf_57>. Acesso em: 1 set. 2015 . p. 204.

37 TUROLLA, Frederico Araujo; LIMA, Maria Fernanda Freire; OHIRA, Thelma Harumi. Políticas públicas para a melhoria da competitividade da aviação regional brasileira. Journal of Transport Literature, v. 5, n. 4, p. 188-231, Oct. 2011. p. 204. Disponível em: <http://www.pesquisaemtransportes.net.br/relit/index.php/relit/article/view/jv5n4p11/pdf_57>. Acesso em: 1 set. 2015 . p. 228. 
usuários, ampliar a oferta de transporte aéreo à população brasileira e reconstruir a rede de aviação regional. No que tange à infraestrutura aeroportuária, o programa foi dividido em três etapas, a primeira foi a concessão dos aeroportos de Galeão (RJ) e Confins (MG); ${ }^{38}$ a segunda é o investimento de R 7,3 bilhões em 270 aeroportos regionais; e a terceira é a indução na exploração comercial de aeroportos dedicados à aviação geral. ${ }^{39}$

A meta governamental com tal investimento na aviação regional é que $96 \%$ da população esteja a menos de $100 \mathrm{~km}$ de distância de um aeroporto apto a receber voos regulares. Os valores desse investimento viriam do Fundo Nacional de Aviação Civil, criado pela Lei no 12.462, de 4 de agosto de 2011, alterado pela Lei $n^{\circ}$ 12.648, de 17 de maio de 2012 e regulamentado pelo Decreto no 8.024, de 4 de junho de 2013. Em síntese, trata-se de fundo constituído por recursos decorrentes da receita de outorga recolhida pelos concessionários de aeroportos, do Adicional sobre Tarifa Aeroportuária (ATAERO) ${ }^{40}$, de parcela da Tarifa de Embarque Internacional (TEI) e de Recursos Próprios Financeiros (Rendimento de Aplicação Financeira). O Fundo Nacional de Aviação Civil tem como ações prioritárias a manutenção e aprimoramento da infraestrutura aeronáutica e aeroportuária pública. ${ }^{41}$

Em consonância com essa tentativa de fazer crescer o setor, o Governo Federal criou o projeto inicial do Programa de Desenvolvimento da Aviação Regional, por meio da Medida Provisória no 652, de 25 de julho de 2014. Os objetivos do programa eram: aumentar o acesso da população brasileira ao sistema aéreo de transporte; integrar comunidades isoladas à rede nacional de aviação civil; facilitar o acesso a regiões com potencial turístico; aumentar o número de municípios e rotas atendidos por transporte aéreo regular de passageiros; e aumentar o número de frequências das rotas regionais operadas regularmente. Para tanto, a União iria conceder subvenções para arcar com os custos das tarifas aeroportuárias e de navegação aérea para aeroportos regionais; pagar os valores do adicional de tarifa aeroportuária; e custear parte do montante gasto em voos nas rotas regionais. ${ }^{42}$

Acontece que a referida medida provisória teve o prazo de vigência encerrado no dia 24 de novembro de 2014, sem a respectiva conversão em lei. Apesar disso a comissão mista da Medida Provisória nº 656, de 7 de outubro de 2014, que tinha como relator o senador Romero Jucá (PMDB-RR), incorporou na íntegra o texto aprovado para a Medida Provisória no 652, após as alterações propostas pelo senador Flexa Ribeiro (PSDB-PA). ${ }^{43}$ Comparando-se o texto proposto inicialmente pelo governo com a versão final, incorporada pela Medida Provisória no 656, que foi convertida na Lei 13.097, de 19 de janeiro de 2015, destacam-se quatro relevantes alterações.

A primeira é a definição mais específica de aeroporto regional, que seria aquele com movimentação anual inferior a 800.000 passageiros na Amazônia Legal e 600.000 nas demais regiões. A segunda é a autorização

38 De toda forma, vale ressaltar que o Governo Federal anunciou em junho de 2015 a concessão dos aeroportos Pinto Martins, Fortaleza (CE); Luiz Eduardo Magalhães, Salvador (BA); Hercílio Luz, Florianópolis (SC); e Salgado Filho, Porto Alegre (RS). BRASIL. Secretaria de Aviação Civil. Governo anuncia quatro novas concessões de aeroportos. Disponível em: < http://www.aviacao.gov.br/ noticias/2015/06/governo-anuncia-quatro-novas-concessoes-de-aeroportos>. Acesso em: 20 set. 2015.

39 PROGRAMA DE INVESTIMENTO EM LOGÍSTICA. Aeroportos. Disponível em: <http://www.logisticabrasil.gov.br/ aeroportos1>. Acesso em: 19 set. 2015.

40 Abaixo discute-se a possível extinção da ATAERO.

41 A arrecadação do Fundo Nacional de Aviação Civil em 2014 foi de“ $\mathrm{R} \$ 3.225,4$ milhões, sendo R \$ 1.459,9 milhões provenientes da receita de outorga recolhida pelos concessionários dos aeroportos de Campinas, Guarulhos, Confins, Galeão, Natal e Brasília; R\$ 1.118,7 milhões oriundos do Adicional sobre Tarifa Aeroportuária (ATAERO); R \$ 395,1 milhões da parcela da Tarifa de Embarque Internacional (TEI) e R \$251,7 milhões de Recursos Próprios Financeiros (Rendimento de Aplicação Financeira). A partir de 2016, o caixa do FNAC vai dar um salto com as concessões dos aeroportos de Porto Alegre, Florianópolis, Salvador e Fortaleza". (BRASIL. Secretaria da Aviação Civil. Fundo Nacional de Aviação Civil. Publicado em 4 jun. 2013. Disponível em: <http:/ /www.aviacao.gov. $\mathrm{br} /$ acesso-a-informacao/acoes-e-programas/fundo-nacional-de-aviacao-civil>. Acesso em: 19 de set. 2015.)

42 Cf. BRASIL. Exposição de motivos da Medida Provisória no 652, de 25 de julho de 2014. Disponível em: <http://www.planalto.gov.br/ ccivil_03/_Ato2011-2014/2014/Exm/ExmMPv652-14.doc>. Acesso em: 1 set. 2015.

43 BRASIL. Senado Federal. Aprovado Programa de Desenvolvimento Regional. Brasília, 17 dez. 2014. Disponível em: <http://www12.senado. gov.br/noticias/materias/2014/12/18/aprovado-programa-de-desenvolvimento-da-aviacao-regional/tablet>. Acesso em: 19 set. 2015. 
para a União conceder subvenção de no máximo 30\% do Fundo Nacional de Aviação Civil. A terceira é o limite de custear até 60 passageiros transportados em voos diretos nas rotas regionais em função do aeroporto atendido, quantidade de quilômetros voados e do consumo de combustível, podendo ser subvencionados até 50\% dos assentos disponíveis por aeronave, exceto na Amazônia Legal, na qual não se aplica esse limite. A quarta e última é que esse programa tem duração de cinco anos, mas pode ser renovável por mais cinco, com o necessário embasamento técnico.

Frisa-se que a imprensa noticiou esse processo de incorporação do conteúdo da Medida Provisória $n^{\circ}$ 652 na de $n^{\circ} 656$ como uma articulação de congressistas do PMDB para a liberação da construção de aeroportos privados para voos comerciais. Sob a liderança do Deputado Federal Eduardo Cunha (PMDB-RJ), a intenção era viabilizar o Novo Aeroporto de São Paulo (Nasp), no município de Caieras/SP, idealizado pela Andrade Gutierrez e pela Camargo Corrêa. ${ }^{44}$ Entretanto, a Presidenta vetou o então art. 63-B, que versava sobre a possibilidade de outorga e aeródromos civis públicos sob regime de permissão. As razões apresentadas foram duas: i. os dispositivos criariam um desarranjo regulatório e ii. as medidas poderiam prejudicar o programa de incremento da aviação regional, em curso por meio do Programa de Aceleração do Crescimento - PAC. ${ }^{45}$

A “desnaturação do modelo setorial de exploração de infraestrutura aeroportuária” e o "desarranjo regulatório no setor" podem ser interpretados atrelados à valorização do modelo de concessão de aeródromos a iniciativa privada, com preservação das bases econômicas e financeiras das concessões aeroportos de Guarulhos, Galeão, Confins, Viracopos e Brasília. De toda sorte, o Programa de Desenvolvimento da Aviação Regional foi recebido com muito entusiasmo pelas empresas de aviação civil. Por exemplo, antes mesmo de sua aprovação, a Azul havia anunciado a ampliação da frota de aviões da Embraer. ${ }^{46}$ Em novembro de 2014, o presidente da Gol disse que o plano era positivo e abria oportunidades para a empresa. ${ }^{47}$

Apesar disso, o ano de 2015 foi marcado por muitas inseguranças quanto à efetividade do referido programa. Isso porque no final de 2014, o então Ministro Moreira Franco (PMDB/RJ) afirmava que os investimentos iriam ocorrer logo no início do ano seguinte e o que não aconteceu. ${ }^{48} \mathrm{Na}$ realidade, foi deflagrada uma intensa crise política e econômica no país, que, atrelada ao ajuste fiscal proposto pelo governo, freou os investimentos públicos em vários setores. Além disso, a própria mudança de ministro, Eliseu Padilha (PMDB/RS) no lugar de Moreira Franco (PMDB/RJ), foi vista por alguns como um ponto negativo na sequência das políticas púbicas para o setor.

No início de maio de 2015, em audiência pública no Senado para discutir o assunto, vários senadores afirmaram que o Programa de Aviação Regional era uma "peça de ficção". O ministro Eliseu Padilha, por sua vez, apontou que os recursos do Fundo Nacional de Aviação Civil não são atingidos pelos cortes orçamentários, de maneira que haverá continuidade nos investimentos públicos no setor. Na ocasião, ele aproveitou para informar que dos 270 aeroportos incluídos no programa 55 aguardam o licenciamento ambiental. ${ }^{49}$

44 LIMA, Vandson. Benefícios à aviação regional são retomados na MP 656. Valor Econômico, Brasília, 11 dez. 2014. Disponível em: <http://www8.valorinternational.com.br/politica/3812464/beneficios-aviacao-regional-sao-retomados-na-mp-656>. Acesso em: 20 set. 2015.

45 BRASIL. Mensagem de veto da Lei no 13.097, de 19 de janeiro de 2015. Disponível em: <http://www.planalto.gov.br/ccivil_03/_ato2015-2018/2015/Msg/VEP-21.htm>. Acesso em: 1 set. 2015.

46 OLIVEIRA, João José; MARCHESINI, Lucas. Azul ampliará frota com apoio à aviação regional. Valor Econômico, São Paulo, 30 jul. 2014. Disponível em: <http://www.valor.com.br/brasil/3631532/azul-ampliara-frota-com-apoio-aviacao-regional>. Acesso em: 21 set. 2015.

47 OLIVEIRA, João José. 'Plano regional é oportunidade para a Gol', diz presidente da empresa. Valor Econômico, São Paulo, 12 nov. 2014. Disponível em: <http://www.valor.com.br/empresas/3776300/plano-regional-e-oportunidade-para-gol-diz-presidenteda-empresa>. Acesso em: 19 set. 2015.

48 BRASIL. Secretaria da Aviação Civil. Aviação regional terá subsídio a partir de 2015. Brasília, 29 jul. 2014. Disponível em: <http:// www.aviacao.gov.br/noticias/2014/07/aviacao-regional-tera-subsidio-a-partir-de-2015 >. Acesso em: 21 set. 2015.

49 BAPTISTA, Rodrigo. Programa de aviação regional ainda é 'peça de fição', dižem senadores em audiência. Brasília: Senado Federal, 6 maio 2015. Disponível em: <http://www12.senado.leg.br/noticias/materias/2015/05/06/programa-de-aviacao-regional-ainda-e-pecade-ficcao-dizem-senadores-em-audiencia>. Acesso em: 21 set. 2015. 
A problemática do licenciamento ambiental só foi solucionada com a Resolução do Conselho Nacional do Meio Ambiente (CONAMA) de no 470, de 27 de agosto de 2015. Ela dispõe sobre a regularização ambiental dos aeroportos regionais que já estão em operação; o licenciamento ambiental para ampliação de aeroportos regionais; e o licenciamento ambiental para novos aeroportos regionais. Para tanto, ela reproduziu o critério legal para definir se um aeroporto é regional, qual seja, ter movimentação anual inferior a 800.000 passageiros por ano, quando localizado na Amazônia Legal, e menos de 600.000 passageiros por ano nas demais regiões. A intenção dessa resolução é padronizar os procedimentos e simplificá-los com o objetivo de diminuir a demora da análise do licenciamento de 2 anos para 6 meses. Essa preocupação ganha especial relevância se for levado em consideração que apenas $8 \%$ dos 270 aeroportos contemplados no programa de aviação regional têm licenciamento regularizado. ${ }^{50}$

De toda sorte, a demora para dar seguimento às políticas públicas de desenvolvimento da aviação regional, decorrente da fragilidade política e econômica do país, gerou uma inquestionável insegurança a algumas empresas do setor. A Azul, por exemplo, comprou 125 aviões em 2014 e planejava comprar mais 20 no ano de 2015, mas desistiu pela demora na efetividade do referido programa, especialmente no que tange aos subsídios, que aguardam regulamentação. ${ }^{51}$

Além dessa questão de infraestrutura e de subsídios, outro ponto controvertido reiteradamente apresentado como solução para ampliar os investimentos no setor é a flexibilização da quantidade de capital estrangeiro em empresas aéreas brasileiras. Nesse contexto, a comissão de especialistas que foi instaurada para apresentar o anteprojeto de reforma do Código Brasileiro de Aeronáutica debate, dentre outras reformas, a possibilidade alterar o art. 181 do referido documento legal, que dispõe sobre as condições da concessão para serviços aéreos públicos. ${ }^{52}$

A redação original do dispositivo determinava que os serviços aéreos públicos somente poderiam ser concedidos ou autorizados à pessoa jurídica brasileira, com sede no Brasil; com, pelo menos, quatro quintos do capital com direito a voto pertencentes a brasileiros; e com direção confiada exclusivamente a brasileiros. Além disso, de acordo com o $\int 4^{\circ}$, "Desde que a soma final de ações em poder de estrangeiros não ultrapasse o limite de $1 / 5$ (um quinto) do capital, poderão as pessoas estrangeiras, naturais ou jurídicas, adquirir ações do aumento de capital".

Paralelamente às discussões de reformar do Código Brasileiro de Aeronáutica, ocorridas no âmbito legislativo, foi editada a já mencionada Medida Provisória no 714 , de $1^{\circ}$ de março de 2016, que modificou a redação do art. 181 do referido Código.

A nova redação flexibiliza a exigência de composição de capital das concessionárias ou autorizatárias, exigindo que "pelo menos 51\% (cinquenta e um por cento) do capital com direito a voto pertencente a bra-

50 RITTNER, Daniel. Resolução acelera licença ambiental para aeroportos. Valor Econômico, Brasília, 14 ago. 2015. Disponível em: <http://www.valor.com.br/brasil/4179582/resolucao-acelera-licenca-ambiental-para-aeroportos>. Acesso em: 26 set. 2015.

51 GALLO, Ricardo. Azul e Gol esperam plano de aviação regional, enquanto TAM já cria voos. Folha de São Paulo, São Paulo, 31 ago. 2015. Disponível em: <http://www1.folha.uol.com.br/mercado/2015/08/1675651-azul-e-gol-esperam-plano-de-aviacao-regional-enquanto-tam-ja-cria-voos.shtml>. Acessado em: 26 set. 2015.

52 A referida comissão é presidida por Georges de Moura Ferreira, professor de Direito Aeronáutico e aviador, e tem como relatora a Professora de Direito Internacional e Doutora em Direito Espacial Maria Helena Fonseca. Ela foi instaurada no dia 16 de novembro de 2015 e teve como prazo final o dia 12 de dezembro de 2015. Dentre as principais discussões desenvolvidas pelas Comissão, destaca-se reunião ocorrida em 14 de setembro de 2015, na qual Fernando Soares Vieira, representante da Comissão de Valores Mobiliários, discorreu sobre os arranjos societários que, na prática, possibilitam capitalização estrangeira maior que o limite previsto em lei. De acordo com ele, desde 2001, a proporção entre ações ordinárias e preferenciais nas companhias de capital aberto é de $50 \%$ para cada espécie. Entretanto, para conseguir maiores investimentos estrangeiros, as empresas passaram a garantir vantagens extras às novas emissões de papéis preferenciais. Fernando Soares Vieira afirmou que esse tipo de organização societária pode dificultar a fiscalização da CVM, pois não se aplica à Lei de Sociedades Anônimas. Ele citou como exemplo a TAM, que, depois que fundiu com a LAN, obteve registro na CVM como empresa estrangeira. Naquele contexto realizou-se propostas de duas possíveis soluções para redação do art. 181 do Código de Aeronáutica: uma de limitar a 49\% das ações para estrangeiros e outra de possibilitar empresas aéreas com $100 \%$ do capital estrangeiro. 
sileiros, prevalecendo essa limitação nos eventuais aumentos do capital social". O limite poderá ser diminuído nos termos do novo $\int 5^{\circ}$ do art. 181, que dispõe que, desde que "observada a reciprocidade, os acordos sobre serviços aéreos celebrados pela República Federativa do Brasil poderão prever limite de capital social votante em poder de brasileiros inferior ao mínimo estabelecido no inciso II do caput, com validade apenas entre as partes contratantes". Foi igualmente excluída a exigência de que a direção das concessionárias ou autorizatárias seja confiada exclusivamente a brasileiros.

A limitação de capital estrangeiro permite maior capitalização das empresas brasileiras, sem perder de vista o desenvolvimento destas, que, em última instância consolidam o desenvolvimento e apropriação de inovações tecnológicas para o país, elemento central para a diminuição da dependência da economia do Brasil. As alterações previstas pela Medida Provisória nº 714, de $1^{\circ}$ de março de 2016 mantém referida limitação de capital estrangeiro, apesar de ter ampliado a sua margem de participação.

Além desse aspecto, outra medida que tem como objetivo desenvolver o setor foi apresentada por Daniel Alves da Cunha, representante do setor de regulação da ANAC, a possibilidade de flexibilização da regulamentação nos aeroportos. Em síntese, o que se propõe é que seja reduzida a burocracia visando à atração de empresas e novas linhas em aeroportos de menor movimento operacional, levando-se em consideração, também, o padrão de riscos de cada aeródromo. ${ }^{53}$

É preciso alinhar todas essas questões à operacionalização das outorgas aeroportuárias, cuja regulamentação é atualmente feita pela Portaria SAC nº 183, de 10 de setembro de 2014. O veto aos art. 123 e 124 não pode ser interpretado como absoluta vedação à realização de outorgas de aeroportos regionais. Destaca-se, por exemplo, a recente autorização para concessão do aeroporto de Comandatuba. O Estado da Bahia é delegatário desse aeródromo desde 2014 e com a autorização conferida pela Portaria no 9 de 22 de janeiro de 2016 da Secretaria de Aviação Civil poderá conceder a exploração do terminal à iniciativa privada.

A Secretaria de Aviação ${ }^{54}$ noticia que outros aeródromos já possuem processos a exploração à iniciativa privada sendo eles Amarais, Araras, Bragança Paulista, Guarujá, Itanhaém, Jundiaí e Ubatuba, no Estado de São Paulo, Caldas Novas (GO), Zona da Mata (MG) e Campos dos Goytacazes (RJ). A Secretaria indica ainda que mais seis localidades receberão a anuência para concessão entre elas: Barreiras, Caravelas e Teixeira de Freitas, na Bahia; Pouso Alegre e São Lourenço, em Minas Gerais; e Anápolis, em Goiás.

A existência desses projetos evidencia que apesar da crise e das restrições orçamentárias dela derivadas, há um cenário de possibilidade de desenvolvimento de projetos com a participação dos agentes privados. Por óbvio essa participação não supre a necessidade de realização de investimentos públicos, sobretudo nos casos em que a modelagem econômica dos projetos não evidencia taxa de atratividade suficiente para viabilizar a concessão dos aeródromos.

Nesse contexto, mesmo em meio as incertezas políticas e econômicas do país em 2015, cumpre ressaltar que o estado da Bahia e do Rio de Janeiro possuem planos avançados para impulsionar a aviação regional. Para tanto, o Governo baiano reduziu a alíquota do Imposto sobre Circulação de Mercadorias e Serviços (ICMS) sobre o querosene de aviação, em algumas situações, de 17\% a 7\%. Além disso, prevê-se a construção de um novo aeroporto em Vitória da Conquista com verbas federais e estaduais. No Rio de Janeiro, por sua vez, o ponto principal é construir o aeroporto do Vale do Aço, entre Volta Redonda e Piraí. ${ }^{55}$ Todavia o que se percebe é que, apesar dos esforços em sinalizar avanços nesse programa de investimento na aviação regional, existe uma substancial diminuição do ritmo de investimentos públicos, tal qual foi previsto e sina-

53 BRASIL. Senado Federal. Comissão discute aumento do capital estrangeiro em empresas aéreas. Brasília, 14 set. 2015. Disponível em: <http://www12.senado.leg.br/noticias/materias/2015/09/14/comissao-discute-aumento-do-capital-estrangeiro-em-empresasareas $>$. Acesso em: 20 set. 2015.

54 BRASIL. Secretaria de Aviação Civil. Aeroporto de Comandatuba é autorizado para concessão. Brasília, 25 jan. 2016 <http://www. aviacao.gov.br/noticias/2016/01/aeroporto-de-comandatuba-e-autorizado-para-concessao >. Acesso em: 14 mar. 2016.

55 ZAPAROLLI, Domingos. Bahia e Rio têm planos avançados. Valor Econômico, São Paulo, 10 ago. 2015. Disponível em: <http:// www8.valorinternational.com.br/empresas/4171878/bahia-e-rio-tem-planos-avancados >. Acessado em: 26 ago. 2015. 
lizado às empresas do setor no final de 2014.

Resta a esperança de que tal ritmo de investimentos se recupere, seja pela boa administração do Fundo Nacional de Aviação Civil e efetivação das subvenções econômicas para empresas participantes do Programa de Desenvolvimento da Aviação Regional, como previsto no art. 117 da Lei 13.097/2015, seja pelo desenvolvimento de mecanismo de outorga aeroportuária que possibilitem o ingresso de capital privado na gestão dos aeroportos regionais.

\section{Considerações finais}

O presente estudo permitiu concluir que a aviação regional tem relevância estratégica para o desenvolvimento econômico do Brasil. Isso decorre tanto do seu potencial de fomentar a concorrência no setor aéreo, quando da geração de empregos e promoção da sustentação das diversas economias regionais. Para tanto, o Estado brasileiro deve reformular o seu modelo de intervenção para reduzir a contração da aviação regional no país.

Conforme visto, várias medidas são propostas por teóricos da economia dos transportes e da regulação econômica. As mais relevantes e adequadas estão no campo do direito da concorrência, tributário, regulatório, econômico. Diante desse contexto, ganha especial relevância os desafios políticos, econômicos e jurídicos do Programa Nacional de Aviação Regional, lançado pelo Governo Federal em 2012.

Em síntese, constata-se que a aviação regional é um setor que tem ganhado uma especial atenção do Governo Federal nos últimos anos, o que se percebe ao fazer o levantamento das concessões de infraestrutura no setor. Apesar disso, a crise política e econômica do país impede uma saída mais consistente para o estrangulamento da aviação regional no país, colocando em xeque essa dimensão da economia, que central para o desenvolvimento do país.

\section{REFERÊNCIAS BIBLIOGRÁFICAS}

ASSOCIAÇÃO BRASILEIRA DAS EMPRESAS AÉREAS. Aviação brasileira: Agenda 2020, Brasília: ABEAR, 2014. p. 29-30. Disponível em: <http://www.abear.com.br/uploads/pdf/releases/agenda2020.pdf>. Acesso em: 2 set. 2015.

BAPTISTA, Rodrigo. Programa de aviação regional ainda é 'peça de fiçãao', dižem senadores em andiência. Brasilia: Senado Federal, 6 maio 2015. Disponível em: <http:/ /www12.senado.leg.br/noticias/materias/2015/05/06/ programa-de-aviacao-regional-ainda-e-peca-de-ficcao-dizem-senadores-em-audiencia $>$. Acesso em: 21 set. 2015.

BETTINI, Humberto Filipe; OLIVEIRA, Alessandro V. M. Transporte aéreo regional: entre economias de escala e custos de transação. Journal of Transport Literature, v. 5, n. 4, p. 171-187, Oct. 2011. Disponível em: $<$ https: $/ /$ www.google.com.br/url? sa $=\mathrm{t} \& \mathrm{rct}=\mathrm{j} \& \mathrm{q}=\&$ esrc $=\mathrm{s} \&$ source $=$ web\&cd $=1 \& \mathrm{cad}=\mathrm{rja} \& u a c t=8 \& v e d=$ 0CBwQFjAAahUKEwiW5e_klMDIAhWIth4KHeYVB0c\&url=http $\% 3 \mathrm{~A} \% 2 \mathrm{~F} \% 2 \mathrm{Fwww}$.pesquisaemtransportes.net.br $\% 2$ Frelit $\% 2$ Findex.php $\% 2$ Frelit $\% 2$ Farticle $\% 2$ Fdownload $\% 2 F j v 5 n 4 p 10 \% 2 F 135 \&$ usg=AFQj CNG1IqNxCI-1hoekrUSxBNxUymmI8Q\&sig2=ZPwA68Bu_OzMku67dsOwyg\&bvm=bv.104819420,d. dmo>. Acesso em: 1 set. 2015.

BETTINI, Humberto. Um retrato da aviação regional no Brasil. Journal of Transport Literature, v. 1, n. 1, p. 46-65, jan. 2007. Disponível em: < http://pesquisaemtransportes.net.br/relit/index.php/relit/article/ viewFile/11/70>. Acesso em: 1 set. 2015. 
BANCO NACIONAL DO DESENVOLVIMENTO. Aviação regional brasileira: modal aéreo IV. Informe infra-estrutura, n. 50, p. 7, 2002. Disponível em: <http://www.bndes.gov.br/SiteBNDES/export/sites/default/bndes_pt/Galerias/Arquivos/conhecimento/infra/Inf02-50.pdf>. Acesso em: 28 de ago. 2015.

BRASIL. Exposição de motivos da Medida Provisória nº 652, de 25 de julho de 2014. Disponível em: <http:/ /www. planalto.gov.br/ccivil_03/_Ato2011-2014/2014/Exm/ExmMPv652-14.doc>. Acesso em: 1 set. 2015.

BRASIL. Mensagem de veto da Lei no 13.097, de 19 de janeiro de 2015. Disponível em: <http://www.planalto.gov.br/ccivil_03/_ato2015-2018/2015/Msg/VEP-21.htm>. Acesso em: 1 set. 2015.

BRASIL. Secretaria da Aviação Civil. Aviação regional terá subsídio a partir de 2015. Brasília, 29 jul. 2014. Disponível em: <http://www.aviacao.gov.br/noticias/2014/07/aviacao-regional-tera-subsidio-a-partirde-2015>. Acesso em: 21 set. 2015.

BRASIL. Secretaria de Aviação Civil. Governo anuncia quatro novas concessões de aeroportos. Disponível em: <http://www.aviacao.gov.br/noticias/2015/06/governo-anuncia-quatro-novas-concessoes-de-aeroportos>. Acesso em: 20 set. 2015.

BRASIL. Secretaria de Aviação Civil. Aeroporto de Comandatuba é autorizado para concessão. Brasília, 25 jan. 2016 <http://www.aviacao.gov.br/noticias/2016/01/aeroporto-de-comandatuba-e-autorizado-para-concessao >. Acesso em: 14 mar. 2016.

BRASIL. Secretaria de Aviação Civil. Fundo Nacional de Aviação Civil. Publicado em 4 jun. 2013. Disponível em: $\quad<$ http://www.aviacao.gov.br/acesso-a-informacao/acoes-e-programas/fundo-nacional-de-aviacaocivil>. Acesso em: 19 de set. 2015.

BRASIL. Senado Federal. Aprovado Programa de Desenvolvimento Regional. Brasília, 17 dez. 2014. Disponível em: <http://www12.senado.gov.br/noticias/materias/2014/12/18/aprovado-programa-de-desenvolvimentoda-aviacao-regional/tablet>. Acesso em: 19 set. 2015.

BRASIL. Senado Federal. Comissão discute aumento do capital estrangeiro em empresas aéreas. Brasília, 14 set. 2015. Disponível em: < http://www12.senado.leg.br/noticias/materias/2015/09/14/comissao-discute-aumentodo-capital-estrangeiro-em-empresas-areas >. Acesso em: 20 set. 2015.

CAMAROTTO, Murillo; IZAGUIRRE, Mônica. Exploração comercial de aeroportos em regime de autorização é vetada. Valor Econômico, Brasília, 20 jan. 2015. Disponível em: <http://www.valor.com.br/brasil/3868062/exploracao-comercial-de-aeroportos-em-regime-de-autorizacao-e-vetada $>$. Acesso em: 20 set. 2015.

CAVES, Douglas; CHRISTENSEN, Laurits; TRETHEWAY, Michael. Economies of density versus economies of scale: why trunk and local airline costs differ? Rand Journal of Economics, v. 15, p. 471-489, 1984. Disponível em: <http://econpapers.repec.org/scripts/redir.pf?u=http\%3A\%2F\%2Flinks.jstor. org\%2Fsici\%3Fsici\%3D0741-6261\%2528198424\%252915\%253A4\%253C471\%253AEODVEO\%253E2. 0.CO\%253B2-S\%26origin\%3Drepec;h=repec:rje:randje:v:15:y:1984:i:winter:p:471-489>. Acesso em: 1 set. 2015.

DEMANT, Marcos Alexandre. Infraestrutura aeroportuária e o desenvolvimento do tráfego aéreo regional no Brasil. Journal of Transport Literature, v. 5, n. 1, p. 124-160, Jan. 2011. Disponível em: <https://www. google.com.br $/$ url? sa $=t \& r c t=j \& q=\& e s r c=s \&$ source $=$ web\&cd $=1 \& \mathrm{cad}=$ rja\&uact $=8 \& v e d=0 \mathrm{CBwQFjA}$ AahUKEwiCkceZn8DIAhWIVh4KHa1XAQs\&url=http $\% 3 \mathrm{~A} \% 2 \mathrm{~F} \% 2 \mathrm{Fwww}$.pesquisaemtransportes.net. br $\% 2$ Frelit $\% 2$ Findex.php $\% 2$ Frelit $\% 2$ Farticle $\% 2$ Fdownload $\% 2 F j v 5 n 1 p 7 \% 2 F 83 \& u s g=A F Q j C N E o d E 0 M$ g9BV9erZMWira_tijZVSjw\&sig2=FuuWkoz1LyJhSso3xW4bOw\&bvm=bv.104819420,d.dmo>. Acesso em: 1 set. 2015.

GALLO, Ricardo. Azul e Gol esperam plano de aviação regional, enquanto TAM já cria voos. Folha de São Paulo, São Paulo, 31 ago. 2015. Disponível em: <http://www1.folha.uol.com.br/mercado/2015/08/1675651- 
azul-e-gol-esperam-plano-de-aviacao-regional-enquanto-tam-ja-cria-voos.shtml>. Acessado em: 26 set. 2015.

INSTITUTO DE PESQUISA ECONÔMICA APLICADA. Mangabeira Unger toma posse como novo ministro da SAE. Brasília, 2 fev. 2015. Disponível em: <http://www.ipea.gov.br/portal/index.php?option=com_ content\&view $=$ article\&id $=24432>$. Acesso em: 2 set. 2015.

LEURQUIN, Pablo. Os impactos da regulação da aviação civil na integração inter-regional do Brasil. 2013. Dissertação (Mestrado) - Universidade Federal de Minas Gerais, Belo Horizonte, 2013.

LIMA, Vandson. Benefícios à aviação regional são retomados na MP 656. Valor Econômico, Brasília, 11 dez. 2014. Disponível em: < http://www8.valorinternational.com.br/politica/3812464/beneficios-aviacaoregional-sao-retomados-na-mp-656>. Acesso em: 20 set. 2015.

OLIVEIRA, Alessandro; SALGADO, Lúcia Helena. Constituição do marco regulatório para o mercado brasileiro de aviação regional. abr. 2008. Disponível em: <http://pantanalbraziltourism.com/fotos/arquivos/96.pdf>. Acesso em: 1 set. 2015.

OLIVEIRA, Alessandro; SALGADO, Lúcia Helena. Popularização do transporte aéreo no Brasil: onde falta avançar nas políticas públicas? In: SILVA, Leandro Novais (Org.). Regulação e concorrência no setor aéreo no Brasil: alternativas possíveis. São Paulo: Singular, 2014.

OLIVEIRA, João José. 'Plano regional é oportunidade para a Gol', diz presidente da empresa. Valor Econômico, São Paulo, 12 nov. 2014. Disponível em: <http://www.valor.com.br/empresas/3776300/plano-regionale-oportunidade-para-gol-diz-presidente-da-empresa>. Acesso em: 19 set. 2015.

OLIVEIRA, João José; MARCHESINI, Lucas. Azul ampliará frota com apoio à aviação regional. Valor Econômico, São Paulo, 30 jul. 2014. Disponível em: < http://www.valor.com.br/brasil/3631532/azul-ampliara-frota-com-apoio-aviacao-regional>. Acesso em: 21 set. 2015.

PINTO, Victor Carvalho. Dirigismo versus livre-iniciativa na regulação econômica do transporte aéreo. In: SILVA, Leandro Novais (Org.). Regulação e concorrência no setor aéreo no Brasil: alternativas possíveis. São Paulo: Singular, 2014.

PROGRAMA DE INVESTIMENTO EM LOGÍSTICA. Aeroportos. Disponível em: < http://www.logisticabrasil.gov.br/aeroportos1>. Acesso em: 19 set. 2015.

RÁDIO CÂMARA. Mangabeira Unger explica ações do governo para Amazônia e desenvolvimento regional. Câmara dos Deputados, Brasilia, 10 mar. 2009. (3'57'). Disponível em: <http://www2.camara.leg.br/ camaranoticias/radio/materias/ULTIMAS-NOTICIAS/364792-MANGABEIRA-UNGER-EXPLICA-A $\%$ C3\%87\%C3\%95ES-DO-GOVERNO-PARA-AMAZ $\%$ C3\%94NIA-E-DESENVOLVIMENTO-REGIONAL-(03'57\%22).html>. Acesso em: 2 de set. 2015.

RAGAZZO, Carlos Emmanuel Joppert; ALBUQUERQUE, Cristiane Landerdahl de. Concorrência e universalização: incentivos regulatórios à aviação regional. In: SILVA, Leandro Novais (Org.). Regulação e concorrência no setor aéreo no Brasil: alternativas possíveis. São Paulo: Singular, 2014.

RITTNER, Daniel. Resolução acelera licença ambiental para aeroportos. Valor Econômico, Brasília, 14 ago. 2015. Disponível em: < http://www.valor.com.br/brasil/4179582/resolucao-acelera-licenca-ambiental-para-aeroportos>. Acesso em: 26 set. 2015.

ROSEMAIN, Mathieu. Grevistas agridem executivos da Air France. Valor Econômico, São Paulo, 6 out. 2015. Disponível em: <http://www.valor.com.br/empresas/4257122/grevistas-agridem-executivos-da-air-france>. Acesso em: 8 out. 2015.

RUIZ, Ricardo Machado; HECKTHEUER, Leticiá Monteiro; BARROS, Gabriel Gil Barreto. Concentração e rivalidade em transporte aéreo de passageiros: reflexões a partir de casos recentes. In: SILVA, Le- 
andro Novais (Org.) Regulação e concorrência no setor aéreo no Brasil: alternativas possíveis. São Paulo: Singular, 2014. p. 201-230.

TUROLLA, Frederico Araujo; LIMA, Maria Fernanda Freire; OHIRA, Thelma Harumi. Políticas públicas para a melhoria da competitividade da aviação regional brasileira. Journal of Transport Literature, v. 5, n. 4, p. 188-231, Oct. 2011. Disponível em: <http://www.pesquisaemtransportes.net.br/relit/index.php/relit/ article/view/jv5n4p11/pdf_57>. Acesso em: 1 set. 2015.

ZAPAROLLI, Domingos. Bahia e Rio têm planos avançados. Valor Econômico, São Paulo, 10 ago. 2015. Disponível em: <http://www8.valorinternational.com.br/empresas/4171878/bahia-e-rio-tem-planos-avancados>. Acessado em: 26 ago. 2015. 


\title{
Homeschooling no Brasil: conformação deôntico-axiológica do sistema jurídico como plus à política pública de educação fundamental*
}

\author{
Homeschooling in Brazil: deontic-axiological \\ conformation of the legal system as a plus to \\ the basic education public policy.
}

\author{
Cláudio Márcio Bernardes** \\ Carlos Alberto Simões Tomaz***
}

\section{Resumo}

Tem-se entendido que o ensino domiciliar, movimento social mundialmente conhecido como Homeschooling, não é permitido no Brasil. Por outro lado, considerando-se o aumento no número de adeptos ao fenômeno, torna-se imperioso ampliar o debate para entendê-lo como parte de um importante processo de evolução social. Para cumprir esse propósito, será feita uma abordagem das regras e dos princípios, tomando-se por base a dimensão deontológica e axiológica das relações sociais em face da normatividade vigente. Para tanto, a abordagem ampara-se na lógica dedutiva com exame analítico e sistemático do contexto normativo e de aportes teoréticos a guisa de validar a conclusão no sentido de conformar o homeschooling com o sistema jurídico brasileiro.

Palavras-chave: ensino domiciliar; ensino escolarizado; princípios; regras.

* Recebido em 13/07/2016 Aprovado em 22/09/2016

** Possui graduação em Letras - Português e Inglês pela Fundação Educacional de Divinópolis (1995), especialização em Linguística pela Faculdade São Luís (SP), graduação em Direito pela Fundação Universidade de Itaúna (2005) e especialização pelo Centro Universitário Newton Paiva (2006), Mestrado em Direito pela Universidade de Itaúna (em andamento). Tem experiência na área de Letras, com ênfase em Língua Portuguesa e na área de Direito Público. E-mail: claudiombernardes@yahoo.com.br

*** Professor da Universidade de Itaúna. Email: carlos.simoes@trf1.jus.br

\section{Abstract}

Homeschooling, social movement known worldwide, is not legally permitted in Brazil. On the other hand, considering the increase in the number of followers to the phenomenon, it is imperative to broaden the debate to understand it as part of a important process of social evolution. To this purpose, it's necessary an approach of rules and principles, based on axiological and ethical dimension of social relations. Therefore, the approach seeks refuge in deductive logic with analytical and systematic examination of the regulatory framework and theoretic contributions to validate the homeschooling with the Brazilian legal system.

Keywords: homeschooling; schooled education; principle; rules.

\section{INTRODUÇÃo}

Sob a perspectiva do Estado Democrático de Direito, algumas questões, em um regime autoritário, não teriam ambiente favorável, possibilitam deba- 
tes jurídicos e suscitam teses das mais variadas fontes. Esse contexto se torna mais efetivo, dada a superação da dicotomia Direito público e Direito privado, como salienta Almeida, evidenciado pela nova summa divisio constitucionalizada no País, que enumera, de forma aberta e flexível, os direitos fundamentais individuais e os coletivos previstos no artigo $5^{\circ}$ da $\mathrm{CF} / 88^{1}$.

Sob esse aspecto, a Constituição da República de 1988 garantiu o direito fundamental à educação, como dever da família, da sociedade e do Estado, cuja responsabilidade é corroborada no artigo 205 da Constituição. Como previsto no referido artigo, a Constituição menciona direito à educação e elege os atores principais garantidores desse direito: a Família, o Estado e a Sociedade. Nesse ponto, cabe uma investigação acadêmica acerca das responsabilidades desses entes, em especial no que diz respeito ao dever da família de proporcionar o ensino dos seus filhos, sobremodo, se ele pode ou deve ser concorrente com a educação estatal.

O sistema jurídico brasileiro elegeu o Estado como o grande provedor da educação fundamental. Coube às famílias o papel de coadjuvante no que diz respeito ao ensino. As sanções específicas em caso de descumprimento dessa obrigação visam atingir pais negligentes, que não se preocupam com a instrução dos seus filhos, o que descortina a possibilidade de as famílias, que não se encaixem nessa configuração, proverem tais estudos no âmbito doméstico, de forma concorrente. Uma discussão analítica das regras e dos princípios pode lançar luz ao tema e, quem sabe, trazer alguma contribuição para uma mudança de paradigma quanto ao oferecimento exclusivo do ensino tradicional praticado no País. Para tanto, a lógica dedutiva será utilizada com base em exame analítico-sistemático da regência normativa que envolve a matéria e, se amparando em aportes da doutrina especializada, o presente artigo foi divido em cinco tópicos a guisa de viabilizar, com base nesse viés metodológico, o exame da matéria. No primeiro, será conceituado o ensino doméstico, como um fenômeno social que vem crescendo no Brasil e no mundo. Em seguida, a Teoria do Status de Jellinek será abordada no âmbito do direito-dever à educação fundamental. Importante, também, será falar do ensino escolarizado oferecido pelo Estado na Constituição da República de 1988. No quarto tópico, o ensino domiciliar será entendido como um dos pilares do direito à liberdade individual. Em última análise, numa visão deôntico-axiológica, serão avaliadas dialogicamente as regras e os princípios que preceituam a (im) possibilidade do ensino domiciliar no Brasil. A conclusão aposta na possibilidade do homeschooling no Brasil como um plus à política pública de educação fundamental.

\section{O ENSINO domÉSTICO: UM FENÔMENO SOCIAL QUE VEM CRESCENDO NO BRASIL E NO MUNDO}

Existe, no Brasil e em outros vários países, uma tendência voltada para o ensino doméstico ou domiciliar. Em inglês o ensino que se dá no domicílio do aluno por intermédio de um familiar ou por pessoa que com ele habite é chamado de homeschooling. Diverso do ensino tradicionalmente oferecido, em que uma instituição pública, privada ou cooperativa tem funcionamento espacial previamente definido, sendo todas fiscalizadas por entes estatais.

Em alguns países como Estados Unidos, Áustria, Bélgica, Canadá, Austrália, França, Noruega, Portugal, Rússia, Itália e Nova Zelândia, o ensino doméstico é legalizado. Em outros, proibido, como na Alemanha e na Suécia. Onde é permitido, costuma-se exigir uma avaliação anual dos alunos que recebem educação domiciliar.

No Brasil, não há previsão explícita dessa possibilidade pedagógica, cabendo aos pais ou responsável matricularem, obrigatoriamente, seus filhos entre os 4 e 17 anos em uma escola pública, privada ou em regime de cooperativa. As crianças já devem ser matriculadas na educação infantil a partir dos quatro anos e permanecer na escola até os dezessete, segundo a Lei no 9.394, de 20 de dezembro de 1996 (Lei de Diretrizes e Bases da Educação Nacional).

1 ALMEIDA, Gregório Assagra de. Direito material coletivo: superação da summa divisio clássica direito público e direito privado por uma nova summa divisio constitucionalizada. Belo Horizonte: Del Rey, 2008. 
$\mathrm{Na}$ medida em que o legislador foi silente quanto ao assunto, e houve um recrudescimento do ensino domiciliar no País, a matéria foi colocada pauta de discussão, sobretudo no momento em que o Judiciário, sistematicamente, tem aplicado sanções aos pais educadores, sob a alegação, entre outras cominações, de abandono intelectual. O que será visto mais adiante.

\section{A teoria do status de Jellinek no Âmbito do diReito-deVer À educaÇão fundamental}

Para entender um dispositivo normativo necessário, faz-se necessário inseri-lo num determinado contexto socio-histórico-cultural. Retirar essa análise precedente seria o mesmo que considerar o texto normativo como sendo friamente um signo linguístico, dissociado dos seus significados.

Nessa concepção de língua como código - portanto, como mero instrumento de comunicação - e de sujeito como (pre) determinado pelo sistema, o texto é visto como simples produto da codificação de um emissor a ser decodificado pelo leitor/ouvinte, bastando a este, para tanto, o conhecimento do código utilizado².

O contexto, portanto, pode fornecer os elementos necessários para o entendimento desses sentidos produzidos. Koch e Elias relembram que Van Dijk define contexto como sendo "o conjunto de todas as propriedades da situação social que são sistematicamente relevantes para a produção, compreensão ou funcionamento do discurso e de suas estruturas"3.

Nesse processo de interação entre o receptor e o leitor, no que diz respeito ao texto normativo, surge a necessidade de perquirir os elementos textuais constitutivos para ir além do significante, que representa meramente o código. Durante o processo de leitura, alguns aspectos de divergência costumam ser identificados. Ficar na superfície do texto, por exemplo, pode gerar problemas da ordem da significação, causados pela vagueza de sentido. Ao imergir no contexto, os ruídos podem ser provocados pela ambiguidade, ou seja, mais de um sentido para o mesmo dispositivo. Para a superação desses problemas de ordem comunicativa, autores como Marcelo Neves propõem a interpretação para evitar a ambiguidade e a concretização da norma a ultrapassar a vagueza textual ${ }^{4}$.

Ainda de acordo com o autor,

O processo de passagem da ambiguidade (imprecisão conotativa) prima facie da disposição normativa à superação da vagueza (imprecisão denotativa) exige não propriamente que se "considerem todos os fatores" do contexto, mas que se determine seletivamente se os fatos jurídicos relevantes ao caso enquadram-se na hipótese normativa ${ }^{5}$.

Diante dessas considerações, a hermenêutica da evolução da tutela jurídica do direito fundamental à educação deve ser entendida sobre os diferentes vieses, ainda que de breve passagem, do Estado Liberal de Direito, do Estado Social e do Estado Democrático de Direito.

Quem se propuser a uma análise em profundidade da evolução constitucional do Brasil não terá dificuldade em distinguir três fases históricas perfeitamente identificáveis em relação aos valores políticos, jurídicos e ideológicos que tiveram influxo preponderante na obra de caracterização formal das instituições: a primeira, vinculada ao modelo constitucional francês e inglês do Século XIX; a segunda, representando já uma ruptura, atada ao modelo norte-americano e, finalmente, a terceira, em curso, em que se percebe, com toda a evidência, a presença de traços fundamentais presos ao constitucionalismo alemão do corrente século .

2 KOCH, Ingedore Vilaça; ELIAS, Maria Vanda. Ler e compreender os sentidos do texto. São Paulo: Contexto, 2006. KOCH; ELIAS, 2006, passim.

NEVES, Marcelo. Entre Hydra e Hércules. São Paulo: WMF Martins Fontes, 2013.

NEVES, 2013, passim

BONAVIDES, Paulo. Curso de Direito Constitucional. 29 ed. São Paulo: Malheiros, 2014. 
E, nesse propósito, Alexy considera que a Teoria do Status de Jellinek ajuda a compreender o papel do Estado em relação ao cidadão ${ }^{7}$. Analiticamente, Jellinek ${ }^{8}$ caracterizou o status como sendo: passivo, negativo, positivo e ativo?

O status passivo ou status subiectionis representa uma sujeição do indivíduo ao Estado. Jellinek propõe duas interpretações que implicam essa sujeição. Na primeira, o Estado exerce algum poder de dever ou proibição diante do cidadão. Na segunda, há uma totalidade de deveres e proibições do Estado perante o cidadão. Por estar situado na esfera das obrigações sociais, o status passivo é inerente à estrutura das sociedades modernas, menos presente num Estado Democrático de Direito e mais intervencionista nos regimes autoritários.

O status negativo ou status libertatis pode ser associado à primeira dimensão dos direitos fundamentais, em que se impõe ao Estado uma atitude de abstenção diante dos direitos do cidadão. Corresponde ao Estado Liberal. O status negativo é composto, exclusivamente, de faculdades, de liberdades jurídicas não protegidas. São os direitos de defesa do cidadão a provocar um não-embaraço do Estado. Segundo Jellinek, "a liberdade existe apenas no singular". Todas as ações que não são nem obrigatórias nem proibidas estão no espaço das liberdades.

No status positivo ou status civitatis, o Estado reconhece ao indivíduo "a capacidade jurídica para recorrer ao aparato estatal e utilizar as instituições estatais, ou seja, garante ao indivíduo pretensões positivas". Confere-lhe, ainda, o status cívico quando (1) lhe garante "pretensões à sua atividade" e (2) "cria meios jurídicos para a realização desse fim". O direito do cidadão corresponde à segunda dimensão dos direitos fundamentais, ligados aos direitos sociais, marcados pela igualdade ${ }^{10}$.

No status ativo ou status da cidadania, as capacidades outorgadas ao cidadão pelo Estado, como, por exemplo, o direito de votar e ser votado, o legitimam para participar mais ativamente do Poder. Corresponde à terceira dimensão dos direitos fundamentais em que se destaca a atividade do cidadão, apto a participar do macrossistema, como na ação popular para reparar danos ao meio ambiente ou ao patrimônio público. Pela natureza altruística, pode ser associado à fraternidade.

\section{O ENSINO ESCOLARIZADO GARANTIDO E IMPOSTO PELA FORTE PRESENÇA ESTATAL NA Constituição da República de 1988}

Ao garantir o direito à educação, a Constituição da República de 1988 impôs o dever da família, da sociedade e do Estado em assegurar à criança e ao adolescente o direito à educação e à convivência comunitária, nos seguintes termos:

Art. 227. É dever da família, da sociedade e do Estado assegurar à criança e ao adolescente, com absoluta prioridade, o direito à vida, à saúde, à alimentação, à educação, ao lazer, à profissionalização, à cultura, à dignidade, ao respeito, à liberdade e à convivência familiar e comunitária, além de colocá-los a salvo de toda forma de negligência, discriminação, exploração, violência, crueldade e opressão.

A responsabilidade da família, do Estado e da sociedade é legitimada no artigo 205 da Constituição da República:

Art. 205. A educação, direito de todos e dever do Estado e da família, será promovida e incentivada com a colaboração da sociedade, visando ao pleno desenvolvimento da pessoa, seu preparo para o exercício da cidadania e sua qualificação para o trabalho.

7 ALEXY, Robert. Teoria Dos Direitos Fundamentais. $2^{\text {a }}$ Ed. São Paulo: Malheiros, 2011.

8 JELLINEK, Georg. Systerm der subjecktiven öffentlichen Rechte. Tübingen: Mohr, 1905.

9 JELLINEK, Georg. Allgemeine Staatslehre. Bad Homburg: Gentner, 1960.

10 ALEXY, 2011, passim. 
Tem-se, portanto, a responsabilidade da família, do Estado e da sociedade quanto ao dever de promover a educação. Será necessária, nesse sentido, a participação desses três parceiros (família, Estado e sociedade) para que se possam efetivar os objetivos constitucionais previstos no artigo 205, acerca do pleno desenvolvimento da pessoa, do preparo para o exercício da cidadania e da qualificação para o trabalho.

O Estado brasileiro entendeu que a família, por si só, não poderá atingir esse amplo objetivo constitucional na formação de seus filhos, sem a participação estatal e da sociedade no cumprimento desse dever. Assim, a obrigação da família não exclui a das outras entidades e nenhum tem prioridade sobre o outro.

Por outro, o artigo 208 da Constituição da República aborda a obrigatoriedade da educação básica dos quatro aos dezessete anos de idade, como direito público subjetivo e incumbindo ao Poder Público zelar pela frequência à escola, como segue:

Art. 208. O dever do Estado com a educação será efetivado mediante a garantia de:

$[\ldots]$

I - educação básica obrigatória e gratuita dos 4 (quatro) aos 17 (dezessete) anos de idade, assegurada inclusive sua oferta gratuita para todos os que a ela não tiveram acesso na idade própria;

$[\ldots]$

$\int 1^{\circ}-\mathrm{O}$ acesso ao ensino obrigatório e gratuito é direito público subjetivo.

$\sqrt{ } 2^{\circ}$ - O não-oferecimento do ensino obrigatório pelo Poder Público, ou sua oferta irregular, importa responsabilidade da autoridade competente.

$\int 3^{\circ}$ - Compete ao Poder Público recensear os educandos no ensino fundamental, fazer-lhes a chamada e zelar, junto aos pais ou responsáveis, pela frequência à escola.

Diante da determinação contida no citado artigo 208, o não oferecimento do ensino obrigatório pelo Poder Público, ou sua oferta irregular, importa responsabilidade da autoridade competente. O Poder Público não pode, pois, se eximir da obrigação de buscar o aluno (censo escolar), disponibilizar a matrícula e zelar, junto com os pais, pela sua frequência regular à escola. A Constituição deixa claro, desse modo, a importância da presença do aluno na escola, especialmente na faixa etária relativa ao ensino obrigatório.

O Conselho Nacional de Educação, por meio da Câmara de Educação Básica, analisou a questão da educação domiciliar no Parecer CNE/CEB no 34/2000, homologado em 15/12/2000 e publicado no Diário Oficial da União em 18/12/2000. O citado parecer foi conclusivo no sentido da impossibilidade da educação familiar:

Portanto, família, sociedade, organizações culturais e outras, são todas cooperadoras no desenvolvimento de uma educação plena, visando à plena cidadania. Mas a escola é agência indispensável, na conjugação dos deveres "da família e do Estado", conforme o art. $2^{\circ}$ da LDB. Não da família sem o Estado ou do Estado sem a família, com inspiração "nos princípios de liberdade e nos ideais de solidariedade humana", tendo "por finalidade o pleno desenvolvimento do educando, seu preparo para o exercício da cidadania e sua qualificação para o trabalho". Certamente, foi sábio o legislador, ao envolver a tríade mencionada na consecução de objetivos tão amplos. Porque a família, ela só, jamais reunirá as condições mínimas necessárias para alcançar objetivos tão amplos e complexos.

Os direitos à educação e à cidadania são direitos individuais indisponíveis assegurados pela Constituição e também presentes na legislação infraconstitucional.

Nesse sentido, a Lei 9394/96 (Lei de Diretrizes e Bases da Educação Nacional - LDB) define a abrangência do ensino e determina que a educação ocorra, predominantemente, em instituições próprias:

Art. $1^{\circ}$ A educação abrange os processos formativos que se desenvolvem na vida familiar, na convivência humana, no trabalho, nas instituições de ensino e pesquisa, nos movimentos sociais e organizações da sociedade civil e nas manifestações culturais. 
$\int 1^{\circ}$ Esta Lei disciplina a educação escolar, que se desenvolve, predominantemente, por meio do ensino, em instituições próprias.

$\int 2^{\circ} \mathrm{A}$ educação escolar deverá vincular-se ao mundo do trabalho e à prática social.

A LDB estabelece a obrigação da matrícula, tarefa da qual os pais não podem se omitir:

Art. $6^{\circ}$ É dever dos pais ou responsáveis efetuar a matrícula das crianças na educação básica a partir dos 4 (quatro) anos de idade (Redação dada pela Lei no 12.796, de 2013).

Essa obrigatoriedade, também, está prevista no artigo 55 do Estatuto da Criança e do Adolescente ECA, Lei no 8.069/1990: "Art. 55. Os pais ou responsável têm a obrigação de matricular seus filhos ou pupilos na rede regular de ensino".

Para o caso de omissão dos pais ou responsáveis, que viole ou ameace direitos dos menores, a exemplo da recusa de matrícula objetivando a educação domiciliar, o Estatuto da Criança e do Adolescente prevê a aplicação de medidas protetivas (Artigo 98, inciso II; artigo 129 e artigo 249).

O artigo 24 da LDB prevê a possibilidade de classificação do aluno pela escola, possibilitando a matrícula desse aluno, que tenha iniciado os estudos fora do ambiente escolar, em série compatível com sua idade e nível de conhecimento.

Esse mesmo artigo, também, exige a frequência mínima de 75\% nas 800 horas anuais para a aprovação, dando destaque à presença do aluno na sala de aula.

Art. 24. A educação básica, nos níveis fundamental e médio, será organizada de acordo com as seguintes regras comuns:

I - a carga horária mínima anual será de oitocentas horas, distribuídas por um mínimo de duzentos dias de efetivo trabalho escolar, excluído o tempo reservado aos exames finais, quando houver;

II - a classificação em qualquer série ou etapa, exceto a primeira do ensino fundamental, pode ser feita:

$[\ldots]$

c) independentemente de escolarização anterior, mediante avaliação feita pela escola, que defina o grau de desenvolvimento e experiência do candidato e permita sua inscrição na série ou etapa adequada, conforme regulamentação do respectivo sistema de ensino;

$[\ldots]$

VI - o controle de frequência fica a cargo da escola, conforme o disposto no seu regimento e nas normas do respectivo sistema de ensino, exigida a frequência mínima de setenta e cinco por cento do total de horas letivas para aprovação.

O já mencionado Parecer CNE/CEB no 34/2000 ponderou acerca do artigo 24 da LDB enfocando a necessidade do convívio escolar do educando para sua formação:

Poder-se-ia invocar o art. 24, inciso II, alínea "c", ad argumentandum. Efetivamente, ali está disposto que "independentemente de escolarização anterior mediante avaliação feita pela escola, que defina o grau de desenvolvimento e experiência do candidato e permita sua inscrição na série ou etapa adequada, conforme regulamentação do respectivo sistema", o aluno poderá ser classificado em qualquer série, nos níveis fundamental e médio. Não se trata, obviamente, de um estímulo à desescolarização do ensino. O dispositivo é sábio, visando à viabilização de inserção de alunos desgarrados do processo regular, a qualquer tempo.

Principalmente, em se tratando do ensino fundamental, que é o caso considerado, além dos dispositivos legais enunciados, dos quais o art. $6^{\circ}$ é emblemático, outro merece especial atenção. Trata-se do que se contém no art. 32. O caput, voltando a afirmar que o "ensino fundamental, com duração mínima de oito anos", é obrigatório (e gratuito na escola pública), enuncia, em seus quatro incisos, os objetivos do ensino fundamental. O último deles, ao mesmo tempo que fala no "fortalecimento dos vínculos da família", acrescenta também os laços de solidariedade humana e de tolerância recíproca em que se assenta à vida social". 
Ora, se o fortalecimento dos vínculos da família é de capital significado, não menos importantes são a solidariedade humana, a tolerância recíproca que fundamentam a vida social. E estes, não deverão ser cultivados no estreito (no sentido de limitado) espaço familiar. A experiência do coexistir no meio de outras pessoas, a oportunidade do convívio com os demais semelhantes, tudo são situações educativas que só a família não proporciona e que, portanto, não garante o que a lei chama de preparo para a "cidadania plena".

E mais adiante:

Ao determinar que o ensino fundamental é presencial, na escola, é claro, e que nele se exige um mínimo de $75 \%$ de frequência, a lei enfatizou a importância da troca de experiências, do exercício da tolerância recíproca, não sob o controle dos pais mas no convívio das salas de aula, dos corredores escolares, dos espaços de recreio, nas excursões em grupo fora da escola, na organização de atividades esportivas, literárias ou de sociabilidade, que demandam mais que os irmãos apenas, para que reproduzam a sociedade, onde a cidadania será exercida. Porque o preparo para esse exercício é uma das três finalidades fundamentais da educação. As outras sendo o pleno desenvolvimento do educando e sua qualificação para o trabalho (art. $2^{\circ}$, LDBEN).

O Superior Tribunal de Justiça, em sede do Mandado de Segurança nº. 7.407/DF, de relatoria do Ministro Francisco Peçanha Martins já se posicionou acerca da impossibilidade do ensino domiciliar. A mencionada decisão asseverou que a frequência à escola é direito dos menores, previsto na Constituição Federal e regulamentado pela Lei de Diretrizes e Bases da Educação e pelo Estatuto da Criança, sendo que a referida regulamentação não pode ser excepcionada pela convicção filosófica dos pais. Afirmou, também, que a mera demonstração da capacidade dos pais para o exercício do magistério não é suficiente para excluir os menores do direito ao convívio escolar. E, por fim, ressaltou que o Poder Judiciário não pode desprezar o ordenamento jurídico, a fim de privilegiar as convicções filosóficas dos genitores.

Os filhos não são dos pais, como pensam os Autores. São pessoas com direitos e deveres, cujas personalidades se devem forjar desde a adolescência em meio a iguais, no convívio social formador da cidadania. Aos pais cabem, sim, as obrigações de manter e educar os filhos consoante a Constituição e as leis do País, asseguradoras do direito do menor à escola (art. $5^{\circ}$ e 53, I, da Lei no 8.096/90) e impositivas de providências e sanções voltadas à educação dos jovens como se observa no art. 129, e incisos, da Lei $n^{\circ}$ 8.096/90 supra transcritos, e art. 246, do Código Penal, que define como crime contra a assistência familiar "deixar, sem justa causa, de prover à instrução primária de filho em idade escolar", cominando a pena de "detenção de quinze dias a um mês, ou multa, de vinte centavos a cinquenta centavos". (STJ, Relator: Ministro Francisco Peçanha Martins, Data de Julgamento: 24/04/2002, S1 - Primeira Seção).

Sob o mesmo prisma, alguns tribunais têm condenado os pais sob a alegação de abandono intelectual, arrogando o Art. 246 do Código Penal: "Deixar, sem justa causa, de prover à instrução primária de filho em idade escolar: Pena - detenção, de quinze dias a um mês, ou multa."

JUSTIÇA DA INFÂNCIA E DA JUVENTUDE - EDUCAÇÃO DOS FILHOS - CONCEITO. Promover a educação dos filhos é dever inerente ao pátrio poder, assim como a subordinação dos filhos ao mando paterno. Por educação compreende-se o esforço tendente a promover o desenvolvimento físico, intelectual e moral do indivíduo e ajustá-lo às normas comuns de comportamento. A transição do indivíduo para o cidadão é fruto das práticas educativas, implícitas no instituto em estudo. O Código Penal, art. 246, reprime o crime de abandono intelectual, informado pelo fato de deixar, sem justa causa, de prover a instrução primária de filho em idade escolar... Fora de dúvidas que a subordinação do filho ao mando paterno se inclui no curso ativo da educação. (TJ-SP - Apelação Cível 28180- 0/5 - Acórdão COAD 76534 - Rel. Des. Pereira da Silva - Julgamento em 29-8-1996).

A Constituição de 1988, promulgada num ambiente pós-Ditadura, elegeu o Estado Democrático de Direito para irradiar o ordenamento jurídico nacional. Os direitos fundamentais, cerceados durante o período ditatorial, foram elevados à máxima potência. O direito à liberdade de expressão, por exemplo, sepultou uma era marcada pela censura prévia. Mas, sem dúvida, os direitos sociais são elencados ao longo da Constituição de forma marcante, haja vista o seu primeiro artigo que afirma: “Todo o Poder emana do povo”. É por isso que Bonavides afirma: 
A Constituição de 1988 é basicamente em muitas de suas dimensões essenciais uma Constituição do Estado social. Portanto, os problemas constitucionais referentes a relações de poderes e exercício de direitos subjetivos têm que ser examinados e resolvidos à luz dos conceitos derivados daquela modalidade de ordenamento. Uma coisa é a Constituição do Estado liberal, outra a Constituição do Estado social. A primeira é uma Constituição antigoverno e antiestado; a segunda uma Constituição de valores refratários ao individualismo no Direito e ao absolutismo no Poder $^{11}$.

Os direitos sociais previstos na Lei Magna revelam um gigantismo estatal e desnudam a mão de ferro do Estado-Leviatã, onipresente e onipotente. Nesse modelo, o status passivo mencionado por Jellinek aparece a toda evidência. $\mathrm{O}$ cidadão se submete aos comandos estatais, esperando sempre uma prestação positiva. Abre-se caminho para governos populistas e caudilhos aventureiros. A educação sofre essa intervenção, estando quase exclusivamente sob o controle do Estado, seja pela construção e manutenção de escolas públicas, seja na regulação e fiscalização das escolas privadas, ditando-lhes inclusive as disciplinas a lecionar. Essa ubiquidade é deletéria na medida em que se consideram as avaliações internacionais a que o Brasil tem-se submetido. No último Programa Internacional de Avaliação de Alunos, Pisa (2014), por exemplo, que avaliou a capacidade de 85 mil estudantes do mundo inteiro, na faixa etária de 15 anos, para resolver problemas de matemática aplicados à vida real, o Brasil ficou em $38^{\circ}$ lugar, com 428 pontos, em um total de 44 países. Os dados disponíveis no sítio do Instituto Nacional de Estudos e Pesquisas Educacionais Anísio Teixeira, INEP (1 de abril de 2014), do Governo Federal, revelam que o ensino estatal evoluiu, mas está longe de ser comparado aos países que são excelência no assunto, como Cingapura, China e Japão. Um dos problemas apontados por educadores para essa defasagem de ensino reside nos Parâmetros curriculares que engessam os currículos, padronizam materiais didáticos e adotam as mesmas estratégias pedagógicas num país de dimensão continental, com as suas idiossincrasias culturais, que se mostram diversas e complexas. E o Estado, definitivamente, não tem obtido êxito no confronto com essas diversidades.

À medida que se revele exitosa a prática pedagógica adotada pelos pais no âmbito doméstico, acaba-se criando um comparativo com o ensino oferecido pelo Estado. E suas mazelas já conhecidas pelo senso comum e traduzidas nas avaliações internacionais tornam-se cada vez mais evidentes.

\section{A liberdade indiVIDUAL de OS PRÓPRIOS PAis PROMOVEREM O ENSINO dOS SEUS FILHOS NO ÂMBITO DOMÉSTICO - HOMESCHOOLING}

A educação domiciliar aparecia em linhas gerais na Constituição de 1937. Surgia como direito primordial dos pais e apresentava o caráter meramente colaborativo da atuação estatal. Refletia, portanto, o Estado liberal, destacando a família como ente essencial para a educação dos filhos.

Art. 125 - A educação integral da prole é o primeiro dever e o direito natural dos pais. O Estado não será estranho a esse dever, colaborando, de maneira principal ou subsidiária, para facilitar a sua execução ou suprir as deficiências e lacunas da educação particular.

A Declaração Universal dos Direitos Humanos, adotada e proclamada pela Resolução no 217 A (III) da Assembleia Geral das Nações Unidas em 10 de dezembro de 1948, assinada pelo Brasil na mesma data, estabeleceu o direito à liberdade de escolha dos pais quanto à educação dos seus filhos. Em seu Artigo 26, \$3, preceitua que: "os pais têm prioridade de direito na escolha do gênero de instrução que será ministrada a seus filhos". Essa liberdade representa a autonomia individual do cidadão em face do Estado-provedor.

A consideração do indivíduo como sujeito da autonomia individual, moral e intelectual (essência da filosofia das luzes), justificará a exigência revolucionária da constatação ou declaração dos direitos do homem, existentes a priori. O sentido destas declarações não se reconduzia à reafirmação de uma teoria da tolerância, ou seja, de apelos morais dirigidos ao soberano, tendentes a obter garantias para os súditos.

11 BONAVIDES, 2014, passim. 
A tolerância ficava sempre no domínio reservado do soberano e, consequentemente, na sua completa disponibilidade. As declarações dos direitos vão mais longe: os direitos fundamentais constituem uma esfera própria e autônoma dos cidadãos, ficam fora dos ataques legítimos do poder e contra o poder podiam ser defendidos ${ }^{12}$.

Os direitos fundamentais liberais costumam ser entendidos como um mecanismo de resistência às intervenções autoritárias por parte do Estado.

Neste contexto, os direitos fundamentais liberais decorriam não tanto de uma declaração revolucionária de direitos mas do respeito de uma esfera de liberdade individual. Compreende-se, por isso, que os direitos fundamentais - liberdade e propriedade (Freibeit und Eigentum) - só pudessem sofrer intervenções autoritárias por parte da administração quando tal fosse permitido por uma lei aprovada pela representação popular (doutrina da lei protectora dos direitos de liberdade e de propriedade e doutrina da reserva de lee). (CANOTILHO, 2003, p. 97)

Com o avanço da legislação brasileira, abalizado pelo processo de redemocratização, os pais ficaram responsáveis por colocar as crianças na educação infantil a partir dos quatro anos e por sua permanência até os 17 anos (Lei de Diretrizes e Bases da Educação Nacional). O artigo 1.634 do Código Civil Brasileiro assevera que compete aos pais, quanto aos filhos menores, dirigir-lhes a criação e a educação. $\mathrm{O}$ artigo 22 do Estatuto da Criança e do Adolescente (ECA) prevê que aos pais incumbe o dever de sustento, guarda e educação dos filhos menores. Nas entrelinhas, lê-se a influência da Constituição de 1937 nos referidos artigos. Nesses trechos lançou-se luz à importância dos pais no processo de educação dos seus filhos. A Constituição menciona o dever do Estado e da família como provedores da educação fundamental, mas não descreve o papel de cada ente, cabendo-lhes, pois, a função cooperativa. Já a legislação infraconstitucional, como visto, prevê a obrigação dos pais de matricularem seus filhos na escola e, ainda, a possibilidade de sanção quanto ao seu descumprimento.

Andrade, em tese defendida no doutorado da Universidade de São Paulo (USP), aborda essa lacuna constitucional ${ }^{13}$.

Como vimos, excetuando um dever que vem sendo interpretado, a contrario sensu, como um dever dos pais ou responsáveis da criança por matriculá-la e zelar por sua frequência à escola, não há, na Constituição Federal, nenhuma obrigação específica atribuída à família, apenas se declara o seu dever em promover a Educação Nacional, sem especificar como. Ao mesmo tempo, existem muitas obrigações delineadas quanto ao Estado. É na LDB que surge o comando dirigido aos pais das crianças e adolescentes quanto a matricular e zelar pela frequência de seus filhos à escola.

Conforme já delineado, em uma leitura prima facie de toda a legislação nacional, a função primordial dos pais na educação de seus filhos consiste em matriculá-los em uma escola, pública ou privada, mantendo-os com frequência regular. O restante fica por conta do Estado-provedor. Para corrigir essa desproporcionalidade, a Câmara dos Deputados recolocou em pauta o Projeto de Lei no 3179/2012, de autoria do Deputado Lincoln Portela. Nele, fica admitido o ensino no âmbito doméstico, ministrado por pais ou tutores responsáveis pelos estudantes.

Art. $1^{\circ} \mathrm{O}$ art. 23 da Lei no 9.394 , de 20 de dezembro de 1996, passa a vigorar acrescido do seguinte parágrafo:

Art. $23[\ldots]$

$\int 3^{\circ}$ É facultado aos sistemas de ensino admitir a educação básica domiciliar, sob a responsabilidade dos pais ou tutores responsáveis pelos estudantes, observadas a articulação, supervisão e avaliação periódica da aprendizagem pelos órgãos próprios desses sistemas, nos termos das diretrizes gerais estabelecidas pela União e das respectivas normas locais.

12 CANOTILHO, José Joaquim Gomes. Direito Constitucional e Teoria da Constituição. Almedina: São Paulo. 2003.

13 ANDRADE, Édison Prado de. A educação familiar desescolarizada como um direito da criança e do adolescente: relevância, limites e possibilidades na ampliação do direito à educação. Tese de doutorado da Universidade de São Paulo (USP), orientação: Roberto da Silva, São Paulo: s.n., 2014. Disponível em: http://www.teses.usp.br/teses/disponiveis/48/48134/tde-10112014111617/pt-br.php. Acesso em 10/07/2015. 
$\mathrm{Na}$ Justificação do Projeto, é patente a intenção do legislador de ampliar a responsabilidade do ensino, atualmente concentrada nas mãos do Estado, para a família, afiançando-lhe o direito-dever de educar os filhos: "Garantir na legislação ordinária essa alternativa é reconhecer o direito de opção das famílias com relação ao exercício da responsabilidade educacional para com seus filhos”.

Recentemente, nesse mesmo passo, o Supremo Tribunal Federal admitiu, em sede de Recurso Extraordinário, a repercussão geral do assunto aqui discutido.

Ementa: DIREITO CONSTITUCIONAL. EDUCAÇÃO. ENSINO DOMICILIAR. LIBERDADES E DEVERES DO ESTADO E DA FAMÍLIA. PRESENÇA DE REPERCUSSÃO GERAL. 1. Constitui questão constitucional saber se o ensino domiciliar (bomeschooling) pode ser proibido pelo Estado ou viabilizado como meio lícito de cumprimento, pela família, do dever de prover educação, tal como previsto no art. 205 da CRFB/1988. 2. Repercussão geral reconhecida. (STF, Recurso Extraordinário (RE) 888815, TJRS, ministro-relator Luís Roberto Barroso, 15 de maio de 2015).

O recurso fundamentou-se no art. 102, III, a, da Constituição Federal. A parte recorrente alegou violação aos arts. 205, 206, 208, 210, 214 e 229, da Constituição.

Restringir o significado da palavra educar simplesmente à instrução formal numa instituição convencional de ensino é não apenas ignorar as variadas formas de ensino - agora acrescidas de mais recursos com a tecnologia - como afrontar um considerável número de garantias constitucionais, cujo embasamento se dá, entre outros, pelos princípios da liberdade de ensino (art. 206, II, CF) e do pluralismo de ideias e de concepções pedagógicas (art. 206, III, CF), tendo-se presente a autonomia familiar assegurada pela Constituição.

O ministro-relator, Luís Roberto Barroso, reconhece a concorrência do direito fundamental da educação como dever do Estado e da família. O artigo 208 da Constituição tão somente apresenta a obrigação estatal: "a controvérsia envolve, portanto, a definição dos contornos da relação entre Estado e família na educação das crianças e adolescentes, bem como os limites da autonomia privada contra imposições estatais".

Em sua conclusão, o ministro reconhece a repercussão geral do assunto sob dois enfoques: 1) a liberdade pedagógica dos pais em relação ao ensino dos seus filhos e em respeito às suas convicções axiológicas e 2) os limites de atuação do Estado, respeitando, justamente, essa liberdade:

O debate apresenta repercussão geral, especialmente do ponto de vista social, jurídico e econômico: social, em razão da própria natureza do direito pleiteado; jurídico, porque relacionado à interpretação e alcance das normas constitucionais que preveem a liberdade de ensino e o pluralismo de ideias e concepções pedagógicas e à definição dos limites da relação entre Estado e família na promoção do direito fundamental à educação; e econômico, tendo em conta que, segundo estudos o reconhecimento do homeschooling poderia reduzir os gastos públicos com a educação (STF, Recurso Extraordinário (RE) 888815, TJRS, ministro-relator Luís Roberto Barroso, 15 de maio de 2015).

Espera-se que o STF, ante tão fortes e relevantes argumentos, abra, inclusive, espaço dialógico em audiência pública para a manifestação de todos os interessados.

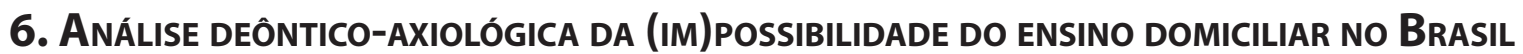

A evolução jurídica nas sociedades contemporâneas reflete os modelos axiológicos por elas adotados. Não há falar em uma moral absoluta, que atenda aos diferentes propósitos humanos. Da mesma forma, não se pode vislumbrar dispositivos normativos que deem conta de todas as idiossincrasias sociais. Basta imaginar a discussão atual da união homoafetiva para entender como as regras e os princípios se transformam para se amoldarem à dinâmica social. O contrário disso não se aplica.

$\mathrm{Na}$ sociedade moderna, os pontos de observação se multiplicam cada vez mais, sendo inusitado que se possa falar de um ideal regulativo capaz de descortinar o consenso subjacente na moralidade comunitária. 
Antes se impões discutir quais são os processos e estruturas normativos adequados à absorção legítima do dissenso estrutural presente na esfera pública a respeito da determinação dos direitos e deveres constitucionais. A articulação paradoxal de princípios e regras na cadeia (talvez seja melhor na rede) argumentativa da concretização constitucional tem um importante papel nesse contexto ${ }^{14}$.

As críticas de Alexy quanto à tese de que as regras são aplicadas à maneira do "tudo-ou-nada", abarcando todas as possibilidades através das normas de exceção, são adequadas para entender essa evolução social $^{15}$. Nenhum sistema jurídico possui a competência de regramento exaustivo tampouco é capaz de criar exceções enumeráveis fatuais ou contrafatuais. A qualquer pessoa que leia, prima facie, o artigo 155 do Código Penal não caberia outra interpretação do dispositivo que não fosse a responsabilização penal pelo crime de furto. No entanto, como o legislador não tem o condão de imaginar todas as hipóteses de exceção e, convenhamos, seria impossível a sua previsão absoluta, cabe ao juiz a melhor interpretação da Lei na subsunção do fato à norma. Nesse campo da aplicação do artigo 155 do Código Penal, tem-se levado em conta o princípio da insignificância para excluir a punibilidade do autor. Ora, se o agente subtraiu para si coisa alheia móvel, no campo do "tudoou nada", não interessaria o pequeno valor do bem. Em várias decisões judiciais, não é esse o entendimento, ampliando-se as possibilidades de diálogo com o catálogo de princípios disponíveis no ordenamento jurídico.

Ementa: PENAL. AGRAVO REGIMENTAL NO RECURSO ESPECIAL. TENTATIVA DE FURTO. PRINCÍPIO DA INSIGNIFICÂNCIA. DIMINUTO VALOR. RESTITUIÇÃO À VÍTIMA. PREPONDERÂNCIA SOBRE A REITERAÇÃO DELITIVA. AGRAVO PROVIDO. 1. Sedimentou-se a orientação jurisprudencial no sentido de que a incidência do princípio da insignificância pressupõe a concomitância de quatro vetores: a) mínima ofensividade da conduta do agente; b) nenhuma periculosidade social da ação; c) reduzidíssimo grau de reprovabilidade do comportamento e d) inexpressividade da lesão jurídica provocada. 2. A reiteração delitiva tem sido compreendida como obstáculo inicial à tese da insignificância, ressalvada excepcional peculiaridade do caso penal. 3. Em razão da coisa que se tentou furtar (dois cosméticos), seu diminuto valor (R \$ 8,38 - oito reais e trinta e oito centavos), com restituição à vítima, estabelecimento comercial, admite-se a insignificância, excepcionando-se a condição de reiteração delitiva do agente. 4. Agravo regimental provido. Recurso especial a que se nega provimento. (STJ - AGRAVO REGIMENTAL NO RECURSO ESPECIAL AgRg no REsp 1377789 MG 2013/0127099-0. Data de publicação: 21/10/2014.

A educação fundamental como direito-dever permite, a partir da sua imanência, discutir a natureza das regras e dos princípios constitucionais considerando duas vertentes hermenêuticas distintas: a deontologia, voltada para os deveres e obrigações e a axiologia, ciência dos valores.

O cidadão que se vê diante de uma situação fática que lhe permite agir ou lhe proíbe de fazê-lo processa uma série de valores que fazem parte da sua vivência social. Desde cedo, a criança testa seus limites como a dizer para os adultos: "olha o que estou fazendo, ninguém vai me censurar? Eu sei que isso é errado, mas, se ninguém me impedir, vou fazer assim mesmo”. Uma criança de rua, abandonada a própria sorte, costuma agir da mesma forma. Mas o receptor torna-se a sociedade que o cerca. Esses limites axiológicos costumam nortear todas as relações sociais.

Para o senso comum, causa maior repreensão o fato de uma pessoa furtar um bem alheio. Não se pode dizer o mesmo, havendo, inclusive, uma excludente de ilicitude, do cidadão de bem que, para defender a sua família, mata um bandido dentro da sua residência. Não estaríamos diante de dois crimes, um dos quais é capital, ferindo o princípio do direito à vida? Nesse caso, quando está em jogo a noção de escolha do ser humano pelos valores morais, éticos, estéticos e espirituais, há de se levar em consideração o aspecto axiológico.

Considerando-se a dimensão axiológica, um pai e/ou uma mãe que faz (fazem) a escolha pelo ensino domiciliar estaria(m) abandonando os filhos à própria sorte? Não se estaria diante de uma situação contrária, de proteção, a considerar a liberdade axiológica de conduzir a educação moral, ética e religiosa dos filhos?

14 NEVES, 2013, passim

15 ALEXY, 2011, passim. 
Como visto, a questão do ensino domiciliar está longe de ser resolvida. Afinal, não se pode perder de vista que uma parcela da sociedade fez a opção de ela própria prover os estudos dos seus filhos. Nesse sentido, há, nitidamente, um conflito entre regras e princípios. Existe um regramento no Brasil que impede a prática. Essa nova tendência social acrescenta o viés principiológico ao caldeirão das possibilidades éticas.

O valor, ou aquilo que é valorizado pelas pessoas, é uma escolha individual, subjetiva e produto da cultura onde o indivíduo está inserido. Tanto o princípio quanto as regras submetem-se ao dever-ser como premissa de comportamento. Alexy destaca esse ponto que aproxima os princípios das regras, ou seja, a noção do dever-ser: "Princípios são, tanto quanto as regras, razões para juízos concretos de dever-ser, ainda que de espécie muito diferente. A distinção entre regras e princípios é, portanto, uma distinção entre duas espécies distintas" $"$.

A perspectiva axiológica adotada por Alexy em sua Teoria dos Direitos Fundamentais é criticada por não ter levado em conta o pluralismo social em virtude de não ter levado em conta as diferentes conjunturas das sociedades contemporâneas, que compartilham valores éticos intersubjetivamente. Habermas, citado por Marcelo Neves (2013), parece se aproximar mais dessa visão pluralista da sociedade, com base em perspectiva deontológica, assumindo a distinção entre princípios e valores.

Outra alternativa reside em definir o valor como preferência de um indivíduo ou de um grupo ou coletividade, o que nos põe, respectivamente, perante a ética individual e a ética política no sentido de Habermas. O que interessa aqui é a noção de valor ético-político (de uma coletividade). Nesse caso, apresenta-se a seguinte questão: "o que é bom para nós?". Trata-se do problema ético da forma particular de vida que é considerada boa para uma determinada coletividade. Habermas distingue esse problema da questão moral, referente a princípios (deontológicos) com pretensão de universalidade ${ }^{17}$.

Immanuel Kant também forneceu elementos para entender a deontologia, dividindo-a em dois conceitos: razão prática e liberdade. Para Kant, o dever-ser somente se estabelece, de fato, se estiver associado ao seu valor moral, que só pode ser atingida por uma livre vontade. Não se desvinculou a relevância da lei, mas a liberdade de obedecer à lei moral ganhou contornos de legitimação. O sentimento de obrigação deve estar harmonizado com as aspirações sociais, desde que não ofendam os princípios ligados à moral ${ }^{18}$.

O ensino domiciliar representa um direito-dever à educação fundamental dos filhos. O desejo de uma coletividade de ela própria prover a educação de seus filhos, baseada nos valores morais, éticos, religiosos e culturais deve ser entendido como uma maneira legítima de exercício da liberdade.

Esse mesmo princípio, pela própria experiência coletiva, costuma ser mitigado, pois implica uma interaplicação social. Para tanto, deve ser sopesada a sua noção de valor e desvalor em um critério mais ou menos objetivo de moralidade. A criação de um sindicato de criminosos para defender a liberdade de subtrair bens alheios supera a expectativa de moralidade social. Afinal se esbarra na liberdade que o cidadão tem de adquirir seus bens de maneira lícita e honesta. O contrário disso seria o caos social. O desvalor de tal hipótese reside no fato de existir um ganhador ilegítimo e um perdedor, que, nesse caso, é respaldado pela lei, quando ela lhe garante o direito à propriedade. Uma família que decide prover os estudos dos seus filhos a partir de suas convicções morais, filosóficas e religiosas não está, em tese, a provocar um desvalor. Pode-se dizer que as crianças ou adolescentes ficariam isoladas da possibilidade de ter acesso ao ensino acadêmico, por exemplo. Não se pode olvidar que o bilhete de entrada para as universidades ainda é proporcionado pelos vestibulares. E por que não considerar esse universo e lhes dar o direito de ingresso acadêmico via provas avaliativas? Não haveria um receio de o Estado por a prova sua competência quanto à política pública de oferecimento da educação fundamental ao admitir essa possibilidade pedagógica? Para responder a essa questão, não se deve pensar o ensino domiciliar simplesmente como concorrente, mas como alternativo ao modelo tradicional de ensino.

16 ALEXY, 2011, passim.

17 NEVES, 2013, passim

18 KANT, Immanuel. Crítica da razão prática. São Paulo: Escala, 2006 
A outra argumentação contrária ao ensino domiciliar diz respeito ao cerceamento dos filhos ao convívio comunitário. Ora, o ambiente escolar não pode ser considerado o único meio de convivência social. Existe, obviamente, uma infinita gama de possibilidades de interação humana proporcionada pelo lazer, cultura, religião, esporte, voluntariado. As redes sociais, também, podem representar uma importante ferramenta de comunicação entre os grupos de pessoas e diminuir sobremaneira esse isolamento provocado pela falta de convívio no ambiente escolar.

O Estado não pode desconsiderar o movimento adepto ao ensino doméstico. A simples exclusão desse grupo implica discriminação que não se coaduna com o Estado Democrático de Direito. As sociedades contemporâneas evoluem de forma dinâmica e imprevisível. Os mecanismos legais do Direito devem se harmonizar com essa dinâmica, sob pena de tornar o Direito anacrônico e autoritário. Criminalizar os pais que buscaram um modelo alternativo de efetivar seu dever quanto à educação dos seus filhos constitui medida jurídica desproporcional e desarrazoada.

O ensino fundamental deve ser entendido como direito-dever. As famílias concorrem para a concretização desse desígnio e podem colaborar harmonicamente nesse sentido. Os jovens submetidos à educação domiciliar podem ser matriculados no sistema estatal de ensino e, com isso, fazerem parte das estatísticas, podem receber material didático do Estado e ser avaliados periodicamente. Os pais, também, podem participar desse processo de interação e receber orientações de equipe pedagógica da escola além de ter a possibilidade de se fazer cursos de atualização de conteúdos. Seria uma maneira de romper o cabo de guerra formado pela divisão que colocou de um lado o Estado centralizador e provedor de tudo; de outro, as famílias que buscam uma alternativa de ensino aos seus filhos, baseado nas suas convicções morais, éticas, políticas, filosóficas e religiosas.

\section{Considerações finais}

Como visto, o direito-dever ao ensino fundamental costuma ser, tradicionalmente, atribuição do Estado sob o manto de uma interpretação do contexto normativo que conduziria à sua proibição. $\mathrm{O}$ movimento social, denominado mundialmente homeschooling, tem encontrado resistência por essa razão. $\mathrm{O}$ ensino domiciliar no Brasil, apesar disso, tem conseguido cada vez mais simpatizantes e adeptos. Pensando nessa ascensão, o Legislativo brasileiro tem discutido o assunto a partir do Projeto de Lei no 3179/2012. O Supremo Tribunal Federal, nessa esteira, perfilhou a constitucionalidade do ensino domiciliar e reconheceu a repercussão geral do tema.

Para pavimentar o caminho do entendimento, criou-se uma dicotomia, que, inevitavelmente, foi trazida à argumentação. O Estado provedor do ensino fundamental e as famílias que ministram conteúdos didáticos aos seus filhos, de acordo com suas convicções. Não se buscou falar em qualidade de ensino, apenas intentou-se trazer à baila um comportamento social, que não deve ser menosprezado. Para além disso, essa possibilidade pedagógica deve ser vista como aliada na formação educacional dos jovens brasileiros.

Enfim, na definição do conteúdo em favor do homeschooling pela via legislativa ou a conformação do conteúdo pela via judicial no âmbito da repercussão geral, não podem legisladores ou juízes desconsiderarem a composição do viés deôntico com o viés axilógico de modo a fazer evidenciar a condensação de uma expectativa social legítima no âmbito do Estado Democrático de Direito. Seja qual for a via de validação, não poderão ser desconsiderados, como aqui alvitramos, mecanismos de avaliação e de interação e inserção de pais e responsáveis.

Por esse caminho, o homeschooling longe de constituir uma ameaça à política pública de ensino fundamental do Estado brasileiro, se avulta como um plus para realizá-la. 


\section{ReferênCIAS BIBLIOGRÁFICAS}

ALEXY, Robert. Teoria Dos Direitos Fundamentais. 2a Ed. São Paulo: Malheiros, 2011.

ALMEIDA, Gregório Assagra de. Direito material coletivo: superação da summa divisio clássica direito público e direito privado por uma nova summa divisio constitucionalizada. Belo Horizonte: Del Rey, 2008.

ANDRADE, Édison Prado de. A educação familiar desescolarizada como um direito da criança e do adolescente: relevância, limites e possibilidades na ampliação do direito à educação. Tese de doutorado da Universidade de São Paulo (USP), orientação: Roberto da Silva, São Paulo: s.n., 2014. Disponível em: http:/ / www.teses.usp.br/teses/disponiveis/48/48134/tde-10112014-111617/pt-br.php. Acesso em 10/07/2015.

BONAVIDES, Paulo. Curso de Direito Constitucional. 29 ed. São Paulo: Malheiros, 2014.

BRASIL. Projeto de Lei no 3179/2012. Brasília: Câmara dos Deputados. Apresentado em 08/02/2012. Disponível em URL: http://www.camara.gov.br/proposicoesWeb/fichadetramitacao?idProposicao=534328. Acesso em 16 de julho de 2015.

BRASIL. Lei 8.069/1990, Estatuto da Criança e do Adolescente. Disponível em: http://www.planalto.gov. br/CCIVIL_03/leis/L8069.htm. Acesso em 15/07/2015.

BRASIL. Constituição da República Federativa do Brasil de 1988, disponível em: http://www.planalto.gov. br/ccivil_03/constituicao/constituicao.htm. Acesso em 16/07/2015.

BRASIL. Lei no 9.394, de 20 de dezembro de 1996, Lei de Diretrizes e Bases da Educação Nacional, disponível em: http://www.planalto.gov.br/ccivil_03/LEIS/L9394.htm. Acesso em 15/07/2015.

BRASIL. Parâmetros Curriculares Nacionais. Disponível em: http://portal.mec.gov.br/seb/arquivos/pdf/ livro01.pdf. Acesso em: 15/07/2015.

BRASIL. Parecer CNE/CEB no 34/2000. Disponível em: http://portal.mec.gov.br/cne/arquivos/pdf/ pceb34_00.pdf. Acesso em 15/07/2015.

BRASIL. Lei no 10.406, de 10 de janeiro de 2002, Código Civil. Disponível em: http://www.planalto.gov. br/ccivil_03/leis/2002/L10406.htm. Acesso em 15/07/2015.

CANOTILHO, José Joaquim Gomes. Direito Constitucional e Teoria da Constituição. Almedina: São Paulo. 2003.

Declaração Universal dos Direitos Humanos. Disponível em: http://www.dhnet.org.br/direitos/deconu/ textos/integra.htm. Acesso em 27/07/20015.

JELLINEK, Georg. Systerm der subjecktiven öffentlichen Rechte. Tübingen: Mohr, 1905.

JELLINEK, Georg. Allgemeine Staatslehre. Bad Homburg: Gentner, 1960.

KANT, Immanuel. Crítica da razão prática. São Paulo: Escala, 2006.

KOCH, Ingedore Vilaça; ELIAS, Maria Vanda. Ler e compreender os sentidos do texto. São Paulo: Contexto, 2006.

NEVES, Marcelo. Entre Hydra e Hércules. São Paulo: WMF Martins Fontes, 2013. 


\section{Barreiras à cidadania nas políticas sociais para a população em situação de rua*}

\section{Barriers to citizenship in social policies for population in street situation}

\author{
Luciano Roberto Gulart Cabral Júnior** \\ José Ricardo Caetano Costa***
}

\section{Resumo}

A situação de rua é um estágio de exclusão social que traz consigo, além da ausência de moradia, o prejuízo a outros direitos sociais. As políticas sociais devem buscar a superação da situação de rua, habilitando os sujeitos com capacidade para a construção de sua história. A assistência, embora de relevância salutar, precisa ser manejada de modo provisório em tal conjuntura, para propiciar a trilha para a emancipação. O objetivo deste artigo, dessa forma, é identificar as barreiras à cidadania nas políticas sociais para a população em situação de rua e, consequentemente, a intervenção estatal terá um diagnóstico para agir sem freios ou evitando embaraços pelo obstáculo. Assim agindo, preconiza-se, em última análise, a dignidade da pessoa humana. Basicamente, tais barreiras constituem a consideração da situação de rua como um estado, a dificuldade de pesquisa sobre as pessoas em situação de rua, a dificuldade de cientificação da população em situação de rua acerca dos direitos que lhe pertencem, o estabelecimento de um mínimo social para a população em situação de rua, o tratamento homogênico do Estado para com a população em situação de rua, a ausência de voz direta e de representatividade política das pessoas em situação de rua nos espaços públicos, o caráter assistencialista que pode assumir as políticas sociais para a população em situação de rua, e a intimidade atual do cenário político brasileiro com o neoliberalismo. Nesse cenário que se realiza a presente pesquisa qualitativa, por meio do método de abordagem dedutivo e do método de procedimento monográfico.

Palavras-chave: cidadania; políticas sociais; população em situação de rua.

\section{Abstract}

The street situation is a social exclusion stage that brings, besides the lack of housing, the damage to other social rights. Social policies must seek to overcome the homelessness, enabling individuals with ability to build your story. The assistance, though salutary relevance, needs to be managed on an interim basis in such circumstances, to provide the path to emancipation. The objective of this article, thus, it is to identify the barriers to citizenship in social policies for the people in street situation, and consequently the State intervention will have a diagnosis to act without brakes or avoiding 
embarrassment by the obstacle. In so doing, it is profess, in the final analysis, the dignity of the human person. Basically, these barriers are the consideration the street situation as a state, the difficulty of research on people in street situation, the difficulty of scientification of people in street situation about the rights that belong to them, the establishment of a social minimum for the people in street situation, the homogeneous treatment of the State with the people in street situation, the absence of direct voice and political representation of the people in street situation in public areas, the welfarist character that can take on the social policies for the people in street situation, and the intimacy of the current Brazilian political scene with neoliberalism. In this stage which takes this qualitative research, through the deductive method of approach and the monographic method of procedure.

Keywords: citizenship; social policies; population in street situation.

\section{INTRODUÇÃo}

A população em situação de rua vive à margem da sociedade, enfrentando inúmeros desafios para uma existência digna, máxime no que atine à fruição dos direitos sociais. Como a cidadania é intimamente imbricada com tal conjuntura, políticas sociais para as ditas pessoas são de importância ímpar, diante do caráter central do Estado na intervenção social.

Com base, portanto, em uma pesquisa qualitativa, tendo como método de abordagem o dedutivo, por meio de pesquisa bibliográfica e legislativa sobre o tema, utilizando-se do método de procedimento monográfico, ${ }^{1}$ indagar-se-á quais são os principais fatores que obstaculizam a implementação de políticas sociais para a população em situação de rua em prol de uma cidadania plena. A importância da problemática reside na relevância jurídico-social do tratamento dispensado à população em situação de rua, marginalizada e invisível aos olhos da sociedade. Em razão disso, pontuar - embora não de modo exaustivo, por óbvio, diante da complexidade do embate, somado à disparidade sociocultural que permeia as diferentes regiões brasileiras - os empecilhos à cidadania da população em situação de rua oportuniza se conhecer quais os inimigos a serem enfrentados para que o desiderato de uma intervenção estatal, quando dirigida ao alvo aludido, atinja o objetivo de emancipação.

\section{População em Situação de RUa: delimitação}

A terminologia é variada: povo da rua, população de rua, população moradora de rua, moradores de rua. São aquelas pessoas de baixíssima renda que, por contingência temporária ou permanente, habitam logradouros públicos (como praças, calçadas, viadutos), áreas degradadas (como galpões, edificações em rúna, tumbas de cemitério), ou ainda pernoitam em albergues públicos, servindo tais lugares como habitat de convívio permanente. ${ }^{2}$ No Brasil, foram identificadas 31.922 pessoas maiores de 18 anos em situação de rua nas 71 cidades pesquisadas, indicando que o número é certamente mais elevado ${ }^{3}$.

Inobstante, considerar uma pessoa como sendo "de rua" significa atribuir às outras a condição de serem "de casa", "de apartamento". No entanto, vive-se em casas, ou em apartamentos, ou no espaço da rua. Quer-se dizer que se trata de uma situação contingente, portanto, vislumbrar a situação de rua como um estado,

1 LAKATOS, Eva Maria; MARCONI, Marina de Andrade. Metodologia do trabalho científico: procedimentos básicos, pesquisa bibliográfica, projeto e relatório, publicações e trabalhos científicos. $7^{\mathrm{a}}$ ed. São Paulo: Atlas, 2012. p. 110.

2 SIMÕES JÚNIOR, José Geraldo. Moradores de rua. São Paulo: Pólis, 1992. p. 17.

3 BRASIL. Ministério do Desenvolvimento Social e Combate à Fome. Rua: Aprendendo a contar: Pesquisa Nacional sobre a população em situação de rua. Brasília: Ministério do Desenvolvimento Social e Combate à Fome, Secretaria de Avaliação e Gestão da Informação, Secretaria Nacional de Assistência Social, 2009. p. 85. 
e não como um processo, é um modo de reforçá-la, omitindo a perspectiva emancipatória ao movimento. O determinismo atribuído à situação de rua como estado ofusca as esperanças de superação de dito estágio. ${ }^{4}$

\section{Entende-se emancipação como}

o processo ideológico e histórico de liberação por parte de comunidades políticas ou de grupos sociais da dependência, tutela e dominação nas esferas econômicas, sociais e culturais. Emancipar-se significa livrar-se do poder exercido por outros, conquistando, ao mesmo tempo, a plena capacidade civil e cidadã no Estado democrático de direito. Emancipar-se denota ainda aceder à maioridade de consciência, entendendo-se, por isso, a capacidade de conhecer e reconhecer as normas sociais e morais independentemente de critérios externos impostos ou equivocadamente apresentados como naturais. ${ }^{5}$

Por outro lado, não se mora na rua. A moradia (que não se confunde com o direito à propriedade) representa um direito fundamental de conexão íntima com a dignidade da pessoa humana, pois o direito à moradia digna não significa, apenas, um espaço físico para viver, mas pressupõe critérios qualitativos mínimos ${ }^{6}$. A vivência na rua por absoluto não representa a concretização do direito social à moradia, sob pena de esvaziar por completo as respectivas previsões constitucionais (mormente o artigo $6^{\circ}$, caput, e o artigo 23, inciso IX). Além disso, a rua não é um espaço digno e adequado para adquirir o status de moradia.

Observando-se essas pontuações, o Decreto n ${ }^{\circ}$ 7.053, de 23 de dezembro de 2009 (que institui a Política Nacional para a População em Situação de Rua e seu Comitê Intersetorial de Acompanhamento e Monitoramento, e dá outras providências) dispõe, no seu artigo $1^{\circ}$, parágrafo único:

Para fins deste Decreto, considera-se população em situação de rua o grupo populacional heterogêneo que possui em comum a pobreza extrema, os vínculos familiares interrompidos ou fragilizados e a inexistência de moradia convencional regular, e que utiliza os logradouros públicos e as áreas degradadas como espaço de moradia e de sustento, de forma temporária ou permanente, bem como as unidades de acolhimento para pernoite temporário ou como moradia provisória.

Por tais razões, considerando-se a vivência na rua como um processo, e não como um estado da pessoa, bem como se desvencilhando da noção de que a rua pode ser tratada como uma morada, a expressão "população em situação de rua" é mais adequada do que as outras supra-aludidas. Eis aí a primeira barreira para se atingir uma cidadania plena a tal população: dissociá-la de um estado fixo, buscando-se a superação da situação desfavorável na qual está submetida, fornecendo-lhe perspectivas por intermédio das ações estatais.

Uma segunda barreira deriva da própria característica da população em situação de rua: "é difícil pesquisar a população em situação de rua, porque ela é flutuante, temporária e nômade" ". Isso acaba gerando um estorvo para se conhecer a quantidade de pessoas, os hábitos, as necessidades, as vicissitudes de cada comunidade, enfim, para se realizar um estudo mais pormenorizado que retrate a especificidade da população investigada. A despeito disso,

sabe-se que o coletivo de pessoas em situação de rua é amplo, múltiplo e mutável, e que varia de acordo com o momento político e socioeconômico do país e região em que se estuda tal fenômeno. Sabe-se ainda que a problemática social da existência de um grande número de pessoas em situação de rua não atinge somente aos adultos do gênero masculino. Crianças, mulheres, idosos e muitas vezes famílias inteiras fazem parte dessa realidade, social e historicamente construída, em um cenário mundial marcado pela injustiça social. ${ }^{8}$

4 PRATES, Jane Cruz; PRATES, Flavio Cruz; MACHADO, Simone. Populações em situação de rua: os processos de exclusão e inclusão precária vivenciados por esse segmento. Temporalis. Brasília, n. 22, jul./dez. 2011. p. 194.

5 CATTANI, Antonio David. Emancipação social. In: HESPANHA, Pedro et al (Orgs.). Dicionário internacional de outra economia. São Paulo: Almedina, 2009. p. 175.

6 SARLET, Ingo Wolfgang. O direito fundamental à moradia na Constituição: algumas anotações a respeito de seu contexto, conteúdo e possível eficácia. Revista Brasileira de Direito Público. Belo Horizonte, n. 2, jul./set. 2003. p. 17-19.

7 ARAÚJO, Carlos Henrique. Migrações e vida nas ruas. In: BURSZTYN, Marcel (Org.). No meio da rua: nômades, excluídos e viradores. Rio de Janeiro: Garamond, 2003. p. 89.

8 ALCANTARA, Stefania Carneiro de; ABREU, Desirée Pereira; FARIAS, Alessandra Araújo. Pessoas em situação de rua: das trajetórias de exclusão social aos processos emancipatórios de formação de consciência, identidade e sentimento de pertença. Revista 
Em decorrência, o contato direto com tais pessoas para cientificá-las e instruí-las sobre a maneira de auferir um beneficio assistencial também é dificultoso, desvelando a terceira barreira. Ratificando tais assertivas, a pesquisa nacional sobre a população em situação de rua constatou que $88,5 \%$ não recebem qualquer benefício da Seguridade Social ${ }^{9}$.

\section{Políticas sociais para a população em Situação de RUa}

Conforme lições de Pereira ${ }^{10}$, é mediante políticas sociais que direitos sociais se materializam e as necessidades humanas são atendidas, sempre sob o ponto de vista de uma cidadania ampliada. A política social é, dialeticamente contraditória, e não pode ser compreendida como um processo linear, a serviço unicamente de um setor da sociedade, pois é, concomitantemente, positiva e negativa, isto é, beneficia interesses que são contrários, de acordo com a disputa de forças.

Políticas sociais se referem a ações que determinam o padrão de proteção social implementado pelo Estado, voltadas, em princípio, para a redistribuição dos benefícios sociais visando a diminuição das desigualdades estruturais produzidas pelo desenvolvimento socioeconômico. ${ }^{11}$

A política social é uma política de ação, relacionada ao Estado e aos movimentos da sociedade, escolhendo e executando decisões de interesse público, tendo como escopo influenciar o bem-estar dos indivíduos, regida por princípios de justiça social. A política social é espécie do gênero políticas públicas, compreendendo esta última todas as políticas que pressupõem a participação ativa estatal para a consecução das necessidades sociais (englobando as ações do Estado e da seara privada); ou seja, políticas públicas são "a conversão de demandas e decisões privadas e estatais em decisões e ações públicas que afetam e comprometem a todos". ${ }^{12}$

A Lei no 8.742, de 7 de dezembro de 1993 (Lei Orgânica da Assistência Social - LOAS), institui, no seu $\operatorname{artigo} 1^{\circ}$, que

a assistência social, direito do cidadão e dever do Estado, é Política de Seguridade Social não contributiva ${ }^{13}$, que provê os mínimos sociais, realizada através de um conjunto integrado de ações de iniciativa pública e da sociedade, para garantir o atendimento às necessidades básicas.

Mínimo existencial é "um direito às condições mínimas de existência humana digna" e, por conta disso, exige prestações estatais positivas para sua materialização. Em que pese careça de conteúdo precisamente específico, o mínimo existencial abrange direitos essenciais, inalienáveis e imensuráveis (pois envolve mais o aspecto qualitativo do que o quantitativo). A carência do mínimo existencial poda toda condição para o exercício da liberdade e, deveras, impossibilita a sobrevivência humana. ${ }^{14}$

O texto legal retrorreferido peca pela imprecisão por confundir "mínimo" e "básico”, porque o primeiro liga-se a uma noção de algo menor possível, o segundo reflete algo que serve de sustentação indispensável, uma base fundamental. Dever-se-ia, entretanto, almejar o "padrão ótimo" de satisfação das necessidades humanas, salientando-se que dito patamar depende da moralidade de cada cultura e não é sinônimo de um

Colombiana de Psicologia. Bogotá, v. 24, n. 1, ene./jun. 2015. p. 142.

9 BRASIL. Ministério do Desenvolvimento Social e Combate à Fome. Rua: Aprendendo a contar: Pesquisa Nacional sobre a população em situação de rua. Brasília: Ministério do Desenvolvimento Social e Combate à Fome, Secretaria de Avaliação e Gestão da Informação, Secretaria Nacional de Assistência Social, 2009. p. 97.

10 PEREIRA, Potyara Amazoneida Pereira. Política social: temas \& questões. $2^{a}$ ed. São Paulo: Cortez, 2009. p. 165-166.

11 HÖFLING, Eloisa de Mattos. Estado e políticas (públicas) sociais. Cadernos Cedes, no 55, nov. 2001. p. 31.

12 PEREIRA, Potyara Amazoneida Pereira. Política social: temas \& questões. $2^{a}$ ed. São Paulo: Cortez, 2009. p. 166-174.

13 Artigo 203 da Constituição Federal: A assistência social será prestada a quem dela necessitar, independentemente de contribuição à seguridade social [...].

14 TORRES, Ricardo Lobo. O mínimo existencial e os direitos fundamentais. Revista de Direito Administrativo. Rio de Janeiro, v. 177, jul./set. 1989. p. 29-30. 
utópico "máximo", mas sim relativo a medidas mais elevadas de aquisições de bens, serviços, direitos, alcançadas pelo dinamismo e positividade nas políticas sociais e nas políticas econômicas. ${ }^{15}$

A quarta barreira, nesse paradigma, é a percepção da substância dos “mínimos sociais" à população em situação de rua. Sposati ${ }^{16}$ aduz que os mínimos sociais compreendem a cobertura dos riscos e das garantias para os cidadãos de uma sociedade, sendo incompatível com a seletividade e o focalismo. Estabelecendo-se um "padrão societário de civilidade", ou um "padrão básico de inclusão", ou um "padrão de vida básico", por meio de uma interpretação ampla e cidadã de mínimos sociais — isto é, fugindo-se de uma concepção minimalista de mínimos sociais -, visa-se atingir a sobrevivência biológica, a condição de possibilidade para trabalhar, a qualidade de vida, o desenvolvimento humano e as necessidades humanas.

A ideia de mínimo existencial tem sido utilizada para contornar barreiras impostas à concretização dos direitos básicos (notadamente em sua dimensão prestacional). Ao se reconhecer que determinado direito integra o mínimo existencial, deve-se entender que se está diante de direito subjetivo, não cabendo, assim, a alegação de ausência de recursos para efetivar as prestações estatais. ${ }^{17}$

Para se assegurar os direitos sociais às pessoas em situação de rua, imperiosa a adoção, de um lado, de políticas pública de proteção social para a cobertura das vulnerabilidades, reduzindo os riscos sociais e preconizando o estabelecimento de um padrão de vida básico, e, de outro, de políticas públicas de desenvolvimento social como educação, cultura, saúde, que enxerguem as potencialidades humanas para que, em comunhão com a tecnologia, propiciem uma vivência mais longeva e de melhor qualidade. ${ }^{18}$

A Política Nacional para a População em Situação de Rua institui princípios, diretrizes e objetivos ao seu público. Destaca-se, no ordenamento jurídico brasileiro, por ser um instrumento normativo voltado especificamente às pessoas em situação de rua. Tal Política é "implementada de forma descentralizada e articulada entre a União e os demais entes federativos que a ela aderirem por meio de instrumento próprio" (artigo $2^{\circ}$, caput, da própria Política Nacional para a População em Situação de Rua).

Os princípios dessa Política, insculpidos no artigo $5^{\circ}$, preconizam, em síntese, a busca da igualdade e o repúdio às discriminações para com as pessoas em situação de rua, respeitando-as e atendendo-as como pessoas humanas dignas, com direito à convivência com a família e a comunidade, privilegiando, em última instância, a cidadania e a vida.

O tratamento homogeneizante do Estado à população em situação de rua configura, assim, a quinta barreira para uma consolidação da cidadania por intermédio de políticas sociais. Com efeito, os serviços públicos não desenvolvem suas "estratégias levando em conta o princípio da heterogeneidade. A indiferenciação parece ser a máxima dos serviços, quando o que se necessita são respostas diferentes para questões múltiplas" ${ }^{19}$. O desrespeito à diversidade e às diferenças de cada pessoa em situação de rua, inclusive quanto ao motivo de se estar em tal estágio, não legitima que soluções idênticas sejam tomadas invariavelmente aos distintos casos.

As diretrizes (artigo $\left.6^{\circ}\right)^{20}$ da Política Nacional para a População em situação de Rua retratam, basicamen-

15 PEREIRA, Potyara Amazoneida Pereira. Necessidades humanas: subsídios à crítica dos mínimos sociais. $3^{a}$ ed. São Paulo: Cortez, 2006. p. 26-31.

16 SPOSATI, Aldaíza. Mínimos sociais e seguridade social: uma revolução da consciência da cidadania. Serviço Social \& Sociedade. n. 55 , nov. 1997. p. 10-16.

17 SOUZA, Pedro Bastos de. Benefícios de renda mínima como um direito fundamental: acesso à justiça e inclusão social. Revista Brasileira de Politicas Públicas. Brasília, v. 6, n. 1, 2016. p. 171.

18 SPOSATI, Aldaíza. Mínimos sociais e seguridade social: uma revolução da consciência da cidadania. Serviço Social \& Sociedade. n. 55 , nov. 1997. p. 28-29.

19 SILVA, Rosimeire Barboza da; COSTA, Alderon Pereira da. Direitos humanos da população em situação de rua? Paradoxos e aproximações à uma vida digna. Revista Direitos Humanos e Democracia. n. 6, jul./dez. 2015. p. 124.

20 Art. $6^{\circ}$ : São diretrizes da Política Nacional para a População em Situação de Rua: I - promoção dos direitos civis, políticos, econômicos, sociais, culturais e ambientais; II - responsabilidade do poder público pela sua elaboração e financiamento; III - articulação das políticas públicas federais, estaduais, municipais e do Distrito Federal; IV - integração das políticas públicas em cada nível 
te, a promoção dos direitos sociais, civis, econômicos e políticos, que produzirão efeitos em todas as áreas do convívio social da população sem-teto, incumbindo, precipuamente, o Estado como o ator obrigatório para a concretização de seus preceitos, com a comunhão de esforços das políticas públicas entre todos os entes da federação e prevendo a participação ativa da população alvo em tais intervenções estatais. O caráter democrático, como não poderia deixar de sê-lo, é subjacente no texto da Política.

Os objetivos ${ }^{21}$ da Política Nacional para a População em Situação de Rua estipulam um passo além da concessão da moradia às pessoas beneficiárias, mormente por não ser a visão minimalista - que cercasse a questão social à habitação ${ }^{22}$ - adequada sequer a um atingimento de um padrão básico de vida. Por consequência, o papel visceral da Assistência Social, integrante da Seguridade Social, como "um direito social e uma ampliação para a cidadania e explicitamente reivindicada como um estatuto de política social"23, em especial para criar programas de amparo às pessoas em situação de rua (consoante previsão do artigo $23, \mathbb{S}$ $2^{\circ}$, inciso II, da Lei Orgânica da Assistência Social, incluído pela Lei no 12.435/2011).

A Política Nacional para Inclusão Social da População em Situação de Rua, por sua vez, reconhece, em seu título - que estampa seu objetivo -, que as pessoas em situação de rua imprescindem de reinserção social. O documento ressalta que o Estado e a sociedade dirigem às pessoas sem-teto uma visão estigmatizante, desencadeando ações autoritárias e higienizantes ${ }^{24}$. Ainda,

a rua não deve ser vista somente como lugar de circulação entre espaços privados, uma espécie de limbo entre situações reconhecidas, mas como espaço em si, tão abarcador e produtor de realidades como

de governo; V - integração dos esforços do poder público e da sociedade civil para sua execução; VI - participação da sociedade civil, por meio de entidades, fóruns e organizações da população em situação de rua, na elaboração, acompanhamento e monitoramento das políticas públicas; VII - incentivo e apoio à organização da população em situação de rua e à sua participação nas diversas instâncias de formulação, controle social, monitoramento e avaliação das políticas públicas; VIII - respeito às singularidades de cada território e ao aproveitamento das potencialidades e recursos locais e regionais na elaboração, desenvolvimento, acompanhamento e monitoramento das políticas públicas; IX - implantação e ampliação das ações educativas destinadas à superação do preconceito, e de capacitação dos servidores públicos para melhoria da qualidade e respeito no atendimento deste grupo populacional; e X - democratização do acesso e fruição dos espaços e serviços públicos.

21 Art. $7^{\circ}$ : São objetivos da Política Nacional para a População em Situação de Rua: I - assegurar o acesso amplo, simplificado e seguro aos serviços e programas que integram as políticas públicas de saúde, educação, previdência, assistência social, moradia, segurança, cultura, esporte, lazer, trabalho e renda; II - garantir a formação e capacitação permanente de profissionais e gestores para atuação no desenvolvimento de políticas públicas intersetoriais, transversais e intergovernamentais direcionadas às pessoas em situação de rua; III - instituir a contagem oficial da população em situação de rua; IV - produzir, sistematizar e disseminar dados e indicadores sociais, econômicos e culturais sobre a rede existente de cobertura de serviços públicos à população em situação de rua; V - desenvolver ações educativas permanentes que contribuam para a formação de cultura de respeito, ética e solidariedade entre a população em situação de rua e os demais grupos sociais, de modo a resguardar a observância aos direitos humanos; VI incentivar a pesquisa, produção e divulgação de conhecimentos sobre a população em situação de rua, contemplando a diversidade humana em toda a sua amplitude étnico-racial, sexual, de gênero e geracional, nas diversas áreas do conhecimento; VII - implantar centros de defesa dos direitos humanos para a população em situação de rua; VIII - incentivar a criação, divulgação e disponibilização de canais de comunicação para o recebimento de denúncias de violência contra a população em situação de rua, bem como de sugestões para o aperfeiçoamento e melhoria das políticas públicas voltadas para esse segmento; IX - proporcionar o acesso das pessoas em situação de rua aos benefícios previdenciários e assistenciais e aos programas de transferência de renda, na forma da legislação específica; X - criar meios de articulação entre o Sistema Único de Assistência Social e o Sistema Único de Saúde para qualificar a oferta de serviços; XI - adotar padrão básico de qualidade, segurança e conforto na estruturação e reestruturação dos serviços de acolhimento temporários, de acordo com o disposto no art. $8^{\circ}$; XII - implementar centros de referência especializados para atendimento da população em situação de rua, no âmbito da proteção social especial do Sistema Único de Assistência Social; XIII - implementar ações de segurança alimentar e nutricional suficientes para proporcionar acesso permanente à alimentação pela população em situação de rua à alimentação, com qualidade; e XIV - disponibilizar programas de qualificação profissional para as pessoas em situação de rua, com o objetivo de propiciar o seu acesso ao mercado de trabalho.

22 Embora seja controverso, há quem distinga moradia de habitação, sendo esta a efetivação fática daquela. "A moradia é a expressão social concreta do problema de urbanização, que essencialmente consiste em uma concentração de proporções crescentes de população em determinadas cidades e uma mudança das condições de consumo e acesso a emprego da população urbanizada. A habitação é a forma física que toma a solução desse problema.” (PEDRÃO, 1989. p. 20)

23 SCHONS, Selma Maria. Assistência social entre a ordem e a "des-ordem": mistificação dos direitos sociais e da cidadania. São Paulo: Cortez, 1999. p. 191.

24 BRASIL. Governo Federal. Política Nacional para Inclusão Social da População em Situação de Rua. Brasília, 2008. Disponível em: <http://www.recife.pe.gov.br/noticias/arquivos/2297.pdf>. Acesso em 07 jun. 2016. p. 4. 
qualquer outro. Estar na rua é ocupá-la, não como violação do espaço limpo e vazio. ${ }^{25}$

A citada Política, então, intenta a (re)inclusão das pessoas em situação de rua em suas famílias e na comunidade, o acesso aos direitos de todo cidadão, e o oferecimento de oportunidade de desenvolvimento social pleno, isto é, o estabelecimento de uma reinserção social que pressupõe uma intervenção estatal para a provisão de um mínimo [ou básico, ou ótimo] de bem-estar, de padrões básicos de dignidade, para considerá-las "cidadãs integrais", sob a luz dos direitos sociais. ${ }^{26}$

Os princípios da Política Nacional, para Inclusão Social da População em Situação de Rua ${ }^{27}$, são: a promoção e a garantia da cidadania e dos direitos humanos; o respeito à dignidade do ser humano, sujeito de direitos civis, políticos, sociais, econômicos e culturais; o direito ao usufruto, permanência, acolhida e inserção na cidade; a não discriminação por motivo de gênero, orientação sexual, origem étnica ou social, nacionalidade, atuação profissional, religião, faixa etária e situação migratória; e a supressão de todo e qualquer ato violento e ação vexatória, inclusive os estigmas negativos e preconceitos sociais em relação à população em situação de rua.

A Política ${ }^{28}$ estabelece ações estratégicas para a população sem-teto, das quais se salienta: a capacitação dos agentes do Estado ligados diretamente ao Direito (especialmente a força policial) quanto aos direitos humanos, principalmente àqueles concernentes à população em situação de rua; a responsabilização e combate à impunidade dos crimes e atos de violência contra a população em situação de rua, ampliando, assim, a possibilidade de que a rua seja um espaço de maior segurança; a promoção de capacitação, qualificação e requalificação profissional da população em situação de rua para o trabalho e emprego; a ampliação da discussão sobre níveis de renda para a população em situação de rua; a criação de alternativas de moradia para população em situação de rua nos projetos habitacionais financiados pelo Governo Federal; a estruturação da rede de acolhida, de acordo com a heterogeneidade e diversidade da população em situação de rua, reordenando práticas homogeinizadoras, massificadoras e segregacionistas na oferta dos serviços, especialmente os albergues; a inclusão de pessoas em situação de rua no Benefício de Prestação Continuada e no Programa Bolsa Família; a oferta regular de educação de jovens e adultos, especialmente no que se refere à alfabetização, com facilitação de ingresso em sala de aula em qualquer época do ano; a promoção do direito à segurança alimentar e nutricional da população em situação de rua, por meio de restaurantes populares; a garantia da atenção integral à saúde das pessoas em situação de rua e adequação das ações e serviços existentes, assegurando a equidade e o acesso universal no âmbito do Sistema Único de Saúde, com dispositivos de cuidados interdisciplinares e multiprofissionais; e a promoção de amplo acesso aos meios de informação, criação, difusão e fruição cultural.

É sabido, porém, que historicamente no Brasil a representatividade social na esfera política é marcada por partidos políticos que voltam seus holofotes muito mais ao Estado do que à sociedade civil, com raras exceções, restringindo a busca pela representatividade na sociedade civil aos momentos eleitorais e aos demais mecanismos espúrios, tais como o clientelismo e as "relações de favores". ${ }^{29}$ A representatividade por aqueles que deveriam fazê-lo à população em situação de rua, nesse cenário, é inexpressiva. Além disso,

a experiência vivida, de sofrimento e privação traz, à pessoa em situação de rua, a memória da construção social da sua inferiorização. É, dentre outras coisas, um lugar de conhecimento sobre a sociodinâmica

25 BRASIL. Governo Federal. Política Nacional para Inclusão Social da População em Situação de Rua. Brasília, 2008. Disponível em: $<$ http://www.recife.pe.gov.br/noticias/arquivos/2297.pdf>. Acesso em 07 jun. 2016. p. 4.

26 BRASIL. Governo Federal. Politica Nacional para Inclusão Social da População em Situação de Rua. Brasília, 2008. Disponível em: <http://www.recife.pe.gov.br/noticias/arquivos/2297.pdf>. Acesso em 07 jun. 2016. p. 4-6.

27 BRASIL. Governo Federal. Política Nacional para Inclusão Social da População em Situação de Rua. Brasília, 2008. Disponível em: <http://www.recife.pe.gov.br/noticias/arquivos/2297.pdf>. Acesso em 07 jun. 2016. p. 14.

28 BRASIL. Governo Federal. Política Nacional para Inclusão Social da População em Situação de Rua. Brasília, 2008. Disponível em: <http://www.recife.pe.gov.br/noticias/arquivos/2297.pdf>. Acesso em 07 jun. 2016. p. 16-22.

29 DAGNINO, Evelina. Sociedade civil, espaços públicos e a construção democrática do Brasil: limites e possibilidades. In: DAGNINO, Evelina (Org.). Sociedade civil e espaços públicos no Brasil. São Paulo: Paz e Terra, 2002. p. 279. 
da apartação e expõe, na explicitação das estratégias de extrema submissão, a falibilidade das políticas assistenciais, de habitação, de saúde, de trabalho e emprego. A sociedade brasileira precisa avançar para apoiar que essa memória e esse conhecimento sejam vocalizados, socializados e tidos em conta em arenas que o convertam e disponibilizem para um novo patamar de políticas públicas e civilidade. ${ }^{30}$

O precipício que intermedeia o diálogo direto entre população em situação de rua e Estado é a sexta barreira que se depara. Os espaços públicos devem lhes propiciar instrumentos hábeis para a participação ativa e democrática na seara pública, haja vista que, nos termos da Pesquisa Nacional sobre a População em Situação de Rua ${ }^{31}$, 95,5\% dos sem-teto não participam de qualquer movimento social ou de qualquer atividade associativa, e 61,6\% não possuem título de eleitor e, consequentemente, não votam. Do contrário, prejudica-se a participação política e, assim, elide-se a construção de uma democracia participativa em razão da rejeição da constituição de espaços públicos que sirvam à inclusão social mediante políticas públicas de bem-estar social ${ }^{32}$. A conjuntura em tela é imbricada de modo indissociável com o exercício da cidadania.

\section{Cidadania e população em Situação de RUa}

A noção sobre cidadania é diversa, dependendo do momento histórico em que se está analisando-a. Sua origem remonta à Grécia antiga, onde, em suma, cidadão era quem pertencesse a polis. A democracia direta ateniense era exercida, somente pela parcela pequena e limitada de cidadãos (que compunham a também restrita parcela de habitantes que detinham o atributo da cidadania), se comparada com o número total de habitantes, o que diferencia a concepção antiga e hodierna de cidadania. ${ }^{33}$

Isso porque, veiculando um fundamento da República Federativa do Brasil (artigo $1^{\circ}$, inciso II, da Constituição Federal),

a cidadania é um status concedido àqueles que são membros integrais de uma comunidade. Todos aqueles que possuem o status são iguais com respeito aos direitos e obrigações pertinentes ao status. Não há nenhum princípio universal que determine o que estes direitos e obrigações serão, mas as sociedades nas quais a cidadania é uma instituição em desenvolvimento criam uma imagem de uma cidadania ideal em relação à qual o sucesso pode ser medido e em relação à qual a aspiração pode ser dirigida. ${ }^{34}$

Para a existência da cidadania, é necessário que os sujeitos ajam e lutem pelos seus direitos, trazendo os assuntos aos olhos do político, transformando o cotidiano. A revolução interna, logo, deve configurar o estopim para uma cidadania plena, rompendo-se com o autoritarismo e com o consumismo típico do capitalismo, inclusive com a participação política democrática, dirigindo os sujeitos ao mundo utópico. ${ }^{35}$

A cidadania deve ser plena ${ }^{36}$, como a "competência humana de fazer-se sujeito, para fazer história própria

30 VALENCIO, Norma Felicidade Lopes da Silva et al. Pessoas em situação de rua no Brasil: estigmatização, desfiliação e desterritorialização. Revista Brasileira de Sociologia da Emoção. v. 7, n. 21, dez. 2008. p. 595.

31 BRASIL. Ministério do Desenvolvimento Social e Combate à Fome. Rua: Aprendendo a contar: Pesquisa Nacional sobre a população em situação de rua. Brasília: Ministério do Desenvolvimento Social e Combate à Fome, Secretaria de Avaliação e Gestão da Informação, Secretaria Nacional de Assistência Social, 2009. p. 99.

32 SPENGLER, Fabiana Marion; OLIVEIRA, Luthyana Demarchi de. Mediação como política pública de fortalecimento da democracia participativa. Revista Brasileira de Políticas Públicas. Brasília, v. 2, n. 2, 2012. p. 139.

33 COSTA, Eder Dion de Paula. Povo e cidadania no Estado Democrático de Direito. Revista da Faculdade de Direito da Universidade Federal do Paraná. Curitiba, v. 38, 2003. p. 101-103.

34 MARSHALL, Thomas Humphrey. Cidadania, classe social e status. Tradução de Meton Porto Gadelha. Rio de Janeiro: Zahar Editores, 1967. p. 76.

35 COVRE, Maria de Lourdes Manzini. O que é cidadania. São Paulo: Brasiliense, 2002. p. 73-73.

36 Nem a cidadania tutelada nem a cidadania assistida devem ser o escopo das políticas sociais. Diferentemente da cidadania plena, (a) a cidadania tutelada caracteriza-se pela concessão paternalista ou clientelista, mantendo inalterada a pobreza política, negando a cidadania plena, e (b) a cidadania assistida é uma forma mais amena de pobreza política, que, ao preferir a assistência à emancipação, reproduz igualmente a aludida pobreza, não se implicando a equalização das oportunidades, maquiando a marginalização (DEMO, 1995, p. 6-7). "Por pobreza política compreende-se a dificuldade histórica de o pobre superar a condição de objeto 
e coletivamente organizada". Acarreta o direito à assistência aos que dela necessitarem, sempre sob o viés emancipatório, realocando o mercado à posição de meio, e não como fim (característica do sistema capitalista), lugar este a ser assumido pela cidadania (ou seja: a economia a serviço da cidadania, e não o revés), perpassando pela prioridade estratégica para a educação e o conhecimento, a promoção do bem-estar e dos direitos humanos, a identidade cultural, a organização política. O Estado possui papel singular nessa trajetória rumo à emancipação. ${ }^{37}$

Realmente, os pobres são excluídos da cidadania seja pela ausência de trabalho, de renda regular, de vínculos coletivos estáveis que não se limitem ao convívio familiar ou de vizinhança (sentido material), seja por não possuírem documentos atualizados (sentido formal) ${ }^{38}$ - a pesquisa nacional sobre a população em situação de rua ${ }^{39}$ constatou que $24,8 \%$ dessas pessoas não possuem qualquer documento de identificação.

A sétima barreira se ergue, portanto, pela ação assistencialista que pode revestir as políticas sociais para a população em situação de rua. O mero implemento de ações de bem-estar social para solucionar efetivamente os problemas sociais (como a exploração e a miséria), olvidando de erradicar as causas da dependência, a despeito da perspectiva da igualdade e da justiça social, configura a prática assistencialista (e não de assistência $)^{40}$.

Os programas sociais desenvolvidos nesse contexto trazem a marca ideológica do descarte social de uma população que é tratada como excedente. São programas marcados pela institucionalização de práticas que visam à retirada dessas pessoas das ruas, oferecendo, entretanto poucas possibilidades de uma reestruturação de suas vidas. O descarte introjetado pelo próprio sujeito o destitui de seu papel social. ${ }^{41}$

A assistência é um direito que deve pretender a futura desvinculação do assistido, fornecendo-lhe meios para a sobrevivência independente, ressalvados os casos em que ela é permanente e presumidamente enfrentada arduamente pelo indivíduo, como nos casos de idosos, por exemplo, onde a assistência deve ser perene. Dessa forma, "a finalidade da assistência é restaurar condições mínimas para que, no menor prazo possível, seja possível dispensá-la”, conferindo emancipação ao cidadão para que seja possível a construção de seu projeto de vida independentemente de auxílio alheio. ${ }^{42}$

Até porque "os programas sociais vindos de cima para baixo são pagos e financiados pelos trabalhadores e se inscrevem num contexto muito mais complexo, que os discursos nem sequer prenunciam, ou melhor, distorcem e camuflam" ${ }^{33}$. De fato, cada cidadão, principalmente por meio da carga tributária advinda dos impostos (que, diga-se, não são amenos no Brasil), financia ${ }^{44}$ o sistema da Assistência Social. É a sociedade que se solidariza com aqueles que necessitam de assistência, sob o fundamento da solidariedade e da justiça social.

manipulado, para atingir a de sujeito consciente e organizado em torno de seus interesses. Manifesta-se na dimensão da qualidade, embora seja sempre condicionada pelas carências materiais também. Mas a essas jamais se reduz, apontando para o déficit de cidadania." (DEMO, 2000, p. 20)

37 DEMO, Pedro. Cidadania tutelada e assistida. Campinas: Autores Associados, 1995. p. 1-6.

38 REGO, Walquiria Leão; PINZANI, Alessandro. Vožes do bolsa família: autonomia, dinheiro e cidadania. $2^{a}$ ed. São Paulo: Editora Unesp, 2014. p. 196.

39 BRASIL. Ministério do Desenvolvimento Social e Combate à Fome. Rua: Aprendendo a contar: Pesquisa Nacional sobre a população em situação de rua. Brasília: Ministério do Desenvolvimento Social e Combate à Fome, Secretaria de Avaliação e Gestão da Informação, Secretaria Nacional de Assistência Social, 2009. p. 97.

40 ALAYÓN, Norberto. Assistência e assistencialismo: controle dos pobres ou erradicação da pobreza? Tradução de Balkys Villalobos de Netto. $2^{\text {a }}$ ed. São Paulo: Cortez, 1995. p. 53-54.

41 VARANDA, Walter; ADORNO, Rubens de Camargo Ferreira. Descartáveis urbanos: discutindo a complexidade da população de rua e o desafio para políticas de saúde. Saúde e Sociedade. São Paulo, v. 13, n. 1, jan./abr. 2004. p. 66.

42 DEMO, Pedro. Cidadania tutelada e assistida. Campinas: Autores Associados, 1995. p. 110.

43 FALEIROS, Vicente de Paula. O que é política social. São Paulo: Brasiliense, 2004. p. 18.

44 Artigo 28, caput, da Lei Orgânica da Assistência Social: O financiamento dos benefícios, serviços, programas e projetos estabelecidos nessa lei far-se-á com os recursos da União, dos Estados, do Distrito Federal e dos Municípios, das demais contribuições sociais previstas no art. 195 da Constituição Federal, além daqueles que compõem o Fundo Nacional de Assistência Social (FNAS). 
Nesse prisma, a crítica que se faz em relação à Política Nacional para a População em Situação de Rua, cujos fundamentos se estendem à Política Nacional para Inclusão Social da População em Situação de Rua, é que, ao ocultar as causas estruturais da situação de rua, filia-se à ideologia liberal e individualizante que culpabiliza o sujeito pelo infortúnio sofrido. Ou seja: não é a situação de rua que é o cerne da Política, mas os seus prováveis beneficiários. Esse modo reducionista de lidar com o problema deságua na ausência de políticas públicas que atendam adequadamente à complexidade inerente à situação de rua. ${ }^{45}$

Ora, "ter um teto ou um chão é um mínimo social plenamente possível, principalmente num país de dimensões continentais como o nosso" ${ }^{46}$. No entanto, o contexto político-econômico que circunda (e penetra) no Estado influi, decisivamente, no modo de se conceber as políticas sociais para os necessitados.

A atual onda neoliberal que permeia o ocidente apregoa a ideia de que o Estado não deve intervir nas políticas sociais de seguridade social, porquanto o mercado regularia as questões de tal ordem por meio de uma economia totalmente livre ${ }^{47}$. Destarte, o neoliberalismo se funda na ideia de menos Estado e mais mercado, favorecendo-se o individualismo e não o igualitarismo ${ }^{48}$. O neoliberalismo iniciou, efetivamente, a sua jornada em terras brasileiras a partir do governo de Fernando Henrique Cardoso e a inauguração do Plano Real, constituído na administração de Itamar Franco ${ }^{49}$.

Corroborando, $\mathrm{Mises}^{50}$, um dos expoentes do neoliberalismo, aduz:

O problema dos incapacitados é um problema específico da civilização humana e da sociedade. Animais aleijados morrem logo; de fome ou nas garras dos adversários de sua espécie. O homem selvagem não se apiedava dos inválidos; muitas tribos praticavam métodos brutais de extermínio, aos quais os nazistas recorreram no nosso tempo. A própria existência de um número relativamente maior de inválidos é, por mais paradoxal que pareça, um traço característico da civilização e do bem-estar material.

Nesse diapasão, a oitava barreira se encontra na postura brasileira de afeição, ainda que com ressalvas, ao neoliberalismo ${ }^{51}$, acarretando a diminuição da intervenção estatal, agente mais relevante no oferecimento de instrumentos para a luta pela cidadania das pessoas em situação de rua. O abstencionismo estatal, em particular quanto à população em situação de rua, reduz deveras as esperanças de reinserção social ${ }^{52}$, obtenção de emprego, de educação, de segurança, enfim, de superação da condição vulnerável da qual as pessoas sem-teto são reféns.

Por isso que é "urgente a organização de uma agenda mínima para a defesa dos direitos sociais ainda remanescentes do Texto Constitucional, bem como na busca da instituição de novos direitos" "53. A aceitação

45 SILVA, Rosimeire Barboza da; COSTA, Alderon Pereira da. Direitos humanos da população em situação de rua? Paradoxos e aproximações a uma vida digna. Revista Direitos Humanos e Democracia. n. 6, jul./dez. 2015. p. 122.

46 SPOSATI, Aldaíza. Mínimos sociais e seguridade social: uma revolução da consciência da cidadania. Serviço Social \& Sociedade. n. 55, nov. 1997. p. 12.

47 COSTA, José Ricardo Caetano. Neoconservadorismo e direitos previdenciários: a (des)constituição dos direitos sociais previdenciários nas duas últimas duas décadas In: BRAUNER, Maria Claudia Crespo; LOBATO, Anderson Orestes Cavalcante (Orgs.). Direito e justiça social: a construção jurídica dos direitos de cidadania. Rio Grande: Editora da Furg, 2015. p. 87-88.

48 MACHADO, Aquidaban F. Políticas públicas no Estado do bem-estar social e no neoliberalismo: alguns aspectos. Direito em Debate. n. 20, jul./dez. 2003. p. 91.

49 CARINHATO, Pedro Henrique. Neoliberalismo, reforma do Estado e políticas sociais nas últimas décadas do século XX no Brasil. Aurora. n. 3, dez. 2008. p. 39.

50 MISES, Ludwig von. Ação humana: um tratado de economia. $3^{\text {a }}$ ed. rev. São Paulo: Instituto Ludwig von Mises Brasil, 2010. p. 945.

51 "Com a tendente afirmação dos neoliberais, nos quais aparece uma declarada indisposição quanto à Assistência, especialmente a do Estado, quando está de volta a ideia do pobre como alguém que não deu certo no mercado e outras limitações [...], pode-se falar em cidadania em Estados onde o bem-estar fica reservado a um contingente quase inexpressivo da população? Seria então a cidadania um privilegio dessa minoria? Como fica, nesse caso, o seu caráter 'universalizante'?” (SCHONS, 1999, p. 49)

52 Já se afirmou que "o neoliberalismo se difere do nazismo apenas nos seus métodos, pois, enquanto no nazismo, como em outros sistemas políticos totalitários, a violência se impõe pelo terror e pela força, no neoliberalismo a violência se dá pela intimidação e pela exclusão social" (MOREIRA, 2007, p. 181).

53 COSTA, José Ricardo Caetano. Neoconservadorismo e direitos previdenciários: a (des)constituição dos direitos sociais previdenciários nas duas últimas duas décadas In: BRAUNER, Maria Claudia Crespo; LOBATO, Anderson Orestes Cavalcante (Orgs.). 
da política neoliberal, no âmbito nacional, em sua pura essência, é inconstitucional, em virtude da orientação preponderantemente social que norteia a Constituição Federal brasileira, alcunhada de "cidadã". A assunção de forma diversa de gerir e conduzir o Estado brasileiro significa romper com o pacto social em detrimento da solidariedade, da redução das desigualdades sociais, da justiça social, e, em última análise, da dignidade da pessoa humana.

\section{Considerações finais}

As políticas sociais enfrentam desafios (barreiras) para uma efetiva cidadania para a população em situação de rua. São empecilhos ligados ora à condição especial que estão submetidas às respectivas pessoas, ora ao modelo econômico vigente, ora à ótica sobre as políticas sociais implantadas pelo Estado, ora a fatores outros.

Sinteticamente, as barreiras são: (a) considerar a situação de rua como um estado, e não como um processo, tolhendo as esperanças de superação, bem como retratar a rua como uma possível moradia; (b) a dificuldade de pesquisa, mapeamento e conhecimento mais detalhado sobre as pessoas em situação de rua; (c) a dificuldade de cientificação da população em situação de rua acerca dos direitos que lhe pertencem; (d) o estabelecimento de um mínimo social, de um padrão de vida básico ou de um padrão de vida ótimo para a população em situação de rua, na conjuntura da Lei Orgânica da Assistência Social; (e) o tratamento homogênico do Estado para com a população em situação de rua; (f) a ausência de voz direta e de representatividade política das pessoas em situação de rua nos espaços públicos; (g) o caráter assistencialista que pode assumir as políticas sociais para a população em situação de rua, não como uma medida emancipatória; e (h) a intimidade atual do cenário político brasileiro com o neoliberalismo.

Diante da complexidade, é impossível se esgotar o diagnóstico das ditas barreiras. No entanto, a identificação daquelas que mais se destacam propicia que se aja objetivando a sua superação. Outrossim, rastreando-se os obstáculos, inevitavelmente se descobrem questões que podem passar desapercebidas na apreciação do objeto central, propiciando um aprofundamento do debate sobre a forma procedimental estatal a respeito da população em situação de rua.

E isso, evidentemente, dialoga com a cidadania e com a dignidade da pessoa humana. Em um sistema em que o mercado dita a forma de vivência da sociedade, com o aval do Estado, o triunfo de um projeto de vida sem os instrumentos necessários para tanto é uma ação quase impossível. É inegável a descrença no sentido de que as pessoas sem-teto não adquirirão, por si sós, moradia, educação de qualidade, saúde, em resumo, condições mínimas existenciais. Daí o papel decisivo do Estado nesse jogo da sobrevivência.

Seja amenizando o apetite insaciável do capitalismo, abrindo-se gigantescas brechas no seu modelo ideal para ingressar uma visão da importância social de respeito aos vulneráveis, submetendo o mercado à cidadania (o que desnaturaria o capitalismo), seja por meio da instauração de uma sociedade alternativa, a população em situação de rua requer proteção e, além disso, de munição social suficiente para que a assistência possa ser, futuramente, dispensada. Dessa forma, a luta da população em situação de rua pela cidadania e pela dignidade da pessoa humana traduz-se em destruir barreiras.

Direito e justiça social: a construção jurídica dos direitos de cidadania. Rio Grande: Editora da Furg, 2015. p. 110. 


\section{ReferênCIAS BIBLIOGRÁFICAS}

ALAYÓN, Norberto. Assistência e assistencialismo: controle dos pobres ou erradicação da pobreza? Tradução de Balkys Villalobos de Netto. 2a ed. São Paulo: Cortez, 1995.

ALCANTARA, Stefania Carneiro de; ABREU, Desirée Pereira; FARIAS, Alessandra Araújo. Pessoas em situação de rua: das trajetórias de exclusão social aos processos emancipatórios de formação de consciência, identidade e sentimento de pertença. Revista Colombiana de Psicologia, Bogotá, v. 24, n. 1, p. 129-143, ene./jun. 2015.

ARAÚJO, Carlos Henrique. Migrações e vida nas ruas. In: BURSZTYN, Marcel (Org.). No meio da rua: nômades, excluídos e viradores. Rio de Janeiro: Garamond, 2003. p. 88-120.

BRASIL. Governo Federal. Política Nacional para Inclusão Social da População em Situação de Rua. Brasília, 2008. Disponível em: http://www.recife.pe.gov.br/noticias/arquivos/2297.pdf. Acesso em: 07 jun. 2016.

BRASIL. Ministério do Desenvolvimento Social e Combate à Fome. Rua: Aprendendo a contar. Pesquisa Nacional sobre a população em situação de rua. Brasília: Ministério do Desenvolvimento Social e Combate à Fome, Secretaria de Avaliação e Gestão da Informação, Secretaria Nacional de Assistência Social, 2009.

CARINHATO, Pedro Henrique. Neoliberalismo, reforma do Estado e políticas sociais nas últimas décadas do século XX no Brasil. Aurora. n. 3, p. 37-46, dez. 2008.

CATTANI, Antonio David. Emancipação social. In: HESPANHA, Pedro et al (Orgs.). Dicionário internacional de outra economia. São Paulo: Almedina, 2009. p. 175-180.

COSTA, Eder Dion de Paula. Povo e cidadania no Estado Democrático de Direito. Revista da Faculdade de Direito da Universidade Federal do Paraná, Curitiba, v. 38, p. 101-121, 2003.

COSTA, José Ricardo Caetano. Neoconservadorismo e direitos previdenciários: a (des)constituição dos direitos sociais previdenciários nas duas últimas duas décadas In: BRAUNER, Maria Claudia Crespo; LOBATO, Anderson Orestes Cavalcante (Orgs.). Direito e justiça social: a construção jurídica dos direitos de cidadania. Rio Grande: Editora da Furg, 2015. p. 85-112.

COVRE, Maria de Lourdes Manzini. O que é cidadania. São Paulo: Brasiliense, 2002.

DAGNINO, Evelina. Sociedade civil, espaços públicos e a construção democrática do Brasil: limites e possibilidades. In: DAGNINO, Evelina (Org.). Sociedade civil e espaços públicos no Brasil. São Paulo: Paz e Terra, 2002. p. 279-302.

DEMO, Pedro. Cidadania tutelada e assistida. Campinas: Autores Associados, 1995.

Politica social, educação e cidadania. $3^{\text {a }}$ ed. Campinas: Papirus, 2000.

FALEIROS, Vicente de Paula. O que épolitica social. São Paulo: Brasiliense, 2004.

HÖFLING, Eloisa de Mattos. Estado e políticas (públicas) sociais. Cadernos Cedes, nº 55, p. 30-41, nov. 2001.

LAKATOS, Eva Maria; MARCONI, Marina de Andrade. Metodologia do trabalho científico: procedimentos básicos, pesquisa bibliográfica, projeto e relatório, publicações e trabalhos científicos. $7^{\mathrm{a}}$ ed. São Paulo: Atlas, 2012.

MACHADO, Aquidaban F. Políticas públicas no Estado do bem-estar social e no neoliberalismo: alguns aspectos. Direito em Debate. n. 20, p. 73-98, jul./dez. 2003.

MARSHALL, Thomas Humphrey. Cidadania, classe social e status. Tradução de Meton Porto Gadelha. Rio de Janeiro: Zahar Editores, 1967.

MISES, Ludwig von. Ação humana: um tratado de economia. $3^{a}$ ed. rev. São Paulo: Instituto Ludwig von Mises Brasil, 2010. 
MOREIRA, Ranúlio Mendes. O neoliberalismo e a banalização da injustiça social. Revista do Tribunal Regional do Trabalho da $3^{a}$ Região. v. 45, n. 75, p. 173-184, jan./jun. 2007.

PEDRÃO, Fernando. A economia da produção social de moradia. Rua, Salvador, v. 2, n. 1, p. 19-35, 1989.

PEREIRA, Potyara Amazoneida Pereira. Necessidades humanas: subsídios à crítica dos mínimos sociais. $3^{a}$ ed. São Paulo: Cortez, 2006.

Politica social: temas \& questões. $2^{a}$ ed. São Paulo: Cortez, 2009.

PRATES, Jane Cruz; PRATES, Flavio Cruz; MACHADO, Simone. Populações em situação de rua: os processos de exclusão e inclusão precária vivenciados por esse segmento. Temporalis. Brasília, n. 22, p. 191-215, jul./dez. 2011.

REGO, Walquiria Leão; PINZANI, Alessandro. Voz̧es do bolsa família: autonomia, dinheiro e cidadania. $2^{\mathrm{a}}$ ed. São Paulo: Editora Unesp, 2014.

SARLET, Ingo Wolfgang. O direito fundamental à moradia na Constituição: algumas anotações a respeito de seu contexto, conteúdo e possível eficácia. Revista Brasileira de Direito Público, Belo Horizonte, n. 2, p. 1-46, jul./set. 2003.

SCHONS, Selma Maria. Assistência social entre a ordem e a "des-ordem": mistificação dos direitos sociais e da cidadania. São Paulo: Cortez, 1999.

SILVA, Rosimeire Barboza da; COSTA, Alderon Pereira da. Direitos humanos da população em situação de rua? Paradoxos e aproximações a uma vida digna. Revista Direitos Humanos e Democracia. n. 6, p. 117-135, jul./dez. 2015.

SIMÕES JÚNIOR, José Geraldo. Moradores de rua. São Paulo: Pólis, 1992.

SPOSATI, Aldaíza. Mínimos sociais e seguridade social: uma revolução da consciência da cidadania. Serviço Social \& Sociedade. n. 55, p. 9-38, nov. 1997.

SOUZA, Pedro Bastos de. Benefícios de renda mínima como um direito fundamental: acesso à justiça e inclusão social. Revista Brasileira de Políticas Públicas. Brasília, v. 6, n. 1, p. 166-183, 2016.

SPENGLER, Fabiana Marion; OLIVEIRA, Luthyana Demarchi de. Mediação como política pública de fortalecimento da democracia participativa. Revista Brasileira de Políticas Públicas. Brasilia, v. 2, n. 2, p. 131-140, 2012.

TORRES, Ricardo Lobo. O mínimo existencial e os direitos fundamentais. Revista de Direito Administrativo. Rio de Janeiro, v. 177, p. 29-49, jul./ set. 1989.

VALENCIO, Norma Felicidade Lopes da Silva et al. Pessoas em situação de rua no Brasil: estigmatização, desfiliação e desterritorialização. Revista Brasileira de Sociologia da Emoção. v. 7, n. 21, 556-605, dez. 2008.

VARANDA, Walter; ADORNO, Rubens de Camargo Ferreira. Descartáveis urbanos: discutindo a complexidade da população de rua e o desafio para políticas de saúde. Saúde e Sociedade, São Paulo, v. 13, n. 1, p. 56-69, jan./abr. 2004. 


\title{
O corte do fornecimento de água em face do inadimplemento do consumidor: análise à luz do Diálogo das Fontes*
}

\author{
The cutting of water supply due to consumer \\ default in payment: an analysis through the \\ dialogue of sources.
}

\author{
Leonardo Roscoe Bessa** \\ Gabriela Gomes Acioli César***
}

\section{Resumo}

$\mathrm{O}$ artigo trata da legalidade da suspensão de fornecimento de água ao consumidor quando inexiste o pagamento do serviço. A questão é analisada com enfoque em diferentes diplomas legais, principalmente em relação ao Código de Defesa do Consumidor (Lei 8.078/90) e à Lei de Concessão e Permissão de Serviços Públicos (Lei 8.987/95). Propõe-se solução com base no diálogo das fontes, com especial releve para a cláusula constitucional de proteção da dignidade da pessoa humana.

Palavras-Chave: Água. Serviço público. Bem essencial. Corte. Inadimplemento do consumidor. Diálogo das Fontes. Dignidade da pessoa humana.

\section{Abstract}

The article deals with the legality of water supply suspension when consumers' payment does not occur. The analyzes is focused on different legislation, particularly in relation to the Brazilian Consumer Protection Code (Law 8.078 / 90) and the Law of Concession and Permission of Public Services (Law 8.987 / 95). A solution is proposed based on the dialogue of sources, with particular attention to the constitutional provision of human dignity protection.

* Recebido em 18/12/2015

Aprovado em 22/08/2016

** Professor de graduação e do Programa de Mestrado e Doutorado do UNICEUB. Mestre em Direito Público pela Universidade de Brasília - UnB, Doutor em Direito Civil pela UERJ. Procurador-Geral de Justiça do Distrito Federal (MPDFT 2014/2016). E-mail: rosce@mpdft. mp.br.

*** Graduada em Direito pelo Centro Universitário de Brasília - UniCEUB e pós-graduada em Direito do Trabalho e Processo do Trabalho pela Universidade Anhanguera - UNIDERP. Servidora do Tribunal de Justiça do Distrito Federal e dos Territórios - TJDFT. E-mail: gabyacioli86@hotmail.com.
Keywords: Water. Public service. Essential good. Court. Consumer default. Dialogue of sources. Human dignity.

\section{INTRODUÇÃo}

O presente artigo aborda a possibilidade jurídica de interrupção do fornecimento de água em face do inadimplemento do consumidor. Embora o tema já tenha sido objeto de inúmeros acórdãos e atenção da doutrina, observa-se que as posições são antagônicas e injustificadamente extremadas, ora permitindo, ora vedando o corte do fornecimento, sem atentar para a possibilidade de, a partir de diálogo das fontes, prestigiar ambas alternativas. 
Com o propósito de demonstrar a necessidade de exame mais cauteloso dos casos que se apresentam no âmbito administrativo e jurisdicional, o presente artigo, em um primeiro momento, destaca a essencialidade da água para a vida e dignidade da pessoa humana. Em seguida, delineia-se panorama normativo do tema para evidenciar, de um lado, a extrema relevância do serviço público e, de outro, a necessidade de contribuição pecuniária de todos para funcionamento adequado e permanente do sistema de abastecimento de água.

Em relação à problematização do tema, demonstra-se a multiplicidade de posições doutrinárias, bem como as divergências no âmbito do Superior Tribunal de Justiça, órgão do Poder Judiciário que possui competência constitucional para definição final da interpretação que deve prevalecer.

Apresenta-se o diálogo das fontes como caminho possível para análise da contradição - aparente - entre os diplomas legais que regem o serviço, destacando a necessidade de exame detido para verificar, no caso concreto, a consequência da interrupção de fornecimento da água, principalmente no que concerne ao desrespeito da cláusula constitucional de proteção da dignidade da pessoa humana (CF, art. $1^{\circ}$, III).

\section{A essencialidade da Água}

A importância da água é uma constante histórica. Na visão mitológica, a água trazia consigo as sementes da vida, além dos medos que corriqueiramente eram evocados pelas figuras míticas dela oriundas ${ }^{1}$. O homem, percebendo a importância desse bem natural, tanto para sua mantença quanto para o desenvolvimento de suas atividades, foi, ao longo do curso da história, aprimorando formas de captação e de gerenciamento da água.

$\mathrm{Na}$ Antiguidade, os fenômenos naturais tinham uma conotação bastante mística vinculada à simbologia religiosa que imperava nas sociedades daquele tempo. A água era considerada a origem da vida e, consequentemente, motivo de devoção para muitas culturas. Povos como os Gregos, Romanos, Egípcios e Mesopotâmios construíram verdadeiros impérios hidráulicos com a finalidade de gerir esse recurso para o desenvolvimento de suas civilizações e para a sobrevivência das sociedades. Entretanto, as técnicas destinadas à administração das águas ainda eram incipientes para que o acesso fosse garantido a todos. Ao longo do tempo, surgiram muitas doenças e epidemias decorrentes da falta de acesso à água tratada. ${ }^{2}$

A situação de escassez e até mesmo de regime de recessão se dava pelo fato de que os grandes líderes de civilizações, como a Egípcia, se utilizavam da sacralidade que envolvia as criaturas da natureza, para subjugar os povos e manter o controle sobre os súditos ${ }^{3}$. Ora, sem água, não se pode viver, portanto, aquele que mantinha a gestão desse bem era visto como poderoso e, nesse caso, divino, tendo em vista toda a religiosidade impregnada dos povos teocráticos.

Com as epidemias, percebeu-se a vinculação existente entre a necessidade de saneamento, abastecimento de água e o devido tratamento à saúde das pessoas. A evolução tecnológica científica, ocorrida na passagem da Idade Média para o Renascimento, permitiu uma mudança de visão, retirando da água esse aspecto eminentemente sacramental ${ }^{4}$, como também de mera utilização para o fomento das atividades agrícolas e direcionando para a questão da saúde pública, adotando, assim, medidas técnicas e sanitárias com o intuito de estancar o mal que assolava as civilizações: o surto epidêmico.

1 SILVA, Elmo Rodrigues da. XI-009 - Um percurso pela história através da água: passado, presente, futuro. Disponível em: < http://www.bvsde.paho.org/bvsaidis/saneab/xi-009.pdf >. Acesso em: 21 jan. 2016.

2 Ibidem.

3 SILVA, Elmo Rodrigues da. XI-009 - Um percurso pela história através da água: passado, presente, futuro. Disponível em: <www.bvsde.paho.org/bvsaidis/saneab/xi-009.pdf>. Acesso em: 21 jan. 2016.

4 A sacralidade da natureza ocorre através do que se denomina 'freios homeostáticos', os quais seriam códigos legislativos empíricos, de fundo religioso, análogos aos princípios ecológicos que regulam o equilíbrio das relações naturais. Pode-se dizer que os 'freios homeostáticos mentais' seriam produzidos pelas normas de comportamento vinculadas às tradições e aos costumes, as quais se manifestam através dos rituais míticos que dão à natureza o seu caráter sagrado. 
A situação se agravou na transição entre o período medieval e o período moderno devido às contínuas guerras, fazendo com que fossem construídas nas cidades fortificações com escavações de fossos canalizados em que as águas ficavam paradas e se tornavam propulsoras de inúmeras doenças. ${ }^{5}$

Com a modernidade e a mudança de paradigmas, os governos europeus tiveram uma maior preocupação com o controle na gestão da água e com o aumento da distribuição desse bem, partindo-se para uma busca de modelo de saneamento adequado a ser implantado.

No que tange à epidemiologia, as descobertas da medicina no século XIX e início do século XX levaram a administração pública a prover uma revolução no campo estrutural das cidades, com o fito de erradicar a insalubridade existente por meio da construção de redes de água canalizadas, voltando sua política para a saúde da coletividade. ${ }^{6}$

Portanto, como se pode perceber, o acesso à água é intrínseco à garantia de uma vida saudável e com dignidade. Estipular medidas que deixem de fora do abastecimento de água uma parcela da população, principalmente aqueles que não podem pagar por seu tratamento e fornecimento, é fomentar a busca por medidas alternativas, como assim fizeram os povos em outras épocas. Isto se torna perigoso e, a longo prazo, dispendioso para o próprio Estado, o qual arcará, inevitavelmente, com custos maiores na área da saúde pública, posto que as consequências possíveis e previsíveis são o alastramento de doenças e epidemias.

Acrescenta-se a isso, em julho de 2014, a crise da água tomou conta do país, a começar por São Paulo. Com o esvaziamento do reservatório Cantareira e as previsões de falta de chuva, a cidade enfrentou a maior crise hídrica dos últimos 80 anos.

A urbanização, que aumenta a poluição dos rios e dificulta o acesso à água potável, associada a vários outros fatores já conhecidos, como a verticalização, a impermeabilização do solo, a falta de planejamento e a sobrecarga do sistema de abastecimento e coleta, contribuiu para a instalação da crise atual. Além disso, a água, que chega até a torneira, passa por tubulações construídas em 1940 ou 1950. Ou seja, um sistema defasado, o que facilita o desperdício. A cada segundo, mais de 1200 litros são jogados fora no processo de distribuição. Com toda a água desperdiçada no país ao longo de um dia, daria para abastecer 932 milhões de pessoas (ou três vezes a população dos EUA). Isso porque explora-se pouco e mal os recursos hídricos aqui existentes.

\section{O fornecimento de Água COMO deVER do Estado}

A água foi consagrada como bem de domínio público na Lei n. 9.433/97, que instituiu a Política Nacional de Recursos Hídricos. O seu fornecimento é de responsabilidade do Poder Público, justamente pelo seu caráter de essencialidade. A Lei de Greve (Lei n. 7.783/89) estabelece, expressamente, que o serviço de abastecimento de água é essencial (art. 10, I).

Este diploma legal reconhece o que a experiência histórica indica. A essencialidade diz respeito à necessidade do ser humano, garantindo, assim, sua saúde, segurança, bem-estar e a vida com dignidade, elemento fundamental para estabelecer quais serviços devem ser prestados pelo Poder Público.

A água, apesar de compor mais de 70\% do planeta, tem como porcentagem servível para consumo menos de $1 \%{ }^{8}$. Com a evolução e o crescimento da população, esse bem da natureza torna-se cada vez mais es-

5 Ibidem.

6 SILVA, Elmo Rodrigues da. XI-009 - Um percurso pela história através da água: passado, presente, futuro. Disponível em: <www.bvsde.paho.org/bvsaidis/saneab/xi-009.pdf>. Acesso em: 21 jan. 2016.

7 VILAVERDE, Carolina, MUNIZ BAPTISTA, Lucas, SOARES, Jessica e SODRÉ, Raquel. O Fundo do Poço. Disponível em: $<$ http://super.abril.com.br/crise-agua/ofundodopoco.shtml>. Acesso em: 05 mai. 2015.

8 UNIVERSIDADE DA ÁGUA. Água no planeta. Disponível em: <http://www.uniagua.org.br/publichtml/website/default. 
casso e o seu consumo precisa ser equilibrado, gerido de forma a garantir a saúde da sociedade no presente, mas com vistas para a geração futura. Por esse motivo, também constitui dever do Estado se responsabilizar por sua gestão, tratamento e distribuição de maneira equitativa e sustentável.

O seu fornecimento não está atrelado, apenas, à dignidade da pessoa humana (em ótica individual), mas também à tutela do Estado no que tange à saúde coletiva, posto ser pressuposto fundamental e dever do Poder Público promover políticas públicas de controle da saúde pública. Sabe-se que os gastos são menores em se tratando de investimento em saneamento básico do que na resolução dos problemas advindos da precariedade e má higienização da sociedade. De acordo com a Lei n. 8.080, de 19 de setembro de 1990, que dispõe sobre as ações e serviços de saúde, o saneamento básico, que inclui o fornecimento de água tratada para consumo, constitui fator determinante para promoção, proteção e recuperação da saúde $\left(\operatorname{art.} 3^{\circ}\right)$.

Esse caráter essencial do fornecimento de água traz consigo outras perspectivas, quais sejam: o direito de acesso a esse serviço deve ser garantido a todas as pessoas em igualdade de condições, ou seja, todos devem poder usufruir do serviço adequadamente, sem distinção de qualquer ordem, principalmente a econômica, bem como a questão da continuidade do serviço, que será abordada mais adiante.

Como visto, a titularidade da prestação do serviço público essencial de fornecimento de água é do Poder Público, em que pese representado pelos três entes federativos que decidirão de acordo com a realidade de cada um e conforme as peculiaridades de cada região. $\mathrm{O}$ art. 175 da Constituição Federal estabelece que a prestação de serviços públicos é de responsabilidade do Poder Público, direta ou indiretamente sob regime de concessão ou permissão, nesses casos, sempre, feito por licitação, em conformidade com a lei.

Devido ao caráter e a especificidade do bem a ser prestado, o Poder Público manteve, por muito tempo, o monopólio do fornecimento sob os seus cuidados, até pela íntima relação do serviço com a saúde da coletividade, com o fito de não transferir para particulares uma atividade que não deve, sob hipótese alguma, se submeter ao alvedrio de empresas que funcionam com finalidade lucrativa e respondendo às leis egoísticas de mercado.

Todavia, a política desenvolvimentista, a globalização e as pressões dos grupos econômicos externos, no sentido de o Brasil desempenhar de maneira satisfatória e rentável o desenvolvimento de suas atividades, cumprindo os compromissos assumidos no âmbito internacional, foram impulsionadores do Estado brasileiro no que diz respeito ao início da prestação dos serviços públicos por meio de terceiros que passaram a executar as tarefas, antes de incumbência, apenas, do Poder Público centralizador, por meio de delegação.

Juridicamente, esse instituto foi previsto na Constituição da República como um dos instrumentos de descentralização do Estado. Assim, o Poder Público possui a incumbência de prestar os serviços públicos diretamente (por seus órgãos e agentes) ou, indiretamente, por meio de concessão ou permissão.

Em 1995, o legislador ordinário cumpriu o determinado pelo art. 175 da Constituição Federal e promulgou, em 13 de fevereiro, a Lei n. 8.987 que trata do regime de Concessão e Permissão no serviço público. Dentre muitos conceitos, a lei estabeleceu uma série de princípios que devem nortear a prestação dos serviços públicos fornecidos direta e indiretamente. Ressalte-se que, tanto os que sejam diretamente prestados pela Administração quanto os que forem fornecidos por particulares, principalmente estes, precisam observá-los no desempenho e qualificação de suas atividades.

Entre os princípios elencados na lei - regularidade, eficiência, segurança, atualidade, generalidade, cortesia, modicidade das tarifas -, recebe destaque para o presente estudo o que trata da continuidade dos serviços. Cabe destacar, todavia, que a própria lei prevê hipóteses nas quais o serviço pode sofrer solução de continuidade: uma delas é justamente quando o usuário deixa de realizar o pagamento pecuniário pelo serviço $\left(\operatorname{art.~} 6^{\circ}, \S 3^{\circ}, \mathrm{II}\right)$.

asp?tp=3\&pag=aguaplaneta.htm $>$. Acesso em: 17 mai. 2015. 
O capítulo da Constituição Federal em que está inserido o instituto da concessão dos serviços públicos é o que dispõe sobre a ordem econômica e financeira. Por essa razão, se faz necessário respeitar os princípios elencados no início da Carta, como também os listados no art. 170, cuja disposição é no sentido de que a ordem econômica na consecução de suas atribuições precisa garantir a todos uma existência digna, assegurada, no inciso $\mathrm{V}$, a defesa do consumidor (v. item seguinte).

\section{Código de Defesa do Consumidor e a proteção conferida a serviços públicos ESSENCIAIS}

O fundamento da proteção do consumidor pelo Estado é sua vulnerabilidade - fragilidade - no mercado do consumo. Ao contrário do que propugnava a Teoria Econômica Clássica, as reais necessidades do consumidor não foram, nem são, tão preponderantes para definição da estrutura e objetivos dos integrantes da cadeia de produção e comercialização de bens e serviços. "Hoje, os economistas reconhecem que a realidade primária, a ser levada em consideração, na análise do mercado, não são as necessidades individuais dos consumidores e sim o poder econômico dos organismos produtores, públicos ou privados."

O consumidor está, sob diversos enfoques, em visível situação de fragilidade - vulnerabilidade - no mercado de consumo, não apenas - ressalte-se - em relação a interesses patrimoniais, mas também, e com maior intensidade, em seus interesses existenciais (projeções da dignidade humana).

Historicamente, tal fragilidade intensificou-se na mesma proporção do processo de industrialização e massificação das relações no mercado de consumo, ocorrido, particularmente, nas décadas posteriores ao término da Segunda Guerra Mundial. Ante essa constatação, diversos países, principalmente a partir da década de 70 , editaram normas de tutela dos interesses dos consumidores. ${ }^{10}$

No Brasil, a Constituição de 1988 referiu-se à proteção jurídica do consumidor em três oportunidades. A defesa do consumidor pelo Estado inclui-se entre os direitos e garantias fundamentais (art. $5^{\circ}$, XXXII). Em outro tópico, como um dos princípios gerais da atividade econômica, indicou-se a proteção dos interesses do consumidor (art. 170, V). Ademais, nos termos do art. 48 das Disposições Constitucionais Transitórias, restou estabelecido que o Congresso Nacional deveria, em prazo máximo de 120 dias, após a promulgação da Constituição, elaborar um código de defesa do consumidor.

Ainda sob perspectiva constitucional, a dignidade da pessoa humana, fundamento expresso da República Federativa do Brasil (art. $1^{\circ}$, III, da CF), justifica a tutela da pessoa humana no mercado de consumo. De fato, "a proteção do consumidor deve ser estudada como momento particular e essencial de uma tutela mais ampla: aquela da personalidade humana."

9 Fábio Konder Comparato. A proteção do consumidor: importante capítulo do Direito econômico. Revista Forense, v. 255, ano 72, jul-set, Rio de Janeiro, 1976, p. 19. Sobre a vulnerabilidade do consumidor no mercado de consumo, v. BESSA, Leonardo Roscoe. Relação de Consumo e Aplicação do Código de Defesa do Consumidor. 2 ed. São Paulo: Revista dos Tribunais, 2009 , p. $27-46$

10 Cite-se, apenas a título de exemplo, a Lei alemã de 09/12/1976, conhecida como AGB-Geseť, sobre condições gerais dos contratos, Lei francesa de 22.12.72 relativa à venda a domicílio, e o Fair Credit Reporting Act de 1970, que, ainda hoje, disciplina os bancos de dados de proteção ao crédito nos Estados Unidos.

11 Gustavo Tepedino, o qual, sustenta, com absoluta propriedade, que o art. $5^{\circ}$, XXXII, art. 170, V, devem ser analisados em conjunto com o disposto no art. $1^{\circ}$, III e $3^{\circ}$, III, da Constituição Federal: “O Constituinte, assim procedendo, não somente inseriu a tutela dos consumidores entre os direitos e garantias individuais, mas afirma que sua proteção deve ser feita do ponto de visa instrumental, ou seja, com a instrumentalização dos seus interesses patrimoniais à tutela de sua dignidade e aos valores existenciais. Trata-se, portanto, do ponto de vista normativo, de proteger a pessoa humana nas relações de consumo, não já o consumidor com uma categoria per se considerada." A responsabilidade civil por acidentes de consumo na ótica Civil-constitucional, in Temas de Direito Civil, Rio de Janeiro, Renovar, p. 279-281. Outros autores têm destacado a importância de análise do Código de Defesa do Consumidor a partir de perspectiva constitucional e com especial destaque para o princípio da dignidade da pessoa humana. 
O mercado de consumo, principalmente em face de sua conformação massificada, enseja, em diversos aspectos, ofensa à dignidade da pessoa humana, tanto pelos inúmeros acidentes de consumo (com ofensa à integridade psicofísica do consumidor), publicidades abusivas, controle de dados pessoais do consumidor (perda da privacidade), cobrança abusiva de débito, quanto - ressalte-se - pela negação de serviços públicos essenciais como o fornecimento de água.

Em 11 de setembro de 1990, editou-se a Lei Federal n. 8.078 (Código de Defesa do Consumidor), a qual dispõe sobre "normas de proteção e defesa do consumidor, de ordem pública e interesse social" (art. 1"). ${ }^{12}$ Considerando-se os propósitos do artigo, destacam-se os dispositivos que se aplicam aos serviços públicos.

$\mathrm{O}$ art. $3^{\circ}$, caput estabelece o conceito de fornecedor, enquadrando, também, o Poder Público quando afirma ser "toda pessoa física ou jurídica, pública ou privada" que disponibilize produtos ou serviços no mercado de consumo. Além disso, o parágrafo $2^{\circ}$ do mesmo artigo aponta, de forma ampla, o serviço que será objeto de uma relação de consumo, inseridos os públicos. Mais à frente, no artigo $4^{\circ}$, ao elencar os objetivos da Política Nacional das Relações de Consumo, tutela o atendimento das necessidades dos consumidores tomando como mecanismo para se chegar a esse objetivo o princípio da racionalização e melhoria dos serviços públicos.

Acrescente-se que, entre os direitos básicos do consumidor, está a adequada e eficaz prestação dos serviços públicos em geral (art. $6^{\circ}, \mathrm{X}$ ). Para encerrar o panorama normativo do Código de Defesa do Consumidor, em relação ao tema, o art. 22 dispõe que "os órgãos públicos, por si ou por suas empresas, concessionárias, permissionárias ou sob qualquer outra forma de empreendimento, são obrigados a fornecer serviços adequados, eficientes, seguros e, quanto aos essenciais, contínuos".

Diante do quadro apresentado, chega-se ao problema a ser enfrentado neste artigo. Como resolver a contradição - ao menos aparente - do ordenamento jurídico no tocante ao abastecimento individual de água quando há solução de continuidade no pagamento por parte do usuário. De um lado, considera-se o fornecimento de água serviço essencial e que, portanto, não pode ser interrompido (Lei de Greve e Código de Defesa do Consumidor, Leis n. 7.783/89 e 8.078/90, respectivamente). De outro, admite-se a suspensão do fornecimento em face de inadimplemento do consumidor (Lei n. 8.987/97, art. $6^{\circ}$, $\ 3^{\circ}$, II). Qual norma deve prevalecer? A questão deve ser resolvida pelos critérios tradicionais de conflito de leis no tempo?

Propõe-se, como desenvolvido na sequência, a necessidade de realizar diálogo das fontes para obtenção das respostas possíveis.

\section{Diálogo dAS FonTES}

Em todo e qualquer debate relativo à aplicação do Código de Defesa do Consumidor, é fundamental perceber que a incidência do diploma de proteção ao consumidor a determinado suporte fático não afasta, além de perspectiva constitucional (dignidade da pessoa humana), análise simultânea e harmoniosa com outras fontes legais.

12 O CDC inspirou-se em importantes modelos legislativos de outros países. A maior influência veio do Projet de Code de la Consommation. Os direitos básicos do consumidor foram extraídos da Resolução 39/248, da ONU. Merecem referência, também, a Lei General para la Defensa de los Consumidores y Usuários da Espanha (Lei 26/1984), a Lei 29/81, de Portugal, a Lei Federal de Protección ao Consumidor, de 05 de fevereiro de 1976, do México e a Loi sur la Protection du Consommateur, promulgada em 1979, no Quebec.Em relação a matérias específicas, houve inspiração no Direito Comunitário europeu: Diretivas 84/450 (publicidade) e 85/374 (responsabilidade civil pelos acidentes de consumo). Concernente à proteção contratual do consumidor, citem-se o Decreto-lei 446/85 de Portugal e a Gesetz zur Regelung des Rechts des Allgemeinen Geschaftsbedingungen - AGB Gesetz, de dezembro de 1976, da Alemanha. A influência do direito norte-americano decorreu diretamente do Federal Trade Comission Act, do Consumer Product Safety Act, do Truth in Lending Act, do Fair Credit Reporting Act e do Fair Debt Collection Practices Act. Registre-se, ainda, influência indireta na medida em que as regras européias mais modernas de proteção ao consumidor inspiraramse nos cases e estatutes americanos. 
A velocidade dos fatos tem conduzido a uma inflação de leis específicas nas mais diversas áreas. A Constituição Federal, em razão de sua superioridade hierárquica e da complexidade cada vez maior do ordenamento jurídico, ganha missão - principalmente pelas mãos dos intérpretes - de conferir coerência a essa multiplicidade de fontes normativas.

Nessa linha, Pietro Perlingieri destaca a importância da Constituição Federal como unificadora de valores do ordenamento jurídico, o qual tem sido representado por um número crescente de fontes legislativas fragmentadas. Ressalta o jurista italiano que "numerosas leis especiais têm disciplinado, embora de modo fragmentado e por vezes incoerente, setores relevantes" e que a perda de centralidade do Código Civil no séc. XX transfere o papel unificador do sistema para a Constituição, a qual passa a estabelecer um desenho global para unir as mais variadas fontes legais. ${ }^{13} \mathrm{Com}$ base nessa perspectiva constitucional, há que se buscar uma convivência harmônica entre diversas fontes legais.

O Código de Defesa do Consumidor (Lei n. 8.078/90), em razão do corte horizontal nas mais diversas relações jurídicas, é significativo exemplo da necessidade atual de convivência com diversos outros diplomas. A par da necessária utilização de base conceitual do Código Civil, o art. $7^{\circ}$, caput, ${ }^{14}$ do CDC é expresso no sentido de que não é exclusividade dele estabelecer os direitos do consumidor. Outras normas podem, especialmente quando mais vantajosas ao consumidor, ser invocadas e aplicadas e, inevitavelmente, analisadas em conjunto, buscando-se, sempre, coerência e harmonia nas conclusões.

O Código de Defesa do Consumidor é, em relação ao Código Civil, norma especial que considera, preponderantemente, a vulnerabilidade do consumidor no mercado. É, em regra, norma especial quanto ao sujeito. Sua incidência, entretanto, não afasta, a priori, a aplicação de outras normas especiais. O serviço de fornecimento de água bem exemplifica a crescente edição de leis especiais - em relação à matéria - que convivem com esse diploma legal.

Reitere-se a necessidade da perspectiva constitucional apontada: na análise simultânea de diversas normas do mesmo nível hierárquico, deve o intérprete, em ponderação de bens, conferir eficácia aos princípios, valores e direitos garantidos constitucionalmente. ${ }^{15}$

Hoje, a tarefa do intérprete e aplicador do direito de hoje é bem mais complexa e dinâmica, requer exame concomitante de diversos atos normativos em que pouca utilidade terão os critérios tradicionais de solução de conflitos (antinomia) de leis, estabelecidos na Lei de Introdução às Normas do Direito Brasileiro. ${ }^{16}$ A propósito, Cláudia Lima Marques, baseando-se em Erik Jayme, ressalta a necessidade de haver o que, sugestivamente, denomina diálogo das fontes: "Aqui a preocupação do direito é a legitimidade da solução, pois todas as normas em conflito são 'válidas' e devem ter alguma eficácia, mesmo que auxiliar. O diálogo das fontes é, pois, a aplicação simultânea, compatibilizadora, das normas em conflito, sob a luz da Constituição, com efeito útil para todas as leis envolvidas, mas com eficácias (brilhos) diferenciadas a cada uma das normas em colisão, de forma a atingir o efeito social (e constitucional) esperado. O 'brilho' maior será da norma que concretizar os direitos humanos envolvidos no conflito, mas todas as leis envolvidas participarão da solução concorrentemente."17

Em outra sede, a autora esclarece: "Em seu curso Geral de Haia, de 1995, o mestre de Heidelberg, Erik Jayme, ensinava que, em face do atual ‘pluralismo pós-moderno’ de um Direito com fontes legislativas plúri-

13 Perfis do direito civil: introdução ao direito civil constitucional. 2. ed., Rio de Janeiro: Renovar, 2002, p. 04-06.

14 Art. 7. ${ }^{\circ}$, caput, do CDC: "Os direitos previstos nesse código não excluem outros decorrentes de tratados ou convenções internacionais de que o Brasil seja signatário, da legislação interna ordinária, de regulamentos expedidos pelas autoridades administrativas competentes, bem como dos que derivem dos princípios gerais do direito, analogia, costumes e equidade."

15 Sobre ponderação de valores constitucionais, v., por todos, A nova interpretação constitucional: ponderação, direitos fundamentais e relações privadas. (Org.: Luis Roberto Barroso), Rio de Janeiro: Renovar, 2003.

16 O Dec-lei 5.657/42 estabelece que as leis gerais não revogam as especiais e não são revogadas por elas (art. $2^{\circ}$ ). A dificuldade, entretanto, reside em definir o que é geral e especial e, invariavelmente, harmonizar a existência de duas leis especiais, uma em relação aos sujeitos da relação (consumidor e fornecedor) e outra em relação ao objeto (plano de saúde, por exemplo).

17 Contratos no Código de Defesa do Consumidor. 5 ed. São Paulo: Revista dos Tribunais, 2011, p. 611-613. 
mas, ressurge a necessidade de coordenação entre as leis no mesmo ordenamento, como exigência para um sistema eficiente e justo. Efetivamente, cada vez mais se legisla, nacional e, internacionalmente, sobre temas convergentes. A pluralidade de leis é o primeiro desafio do aplicador da lei contemporâneo." ${ }^{18}$

Diante desse quadro, é absolutamente insuficiente sustentar que, por existir lei especial disciplinando determinado setor, afasta-se a aplicação do Código de Defesa do Consumidor (Lei n. 8.078/90). Deve-se, ao contrário, buscar o convívio harmônico dos variados diplomas legais: um auxiliando e oferecendo elementos de interpretação para o outro, sempre, destaque-se, sob as luzes dos princípios e valores constitucionais. Antes de afastar a aplicação de uma das fontes, deve-se buscar a possibilidade de interpretação coerente entre as diversas fontes. É o que se pretende fazer para análise da polêmica relativa ao corte do fornecimento de água em face de inadimplemento do consumidor.

\subsection{O diálogo das fontes como solução}

Antes de melhor explicitar o diálogo das fontes como caminho adequado para análise da questão, importante fazer breve revisão bibliográfica para apontar como são díspares as posições doutrinárias sobre a possibilidade de corte do fornecimento de água em face da inadimplência do consumidor.

Zelmo Denari sustenta a legalidade de corte em razão do inadimplemento, mas destaca que "a interrupção no fornecimento do serviço público não pode ser efetivada ex abrupto, como instrumento de pressão contra o consumidor, para forçá-lo ao pagamento da conta em atraso." ${ }^{19}$ Acrescenta que, se o usuário for pessoa jurídica de direito público, "a interrupção é inadmissível, porque, além de estar em causa o interesse público - cuja supremacia é indiscutível em termos principiológicos -, o ente público pode invocar, em sentido diametralmente oposto, o postulado dos serviços que presta à população em geral."20

Fabio Amorim da Rocha defende a relativização do princípio da continuidade. Para o autor é inteiramente eficaz e válida a disposição normativa que estabelece não figurar descontinuidade do serviço a interrupção nos casos emergenciais ou, após prévio aviso, por razões de ordem técnica ou de segurança, bem como por inadimplência do usuário, levando em conta o interesse da coletividade (art. $6^{\circ}$, $\int 3^{\circ}$, I e II da Lei n. $8.978 / 95) .^{21}$

Fernando Costa de Azevedo propugna não aplicar o disposto na norma autorizadora da suspensão nos casos de inadimplência consiste em fomentar o enriquecimento sem causa por parte de muitos usuários-consumidores, os quais, de má-fé, se aproveitam do princípio destinado à proteção dos seus interesses. Dessa maneira, tornar-se-ia inviável a manutenção do serviço, tendo em vista que, sem o retorno de todos os usuários, não existiria suporte financeiro suficiente para a melhoria e até mesmo universalização do serviço. Haveria um desequilíbrio financeiro e, também, uma maior oneração para os usuários-consumidores adimplentes, que, por sua vez, arcariam com os custos do serviço. ${ }^{22}$

Para Alessandro Segalla, no que tange, principalmente, ao fornecimento de água, há necessidade de se ter uma visão mais ampla no sentido de que a prestação desse serviço é pautada no interesse público e não apenas no âmbito privado do usuário-consumidor, pois, segundo ele, a instalação de rede de distribuição de água tratada e de coleta de esgotos não se faz como de satisfação do interesse individual dos usuários.

18 DENARI, Zelmo, Diálogo entre o Código de Defesa do Consumidor e o novo Código Civil: do "diálogo das fontes" no combate às cláusulas abusivas, Revista de Direito do Consumidor, São Paulo, n. 45, jan./mar., 2003. p. 71-72.

19 Código de Defesa do Consumidor comentado pelos autores do anteprojeto, cit., p. 216.

20 Ibid., p. 216.

21 ROCHA, Fábio Amorim da. A legalidade da suspensão do fornecimento de energia elétrica aos consumidores inadimplentes. Rio de Janeiro: Lumen Juris, 2004, p. 30-33.

22 AZEVEDO, Fernando Costa de. A suspensão do fornecimento de serviço público essencial por inadimplemento do consumidor-usuário: argumentos doutrinários e entendimento jurisprudencial. Revista do Direito do Consumidor, v. 16, n. 62, abr./jun. 2007, São Paulo: Revista dos Tribunais, p. 99-101. 
Trata-se de instrumento de saúde pública. Por meio desses serviços, eliminaram-se, quase totalmente, as epidemias, transmitidas anteriormente por meio da contaminação da água. A suspensão dos serviços de água e esgoto representaria risco à saúde pública, na medida em que alguns dos integrantes da comunidade poderiam adquirir doenças, evitável por meio do tratamento de água e esgoto. ${ }^{23}$

Rizzatto Nunes, por seu turno, defende que o serviço público não pode ser interrompido. Afirma que a Lei n. 8.987/97 é "de constitucionalidade duvidosa" ao permitir o corte do fornecimento. Consigna que, salvo hipótese de ajuizamento de ação e demonstração que o consumidor está agindo de má-fé ao não pagar as contas, está vedado o corte do fornecimento. ${ }^{24}$

Cláudia Lima Marques, Herman Benjamin e Bruno Miragem, em obra coletiva, afirmam que a continuidade do serviço público essencial é direito do consumidor pessoa física "considerando a sua dignidade como pessoa humana." Para os autores, a interrupção dos serviços somente pode ocorrer excepcionalmente, quando não se constitui "forma de cobrança ou constrangimento, mas sim reflexo de um decisão judicial ou do fim não abusivo do direito. ${ }^{25}$

As divergências e controvérsias sobre o tema também são sensíveis na análise da jurisprudência. $\mathrm{O}$ assunto foi, exaustivamente, debatido no Superior Tribunal de Justiça. Inicialmente, focando os arts. 22 e 42 do CDC, entendeu-se pela ilegalidade do corte de fornecimento de água e de energia elétrica ${ }^{26} \mathrm{em}$ face do inadimplemento do consumidor. Citem-se, na sequência e apenas ilustrativamente, alguns julgados.

No REsp 201.112, Rel. Min. Garcia Vieira, julgado em 20 de abril de 1999, o STJ proferiu a seguinte ementa: "a Companhia Catarinense de Água e Saneamento negou-se a parcelar o débito do usuário e cortou-lhe o fornecimento de água, cometendo ato reprovável, desumano e ilegal. Ela é obrigada a fornecer água à população de maneira adequada, eficiente, segura e contínua, não expondo o consumidor ao ridículo e ao constrangimento."

Alguns meses depois, em 07 de dezembro de 1999, ao julgar o REsp 223.778, proferiu a seguinte decisão: “é defeso à concessionária de energia elétrica interromper o suprimento de força, no escopo de compelir o consumidor ao pagamento de tarifa em atraso. O exercício arbitrário das próprias razões não pode substituir a ação de cobrança."

No dia 05 de dezembro de 2000, no julgamento do REsp 122.812, o STJ, novamente, posicionou-se pela ilegalidade do corte de fornecimento de água em face do inadimplemento do consumidor. A ementa do julgado guarda o seguinte teor: "corte no fornecimento de água. Inadimplência do consumidor. Ilegalidade. 1. É ilegal a interrupção no fornecimento de energia elétrica, mesmo que inadimplente o consumidor, à vista das disposições do Código de Defesa do Consumidor que impedem seja o usuário exposto ao ridículo. 2. Deve a concessionária de serviço público utilizar-se dos meios próprios para receber os pagamentos em atrasos."

Todas as decisões do Superior Tribunal de Justiça que concluíram pela impossibilidade do corte do fornecimento de água analisaram a questão unicamente à luz do Código de Defesa do Consumidor, especialmente dos arts. 22 e 42. Não se dialogou com as disposições da Lei n. 8.987/97, que permitem o corte em face da inadimplência do usuário (consumidor).

Posteriormente, a partir de decisão proferida em 10 de dezembro de 2003, houve radical mudança do entendimento do STJ. Ao analisar o REsp 363.943, a Primeira Seção estabeleceu ser "lícito à concessionária interromper o fornecimento de energia elétrica, se, após aviso prévio, o consumidor de energia elétrica per-

23 SEGALLA, Alessandro. A suspensão do fornecimento de energia elétrica ao usuário inadimplente à luz da Constituição Federal. Revista de Direito do Consumidor. n. 37, Jan- Mar/2001. São Paulo: Revista dos Tribunais, p.139.

24 Ibid., p. 106.

25 Comentários ao Código de Defesa do Consumidor. São Paulo: Revista dos Tribunais, 2013, p. 646.

26 Embora o foco do artigo seja em relação ao fornecimento de água, o serviço público de fornecimento de energia elétrica também é essencial e se sujeita aos mesmos diplomas legais. 
manecer inadimplente no pagamento da respectiva conta (art. $6^{\circ}, \sqrt{\$} 3^{\circ}$, II, da Lei n. 8.987/95)". Embora a referência do julgado seja relativa ao fornecimento de energia elétrica, os mesmos argumentos e raciocínios foram utilizados para permitir o corte do fornecimento de água.

Vários outros julgados se sucederam com igual entendimento. Agora, o Código de Defesa do Consumidor (Lei n. 8.078/90) ficou para um segundo plano: especial atenção foi conferida à Lei n. 8.987/95. Ademais, pouca ou nenhuma importância se conferiu ao princípio constitucional da proteção à dignidade da pessoa humana $\left(\operatorname{art.} 1^{\circ}\right.$, III da CF).

Embora apresentem restrições quanto a débitos antigos, os acórdãos mais recentes reafirmam a possibilidade do corte do fornecimento de água em face de inadimplemento do consumidor, como se observa, ilustrativamente, da leitura da seguinte ementa: "1. Essa Corte Superior pacificou o entendimento de que não é lícito à concessionária interromper o fornecimento do serviço em razão de débito pretérito; o corte de água ou energia pressupõe o inadimplemento de dívida atual, relativa ao mês do consumo, sendo inviável a suspensão do abastecimento em razão de débitos antigos. (...) Agravo Regimental da AES Sul Distribuidora Gaúcha de Energia S/A desprovido. (AgRg no AREsp 239.749/RS, Rel. Min. Napoleão Nunes Maia Filho, julgado em 21/08/2014, DJe 01/09/2014). ${ }^{27}$

Observa-se, pelas divergências apresentadas, que tanto a doutrina como a jurisprudência tendem a assumir posições extremadas, ora para admitir, ora para vedar o corte. $\mathrm{O}$ diálogo das fontes, sob as luzes constitucionais, permite solução intermediária que, ao final, acaba por prestigiar as normas que estão em aparente conflito (Lei n. 8.078/90 e Lei n. 8.987/95), conferindo-se coerência interna ao ordenamento jurídico.

Na hipótese, ganha relevo a cláusula geral de proteção da dignidade da pessoa humana (art. $1^{\circ}$, III, da CF). No campo infraconstitucional, o Código de Defesa do Consumidor (Lei n. 8.078/90) e a Lei n. 8.987/95, que disciplina o regime de concessão e permissão dos serviços públicos (art. 175 da Constituição Federal).

De um lado, o CDC dispõe sobre a importância da dignidade humana, dos direitos existenciais (arts. $4^{\circ}$ e $6^{\circ}$ ). Determina, também, que os serviços essenciais devem ser contínuos (art. 22) e que, na cobrança de débitos, o consumidor "não será submetido a qualquer tipo de constrangimento" (art. 42). De outro, o \ $3^{\circ}$ do art. $6^{\circ}$ da Lei n. 8.987/95 estabelece que "não se caracteriza como descontinuidade do serviço a sua interrupção em situação de emergência ou após prévio aviso, quando: (...) II - por inadimplemento do usuário, considerado o interesse da coletividade."

Em síntese, a solução está em verificar se o corte importa, no caso concreto, em ofensa à dignidade da pessoa humana, ou seja, se pessoas físicas serão diretamente afetadas com a suspensão do fornecimento da água. O critério, ao contrário do que pode aparentar, não deve se pautar unicamente pelo fato de o consumidor ser pessoa jurídica ou física. Exemplifique-se com a sempre lembrada situação e graves consequências de um hospital (pessoa jurídica) que deixa de receber água. Sob outro enfoque, o contratante pode ser pessoa física, mas o fornecimento de água referir-se à unidade residencial que, há muito, está desabitada, não afetando, portanto, a qualidade (mínima) de vida de qualquer pessoa.

É importante perceber, para a solução das situações concretas, que o corte do fornecimento de água ou energia elétrica atinge, diretamente, interesses existenciais de todos os moradores da residência, invariavelmente crianças e idosos, consumidores hipervulneráveis, que não podem sofrer consequências tão drásticas em razão de fato atribuível a terceiro (titular da conta).

27 Na mesma linha, registre-se: “(...) A jurisprudência desta Corte é pacífica no sentido de ser devido o corte no fornecimento de água, após prévio aviso, ante a inadimplência de conta atual do usuário. Entretanto, na espécie, não houve o prévio aviso, segundo consignado no acórdão recorrido, motivo pelo qual o corte se deu de forma ilegal. Registre-se que para averiguar a existência de prévia comunicação feita pela concessionária, há necessidade de revolvimento de matéria probatória, o que é vedado nesta seara recursal, ante o óbice da Súmula 7/STJ. (...) (AgRg no AREsp 412.822/RJ, Rel. Ministro Mauro Campbell Marques, julgado em $19 / 11 / 2013$, DJe 25/11/2013) 
Há, ainda, outro argumento. O intérprete deve conferir coerência, a partir dos valores constitucionais, aos inúmeros diplomas (fontes) legais. Ora, no mínimo, deveria ser aplicado o mesmo prazo concedido pela Lei n. 9.870/99, relativa a anuidades escolares, que, mesmo em face de inadimplência, veda qualquer providência que impeça a conclusão do período escolar. ${ }^{28}$ Considerando-se a relevância do serviço prestado (educação), não se permite a interrupção imediata dos serviços por falta de pagamento da mensalidade. Sem qualquer propósito de estabelecer hierarquia entre valores, o fato é que o corte do fornecimento de água traz riscos à saúde humana (limpeza dos alimentos, higiene pessoal, etc.)

Não se sustenta que o inadimplemento relativo às contas de água não deva acarretar qualquer consequência para o devedor. O não pagamento ou atraso gera a incidência dos encargos próprios (juros de mora, multa, correção monetária). Ademais, o consumidor pode ter o nome inscrito em banco de dados de proteção ao crédito. ${ }^{29} \mathrm{O}$ que não pode haver é contrariedade a um minimo existencial (patrimônio mínimo personalíssimo) em face de vedação pelo ordenamento nacional, pois, como sintetiza Edson Fachin: "a pessoa natural, ao lado de atributos inerentes à condição humana, inalienáveis e insuscetíveis de apropriação, pode ser também, à luz do Direito Civil brasileiro contemporâneo, dotado de uma garantia patrimonial que integra sua esfera jurídica. Trata-se de um patrimônio mínimo mensurado consoante parâmetros elementares de uma vida digna e do qual não pode ser expropriada ou desapossada." ${ }^{30}$

Parte da dificuldade em lidar com a matéria é, justamente, a falta de sensibilidade de que os problemas jurídicos atuais, tanto pela variedade de situações fáticas - apenas aparentemente idênticas - como pela complexidade do ordenamento jurídico exigem um olhar "para o caso concreto", um balanceamento dos valores constitucionais em jogo, os quais indicarão a melhor interpretação.

No caso, o diálogo das fontes permite, a partir do enfoque constitucional, prestigiar ambas as fontes normativas, sem qualquer exclusão prévia. O projeto constitucional de proteção à dignidade da pessoa humana, confere, em concreto, relevância à continuidade do serviço (Lei n. 8.078/90) ou à possibilidade do corte (Lei n. 8.987/95), quando não houver ofensa, direta ou indireta, à dignidade da pessoa humana. ${ }^{31}$ É, em última análise, esta a preocupação dos votos vencidos no Superior Tribunal de Justiça, proferidos há dez anos. ${ }^{32}$

28 Interpretação conjugada dos artigos $5^{\circ}$ e $6^{\circ}$ Lei 9.870/99 permite concluir que, mesmo em face de inadimplência durante o semestre ou ano letivo, o estabelecimento de ensino não pode tomar qualquer medida que impeça a conclusão do período: “ Art. $5^{\circ}$ Os alunos já matriculados, salvo quando inadimplentes, terão direito à renovação das matrículas, observado o calendário escolar da instituição, o regimento da escola ou cláusula contratual. Art. $6^{\circ}$ São proibidas a suspensão de provas escolares, a retenção de documentos escolares ou a aplicação de quaisquer outras penalidades pedagógicas por motivo de inadimplemento, sujeitando-se o contratante, no que couber, às sanções legais e administrativas, compatíveis com o Código de Defesa do Consumidor, e com os arts. 177 e 1.092 do Código Civil Brasileiro, caso a inadimplência perdure por mais de noventa dias. \ $1^{\circ}$ Os estabelecimentos de ensino fundamental, médio e superior deverão expedir, a qualquer tempo, os documentos de transferência de seus alunos, independentemente de sua adimplência ou da adoção de procedimentos legais de cobranças judiciais."

29 O Código de Defesa do Consumidor em nenhum momento veda os registros de inadimplementos em entidades de proteção ao crédito relativos a serviços públicos - independentemente da sua essencialidade.

30 Estatuto jurídico do patrimônio mínimo. 2 ed. Rio de Janeiro: Renovar, 2006, p. 01.

31 Talvez, seja esta a coerência que está por trás de decisões aparentemente contraditórias, uma proferida em ação civil pública - na qual é mais problemática a análise de situações individuais - e outra proferida em ação ajuizada individualmente pelo consumidor. Nessa linha, o Tribunal de Justiça do Distrito Federal, em 11 de novembro de 1996, ao julgar AI 7.345/96, e o AI 7.110/96, sem qualquer referência ao CDC, entendeu que "sendo energia elétrica um bem essencial à vida das pessoas, na vida urbana, o seu fornecimento não pode ser suspenso, salvo em situações gravíssimas e sempre após decisão judicial transitado em julgado. O mesmo Tribunal, entretanto, ao julgar, em 12 de fevereiro de 2001, ação civil pública ajuizada pelo Ministério Público do Distrito Federal (Promotoria de Defesa do Consumidor), contra a CEB (Companhia Energética de Brasília) decidiu que "considerando o interesse da coletividade, a suspensão do fornecimento de energia elétrica, por inadimplência do usuário no pagamento da tarifa, não caracteriza descontinuidade, se precedida da comunicação ao usuário".

32 A propósito e unicamente a título ilustrativo, registre-se ementa do Resp. 684.442, julgado em 03 de fevereiro de 2005, que reflete o entendimento (minoritário) do Min. Luiz Fux: “(...) A 1ª Seção, no julgamento do RESP no 363.943/MG, assentou o entendimento de que é lícito à concessionária interromper o fornecimento de energia elétrica, se, após aviso prévio, o consumidor de energia elétrica permanecer inadimplente no pagamento da respectiva conta (Lei 8.987/95, art. $6^{\circ}, \int 3^{\circ}$, II).3. Ademais, a $2^{\mathrm{a}}$ Turma desta Corte, no julgamento do RESP n ${ }^{\circ} 337.965 / \mathrm{MG}$ concluiu que o corte no fornecimento de água, em decorrência de mora, além de não malferir o Código do Consumidor, é permitido pela Lei no 8.987/95. 4. Não obstante, ressalvo o entendimento de que o corte do fornecimento de serviços essenciais - água e energia elétrica - como forma de compelir o usuário ao pagamento de tarifa ou multa, extrapola os limites da legalidade e afronta a cláusula 
Em conclusão, as posições extremadas da doutrina e da jurisprudência - tanto para permitir como para proibir o corte da água - não são as melhores. A solução está em, a partir do diálogo das fontes entre a Lei n. 8.078/90 e a Lei n. 9.897/95, com perspectiva constitucional da cláusula de proteção da dignidade da pessoa humana, optar pelo corte ou manutenção do serviço público.

\section{REFERÊNCIAS BIBLIOGRÁFICAS}

AZEVEDO, Fernando Costa de. A suspensão do fornecimento de serviço público essencial por inadimplemento do consumidor-usuário: argumentos doutrinários e entendimento jurisprudencial. Revista do Direito do Consumidor, v. 16, n. 62, abr./jun. 2007, São Paulo: Revista dos Tribunais.

BARROSO, Luis Roberto. A nova interpretação constitucional: ponderação, direitos fundamentais e relações privadas. Rio de Janeiro: Renovar, 2003.

BESSA, Leonardo Roscoe. Relação de Consumo e Aplicação do Código de Defesa do Consumidor. 2 ed. São Paulo: Revista dos Tribunais, 2009.

COMPARATO, Fábio Konder. A proteção do consumidor: importante capítulo do Direito econômico. Revista Forense, v. 255, ano 72, jul-set, Rio de Janeiro, 1976.

DENARI, Zelmo, Diálogo entre o Código de Defesa do Consumidor e o novo Código Civil: do "diálogo das fontes" no combate às cláusulas abusivas, Revista de Direito do Consumidor, São Paulo, n. 45, jan./ mar., 2003.

FACHIN, Luiz Edson. Estatuto jurídico do patrimônio mínimo. 2 ed. Rio de Janeiro: Renovar, 2006.

MARQUES, Cláudia Lima. Contratos no Código de Defesa do Consumidor. 5 ed. São Paulo: Revista dos Tribunais, 2011.

MARQUES, Claudia Lima. Diálogo entre o Código de Defesa do Consumidor e o novo Código Civil: do diálogo das fontes no combate às cláusulas abusivas. Revista de Direito do Consumidor, São Paulo, n. 45, jan./mar., 2003

MARQUES, Claudia Lima; BENJAMIM, Antônio Herman; MIRAGEM, Bruno. Comentários ao Código de Defesa do Consumidor. São Paulo: Revista dos Tribunais, 2013.

PERLINGIERI, Pietro. Perfis do direito civil: introdução ao direito civil constitucional. 2. ed., Rio de Janeiro: Renovar, 2002.

pétrea de respeito à dignidade humana, porquanto o cidadão se utiliza dos serviços públicos posto essenciais para a sua vida. 5. Hodiernamente, inviabiliza-se a aplicação da legislação infraconstitucional impermeável aos princípios constitucionais, dentre os quais sobressai o da dignidade da pessoa humana, que é um dos fundamentos da República, por isso que inaugura o texto constitucional, que revela o nosso ideário como nação. 6. In casu, o litígio não gravita em torno de uma empresa que necessita da energia para insumo, tampouco de pessoas jurídicas portentosas, mas de uma pessoa física miserável e desempregada, de sorte que a ótica tem que ser outra. Como afirmou o Ministro Francisco Peçanha Martins noutra ocasião, temos que enunciar o direito aplicável ao caso concreto, não o direito em tese. Forçoso, distinguir, em primeiro lugar, o inadimplemento perpetrado por uma pessoa jurídica portentosa e aquele inerente a uma pessoa física que está vivendo no limite da sobrevivência biológica. 7. Em segundo lugar, a Lei de Concessões estabelece que é possível o corte considerado o interesse da coletividade, que significa interditar o corte de energia de um hospital ou de uma universidade, bem como o de uma pessoa que não possui condições financeiras para pagar conta de luz de valor módico, máxime quando a concessionária tem os meios jurídicos legais da ação de cobrança. A responsabilidade patrimonial no direito brasileiro incide sobre o patrimônio do devedor e, nesse caso, está incidindo sobre a própria pessoa. 8. Outrossim, é voz corrente que o 'interesse da coletividade' refere-se aos municípios, às universidades, hospitais, onde se atingem interesses plurissubjetivos. 9. Destarte, mister analisar que as empresas concessionárias ressalvam evidentemente um percentual de inadimplemento na sua avaliação de perdas, e os fatos notórios não dependem de prova (notoria nom egent probationem), por isso que a empresa recebe mais do que experimenta inadimplementos. 10. Esses fatos conduzem a conclusão contrária à possibilidade de corte do fornecimento de serviços essenciais de pessoa física em situação de miserabilidade, em contrapartida ao corte de pessoa jurídica portentosa, que pode pagar e protela a prestação da sua obrigação, aproveitando-se dos meios judiciais cabíveis.10. Recurso Especial provido, ante a função uniformizadora desta Corte". 
ROCHA, Fábio Amorim da. A legalidade da suspensão do fornecimento de energia elétrica aos consumidores inadimplentes. Rio de Janeiro: Lumen Juris, 2004.

SEGALLA, Alessandro. A suspensão do fornecimento de energia elétrica ao usuário inadimplente à luz da Constituição Federal. Revista de Direito do Consumidor. n. 37, Jan- Mar/2001. São Paulo: Revista dos Tribunais.

SILVA, Elmo Rodrigues da. XI-009 - Um percurso pela história através da água: passado, presente, futuro. Disponível em: <http://www.bvsde.paho.org/bvsaidis/saneab/xi-009.pdf >.

TEPEDINO, Gustavo. A responsabilidade civil por acidentes de consumo na ótica Civil-constitucional, in Temas de Direito Civil. $3^{\text {a }}$ ed. Rio de Janeiro: Renovar, 2004.

UNIVERSIDADE DA ÁGUA. Água no planeta. Disponível em: < http://www.uniagua.org.br/publichtml/website/default.asp?tp=3\&pag=aguaplaneta.htm $>$.

VILAVERDE, Carolina, MUNIZ BAPTISTA, Lucas, SOARES, Jessica e SODRÉ, Raquel. O Fundo do Poço. Disponível em: <http://super.abril.com.br/crise-agua/ofundodopoco.shtml>. 


\section{A necessidade de realização de políticas públicas para a universalização do direito ao saneamento básico*}

\section{The need for public policies to universalizing the right to sanitation}

\author{
Ruth Santos** \\ Renata Menezes***
}

* Recebido em 02/09/2016

Aprovado em 24/09/2016
** Doutoranda em Ciências Jurídico-Internacional e Europeia na Faculdade de Direito da Universidade de Lisboa. Mestre em Direito das Relações Internacionais. Pesquisadora Bolsista da Coordenação de Aperfeiçoamento de Pessoal de Nível Superior (CAPES) - Proc. n. 1806/2015-07. Pesquisadora Voluntária do Centro de Investigação \& Desenvolvimento sobre Direito e Sociedade (CEDIS). E-mail: ruthmpsantos@gmail.com.

*** Mestranda em Ciências Jurídico Ambientais na Faculdade de Direito de Lisboa, da Universidade de Lisboa e Advogada. E-mail: renata.acradv@gmail.com.

\section{Resumo}

A ausência de saneamento básico ainda consiste em uma problemática global que atinge cerca de 2,5 milhões de pessoas, ou seja, $40 \%$ da população mundial. Esta realidade incompatível com a dignidade humana, em virtude das consequências desastrosas à saúde, à moradia, à privacidade e ao direito ao meio ambiente ecologicamente equilibrado. O Direito ao saneamento básico foi consagrado como direito humano juntamente com o direito à água pela Assembleia Geral das Nações Unidas por meio da Resolução 64/292, em julho de 2010, sendo essencial para concretização do direito à vida. Além disso há outros documentos internacionais e a legislação nacional brasileira que reconhece o direito ao saneamento básico como indispensável à sobrevivência digna. Desse modo, é dever do Estado, em virtude ao mínimo existencial ecológico, prover mecanismos e políticas públicas capazes de conceder universalmente este direito ao ser humano. No entanto, verificou-se que este é um problema em diversos países, a exemplo do Brasil, uma vez que o direito ao saneamento básico é reconhecido, todavia, a sua efetivação em alguns casos se torna difícil ou impossível. Nesse sentido o problema de pesquisa é averiguar quais os instrumentos que o Estado Brasileiro poderia utilizar para ampliar o sistema de saneamento, prezando pela sua universalização. Como paradigma de políticas públicas, foi utilizado o caso da Colômbia, que adota em conjunto práticas jurisdicionais e administrativas para a ampliar o referido direito. A metodologia utilizada foi a bibliográfica, legislativa e jurisprudencial, a fim de verificar a possibilidade de efetivação de políticas públicas para o cenário brasileiro.

Palavras Chaves: Direito ao Saneamento Básico; Direitos Humanos; Meio Ambiente Sustentável; Proteção Ambiental.

\section{Abstract}

The absence of basic sanitation still consists of a global problem that reaches about 2,500,000 people, this is a $40 \%$ of the world's population. This reality is incompatible with human dignity, because of the disastrous consequences to health, to housing, to privacy and the right to an ecologi- 
cally balanced environment. The right to sanitation was consecrated as a human right along with the right to water by the UN General Assembly through Resolution 64/292, in July 2010, is essential to realization of the right to life. In addition, there are other international documents and the Brazilian national legislation that recognizes the right to sanitation as indispensable to dignified survival. Thus, it is the duty of the State, due to the existential minimum ecological, provide mechanisms and public policies able to grant this right to universally human. However, it was found that this is a problem in several countries, like Brazil, since the right to sanitation is recognized, however, its effectiveness in some cases becomes difficult or impossible. In this sense the problem of research is to find out what are the instruments that the State could use to expand the sanitation system, maintaining for its universalization. As a paradigm of public policy, was used in the case of Colombia, which adopts judicial and administrative practices together to expand entitlement. The methodology used was the judicial, legislative and bibliographical, in order to verify the possibility of implementation of public policies for the Brazilian scenario.

Key Words: Sanitation; Human Rights; Sustainable Environment; Environmental Protection.

\section{INTRODUÇão}

O presente trabalho apresenta uma problemática que assola 2,4 bilhões de pessoas no mundo, a ausência de saneamento básico e, consequentemente, a inexistência de condições condignas de vida, que burla totalmente o entendimento sobre dignidade humana. A questão versa sobre dois âmbitos: o direito social e o direito ambiental, que neste aspecto estão interligadas, uma vez que a legislação internacional e o sistema normativo brasileiro preveem a universalização do sistema de saneamento básico, como indispensável para a sobrevivência humana.

Nessa perspectiva, o trabalho não vem discutir o reconhecimento deste direito, mas sim, contestar a ausência de políticas públicas no contexto brasileiro para a sua efetivação, uma vez que são 100 milhões de pessoas que tem esse direito negligenciado, bem como, são 1,2 bilhão $\mathrm{m}^{3}$ de volume de esgoto despejado na natureza. Dessa maneira, o problema de pesquisa é verificar quais são os mecanismos/instrumentos que Brasil pode utilizar para a realização de políticas públicas para alcançar a universalização do direito ao saneamento?

Para tanto, o trabalho foi divido em três partes. A primeira versa sobre a efetivação do direito humano ao saneamento básico, uma vez que há inúmeros instrumentos internacionais e nacionais que convalidam este direito, seja como direito humano ou como direito fundamental, e negligencia-lo é uma afronta aos direitos individuais e ao meio ambiente. $\mathrm{Na}$ segunda parte, apresenta-se a aplicação do direito ao saneamento básico sob o prisma do mínimo existencial ecológico, que concatena a relação entre os aspectos sociais e ecológicos necessários para a sobrevivência em condições dignas.

Por fim, na terceira parte, demonstra-se que é possível efetivar o direito ao saneamento básico, a partir de políticas públicas efetivas, e que não estejam meramente no papel, com a participação popular e com o compromisso do Estado em realiza-las. Este é o exemplo da Colômbia, que tem o IDH menor que o brasileiro, e com políticas públicas direcionadas ao saneamento básico e a universalização deste sistema conseguiu, alcançar quase que $100 \%$ da população urbana e rural tivesse acesso ao sistema de esgoto e água potável. Nesse sentido, o caso colombiano é paradigma para que os municípios e estados brasileiros promovam políticas públicas para a melhoria e efetivação do direito ao saneamento básico.

Ressalta-se que a metodologia utilizada no trabalho foi a documental, a partir de referências nacionais e internacionais, assim como os instrumentos normativos, dados sobre o desenvolvimento da universalização do sistema de saneamento básico no mundo. De igual modo, a jurisprudência colombiana serviu de subsídio para a construção do paradigma em que o Brasil deve se inserir para a consecução e efetivação desse direito, tão descurado nos dias atuais. 


\section{A efetivação do diREITo humano ao SANEAMENTO BÁsico}

A problemática em torno da ausência de saneamento básico para as populações em torno do mundo, além das consequências sanitárias, são os problemas sociais e ambientais. Tal questão é motivada por fatores que decorrem da crise ambiental global de grande complexidade, que está associada às desigualdades sociais, ao crescimento demográfico, ao desenvolvimento desorganizado das cidades que dificultam o acesso ao saneamento de forma igualitária. Estas situações são proporcionadas pela sociedade de risco que tem com efeitos colaterais nas populações mais carentes, que tem o seu direito ao saneamento básico negado pelo Estado.

Em verdade, esse direito já está reconhecido pela Organização das Nações Unidas, por meio da Resolução A/RES/64/292. A resolução da ONU reconhece pela primeira vez que o saneamento básico e a água potável são indispensáveis para a efetivação de todos os direitos humanos. Ademais, pede aos Estados e as organizações internacionais que promovam a concretização do direito ao saneamento básico por meio da disponibilização de recursos públicos para o desenvolvimento de capacidades e para a transferência de tecnologia, a fim de contribuir para a melhoria destes serviços, sobretudo, em países em desenvolvimento ou em vias de desenvolvimento ${ }^{1}$.

Muito embora, o direito ao saneamento seja reconhecido pela ONU é importante saber que:

\section{“(...) 2,4 bilhões de pessoas no mundo vivendo sem saneamento adequado;}

Em 2015, 68\% da população mundial tem acesso ao saneamento adequado, contra os 77\% esperado dos ODM;

2,1 bilhões de pessoas passaram a ter acesso a um saneamento adequado, desde 1990;

$82 \%$ da população urbana tem acesso ao saneamento, contra $51 \%$ da população rural;

São 7 pessoas em cada 10 vivendo sem saneamento adequado ${ }^{2}$. (grifo nosso)

Além disso, destaca-se também que mais de 1 bilhão de pessoas no mundo fazem as suas necessidades fisiológicas ao ar livre, pois 13\% da população mundial não tem acesso ao banheiro, 9 em cada 10 pessoas defecam a céu aberto nas áreas rurais ${ }^{3}$. No Brasil, são 4 milhões de pessoas sem acesso a um banheiro, isto demostra a negligência com políticas públicas para implementação de saneamento básico. São avanços inexpressivos, os dados apresentados em 2013 pelo Ministério das Cidades (Sistema Nacional de Informações sobre Saneamento - SNIS), afirmam que $82,5 \%$ da população da brasileira tem acesso a água tratada, apresentando uma margem de, mais de 35 milhões de brasileiros não possuíam este serviço4.

Diante do acesso ao saneamento básico, apenas 48,6\% da população recebia este serviço, inteirando aproximadamente 100 milhões de brasileiros, que tem o acesso ao saneamento negligenciados. O espantoso foi em relação a situação dos esgotos tratados, que de acordo com os dados apresentados, são apenas 39\% dos esgotos, supondo em comparação a mais de 5 mil piscinas olímpicas de esgotos, que são não tratados e despejados diariamente na natureza ${ }^{5}$.

1 UNITED NATIONS. O Direito Humano à água e ao saneamento: marcos. Programa da Década da Água da ONU-Água sobre Advocacia e Comunicação (UNW-DPAC). Disponível em: < http://www.un.org/waterforlifedecade/pdf/human_right_to_ water_and_sanitation_milestones_por.pdf>. Acesso em 2.9.2016, p. 3.

2 Dados disponibilizados pela Organização Mundial de Saúde (OMS) e Unicef em 2015. TRATA BRASIL. Imprensa: Ranking do Saneamento no mundo. Disponível em < http://www.tratabrasil.org.br/ranking-do-saneamento-2015>. Acesso em 01.09.2016 3 Dados disponibilizados pela Progress on Sanitation and Drinking-Water", 2015 - (OMS)/ UNICEF. . TRATA BRASIL. Imprensa: Ranking do Saneamento no mundo. Disponível em <http://www.tratabrasil.org.br/ranking-do-saneamento-2015>. Acesso em 01.09.2016

4 TRATA BRASIL. Imprensa: Ranking do Saneamento em 2015. Disponível em < http://www.tratabrasil.org.br/ranking-dosaneamento-2015>. Acesso em 01.09.2016.

5 TRATA BRASIL. Imprensa: Ranking do Saneamento em 2015. Disponível em < http://www.tratabrasil.org.br/ranking-dosaneamento-2015>. Acesso em 01.09.2016. 
Os dados apresentados demonstram que a definição de saneamento dado pela ONU e pela Organização Mundial de Saúde (OMS) é ignorada, tendo em vista que se entende que saneamento é "o sistema de recolha, transporte, tratamento, eliminação ou reciclagem de excrementos, e higiene ligados a estas questões" . Além disso, "refere-se à manutenção de condições de higiene, através de serviços como coleta de lixo e eliminação de águas residuais"”. Por essa razão, é importante o acesso da população ao banheiro, pois a prática de depositar excrementos ao ar livre é propulsor de doenças e de contaminação da água.

Ademais, a ausência de saneamento básico consiste em uma problemática incompatível com a dignidade humana, não apenas em razão das pessoas conviverem com o esgoto a céu aberto, com o risco iminente de doenças. Mas também, com consequências desastrosas na moradia, na privacidade e no direito ao meio ambiente ecologicamente equilibrado. Essa realidade é ainda negada ou desacreditada por muitos, pois a falta de acesso ao saneamento básico atinge os grupos sociais marginalizados e que vivem em extrema pobreza.

Neste sentido, é fundamental a efetivação do direito ao saneamento, por ser um fator condicional mínimo para a manutenção da vida e do bem-estar físico e psíquico do próprio ser humano, além de ser um método preservação e conservação do meio ambiente. Ressalta-se ainda que o direito ao saneamento é indispensável para a garantia da saúde pública, pois a ausência de fornecimento adequado do serviço, contribui para a mortalidade infantil e diversas doenças endêmicas.

Não se trata de reconhecimento do direito, ou de um direito abstrato, ao contrário, o direito ao saneamento básico é um direito material, que necessita de políticas públicas para ser efetivado e garantir à população mundial condições dignas de sobrevivência. Como pode se ver desde 1977 discute-se a promoção ao direito humano ao saneamento e das águas. Em Estocolmo, houve diversas conferências específicas sobre o meio ambiente, sendo a Conferência de Mar del Plata em 1977, a primeira sobre a água de caráter multilateral e global, que tinha objetivo reforçar cooperação internacional para resolução dos problemas vinculados as águas.

Na conferência de Mar del Plata foram lançados o Plano de Ação então adotado reconheceu a conexão intrínseca entre os projetos de desenvolvimento de recursos hídricos e suas significativas repercussões físicas, químicas, biológicas, sanitárias, sociais econômicas. Isto constitui a Década de 1980 como a "Década Internacional do Fornecimento da Água Potável e do Saneamento" sob a premissa de que "todos os povos, quaisquer que sejam seu estágio de desenvolvimento e suas condições sociais e econômicas, têm direito ao acesso à água potável em quantidade e qualidade à altura de suas necessidades básicas"».

O Plano de Ação incluía uma série de recomendações e resoluções, que abarcava vários assuntos ligados à água, quesitos fundamentais que incluíam a avaliação dos recursos hídricos; o uso eficiente da água. Além da proteção do meio ambiente, da saúde humana e do controle da poluição; incluiu também políticas, planejamento e gestão interligada a cooperação regional e internacional ${ }^{9}$.

O Decênio Internacional do Fornecimento de Água Potável e Saneamento foram divulgados pela ONU em novembro de 1980, com a participação dos atores internacionais, com investimentos financeiros e técnicos, que tinham por objetivo promover o acesso à água potável e o saneamento básico ao maior número de pessoas possíveis, em especial às populações marginalizas e carentes. Em 1990, após passar o prazo da Década da Água, foi realizada em Nova Délhi, na Índia uma reunião para averiguações dos resultados, porém as expectativas foram frustradas diante dos índices abaixo do esperado ${ }^{10}$.

6 ALBUQUERQUE, Catarina. Marcos de Legislación, regulaciones y políticas. In: Manual Prático para la realización de los Derechos Humanos al Agua y al Saneamiento de La Relatora Especial de La ONU. Handbook, Portugal, 2014. Disponível em < http://www.righttowater.info/handbook/> p.06 Acesso em 01.09.2016

7 WORLD HEALTH ORGANIZATION. Sanitation. Disponível em <http://www.who.int/topics/sanitation/en/>. Acesso em 2.9.2016.

8 VARGAS, Éverton Vieira. Água e relações internacionais. Rev. bras. polít. int. [online]. 2000, vol.43, n.1, pp. 178-182. Disponível em < http://www.scielo.br/pdf/rbpi/v43n1/v43n1a10.pdf> Acesso em 31.08.2016, p.5.

9 ESPADA, Gildo. O Direito Humano à Água. In: GOUVEIA, Jorge Bacelar (org.). III Congresso do Direito de Língua Portuguesa - Justiça, Desenvolvimento e cidadania. pp.235 - 250 Almedina: Coimbra, 2014, p.238.

10 RIBEIRO, Wagner Costa. Geografia política da água. São Paulo: Annablume, 2008, p.78. 
Porém, há que se destacar alguns resultados positivos no decênio, como a criação pela UNESCO do Programa Hídrico Internacional (PHI), que tinha por objetivo padronizar a coleta de dados sobre a água no mundo. Houve incentivos para investigação e aperfeiçoamento técnico dos profissionais do setor da engenharia sanitária, que aprimoraram os seus conhecimentos e as doenças endêmicas de veiculação hídrica foram minimizadas ou erradicadas do quadro geral da saúde ${ }^{11}$.

Posteriormente, distintos instrumentos internacionais mencionaram o direito à água e o acesso ao saneamento como meio de erradicar a desigualdade e discriminação. Destaca-se a Conferência sobre a Eliminação de Todas as Formas de Discriminação Contra as Mulheres (1979) ${ }^{12}$, a Convenção Internacional sobre os Direitos da Criança (1989) ${ }^{13}$. Somente, em 1992, com a Conferência Internacional sobre a Água e Meio Ambiente organizada pela ONU, em Dublin, foi abordado diretamente o tema, sobre a água limpa e o acesso ao saneamento, apresentando-se compromissos e recomendações para ações em níveis local, nacional e internacional.

A Conferência do Rio de Janeiro de 1992 reafirmou os princípios e propósitos estabelecidos na Conferência de Estocolmo e incluiu o princípio do desenvolvimento sustentável. Enfatizou a necessidade de reconhecimento do direito humano ao meio ambiente como centro das preocupações, como uma vida saudável e produtiva (economicamente) em harmonia com a natureza, sendo intrínseco o direito ao meio ambiente sadio e o direito ao desenvolvimento ${ }^{14}$.

Destaca-se ainda, a Agenda 21, no Capítulo 18, regulamenta sobre a proteção da qualidade e do abastecimento dos recursos hídricos e evidência a água como direito que deve ser assegurado ao homem ${ }^{15}$. Em 1999, a Assembleia Geral das Nações Unidas aprovou a Resolução A/Res/54/175, que afirma o direito à concretização total ao desenvolvimento, promovendo o direito a água como parte dos direitos humanos. $\mathrm{O}$ art. 12 da referida resolução determina que "os direitos à alimentação e à água limpa são direitos fundamentais e a sua promoção constitui um imperativo moral tanto para os governos nacionais como para a comunidade internacional" ${ }^{16}$.

Declaração Política, da Cimeira Mundial sobre Desenvolvimento Sustentável de Johanesburgo, realizada em 2002, mencionou "sobre a indivisibilidade da dignidade humana (...) o acesso aos requisitos básicos, tais como água limpa, saneamento, energia, cuidados de saúde, segurança alimentar e proteção da biodiversidade" ${ }^{17}$. Em novembro no mesmo ano, foi enunciado o Comentário Geral no 15 do Comitê dos Direitos Econômicos, Sociais e Culturais, que inclui definitivamente o direito à água nos Direitos humanos. Este documento alertou que o direito à água está associado diretamente aos direitos básicos e possui a centralidade para a concretização de direitos como a alimentação, a saúde, moradia, além de outros interligados a dignidade da pessoa humana.

11 RIBEIRO, Wagner Costa. Geografia política da água. São Paulo: Annablume, 2008, p.78.

12 (Vejamos o que institui o artigo 14 (2), h): "gozar de condições de vida adequadas, particularmente nas esferas da habitação, dos serviços sanitários, da eletricidade e do abastecimento de água, do transporte e das comunicações”. ONU. Convenção sobre a Eliminação de todas as Formas de Descriminação contra a Mulher 1979. Disponível em <http://www.unicef.org/brazil/pt/ resources_10233.htm>. Acesso em 08.10.2015.

13 Vide artigo $24^{\circ}$, c) “Combater a doença e a má nutrição, no quadro dos cuidados de saúde primários, graças nomeadamente à utilização de técnicas facilmente disponíveis e ao fornecimento de alimentos nutritivos e de água potável, tendo em consideração os perigos e riscos da poluição do ambiente". ONU. Convenção sobre os Direitos da Criança 1989. Disponível em: https://www. unicef.pt/docs/pdf_publicacoes/convencao_direitos_crianca2004.pdf. Acesso em 01.09.2016.

14 SILVA, José Afonso da. Direito Ambiental Constitucional. São Paulo: Malheiros, 2010, p. 64.

15 BRASIL. Câmara dos Deputados. Comissão de Defesa do Consumidor, Meio Ambiente e Minorias. Conferência das Nações Unidas sobre Meio Ambiente e Desenvolvimento: Agenda 21. Brasília: 1995 Disponível em : http://www.onu.org.br/ rio20/img/2012/01/agenda21.pdf Acesso em 01.09.2016.

16 ONU. Resolução 54/175. Disponível em < http://www.un.org/ga/search/view_doc.asp?symbol=A/RES/54/175>. Acesso em 02.09.2016.

17 UNITED NATIONS. O Direito Humano à água e ao saneamento: marcos. Programa da Década da Água da ONU-Água sobre Advocacia e Comunicação (UNW-DPAC). Disponível em: < http://www.un.org/waterforlifedecade/pdf/human_right_to_ water_and_sanitation_milestones_por.pdf $>$. Acesso em 2.9.2016, p. 3. 
Observa-se que em todos esses documentos internacionais mencionava-se o direito à água como um todo, não havia a separação entre água e saneamento básico, que eram entendidos como um mesmo direito. Somente com a Resolução 64/262, mencionada anteriormente, é que esses direitos são reconhecidos de forma separada e essenciais para o desenvolvimento humano saudável.

A partir de então, a ONU, por meio da Resolução A/HRC/RES/15/9, do Conselho dos Direitos Humanos, reconhece o direito ao saneamento básico como parte do direito internacional, portanto, são legalmente vinculativos para os Estados. Dessa maneira, os Estados deveriam desenvolver "ferramentas e mecanismos adequados para alcançarem, gradualmente, a concretização integral das obrigações em termos de direitos humanos relacionadas com o acesso a água potável segura e saneamento ${ }^{18 ”}$.

Por fim, o direito ao saneamento básico deve garantir o acesso de forma igualitária a todas as pessoas. Não se trata de reconhecer um direito, mas sim de possibilitar às populações mais pobres condições dignas de vida. Porquanto diante de um quadro em que inexiste a proteção ao direito à intimidade, quando não se pode fazer as necessidades fisiológicas em um banheiro; quando há uma crise sanitária diante pelo fato do esgoto está a correr a céu aberto.

No caso brasileiro, Constituição Federal determina que é de competência da União para criar diretrizes para gerir o saneamento básico o sistema nacional de recursos hídricos (art. 21) ${ }^{19}$. Bem como, competência comum da União, dos Estados, do Distrito Federal e dos Municípios para promover programas para a melhoria das condições de saneamento básico e para a proteção do meio ambiente e combate à poluição ${ }^{20}$.

Quanto à legislação infraconstitucional, destaca-se, especialmente, a Lei 11.445/2007, que estabelece as diretrizes nacionais para o saneamento básico. A referida norma possui dez capítulos, divididos em sessenta artigos, qual se destaca o capítulo IX, que trata da política federal de saneamento básico. Neste capítulo são dispostos inúmeras políticas públicas e mecanismos para a efetivação de um sistema de saneamento básico igualitário, com atenção à população de baixa renda.

Sendo assim, em um contexto internacional e nacional, trata-se, na verdade, de efetivação da dignidade humana, muito discutida como princípio norteador dos direitos humanos, porém pouco efetiva. É, portanto, necessário que os Estados criem políticas públicas efetivas e mecanismos reais capazes de modificar a realidade desigual que se tem atualmente quando se trata de saneamento básico. O direito ao saneamento básico está posto, seja em nível nacional, regional ou internacional, o que se precisa ter atenção é aplicação desse direito e os mecanismos existentes para a consecução deste direito.

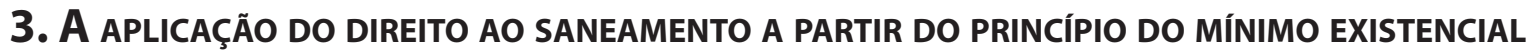 ECOLÓGICO}

A preservação do meio ambiente e o acesso universal ao saneamento básico está associado ao princípio da dignidade humana, pois a proteção desses direitos consiste na garantia à vida, à saúde, à moradia e à alimentação, necessários para a subsistência digna e saudável do ser humano ${ }^{21}$. Todavia, o princípio da dig-

18 UNITED NATIONS. O Direito Humano à água e ao saneamento: marcos. Programa da Década da Água da ONU-Água sobre Advocacia e Comunicação (UNW-DPAC). Disponível em: < http://www.un.org/waterforlifedecade/pdf/human_right_to_ water_and_sanitation_milestones_por.pdf $>$. Acesso em 2.9.2016, p. 3.

19 XIX - instituir sistema nacional de gerenciamento de recursos hídricos e definir critérios de outorga de direitos de seu uso; XX - instituir diretrizes para o desenvolvimento urbano, inclusive habitação, saneamento básico e transportes urbanos;

20 Art. 23. É competência comum da União, dos Estados, do Distrito Federal e dos Municípios: IX - promover programas de construção de moradias e a melhoria das condições habitacionais e de saneamento básico; VI - proteger o meio ambiente e combater a poluição em qualquer de suas formas;

21 Além disso, "Como direito fundamental, ao equilíbrio ecológico, atribui-se irrenunciabilidade, inalienabilidade e imprescritibilidade, características que, posteriormente, informarão a ordem pública ambiental e o próprio marco jurídico dorsal”. BENJA- 
nidade humana, no caso em tela, se torna inócuo, pois a sua efetividade não é completa, tendo em vista os milhões de pessoas no mundo que vivem sem acesso ao saneamento básico.

Para que o princípio da dignidade humana seja consagrado no direito ambiental, é necessário um nível mínimo de qualidade ambiental, com garantia do desenvolvimento humano alinhado ao bem-estar existencial $^{22}$, o que inexiste em diversos países ainda. Nesse sentido, a proteção do meio ambiente, e nisto consiste a efetivação do direito ao saneamento básico, depende de atuação do Estado e do próprio cidadão, pois sem participação conjunta de ambos se torna impossível a promoção dos direitos fundamentais.

É necessário associar a proteção do meio ambiente ao âmbito da proteção jurídica subjetiva a partir dos direitos fundamentais. Haja vista que a congregação de um direito fundamental ao ambiente leva, consequentemente, à sua proteção contra agressões ilegais, seja das esferas pública ou privada. Para Vasco Pereira da Silva, a partir do momento que o Estado de Direito Ambiental determina a obrigação em conjugar direitos fundamentais (e entende-se aqui, na esfera internacional, direitos humanos) com questões ambientais, torna-se possível a preservação da natureza e dos direitos fundamentais ali envolvidos. ${ }^{23}$

Isto significa dizer que a proteção ambiental está associada ao resguardo dos direitos sociais que, uma vez que estão vinculados às condições ambientais favoráveis. O Estado Ambiental de Direito deve permitir o acesso à água potável, ao saneamento básico, à alimentação saudável e sem contaminação, a moradia fora de riscos de contaminação e transmissão de doenças, ou de desabamentos. "A efetividade dos serviços de abastecimento de água e de esgotamento sanitário integra, direta ou indiretamente, o âmbito normativo de diversos direitos fundamentais ${ }^{24}$,

Nesse sentido, é que se destaca o direito ao um mínimo ecológico de existência, segundo Canotilho, este direito é o resultado do Estado Socioambiental, que deve ter preocupações sociais focadas também na proteção e promoção do meio ambiente ${ }^{25}$. O mínimo existencial ecológico é a tentativa de proteger os direitos fundamentais diante das opressões associadas à degradação ambiental ${ }^{26}$. Portanto, o Estado Sociambiental de Direito assume a função de resguardar os cidadãos que seus direitos fundamentais não sejam infringidos em decorrência do impacto e degradação ambiental, a este despeito, mais adiante ver-se-á a concretização dessa ideia, a partir do caso da Colômbia, que criou o precedente em sua Corte Constitucional em reconhecer o direito ao saneamento básico, como um direito fundamental, sendo obrigação do Estado em prover e manter políticas públicas essenciais para efetivação desse direito.

O direito ao mínimo existencial ecológico possui um conteúdo de uma necessidade comum, definida por um caráter difuso dos direitos fundamentais ${ }^{27}$. Nessa linha, o Supremo Tribunal Federal no Mandado de Segurança 22.164, entendeu que a proteção e a defesa do meio ambiente são um direito difuso, que per-

MIN, Antonio Herman. Constitucionalização do ambiente e ecologização da constituição brasileira. In.: CANOTILHO, J. J. Gomes. LEITE, Jose Rubens Morato (org). Direito Constitucional Ambiental Brasileiro. 2 ed. São Paulo: Saraiva, 2008 , p. 98.

22 FENSTERSEIFER, Tiago; SARLET, Ingo Wolfgang. Estado socioambiental e mínimo existencial (ecológico?): algumas aproximações. In: Estado Socioambiental e Direitos Fundamentais. SARLET, Ingo Wolfgang (org.) Porto Alegre: Livraria do Advogado, 2010.p. 13.

23 SILVA, Vasco Pereira da. Verde: Cor de Direito - Lições de Direito do Ambiente. Coimbra: Almedina, 2002, p. 67

24 SIQUEIRA GARCIA, Denise Schmitt; GARCIA, Heloise Siqueira. Mínimo existencial ecológico: a intrínseca relação entre a dignidade da pessoa humana e à qualidade ambiental. 2015. Disponível em <http://emporiododireito.com.br/minimo-existencial-ecologico-a-intrinseca-relacao-entre-a-dignidade-da-pessoa-humana-e-a-qualidade-ambiental-por-denise-schmitt-siqueiragarcia-e-heloise-siqueira-garcia/>. Acesso em 2.9.2016.

25 CANOTILHO, J. J. Gomes. Jurisdicização da ecologia ou ecologização do Direito. In: Revista Jurídica do Urbanismo e do Ambiente, no 4, dezembro de 1995, p. 73 e segs. Apud MIRANDA, Jorge. O Meio Ambiente e a Constituição. In: Diálogo Ambiental, Constitucional e Internacional. Fortaleza: Premius, 2013. p. 25 -44.

26 AYLA, Patryck de Araújo. Direito fundamental ao ambiente e a proibição de regresso aos níveis de proteção ambiental na Constituição Brasileira. In: Princípio da Proibição de retrocesso Ambiental. Brasília: Comissão de Meio ambiente do Senado Federal. pp. 207-246. Disponível em: <http://www.mma.gov.br/port/conama/processos/93127174/Voto_APROMAC_ ANEXO.pdf>. Acesso 2.9.2016

27 MIRANDA, Jorge. Manual de Direito Constitucional - Direito Fundamentais. Parte IV. $3^{\text {a }}$ Ed. Coimbra: Coimbra Editora, 2000, p. 68-69. 
tence a toda coletividade por se tratarem de direitos de terceira geração, portanto, consagram o princípio da solidariedade ${ }^{28}$.

Ressalta-se que o mínimo existencial ecológico se baseia na relação entre os aspectos sociais e ecológicos necessários para a dignidade humana, decorrente da evolução dos direitos fundamentais, que se realiza por meio de um arcabouço indispensável para a prestação do conteúdo ecológico, social, econômico e cultural inerentes ao desenvolvimento e a manutenção da vida em condições dignas ${ }^{29}$. O direito ao saneamento básico é a concretização desta correlação entre direito ambiental e direitos sociais, uma vez que é necessária a articulação entre esses dois direitos para o acesso universal ao saneamento básico e todos os outros direitos fundamentais decorrentes daquele.

Para o alcance de um patamar mínimo de qualidade ecológica direitos e deveres fundamentais são atribuídos ao Estado. O objetivo é preservar e proteger os bens ambientais e garantir para a presente e futuras gerações um meio ambiente socialmente equilibrado, com qualidade de vida, e que os direitos à vida, à privacidade, à saúde sejam resguardados, por meio da tutela ambiental, como se faz necessário na efetivação do direito ao saneamento básico.

Como mencionado outrora, este direito é devidamente reconhecido, seja no plano internacional ou nacional. O desafio e/ou problema que os países encontram é como efetivar, de fato, este direito, uma vez que não existe ou não realizam políticas públicas adequadas para a universalização de um sistema de saneamento básico. Além disso, o desinteresse da população em participar democraticamente das decisões tomadas em relação à sua comunidade. Além disso, há problemas orçamentários decorrentes da má gestão administrativa ou mesmo da corrupção que assola os países, como no caso brasileiro.

Portanto, o direito humano ao saneamento é em si uma via de mão dupla, como se verificará a partir do caso colombiano. Haja vista a corte constitucional colombiana, determina que é um dever prestacional por parte do Estado em fornecer mecanismos e políticas públicas para a consecução desse direito. Em contrapartida, o cidadão está legitimado a exigir do Estado a defesa do ambiente e o bem-estar existencial, resultando a estimulação da participação no acompanhamento de políticas públicas ambientais ${ }^{30}$.

A configuração do mínimo existencial ambiental no direito ao saneamento tem por ideia de justiça social ${ }^{31}$, no sentido de garantir um mesmo universal a todas as pessoas. Neste sentido, a garantia de efetivação do direito ao saneamento deve ser realizada por meio de políticas públicas estruturadas em diretrizes e objetivos que possam promover a acessibilidade de forma universal em parâmetros geográficos e sociais. Ou seja, instituindo os princípios basilares para concretização do direito ao saneamento, como o da participação cidadã nas tomadas de decisão, acesso a informação, a não discriminação, acesso igualitário e sustentabilidade.

\section{EFETIVAÇÃo do diREITO HUMANO AO SANEAMENTO BÁSICO: O EXEMPLO COLOMBIANO DE POLÍTICAS PÚBLICAS}

A preocupação existente hoje, a partir dos dados mencionados na primeira parte, é como o Brasil pode melhorar o acesso ao saneamento básico às populações de baixa renda, promovendo também o acesso à

28 BRASIL. Mandando de Segurança 22.164. Brasília: Supremo Tribunal Federal. 1995. Rel. Min. Celso de Mello, julgamento em 30-10-1995, Plenário, DJ de17-11-1995.

29 SILVA, Brisa Arnoud da. A importância da garantia do mínimo existencial ecológico para a concretização do estado democrático socioambiental. Justiça do Direito, v. 28, n. 1, p. 84-107, jan./jun. 2014. Disponível em <http://dx.doi.org/10.5335/ rjd.v28i1.4832>. Acesso em 2.9.2016, p. 92-93.

30 MIRANDA, Jorge; MEDEIROS, Rui. Constituição Portuguesa Anotada. Tomo I, $2^{\circ}$ Ed. Coimbra: Coimbra Editora, 2010 , p. 1348 .

31 FENSTERSEIFER, Tiago; SARLET, Ingo Wolfganf. Estado socioambiental e mínimo existencial (ecológico?): algumas aproximações. In: Estado Socioambiental e Direitos Fundamentais. SARLET, Ingo Wolfganf (org.) Porto Alegre: Livraria do Advogado, 2010, p. 36 
uma vida digna e saudável. O Brasil por ser um país muito grande, e consequentemente as desigualdades também, pode ao mesmo tempo ser exemplo positivo e negativo para o fornecimento do serviço de saneamento básico. E este é o desafio, de como criar uma igualdade no cenário brasileiro, quais as políticas públicas podem ser implementadas?

A exemplo disso, o estado de Porto Alegre, que está na região sul, tem uma gestão municipal de serviços que fornece um sistema universal de água potável e de saneamento básico à população. Isto foi alcançado pelo governo de Porto Alegre por meio da utilização adequada de recursos públicos que foram destinados à infraestrutura do sistema e isenções tributárias que permitiram o governo criar tarifas sociais de modo sustentáveis. Além disso, a gestão desses serviços conta com a participação ativa dos usuários, de um corpo deliberativo, que é composto por engenheiros, ambientalistas e representantes da sociedade civil, o que permite que o sistema de saneamento básico se desenvolva e se mantenham a favor da população ${ }^{32}$.

Em contrapartida, somente nas capitais da região norte são 82\% (oitenta e dois por cento) de pessoas que vivem sem que o esgoto seja tratado, isso significa que são 211 milhões de metros cúbicos de esgotos jogados na natureza. Já na região nordeste, as capitais, totalizam 46\% (218 milhões de $\mathrm{m}^{3}$ de esgotos na natureza) não são tratados, isso significa dizer somente $71 \%$ das pessoas tem acesso à água tratada e apenas $21 \%$ tem coleta de esgotos ${ }^{33}$.

Quanto à região centro-oeste, em relação às capitais, 70\% das pessoas tem acesso ao tratamento de esgoto, sendo considerado o melhor nível das regiões brasileiras, seguido pela região sudeste que $61 \%$ do esgoto é tratado nas quatro capitais. Contrariando os dados da cidade de Porto Alegre, na região Sul, em suas três capitais, $60 \%$ do esgoto não é tratado e as pessoas não tem acesso ao mínimo de saneamento básico ${ }^{34}$.

Os dados não levam em consideração as outras cidades brasileiras, tampouco, as zonas rurais e o interior do Brasil. Somente em relação às vinte e seis capitais brasileiras o volume de esgoto lançado na natureza totaliza 1.164 milhões (1,2 bilhão) de $\mathrm{m}^{3}$. Isso significa dizer que o Brasil está distante de ter um acesso universal de água tratada e coleta e tratamento de esgoto, o que leva a um impacto ambiental e de saúde pública, causado pelas doenças decorrentes da falta de saneamento.

Para corroborar com o entendimento o estudo "Benefícios Econômicos da Expansão do Saneamento no Brasil", realizado em 2014, pelo Conselho Empresarial Brasileiro para o Desenvolvimento Sustentável e do Instituto Trata Brasil, indica que o Brasil ocupa a $112^{a}$ posição em um ranking de saneamento entre 200 países. A pontuação brasileira no Índice de Desenvolvimento de Saneamento ${ }^{35}$ foi de 0,581 em 2011, sendo inferior às médias da América do Norte e da Europa, mais absurdamente, de alguns países do Norte da África e Oriente Médio, em que a população de renda média é inferior ao Brasil ${ }^{36}$. Numa comparação na América Latina, no que se refere à atendimento Urbano de Esgoto, o Brasil está abaixo do Chile, México, Colômbia, Bolívia, Peru, Equador, Argentina, Guatemala, Honduras, Uruguai e El Salvador ${ }^{37}$.

Em contrapartida alguns casos, como o de Porto Alegre, merecem ser destacados, como nas cidades de Cascavel (PR), Curitiba (PR), Franca (SP), Jundiaí (SP), Londrina (PR), Maringá (PR), Niterói (RJ), Santos

32 JUSTO, Juan Bautista. El Derecho Humano al agua y Saneamiento frente a los Objetivos de Desarrollo del Milenio (ODM). CEPAL: 2013. Disponível em <http://www.ohchr.org/Documents/Issues/Water/ContributionsSustainability/ECLAC7.pdf>. Acesso em 2.9.2016, p. 47.

33 TRATA BRASIL. Imprensa: Ranking do Saneamento em 2015. Disponível em < http://www.tratabrasil.org.br/ranking-dosaneamento-2015>. Acesso em 01.09.2016.

34 TRATA BRASIL. Imprensa: Ranking do Saneamento em 2015. Disponível em < http://www.tratabrasil.org.br/ranking-dosaneamento-2015>. Acesso em 01.09.2016.

35 Um indicador que leva em consideração a cobertura por saneamento atual e sua evolução recente

36 CEBDS; TRATA BRASIL. Benefícios Econômicos da expansão do Saneamento Brasileiro. 2014. Disponível em <http://cebds.org/wp-content/uploads/2014/03/BeneficiosEconomicosdaexpans\%C3\%A3odoSaneamentoBrasileiro.pdf>. Acesso em 2.9.2016, p. 4.

37 TRATA BRASIL. Ranking do Saneamento. 2016. Disponível em <http://www.tratabrasil.org.br/datafiles/estudos/ranking/2016/relatorio-completo.pdf $>$.Acesso em 2.9.2016, p. 111 
(SP), São José do Rio Preto (SP), São José dos Campos (SP), Taubaté (SP) e Uberlândia (MG) ${ }^{38}$. Essas cidades adotaram políticas públicas para a modificação do sistema de saneamento básico para que se alcance a universalização desse direito com 100\% de água tratada, coleta e tratamento de esgotos. Dentre as políticas públicas destacam-se o investimento de valores para a melhoria e/ou construção da rede de esgoto e tratamento da água, com a melhor distribuição dos recursos públicos.

No entanto, outra situação que se destaca é a da Colômbia, que segundo o Relatório do Desenvolvimento Humano $2015^{39}$, o Índice de Desenvolvimento Humano (IDH) é de 0,720, ocupando a $97^{a}$ posição; em contrapartida, o Brasil ocupa a $75^{a}$ posição, com o IDH de 0,755. Contudo, a Colômbia, ocupa na América Latina o terceiro lugar no tratamento de esgoto, ou seja, garante a efetivação do direito à universalização do saneamento básico, servindo de fonte de inspiração e modelo a ser seguido pelos municípios e estados brasileiros.

A melhoria no serviço de saneamento básico e água potável na Colômbia foi possível em virtude das políticas públicas determinas pela Corte Constitucional Colombiana, que tem enfatizado que o Direito Humano à água e ao saneamento básico é uma obrigação do Estado. Para a Corte não basta que as políticas públicas estejam delimitadas no papel. É necessário criar condições para pôr em prática estas políticas, isto quer dizer que a política efetivamente exista, a partir de um programa de ação que permita às autoridades responsáveis adotar as medidas necessárias e adequadas para a efetivação desse direito humano.

Ademais, a Corte estabeleceu que a finalidade da política pública deve ter como prioridade a garantia do gozo efetivo do direito, não deve ser uma medida simbólica, sem uma previsão real e concreta da sua realização. Por fim, a terceira condição que a Corte determina exista a participação democrática em todo o processo de decisão, elaboração, implementação e avaliação das políticas públicas, é necessário, portanto, que o cidadão seja ouvido em espaços próprios e em diferentes etapas ${ }^{40}$.

Para confirmar o entendimento da Corte Constitucional da Colômbia destaca-se o Acórdão T-707, de 2012, que tem como demandante Juan Carlos Chamorro Arrieta e como demandando a Alcaldia de Miranda e a Empresa de Servicios Públicos Domiciliarios de Miranda. A síntese do caso é a reclamação do demandante e dos demais vizinhos que tem seus imóveis situados no município de Miranda e estão situados ao lado de um córrego que recebe as águas de esgoto, que não estão ligadas a um plano diretor de saneamento ${ }^{41}$.

A parte demandante alegou que todos os resíduos produzidos por humanos ou animais vão para a região de sua residência, pois o córrego atravessa o quintal das casas sem receber qualquer tratamento de esgoto; ademais, o riacho desemboca no rio Guanabano e posteriormente no rio Las Cañas, um afluente do rio Guegue dentro da bacia do rio Cauca. Por fim, o demandante alega que a situação promove o surgimento de doenças, maus cheiros e degradação do meio ambiente.

Em contrapartida, a parte demandada, argumenta que não tem responsabilidade para a proteção da área, que isto é de competência exclusiva dos moradores da região, portanto, não poderia ser atribuído violação aos direitos fundamentais. Como segundo argumento, informaram que não poderia ser realizado uma obra pública de esgotos para evitar o despejo no córrego, uma vez que o ano fiscal já teria iniciado no ano de 2011, e não havia disponibilidade de orçamento para a obra.

Também destacaram o agravante de que os moradores estão em uma zona que é propícia para a propagação de odores e de poluição das águas devido à criação de animais domésticos cujo os excrementos eram

38 TRATA BRASIL. Casos de Sucesso. Disponível em < http://www.tratabrasil.org.br/casos-de-sucesso>. Acesso em 2.9.2016.

39 PNUD. Relatório do Desenvolvimento Humano 2015: trabalho como motor de desenvolvimento humano. Disponível em: <http://hdr.undp.org/sites/default/files/hdr15_overview_pt.pdf>. Acesso em 92.9.2016.

40 COLÔMBIA. Sentencias T-418 de 2010 y T-595 de 2002. Corte Constitucional.

41 COLÔMBIA. Sentencia T-707/12. Corte Constitucional. Publicação em 11.9.2012. Disponível em < http://www.corteconstitucional.gov.co/relatoria/2012/T-707-12.htm>. Acesso em 2.9.2016. Toda a descrição dos fatos adiante foi baseada no caso em tela. 
misturados aos humanos e jogados diretamente no córrego. Portanto, a Prefeitura de Miranda não poderia proteger um direito que era violado pelos próprios moradores da área.

Por fim, arguiram que o demandante não possui o serviço de saneamento básico porque se recusou a pedir a ligação do serviço à empresa Clerk City, para evitar o pagamento do serviço de esgoto. Bem como inexistem provas de poluição da fauna e da flora, como das fontes hídricas, não podendo haver a responsabilidade dos demandados.

Com base no exposto pelas partes a Corte Constitucional da Colômbia, por meio do juiz Luiz Ernesto Vargas Silva, decidiu conceder a tutela ao demandante como base nos seguintes argumentos. A Corte demonstrou que o direito ao saneamento básico é parte integrante da jurisprudência constitucional da Colômbia e dos instrumentos internacionais.

Primeiramente a Corte enfatizou que tem reconhecido que a ausência de saneamento básico ignora o direito coletivo a um ambiente saudável, uma vez que a ineficiência ou a falta desse serviço ignora os direitos à privacidade, à vida digna e à saúde das pessoas afetadas. Os precedentes da corte sobre saneamento básico destacam a relação entre o acesso a sistemas adequados de eliminação de dejetos, incluindo esgoto, com outros direitos fundamentais como o direito à saúde, à vida digna, à habitação decente, à privacidade e à água potável.

Ademais, a garantia de acesso ao sistema de saneamento básico retrata a obrigação dos direitos fundamentais indispensáveis para garantir a dignidade humana, pois pessoas que não tem acesso ao direito ao saneamento básico são restringidas de terem condições de higiene e segurança para viver. Isto porque pessoas que necessitam de saneamento básico estão expostas a epidemias e doenças que aumentam os níveis de mortalidade infantil, impede de que as crianças tenham assegurado seu direito à educação, por inexistir locais de trabalhos dignos.

Diante dos precedentes da Corte, foi concedido a tutela aos direitos à dignidade, à saúde e à vida digna em relação com às obrigações de saneamento básico, tendo em vista que os habitantes do município de Miranda careciam de um sistema adequado de disposição e canalização das águas residuais provenientes do interior de suas casas. Determinou que os demandados iniciassem um plano detalhado para a execução das obras de esgoto, que deveria ser terminada em seis meses a contar da notificação.

Além das medidas judiciais adotadas pela Colômbia, o governo deste país elaborou um Plano Nacional de Desenvolvimento, com políticas públicas, para o crescimento sustentável do país, a partir de programas de investimento direcionados ao meio ambiente, sobretudo em relação à agua e ao saneamento básico ${ }^{42}$. Também foram estabelecidos cumprimentos de metas para o saneamento básico, que estão focadas em alcançar $100 \%$ da cobertura do serviço público doméstico de esgoto, com a perspectiva de lograr uma cobertura de 97,6\% para o âmbito urbano e de 70\% para o rural, até o ano de $2019^{43}$.

Dentre as políticas públicas adotadas pela Colômbia destacam-se:

42 Estos programas y las entidades encargadas de realizarlos se enuncian a continuación: a) Inventario Nacional de Calidad del Agua. Ministerio de Salud Pública, b) Programa Nacional de Sostenibilidad. Ministerio de Desarrollo Económico, c) Modernización empresarial. Ministerio de Desarrollo Económico, d) Vigilancia de la Superintendencia de Servicios Públicos Domiciliarios. Superintendencia de Servicios Públicos Domiciliarios adscrita al Ministerio de Desarrollo Económico, e) Normas de regulación en el funcionamiento de las empresas. Comisión Reguladora de Agua Potable y Saneamiento Básico. Adscrita al Ministerio de Desarrollo Económico, f) Control y recuperación ambiental. Ministerio del Medio Ambiente. Los diversos programas desarrollados por el Gobierno están limitados por varios factores, unos internos a las entidades y otros externos a las mismas, dando lugar a: a) Deficiente gestión empresarial, b) Baja capacidad de inversión y capital de trabajo limitado, c) Poca capacitación técnica y rezago tecnológico, d) Información del sector dispersa, e) Regulación y control inadecuados, f) Problemas de orden público (BANCO MUNDIAL. SANEAMIENTO PARA EL DESARROLLO ¿Cómo estamos en 21 países de América Latina y el Caribe? Programa de Agua y Saneamiento para América Latina y el Caribe (WSP-LAC). 2007. Disponível em <http://www.wsp.org/sites/wsp. org/files/publications/11282007125731_Latinosan_Final.pdf>. Acesso em 2.9.2016, p. 48).

43 CEPAL. Informe Nacional Sobre la Gestion del Agua en Colombia. Disponível em <http://www.cepal.org/samtac/ noticias/documentosdetrabajo/5/23345/inco00200.pdf>. Acesso em 2.9.2016, p. 13. 
1. Políticas y estratégias: Consolidar la formulación e implementación de los Planes Departamentales de Agua y Saneamiento en todos los departamentos y municipios del país, como estrategia para mejorar la cobertura y calidad de los servicios de alcantarillado y aseo; Adelantar programas que articulen la política de agua y saneamiento con las políticas ambiental y de vivienda. Las autoridades ambientales deben implementar objetivos de calidad que sean alcanzables por parte de sus regulados y, por su parte, los prestadores de los servicios deben formular sus planes de saneamiento y manejo de vertimientos como herramienta de planificación.

2. Marco legal: Promover la unificación de la normatividad sectorial, en aras de mejorar el proceso de capacitación y de asistencia técnica a los diferentes actores; Armonizar las herramientas normativas para que sean consistentes con los instrumentos de planificación; Con el objeto de garantizar la correcta aplicación, la divulgación de las normas expedidas por el Gobierno Nacional debe realizarse con todos los actores vinculados; alcaldes, gobernadores, prestadores de servicios públicos y comunidad en general.

3. Marco institucional: Es necesario adelantar las obras requeridas para resolver la problemática de contaminación hídrica en las cuencas priorizadas, generada por los vertimientos municipales; Armonizar los diferentes instrumentos de planeación implementados por las diferentes instancias del Gobierno Nacional (PSMV, PMAR, PGAR, POMCA); Fortalecer el sector de aseo, a través de la capacitación y la generación de una cultura empresarial; Fomentar los procesos de regionalización en el servicio, en especial en la disposición final de residuos sólidos.

4. Financiamiento: Se requiere el compromiso de los recursos de las entidades territoriales a largo plazo, para garantizar el logro de las metas fijadas; El país debe brindar el apoyo necesario en los casos en que se requiera de operaciones de crédito con la banca multilateral; Se requiere mayor conciencia de la necesidad de adelantar inversiones en plantas de tratamiento de aguas residuales, donde sea prioritario. Para ello se requiere la articulación de las fuentes de financiación proveniente de todos los actores.

5. Monitoreo y evaluación: Disminuir la dispersión en la asignación de los recursos para el sector de agua potable y saneamiento básico, con el objeto de asegurar un mejor seguimiento de los mismos; Diseñar herramientas que permitan realizar el seguimiento a la eficiencia de las estrategias de política definidas.

6. Capacidades: Optimizar la operación de sistemas de tratamiento de aguas residuales ya construídos; Fortalecer la formulación e implementación de los PSMV; Fomentar alternativas de manejo y tratamiento de aguas residuales y subproductos ${ }^{44}$.

Com isso, a Colômbia conseguiu aumentar a cobertura dos serviços de água e esgoto em nível nacional, incluindo as áreas rurais, de modo que entre os anos de 1985, 1993 e 2005 teve um aumento de 11\% na acessibilidade de água potável e 17\% no sistema de esgoto, alcançando o nível de 81, 91\% de acesso à água potável e 76, 32\% à rede de esgoto. Até o ano de 2013, o acesso ao direito à saneamento básico teve uma elevação de 24\% para a água potável e de 21\% para a cobertura de serviço de esgoto, considerando que $97,18 \%$ da população urbana e $91,18 \%$ da população rural tem acesso à agua; e respectivamente, 73,34\% (urbano) e 69,9\% (rural) tem acesso ao sistema de esgoto ${ }^{45}$.

Para corroborar com esse entendimento, a partir do melhoramento dos serviços de saneamento básico a Colômbia conseguiu diminuir a pobreza, segundo o Índice de Pobreza Munltidimensional. No período de 2010 a 2013 a pobreza foi reduzida em 7\%, o que significa que 2,1 milhões de pessoas saíram da condição de pobreza; ainda na zona rural, 7,2\% da população melhoraram sua condição de vida, em virtude do acesso aos serviços públicos domiciliares e condições de vida com melhoria nas condições de habitação.

A partir das medidas adotadas pela demonstra-se a preocupação em promover o acesso à universalização do saneamento básico à população que se encontra em áreas vulneráveis. Tanto os precedentes da Corte, com a decisão em tela, servem de paradigma para a criação de políticas públicas para o Brasil.

44 BANCO MUNDIAL. SANEAMIENTO PARA EL DESARROLLO ¿Cómo estamos en 21 países de América Latina y el Caribe? Programa de Agua y Saneamiento para América Latina y el Caribe (WSP-LAC). 2007. Disponível em <http:// www.wsp.org/sites/wsp.org/files/publications/11282007125731_Latinosan_Final.pdf>. Acesso em 2.9.2016, p. 50.

45 DEPARTAMENTO NACIONAL DE PLANEACIÓN. Evolución de las coberturas de los servicios de acueducto y alcantarillado (1985-2013). Disponível em < http://www.wsp.org/sites/wsp.org/files/publications/11282007125731_Latinosan_ Final.pdf $>$. Acesso 2.9.2016, p. 53-54. 
Se por um lado o Estado deve promover a realização de obras de esgoto e todos os mecanismos necessários para a realização do saneamento básico às comunidades. Por outro, o cidadão deve ser proativo em relação ao tema, pois, além do seu direito ser reconhecido em uma escala global; há a contraprestação pecuniária direcionadas à manutenção do sistema de saneamento básico. Existe, portanto, uma inércia por parte do Estado e do cidadão. Por parte do Estado que não promove políticas públicas eficientes com a participação democrática da população envolvida; e do cidadão, que se acomoda com a situação existe e não demanda os seus direitos em juízo, a exemplo da Colômbia.

\section{Considerações finais}

O artigo tratou de analisar os mecanismos e/ou instrumentos para a consecução de políticas públicas efetivas para a universalização do direito ao saneamento básico. Primeiramente, fez-se uma explanação da diferença entre o reconhecimento e efetivação do direito ao saneamento básico, concluindo-se que este direito se encontra devidamente positivado, a partir de documentos internacionais e da própria legislação brasileira, sendo necessário a elaboração de políticas públicas para a sua realização.

Ademais, verificou-se que a aplicação do direito ao saneamento básico, enquanto direito humano e fundamental, se dá por meio do entendimento do mínimo existencial ecológico, que conjuga os direitos sociais ao direito ambiental a fim de se alcançar condições dignas de vida e de proteção ao meio ambiente. Sendo assim, o Estado tem o dever de prover condições à população condignas a partir de um sistema de saneamento básico universal.

Por fim, apresentou-se a situação da Colômbia, que por meio da sua Corte Constitucional, determinou que o saneamento básico é uma obrigação do Estado, portanto, responsável em criar e executar políticas públicas efetivas para a universalização desse direito. Associado a isso, o governo colombiano adotou um Plano Nacional de Desenvolvimento, que estava focado na proteção do meio ambiente e na acessibilidade do saneamento básico, a partir da promoção à água potável e rede de esgoto. Com isso, a Colômbia conseguiu ampliar o direito ao saneamento básico na região urbana e rural, retirando milhares de pessoas da zona de extrema pobreza.

Nesse sentido, concluiu-se que no Brasil é necessário mais que a elaboração de políticas públicas. Mas sim de instrumentos reais que permitam a concretização dessas políticas a favor do desenvolvimento do sistema de saneamento básico brasileiro. Para tanto, é imperioso a participação da população brasileira, que realiza o pagamento de taxas para o oferecimento deste direito, mas que tem negado, e deve cobrar das autoridades o seu acesso.

Ademais, os entes federados brasileiros devem assumir compromissos sérios em relação ao orçamento, destinando dinheiro para a realização de obras essenciais para a construção de um sistema de esgoto nas comunidades carentes, bem como, efetivar a recolha do lixo, programas destinados ao combate e à educação relacionados às doenças sanitárias. Espera-se que os governos brasileiros se espelhe no bom exemplo colombiano e compreenda que o direito ao saneamento básico é um direito inerente e indispensável ao ser humano.

\section{REFERÊNCIAS BIBLIOGRÁFICAS}

ALBUQUERQUE, Catarina. Marcos de Legislación, regulaciones y políticas. In: Manual Prático para la realización de los Derechos Humanos al Agua y al Saneamiento de La Relatora Especial de La ONU. Handbook, Portugal, 2014. Disponível em < http:/ /www.righttowater.info/handbook/> p.06 Acesso em 01.09.2016 
AYLA, Patryck de Araújo. Direito fundamental ao ambiente e a proibição de regresso aos níveis de proteção ambiental na Constituição Brasileira. In: Princípio da Proibição de retrocesso Ambiental. Brasília: Comissão de Meio ambiente do Senado Federal. pp. 207-246. Disponível em: < http://www.mma. gov.br/port/conama/processos/93127174/Voto_APROMAC_ANEXO.pdf>. Acesso 2.9.2016

BANCO MUNDIAL. SANEAMIENTO PARA EL DESARROLLO ¿Cómo estamos en 21 países de América Latina y el Caribe? Programa de Agua y Saneamiento para América Latina y el Caribe (WSPLAC). 2007. Disponível em <http://www.wsp.org/sites/wsp.org/files/publications/11282007125731_Latinosan_Final.pdf>. Acesso em 2.9.2016, p. 48.

BENJAMIN, Antonio Herman. Constitucionalização do ambiente e ecologização da constituição brasileira. In.: CANOTILHO, J. J. Gomes. LEITE, Jose Rubens Morato (org). Direito Constitucional Ambiental Brasileiro. 2 ed. São Paulo: Saraiva, 2008, p. 98.

BRASIL. Câmara dos Deputados. Comissão de Defesa do Consumidor, Meio Ambiente e Minorias. Conferência das Nações Unidas sobre Meio Ambiente e Desenvolvimento: Agenda 21. Brasilia: 1995 Disponível em : http://www.onu.org.br/rio20/img/2012/01/agenda21.pdf Acesso em 01.09.2016.

BRASIL. Mandando de Segurança 22.164. Brasília: Supremo Tribunal Federal. 1995. Rel. Min. Celso de Mello, julgamento em 30-10-1995, Plenário, DJ de17-11-1995.

CANOTILHO, J. J. Gomes. Jurisdicização da ecologia ou ecologização do Direito. In: Revista Jurídica do Urbanismo e do Ambiente, $\mathrm{n}^{\circ}$ 4, dezembro de 1995, p. 73 e segs. Apud MIRANDA, Jorge. O Meio Ambiente e a Constituição. In: Diálogo Ambiental, Constitucional e Internacional. Fortaleza: Premius, 2013. p. $25-44$.

CEBDS; TRATA BRASIL. Benefícios Econômicos da expansão do Saneamento Brasileiro. 2014. Disponível em <http://cebds.org/wp-content/uploads/2014/03/BeneficiosEconomicosdaexpans\%C3\% A3odoSaneamentoBrasileiro.pdf $>$. Acesso em 2.9.2016, p. 4.

CEPAL. Informe Nacional Sobre la Gestion del Agua en Colombia. Disponível em <http://www. cepal.org/samtac/noticias/documentosdetrabajo/5/23345/inco00200.pdf>. Acesso em 2.9.2016, p. 13.

COLÔMBIA. Sentencia T-707/12. Corte Constitucional. Publicação em 11.9.2012. Disponível em $<$ http://www.corteconstitucional.gov.co/relatoria/2012/T-707-12.htm>. Acesso em 2.9.2016. Toda a descrição dos fatos adiante foi baseada no caso em tela.

DEPARTAMENTO NACIONAL DE PLANEACIÓN. Evolución de las coberturas de los servicios de acueducto y alcantarillado (1985-2013). Disponível em <http://www.wsp.org/sites/wsp.org/files/ publications/11282007125731_Latinosan_Final.pdf>. Acesso 2.9.2016, p. 53-54.

ESPADA, Gildo. O Direito Humano à Água. In: GOUVEIA, Jorge Bacelar (org.). III Congresso do Direito de Língua Portuguesa - Justiça, Desenvolvimento e cidadania. pp.235 - 250 Almedina: Coimbra, 2014, p.238.

FENSTERSEIFER, Tiago; SARLET, Ingo Wolfgang. Estado socioambiental e mínimo existencial (ecológico?): algumas aproximações. In: Estado Socioambiental e Direitos Fundamentais. SARLET, Ingo Wolfgang (org.) Porto Alegre: Livraria do Advogado, 2010.p. 13.

JUSTO, Juan Bautista. El Derecho Humano al agua y Saneamiento frente a los Objetivos de Desarrollo del Milenio (ODM). CEPAL: 2013. Disponível em < http://www.ohchr.org/Documents/Issues/Water/ContributionsSustainability/ECLAC7.pdf>. Acesso em 2.9.2016, p. 47.

MIRANDA, Jorge. Manual de Direito Constitucional - Direito Fundamentais. Parte IV. $3^{a}$ Ed. Coimbra: Coimbra Editora, 2000, p. 68-69.

MIRANDA, Jorge; MEDEIROS, Rui. Constituição Portuguesa Anotada. Tomo I, $2^{\circ}$ Ed. Coimbra: 
Coimbra Editora, 2010, p. 1348.

ONU. Convenção sobre a Eliminação de todas as Formas de Descriminação contra a Mulher 1979. Disponível em < http://www.unicef.org/brazil/pt/resources_10233.htm>. Acesso em 08.10.2015.

ONU. Convenção sobre os Direitos da Criança 1989. Disponível em: https://www.unicef.pt/docs/pdf_ publicacoes/convencao_direitos_crianca2004.pdf. Acesso em 01.09.2016.

ONU. Resolução 54/175. Disponível em < http://www.un.org/ga/search/view_doc.asp?symbol=A/ RES/54/175>. Acesso em 02.09.2016.

PNUD. Relatório do Desenvolvimento Humano 2015: trabalho como motor de desenvolvimento humano. Disponível em: <http://hdr.undp.org/sites/default/files/hdr15_overview_pt.pdf>. Acesso em 92.9.2016.

RIBEIRO, Wagner Costa. Geografia política da água. São Paulo: Annablume, 2008, p.78.

SILVA, Brisa Arnoud da. A importância da garantia do mínimo existencial ecológico para a concretização do estado democrático socioambiental. Justiça do Direito, v. 28, n. 1, p. 84-107, jan./jun. 2014. Disponível em < http://dx.doi.org/10.5335/rjd.v28i1.4832>. Acesso em 2.9.2016, p. 92-93.

SILVA, José Afonso da. Direito Ambiental Constitucional. São Paulo: Malheiros, 2010, p. 64.

SILVA, Vasco Pereira da. Verde: Cor de Direito - Lições de Direito do Ambiente. Coimbra: Almedina, 2002, p. 67

SIQUEIRA GARCIA, Denise Schmitt; GARCIA, Heloise Siqueira. Mínimo existencial ecológico: a intrínseca relação entre a dignidade da pessoa humana e à qualidade ambiental. 2015. Disponível em <http:// emporiododireito.com.br/minimo-existencial-ecologico-a-intrinseca-relacao-entre-a-dignidade-da-pessoahumana-e-a-qualidade-ambiental-por-denise-schmitt-siqueira-garcia-e-heloise-siqueira-garcia/>. Acesso em 2.9.2016.

TRATA BRASIL. Casos de Sucesso. Disponível em < http://www.tratabrasil.org.br/casos-de-sucesso>. Acesso em 2.9.2016.

TRATA BRASIL. Imprensa: Ranking do Saneamento no mundo. Disponível em < http://www.tratabrasil.org.br/ranking-do-saneamento-2015>. Acesso em 01.09.2016

TRATA BRASIL. Imprensa: Ranking do Saneamento no mundo. Disponível em < http:/ /www.tratabrasil.org.br/ranking-do-saneamento-2015>. Acesso em 01.09.2016

UNITED NATIONS. O Direito Humano à água e ao saneamento: marcos. Programa da Década da Água da ONU-Água sobre Advocacia e Comunicação (UNW-DPAC). Disponível em: <http://www. un.org/waterforlifedecade/pdf/human_right_to_water_and_sanitation_milestones_por.pdf $>$. Acesso em 2.9.2016, p. 3 .

UNITED NATIONS. O Direito Humano à água e ao saneamento: marcos. Programa da Década da Água da ONU-Água sobre Advocacia e Comunicação (UNW-DPAC). Disponível em: <http://www. un.org/waterforlifedecade/pdf/human_right_to_water_and_sanitation_milestones_por.pdf $>$. Acesso em 2.9.2016, p. 3 .

VARGAS, Éverton Vieira. Água e relações internacionais. Rev. bras. polít. int. [online]. 2000, vol.43, n.1, pp. 178-182. Disponível em < http://www.scielo.br/pdf/rbpi/v43n1/v43n1a10.pdf> Acesso em 31.08.2016, p.5.

WORLD HEALTH ORGANIZATION. Sanitation. Disponível em < http://www.who.int/topics/sanitation/en/>. Acesso em 2.9.2016. 


\section{Normas Editoriais}

1. Serão aceitas colaborações inéditas e a publicação de um artigo está condicionada à sua adequação às normas editoriais, e seu simples recebimento desobriga a sua publicação. A revista Prismas: Direito, Políticas Públicas e Mundialização classificará as colaborações de acordo com as seguintes seções:

1.1 Artigos: compreende textos que contenham relatos completos de estudos ou pesquisas concluídas, matérias de caráter opinativo, revisões da literatura e colaborações assemelhadas.

1.2 Resenhas: compreende análises críticas de livros, de periódicos recentemente publicados, dissertações e teses.

2. Excepcionalmente, a equipe editorial poderá aceitar a submissão de trabalhos que já tenham sido publicados e caso isso ocorra, serão submetidos ao mesmo processo de avaliação pelos pares que aqueles inéditos. $\mathrm{O}$ autor deverá apresentar autorização por escrito do editor da revista na qual seu trabalho tenha sido originalmente publicado, acompanhado de cópia do mesmo.

3. O processo de avaliação dos artigos e resenhas compreende duas fases: a primeira destinada à análise da adequação do trabalho à linha editorial da revista (Equipe Editorial) e a segunda referente à avaliação do conteúdo e qualidade dos trabalhos. Esta segunda fase é realizada mediante o processo de avaliação pelos pares, ou seja, os artigos serão submetidos à aprovação de no mínimo 2 pareceristas adhoc.

4. Os trabalhos serão enviados para a avaliação sem a identificação de autoria

5. Os trabalhos devem ser enviados no seguinte padrão:

$1^{a}$ Página: Começar com o título do título do trabalho, seguido do texto. Não inseriro nome dos autores ou outros elementos queidentifiquem a autoria. A autoria do artigo e a qualificação dos autores são inseridas nos campos específicos do formulário eletrônico. O objetivo aqui é garantir uma avaliação cega por pares. Os textos deverão ser digitados em Arial 12, espaço 1,5 margem de 2,5 $\mathrm{cm}$, numeração arábica das páginas no ângulo superior direito, em programa compatível com o Word para Windows.

Título do trabalho: o título deve ser breve e suficientemente específico e descritivo para representar o conteúdo do texto e deverá ter a sua tradução para o inglês.

Resumo: em todos os artigos submetidos deve ser incluído um resumo informativo com o máximo de 250 palavras e espaço entre linhas simples. O resumo deve ser estruturado com as seguintes informações:

Objetivo do artigo (obrigatório);

Metodologia (obrigatório);

Conclusões (obrigatório);

Limitações da pesquisa e suas implicações (se aplicável);

Limitações práticas (se aplicável)

Originalidade ou valor (obrigatório); 
A evolução da comunicação científica e da transmissão de conhecimentos possibilitou ao UniCEUB a criação de meios para o intercâmbio de idéias entre pares e a disseminação de informações.

As novas tecnologias da informação produzem sensíveis alterações nos processos de comunicação científica. Atualmente, a editoração das publicações acadêmicas do UniCEUB é informatizada em todas as suas etapas, com a utilização da plataforma SEER, Sistema de Editoração Eletrônico de Revistas. A aplicação do SEER permitiu acrescentar, no processo editorial, a avaliação dos pareceristas ad hoc e deu aos membros dos comitês editoriais e aos editores condições para consolidar a produção científica no UniCEUB e difundi-la por meio dos periódicos acadêmicos em mídia impressa e eletrônica.

Todas as edições das publicações científicas do UniCEUB estão disponíveis no site www.publicacoesacademicas.uniceub.br, com infraestrutura para acesso livre.

O UniCEUB publica as seguintes revistas:

- Revista Brasileira de Políticas Públicas

- Revista de Direito Internacional

- Universitas Arquitetura e Comunicação Social

- Universitas Ciências da Saúde

- Universitas Gestão e TI

- Universitas Humanas

- Universitas JUS

- Universitas Relações Internacionais

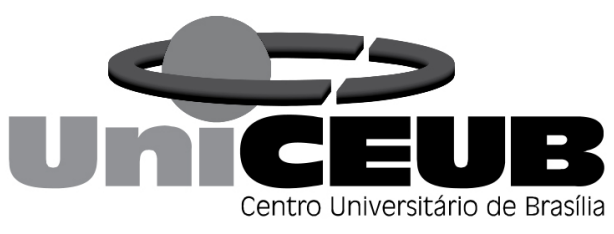


Destacar no mínimo três e no máximo seis palavraschave que representem o conteúdo do texto. O resumo e as palavras-chave deverão ter a sua tradução para o inglês.

Agradecimentos: agradecimentos a auxílios recebidos para a elaboração do trabalho deverão ser mencionados no final do artigo.

Notas: notas referentes ao corpo do artigo deverão vir no rodapé do texto.

Apêndices: apêndices podem ser empregados no caso de listagens extensivas, estatísticas e outros elementos de suporte.

Materiais gráficos: fotografias nítidas e gráficos (estritamente indispensáveis à clareza do texto) poderão ser aceitos e cada fotografia ou gráfico deverá vir no texto e além disso cada um deverá ser enviado em arquivo separado. Se as ilustrações enviadas já tiverem sido publicadas, mencionar a fonte e a permissão para reprodução.

Quadros: os quadros deverão ser acompanhados de cabeçalho que permita compreender o significado dos dados reunidos, sem necessidade de referência ao texto. Assinalar, no texto, pelo seu número de ordem, os locais onde os quadros devem ser intercalados.

Referências: as referências redigidas segundo a norma NBR 6023/2002 da Associação Brasileira de Normas Técnicas (ABNT), deverão ser apresentadas por ordem alfabética e constituir uma lista única no final do artigo. A exatidão e adequação das referências a trabalhos que tenham sido consultados e mencionados no texto do artigo são da responsabilidade do autor. Informações procedentes de comunicação pessoal, de trabalhos em andamento ou não publicados não devem ser incluídas na lista de referências, mas indicada em nota de rodapé. Não utilizar o sistema Autor data para citações. O formato utilizado pela revista é o sistema numérico, onde a citação é indicada por número sobrescrito e a referência mencionada em nota de rodapé.

Recomendações: recomenda-se que se observem as normas da ABNT referentes à apresentação de artigos em publicações periódicas (NBR 6022/2002), apresentação de citações em documentos (NBR 10520/2002), apresentação de originais (NBR 12256), norma para datar (NBR 892), numeração progressiva das seções de um documento (NBR 6024/2003) e resumos (NBR $6028 / 2003)$.

A revista se reserva o direito de efetuar nos originais alterações de ordem normativa, ortográfica e gramatical, com vistas a manter o padrão culto da língua, respeitando, porém, o estilo dos autores.

A partir de 2009, consideramos útil formular algumas sugestões (não obrigatórias) aos autores, com base nos principais motivos por recusa de artigos nos anos anteriores.

8. Responsabilidades e conflitos de interesse: A responsabilidade pelas informações e opiniões indicadas nos artigos é exclusiva dos autores. Eventuais conflitos de interesse serão de responsabilidade dos próprios autores e não do periódico.

\section{Envio dos trabalhos:}

1. Os trabalhos deverão ser enviados para a equipe editorial da revista no endereço eletrônico www.rdi.uniceub.br

2. Cada autor deve enviar declaração de responsabilidade nos termos abaixo:

“Eu XXXX certifico que participei da concepção do trabalho tornar pública minha responsabilidade pelo seu conteúdo, que não omiti quaisquer ligações ou acordos de financiamento entre os autores e companhias que possam ter interesse na publicação deste artigo."

3. Para as colaborações inéditas, cada autor deve enviar a transferência de direitos autorais nos termos abaixo:

"Eu XXXX declaro que em caso de aceitação do artigo inédito, a revista Revista Brasileira de Políticas Públicas passa a ter os direitos autorais a ele referentes. 


\section{REVISTA BRASILEIRA DE POLÍTICAS PÚBLICAS \\ V. $6, n^{\circ} 2$}

Uma perspectiva comparada acerca da (não) efetividade da democracia local no Brasil e em Portugal

Matheus Passos Silva

Uma perspectiva comparada acerca da (não) efetividade da democracia local no Brasil e em Portugal

Matheus Passos Silva e Paulo Afonso Cavichioli Carmona

Transparência administrativa, lei federal n० 12.527/2011 e sigilo dos documentos públicos: A inconstitucionalidade das restrições ao acesso à informação

Emerson Affonso da Costa Moura

A influência do Direito Administrativo Global no processo brasileiro de Contratação Pública à luz do Princípio da Transparência

Alice Rocha da Silva e Ruth Maria Pereira dos Santos

Interna Corporis Acta e os limites do controle judicial dos atos legislativos

Cintia Garabini Lages

A releitura do princípio da actio nata quanto aos direitos difusos na judicialização brasileira

Luiz Gustavo Gonçalves Ribeiro e Lorena Machado Rogedo Bastianetto

A defensoria pública como garantia constitucional processual de acesso à justiça na América do Sul

Antonio Henrique Graciano Suxberger e Alberto Carvalho Amaral

Judicialização da saúde pública brasileira

Maria Socorro de Araújo Dias, Diógenes Farias Gomes, Thaís Araújo Dias, Lielma Carla Chagas da Silva, Maria da Conceição Coelho Brito e Manoel de Castro Carneiro Neto

A política de assistência social e a promoção ao trabalho: uma análise do PRONATEC BSM com base em um estudo com egressos em Fortaleza-CE

Aline de Araújo Araújo Martins e Mônica Duarte Cavaignac

Intervenção estatal na agricultura: a possibilidade de uma ação ética a fim de materializar a Constituição brasileira

Davi Augusto Santana de Lelis e Giovani Clark

Agricultura orgânica: solução para o século XXI?

Eloir Trindade Vasques Vieira, Denilson de Oliveira Guilherme, Luis Carlos Vinhas Itavo e Lucelia da Costa Nogueira Tashima

Os desafios jurídicos e econômicos da aviação regional no Brasil

Pablo Leurquin e Mariana Magalhães Avelar

Homeschooling no Brasil: conformação deôntico-axiológica do sistema jurídico como plus à política pública de educação fundamental

Cláudio Márcio Bernardes e Carlos Alberto Simões Tomaz

Barreiras à cidadania nas políticas sociais para a população em situação de rua

Luciano Roberto Gulart Cabral Júnior e José Ricardo Caetano Costa

O corte do fornecimento de água em face do inadimplemento do consumidor: análise à luz do Diálogo das Fontes

Leonardo Roscoe Bessa e Gabriela Gomes Acioli César

A necessidade de realização de políticas públicas para a universalização do direito ao saneamento básico

Ruth Santos e Renata Menezes 